\title{
Acceptable Knowledge Document for INEEL Stored Transuranic Waste - Rocky Flats Plant Waste
}

\section{Revision 2}

January 23, 1998

\author{
Prepared for: \\ Lockheed Martin Idaho Technologies Company \\ P. O. Box 1625 \\ Idaho Falls, ID 83415-2424
}

Prepared by:

WASTREN, Inc.

1333 W 120th Ave, Suite 300

Westminster, CO 80234

DIGTRIBUTION OF THE DOCUMENT IS UNL WTED

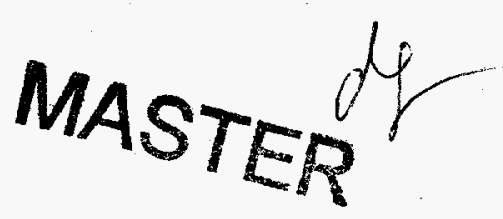




\section{DISCLAIMER}

Portions of this document may be illegible electronic image products. Images are produced from the best available original document. 


\section{EXECUTIVE SUMMARY}

This document and supporting documentation provide a consistent, defensible, and auditable record of acceptable knowledge for waste generated at the Rocky Flats Plant which is currently in the accessible storage inventory at the Idaho National Engineering \& Environmental Laboratory (INEEL). The inventory consists of transuranic (TRU) waste generated from 1972 through 1989. The waste consists of a wide variety of matrices generated during plutonium parts production and support operations including recovery, treatment, maintenance, laboratory, and research and development. The inventory also contains TRU waste generated by non-routine events including renovations, spills, fires, and decommissioning.

The Resource Conservation and Recovery Act (RCRA) and New Mexico Hazardous Waste Management Regulations authorize waste generators and treatment, storage, and disposal facilities to use acceptable knowledge in appropriate circumstances to make hazardous waste determinations. Knowledge of the materials and processes that generate a waste is used for TRU waste characterization when documentation relating to the generating process and composition of the waste is available. For example, waste contaminated with a spent solvent will be characterized as a listed hazardous waste if the compound was used for its solvent properties by the process generating the waste.

Acceptable knowledge includes information relating to plant history, process operations, and waste management, in addition to waste-specific data generated prior to the effective date of the RCRA regulations. Acceptable knowledge, as an alternative to sampling and analysis, can be used to meet all or part of the waste characterization requirements under RCRA.

In addition to published documents describing the inventory and historical operations, acceptable knowledge documentation was collected from numerous other sources including the Rocky Flats library, historical document archives, operator historical records, and interviews with cognizant personnel. Nearly 500 sources of information were obtained, reviewed, and incorporated into a data management system. The information presented is referencable to the source by the alpha-numeric superscripts in the text of this document. The references were divided into published documents, unpublished data, and correspondence, which correspond to the "P", "U", and "C" superscripts.

In an effort to facilitate the review of the available acceptable knowledge documentation, the inventory was subdivided into "waste groups" consisting of materials with similar physical and chemical properties. Once acceptable knowledge information was identified and obtained, the documentation was incorporated into Source Files. As the sources were reviewed, excerpts relevant to a specific waste group were copied and incorporated into Waste Group Files. The excerpts consist of only the information from the source relevant to the waste group. This approach makes it possible for the reader to access the specific source of the information without having to review the entire source document. As the document is reviewed the reader can access either the Waste Group File to review the excerpt specific to the reference or access the Source File to review the source. In addition to a file for each waste group, a file of excerpts has been created for the information presented in Sections 1 through 3.

This document is organized to provide the reader a comprehensive presentation of the TRU waste inventory ranging from descriptions of the historical plant operations that generated and managed the waste to specific information about the composition of each waste group. Section 2 lists the requirements that dictate and direct TRU waste characterization and authorize the use of the acceptable knowledge approach. In 
addition to defining the TRU waste inventory, Section 3 summarizes the historical operations, waste management, characterization, and certification activities associated with the inventory. Sections 5.0 through 26.0 describe the waste groups in the inventory including waste generation, waste packaging, and waste characterization. Revision 1 of this document includes an expanded discussion for each waste group of potential radionuclide contaminants, in addition to other physical properties and interferences that could potential impact radioassay systems. Appendix A contains the list of the references and acceptable knowledge documentation reviewed during this program. The table in Appendix B was compiled to allow the user to determine the building or area of generation for containers in inventory using the container prefix contained in the drum identification number. The acceptable knowledge relating to historical operations and the date of generation can in turn be used to assess a given container for potential process specific contaminants. The table segregates the accessible storage drum inventory by waste group (numbered the same as the sections in this document), Item Description Code, Container Prefix, and building of generation. The generation dates, process descriptions, and potential radionuclide contaminants are identified for each population. 


\section{TABLE OF CONTENTS}

EXECUTIVE SUMMARY $\ldots \ldots \ldots \ldots \ldots \ldots \ldots \ldots \ldots \ldots \ldots \ldots \ldots \ldots \ldots \ldots$

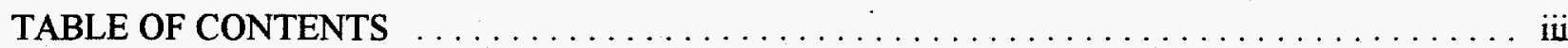

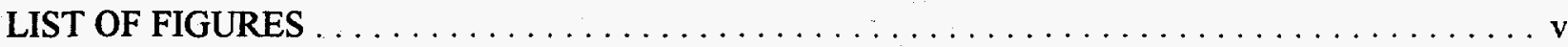

LIST OF ACRONYMS \& ABBREVIATIONS $\ldots \ldots \ldots \ldots \ldots \ldots \ldots \ldots \ldots \ldots \ldots \ldots$ vi

MASTER SOURCE DOCUMENT REFERENCE INDEX $\ldots \ldots \ldots \ldots \ldots \ldots \ldots \ldots \ldots \ldots$ vii

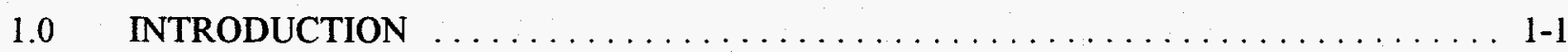

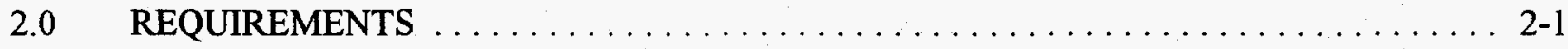

3.0 TRU WASTE GENERATION $\ldots \ldots \ldots \ldots \ldots \ldots \ldots \ldots \ldots \ldots \ldots \ldots \ldots \ldots \ldots \ldots$

$3.1 \quad$ ROCKY FLATS PLANT DESCRIPTION AND MISSION $\ldots \ldots \ldots \ldots \ldots \ldots \ldots$.

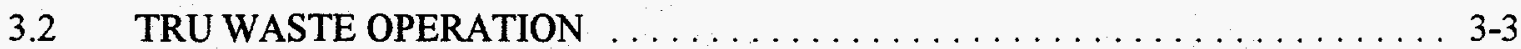

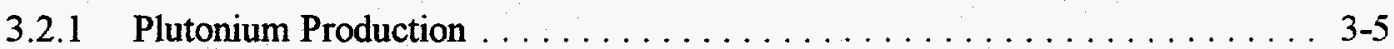

3.2.2 Plutonium Recovery and Purification $\ldots \ldots \ldots \ldots \ldots \ldots \ldots \ldots . \ldots \ldots$

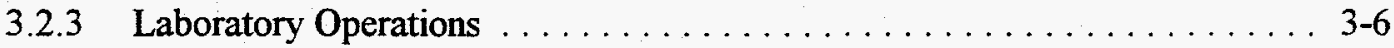

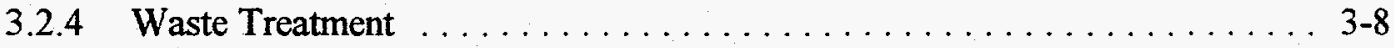

3.2.5 Research and Development . . . . . . . . . . . . . . . . . . 3-9

3.2.6 Routine Maintenance . . . . . . . . . . . . . . . . . . . . . . . 3-12

3.2 .7 Non-Routine Operations . . . . . . . . . . . . . . . . . . . . . . 3-12

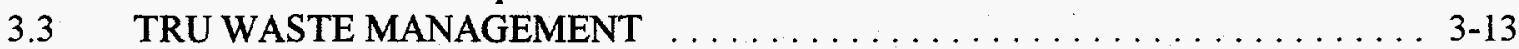

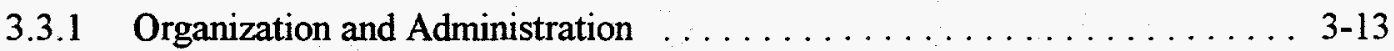

3.3.2 Waste Segregation .......................... 3-13

3.3.3 TRU Waste Packaging, Storage, and Transportation . . . . . . . . . 3-14

3.3.4 Waste Characterization . . . . . . . . . . . . . . . . . 3-15

3.4 TRU WASTE CERTIFICATION $\ldots \ldots \ldots \ldots \ldots \ldots \ldots \ldots \ldots \ldots \ldots \ldots \ldots \ldots$

3.4.1 Rocky Flats Plant Certification . . . . . . . . . . . . . . . . 3-16

3.4 .2 INEL Certification .......................... 3-16

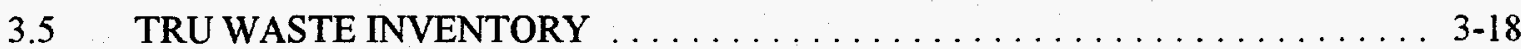

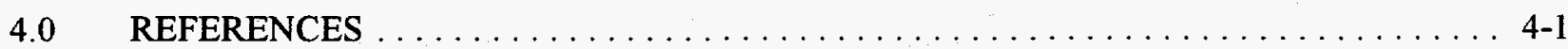

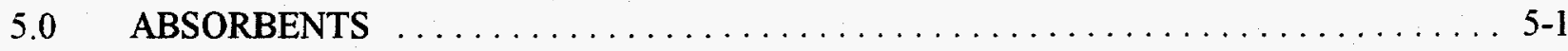

6.0 AMERICIUM PROCESS RESIDUE $\ldots \ldots \ldots \ldots \ldots \ldots \ldots \ldots \ldots \ldots \ldots \ldots \ldots \ldots$

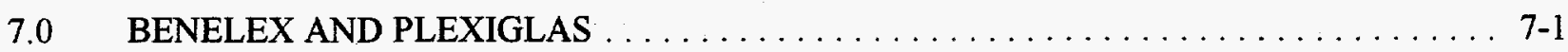

$8.0 \quad$ BLACKTOP, CONCRETE, DIRT, AND SAND $\ldots \ldots \ldots \ldots \ldots \ldots \ldots \ldots \ldots$ 
9.0 COMBUSTIBLES AND PLASTIC

$10.0 \quad$ FILTERS AND INSULATION $\ldots \ldots \ldots \ldots \ldots \ldots \ldots \ldots \ldots \ldots \ldots \ldots \ldots \ldots$

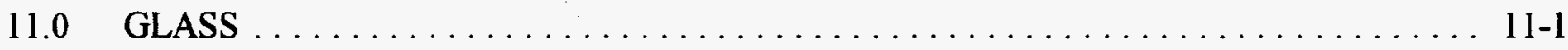

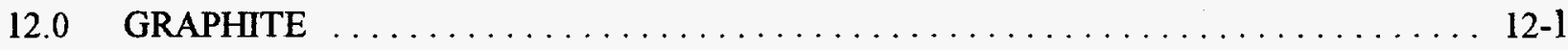

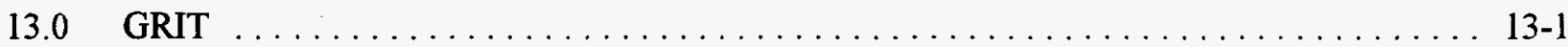

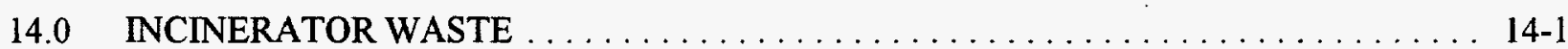

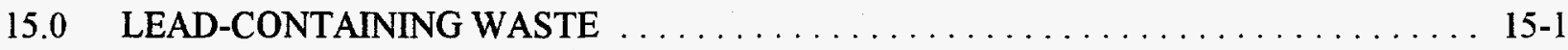

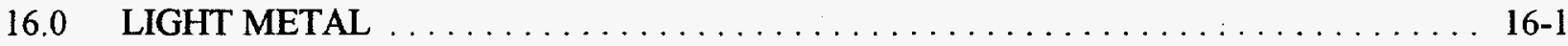

17.0 MISCELLANEOUS CEMENTED WASTE $\ldots \ldots \ldots \ldots \ldots \ldots \ldots \ldots \ldots \ldots \ldots$

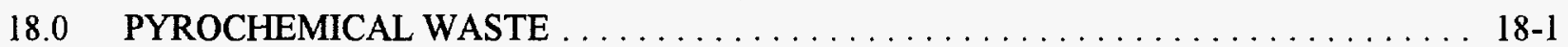

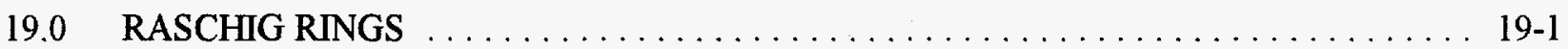

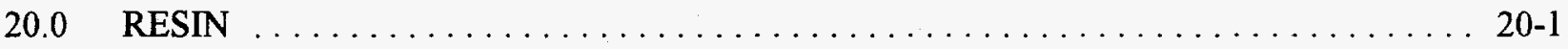

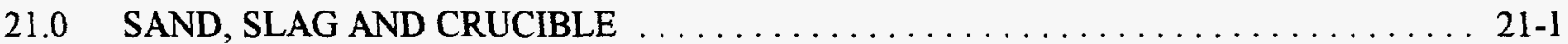

22.0 SOLIDIFIED AQUEOUS SLUDGE-BUILDING $374 \ldots \ldots \ldots \ldots \ldots \ldots \ldots \ldots$

23.0 SOLIDIFIED AQUEOUS SLUDGE-BUILDING $774 \ldots \ldots \ldots \ldots \ldots \ldots \ldots \ldots$

24.0 SOLIDIFIED LABORATORY WASTE $\ldots \ldots \ldots \ldots \ldots \ldots \ldots \ldots \ldots \ldots \ldots \ldots \ldots \ldots$

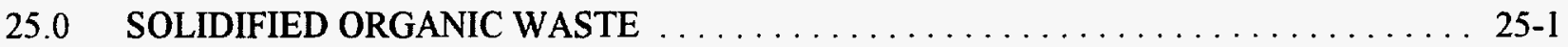

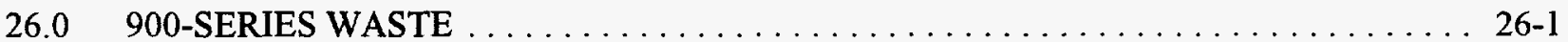

APPENDIX A $\ldots \ldots \ldots \ldots \ldots \ldots \ldots \ldots$ ACCEPTABLE KNOWLEDGE REFERENCES

APPENDIX B . . . . . . . . . INEEL ACCESSIBLE STORAGE TRU WASTE INVENTORYROCKY FLATS WASTE 


\section{LIST OF FIGURES}

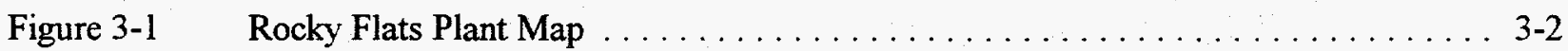

Figure 3-2 Plutonium Production, Recovery, and Purification Flow Diagram . . . . . . . . 3-7

Figure 12-1 Graphite Waste Generation Flow Diagram $\ldots \ldots \ldots \ldots \ldots \ldots \ldots \ldots \ldots \ldots$

Figure $12-2 \quad$ Graphite Waste Generation by Building $\ldots \ldots \ldots \ldots \ldots \ldots \ldots \ldots \ldots \ldots$

Figure 14-1 Plutonium Recovery Incineration Process $\ldots \ldots \ldots \ldots \ldots \ldots \ldots \ldots \ldots$

Figure 14-1 Fluidized-Bed Incineration Process $\ldots \ldots \ldots \ldots \ldots \ldots \ldots \ldots \ldots \ldots \ldots$

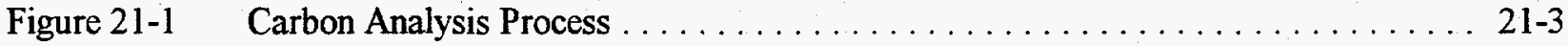

Figure $21-2 \quad$ Reduction and Button Break-Out Process $\ldots \ldots \ldots \ldots \ldots \ldots \ldots \ldots \ldots \ldots$

Figure $21-3 \quad$ Residue Dissolution Process $\ldots \ldots \ldots \ldots \ldots \ldots \ldots \ldots \ldots \ldots \ldots \ldots \ldots$

Figure 22-1 Building 374 Radioactive Decontamination and Evaporation Processes . . . . . . 22-3

Figure 22-2 Building 374 Acid Neutralization and Sludge Immobilization Processes . . . . . . 22-5

Figure 23-1 Building 774 Aqueous Waste Treatment Process $\ldots \ldots \ldots \ldots \ldots \ldots \ldots \ldots \ldots$

Figure $25-1 \quad$ Flow of Organic Liquid Waste into IDC 003 Drum $\ldots \ldots \ldots \ldots \ldots \ldots \ldots$

Figure 25-2 Flow of Organic Liquid Waste into IDCs 700 and 801 Drums . . . . . . 25-4 


\section{LIST OF ACRONYMS \& ABBREVIATIONS}

$\begin{array}{ll}\text { ANL } & \text { Argonne National Laboratory } \\ \text { BWR } & \text { Backlog Waste Reassessment } \\ \text { CAO } & \text { Carlsbad Area Office } \\ \text { CFR } & \text { Code of Federal Regulations } \\ \text { CWS } & \text { Chemical Warfare Service } \\ \text { DOD } & \text { United States Department of Defense } \\ \text { DOE } & \text { United States Department of Energy } \\ \text { DOT } & \text { United States Department of Transportation } \\ \text { EDL } & \text { Economic Discard Limit } \\ \text { EPA } & \text { United States Environmental Protection Agency } \\ \text { ER } & \text { Electrorefining } \\ \text { HEPA } & \text { High Efficiency Particulate Air } \\ \text { HVAC } & \text { Heating, Ventilation, and Air Conditioning } \\ \text { IDC } & \text { Item Description Code } \\ \text { INEEL } & \text { Idaho National Engineering \& Environmental Laboratory } \\ \text { LASL } & \text { Los Alamos Scientific Laboratory } \\ \text { LDR } & \text { Land Disposal Restrictions } \\ \text { LLNL } & \text { Lawrence Livermore National Laboratory } \\ \text { LLW } & \text { Low Level Waste } \\ \text { LRL } & \text { Lawrence Radiation Laboratory } \\ \text { MSE } & \text { Molten Salt Extraction } \\ \text { ORNL } & \text { Oak Ridge National Laboratory } \\ \text { PAN } & \text { Passive/Active Neutron } \\ \text { PRQL } & \text { Program Required Quantitation Limit } \\ \text { PVC } & \text { polyvinylchloride } \\ \text { QAPD } & \text { Quality Assurance Program Description } \\ \text { QAPP } & \text { Quality Assurance Program Plan } \\ \text { R\&D } & \text { Research and Development } \\ \text { RCRA } & \text { Resource Conservation and Recovery Act } \\ \text { RTR } & \text { Real-Time Radiography } \\ \text { SGS } & \text { Segmented Gamma Scan } \\ \text { SRV } & \text { Size Reduction Vault } \\ \text { TRU } & \text { Transuranic } \\ \text { UCL } & \text { Upper Confidence Level } \\ \text { WAC } & \text { Waste Acceptance Criteria } \\ \text { WIPP } & \text { Waste Isolation Pilot Plant } \\ \text { WSRIC } & \text { Waste Stream and Residue Identification and Characterization }\end{array}$




\section{MASTER SOURCE DOCUMENT REFERENCE INDEX}

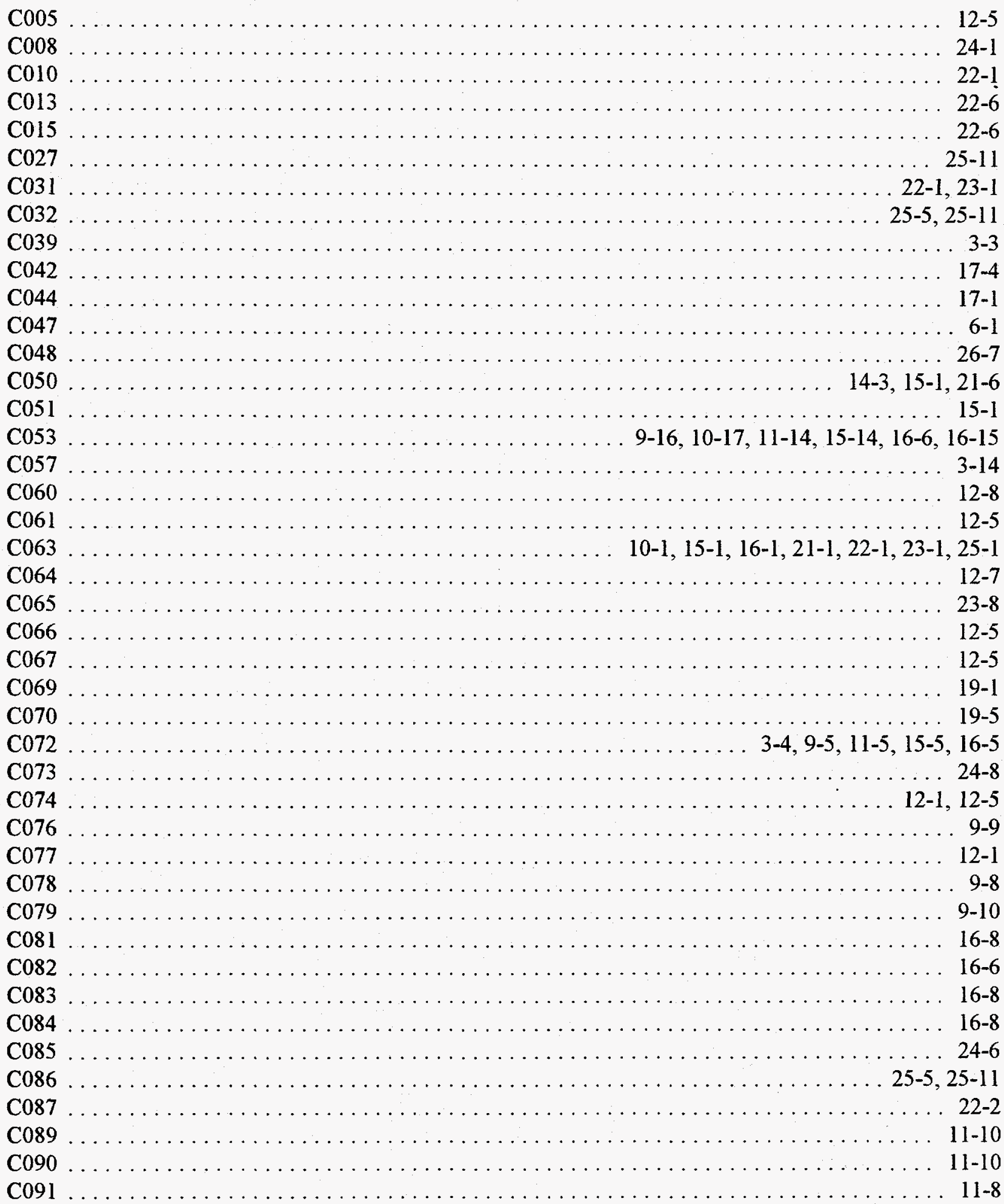


C184 7-5, 8-5, 8-6, 9-12, 9-13, 9-14, 9-15, 9-16, 10-13, 10-14, 10-15, 10-16, 11-11, 11-12, 11-13, 11-14, $12-9,14-13,14-14,15-11,15-12,15-13,15-14,16-11,16-12,16-13,16-14,16-15,19-7$, $19-8,19-9,19-10,22-13,23-12,24-7,25-10,25-11, \mathrm{~B}-10$ C185 ... . 3-8, 8-6, 9-12, 9-14, 10-13, 10-15, 11-11, 11-13, 12-9, 15-11, 15-13, 16-11, 16-13, 19-7, 19-9 
C196

$23-12$

$\mathrm{C} 197$

B-10

P001

$3-16,5-1,5-2,5-3,7-1,9-1,9-2,10-1,10-2,10-5,10-6,10-7,11-1,12-5,13-1,14-1,14-7,15-1$,

$16-1,16-7,17-1,17-2,17-4,17-5,18-1,18-3,19-1,20-1,22-2,22-7,23-1,23-5,23-6$

P002 $25-1,25-2,25-11,26-2$

$\mathrm{P} 004$ $3-15,22-2,22-13,22-14,23-1,23-12,23-13,26-1$

P008 $7,9-8,10-7,11-7,12-6,13-1,14-7,16-7,19-4,21-6$ $\mathrm{P} 009$

$11-7,15-8,16-8,19-5$

P0125-1, 5-2, 5-3, 6-1, 6-2, 6-3, 7-1, 7-2, 7-3, 8-2, 8-3, 9-1, 9-7, 9-9, 9-10, 10-1, 10-7, 10-9, 10-10, 11-1, $11-7,11-8,12-1,12-6,14-7,14-9,15-1,15-6,15-7,15-8,16-1,16-7,16-8,16-9,17-1,17-4$, $18-1,18-3,18-4,18-5,19-1,19-3,19-4,19-5,20-1,20-3,21-1,21-6,21-7,21-8,22-6,23-6$, $23-8,24-1,24-4,24-5,25-1,25-6,25-7,25-8,26-1,26-3,26-4,26-5$

P013 $11-9,14-9,14-10,22-6,22-8,22-13,22-14,23-6,23-8,23-12,24-5,25-7,25-8$

$\mathrm{P} 014$

P015 . 3-3, 3-13, 3-16, 5-1, 8-1, 9-9, 10-1, 11-1, 11-2, 11-8, 12-1, 14-1, 14-2, 15-1, 16-1, 19-3, 19-5 $22-1,23-1,26-1$

P015 3-17, 6-1, 6-2, 6-3, 6-4, 7-2, 7-3, 7-5, 8-6, 9-7, 9-8, 9-9, 9-10, 10-7, 10-9, 10-10, 11-1, 11-7, 11-8, $11-9,11-10,12-6,12-7,12-10,14-5,14-7,14-9,14-10,14-14,15-7,15-8,15-9,16-7$, $16-8,16-9,18-4,18-5,19-5,20-3,20-4,20-5,20-7,22-6,22-8,22-13,22-14$ 23-1, $23-6,23-8,23-12,24-4,24-5,25-7,25-8,26-3,26-4,26-5$

P016 3-17, 7-2, 8-1, 8-2, 9-1, 9-7, 9-9, 10-1, 10-2, 10-5, 10-7, 10-8, 10-9, 10-10, 11-7, 12-1, 12-2, 12-6, $12-7,14-1,14-2,14-3,14-5,14-7,14-13,15-1,15-2,15-7,15-8,15-9,16-7,16-8,17-1$, $17-4,17-5,18-4,18-6,19-2,19-4,19-5,20-3,21-1,21-2,21-6,21-7,21-8,22-6,23-1$, $23-5,23-6,23-8,24-1,24-4,24-5,24-6,25-1,25-2,25-6,25-7,25-8,25-10$

$\mathrm{P} 017$ $12-7,16-8,19-5$

$\mathrm{P} 020$ 3-3

$\mathrm{P} 021$

$\mathrm{P} 022$

$\mathrm{P} 023$

P024

$11-8,11-9,12-6,12-7,16-8,19-5,22-6,22-8,22-13,22-14,23-6,23-8,23-12,25-7,25-8$

$11-9,12-7,15-7,15-8,16-8,18-5,20-4,20-5,24-4,24-5$

5-3, 8-1, 8-4, 9-2, 10-3, 11-2, 15-2, 16-2, 17-6, 20-5, 20-6, 25-5, 26-3 5-1, 5-2, 5-3, 5-4, 5-5, 6-1, 6-2, 6-3, 7-1, 7-2, 7-3, 7-5, 8-1, 8-2, 8-3, 8-6, 9-1, 9-2, 9-7, 9-8, 9-9, $9-10,9-15,9-16,10-1,10-2,10-5,10-6,10-7,10-9,10-10,10-13,10-16,10-17,11-1$, $11-7,11-8,11-9,11-13,12-1,12-5,12-6,13-1,13-2,13-3,14-1,14-2,14-5,14-7,14-9$, $14-13,14-14,14-15,15-2,15-3,15-6,15-7,15-8,15-13,15-14,16-1,16-6,16-7,16-8$, $16-9,16-14,17-8,18-1,18-2,18-3,18-4,18-5,19-1,19-3,19-4,19-5,19-7,20-1,20-3$, $20-6,20-7,21-1,21-2,21-6,21-7,21-8,22-14,23-1,23-5,23-6,23-8,23-12,24-1,24-2$, $24-4,24-5,24-8,25-1,25-2,25-5,25-6,25-7,25-8,25-9,25-10,25-11,26-1,26-2,26-3$,

$26-4,26-5,26-6,26-8$

P026 $22-6$

P028

P029

$\mathrm{P} 032$

$\mathrm{P} 033$

$3-14,3-16,3-17,7-4,7-5,8-4,8-6,9-11,10-12,11-10,12-8,12-10,14-13,14-14,15-9,15-10$, $16-8,16-10,18-6,18-7,18-8,19-6,20-5,20-6,20-7,22-12,23-10,24-6,24-7,25-8$,

$25-9,25-10,26-7$

P035 3-13, 10-13, 12-5, 12-7, 12-10, 13-1, 14-1, 14-2, 14-13, 14-14, 14-15, 15-1, 18-7, 18-8, 18-9, 19-2, $19-3,21-1,21-2,21-9,21-10,26-3$

$\mathrm{P} 037$ $5-1,10-1,14-1,14-3,14-5,15-1$ P038 $12-2,18-1,18-2,18-3,18-4,18-9$ 
$3-13,3-16,5-1,10-2,14-2,14-3,14-7,16-7,20-1,20-3,21-7,21-8,22-1,23-6$

P049 $22-6,22-7$

P050 $5-1,8-1,12-8,13-1,15-1,26-3$

P052 3-5, 3-6, 3-8, 3-16, 5-1, 5-4, 7-1, 8-1, 8-5, 9-1, 9-2, 9-12, 9-13, 9-15, 10-1, 10-2, 10-3, 10-5, 10-6, $10-9,10-11,10-12,10-13,10-14,10-15,10-16,11-1,11-2,11-11,11-12,11-13,11-14$,

$12-1,12-2,12-5,12-7,12-8,12-9,14-1,14-2,14-3,14-5,14-9,14-10,14-12,14-14$, $14-15,15-2,15-3,15-6,15-10,15-11,15-12,15-13,15-14,16-1,16-2,16-6,16-7,16-11$, $16-12,16-14,17-3,18-1,18-2,18-3,18-5,18-6,19-1,19-2,19-3,19-5,19-7,19-8,19-9$, $19-10,20-1,20-2,21-1,21-2,21-7,21-8,21-9,22-1,22-2,22-4,22-6,22-7,22-8,22-9$, $23-1,23-2,23-4,23-5,23-9,25-1,25-2,25-5,25-9,25-10,26-2,26-8, \mathrm{~B}-10$ P053

P055 3-1, 3-4, 3-5, 3-6, 3-8, 3-9, 3-10, 3-11, 3-12, 3-13, 3-15, 3-16, 5-4, 6-4, 8-1, 8-2, 8-5, 9-2, $9-3,9-5,9-7,9-10,9-12,9-13,9-14,9-15,10-3,10-4,10-5,10-6,10-10,10-13,10-14$, $10-15,10-16,11-1,11-2,11-4,11-5,11-6,11-7,11-11,11-12,11-13,11-14,12-2$, $12-9,15-2,15-3,15-5,15-7,15-10,15-11,15-12,15-13,16-2,16-3,16-4,16-5$, $16-7,16-11,16-12,16-13,16-14,17-6,19-1,19-2,19-7,19-8,19-9,20-5,20-6$, $22-1,22-13,23-2,23-11,22-14,24-6,25-8,25-9,25-10,26-2,26-3,26-6,26-7$

P058 19-3

P059 $14-2,15-3$

P060 P061

$12-2,12-5$

9-12, 10-13, 11-11, 12-1, 12-2, 12-7, 12-8, 13-1, 13-3, 15-11, 16-11, 19-2, 19-7 $3-4,3-6,3-8,3-9,3-11,3-12,3-15,3-16,9-3,9-4,9-6,9-13,9-14,9-15,10-1,10-3,10-4$, $10-5,10-6,10-13,10-14,10-15,10-16,11-2,11-3,11-4,11-6,11-11,11-12,11-13,12-2$,

$12-7,14-3,14-14,15-3,15-4,15-6,15-11,15-12,15-13,16-2,16-3,16-4,16-6,16-12$, $16-13,16-14,17-8,19-2,19-8,19-9,20-1,20-2,20-6,20-7,21-1,21-2,21-6,21-10,23-2$, $23-4,25-11,26-3$

P062 . . 3-5, 5-5, 7-5, 7-6, 9-3, 9-13, 9-15, 9-16, 10-4, 10-14, 10-16, 10-17, 11-2, 11-12, 11-13, 11-15, $12-2,12-7,12-8,15-3,15-12,15-13,15-14,16-3,16-12,16-14,16-15,17-7,19-9,20-2$, $22-14,23-13,26-9$ P063 ... . 3-13, 3-14, 5-2, 9-7, 10-7, 11-7, 12-6, 13-1, 14-2, 14-7, 15-7, 16-1, 16-7, 17-1, 17-4, 19-4, $20-3,21-6,24-4,25-1,25-6$ P064 . . . 3-13, 5-2, 7-2, 8-2, 9-7, 10-7, 11-7, 12-6, 13-1, 14-7, 15-7, 16-7, 17-4, 19-4, 21-6, 24-4, 25-6 P065

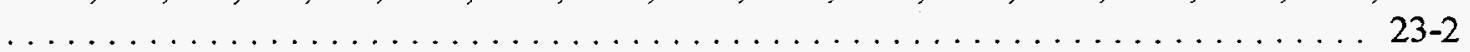

P066

P067 P068 . . . . . 5-5, 7-5, 8-7, 9-16, 10-17, 11-15, 14-15, 15-14, 16-15, 17-8, 19-10, 22-14, 23-12, 26-8

P070

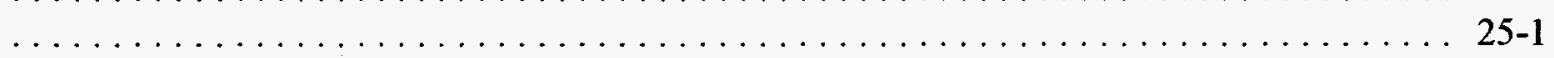
$9-14,9-15,9-16,10-3,10-4,10-5,10-6,10-10,10-13,10-15,10-16,10-17,11-2,11-3$, $11-4,11-6,11-7,11-11,11-12,11-13,11-14,12-1,12-5,12-9,14-1,14-2,14-3,14-5$, $14-14,15-2,15-3,15-4,15-6,15-11,15-12,15-13,15-14,16-2,16-3,16-4,16-6,16-7$, $16-11,16-13,16-14,16-15,19-2,19-3,19-7,19-8,19-9,19-10,20-6,21-6,24-1$

$\mathrm{P} 073$ $24-1,24-2,24-8,26-2$ P076 . . 5-4, 5-5, 7-5, 9-14, 9-16, 10-17, 11-15, 15-14, 16-15, 19-1, 19-3, 19-8, 20-2, 20-6, 20-7, 22-14, $23-13,26-9$ 
P078

P079

P080

P081

P083

P084

P090

P091

P092

P095

P096

P097

P098

P102

P103

P104

P105

P106

P107

P108

P109

P110

P113

P1 14

P115

P116

P117

P119

P120

P122

P123

P124

P125

P126

P127

P128

P130

P131

P132

P134

P136
$3-4,3-5,7-5,8-6,17-7,19-2,19-10,20-6,22-13,23-12,24-7,25-11$ $3-6,3-12,5-5,8-5,8-6,9-12,9-14,9-15,9-16,10-13,10-15,10-16,10-17,11-11,11-12,11-13$, $15-11,15-12,15-13,15-14,16-11,16-13,16-14,19-2,19-7,19-9,22-14,23-13,25-10$,

$25-11$

$5-3,8-4,9-10,10-10,14-10,16-9,17-6,19-5,22-10,23-9,24-6,25-8,26-6$ $3-6,3-9,3-11,3-15,3-16,8-5,9-3,9-4,9-14,9-16,10-4,10-14,11-3,11-4,11-12,11-14$,

$15-3,15-4,15-12,16-3,16-4,16-6,16-12,16-14,16-15,19-8$ . 3-9, 3-11, 3-15, 3-16, 8-1, 9-3, 9-4, 11-1, 11-2, 11-4, 11-6, 15-1, 15-3, 15-4, 16-1, 16-2, 16-3,

$16-4,16-6$ $25-6$ $8-1,10-6$ $16-8,22-4,24-3,24-2,24-6,25-6$ $21-6$ $20-2,20-6,20-7$ $20-2,20-3,20-6,20-7$ $12-5$ $14-2,14-3,17-1,17-7,20-1,20-3,20-7,21-6$ 20-2, 20-3, 20-7 $21-2$ $12-5,12-10$ $20-2,20-3$ $9-15,10-5,10-16,11-14,15-14,16-14,22-2,22-4,22-6,26-8$ $24-6,25-9$ $3-12,7-3,9-6,9-7,11-6,11-7,15-6,16-7$ $9-5,9-6,10-5,11-5,11-6,12-8,15-5,15-6,16-5,16-6,23-1,23-4,26-2$ $9-6,10-6,11-6,15-6,16-6$ $3-6,5-5,6-1,6-4,7-6,9-3,9-16,10-3,10-17,11-2,11-15,15-3,15-14,16-2,16-3,16-15,20-2$, $20-5,20-6,20-7,22-2,22-4,22-6,22-14,23-1,23-2,23-4,23-5,26-9$

$8-1,16-1$ $10-14,12-9$ 15-1 $14-3$ 24-3 $15-2,15-9$ $23-9,23-12$ 3-15 $10-5,23-1,23-2,23-8$ $14-5,14-8,14-11,14-12,14-13,14-14,14-15,23-9$ 23-4 $5-1,6-1,7-1,8-1,9-1,9-8,10-1,10-8,10-12,11-1,12-1,13-1,14-1,15-1,15-8,16-1,17-1,18-1$, $18-2,19-1,19-4,20-1,21-1,21-2,21-6,22-1,23-1,24-1,24-4,25-1,26-1,26-2,26-3$ 
P137

P139

P140

P141

P142

P143

P144

P145

P146

P147

P148

P149

P150

P151

P152

P154

P161

P163
$18-1,18-2,18-3,18-4,18-5,18-8,18-9$

$18-5,18-8,18-9$

$5-2,6-2,7-2,8-2,9-8,10-8,11-8,12-6,13-2,14-8,15-7,16-8,17-4,18-4,20-4,21-7,22-7,23-7$,

$24-4,25-7,26-4$

25-5

$22-4$

$22-4$

22-4

22-4

22-4

$22-4$

$22-4$

$22-4$

$20-5,26-7$

3-3

$3-18,12-10$

3-3

$7-5,8-5,8-6,9-13,9-15,10-13,10-14,10-16,11-11,11-12,11-14,14-13,14-14,15-11,15-12$, $15-14,16-12,16-14,17-7,18-7,19-8,20-7,26-8$

P164 3-6, 3-8, 3-10, 6-4, 8-5, 8-6, 9-12, 9-13, 9-14, 9-15, 9-16, 10-13, 10-14, 10-15, 10-16, 10-17, $11-11$, $11-13,11-14,12-9,15-11,15-13,15-14,16-11,16-12,16-13,16-14,16-15,19-7,19-8$, $19-9,22-13,22-14,23-11,23-12,24-7,25-11,26-8$

P166

P167

P169

P175

P178

P179

P180

P181

P182

P183

P184

P187

P189

P190

P191

P192

P193

P194

P195

P196

P197

P198

P199

P200 $\ldots \ldots \ldots \ldots \ldots \ldots \ldots \ldots \ldots \ldots \ldots \ldots \ldots$ $3-10,9-12,9-14,10-13,10-15,11-11,11-13,12-9,15-11,15-13,16-11,16-13,19-7,19-9$ $9-13,10-14,11-12,15-12,16-12,18-7,18-8$ $3-9,3-10,3-11$ $3-8,3-9,3-10,3-11$ $3-9,3-10,3-11$ $3-9,3-10$ $3-9,3-10$ ... 3-9 $3-9,3-10$ $3-9,3-10,3-11,18-8$ $3-9,3-10,9-14,10-15,11-13,15-13,16-13,19-9$ $3-9,3-10,3-11$ $3-9,3-11$ 3-9, 3-10, 3-11 $3-9,3-11,9-14,10-15,11-13,15-13,16-13,19-9,22-13,23-11,25-11$ $3-9,3-11,9-14,10-15,11-13,15-13,16-13,19-9$ 3-9, 3-11 $3-9,3-10,3-11$ $3-9,3-10,3-11,8-6,9-14,10-15,11-13,15-13,16-13,19-9,22-13,23-11,24-7,25-11$ $3-9,3-10,3-11$ $3-9,3-10,3-11,9-14,10-15,11-13,15-13,16-13,19-9,22-13,23-11,25-11$ $3-9,3-10,3-11,9-14,10-15,11-13,15-13,16-13,19-9,22-13,23-11,25-11$ 
U045

U047

U049

U050

U051

U053

U054

U056

U057

U059

U060

U061

U062

U064

U069

U073

U077

U078

U084

U085

U086

U087

U088

U089

$10-8,10-9,15-7,15-8,16-8,16-9$

3-13, 3-14

16-11

10-10

10-8

$22-10,22-11,22-12,23-10$

$9-11,10-12,11-10,15-9,15-10,16-10,22-12,23-11$

$12-1,12-2,12-8$

23-8

$25-1,25-2,25-5,25-10,25-11$

$5-5,7-6,9-16,10-17,11-15,15-14,16-15,22-14,23-4,23-13,24-1,24-2,24-5,24-6,24-7,24-8$,

$25-1,25-2,25-5,25-9,26-9$

$22-2,22-4$

$3-6,3-8,6-1,6-4,9-3,9-5,9-6,10-3,10-4,10-6,11-2,11-5,11-6,14-3,15-3,15-5,15-6,16-2$, $16-3,16-5,16-6,19-2,23-2,23-13$

$22-2,22-8$ $22-8$ $22-2$ $22-13,23-11$ 24-5 $10-6$ $3-4,3-12$

$3-14,5-1,5-4,7-5,8-1,8-5,8-6,9-12,9-13,9-14,9-15,9-16,10-13,10-14,10-15,10-16,11-11$, $11-12,11-13,11-14,12-1,12-9,14-13,14-14,15-1,15-11,15-12,15-13,15-14,16-11$, $16-12,16-13,16-14,16-15,17-7,18-1,19-7,19-8,19-9,19-10,21-2,22-13,23-12,24-7$, $25-11,26-1,26-2,26-3,26-8, \mathrm{~B}-10$ $6-1,6-2,9-9,9-10,10-9,14-9,19-5,20-4,22-8,23-8,24-5$ $18-4$ $18-4,18-6$ $3-3,3-8,9-14,10-15,11-13,15-13,16-13,19-9$ B-10 $5-4,9-14,10-15,11-12,12-9,15-12,16-13,19-8$ $9-16,10-16,11-14,12-9,14-14,15-14,16-15,19-10$ $9-14,10-15,11-12,15-12,16-13$ 23-5 $12-8$ $12-8$ $12-8,12-9$ $12-8,12-9$ $12-6,12-8,12-9$ 


\subsection{INTRODUCTION}

The purpose of this document and supporting documentation is to present the acceptable knowledge available for Rocky Flats Plant waste stored in accessible storage at the Idaho National Engineering Laboratory (INEL). The accessible storage inventory contains drums and boxes of transuranic (TRU) waste shipped to INEL from 1970 through 1989. This document focuses on the generation, packaging, and characterization of the drummed waste, since the waste boxes will be reprocessed prior to disposal. The primary objective of this document is to provide a consistent, defensible, and auditable record of acceptable knowledge for the inventory.

The Resource Conservation and Recovery Act (RCRA) and New Mexico Hazardous Waste Management Regulations authorize waste generators and treatment, storage, and disposal facilities to use acceptable knowledge in appropriate circumstances to make hazardous waste determinations. Acceptable knowledge includes information relating to plant history, process operations, and waste management, in addition to waste specific data generated prior to the effective date of the RCRA regulations. Acceptable knowledge, as an alternative to sampling and analysis, can be used to meet all or part of the waste characterization requirements under RCRA. ${ }^{\mathrm{P} 131, \mathrm{P} 132, \mathrm{P} 134, \mathrm{P} 136, \mathrm{P} 137}$

Since TRU waste presents serious health and safety risks to waste characterization personnel, excessive handling and manipulation of the waste is to be minimized. In addition, TRU waste generated by Department of Energy (DOE) facilities consists of debris and other complex matrix materials that are extremely difficult to sample. The collection of representative samples of TRU waste is extremely costly and increases the potential of human exposure to radiation and, under most circumstances, is not feasible. TRU waste can be characterized using acceptable knowledge in conjunction with radiography, headspace gas analysis, and solidified waste analysis, while limiting exposure to personnel and the environment. ${ }^{\text {P131 }}$

This document presents data collected from a variety of sources relating to historical Rocky Flats Plant operations, waste generating processes, and waste management practices. In addition, available information has been reviewed to determine the physical, chemical, and radiological composition of the TRU waste inventory. The inventory has been divided into waste groups that consist of populations of drums that contain similar waste matrices. The acceptable knowledge reviewed consists of Rocky Flats and INEL information from the following sources:

Published Documentation - In general, published documents represent the most reliable, reviewed, and controlled sources of information. This documentation consists primarily of controlled documents, previously controlled documents, and procedures, in addition to formal reports, studies, and databases. Published sources are referenced by the "P" superscripts in this document.

Unpublished data - Unpublished data consist of information from a variety of sources that has typically not received peer review and may not have been formally controlled. In many cases, this information will consist of the raw data used during the development of published documentation. Unpublished data include, but are not limited to, draft documents, analytical data packages, log books, and inventory lists, in addition to internal reports, studies, and databases. Unpublished sources are referenced by the " $U$ " superscripts in this document.

Correspondence - Correspondence consists of communication records relating to specific TRU 
waste streams or TRU waste management. Typically, this information consists of uncontrolled records of internal and external communications. Correspondence includes, but is not limited to, internal and external letters, memos, directives, telecommunication records, meeting minutes, personnel interview summaries, and discrepancy reports. Correspondence sources are referenced by the " $C$ " superscripts in this document.

Nearly 500 sources were collected and reviewed during the development of this document. The sources were incorporated into a data management system that assured that relevant data were incorporated as acceptable knowledge. When possible, discrepancies between sources were resolved by contacting cognizant personnel or collecting additional information. If the inconsistency was unresolvable, the most conservative information was incorporated into the document. Discrepancy reports were generated and referenced where the information was used in the document. Appendix A contains the Acceptable Knowledge References that lists the data sources reviewed and the discrepancy reports. Appendix B provides a table that segregates the accessible storage drum inventory by waste group (numbered the same as the sections in this document), Item Description Code, Container Prefix, and building of generation. The generation dates, process description, and potential radionuclide contaminants are identified for each population. 


\subsection{REQUIREMENTS}

This section lists the requirement and guidance documents that dictate or direct waste characterization and certification activities associated with this program.

-

TRU Waste Acceptance Criteria for the Waste Isolation Pilot Plant (WIPP WAC), WIPP/DOE-069

The WIPP WAC defines the quality requirements associated with the certification of compliance with WIPP operational and safety criteria. The WIPP WAC requires the preparation of certification plans and associated quality assurance plans describing site-specific TRU waste certification programs.

- 40 CFR Parts 260 through 265, 268, and 270

Title 40 of the Code of Federal Regulations (CFR) describes the federal hazardous waste regulations implementing the Resource Conservation and Recovery Act (RCRA). The regulations define the requirements for making a hazardous waste determination and obtaining hazardous waste permits, as well as control the land disposal of hazardous wastes. Also included are standards for waste generators; transporters; and treatment, storage, and disposal facilities.

Transuranic Waste Characterization Quality Assurance Program Plan (QAPP), CA0-94-1010

The QAPP provides a detailed description of the quality assurance and quality control requirements for the TRU waste characterization program. The plan establishes the characterization parameters that must be addressed during the characterization of TRU waste. For each parameter, the QAPP provides requirements for waste characterization, including the use of acceptable knowledge, nondestructive testing, sampling and analysis.

- Quality Assurance Program Document (QAPD), CA0-94-1012

The QAPD identifies federal and industry quality requirements applicable to the Carlsbad Area Office (CAO) quality assurance program. The QAPD also establishes the minimum requirements for CAO personnel, and guidance for the development and implementation of quality assurance programs by all participants managed by the CAO.

- Waste Analysis at Facilities that Generate, Treat, Store, and Dispose of Hazardous Wastes; $A$ Guidance Manual, EPA-530-R-94-024

This EPA manual provides general waste analysis guidance for facilities that generate or manage hazardous wastes. Specifically, the document promotes the use of acceptable knowledge characterization as an alternative to or in conjunction with sampling and laboratory analysis under certain circumstances. 
This Quality Assurance Project Plan (QAPjP) specifies the quality of data necessary and the characterization techniques employed at INEEL to meet the requirements of the WIPP QAPP. The QAPjP describes the roles and responsibilities of all participants in the Transuranic Waste Characterization Program.

- Collection, Review, and Management of Acceptable Knowledge Documentation, MCP-2989

This INEEL procedure outlines the method for compiling, reviewing, and managing acceptable knowledge documentation. This procedure was implemented to assure that a consistent, defensible, and auditable record is created. 


\subsection{TRU WASTE GENERATION}

This section describes the Rocky Flats operations associated with the generation of the TRU waste inventory stored at INEEL, including a brief history of the plant that summarizes the mission of the site. In addition, plutonium operations, uranium operations, TRU waste management, TRU waste certification, and the inventory are described.

\subsection{Rocky Flats Plant Description and Mission}

The DOE's Rocky Flats Plant is located in northern Jefferson County, Colorado, approximately 16 miles northwest of Denver. The 6,550 acre government-owned and contractor-operated facility was part of the nationwide nuclear weapons production complex. Ground-breaking for the first permanent buildings for the plant began in 1951. By 1954, approximately 700,000 square feet of building space had been completed. As the plant operations expanded, as much as 1.6 million square feet were occupied by manufacturing, chemical processing, plutonium recovery, and waste treatment operations. Plutonium operations were located primarily in the 384 acre high-security area (Protected Area). A map of the plant highlighting the buildings that generated TRU waste is provided in Figure 3.1. ${ }^{\text {P0S3 }}$

The plant had two primary missions during the period of operations from 1952 through 1990: the production of triggers for nuclear weapons, and the processing of retired weapons for plutonium recovery. The triggers, also known as pits, were the first-stage fission bombs used to initiate the second-stage fusion reaction in hydrogen bombs. ${ }^{\text {P053 }}$ Plutonium metal was recovered from retired warheads and manufacturing residues, and was also imported from the Hanford Reservation in Washington State and the Savannah River Plant in South Carolina. Weapons parts were manufactured from plutonium, uranium, beryllium, stainless steel, and various other metals. ${ }^{\mathrm{P} 53}$

In general, the plant's primary mission changed little from 1952 until 1990 when plutonium operations were suspended. In the early 1960 s, the DOE implemented the single mission concept to reduce redundant operations between DOE facilities. At that time, Rocky Flats became the primary manufacturer for nuclear weapon triggers. With the exception of periodic refinements, only three trigger configurations were manufactured at the plant. The first two trigger designs were solid units manufactured primarily of uranium, similar to the devices used during World War II. In 1957, the trigger design was changed to sealed hollow spheres which were manufactured with much less uranium and more plutonium. This design change resulted in lighter, smaller, and more powerful weapons. ${ }^{\text {POS3 }}$

The general design of the trigger has not changed dramatically since 1958, although modifications to the relative amounts of metals, dimensions, and other features of the parts were modified over the years. The primary materials of construction included plutonium, uranium, beryllium, aluminum, and stainless steel. Other metals such as cadmium, vanadium, silver, and gold were also used in some of the parts. The plant also supported weapons development programs responsible for fabricating, testing, and assembling parts with new geometries or metal compositions. Because of the plant's metal manufacturing capabilities, Rocky Flats often fabricated other weapons parts, including components made of stainless steel and beryllium. ${ }^{\text {P053 }}$ 


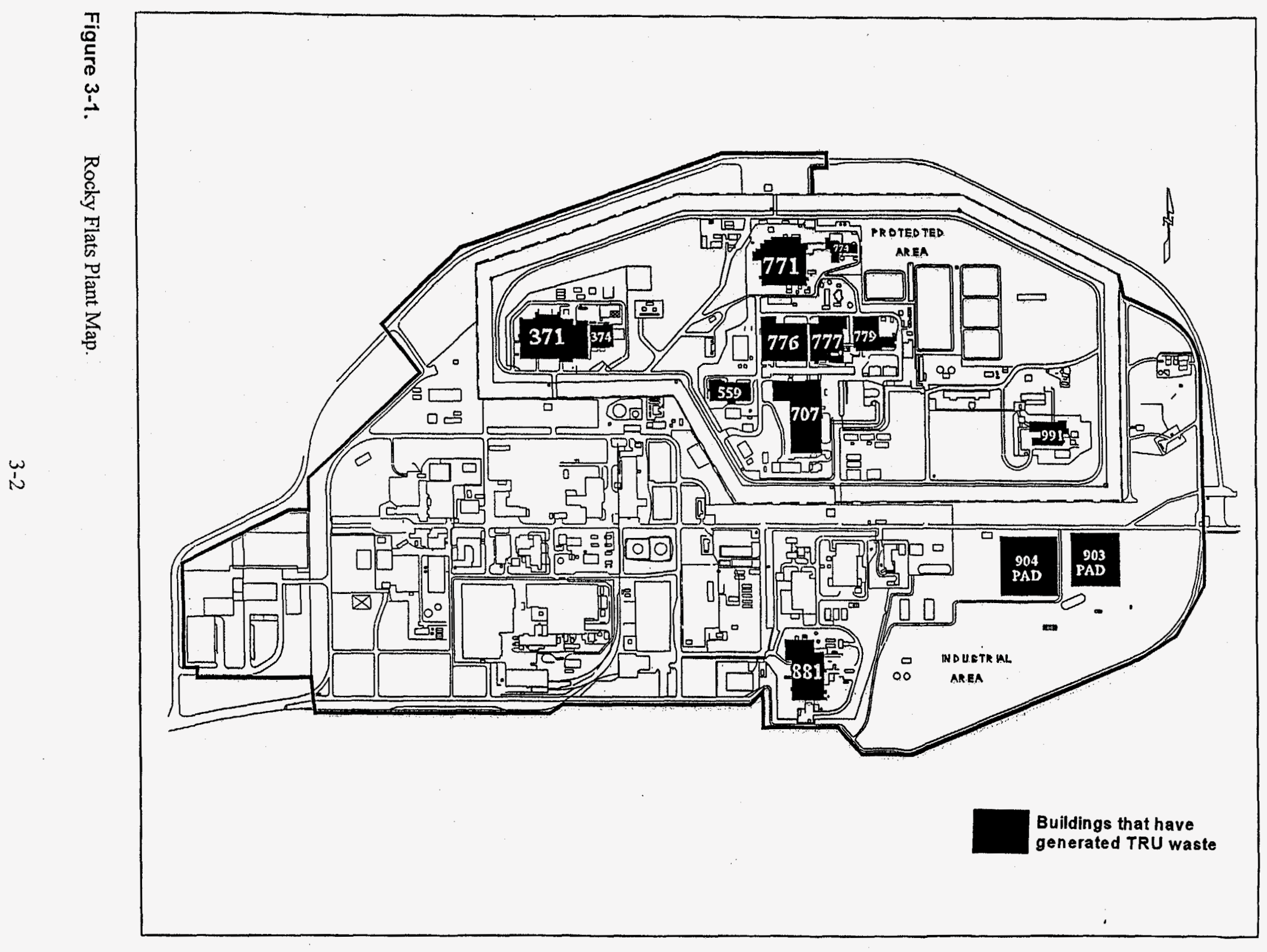




\subsection{TRU Waste Operations}

Waste materials contaminated with transuranic radionuclides are generated during the fabrication, assembly, and processing of nuclear weapons components in the DOE weapons production complex. ${ }^{\mathrm{P} 28}$ The term "transuranic" refers to the man-made actinide elements with atomic numbers greater than uranium (atomic number 92). Plutonium and americium are the primary transuranic actinides encountered in DOE weapons facilities. ${ }^{\text {P020 }}$ Since the mid 1980 s, the DOE has defined transuranic waste as materials contaminated with greater than or equal to 100 nanocuries of alpha-emitting transuranic radionuclides with a half-life greater than 20 years per gram of waste matrix. ${ }^{\text {P028 }}$

In 1973, the DOE established 10 nanocuries per gram of alpha activity as the threshold at which waste would be defined as TRU. This definition included all radionuclides with "long" half-lives and the transuranic isotopes except plutonium-238 and -241 . In addition, the uranium-233 isotope and daughter products were included in the definition. For this reason, the INEEL inventory will contain waste that will be low-level by the current DOE standard. ${ }^{\mathrm{P} 020}$

It has been estimated that approximately 95 percent of the radioactive waste volume generated at Rocky Flats was a result of processing plutonium. A majority of the remaining 5 percent was generated during the processing of depleted uranium. After processing, approximately 70 percent of the volume of waste shipped off site was low-level and 30 percent was TRU. ${ }^{\text {POI4 }}$ Most of the LLW was shipped to the Nevada Test Site.

The primary radionuclides contained in Rocky Flats TRU waste will be weapons-grade plutonium, americium-241, and enriched uranium. In addition, waste generated by liquid waste treatment operations will also contain depleted uranium (see Section 3.2.4). The nominal isotopic compositions of weapons-grade plutonium, enriched uranium, and depleted uranium are:C039,C130,P152,P161,P166,P169,U064

\begin{tabular}{|c|c|c|c|c|c|}
\hline \multicolumn{2}{|c|}{ Weapons-Grade Plutonium } & \multicolumn{2}{|c|}{ Enriched Uranium } & \multicolumn{2}{|c|}{ Depleted Uranium } \\
\hline${ }^{238} \mathrm{Pu}$ & $0.01-0.05 \%$ & ${ }^{231} \mathrm{Th}$ & negligible & ${ }^{231} \mathrm{Th}$ & negligible \\
\hline${ }^{239} \mathrm{Pu}$ & $92.8-94.4 \%$ & ${ }^{234} \mathrm{Th}$ & negligible & ${ }^{234} \mathrm{Th}$ & negligible \\
\hline${ }^{240} \mathrm{Pu}$ & $4.85-6.5 \%$ & ${ }^{234} \mathrm{U}$ & $\sim 0.1 \%$ & ${ }^{234} \mathrm{U}$ & $\sim 0.0006 \%$ \\
\hline${ }^{241} \mathrm{Pu}^{*}$ & $0.3-1.0 \%$ & ${ }^{235} \mathrm{U}$ & $\sim 90-93 \%$ & ${ }^{235} \mathrm{U}$ & $\sim 0.2$ \\
\hline \multirow[t]{2}{*}{${ }^{242} \mathrm{Pu}$} & $0.005-0.60 \%$ & ${ }^{236} \mathrm{U}$ & $\sim 0.4 \%$ & ${ }^{238} \mathrm{U}$ & $\sim 99.8 \%$ \\
\hline & & ${ }^{238} \mathrm{U}$ & $\sim 5.3 \%$ & & \\
\hline
\end{tabular}

* $\quad$ includes ${ }^{241} \mathrm{Am}$ daughter product

TRU wastes generated at the Rocky Flats Plant were primarily associated with operations that manufactured, recovered, and treated plutonium metal and plutonium containing materials. In addition, TRU waste was generated during activities that supported plutonium production, including maintenance, laboratory, and research and development operations. Non-routine events including renovations, spills, fires, and decommissioning also generated TRU waste. Plutonium-related operations conducted in Buildings 371, 374, 
$559,707,771,774,776,777$, and 779 generated a vast majority of the TRU waste at the plant. Table 3-1 briefly summarizes the operations of these buildings associated with the TRU waste inventory.

In addition to the waste generated by plutonium operations, a small amount of TRU waste may have been generated by "special order" work in Building 881 . The non-routine operations involved the machining of uranium-233 in an area normally used for uranium-235. Materials shipped to INEEL contaminated with uranium-233 would be managed as TRU waste. Some plutonium-contaminated waste may have also been generated during the leaching of uranium and beryllium site-return parts in Building 881 . These parts were sprayed with nitric acid to remove surface plutonium contamination. The uranium and beryllium leaching process was moved to Building 771 between 1973 and 1975. ${ }^{\text {C072,C110,U057 }}$

Table 3-1. Plutonium Operations.

\begin{tabular}{|c|c|c|}
\hline Building & Operations & Primary Functions \\
\hline \multirow[t]{4}{*}{371} & Recovery & Electrorefining of non-specification plutonium metal ${ }^{\mathrm{P} 067}$ \\
\hline & Waste Treatment & $\begin{array}{l}\text { Stabilization of incinerator sludge, heels (sand, slag, and } \\
\text { crucibles), and resins }{ }^{\text {P067 }}\end{array}$ \\
\hline & Storage & Automated materials handling system ${ }^{\mathrm{P} 067}$ \\
\hline & Laboratory & Analytical and chemical standards laboratory ${ }^{\mathrm{P} 053}$ \\
\hline 374 & Waste Treatment & $\begin{array}{l}\text { Aqueous waste treatment, sludge stabilization, and salt } \\
\text { immobilization }^{\text {P053 }}\end{array}$ \\
\hline 559 & Laboratory & $\begin{array}{l}\text { Plutonium analytical laboratory conducting spectrochemical, } \\
\text { chemical, and mass spectrometric analyses }\end{array}$ \\
\hline \multirow[t]{4}{*}{707} & \multirow[t]{4}{*}{ Production } & Plutonium foundry and casting ${ }^{\mathrm{P} 053}$ \\
\hline & & Part rolling, cutting, forming, and machining ${ }^{\mathrm{P} 053}$ \\
\hline & & Part assembly ${ }^{\mathrm{P} 053}$ \\
\hline & & Part calibration, weighing, leak testing, and measurement ${ }^{\mathrm{P} 053}$ \\
\hline \multirow[t]{4}{*}{771} & Recovery & $\begin{array}{l}\text { Recovery of plutonium from solid wastes, liquids, and } \\
\text { plutonium oxide using dissolution, incineration, leaching and } \\
\text { ion exchange technology }{ }^{\text {P061 }}\end{array}$ \\
\hline & Laboratory & $\begin{array}{l}\text { Radiochemistry, chemical standards, reagent preparation, and } \\
\text { R\&D support } \mathrm{r}^{\mathrm{P} \& 61, \mathrm{P} 067}\end{array}$ \\
\hline & \multirow{2}{*}{$\begin{array}{l}\text { Research and } \\
\text { Development }\end{array}$} & Plutonium metallurgy supporting production operations ${ }^{\mathrm{P} 053}$ \\
\hline & & $\begin{array}{l}\text { Chemical technology supporting actinide recovery, separation, } \\
\text { and purification }{ }^{\text {PO53 }}\end{array}$ \\
\hline 774 & Waste Treatment & $\begin{array}{l}\text { Aqueous and organic liquid waste treatment and sludge } \\
\text { stabilization }^{\text {P077 }}\end{array}$ \\
\hline 776 & Recovery & $\begin{array}{l}\text { Pyrochemical processing to extract, purify, and recover } \\
\text { plutonium and americium using molten salt extraction, direct } \\
\text { oxide reduction, pyroredox, and electrorefining technology }{ }^{\text {P078 }}\end{array}$ \\
\hline
\end{tabular}




\begin{tabular}{|c|c|c|}
\hline Building & Operations & Primary Functions \\
\hline \multirow{8}{*}{777} & & Processing of pyrochemical salt to recover plutonium ${ }^{\mathrm{P} 078}$ \\
\hline & $\begin{array}{l}\text { Research and } \\
\text { Development }\end{array}$ & $\begin{array}{l}\text { Development of coating technologies and pilot plant fluidized } \\
\text { bed incinerator }\end{array}$ \\
\hline & Waste Treatment & $\begin{array}{l}\text { Fluidized bed incinerator for liquid and solid low-level } \\
\text { waste }^{\text {P067 }}\end{array}$ \\
\hline & & $\begin{array}{l}\text { Size reduction, sorting, washing, and packaging of solid waste } \\
\text { materials }{ }^{0.53}\end{array}$ \\
\hline & Production & $\begin{array}{l}\text { Back-up and special assembly of parts using welding and } \\
\text { joining technologies }{ }^{\text {P053 }}\end{array}$ \\
\hline & & $\begin{array}{l}\text { Disassembly, cleaning, and briquetting of site-return parts and } \\
\text { metal for further processing }\end{array}$ \\
\hline & & Part machining, coating, and etching ${ }^{\mathrm{P} 067}$ \\
\hline & & $\begin{array}{l}\text { Dimensional, weight, radiography, density, stress, and pressure } \\
\text { testing of parts for production control }{ }^{\text {P053,P067 }}\end{array}$ \\
\hline \multirow{4}{*}{779} & $\begin{array}{l}\text { Research and } \\
\text { Development }\end{array}$ & $\begin{array}{l}\text { Fabrication of classified parts and fitting specialty parts and } \\
\text { materials } \mathrm{s}^{\mathrm{P} 53}\end{array}$ \\
\hline & Laboratory & Plutonium metallurgy and tritium analysis ${ }^{\mathrm{P} 067}$ \\
\hline & $\begin{array}{l}\text { Research and } \\
\text { Development }\end{array}$ & $\begin{array}{l}\text { Development and refinement of production, recovery, } \\
\text { purification, and waste treatment technologies }{ }^{\text {P053 }}\end{array}$ \\
\hline & Recovery & $\begin{array}{l}\text { Leaching of parts to remove and recover surface } \\
\text { contaminants }^{\mathrm{POS3,P062,P067}}\end{array}$ \\
\hline
\end{tabular}

\subsubsection{Plutonium Production}

Plutonium production consists of operations directly associated with the manufacturing of plutonium metal parts including casting, rolling, forming, machining, and assembly processes. Building 707 , constructed in 1972, was the primary weapons components production facility at the Rocky Flats Plant. Building 707 was constructed after a fire in 1969 shut down foundry and machining operations in Building 776. ${ }^{\text {P053 }}$ Figure 3-2 illustrates the general flow of plutonium through the production, recovery, and purification operations at the plant.

The foundry in Building 707 cast acceptable-purity metal into ingots that were shaped by rolling, forming, and machining processes. The resulting shapes were assembled into the finished parts. Rejected parts, metal scraps, and turnings were returned to the foundry to be recast. Small pieces of metal, fines, and sweepings were typically burned to oxide and sent to be recovered in Building 771. Assembled units were either sent to Pantex for final assembly or retained at the plant for testing or surveillance. ${ }^{\text {Pos2 }}$

\subsubsection{Plutonium Recovery and Purification}

Several operations at the plant were responsible for either the purification of non-specification plutonium metal or the recovery of plutonium from production waste and residues. Dissolution and leaching 
technologies were used in Building 771 recovery operations to extract plutonium from waste materials and other residues. Plutonium purification was performed primarily in Buildings $371,776,771$, and 779 . Figure 3-2 illustrates the relationship between the production, recovery, and purification operations at the plant. ${ }^{\text {P052 }}$

Recovery operations in Building 771 used acid dissolution to dissolve solid materials containing plutonium. The resulting liquid was processed by a series of ion exchange, precipitation, evaporation, calcination, fluorination, and reduction operations to produce plutonium metal to be recycled back into production operations. ${ }^{\text {P052 }}$ Building 771 also recovered plutonium surface contamination from enriched uranium hemishells and recovered and purified americium-241. ${ }^{\mathrm{P} 164}$

Plutonium metal from returned parts and metal from other DOE facilities was purified at the Rocky Flats Plant. Parts containing plutonium and enriched uranium returned to Rocky Flats were disassembled in Building 777. ${ }^{\text {P079 }}$ Beginning in 1967, molten salt extraction was used in Building 776 to recover americium from plutonium metal using sodium chloride, potassium chloride, and magnesium chloride. The purified plutonium metal was sent either to the Building 707 foundry or the electrorefining processes in Building 371 or to Building 776 if the metal contained other impurities. Americium in the extraction salts were recovered using a variety of technologies including ion exchange and a salt scrub process that used a magnesium salt extractant. $^{\text {P052,P053,P1 13, U047 }}$

Electrorefining operations in Buildings 371 and 776 were used primarily to purify metal from other production processes that did not meet the purity specification required by the foundry. The metal included nonspecification metal from direct oxide reduction, molten salt extraction, plutonium fluoride reduction, and miscellaneous metal from the foundry. Electrorefining buttons were sent to the foundry to be batched and then cast. Anode heel from electrorefining operations was alloyed with aluminum for processing at the Savannah River Site. ${ }^{\text {P052 }}$

\subsubsection{Laboratory Operations}

The laboratories in Buildings 371,771 , and 559 supported production operations at the site. The primary function of the laboratories was to provide sampling and analysis support for production activities. In addition, the laboratories supported recovery, purification, and liquid waste treatment operations.

Building 371 had an analytical laboratory and a chemical standards laboratory. The chemical standards laboratory prepared standards for various users and inspected standards used in the other operations. The analytical laboratory analyzed samples from various operations on site. ${ }^{\mathrm{P} 081}$

Building 559 housed the Plutonium Analytical Laboratory responsible for spectrochemical, chemical, and mass spectrometric analyses of samples from plutonium production operations. Uranium, Raschig rings, solutions, and commercial product and gas samples were also analyzed in the laboratory. Plutonium production samples, including metal and oxide, were prepared and subdivided for analysis in the sample cutting process. $^{\text {P067 }}$

Building 771 housed analytical and chemical standards laboratories. The chemical standards laboratory prepared control sample standards for the analytical laboratories in Buildings 371, 559, and 771. The analytical laboratory provided analytical support for plutonium operations. ${ }^{\mathrm{P} 061, \mathrm{P} 067}$ 


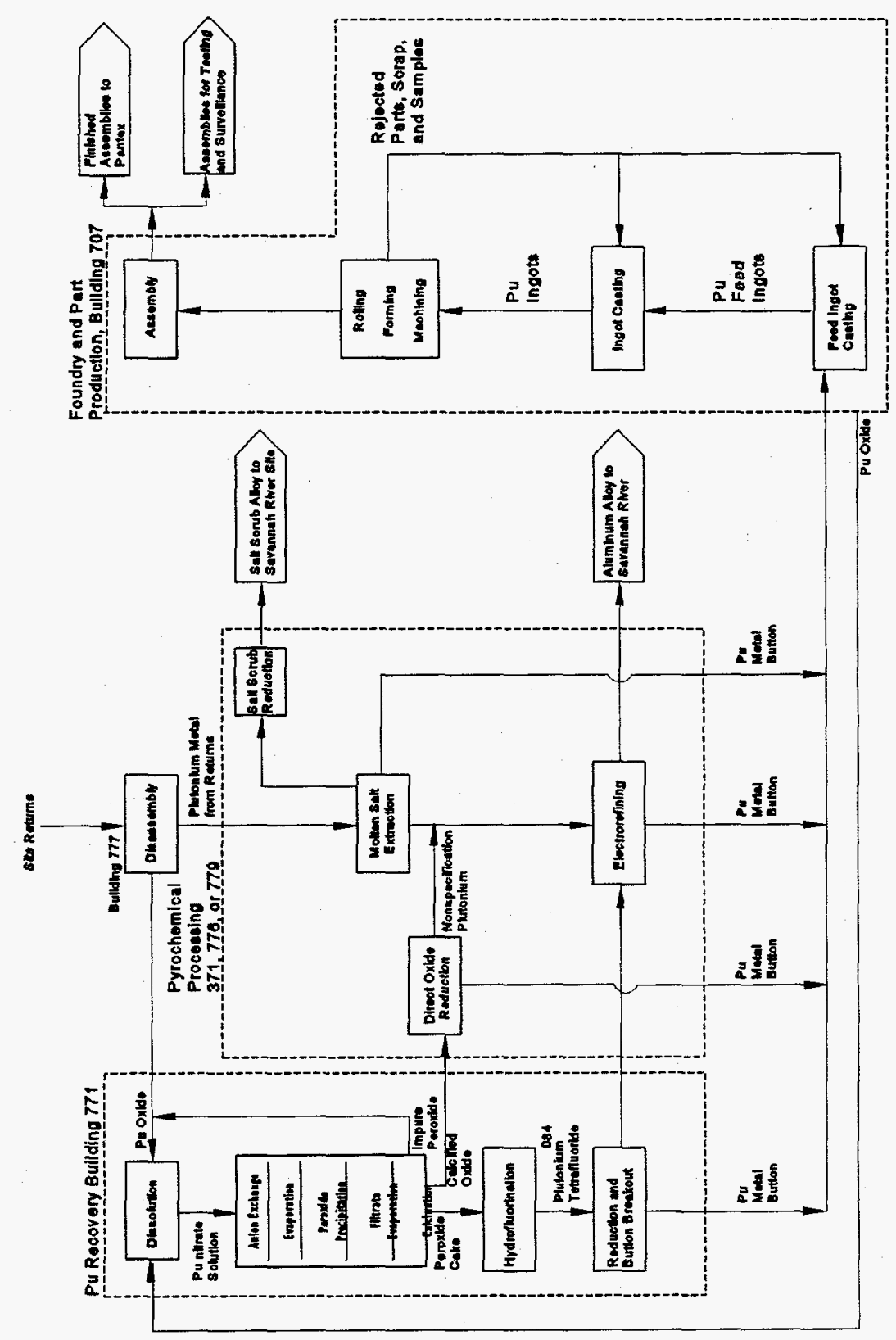

Figure 3-2. Plutonium Production, Recovery, and Purification Flow Diagram. 


\subsubsection{Waste Treatment}

Waste processing at Rocky Flats has treated both liquid and solid process wastes. Liquid waste treatment was conducted in Buildings 374 and 774. Solid transuranic waste treatment was performed in Buildings 771 and 776.

Treatment of solid transuranic wastes was conducted in Buildings 771 and 776. Building 771 processed wastes containing recoverable amounts of plutonium. Building 776 processed wastes contaminated with concentrations of plutonium that would not be economical to recover. Waste treatment operations in Building 776 consisted primarily of size reduction, sorting, washing, and packaging of solid waste materials for disposal. The fluidized-bed incinerator in Building 776 received low-level plutonium-contaminated combustible solid and liquid wastes. Building 771 also housed an incinerator for processing combustible wastes. ${ }^{\mathrm{P} 533, \mathrm{P} 061, \mathrm{P} 067, \mathrm{U} 047}$

Liquid waste treatment operations have had relatively few process changes over the years. When Building 774 was built in 1952, its primary purpose was to treat radioactive aqueous waste from Building 771 . Radionuclides were removed from the aqueous waste by precipitation technology. ${ }^{\text {P } 53}$ Liquid process waste streams contained varying amounts of most radioactive and chemical compounds used at the plant. The most common radioactive materials handled consisted of weapons-grade plutonium, americium, enriched uranium, and depleted uranium. ${ }^{\text {P164 }}$ Around 1965, an evaporator was installed in Building 774 to treat liquids, including waste water from solar ponds. The Building 774 evaporator was taken out in 1979, and the liquids were transferred to Building 374. Building 774 also processed organic liquid wastes such as plutoniumcontaminated oil and solvent mixtures generated from plutonium machining. The spent organic liquids were filtered and then mixed with a solidifying agent. ${ }^{\mathrm{P} 52, \mathrm{PO} 053, \mathrm{U} 047}$

Liquid waste streams containing depleted uranium originated primarily from operations conducted in Buildings $444,447,865$, and 883 . Uranium casting, machining, and assembly were performed in Building 444 until 1989 when the foundry in this building was shut down. Building 447 operations included casting, welding, chemical milling, and heat treatment. Building 865 was built in 1972 to support research and development of beryllium and depleted uranium operations associated with casting, machining, rolling, heat treating, chemical etching, and cleaning. Uranium rolling, shearing, blanking, trepanning, forming, and heat treating were conducted in Building 883. Uranium processing in Building 883 increased considerably between 1980 and 1985 to support the manufacturing of hundreds of tons of depleted uranium for armor plates for the Army's MlAl tank. ${ }^{\text {P053 }}$

In addition to uranium and plutonium contaminants, other radioactive elements may have been introduced from streams originating from special order work, laboratory, and research and development activities. ${ }^{\text {P164 }}$ Radionuclides that Rocky Flats has handled or had the potential to handle in kilogram quantities included americium-241, natural uranium and thorium, and uranium-233. ${ }^{\mathrm{Cl}} 159, \mathrm{U} 064$ Radioisotopes handled in gram quantities, primarily for research and analytical activities, included curium-244, neptunium-237, thorium228 , uranium-233, plutonium-238 and -242 , low NGS plutonium $(\approx 3 \%$ plutonium- 240$)$, and power grade

plutonium (up to $20 \%{ }^{240} \mathrm{Pu}$ and $1 \%{ }^{241} \mathrm{Pu}$ ). ${ }^{\mathrm{Cl34}, \mathrm{Cl} 137, \mathrm{C1} 185, \mathrm{P} 179, \mathrm{U} 064}$ Radioisotopes used for research and analytical activities included: ${ }^{\text {Uo64 }}$ 


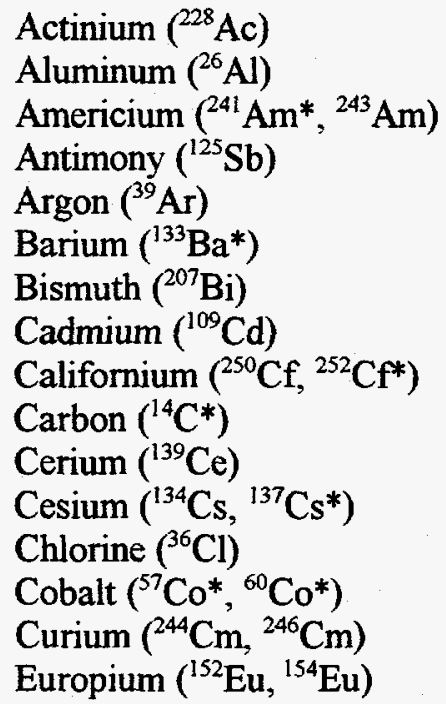

Holmium ( $\left.{ }^{166 m} \mathrm{Ho}^{*}\right)$

Iodine $\left({ }^{129} \mathrm{I},{ }^{131} \mathrm{I}\right)$

Iridium $\left({ }^{192} \mathrm{Ir} \mathrm{r}^{*}\right)$

Iron $\left({ }^{55} \mathrm{Fe}^{*}\right)$

Krypton $\left({ }^{85} \mathrm{Kr}\right)$

Lead $\left({ }^{10} \mathrm{~Pb}^{*}\right)$

Manganese $\left({ }^{54} \mathrm{Mn}\right)$

Mercury $\left({ }^{203} \mathrm{Hg}\right)$

Neptunium $\left({ }^{237} \mathrm{~Np}\right)$

Nickel $\left({ }^{63} \mathrm{Ni}\right)$

Plutonium $\left({ }^{236} \mathrm{Pu},{ }^{238} \mathrm{Pu}\right.$, $\left.{ }^{239} \mathrm{Pu}^{*}{ }^{240} \mathrm{Pu}^{* 241} \mathrm{Pu}^{*},{ }^{242} \mathrm{Pu}\right)$

Polonium ( $\left.{ }^{210} \mathrm{Po}^{*}\right)$

Potassium $\left({ }^{40} \mathrm{~K}\right)$

Promethium $\left({ }^{147} \mathrm{Pm}^{*}\right)$

Protactinium $\left({ }^{231} \mathrm{~Pa},{ }^{234} \mathrm{~Pa}\right)$
Radium $\left({ }^{226} \mathrm{Ra}^{*}\right)$

Ruthenium $\left({ }^{106} \mathrm{Ru}\right)$

Selenium $\left({ }^{75} \mathrm{Se}^{*}\right)$

Silver $\left({ }^{110} \mathrm{Ag}\right)$

Sodium $\left({ }^{22} \mathrm{Na}\right)$

Strontium $\left({ }^{85} \mathrm{Sr},{ }^{90} \mathrm{Sr}^{*}\right)$

Technetium $\left({ }^{99} \mathrm{Tc}\right)$

Thallium $\left({ }^{204} \mathrm{Tl} *\right)$

Thorium $\left({ }^{228} \mathrm{Th},{ }^{230} \mathrm{Th}\right)$

Tin $\left({ }^{113} \mathrm{Sn}\right)$

Tritium $\left({ }^{3} \mathrm{H}^{*}\right)$

Uranium $\left({ }^{232} \mathrm{U},{ }^{233} \mathrm{U}^{*},{ }^{235} \mathrm{U}^{*},{ }^{236} \mathrm{U}\right)$

Ytterbium $\left({ }^{169} \mathrm{Yb}^{*}\right)$

Yttrium $\left({ }^{88} \mathrm{Y},{ }^{90} \mathrm{Y}\right)$

Zinc $\left({ }^{65} \mathrm{Zn}\right)$

* $\quad$ Sources: sealed solids $>10 \mu \mathrm{Ci}$, plated $>1 \mu \mathrm{Ci}$, or liquids $>10^{-3} \mu \mathrm{Ci}$

\subsubsection{Research and Development}

Research and Development (R\&D) included activities related to production, recovery, and purification as well as "special order" work. Building 779, which was built in 1965 , housed much of the R\&D operations at the plant. Other areas at the plant supporting R\&D included Buildings $771,776,777,865$, and 881 . $^{\text {P053 }}$ Table 3-2 provides a history of R\&D and special order activities.

Table 3-2. Summary of Radionuclides Used For Research and Development and Special Order Work

\begin{tabular}{|c|c|}
\hline Date & Research and Development Activity \\
\hline & Americium \\
\hline $1968-1986$ & $\begin{array}{l}\text { Americium research projects have included recovery of }{ }^{241} \mathrm{Am} \text { by MSE and from } \\
\text { MSE salt residues and solid process wastes, separation of cerium and other rare } \\
\text { earth elements from americium oxide, and preparation of americium metal from } \\
\text { americium tetrafluoride. }\end{array}$ \\
\hline July 1970 & Development of the oxalate precipitation process for ${ }^{241} \mathrm{Am}$ purification began. ${ }^{\mathrm{P} 183}$ \\
\hline October 1970 & $\begin{array}{l}\text { Development began on a tracer method using alpha spectroscopy and the addition of } \\
{ }^{243} \mathrm{Am} \text { spike for the determination of }{ }^{241} \mathrm{Am} \text { in plutonium metal }{ }^{\mathrm{P} 184}\end{array}$ \\
\hline $\begin{array}{l}\text { November } 1979- \\
\text { September } 1981\end{array}$ & $\begin{array}{l}{ }^{241} \text { Am-Ce disks were cast for the Lawrence Livermore National Laboratory (LLNL) } \\
\text { Radiochemical Diagnostic Tracer Program. }{ }^{\text {P196 }}\end{array}$ \\
\hline $\begin{array}{l}\text { November } 1980- \\
\text { September } 1981\end{array}$ & Recovery of ${ }^{241} \mathrm{Am}$ from the residues generated from the Tracer Program. ${ }^{\mathrm{P} 197}$ \\
\hline $\begin{array}{l}\text { October 1984- } \\
\text { September } 1985\end{array}$ & $\begin{array}{l}\text { Methods were investigated for the separation of plutonium and americium from } \\
\text { contaminated coral from Johnston Island through a request by the Defense Nuclear } \\
\text { Agency. }{ }^{\mathrm{P} 01}\end{array}$ \\
\hline Unknown & ${ }^{240} \mathrm{Am}$ reportedly used as a tracer material. ${ }^{\mathrm{Cl59}, \mathrm{P} 053}$ \\
\hline
\end{tabular}




\begin{tabular}{|c|c|}
\hline Date & Research and Development Activity \\
\hline & Californium \\
\hline \multirow[t]{2}{*}{$\begin{array}{l}\text { January } 1973- \\
\text { June } 1973\end{array}$} & $\begin{array}{l}\text { Study was conducted to determine the applicability of }{ }^{252} \mathrm{Cf} \text { for reactor neutron } \\
\text { interrogation of } 55 \text {-gallon drums with } \leq 1 \mathrm{mg} \text { plutonium content. }{ }^{\mathrm{Pl91}}\end{array}$ \\
\hline & Curium \\
\hline $1965-1970$ & $\begin{array}{l}\text { Weapons-grade plutonium was alloyed with }{ }^{244} \mathrm{Cm} \text { for use in the LLNL } \\
\text { Radiochemical Diagnostic Tracer Program prior to } 1970 .{ }^{\text {C159,P053,P164 }}\end{array}$ \\
\hline \multirow[t]{2}{*}{$1965-1975$} & $\begin{array}{l}\text { Residues from Tracer Program were chemically processed in Building } 771 \text { to } \\
\text { recover the plutonium. }\end{array}$ \\
\hline & Neptunium \\
\hline $\begin{array}{l}\text { October } 1968- \\
\text { June } 1969\end{array}$ & $\begin{array}{l}\text { Studies conducted to investigate the voltammetry of neptunium complexes and the } \\
\text { thermal behavior of neptunium(IV) oxalate hexahydrate. }\end{array}$ \\
\hline \multirow{3}{*}{$\begin{array}{l}\text { April 1969- } \\
\text { September } 1969\end{array}$} & ${ }^{237} \mathrm{~Np}$ metal foil fabricated for Los Alamos Scientific Laboratory (LASL). ${ }^{\mathrm{P} 179, \mathrm{P} 180}$ \\
\hline & ${ }^{237} \mathrm{~Np}$ metal purified for Argonne National Laboratory (ANL). ${ }^{\mathrm{P} 179, \mathrm{P} 180}$ \\
\hline & ${ }^{237} \mathrm{~Np}$ oxide purified for $\mathrm{ORNL}{ }^{\mathrm{P} 179, \mathrm{P} 180}$ \\
\hline $\begin{array}{l}\text { July 1969- } \\
\text { September } 1969\end{array}$ & $\begin{array}{l}\text { Experiments on the oxidation of alpha-phase neptunium metal foil in air were } \\
\text { conducted. } \text { P180 }^{\text {. }}\end{array}$ \\
\hline $\begin{array}{l}\text { January } 1972- \\
\text { June } 1972\end{array}$ & $\begin{array}{l}{ }^{237} \mathrm{~Np} \text { metal disks and }{ }^{237} \mathrm{~Np} \text { oxide diagnostic neutron detectors were prepared for } \\
\text { the Liquid-Metal Fast Breeder Reactor neutron dosimetry program. }\end{array}$ \\
\hline $\begin{array}{l}\text { July 1974- } \\
\text { December } 1974\end{array}$ & Studies conducted on the storage of ${ }^{237} \mathrm{~Np}$ metal. ${ }^{\mathrm{P} 193}$ \\
\hline $\begin{array}{l}\text { November } 1980- \\
\text { September } 1982\end{array}$ & $\begin{array}{l}\text { Anion exchange and solvent extraction techniques were investigated for the } \\
\text { separation and purification of plutonium from neptunium residues. }{ }^{\mathrm{P} 197 . P 198}\end{array}$ \\
\hline $\begin{array}{l}\text { November } 1980- \\
\text { September } 1985\end{array}$ & $\begin{array}{l}{ }^{237} \mathrm{~Np} \text { metal and oxide prepared for the LLNL Radiochemical Diagnostic Tracer } \\
\text { Program. }{ }^{\text {P197,P198,P199,P200,P201 }}\end{array}$ \\
\hline \multirow{2}{*}{$\begin{array}{l}\text { October 1982- } \\
\text { September } 1984\end{array}$} & ${ }^{237} \mathrm{~Np}$ oxide was purified for the ORNL Isotope Pool. ${ }^{\mathrm{P} 199, \mathrm{P} 200}$ \\
\hline & Plutonium \\
\hline 1970 & $\begin{array}{l}\text { Research was conducted on the synthesis of organoplutonium compounds for future } \\
\text { applications in chemical vapor deposition and plutonium processing. }{ }^{\mathrm{P} 181, \mathrm{P} 182, \mathrm{P} 184}\end{array}$ \\
\hline \multirow{2}{*}{$\begin{array}{l}\text { April 1970- } \\
\text { June } 1970\end{array}$} & Studies were done to determine the half-life of ${ }^{239} \mathrm{Pu}$ by calorimetry. ${ }^{\mathrm{P} 182}$ \\
\hline & $\begin{array}{l}\text { Lead-plutonium alloys and oxides were received from Lawrence Radiation } \\
\text { Laboratory (LRL) for plutonium recovery. }{ }^{\mathrm{P} 82}\end{array}$ \\
\hline $\begin{array}{l}\text { July } 1971- \\
\text { September } 1971\end{array}$ & Three metal disks fabricated from highly enriched $(98 \%)^{242} \mathrm{Pu}$ metal for LASL. ${ }^{\mathrm{P} 187}$ \\
\hline \multirow[t]{2}{*}{$\begin{array}{l}\text { July } 1972- \\
\text { December } 1972\end{array}$} & $\begin{array}{l}\text { A plutonium metal plate was fabricated for LASL using low NGS material ( } 97.7 \\
\text { wt } \%{ }^{239} \mathrm{Pu} \text { and } 2.2 \mathrm{wt} \%{ }^{240} \mathrm{Pu} \text { ), and recovery of the low NGS plutonium from the } \\
\text { residues. }\end{array}$ \\
\hline & ${ }^{242} \mathrm{Pu}$ metal target foil was fabricated for LLNL. ${ }^{\mathrm{P} 90}$ \\
\hline
\end{tabular}




\begin{tabular}{|c|c|}
\hline Date & Research and Development Activity \\
\hline $\begin{array}{l}\text { January 1973- } \\
\text { June } 1973\end{array}$ & Three ${ }^{241} \mathrm{Pu}$ metal target disks were fabricated for the Aerojet Nuclear Company. ${ }^{\mathrm{P} 191}$ \\
\hline $\begin{array}{l}\text { January } 1977- \\
\text { June } 1977\end{array}$ & $\begin{array}{l}\text { A plutonium metal rod }\left(12 \mathrm{wt} \%{ }^{238} \mathrm{Pu} \text { and } \sim 6 \mathrm{wt} \%{ }^{240} \mathrm{Pu} \text { ) was prepared for }\right. \\
\text { LLNL. }\end{array}$ \\
\hline $\begin{array}{l}\text { November } 1979- \\
\text { October } 1981\end{array}$ & $\begin{array}{l}{ }^{242} \text { Pu tracer disks prepared for the LLNL Radiochemical Diagnostic Tracer } \\
\text { Program. }\end{array}$ \\
\hline $\begin{array}{l}\text { October } 1981- \\
\text { September } 1982\end{array}$ & $\begin{array}{l}\text { Residues generated from the Tracer Program were processed to recover the } \\
\text { plutonium. }\end{array}$ \\
\hline $\begin{array}{l}\text { October } 1983- \\
\text { September } 1984\end{array}$ & ${ }^{242} \mathrm{Pu}$ oxide was purified and converted to metal for the LLNL Tracer Program. ${ }^{\mathrm{P} 200}$ \\
\hline \multirow[t]{2}{*}{ Unknown } & ${ }^{238} \mathrm{Pu}$ reportedly used as a tracer material. ${ }^{\mathrm{C} 159}$ \\
\hline & Thorium \\
\hline \multirow[t]{2}{*}{$\begin{array}{l}\text { January } 1975- \\
\text { June } 1975\end{array}$} & $\begin{array}{l}\text { A } 100 \text { gram batch of high purity thorium oxide was received from ORNL for } \\
\text { conversion to metal. Rocky Flats converted the oxide to metal and fabricated it into } \\
\text { targets to be used for a particle accelerator experiment at ORNL. }{ }^{\text {P194 }}\end{array}$ \\
\hline & Uranium \\
\hline $\begin{array}{l}1968,1977, \text { and } \\
1979-1984\end{array}$ & $\begin{array}{l}\text { Development of several processes for the separation and recovery of the uranium } \\
\text { and plutonium. }{ }^{\mathrm{P} 78, \mathrm{P} 195-\mathrm{P} 200}\end{array}$ \\
\hline $\begin{array}{l}\text { October 1968- } \\
\text { December } 1968\end{array}$ & A single ${ }^{236} \mathrm{U}$ metal button was produced for ORNL. ${ }^{\mathrm{P} 178}$ \\
\hline $\begin{array}{l}\text { April 1969- } \\
\text { June } 1969\end{array}$ & Prepared mixed plutonium and uranium oxide for ANL. ${ }^{\mathrm{P} 179}$ \\
\hline \multirow{2}{*}{$\begin{array}{l}\text { July } 1969- \\
\text { September } 1969\end{array}$} & ${ }^{233} \mathrm{U}$ metal prepared from ${ }^{233} \mathrm{U}$ oxide for $\mathrm{ORNL} .{ }^{\mathrm{P} 180}$ \\
\hline & Nickel and copper disks coated with ${ }^{235} \mathrm{U}$ oxide for $\mathrm{LRL}{ }^{\mathrm{P} 180}$ \\
\hline $\begin{array}{l}\text { July } 1971- \\
\text { September } 1971\end{array}$ & Four ${ }^{233} \mathrm{U}$ metal disks were fabricated for ORNL. ${ }^{\mathrm{P} 187}$ \\
\hline $\begin{array}{l}\text { January } 1972- \\
\text { June } 1972\end{array}$ & $\begin{array}{l}\text { Three uranium buttons prepared for the Liquid-Metal Fast Breeder Reactor neutron } \\
\text { dosimetry program. Each button was prepared with a different uranium isotope } \\
\left({ }^{235} \mathrm{U},{ }^{236} \mathrm{U} \text {, and }{ }^{238} \mathrm{U}\right) .{ }^{\mathrm{P} 189}\end{array}$ \\
\hline $\begin{array}{l}\text { July } 1973- \\
\text { December } 1973\end{array}$ & $\begin{array}{l}\text { A passive-active gamma-ray system for the nondestructive assay of waste packages } \\
\text { containing }{ }^{233} \mathrm{U} \text { was investigated. }{ }^{\mathrm{P} 192}\end{array}$ \\
\hline $\begin{array}{l}\text { July 1974- } \\
\text { June } 1975\end{array}$ & $\begin{array}{l}\text { Research performed on removal of }{ }^{232} \mathrm{U} \text { daughters from }{ }^{233} \mathrm{U} \text {. The in-growth } \\
\text { reaches equilibrium at } 10.3 \text { years. }{ }^{\mathrm{P} 193, \mathrm{P} 194}\end{array}$ \\
\hline $\begin{array}{l}\text { November } 1979- \\
\text { September } 1982\end{array}$ & $\begin{array}{l}\text { A study was performed on the feasibility of reducing the plutonium in uranium } \\
\text { oxide product shipped to ORNL for further processing. }{ }^{\mathrm{P} 97}\end{array}$ \\
\hline $\begin{array}{l}\text { October } 1980- \\
\text { September } 1982\end{array}$ & $\begin{array}{l}{ }^{233} \text { U tracer disks prepared for the LLNL Radiochemical Diagnostic Tracer } \\
\text { Program. }{ }^{\text {P197,P198 }}\end{array}$ \\
\hline $\begin{array}{l}\text { October } 1983- \\
\text { September } 1984\end{array}$ & $\begin{array}{l}\text { Research was conducted on the adsorption of halogenated solvents on uranium } \\
\text { dioxide. }\end{array}$ \\
\hline
\end{tabular}


A description of the $R \& D$ areas is provided below. Most of the documentation pertaining to $R \& D$ activities do not specify locations in which the work was performed. Therefore, unless otherwise noted, it will be assumed that any of the radioisotopes identified in Table 3-2 could have been handled in the R\&D areas of any of these buildings.

In Building 771, special recovery anion exchange separated plutonium from other materials that were not suitable for the regular recovery processes. Chemical technology conducted various aqueous R\&D activities. Plutonium metallurgy operations in Building 771 included alloy preparation, heat treating, rolling, metal and metallurgical testing, and cutting for $R \& D{ }^{\text {C154,P061 }}$

The coatings laboratory in Building 777 developed various substrates to be coated with uranium or plutonium, including stainless steel, copper, chromium, aluminum, and beryllium. This research and development facility supported production processes. The special weapons area in Building 777 assembled war reserve and other specially fabricated parts. The operation was also responsible for disassembly of surveillance (tracer) parts and drilling of parts for use in analytical testing. ${ }^{\text {P079 }}$

The purpose of Building $779 \mathrm{R} \& \mathrm{D}$ was to gain more knowledge of the chemistry and metallurgy of plutonium and its interactions with other materials which might be used in plutonium operations. Other activities in Building 779 included developing improvements to the manufacturing process, and finding new ways to recover plutonium and associated actinides. Another function was to develop a better understanding of the aging and shelf-life limitations of Rocky Flats products. Most of the materials used and wastes generated in this facility were the same as those in the production and recovery buildings, as much of the work conducted involved improvement of existing processes. ${ }^{\text {P053 }}$

Some radionuclide tracers consisting of neptunium, curium, and cerium were fabricated in Building 881 in the $1960 \mathrm{~s} .{ }^{\text {v057 }}$ The first neptunium processing was also done in the building. ${ }^{\mathrm{Cl} 54, \mathrm{U} 057}$ Other transuranic radionuclides used in Building 881 in the 1960 s included uranium-233. ${ }^{\text {Cl45 }}$ There reportedly was some work performed with uranium-233 in 1975 as well. ${ }^{\mathrm{Cl34,C145}}$

\subsubsection{Routine Maintenance}

Routine maintenance at Rocky Flats consisted of a variety of activities supporting plant operations including utilities, filter testing and replacement, and change-out of oils, coolants, and Raschig rings. Most of the buildings contained maintenance operations for the building and peripheral areas. Utility operations included the up-keep of the HVAC, fume scrubbers, and process vacuum systems. The Filter Testing group was responsible for in-place testing of plenum HEPA filters. ${ }^{\mathrm{P} 053}$ Waste produced by maintenance may have been contaminated by the materials and chemicals used in the area of generation.

\subsubsection{Non-Routine Operations}

Non-routine operations included spill clean up, strip-out operations, renovation, and activities associated with fires and other incidents. Spills of various materials occurred due to leaks or releases from tanks, piping, waste containers, or gloveboxes. Tanks or pipes may have contained acids, bases, or solvents used during normal process operations. ${ }^{\mathrm{P} 053}$ Strip-out of glovebox lines, process piping, valves, and associated systems were also performed as required during renovation or decommissioning. ${ }^{\mathrm{P} 067, \mathrm{P} 108}$ 
Other non-routine activities which generated TRU waste materials included

the 1969 fire which spread through combustible materials in several hundred inter-connected gloveboxes in Buildings 776 and 777.P053

- the 1974 control valve release allowed radioactive particulates to escape from Module $\mathrm{K}$ in Building 707 because a glovebox window had been removed by maintenance, ${ }^{P 053}$ and

the tritium release in 1973 in which tritium-contaminated plutonium was processed in Building 779 causing a tritium release to the atmosphere, as well as elevated tritium levels in surface waters, process wastes, equipment, gloveboxes, and exhaust plenums. ${ }^{\text {P053 }}$

\subsection{TRU Waste Management}

TRU waste management at the Rocky Flats Plant was initiated at the point of waste generation and continued through final waste disposition. Waste management includes segregation, packaging, storage, transportation, RCRA characterization, and certification. Administrative controls were put in place to ensure that TRU waste was properly managed.

\subsubsection{Organization and Administration}

Plutonium Operations and Quality Engineering and Control were the primary organizations at Rocky Flats responsible for ensuring proper management of TRU waste. The Waste Operations Department within Plutonium Operations was responsible for activities related to waste generation and certification including operating programs, policies, and procedures. Quality Engineering and Control supported Waste Operations by performing various testing and inspection activities including nondestructive assay, real-time radiography (RTR), visual inspection, waste analyses, and equipment and instrument calibration. ${ }^{\mathrm{P} 14}$

\subsubsection{Waste Segregation}

When waste was initially packaged, it was segregated by the type of waste matrix using Item Description Codes (IDC). IDCs (also referred to as Content Codes) are a series of numbers (001-999) used to identify nuclear material forms or process materials. ${ }^{\text {P063 }}$ Over the years, new IDCs have been added, obsolete IDCs have been deleted, and descriptions for some IDCs may have been modified. ${ }^{\text {U014 }}$ In addition, deleted IDCs may have been redefined. For example, IDC 807 was used originally for cemented incinerator sludge. After 1987, IDC 807 was reassigned to Building 374 Solidified Bypass Sludge. ${ }^{\text {P043,P063,P064 }}$

Waste was segregated for the purposes of assaying and controlling nuclear material. ${ }^{\mathrm{P} 014}$ Full drums were sent to the appropriate drum counter to determine if they contained recoverable transuranic actinides, or contained TRU or low-level waste. ${ }^{\mathrm{P} 035, \mathrm{U} 016}$ The determination of whether the drum contained recoverable material was based on an economic discard limit (EDL). The EDL compared the cost of manufacturing plutonium in a reactor to recovering the plutonium from specific process wastes and residues. EDLs were established by the DOE for each IDC. ${ }^{\text {P035,P053 }}$

Several types of assay were used at Rocky Flats including segmented gamma scan (SGS), passive/active neutron (PAN), and radiochemical analysis. Low resolution SGS was used on low weight drums such as combustibles or filters to determine if the waste was TRU or low-level. High resolution SGS 
provided assay values for plutonium, americium, and uranium for other IDCs. PAN assay was used on most IDCs to make a TRU or low-level waste determination. ${ }^{\mathrm{U}}{ }^{016}$ The PAN system quantified the amount of TRU activity within a drum, and relative quantities were established based on the isotopic makeup of the waste. The SGS system was developed to verify actual radioisotopes present in the waste. When SGS was used in conjunction with PAN, actual quantities of individual isotopes could be established. ${ }^{\text {P033 }}$ Radiochemical analysis was the primary assay method for batch samples or individual container samples of sludge wastes. However, PAN assay was also used for sludge waste. ${ }^{\mathrm{U} 016}$

Drum prefixes were assigned by the generator before the drum was sent to the counter. Prefixes can be used to identify the originating building or area within a building. The prefix corresponds to a material balance area (MBA) used to control the transfer of nuclear material. The title of an MBA usually corresponds to specific process operations. The prefix is identified by the first four digits of the container number (does not include the letters "RF"). ${ }^{\text {vo59 }}$ The last five digits of the container number indicate the sequence in which drums were packaged within a given prefix.

\subsubsection{TRU Waste Packaging, Storage, and Transportation}

From 1970 to 1971, drummed TRU waste was packaged in DOT 17H 55-gallon drums. Since 1971, DOT 17C 55-gallon drums have been used. The different types of gaskets installed in the drums are shown in Table 3-3. ${ }^{\text {0 }}$.

Table 3-3. Drum Gasket Types.

\begin{tabular}{ll}
\hline \multicolumn{1}{c}{ Gasket Type } & \multicolumn{1}{c}{ Time Frame } \\
\hline Standard Neoprene & Until 1977 \\
Tubular & 1977 to December 1982 \\
Flow-In Ventable & December 1982 to October 1988 \\
Tubular with Carbon Filter & October 1988 to Present \\
\hline
\end{tabular}

Approved liners were required in each TRU waste drum to provide contamination control, corrosion and puncture resistance, and radiation shielding. Other liners or packing materials may have been used inside of the required liners. ${ }^{\mathrm{P} 63}$ Liner and packing material configurations are provided in this document for each waste group in the Waste Packaging discussions in Sections 5.0 through 26.0. The various types of packaging materials used are shown in Table 3-4.

Table 3-4. Packaging Materials

\begin{tabular}{cc}
\hline \multicolumn{1}{c}{ Item } & \multicolumn{1}{c}{ Description } \\
\hline Inner packaging & 3-mil plastic bag, $12 \times 18$ inches $^{\mathrm{P} 008}$ \\
& 6-mil plastic bag, $18 \times 24$ inches $^{\mathrm{P} 008}$ \\
& 12-mil plastic bag, $10 \times 72$ inches $^{\mathrm{P} 008}$ \\
\hline
\end{tabular}




\begin{tabular}{ll}
\hline \multicolumn{1}{c}{ Item } & \multicolumn{1}{c}{ Description } \\
\hline 55-gallon drum liners & 90-mil rigid polyethylene liner \\
& 0.01 inch polyethylene round bottom liner \\
& 0.0055 inch polyethylene liner $^{\mathrm{P} 008}$ \\
& 0.051 inch fiberboard liner, $32 \times 72$ \\
& inches $^{\text {P008 }}$ \\
\hline
\end{tabular}

TRU waste was temporarily stored in buildings at Rocky Flats designated by specific procedures. Drums were staged in areas during drum counting, inspection, and closing operations. Drums of TRU waste accepted for shipment were transferred to Building 664 before they were shipped off site. ${ }^{\mathrm{P} 004}$

TRU waste was shipped to INEEL by ATMX railcar. Drums were placed in cargo containers that were loaded in the railcar. The cargo containers were secured by inflatable dunnage. ${ }^{\mathrm{P} 004}$

\subsubsection{Waste Characterization}

In November of 1985, Rocky Flats submitted RCRA Part B permit applications to the EPA and Colorado Department of Health to comply with the requirements of RCRA. On June 4, 1986, an Agreement in Principle was signed which stipulated that a technical program would be developed to obtain information regarding waste generation and waste management at the plant. From May 1986 to March 1987, every process and process support waste stream at the plant was identified and characterized. EPA Hazardous Waste Numbers were assigned to low-level and nonradioactive wastes based on process knowledge or sampling and analysis of the waste stream. The information was compiled in the Waste Stream Identification and Characterization (WSIC) document. Because the final Compliance Agreement did not apply to transuranic waste, wastes that contained or were thought to contain transuranic materials were not segregated based on their hazardous constituents. Prior to the implementation of WSIC, no wastes (nonradioactive, low-level, or transuranic) were segregated based on their hazardous constituents. ${ }^{\text {P067 }}$

In October of 1989, WSIC was expanded to provide RCRA characterization of TRU waste streams and to address residues (above EDL materials) generated at Rocky Flats. This program, known as Waste Stream and Residue Identification and Characterization (WSRIC), provided details on the nature, quantities, and hazards associated with nonhazardous, hazardous, radioactive, and mixed wastes that resulted from all aspects of operations at Rocky Flats. Field investigations were conducted to identify, evaluate, and verify current Rocky Flats waste- and residue-generating processes, wastes and residues, and waste management units. Sampling and analysis was also performed to characterize mixed wastes and residues that were potentially hazardous based upon preliminary field investigations.

In December 1993, the Backlog Waste Reassessment (BWR) project was implemented. Existing characterization information was compiled for the stored inventory of wastes at Rocky Flats, and a reassessment of that information was conducted to recommend and document the correct RCRA characterization. The universe of wastes included nonradioactive wastes, hazardous wastes, low-level and lowlevel-mixed wastes, TRU and TRU-mixed wastes, and residues and mixed residues in Rocky Flats inventory. Characterization was accomplished primarily using process knowledge and analytical data as sources. Rocky 
Flats cognizant personnel were also interviewed which supplied additional information: In addition, WSRIC Building Books were reviewed for archived and active waste stream characterizations. ${ }^{\text {P052 }}$

\subsection{TRU Waste Certification}

In 1978 and 1979, the Waste Acceptance Criteria (WAC) for the Waste Isolation Pilot Plant (WIPP) were initially developed. ${ }^{\text {POSO }}$ DOE facilities generating or storing TRU waste have implemented certification programs in order to comply with the WIPP WAC. Sections 3.4.1 and 3.4.2 describe the certification activities that have been conducted by Rocky Flats and INEEL for TRU wastes generated at Rocky Flats. ${ }^{\text {P014 }}$

\subsubsection{Rocky Flats Certification}

Rocky Flats implemented a program in May 1983 to certify TRU waste for future shipment to WIPP. The TRU waste certification procedures emphasized an efficient, effective, and auditable program that would comply with all existing orders, guidelines, and regulations. ${ }^{\mathrm{P} 014}$

Waste Operations was responsible for providing assistance to waste generators, and for the promulgation of TRU waste certification operating programs, policies, and procedures. Waste Operations also implemented the certification program which included operator indoctrination, performance of internal departmental program audits, verification inspection, and final certification of waste packages. ${ }^{\mathrm{P} 14}$

After containers were assayed, they were sent to Building 776 for inspection. Containers would undergo a physical inspection that included content verification, free liquid detection, and a waste packaging conformance check. Rejected waste packages were returned to the generator for corrective action. ${ }^{\mathrm{P} 014, \mathrm{P} 043}$ As a final quality assurance verification, RTR was performed on each container to verify correct contents and the absence of free liquids. ${ }^{\mathrm{P} 01}$

Quality Engineering and Control assisted Waste Operations in implementing, continually reviewing, and updating the Rocky Flats Certification Plan for TRU Waste. Quality Engineering and Control was responsible for formal periodic plant audits and surveys of the overall TRU waste certification programs and activities. This group. was also responsible for interfaces, for review and approval functions for the development, design, procurement, manufacture, and utilization of waste containers, and for operational and certification procedures used by Waste Operations. ${ }^{\mathrm{P} 014}$

\subsubsection{INEEL Certification}

In addition to the acceptable knowledge program, several programs and studies have been conducted at INEEL to characterize and certify the TRU waste inventory. The programs have been established to increase knowledge of the waste inventories to properly manage the wastes until final disposal. Specific characterization activities include the review of process knowledge, RTR examinations, radioassay analysis, drum headspace gas sampling, inner bag gas sampling, visual examinations, and core sampling and analysis. ${ }^{\text {P033 }}$

The Characterization and Categorization program was implemented to confirm that drums shipped from Rocky Flats had been assigned the appropriate IDC. During 1979 and 1980, 70 drums were visually inspected and gas samples were collected from the bags in the containers. ${ }^{\mathrm{P} 33}$ 
During the TRU Waste Sampling Program, conducted between 1983 and 1985, containers were examined and sampled to assess compliance of the waste with the WIPP-WAC and to test the INEEL RTR system. RTR examination of 209 containers was performed at INEEL and then the containers were sent to Rocky Flats to verify the RTR examinations with visual inspections. Drum pressure, drum void volume, and headspace gas composition were determined by sampling for 212 drums. Sludge containers were analyzed for $\mathrm{pH}$ and by infrared spectroscopy to determine the general composition of the sludges. ${ }^{\mathrm{P} 15, \mathrm{P} 033}$

Assessment of content codes have been conducted by INEEL to characterize and describe the transuranic waste inventory. The most recent assessment, completed in July 1995, reviewed Rocky Flats containers shipped to INEEL between 1985 and 1989. Analytical data and process knowledge were evaluated to determine if the waste met the WIPP WAC. ${ }^{\mathrm{P} 16}$

The Stored Waste Examination Pilot Plant (SWEPP) was constructed to provide nondestructive examination and certification capabilities for INEEL-stored TRU waste. In addition to waste certification operations, SWEPP has provided waste retrieval, repackaging, and storage capabilities since the facility opened for operations in 1986. From 1985 to $1989,17,252$ containers were examined by RTR and PAN assay in the SWEPP facility. Visual examination has been performed for 81 containers at Rocky Flats. ${ }^{\mathrm{P} 033}$

RTR has been used for a number of certification issues including estimating quantities of free liquids and particulates, verifying the content codes, and identifying the presence of pressurized containers. Visual examination has been used to verify the RTR examination, and to obtain data on waste acceptance criteria that cannot be determined nondestructively. ${ }^{\mathrm{P} 033}$

The WIPP Experimental Test Program encompasses three waste characterization programs conducted at INEEL since 1991. These programs include the WIPP Waste Characterization Program (WWCP), the TRU Waste Characterization Program, and the Bin Program. These programs utilize RTR, radioassay, headspace gas analysis, visual examination, and core sampling to support WIPP certification activities at INEEL. Table 3-5 summarizes the history of the major INEEL and Rocky Flats TRU waste characterization programs from 1979 through 1995 . $^{\text {P03 }}$

Table 3-5. Summary of TRU Waste Characterization Programs. ${ }^{\text {P033 }}$

\begin{tabular}{ll}
\hline \multicolumn{1}{c}{ Year } & \multicolumn{1}{c}{ Program Description or Reference } \\
\hline 1979 & Characterization and Categorization Study of TRU waste for EG\&G \\
1981 & INEEL-Stored TRU Waste Characterization: Nonradiological Hazards Identification, \\
& WM-F1-81-015 \\
1982 & Content Code Assessments for INEEL Contact-Handled Stored TRU Waste, \\
& WM-F1-82-021 \\
1985 & TRU Waste Sampling Program: Volume I-Waste Characterization, EGG-WM-6503 \\
1985 & TRU Waste Sampling Program: Volume II-Gas Generation Studies, EGG-WM-6503 \\
1985 & Waste Characterization for INEEL Remote-Handled/Special-Case Stored TRU Waste, \\
& WM-PD-85-014 \\
$1985-89$ & SWEPP Operations (Production mode certification) \\
\hline
\end{tabular}




\begin{tabular}{|c|c|}
\hline Year & Program Description or Reference \\
\hline 1989 & Waste Drum Gas Generation Sampling Program at Rocky Flats, PSD88-037 \\
\hline 1989 & $\begin{array}{l}\text { Hazardous Waste Constituents of INEEL Contact-Handled Stored TRU Waste, } \\
\text { EDF RWMC-369 }\end{array}$ \\
\hline 1989 & $\begin{array}{l}\text { Description of the SWEPP Certified Waste Sampling Program, Revision } 2 \text {, } \\
\text { EDF RWMC-363 }\end{array}$ \\
\hline 1990 & Chemical Compatibility of Stored TRU Mixed Waste, EDF RWMC -413 \\
\hline $1990-94$ & $\begin{array}{l}\text { WIPP Experimental Test Program } \\
\text { No Migration Petition } \\
\text { QAPP and QAPjP } \\
\text { SWEPP Operation } \\
\text { Headspace Gas sampling } \\
\text { Drum Content Examination } \\
\text { Gas Generation and transport Studies } \\
\text { Development of Sampling and Analytical Protocols for Sludges }\end{array}$ \\
\hline 1990 & $\begin{array}{l}\text { EPA Hazardous Waste Codes for Transuranic Storage Area Item Description Codes } \\
\text { (Revision } 3 \text { in 1996), EDF RWMC-421 }\end{array}$ \\
\hline 1991 & $\begin{array}{l}\text { Program Plan for Certification of INEEL Contact-Handled Stored TRU Waste, } \\
\text { WM-PD-88-01 1-4 }\end{array}$ \\
\hline 1993 & TRU Waste Questionnaire (Non-Rocky Flats Generators) \\
\hline 1994 & Waste Generator Questionnaire, EDF-RWMC-676 \\
\hline 1995 & $\begin{array}{l}\text { Chemical Constituents in Transuranic Storage Area Waste (Revision } 1 \text { in 1996), } \\
\text { EDF-RWMC-803 }\end{array}$ \\
\hline 1995 & INEEL Code Assessment of the Rocky Flats TRU Waste, INEL-95/028 \\
\hline 1995 & Summary of TRU Waste Characterization Programs at the INEEL, INEL-95/0397 \\
\hline
\end{tabular}

Various radioisotopes will be tracked and monitored at the Waste Isolation Pilot Plant (WIPP) site where transuranic waste will be sent for permanent storage. Prior to shipment, each waste container will be radioassayed. In order to meet the WIPP TRU Waste Characterization QAPP nondestructive assay compliance requirements and quality assurance objectives, it will be necessary to determine the total uncertainty of the radioassay results. In order to perform this evaluation, an assessment of the physical and radiological characteristics of graphite which can alter the response of the assay system will be performed. ${ }^{\mathrm{P} 154}$ Specifically, information on the isotopes present in the waste and the isotopic ratio will be determined.

\subsection{TRU Waste Inventory}

The Rocky Flats TRU waste inventory at INEEL addressed by this document consists of 28,796 accessible storage drums generated from 1972 through 1989. The inventory consists of a wide variety of materials generated by the operations described above. Waste materials range from relatively homogenous materials such as sludges from waste treatment operations to extremely heterogeneous wastes such as combustibles which consist of a wide spectrum of materials generated from numerous areas. 
As described in Section 3.3.2, Rocky Flats wastes were segregated by IDC. During the review of acceptable knowledge, similar IDCs were combined to create the "waste groups" presented in Sections 5.0 through 26.0. These sections describe the composition, generation, packaging, and characterization for each waste group. Table 3-6, summarizes the inventory assessed for the development of this document including IDC, IDC Title, number of drums, dates of generation, and the EPA Hazardous Waste Numbers assigned to the populations.

Table 3-6. Rocky Flats Plant TRU Waste Inventory Stored at INEEL.

\begin{tabular}{|c|c|c|c|}
\hline IDC & Title & $\begin{array}{l}\text { Dates of } \\
\text { Generation }\end{array}$ & EPA Hazardous Waste Numbers \\
\hline \multicolumn{4}{|c|}{ Absorbents (see section 50 ) } \\
\hline 375 & Oil Dri & $02-83$ through $08-84$ & $\begin{array}{l}\text { D004-D011, D022, F001-F003, and } \\
\text { F005 }\end{array}$ \\
\hline \multicolumn{4}{|c|}{ Americium Process Residue (see section 60 ) } \\
\hline 241 & Americium Process Residue & $12-72$ & D001, D002, and D008 \\
\hline \multicolumn{4}{|c|}{ Benelex and Plexiglass (see section 7.0) } \\
\hline 302 & Benelex and Plexiglass & $01-73$ through $02-86$ & D005 and D008 \\
\hline 464 & Benelex and Plexiglass & 11-72 through $12-72$ & D005 and D008 \\
\hline \multicolumn{4}{|c|}{ Blacktop, Concrete, Dirt, and Sand (see section 8.0 ) } \\
\hline 374 & $\begin{array}{l}\text { Blacktop, Concrete, Dirt, and } \\
\text { Sand }\end{array}$ & $12-72$ through $06-88$ & $\begin{array}{l}\text { D004-D011, D018, F001-F003, F005- } \\
\text { F007, and F009 }\end{array}$ \\
\hline \multicolumn{4}{|c|}{ Combustibles/Plastic (see section 9.0) } \\
\hline 330 & Paper and Rags-Dry & 04-72 through $04-88$ & $\begin{array}{l}\text { D001, D002, D006-D008, D011, D022 } \\
\text { F001-F003, F005-F007, and F009 }\end{array}$ \\
\hline 336 & Paper and Rags-Moist & $01-72$ through $04-88$ & $\begin{array}{l}\text { D001, D002, D006-D008, D01 I, D022, } \\
\text { F001-F003, F005-F007, and F009 }\end{array}$ \\
\hline 337 & Plastics, Teflon, Wash, PVC & $11-72$ through $04-87$ & $\begin{array}{l}\text { D001, D002, D006-D008, D011, D022 } \\
\text { F001-F003, F005-F007, and F009 }\end{array}$ \\
\hline \multicolumn{4}{|c|}{ Filters and Insulation (see section 10.0 ) } \\
\hline 328 & Ful-flo Incinerator Filters & $04-82$ through $02-83$ & $\begin{array}{l}\text { D002, D005, D007, D008, D011, } \\
\text { F001-F003, and F005 }\end{array}$ \\
\hline 335 & Absolute Filters & $01-73$ through $09-85$ & $\begin{array}{l}\text { D001, D005, D007, D008, D011, } \\
\text { F001-F003, F005-F007, and F009 }\end{array}$ \\
\hline 338 & $\begin{array}{l}\text { Insulation and CWS Filter } \\
\text { Media }\end{array}$ & $01-73$ through $05-73$ & $\begin{array}{l}\text { D001, D005, D007, D008, D011, } \\
\text { F001, and F002 }\end{array}$ \\
\hline 360 & Insulation & $01-73$ & $\begin{array}{l}\text { D005, D007, D008, D011, F001, and } \\
\text { F002 }\end{array}$ \\
\hline 376 & $\begin{array}{l}\text { Processed Insulation and Filter } \\
\text { Media }\end{array}$ & 04-80 through $09-88$ & $\begin{array}{l}\text { D005, D007, D008, D011, F001-F003, } \\
\text { F005-F007, and F009 }\end{array}$ \\
\hline 490 & CWS Filters & $12-72$ through $07-89$ & $\begin{array}{l}\text { D001, D005, D007, D008, D011, } \\
\text { F001-F003, F005-F007, and F009 }\end{array}$ \\
\hline
\end{tabular}




\begin{tabular}{|c|c|c|c|}
\hline IDC & Title & $\begin{array}{l}\text { Dates of } \\
\text { Generation }\end{array}$ & EPA Hazardous Waste Numbers \\
\hline \multicolumn{4}{|c|}{ Glass (see section 11.0 ) } \\
\hline 440 & Glass & $11-72$ through $02-88$ & D001, D005, D008, and D009 \\
\hline \multicolumn{4}{|c|}{ Graphite (see section 12.0 ) } \\
\hline 300 & Graphite & $11-72$ through $06-88$ & None \\
\hline 301 & Graphite Cores & $04-73$ through $02-85$ & None \\
\hline 303 & Scarfed Graphite Chunks & $03-85$ through $04-88$ & None \\
\hline 310 & Graphite Scarfings & $12-83$ & None \\
\hline 312 & Coarse Graphite & 11-83 through $06-84$ & None \\
\hline \multicolumn{4}{|c|}{ Grit (see section 13.0) } \\
\hline 372 & Grit & $11-82$ through $01-84$ & None \\
\hline \multicolumn{4}{|c|}{ Incinerator Waste (see section 14.0) } \\
\hline 292 & Cemented Sludge & $05-80$ through $05-86$ & $\begin{array}{l}\text { D002, D004-D011, F001-F003, and } \\
\text { F005 }\end{array}$ \\
\hline 371 & Fire Brick & 12-72 through $05-87$ & D004-D011, F001-F003, and F005 \\
\hline 377 & Coarse Fire Brick & $03-85$ through $05-87$ & D004-D011, F001-F003, and F005 \\
\hline 420 & Ash, Incinerator (Virgin) & $12-83$ through $04-84$ & D004-D011, F001-F003, and F005 \\
\hline 422 & Soot & $03-82$ through $02-86$ & D004-D011, F001-F003, and F005 \\
\hline 425 & Fluid Bed Ash & $07-81$ & D007, F003, and F005 \\
\hline 807 & $\begin{array}{l}\text { Cemented Incinerator Sludge } \\
\text { (Before March 1987) }\end{array}$ & $11-85$ through $03-87$ & D004-D011, F001-F003, and F005 \\
\hline 818 & Cemented Incinerator Ash & $10-86$ & D004-D011, F001-F003, and F005 \\
\hline 820 & Cemented Soot & 01-86 through $10-86$ & D004-D011, F001-F003, and F005 \\
\hline \multicolumn{4}{|c|}{ Lead Containing Waste (see section 15.0 ) } \\
\hline 320 & Tantalum & 01-73 through 06-88 & D008 \\
\hline 321 & Lead & $10-87$ through $11-87$ & D008 \\
\hline 339 & $\begin{array}{l}\text { Leaded Rubber Gloves and } \\
\text { Aprons }\end{array}$ & $02-73$ through $07-88$ & D003 and D008 \\
\hline \multicolumn{4}{|c|}{ Metal (see section 16.0 ) } \\
\hline 480 & Scrap Metal (Non SS) & $03-72$ through $07-89$ & $\begin{array}{l}\text { D001, D006-D008, D011, F001-F003, } \\
\text { F005-F007, and F009 }\end{array}$ \\
\hline 481 & Leached Metals (Non SS) & $12-72$ through $10-84$ & $\begin{array}{l}\text { D006-D008, D011, F001-F003, F005- } \\
\text { F007, and F009 }\end{array}$ \\
\hline \multicolumn{4}{|c|}{ Miscellaneous Cemented Waste (see section 17:0) } \\
\hline 806 & Cemented Filter Sludge & 04-87 through $03-88$ & D004-D011, F001-F003, and F005 \\
\hline 823 & Cemented Miscellaneous Sludge & $01-87$ through $03-87$ & D004-D011, F001-F003, and F005 \\
\hline
\end{tabular}




\begin{tabular}{|c|c|c|c|}
\hline IDC & Title & $\begin{array}{l}\text { Dates of } \\
\text { Generation }\end{array}$ & EPA Hazardous Waste Numbers \\
\hline \multicolumn{4}{|c|}{ Pyrochemical Waste (see section 18.0 ) } \\
\hline 409 & Molten Salt-30\% Unpulverized & $09-82$ through $01-86$ & None \\
\hline 411 & Electrorefining Salt & $04-82$ through $08-86$ & None \\
\hline 412 & Gibson Salts & $08-80$ & None \\
\hline 414 & Direct Oxide Reduction Salt & $05-82$ through $08-85$ & None \\
\hline 416 & Zinc Manganese Alloy Metals & $06-80$ & None \\
\hline \multicolumn{4}{|c|}{ Raschig Rings (see section 190 ) } \\
\hline 441 & Raschig Rings, Unleached & $04-73$ through $07-86$ & D002, F001, and F002 \\
\hline 442 & Raschig Rings, Leached & $04-79$ through $06-88$ & F001 and F002 \\
\hline \multicolumn{4}{|c|}{ Resin (see section 20.0 ) } \\
\hline 432 & Resin, Leached and Cemented & $01-72$ through $08-86$ & D007 and D008 \\
\hline 822 & Cemented Resin & $01-86$ through $02-87$ & None \\
\hline \multicolumn{4}{|c|}{ Sand, Slag, and Crucible (see section 21.0) } \\
\hline 370 & Leco Crucibles & $10-80$ through $06-82$ & None \\
\hline 391 & Crucible and Sand & 06-80 through $02-84$ & None \\
\hline 392 & Sand, Slag, and Crucible & $07-81$ & None \\
\hline 393 & Sand, Slag, and Crucible Heels & $08-80$ through $10-85$ & D007 \\
\hline 817 & Cemented SS\&C Heels & 10-86 through 01-87 & D007 \\
\hline \multicolumn{4}{|c|}{ Solidified Aqueous Sludge Building 374 (see section 22.0) } \\
\hline 007 & Building 374 Dry Sludge & 12-82 through $03-87$ & $\begin{array}{l}\text { D002, D007, D010, F001-F003, F005- } \\
\text { F007, and F009 }\end{array}$ \\
\hline 803 & Wet Sludge-Cemented & 04-86 through $05-87$ & $\begin{array}{l}\text { D002, D007, D010, F001-F003, F005- } \\
\text { F007, and F009 }\end{array}$ \\
\hline 807 & $\begin{array}{l}\text { Bypass Sludge (After March } \\
1987 \text { ) }\end{array}$ & 03-87 through $07-88$ & $\begin{array}{l}\text { D002, D007, D010, F001-F003, F005- } \\
\text { F007, and F009 }\end{array}$ \\
\hline \multicolumn{4}{|c|}{ Solidified Aqueous Sludge Building 774 (see section 23.0) } \\
\hline 001 & First Stage Sludge & $01-72$ through $08-86$ & $\begin{array}{l}\text { D002, D004-D011, F001-F003, F005- } \\
\text { F007, and F009 }\end{array}$ \\
\hline 002 & Second Stage Sludge & $08-72$ through $07-85$ & $\begin{array}{l}\text { D002, D004-D011, F001-F003, F005- } \\
\text { F007, and F009 }\end{array}$ \\
\hline 800 & First Stage Sludge-Cemented & $12-85$ through $09-88$ & $\begin{array}{l}\text { D002, D004-D011, F001-F003, F005- } \\
\text { F007, and F009 }\end{array}$ \\
\hline \multicolumn{4}{|c|}{ Solidified Laboratory Waste (see section 24.0) } \\
\hline 004 & Special Setups & $12-72$ through $11-86$ & F001-F003, and F005 \\
\hline 802 & Special Setups-Cemented & 06-86 through $04-88$ & F001-F003, and F005 \\
\hline
\end{tabular}




\begin{tabular}{|l|l|l|l|}
\hline IDC & \multicolumn{1}{|c|}{ Title } & $\begin{array}{c}\text { Dates of } \\
\text { Generation }\end{array}$ & \multicolumn{1}{|c|}{ EPA Hazardous Waste Numbers } \\
\hline Solidified Organic Waste (see section 25.0$)$
\end{tabular}




\subsection{REFERENCES}

Nearly 500 sources of information were collected, and reviewed during the development of this document. The acceptable knowledge sources consist of published documentation, unpublished data, and correspondence. Published documentation consist primarily of controlled documents, previously controlled documents, and procedures, in addition to formal reports, studies, and databases. Unpublished data include draft documents, analytical data packages, log books, and inventory lists, in addition to internal reports, studies, and databases. Correspondence includes internal and external letters, memos, directives, telecommunication records, meeting minutes, personnel interview summaries, and discrepancy reports. Appendix A lists and describes the references used by this program. The references are segregated by "C", "P", and " $U$ " sources which coincide with the correspondence, published, and unpublished information, respectively. 


\subsection{ABSORBENTS}

This waste group consists of absorbent clay material generated in Buildings 559 and $771 .^{\text {P001,P127 }}$ Absorbents were used for cleanup of hazardous liquid waste spills, oil absorption, or absorption of other liquids as needed. ${ }^{\text {P037,P049 }}$ Absorbents were also added to waste packages and drums having the potential of containing or generating free liquid. ${ }^{\mathrm{PO} 01 . \mathrm{PO} 14 \mathrm{POA3}}$ Historic IDC descriptions and dates of generation for the INEEL accessible storage inventory are presented by IDC in Table 5-1. ${ }^{\mathrm{P} 127}$

Table 5-1. Absorbents Waste in the Accessible Storage Inventory.

\begin{tabular}{clc}
\hline IDC & \multicolumn{1}{c}{ Title } & Dates of Generation \\
\hline 375 & $\begin{array}{l}\text { Oil-Dri Residue From the Incinerator } \\
\text { Oil Dry }^{\mathrm{P} 032} \\
\text { Oil Dri }^{\mathrm{P001}}\end{array}$ & February 1983- August 1984 \\
\hline
\end{tabular}

Item Description Code 375, Oil-Dri: This waste consists of spent absorbent clay materials. ${ }^{\mathrm{P} 001, \mathrm{P} 012, \mathrm{P} 014, \mathrm{P} 032, \mathrm{P} 043}$ One of the most common absorbents used at Rocky Flats was Oil-Dri ${ }^{\circledR}{ }^{\mathrm{P} 037, \mathrm{P} 049}$ Other absorbents could include floor dry, vermiculite, sorbent booms, and rags. ${ }^{\text {P037,P052 }}$

\subsection{Waste Generation}

There are four drums of absorbents (IDC 375) in the current INEEL accessible storage database. One was generated in February 1983 from recovery operations in Building 771. The other three drums were generated by the analytical laboratories in Building 559 in August 1984. ${ }^{\text {P127, U059 }}$

Absorbents from Building 771 consist of Oil-Dri from the plutonium recovery incinerator sorting box. ${ }^{\mathrm{P} 224}$ Combustible wastes fed to the incinerator were received from production processes in Buildings 371 , $707,771,776,777$, and 779 . $^{\mathrm{P} 12}$ Oil-Dri, which was added to wet combustible wastes when initially packaged, could not be incinerated and was segregated from the combustible waste and repackaged for disposal. ${ }^{\mathrm{P} 024}$ These absorbents may be contaminated with the same compounds as the combustible wastes that were fed to the incinerator (See Section 14.0, Incinerator Waste).

It is possible that the absorbents from the Building 559 analytical laboratory were generated from cleanup of a spill. The source or composition of the spill could not be identified, and the waste may contain any of the chemicals used in the analytical laboratories (See Section 9.0, Combustibles and Plastic).

\subsection{Waste Packaging}

Oil-Dri from the plutonium recovery incinerator sorting box was packaged in polyethylene bottles or metal paint cans and double-bagged out of the glovebox in polyvinyl chloride and polyethylene plastic bags. ${ }^{\mathrm{P} 12, \mathrm{P} 024}$ Each bag was sealed with tape before placement in a prepared 55-gallon drum. The waste may also be packaged in a polyethylene Residue Process Container (clamshell) before being placed in the drum. ${ }^{\mathrm{P} 24}$ 
The exact packaging configuration of absorbents from Building 559 is not known. However, standard glovebox bagout operations (double-bagged in plastic) were most likely used when packaging this waste. ${ }^{\mathrm{P} 001, \mathrm{P} 012}$

Depending on waste packaging requirements at the time, several combinations of bags and liners were used to prepare 55-gallon drums for shipment. Use of 90-mil rigid polyethylene liners began in $1972{ }^{\mathrm{P} 024}$ The rigid liner was placed in each drum and lined with one polyethylene round bottom drum liner or two polyethylene dnum bags. ${ }^{\mathrm{P} 08, \mathrm{P} 012, \mathrm{P} 024, \mathrm{P} 063, \mathrm{P} 064}$ A fiberboard liner and discs may also have been used between the waste and the drum liners. ${ }^{\mathrm{P} 12}$ When a drum was full, the drum liners were twisted and taped closed, the lid was secured with a bolted ring, and a tamper indicating device was attached to the drum. ${ }^{\mathrm{P} 001, \mathrm{P} 012, \mathrm{P} 024}$

After drums were inspected, one to two quarts of absorbent material (Oil-Dri) was placed on top of the outer, sealed polyethylene drum bag. This procedure was changed in February 1982 when vermiculite was used to fill the space between the outer, sealed polyethylene drum bag and the top of the 90 -mil rigid liner. The quantity of vermiculite varied from 3-12 pounds according to the amount of waste contained in each drum. ${ }^{\mathrm{P} 024}$

\subsection{Waste Characterization}

Absorbents are characterized based on knowledge of the material and knowledge of the processes generating the waste. This section provides a RCRA hazardous waste determination for absorbents as well as radionuclide contaminants and potential complexing agents contained in the waste. This waste is at least 50 percent (by volume) inorganic particulates, and is classified as a homogeneous waste. ${ }^{\mathrm{P} 141}$

\subsubsection{Hazardous Waste Determination}

The material in this waste group does not qualify for any of the exclusions outlined in 40 CFR 260 or 261. The waste may exhibit the characteristic of toxicity for arsenic, barium, cadmium, chromium, lead, mercury, selenium, silver, and chloroform. The waste may have been mixed mixed with halogenated- and nonhalogenated-solvents, and is therefore a F-listed hazardous waste. There is no evidence that absorbents exhibit any other characteristic of hazardous waste. EPA Hazardous Waste Numbers applicable to some or all of the absorbents waste group are presented by IDC in Table 5-2. These conclusions are supported by the evaluation in Sections 5.3.1.1 and 5.3.1.2.

Table 5-2. Absorbents Waste Characterization.

\begin{tabular}{ccc}
\hline IDC & Title & EPA Hazardous Waste Numbers \\
\hline 375 & Oil-Dri & D004-D011, D022, F001, F002, F003, and F005 \\
\hline
\end{tabular}

\subsubsection{Characteristic Waste}

The materials in this waste group may exhibit a characteristic of hazardous waste as defined in 40 CFR 261, Subpart $C$ as a toxic waste (40 CFR 261.24). The materials do not exhibit the characteristics of ignitability (40 CFR 261.21), corrosivity (40 CFR 261.22), or reactivity (40 CFR 261.23). 
Ignitability: The materials in this waste group do not meet the definition of ignitability as defined in 40 CFR 261.21. The material is not a liquid, and liquids were prohibited by procedural control from being placed in the drums. The material is not capable of causing fire through friction, absorption of moisture, or spontaneous chemical change. The material is not a compressed gas, and pressurized containers were prohibited by waste packaging procedures. ${ }^{\mathrm{P} 001, \mathrm{P} 012}$ The material is not a DOT oxidizer as defined in 49 CFR 173. The materials in this waste group are therefore not ignitable wastes (D001).

Corrosivity: The materials in this waste group do not meet the definition of corrosivity as defined in 40 CFR 261.22. The material is not a liquid, and corrosive liquids were prohibited by procedural control from being placed in the drums. ${ }^{\mathrm{P} 001, \mathrm{P} 012, \mathrm{P} 024}$ The materials in this waste group are therefore not corrosive wastes (D002).

Reactivity: The materials in this waste group do not meet the definition of reactivity as defined in 40 CFR 261.23. The materials are stable and will not undergo violent chemical change. The materials will not react violently with water, form potentially explosive mixtures with water, or generate toxic gases, vapors, or fumes when mixed with water. The materials do not contain cyanides or sulfides, and are not capable of detonation or explosive reaction. The materials are not forbidden explosives or Division $1.1,1.2$, or 1.3 (Class A or B) explosives as defined in 49 CFR 173, nor do the drums contain explosive materials. ${ }^{\mathrm{P} 001, \mathrm{P} 012, \mathrm{P} 024}$ Explosives were not handled or used around radioactive material. The materials in this waste group are therefore not reactive wastes (D003).

Toxicity: The materials in this waste group may meet the definition of toxicity as defined in 40 CFR 261.24. The toxicity characteristic contaminants fall into one of two categories: metals and organics. Organic compounds include halogenated- and nonhalogenated-solvents, pesticides, herbicides, and other toxic compounds. This waste group may exhibit the characteristic of toxicity for arsenic, barium, cadmium, chromium, lead, mercury, selenium, and silver metals, as well as chloroform.

Arsenic, barium, cadmium, chromium, lead, mercury, selenium, silver, and chloroform were used in the Building 559 analytical laboratory. It is possible that the absorbents contain any of these compounds. Therefore, absorbents from the Building 559 analytical laboratory are assigned EPA Hazardous Waste Numbers D004-D011 and D022. A representative sample of this waste will be obtained for verification purposes.

Tetrachloroethene, trichloroethene, and carbon tetrachloride were commonly used solvents. ${ }^{\mathrm{P} 23}$ The absorbents could potentially have been mixed with these solvents. Since these compounds were typically used as solvents, the waste is regulated as a listed hazardous waste and not a characteristic waste because these compounds are specifically addressed in the treatment standards for the listed hazardous waste. ${ }^{\mathrm{P} 080}$ Since absorbents are characterized as listed hazardous wastes due to spent solvent contamination, the waste is not a toxic waste due to the presence of these organic compounds.

There is no documentation indicating the presence or use of pesticides or herbicides in the areas or processes generating absorbents. Therefore, this waste group does not exhibit the characteristic of toxicity due to pesticides or herbicides (D012-D017). 


\subsubsection{Listed Hazardous Waste}

The material in this waste group may have been mixed with a waste listed in 40 CFR 261, Subpart $D$ as a hazardous waste from non-specific sources (40 CFR 261.31). The waste is not, or was not mixed with, a hazardous waste from specific sources (40 CFR 261.32), or a discarded commercial chemical product, an off-specification species, a container residue, or a spill residue thereof (40 CFR 261.33).

F001-, F002-, F003-, or F005-listed solvents may have been used in the processes that generated absorbents, or absorbent materials may have been used to clean up spills of these spent solvents. Therefore, the materials in this waste group are assigned EPA Hazardous Waste Numbers F001, F002, F003, and F005.

There is no documentation indicating the presence or use of F004-listed solvents in the areas or processes generating absorbents. Therefore, this waste group is not a F004-listed hazardous waste.

The material in this waste group is not a hazardous waste from specific sources since it was not generated from any of the processes listed in 40 CFR 261.32. The material in this waste group is therefore not a K-listed hazardous waste.

The material in this waste group is not a discarded commercial chemical product, an off-specification species, or a container residue (40 CFR 261.33). It is uncertain if the waste was generated from cleanup of a commercial chemical product spill. However, it is highly unlikely that the cleanup of a commercial chemical product would result in the generation of TRU waste. Therefore, the material in this waste group is not a Por U-listed hazardous waste.

\subsubsection{Radionuclides}

The absorbents from the Building 559 analytical laboratory (prefix 29) could potentially be contaminated with any of the radioisotopes processed at Rocky Flats during the time in which this waste was generated. The analytical laboratory performed a variety of analyses, including plutonium, enriched and

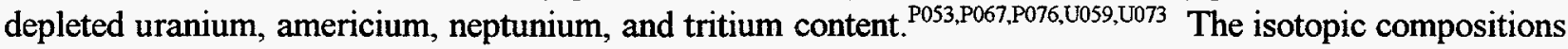
of weapons-grade plutonium, enriched uranium, and depleted uranium are specified in Section 3.0.

Documented assay results for absorbents indicate the presence of plutonium; however, the waste could also be contaminated with americium-241 or enriched uranium because the absorbent waste from Building 771 (prefix 01) was generated by removing Oil-Dri from combustible wastes that originated from numerous production processes on plant site. ${ }^{\mathrm{P} 24, \mathrm{POS} 2}$

Due to the potential variability of the absorbent wastes, documentation on the radionuclide form, particle size, and distribution, interfering waste contaminants, and physical matrix parameters has not been identified. The only exception to this is the assumption that hydrogen is present from plastic packaging materials.

\subsubsection{Complexing Agents}

Because complexing agents can aid in the transport of transuranic radionuclides from the waste after disposal, the waste was assessed for potential complexing agents. This information may also be added to the chemical compatibility studies since limited information was available on these chemicals in the past. 
EDTA represents a group of chelating compounds, such as ethenediaminetetraacetic acid, with similar molecular structures found in many soaps and detergents. Versene (a trade name for EDTA) and citric acid are known constituents of $\mathrm{KW}$ decontamination detergent. ${ }^{\mathrm{P} 24, \mathrm{P} 068} \mathrm{KW}$ was used during a variety of decontamination activities at the plant, including wiping down filter frames. A buffer solution (TISAB) containing diaminocyclohexane tetraacetic acid was used during specific ion electrode analysis in Building 559. ${ }^{\text {P076 }}$ Oxalic acid and tetraphosphoric acid were used to etch plutonium and other

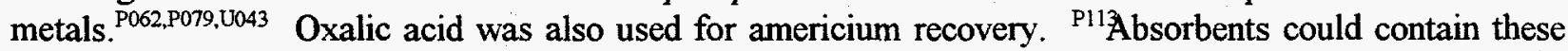
complexing agents if they were used during decontamination activities or spill clean up. 


\subsection{AMERICIUM PROCESS RESIDUE}

This waste group consists of metal, glass, plastic, combustible, and other miscellaneous waste generated from the renovation of the americium recovery line in Building 771 at the Rocky Flats Plant. ${ }^{\mathrm{P} 024}$ Historic IDC descriptions and dates of generation for the INEEL accessible storage inventory are presented by IDC in Table 6-1. P127 $^{2}$

Table 6-1. Americium Process Residue Waste in the Accessible Storage Inventory.

\begin{tabular}{clc}
\hline IDC & \multicolumn{1}{c}{ Title } & Dates of Generation \\
\hline 241 & $\begin{array}{l}\text { Americium Process Residue } \\
\text { Mixed Waste-Paper, Metal, Glass, etc. }{ }^{\mathrm{P} 015}\end{array}$ & December 5, 1972 \\
\hline
\end{tabular}

Item Description Code 241, Americium Process Residue: This waste consists of metal, glass, plastic, combustible, and other miscellaneous wastes. Metal waste items may include piping, flanges, valves, tools, and equipment. Glassware may consist of flasks and broken ion-exchange columns. Plastic items such as PVC sheeting and polyethylene bottles are also included in this waste. The bottles may contain liquids. Other wastes may include HEPA, Ful-Flo, and glass filters; leaded glovebox gloves; rags; and wipes. ${ }^{\mathrm{PO} 12, \mathrm{P} 015, \mathrm{P} 024}$

\subsection{Waste Generation}

In 1963 and 1964, an americium recovery system was installed in Building 771. The process recovered and purified americium from plutonium peroxide precipitation filtrate using anion- and cationexchange, evaporation, precipitation, and calcination techniques. Nitric acid, hydrochloric acid, ammonium thiocyanate, oxalic acid, and water were used in the recovery process. ${ }^{\text {C047,P113,U047 Americium process residues }}$ (IDC 241) were generated from the renovation of the americium recovery line. ${ }^{\text {C115,P024 }}$ Small amounts of process chemicals were washed from equipment with water and then dried with rags or wipes prior to removal from the glovebox line. ${ }^{\mathrm{P} 024}$ Filters removed from the line may contain nitrate salts from the presence of nitric acid. ${ }^{\mathrm{U} 060}$

\subsection{Waste Packaging}

Americium process residue drums (IDC 241) were lined with lead shielding and a 90-mil rigid liner, then by two polyethylene drum bags. The waste items were double bagged in PVC inner and polyethylene outer bags that were sealed with tape. Oil Dri was placed outside of the drum bags in the bottom of the rigid liner. The drum bags were sealed with tape and the rigid liner lid was sealed on the rigid liner. ${ }^{\mathrm{P} 015, \mathrm{P} 024}$

\subsection{Waste Characterization}

Americium process residue is characterized based on knowledge of the material, knowledge of the processes generating the waste, RTR review of the waste, visual inspection, and headspace gas analysis. This section provides a RCRA hazardous waste determination for americium process residue as well as radionuclide contaminants and potential complexing agents contained in the waste. This waste contains at least 50 percent 
(by volume) materials that meet the EPA LDR criteria for classification as debris, and is therefore a heterogeneous waste. ${ }^{\text {P141 }}$

\subsubsection{Hazardous Waste Determination}

The material in this waste group does not qualify for any of the exclusions outlined in 40 CFR 260 or 261. The waste may exhibit the characteristics of ignitability due to cellulosic materials contaminated with nitrate salts, and corrosivity from the presence of acidic free liquids. The waste may also exhibit the characteristic of toxicity for lead. The waste was not mixed with a listed hazardous waste, nor is there any evidence that americium process residue exhibits any other characteristic of hazardous waste. EPA Hazardous Waste Numbers applicable to the americium process residue waste group are presented by IDC in Table 6-2. These conclusions are supported by the evaluation in Sections 6.3.1.1 and 6.3.1.2.

Table 6-2. Americium Process Residue Waste Characterization.

\begin{tabular}{ccc}
\hline IDC & Title & EPA Hazardous Waste Numbers \\
\hline 241 & Americium Process Residue & D001, D002, and D008 \\
\hline
\end{tabular}

\subsubsection{Characteristic Waste}

The materials in this waste group may exhibit a characteristic of hazardous waste as defined in 40 CFR 261, Subpart C as an ignitable waste (40 CFR 261.21), as a corrosive waste (40 CFR 261.22), and as a toxic waste (40 CFR 261.24). The materials do not exhibit the characteristic of reactivity (40 CFR 261.23).

Ignitability: The materials in this waste group may meet the definition of ignitability as defined in 40 CFR 261.21 due to cellulosic materials contaminated with nitrate salts. The material is not a liquid, and absorbents were added to wastes having the potential of generating free liquids (i.e., filters used in acid

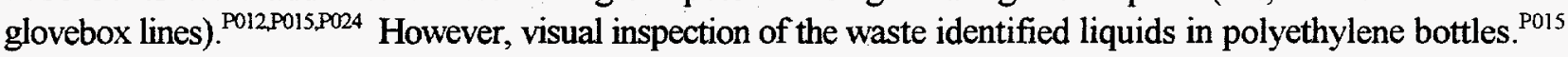
Ignitable liquids were not used in the americium recovery process, or in the renovation of the process. The material is not a compressed gas, nor do the containers contain compressed gases as confirmed by visual inspection. ${ }^{\mathrm{P} 15}$ Filters used in the americium recovery line may have visible nitrate salt contamination, and for this reason, a risk of spontaneous combustion has been identified. The material in this waste group is therefore assigned EPA Hazardous Waste Number D001. ${ }^{\text {U060 }}$

Corrosivity: The liquids in this waste group may meet the definition of corrosivity as defined in 40 CFR 261.22. The materials are not liquid, but visual inspection of one drum identified free liquids contained in bottles. The liquids were not sampled due to the high dose rate of the drum. ${ }^{\mathrm{PO}}{ }^{\mathrm{H}}$ However, nitric and hydrochloric acids were used in the glovebox from which the waste originated, and may be contained in the bottles. ${ }^{\mathrm{Cl}}$ The material in this waste group is therefore assigned EPA Hazardous Waste Number D002. ${ }^{\text {U060 }}$

Reactivity: The materials in this waste group do not meet the definition of reactivity as defined in 40 CFR 261.23. The materials are stable and will not undergo violent chemical change. The materials will not react violently with water, form potentially explosive mixtures with water, or generate toxic gases, vapors, 
or fumes when mixed with water. The materials do not contain cyanides or sulfides, and are not capable of detonation or explosive reaction. The materials are not forbidden explosives or Division $1.1,1.2$, or 1.3 (Class A or B) explosives as defined in 49 CFR 173, nor do the drums contain explosive materials. ${ }^{\text {PO12,P015,P024 }}$ Explosives were not handled or used around radioactive material. The materials in this waste group are therefore not reactive wastes (D003).

Toxicity: The materials in this waste group may meet the definition of toxicity as defined in 40 CFR 261.24. The toxicity characteristic contaminants fall into one of two categories: metals and organics. Organic compounds include halogenated- and nonhalogenated-solvents, pesticides, herbicides, and other toxic compounds. This waste group may exhibit the characteristic of toxicity for lead metal.

During the renovation of the glovebox line, leaded glovebox gloves may have been discarded in the drums. Therefore, the materials in this waste group are assigned EPA Hazardous Waste Number D008 since a representative sample of this waste cannot be obtained for verification purposes.

There is no documentation indicating the presence or use of pesticides or herbicides in the areas or processes generating americium process residue. Therefore, this waste group does not exhibit the characteristic of toxicity due to pesticides or herbicides (D012-D017).

Toxicity characteristic organic compounds were not used in the process which generated americium process residue. Therefore, this waste group does not exhibit the characteristic of toxicity due to organic compounds (D018-D043).

\subsubsection{Listed Hazardous Waste}

The material in this waste group is not, or was not mixed with, a hazardous waste listed in 40 CFR 261, Subpart D as a hazardous waste from non-specific sources (40 CFR 261.31), as a hazardous waste from specific sources (40 CFR 261.32), or a discarded commercial chemical product, an off-specification species, a container residue, or a spill residue thereof (40 CFR 261.33).

The material in this waste group is not a hazardous waste from non-specific sources since F-listed solvents were not used in process that generated americium process residue. Headspace analysis was performed on one drum of this waste and no F-listed solvents were detected. ${ }^{\mathrm{P} 015}$ Therefore, this waste group is not a F-listed hazardous waste.

The material in this waste group is not a hazardous waste from specific sources since it was not generated from any of the processes listed in 40 CFR 261.32. The material in this waste group is therefore not a K-listed hazardous waste.

The material in this waste group is not a discarded commercial chemical product, an off-specification species, a container residue, or a spill residue thereof (40 CFR 261.33). The material in this waste group is therefore not a P- or U-listed hazardous waste. 


\subsubsection{Radionuclides}

The process that generated americium process residue recovered the americium decay product from plutonium used in weapons production and, therefore, the waste will be contaminated with weapons-grade plutonium and significant quantities of americium-241. ${ }^{\text {P053,P164 }}$

Table 6-3. Waste Matrix Evaluation.

\begin{tabular}{|c|c|}
\hline Parameter & Results of Evaluation \\
\hline $\begin{array}{l}\text { Radionuclide Form, } \\
\text { Particle Size, and }\end{array}$ & $\begin{array}{l}\text { The americium was in a chloride, thiocyanate, hydroxide, nitrate, oxalate, and } \\
\text { oxide chemical form during different steps of the process. }\end{array}$ \\
\hline Distribution & $\begin{array}{l}\text { Documentation on the source particle size and distribution was not identified, } \\
\text { but is likely highly variable due to the heterogeneous nature of this waste. }\end{array}$ \\
\hline Hydrogen Content & $\begin{array}{l}\text { Hydrogen content was measured at } 14.4 \mathrm{vol} \% \text { in a drum of IDC } 241 \text {, and } \\
\text { hydrocarbons were measured at only } 0.34 \mathrm{vol} \% \text {. The drum also contained a } \\
\text { moderate amount of combustibles and plastics, including packaging } \\
\text { materials. }\end{array}$ \\
\hline $\begin{array}{l}\text { Other Interfering Waste } \\
\text { Contaminants }\end{array}$ & $\begin{array}{l}\text { Impurities such as aluminum and chromium were removed from the americium } \\
\text { during the process }{ }^{P 113} \text { It is possible that the these compounds could be present } \\
\text { in Ful-Flo filters which were identified in a drum. }{ }^{P 015}\end{array}$ \\
\hline $\begin{array}{l}\text { Physical Matrix } \\
\text { Parameters }\end{array}$ & $\begin{array}{l}\text { This waste is extremely heterogeneous and contains a wide variety of waste } \\
\text { items. There will likely be a great amount of void space throughout the waste, } \\
\text { and the waste contaminants will presumably be unevenly distributed. }\end{array}$ \\
\hline
\end{tabular}

\subsubsection{Complexing Agents}

Because complexing agents can aid in the transport of transuranic radionuclides from the waste after disposal, the waste was assessed for potential complexing agents. This information may also be added to the chemical compatibility studies since limited information was available on these chemicals in the past.

Oxalic acid was used in the americium recovery glovebox line where this waste was

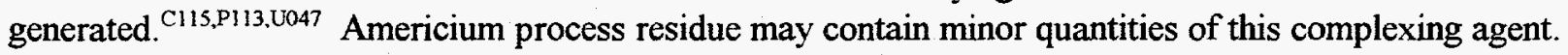




\subsection{BENELEX AND PLEXIGLAS}

This waste group consists of Benelex and Plexiglas which were used for radiation shielding around gloveboxes and tanks. ${ }^{\text {P052 }}$ The waste may have been generated in Buildings $371,374,559,707,771,774,776$, 777, and 779 at the Rocky Flats Plant. ${ }^{\text {P012 }}$ Historic IDC descriptions and dates of generation for the INEEL accessible storage inventory are presented by IDC in Table 7-1. ${ }^{\mathrm{P} 127}$

Table 7-1. Benelex and Plexiglas Waste in the Accessible Storage Inventory.

\begin{tabular}{rrl}
\hline IDC & Title & \multicolumn{1}{c}{ Dates of Generation } \\
\hline 464 & Benelex and Plexiglas $^{\mathrm{P} 012}$ & November 1972-December 1972 \\
302 & Benelex and Plexiglas $^{\mathrm{P} 001}$ & January 1973-February 1986 \\
\hline
\end{tabular}

Item Description Code 302, Benelex and Plexiglas: Benelex is a dense, laminated, lignocellulose hardboard made from wood chips and particles. Benelex was usually coated with fire-retardant paint and sometimes had lead sheeting (1/8 to $1 / 4$ inch thick) attached to it. ${ }^{\mathrm{P} 12, \mathrm{P} 024}$ It was usually two inches thick, although occasionally two 2 -inch thick pieces were bolted together to increase shield thickness. ${ }^{\text {P052 }}$ Plexiglas is a trade name for a transparent plastic material made from methyl methacrylate. Plexiglas glovebox windows were two to four inches thick and were cut to fit the glovebox window. In addition to Benelex and Plexiglas, leaded glass and limited amounts of surgical gloves, metal hinges on Benelex gloveport doors, pieces of angle iron attached to larger pieces of Benelex, and rubber gaskets from glovebox windows may be present. ${ }^{\mathrm{P} 24}$

Item Description Code 464, Benelex and Plexiglas: This waste consists of the same material as IDC 302 . IDC 464 was replaced by IDC 302 in $1973 .^{\text {P024 }}$

\subsection{Waste Generation}

Benelex was used as neutron radiation shielding around gloveboxes and tanks. The shielding was attached to gloveboxes as door coverings for glovebox glove-ports, and as solid shielding mounted on the floor around processes. ${ }^{\mathrm{P} 024}$ Plexiglas was used as radiation shielding in glovebox windows and equipment enclosures. Benelex and Plexiglas were generated during replacement of shielding or strip-out of unnecessary shielding during the installation of new gloveboxes. ${ }^{\mathrm{P} 052}$

\subsection{Waste Packaging}

Benelex and Plexiglas were usually contained in plastic bags or wrapped in plastic sheeting before being placed in a prepared 55-gallon drum. All waste was dry when packaged, however, absorbent (Oil-Dri) may have been added to the waste drums as a precautionary measure. ${ }^{\mathrm{P} 024}$

Depending on waste packaging requirements at the time, several combinations of bags and liners were used to prepare 55-gallon drums for shipment. From 1970 to 1972, waste drums were lined with one or two polyethylene drum bags. Cardboard liners might also have been used to line the inner drum bag. Use of the 90-mil rigid polyethylene liner began in 1972. ${ }^{\text {P024 }}$ The rigid liner was placed in each drum and lined with one 
polyethylene round bottom drum liner or one or two polyethylene drum bags. ${ }^{\text {P008,P012,P016,P024,P064 A polyvinyl }}$ chloride O-ring bag and a polyethylene bag were used if the drum was attached to the glovebox. ${ }^{\text {P016 }} \mathrm{A}$ fiberboard liner and discs may also have been used between the waste packages and the drum liners for

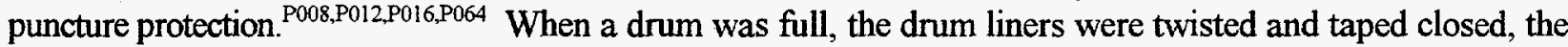
lid was secured with a bolted ring, and a tamper indicating device was attached to the drum. ${ }^{\mathrm{P}}{ }^{2,2016, \mathrm{P} 024}$

After drums were inspected, one to two quarts of absorbent material (Oil-Dri) was placed on the top of the outer, sealed polyethylene drum bag. This procedure changed in February 1982 when vermiculite was used to fill the space between the outer, sealed polyethylene drum bag and the top of the 90 -mil rigid liner. The quantity of vermiculite varied from 3-12 pounds according to the amount of waste contained in each drum. ${ }^{\mathrm{P} 24}$

Waste management and inspection protocol allowed containers of wastes to contain up to 10 percent of another IDC other than that assigned to the container. ${ }^{\text {P016 }}$ Visual inspection of containers of Benelex and Plexiglas identified a variety of items including paper labels and forms, tape, rubber gaskets, and lead sheeting. ${ }^{\text {P015,U011 }}$

\subsection{Waste Characterization}

Benelex and Plexiglas is characterized based on knowledge of the material, knowledge of the processes generating the waste, RTR review of the waste, visual inspection, and headspace gas analysis. This section provides a RCRA hazardous waste determination for Benelex and Plexiglas as well as radionuclide contaminants and potential complexing agents contained in the waste. This waste contains at least 50 percent by volume materials that meet the EPA LDR criteria for classification as debris, and is therefore a heterogeneous waste. ${ }^{\mathrm{P} 141}$.

\subsubsection{Hazardous Waste Determination}

The material in this waste group does not qualify for any of the exclusions outlined in 40 CFR 260 or 261. The waste may exhibit the characteristic of toxicity for barium and lead. The waste is not a listed hazardous waste, and there is no evidence that Benelex and Plexiglas exhibits any other characteristic of hazardous waste. ${ }^{093}$ EPA Hazardous Waste Numbers applicable to some or all of the Benelex and Plexiglas waste group are presented by IDC in Table 7-2. These conclusions are supported by the evaluation in Sections 7.3.1.1 and 7.3.1.2.

Table 7-2. Benelex and Plexiglas Waste Characterization.

\begin{tabular}{ccc}
\hline IDC & Title & EPA Hazardous Waste Numbers \\
\hline 302 & Benelex and Plexiglas & D005 and D008 \\
464 & Benelex and Plexiglas & D005 and D008 \\
\hline
\end{tabular}




\subsubsection{Characteristic Waste}

The materials in this waste group may exhibit a characteristic of hazardous waste as defined in 40 CFR 261, Subpart C, as a toxic waste (40 CFR 261.24). The materials do not exhibit the characteristics of ignitability (40 CFR 261.21), corrosivity (40 CFR 261.22), or reactivity (40 CFR 261.23).

Ignitability: The materials in this waste group do not meet the definition of ignitability as defined in 40 CFR 261.21. The materials are not liquid, and absorbents were added to wastes having the potential of generating free liquids. ${ }^{\mathrm{PO} 2}$ Visual inspection identified free liquids in one drum; however, sampling and analysis indicated that the liquid was aqueous with a $\mathrm{pH}$ of $6 .{ }^{\mathrm{PO} 15}$ The materials are not compressed gases, nor does the waste contain compressed gases. ${ }^{\mathrm{P} 12, \mathrm{PO} 15, \mathrm{PO} 24}$ The materials are not capable of causing fire through friction, absorption of moisture, or spontaneous chemical change. ${ }^{\mathrm{P} 12, \mathrm{P} 024}$ The materials are not DOT oxidizers as defined in 49 CFR 173. The materials in this waste group are therefore not ignitable wastes (D001).

Corrosivity: The materials in this waste group do not meet the definition of corrosivity as defined in 40 CFR 261.22. The materials are not a liquid, and absorbents were added to wastes having the potential of generating free liquids. ${ }^{\mathrm{PO} 2}$ Visual inspection identified free liquids in one drum; however, sampling and analysis indicated that the liquid was aqueous with $\mathrm{a} \mathrm{pH}$ of $6 .{ }^{\mathrm{PO} 15}$ The materials in this waste group are therefore not corrosive wastes (D002).

Reactivity: The materials in this waste group do not meet the definition of reactivity as defined in 40 CFR 261.23. The materials are stable and will not undergo violent chemical change. The materials will not react violently with water, form potentially explosive mixtures with water, or generate toxic gases, vapors, or fumes when mixed with water. The materials do not contain cyanides or sulfides, and are not capable of detonation or explosive reaction. The materials are not forbidden explosives or Division 1.1, 1.2, or 1.3 (Class A or B) explosives as defined in 49 CFR 173, nor do the drums contain explosive materials. ${ }^{\text {P012,P015,P024,U01 } 1 ~ E x p l o s i v e s ~ w e r e ~ n o t ~ h a n d l e d ~ o r ~ u s e d ~ a r o u n d ~ r a d i o a c t i v e ~ m a t e r i a l . ~ T h e ~ m a t e r i a l s ~ i n ~}$ this waste group are therefore not reactive wastes (D003).

Toxicity: The materials in this waste group may meet the definition of toxicity as defined in 40 CFR 261.24. The toxicity characteristic contaminants fall into one of two categories: metals and organics. Organic compounds include halogenated- and nonhalogenated-solvents, pesticides, herbicides, and other toxic compounds. This waste group may exhibit the characteristic of toxicity for barium and lead metals.

Leaded glass, which may be found in waste packages of Benelex and Plexiglas, has been analyzed using the Toxicity Characteristic Leaching Procedure and found to exceed the regulatory limits for lead and barium. ${ }^{\mathrm{P} 108}$ Additionally, some drums may contain lead shielding that was laminated to the Benelex. ${ }^{\mathrm{P} 24}$ Therefore, the materials in this waste group are assigned EPA Hazardous Waste Numbers D005 and D008 since a representative sample of this waste cannot be obtained for verification purposes.

There is no documentation indicating the presence or use of pesticides or herbicides in the areas or processes generating Benelex and Plexiglas. Therefore, this waste group does not exhibit the characteristic of toxicity due to pesticides or herbicides (D012-D017).

Carbon tetrachloride, tetrachloroethene, and trichloroethene may have been used clean Benelex and Plexiglas shielding. However, Benelex and Plexiglas is a nonporous material and should not retain toxicity 
characteristic levels of organics. Therefore, this waste group does not exhibit the characteristic of toxicity due to organic compounds (D018-D043).

\subsubsection{Listed Hazardous Waste}

The material in this waste group is not, or was not mixed with, a waste listed in 40 CFR 261, Subpart D as a hazardous waste from non-specific sources (40 CFR 261.31), as a hazardous waste from specific sources (40 CFR 261.32), or as a discarded commercial chemical product, an off-specification species, a container residue, or a spill residue thereof (40 CFR 261.33).

Tetrachloroethene, trichloroethene, 1,1,1-trichloroethane, carbon tetrachloride, and 1,1,2-trichloro1,2,2-trifluoroethane were commonly used for cleaning and degreasing. Methylene chloride was used primarily for paint removal. Other solvents such as acetone, methanol, xylene, benzene, and toluene were used primarily in laboratory operations. During process operations, Benelex and Plexiglas may have come in contact with these compounds, or may have been cleaned with these solvents. However, Benelex and Plexiglas that were wiped down with solvents for decontamination purposes are not regulated as listed hazardous wastes. This was clarified by the Colorado Department of Public Health and Environment. ${ }^{C 093}$ Therefore, this waste group is not a F001-, F002-, F003-, or F005-listed hazardous waste.

There is no documentation indicating the presence or use of F004-listed solvents in the areas or processes generating Benelex and Plexiglas. Therefore, this waste group is not a F004-listed hazardous waste.

Although this waste group is not a F-listed hazardous waste, headspace analysis performed on samples of Benelex and Plexiglas obtained at INEEL confirms the presence of organic solvents. The detected compounds in which the 90 percent UCL is above the PRQL are provided. ${ }^{\mathrm{P} 33}$

- $\quad$ 1,1,1-trichloroethane
- $\quad$ toluene
trichloroethene

The material in this waste group is not a hazardous waste from specific sources since it was not generated from any of the processes listed in 40 CFR 261.32. The material in this waste group is therefore not a K-listed hazardous waste.

The material in this waste group is not a discarded commercial chemical product, an off-specification species, a container residue, or a spill residue thereof (40 CFR 261.33). The material in this waste group is therefore not a P- or U-listed hazardous waste.

\subsubsection{Radionuclides}

This section identifies the radioisotopes potentially contained in the waste. The primary radionuclides processed at Rocky Flats included weapons-grade plutonium, americium-241, enriched uranium, and depleted uranium. The isotopic compositions of weapons-grade plutonium, enriched uranium, and depleted uranium are specified in Section 3.0. 
The feed materials to the recovery and purification processes (prefixes 01 and 02 ) in Building 771 were impure plutonium residues which were processed to produce plutonium metal for use in the foundry and, therefore, wastes generated will be contaminated primarily with weapons-grade plutonium. ${ }^{\text {P163,U059 }}$

Pyrochemical technology (prefix 52) in Building 779 involved the extraction and recovery of plutonium and americium in support of production operations and, therefore, wastes generated in this area will be contaminated with weapons-grade plutonium and americium-241. ${ }^{\text {P062,U059 }}$

The Size Reduction Vault (SRV) in Building 776 conducted solid waste treatment, repackaging, and size reduction operations. The SRV was divided into two sides. One side was the airlock (prefixes $25,40,41$, and 57) where repackaging was done. The other side (prefixes 19 and 26) was a drybox atmosphere where size reduction and solid waste treatment activities took place. ${ }^{\mathrm{C} 175, \mathrm{C} 184, \mathrm{P} 078, \mathrm{U} 059}$ The repacked containers have the potential to contain contaminated materials from any of the processes within the transuranic waste generating buildings. $\mathrm{P} 067, \mathrm{P} 078$

Table 7-3. Waste Matrix Evaluation.

\begin{tabular}{|c|c|}
\hline Parameter & Results of Evaluation \\
\hline $\begin{array}{l}\text { Radionuclide Form, } \\
\text { Particle Size, and } \\
\text { Distribution }\end{array}$ & $\begin{array}{l}\text { The form of radionuclide contaminants will depend on the process from which } \\
\text { the waste originated. For waste generated in Building } 771 \text {, the forms may } \\
\text { include plutonium nitrate, plutonium chloride, plutonium peroxide, plutonium } \\
\text { dioxide, plutonium tetrafluoride, and plutonium metal. }{ }^{\mathrm{P} 163} \text { The forms in } \\
\text { Building } 771 \text { represent almost every actinide form that will be found from } \\
\text { waste generated in other buildings. }\end{array}$ \\
\hline Hydrogen Content & $\begin{array}{l}\text { Benelex and Plexiglas are both hydrogen-containing materials. In addition, } \\
\text { headspace gas analysis indicates hydrogen content of } 0.03-4.06 \text { vol } \% .{ }^{P 015} \\
\text { Trace quantities of hydrocarbons were also detected. }{ }^{\mathrm{P} 015, \mathrm{P} 033}\end{array}$ \\
\hline $\begin{array}{l}\text { Other Interfering Waste } \\
\text { Contaminants }\end{array}$ & No other interfering waste contaminants were identified. \\
\hline $\begin{array}{l}\text { Physical Matrix } \\
\text { Parameters }\end{array}$ & Type 402 Benelex has a specific weight of $90 \mathrm{lb} / \mathrm{ft}^{3}{ }^{3024}$ \\
\hline
\end{tabular}

\subsubsection{Complexing Agents}

Because complexing agents can aid in the transport of transuranic radionuclides from the waste after disposal, the waste was assessed for potential complexing agents. This information may also be added to the chemical compatibility studies since limited information was available on these chemicals in the past.

EDTA represents a group of chelating compounds, such as ethenediaminetetraacetic acid, with similar molecular structures found in many soaps and detergents. Versene (a trade name for EDTA) and citric acid are known constituents of $\mathrm{KW}$ decontamination detergent. ${ }^{\mathrm{P} 068} \mathrm{KW}$ was used during a variety of decontamination activities at the plant. A buffer solution (TISAB) containing diaminocyclohexane tetraacetic acid was used during specific ion electrode analysis in Building 559. ${ }^{\mathrm{P} 76}$ Oxalic acid and tetraphosphoric acid 
were used to etch plutonium and other metals. ${ }^{\mathrm{P} 062, \mathrm{U} 043}$ Oxalic acid was also used for americium recovery. ${ }^{\mathrm{P} 113}$ Benelex and Plexiglas may contain trace quantities of these complexing agents. 


\subsection{BLACKTOP, CONCRETE, DIRT, AND SAND}

This waste group consists of blacktop, concrete, dirt, and sand materials generated by a variety of cleanup and construction activities in Buildings 371, 374, 559, 707, 771, 774, 776, 779, 991, and the 904 Pad. Historic IDC descriptions and dates of generation for the INEEL accessible storage inventory are presented by IDC in Table $8-1$. $^{\text {P127 }}$

Table 8-1. Blacktop, Concrete, Dirt, and Sand Waste in the Accessible Storage Inventory.

\begin{tabular}{clc}
\hline IDC & \multicolumn{1}{c}{ Title } & Dates of Generation \\
\hline 374 & $\begin{array}{l}\text { Blacktop, Concrete, Dirt, and } \\
\text { Sand }^{\mathrm{P} 24} \\
\text { Blacktop/Concrete/Dirt }^{\mathrm{P} 016} \\
\\
\text { Soil and Cleanup Debris }\end{array}$ & December 1972- June 1988 \\
\hline
\end{tabular}

Item Description Code 374, Blacktop, Concrete, Dirt, and Sand: This waste consists of blacktop, concrete, reinforced concrete, cinder blocks, brick, dirt, sand, rock, and construction rubble. ${ }^{\mathrm{P} 016, \mathrm{P} 024, \mathrm{P} 032}$ The drums may also contain some combustible wastes such as Kimwipes and surgical gloves. ${ }^{\mathrm{P} 024}$

\subsection{Waste Generation}

Blacktop, concrete, dirt, and sand (IDC 374) was generated from cleanup of spills and leaks, and from construction, demolition, maintenance, decontamination, and decommissioning operations in Buildings 371, 374, 559, 707, 771, 774, 776, 779, 991, and the 904 Pad. $^{\text {P014,P016,P024,P032,P049,P052,P114,P127,U059 The }}$ $904 \mathrm{Pad}$ was a waste storage area, and the containers from this area could have been generated from almost any area on plant site. Because this type of waste was generated on a nonroutine basis, only a limited amount of information describing specific generation activities is available.

Much of the waste was generated from the plutonium recovery area of Building 771, machining operations in Building 776/777, cleanup operations from the 1969 fire in Building 776, and cleanup of any plutonium area by Building 776 size reduction personnel. ${ }^{\mathrm{P}}{ }^{024}$

Another source of this waste was from cleanup of the $903 \mathrm{Pad}$ spill. ${ }^{\mathrm{P}} 90$ The $903 \mathrm{Pad}$ was a temporary drum storage area for radioactively contaminated organic liquids. The liquids included carbon tetrachloride, trichloroethene, tetrachloroethene, acetone, and still bottoms. An estimated 5,000 gallons of the liquids leaked from the drums into the soil. The drums were removed and the area was covered with an asphalt pad to prevent further spreading of contaminated soil. ${ }^{\mathrm{P} 53}$ In the 1970 s, soil was excavated from the lip area beside the asphalt pad. $^{\mathrm{P} 090}$

Common chemicals used for decontamination activities include 1,1,1-trichloroethane, trichloroethene, and paint thinner for cleaning, and methylene chloride for paint removal. ${ }^{\text {P023,P053,P083,P114 }}$ Solvents such as carbon tetrachloride, tetrachloroethene, 1,1,1-trichloroethane, and trichloroethene were common solvents used during plutonium operations. These solvents were used in large quantities and may be present in the waste. ${ }^{\text {P023,P053 }}$ Solvent and non-solvent contaminated wastes were not segregted. ${ }^{\mathrm{P} 114}$ 
Information regarding metal contaminants in the waste is extremely limited. Soil and cleanup debris generated in Buildings 374 and 774 may be contaminated with sludge from liquid waste treatment operations. These sludges contain toxic metals (a detailed description of the sludge waste is provided in Sections 22.0 and 23.0). Mercury was used in instruments such as barometers, thermometers, plant machinery, and mercury switches. ${ }^{\text {P053 }}$ Lead-based paint is another source of metal contamination. The waste may include demolished floors and walls that were painted with lead-based paint.

Benzene was reportedly used in a tank in Building 777 for ultrasonic testing of components. The tank, which was used until 1975 , periodically leaked. ${ }^{\text {P0s3 }}$

\subsection{Waste Packaging}

Packaging of blacktop, concrete, dirt, and sand waste (IDC 374) varied depending on the wastegenerating area. The waste may be single- or double-bagged in PVC and/or polyethylene plastic bags, in FibrePaks, or placed directly into prepared 55-gallon drums. ${ }^{\mathrm{P} 24}$

Depending on waste packaging requirements at the time, several combinations of bags and liners were used to prepare 55-gallon drums for shipment. From 1970 to 1972, waste drums were lined with one or two polyethylene drum bags. Cardboard liners might have been used to line the inner drum bag. Use of 90-mil rigid polyethylene liners began in $1972 .{ }^{\text {P024 }}$ A rigid liner was placed in each drum and lined with one polyethylene round bottom drum liner or two polyethylene drum bags. ${ }^{\text {P008,P012,P016,P024,P064 A PVC O-ring bag }}$ and a polyethylene bag placed inside the rigid liner was used if the drum was attached to a glovebox. ${ }^{\mathrm{P} 016} \mathrm{~A}$ fiberboard liner and discs may also have been used between the waste and the drum liners for puncture protection. ${ }^{\mathrm{P} 008, \mathrm{P} 012, \mathrm{P016}, \mathrm{P064}}$ When a drum was full, the drum liners were twisted and taped closed, the lid was secured with a bolted ring, and a tamper indicating device was attached to the drum. ${ }^{\mathrm{P} 12, \mathrm{P} 024}$

After drums were inspected, one to two quarts of absorbent material (Oil-Dri) was placed on top of the outer, sealed polyethylene drum bag. This procedure was changed in February 1982 when vermiculite was used to fill the space between the outer, sealed polyethylene drum bag and the top of the 90 -mil rigid liner. The quantity of vermiculite varied from 3-12 pounds according to the amount of waste contained in each drum. ${ }^{\mathrm{P} 024}$

\subsection{Waste Characterization}

Blacktop, concrete, dirt, and sand are characterized based on knowledge of the material, knowledge of the processes generating the waste, general chemical usage at Rocky Flats, and headspace gas analysis. This section provides a RCRA hazardous waste determination for blacktop, concrete, dirt, and sand as well as radionuclide contaminants and potential complexing agents contained in the waste. This waste is at least 50 percent (by volume) materials that meet the EPA LDR criteria for classification as debris, and is classified as a heterogeneous waste. ${ }^{\mathrm{P} 141}$

\subsubsection{Hazardous Waste Determination}

The material in this waste group does not qualify for any of the exclusions outlined in 40 CFR 260 or 261. The waste may exhibit the characteristic of toxicity for arsenic, barium, cadmium, chromium, lead, mercury, selenium, silver, and benzene. The waste may have been mixed with halogenated- and nonhalogenated-solvents, and is therefore a F-listed hazardous waste. There is no evidence that blacktop, 
concrete, dirt, and sand exhibit any other characteristic of hazardous waste. EPA Hazardous Waste Numbers applicable to some or all of this waste group are presented by IDC in Table 8-2. These conclusions are supported by the evaluation in Sections 8.3.1.1 and 8.3.1.2.

Table 8-2. Blacktop, Concrete, Dirt, and Sand Waste Characterization.

\begin{tabular}{ccc}
\hline IDC & Title & \multicolumn{1}{c}{ EPA Hazardous Waste Numbers } \\
\hline 374 & Blacktop, Concrete, Dirt, and Sand & $\begin{array}{l}\text { D004-D011, D018, F001, F002, F003, F005, F006, } \\
\text { F007, and F009 }\end{array}$ \\
\hline
\end{tabular}

\subsubsection{Characteristic Waste.}

The materials in this waste group may exhibit a characteristic of hazardous waste as defined in 40 CFR 261, Subpart $C$ as as a toxic waste (40 CFR 261.24). The materials do not exhibit the characteristics of ignitability (40 CFR 261.21), corrosivity (40 CFR 261.22), or reactivity (40 CFR 261.23).

Ignitability: The materials in this waste group do not meet the definition of ignitability as defined in 40 CFR 261.21. The material is not a liquid, and liquids were prohibited by procedural control from being placed in the drums. The material is not capable of causing fire through friction, absorption of moisture, or spontaneous chemical change. The material is not a compressed gas, and pressurized containers were prohibited by waste packaging procedures. ${ }^{\text {P012 }}$ The material is not a DOT oxidizer as defined in 49 CFR 173. The materials in this waste group are therefore not ignitable wastes (D001).

Corrosivity: The materials in this waste group do not meet the definition of corrosivity as defined in 40 CFR 261.22. The material is not a liquid, and corrosive liquids were prohibited by procedural control from being placed in the drums. ${ }^{\mathrm{P} 012}$ The materials in this waste group are therefore not corrosive wastes (D002).

Reactivity: The materials in this waste group do not meet the definition of reactivity as defined in 40 CFR 261.23. The materials are stable and will not undergo violent chemical change. The materials will not react violently with water, form potentially explosive mixtures with water, or generate toxic gases, vapors, or fumes when mixed with water. The materials do not contain sulfides and are not capable of detonation or explosive reaction. The materials are not forbidden explosives or Division 1.1, 1.2, or 1.3 (Class A or B) explosives as defined in 49 CFR 173 , nor do the drums contain explosive materials. ${ }^{\mathrm{P} 012, \mathrm{P} 024}$ Explosives were not handled or used around radioactive material. The waste may contain very small amounts of cyanide in wastewater treatment sludges from the treatment of electroplating wastes. However, the cyanide levels in the sludges are not expected to be sufficient to cause the sludge to be reactive. The materials in this waste group are therefore not reactive wastes (D003).

Toxicity: The materials in this waste group may meet the definition of toxicity as defined in 40 CFR 261:24. The toxicity characteristic contaminants fall into one of two categories: metals and organics. Organic compounds include halogenated- and nonhalogenated-solvents, pesticides, herbicides, and other toxic compounds. This waste group may exhibit the characteristic of toxicity for arsenic, barium, cadmium, chromium, lead, mercury, selenium, and silver metals, as well as benzene. 
Possible sources of toxic metals in soil and cleanup debris waste include Buildings 374 and 774 sludges, mercury containing instruments, and lead-based paint. Because specific information regarding chemical contaminants in the waste is limited, it is possible that toxic metals could be present in the waste from unidentified sources. Therefore, the materials in this waste group are assigned EPA Hazardous Waste Numbers D004-D011 since a representative sample of this waste cannot be obtained for verification purposes.

Soil and debris waste from Building 777 may exhibit the characteristic of toxicity for benzene due to cleanup of the periodic leakage of the tank used for ultrasonic testing. The waste is not a F-listed waste for benzene because it was not used for its solvent properties. Therefore, the materials in this waste group are assigned EPA Hazardous Waste Number D018 since a representative sample of this waste cannot be obtained for verification purposes.

Tetrachloroethene, trichloroethene, and carbon tetrachloride were commonly used solvents. ${ }^{\mathrm{P}}{ }^{23}$ Soil and debris could potentially be contaminated with these solvents. Since these compounds were typically used as solvents, the waste is regulated as a listed hazardous waste and not a characteristic waste because these compounds are specifically addressed in the treatment standards for the listed hazardous waste. ${ }^{\text {POBO }}$ Since blacktop, concrete, dirt, and sand are characterized as listed hazardous wastes due to spent solvent contamination, the waste is not a toxic waste due to the presence of these organic compounds.

\subsubsection{Listed hazardous waste.}

The material in this waste group may have been mixed with a waste listed in 40 CFR 261, Subpart $D$ as a hazardous waste from non-specific sources (40 CFR 261.31). The waste is not, or was not mixed with, a hazardous waste from specific sources (40 CFR 261.32), or a discarded commercial chemical product, an off-specification species, a container residue, or a spill residue thereof (40 CFR 261.33).

Solvents such as carbon tetrachloride, tetrachloroethene, 1,1,1-trichloroethane, trichloroethene, and methylene chloride may be present in soil and debris waste as a result of being used for decontamination and decommissioning operations. The waste may also be contaminated with these compounds from spill cleanup. Therefore, the materials in this waste group are assigned EPA Hazardous Waste Numbers F001 and F002.

Soil and debris from cleanup of the 903 Pad may be contaminated with acetone. Because specific information regarding chemical contaminants in the waste is limited, it is possible that other F003-listed solvents could be present in the waste from unidentified sources. Therefore, the materials in this waste group are assigned EPA Hazardous Waste Number F003.

There is no documentation indicating the presence or use of F004-listed solvents in the areas or processes generating blacktop, concrete, dirt, and sand. Therefore, this waste group is not a F004-listed hazardous waste.

Toluene and methyl ethyl ketone were common components of paint and lacquer thinners which were commonly used for cleaning. The waste may also be contaminated with these compounds from spill cleanup. Therefore, the materials in this waste group are assigned EPA Hazardous Waste Number F005.

Headspace analysis performed on samples of blacktop, concrete, dirt, and sand obtained at INEEL confirms the presence of F-listed solvents. The detected F-listed compounds in which the 90 percent UCL is above the PRQL are provided: ${ }^{\mathrm{P} 033}$ 


1,1,1-trichloroethane
- $\quad$ carbon tetrachloride
- toluene
trichloroethene

Aqueous waste treatment operations in Buildings 374 and 774 treated spent stripping, cleaning, and plating solutions from Building 444 electroplating operations. Blacktop, concrete, dirt, and sand may be contaminated with wastewater treatment sludges from spill cleanup or construction activities, and therefore are assigned EPA Hazardous Waste Numbers F006, F007, and F009.

The material in this waste group is not a hazardous waste from specific sources since it was not generated from any of the processes listed in 40 CFR 261.32. The material in this waste group is therefore not a K-listed hazardous waste.

The material in this waste group is not a discarded commercial chemical product, an off-specification species, a container residue, or a spill residue thereof (40 CFR 261.33). It is uncertain if the waste was generated from cleanup of a commercial chemical product spill. However, it is highly unlikely that the cleanup of a commercial chemical product would result in the generation of TRU waste. Therefore, the material in this waste group is not a P-or U-listed hazardous waste.

\subsubsection{Radionuclides}

This section identifies the radioisotopes potentially contained in the waste. In addition, Table 8-3 summarizes matrix and other physical parameters which could affect radioassay. The primary radionuclides processed at Rocky Flats included weapons-grade plutonium, americium-241, enriched uranium, and depleted uranium. The isotopic compositions of weapons-grade plutonium, enriched uranium, and depleted uranium are specified in Section 3.0.

About half of the IDC 374 was generated in Building 777 (prefixes 04, 23, and 24) and Building 771 (prefix 02). ${ }^{\text {vos9 }}$ Building 777 disassembled site-return parts and conducted fabrication operations, including machining, briquetting, and assembly. The waste from this area could be contaminated with weapons-grade plutonium and enriched uranium. ${ }^{\mathrm{Cl} 84, \mathrm{PO} 22_{2} \mathrm{P} 079}$ The feed materials to the Building 771 recovery and purification processes were impure plutonium residues which were processed to produce plutonium metal for use in the foundry and, therefore, wastes generated will be contaminated primarily with weapons-grade plutonium. ${ }^{\text {P052,P163 }}$ Other areas generating IDC 374 are identified below along with the potential radionuclides expected in the waste:

- Weapons-grade plutonium and americium-241 from electrorefining and aqueous recovery areas in Building 371. ${ }^{\mathrm{C} 184, \mathrm{P} 164}$

- Weapons-grade plutonium, americium-241, and enriched and depleted uranium from the analytical and chemical standards laboratories in Buildings 371 and 559. ${ }^{\mathrm{P} 53, \mathrm{PO} 01}$

- Liquids containing weapons-grade plutonium, americium-241, and enriched and depleted uranium were treated in Buildings 374 and $774{ }^{\text {P164 }}$

- Weapons-grade plutonium from Building 707 foundry, casting, and final assembly operations ${ }^{\text {P053 }}$ 
- Weapons-grade plutonium, americium-241, enriched and depleted uranium, uranium-233, neptunium237, and plutonium-242 were processed during research and development activities in Buildings 771 and $779 .{ }^{C 171, C 185, P 164, P 198}$

- Weapons-grade plutonium and americium-241 from the Building 776 pyrochemical operations area. ${ }^{\mathrm{P} 78, \mathrm{P} 163}$

- Weapons-grade plutonium from the pilot-scale fluidized-bed incinerator in Building $776{ }^{\mathrm{P} 024}$

- Weapons-grade plutonium from Building 779 hydriding operations. ${ }^{\text {P164 }}$

In addition, the Size Reduction Vault (SRV) in Building 776 conducted solid waste treatment, repackaging, and size reduction operations. The SRV was divided into two sides. One side was the airlock (prefixes 25, 40,41, and 57) where repackaging was done. The other side (prefixes 19 and 26) was a drybox atmosphere where size reduction and solid waste treatment activities took place. ${ }^{\mathrm{C175,C184,P067,0059} \text { The repacked }}$ containers have the potential to contain contaminated materials from any of the processes within the transuranic waste generating buildings. ${ }^{\mathrm{P} 67, \mathrm{P} 078}$

Table 8-3. Waste Matrix Evaluation.

\begin{tabular}{|c|c|}
\hline Parameter & Results of Evaluation \\
\hline $\begin{array}{l}\text { Radionuclide Form, } \\
\text { Particle Size, and } \\
\text { Distribution }\end{array}$ & $\begin{array}{l}\text { The form of radionuclide contaminants will depend on the process from which } \\
\text { the waste originated. Actinide contaminants from Building } 777 \text { may be in } \\
\text { metal or oxide form. }{ }^{\text {P079 }} \text { For waste generated in Building } 771 \text {, the forms may } \\
\text { include plutonium nitrate, plutonium chloride, plutonium peroxide, plutonium } \\
\text { dioxide, plutonium tetrafluoride, and plutonium metal. }{ }^{\mathrm{P} 163} \text { The forms in } \\
\text { Building } 771 \text { represent almost every actinide form that will be found from } \\
\text { waste generated in other buildings. }\end{array}$ \\
\hline Hydrogen Content & $\begin{array}{l}\text { The primary source of hydrogen will be from the plastic packaging materials } \\
\text { (see Section } 8.3 \text { ). Headspace gas analysis indicates hydrogen content of less } \\
\text { than } 0.5 \text { vol\% and only trace quantities of hydrocarbons. }\end{array}$ \\
\hline $\begin{array}{l}\text { Other Interfering Waste } \\
\text { Contaminants }\end{array}$ & No other interfering waste contaminants were identified. \\
\hline $\begin{array}{l}\text { Physical Matrix } \\
\text { Parameters }\end{array}$ & $\begin{array}{l}\text { Void space and distribution of waste contaminants will vary widely due to the } \\
\text { heterogeneous nature of this waste. }\end{array}$ \\
\hline
\end{tabular}

\subsubsection{Complexing Agents}

Because complexing agents can aid in the transport of transuranic radionuclides from the waste after disposal, the waste was assessed for potential complexing agents. This information may also be added to the chemical compatibility studies since limited information was available on these chemicals in the past. 
EDTA represents a group of chelating compounds, such as ethenediaminetetraacetic acid, with similar molecular structures found in many soaps and detergents. Versene (a trade name for EDTA) and citric acid are known constituents of KW decontamination detergent. ${ }^{\text {P068 }}$ Blacktop, concrete, dirt, and sand could contain trace quantities of $\mathrm{KW}$ which was used during a variety of decontamination activities at the plant. 


\subsection{COMBUSTIBLES AND PLASTIC}

This waste group consists of combustibles and plastic generated by the production, recovery, laboratory, treatment, maintenance, and research and development activities associated with plutonium operations. The waste was generated in Buildings $371,374,559,707,771,774,776,777$, and 779. ${ }^{\text {P001,P012,P016 }}$ Historic IDC descriptions and dates of generation for the INEEL accessible storage inventory are presented by IDC in Table $9-1 .{ }^{\mathrm{P} 127}$

Table 9-1. Combustibles and Plastic Waste in the Accessible Storage Inventory.

\begin{tabular}{|c|c|c|}
\hline IDC & Title & Dates of Generation \\
\hline 330 & $\begin{array}{l}\text { Combustibles-Dry }{ }^{\mathrm{PO} 22} \\
\text { Paper and Rags-Dry }\end{array}$ & April 1972-April 1988 \\
\hline 336 & $\begin{array}{l}\text { Combustibles-Wet }{ }^{\mathrm{P} 032} \\
\text { Paper and Rags-Moist }\end{array}$ & January 1972-April 1988 \\
\hline 337 & $\begin{array}{l}\text { Plastics }^{\mathrm{P} 012} \\
\text { Plastics (Teflon, PVC, Poly, etc.) } \text { P }^{\mathrm{P} 32} \\
\text { Plastic (Teflon, PVC, etc.) and Nonleaded Rubber }{ }^{\mathrm{P} 24}\end{array}$ & November 1972-April 1987 \\
\hline
\end{tabular}

Item Description Code 330, Dry Combustibles: This waste consists of dry combustibles generated by the plutonium production, recovery, treatment, laboratory, and maintenance operations in Buildings 371 , $374,559,707,771,774,776,777$, and 779 . $^{\text {P012 }}$ Dry combustibles consist primarily of cloth, paper, and wood wastes including items such as wipes, towels, rags, coveralls, booties, gloves, and wood filter frames. Dry combustibles may contain up to 50 percent plastic and 10 percent of other waste items including metal, glass, and leaded gloves. Dry combustibles may be contaminated with any of the solvents, acids, bases, and other reagents used in the processes from which they were generated. ${ }^{\text {P001,P024,P032,P052 }}$

Item Description Code 336, Wet Combustibles: This waste consists of wet combustibles generated by the plutonium production, recovery, treatment, laboratory, and maintenance operations in Buildings 371 , $374,559,707,771,774,776,777$, and 779 . $^{\mathrm{P} 012}$ Wet combustibles consist primarily of cloth, paper, and wood wastes including items such as wipes, towels, rags, coveralls, booties, gloves, and wood filter frames. Wet combustibles contained discernable amounts of process liquids. Wet combustibles may contain up to 50 percent plastic and 10 percent of other waste items including metal, glass, and leaded gloves. Wet combustibles may be contaminated with any of the solvents, acids, bases, and other reagents used in the processes from which they were generated. ${ }^{\mathrm{P} 001, \mathrm{P} 024, \mathrm{P} 032, \mathrm{P} 052}$

Item Description Code 337, Plastics: This waste consists of plastics generated by the plutonium production, recovery, treatment, laboratory, and maintenance operations in Buildings $371,374,559,707,771$, $774,776,777$, and 779 . $^{\mathrm{P} 12}$ Plastics consist primarily of polypropylene, polyethylene, polyvinyl chloride, Teflon, Hypalon, Tygon, rubber, and latex items including respirator parts, supplied air suits, filters, hoses, nonleaded glovebox gloves, surgeons gloves, bags, tape, and sheeting. Plastics may contain up to 10 percent of other waste items including combustibles, metal, glass, and leaded gloves. Plastics may be contaminated 
with any of the solvents, acids, bases, and other reagents used in the processes from which they were generated. ${ }^{\mathrm{P} 001, \mathrm{P} 024, \mathrm{P} 032, \mathrm{P} 052}$

\subsection{Waste Generation}

Combustibles and plastic were generated by production, recovery, purification, laboratory, treatment, maintenance, and research and development activities associated with plutonium operations at the site.

\subsubsection{Plutonium Production}

Plutonium production consisted of operations directly associated with the manufacturing of plutonium metal parts including casting, rolling, forming, machining, and assembly processes. Buildings 707 and 777 were the primary weapons components production facilities at the site after the construction of Building 707 in 1972. Building 707 was constructed after the 1969 fire in Building 776 which shut down foundry and machining operations in that building. ${ }^{\text {P053 }}$

The foundry in Building 707 cast molten plutonium into classified components, subassemblies, and assemblies. Other parts were manufactured by rolling, forming, and machining plutonium ingots also cast in the foundry. Components were assembled using a number of welding and joining techniques in Buildings 707 , 777, and 779. Production support operations in Buildings 707 and 777 included a variety of inspection, calibration, measurement, weighing, leak testing, and cleaning activities to assure that the parts met stringent specifications. Rejected plutonium parts, scraps, and turnings were returned to be recast. Small pieces of metal, fines, and sweepings were typically burned to oxide and sent to Building 771 to be recovered. P052, P053

Halogenated solvents were used in production operations to clean and degrease plutonium parts and metal. In addition, the solvents were used with cutting oils to cool plutonium parts during machining. Carbon tetrachloride, tetrachloroethene, 1,1,1-trichloroethane, 1,1,2-trichloro-1,2,2-trifluoroethane, trichloroethene, and methylene chloride were the primary solvents historically used during plutonium production. Tetrachloroethene was replaced by 1,1,1-trichloroethane for degreasing during the 1973 time frame. Several non-halogenated solvents were also used for cleaning and degreasing, primarily during efforts to reduce use of halogenated solvents. ${ }^{\mathrm{P} 23, \mathrm{P} 052}$ These solvents included isopropyl alcohol, ethanol, and acetone. ${ }^{\text {P052, P067, P053 }}$ Building 777 housed the carbon tetrachloride and 1,1,1-trichloroethane systems that collected and filtered solvents generated during production operations. In addition to parts cleaning and degreasing, solvents were also used to clean plutonium operation glovebox lines. ${ }^{\text {P053 }}$

\subsubsection{Plutonium Recovery and Purification}

Several operations at the plant were responsible for either the purification of non-specification plutonium metal or the recovery of plutonium from production waste and residues. Building 771 housed operations that recovered plutonium from waste materials and other sources. ${ }^{\text {P053 }}$ Plutonium purification was performed primarily in Buildings $371,771,776$, and $779 .{ }^{P 052}$

Recovery operations in Building 771 used acid to dissolve solid materials containing plutonium. The resulting solutions were processed by a series of ion exchange, precipitation, calcination, fluorination, and reduction operations to produce purified plutonium metal to be recycled back into production operations. 
Potassium hydroxide, potassium fluoride, hydrogen peroxide, and nitric, hydrochloric, and hydrofluoric acids were the primary reagents used for plutonium recovery operations. ${ }^{\mathrm{P} 053, \mathrm{P} 061, \mathrm{P} 067, \mathrm{P} 083, \mathrm{U} 047}$

Plutonium metal from returned parts and metal from other DOE facilities was purified at Rocky Flats. Plutonium-241 decays to americium-241 which decreases the effectiveness of the plutonium parts. Plutonium parts were disassembled in Building 777. ${ }^{\text {P053,P113 }}$ Beginning in 1967, the molten salt extraction (MSE) process in Building 776 recovered americium from plutonium metal using sodium chloride, potassium chloride, and magnesium chloride. ${ }^{\mathrm{P} 53}$ Americium was separated from the MSE residue salts using potassium hydroxide precipitation followed by an ammonium thiocyanate anion exchange process. In 1975, the process changed to cation exchange followed by anion exchange (no thiocyanate) and then precipitation using oxalic acid. ${ }^{\text {P113, U047 }}$ The process changed again the following year to the salt scrub process which used a magnesium/zinc or a magnesium/aluminum extractant. ${ }^{\mathrm{U} 047}$ The purified plutonium metal from MSE was either sent to the foundry in Building 707 or sent to the electrorefining (ER) process in Building 371 or Building 776 if the metal contained other impurities. ${ }^{\text {P053, U047 }}$

Spray leaching (Building 771) and hydride leaching (Building 779) also used acids to remove plutonium surface contamination from uranium metal and other metals or beryllium contamination from plutonium metal. These processes used nitric, hydrochloric, sulfuric, and sulfamic acids. ${ }^{\mathrm{P} 03, \mathrm{P} 061, \mathrm{P} 062}$

\subsubsection{Laboratory}

Buildings 371,559 , and 771 housed the main analytical laboratories at the site. The laboratories' primary function was to provide analytical support to production activities in addition to supporting recovery, purification, and liquid waste treatment operations. Each of the laboratories used numerous acids, bases, solvents, and other chemical reagents.

Building 371 had an analytical laboratory and a chemical standards laboratory. The chemical standards laboratory prepared standards for various users and inspects standards that have been used in the field. The analytical laboratory analyzed samples from various operations on site. The types of analyses performed included: ${ }^{\mathrm{P} 81}$

$\begin{array}{ll}\text { - } & \text { Total Alpha Activity } \\ \text { - } & \text { Isotopic Analysis } \\ \text { - } & \text { X-Ray Emission } \\ & \text { X-Ray Diffraction }\end{array}$

Plutonium, Uranium, and Americium
Content
Corrosivity
- Ignitability

Building 559 housed the Plutonium Analytical Laboratory responsible for spectrochemical, chemical, and mass spectrometric analyses of samples from plutonium production operations. Uranium, Raschig rings, solutions, and commercial product and gas samples were also analyzed in the laboratory. Plutonium production samples, including metal and oxide, were prepared and subdivided for analysis in the sample cutting process. The types of analyses performed included: ${ }^{\mathrm{P} 067}$ 
$\begin{array}{ll}\text { - } & \text { Emission Spectroscopy } \\ \text { - } & \text { Atomic Absorption } \\ \text { - } & \text { Gallium Analysis } \\ \text { - } & \text { Plutonium Assay } \\ \text { - } & \text { Carbon Analysis } \\ \text { - } & \text { Uranium Analysis } \\ \text { Raschig Ring Analysis }\end{array}$
- Tritium Analyses

- Nonroutine Chemical Analysis

- Anion/Cation Solution Analysis

- Isotopic Analysis

- Thermal Analysis

- Gas Analysis

- $\quad$ Spark Source Mass Spectroscopy

- X-ray Analysis

Building 771 housed analytical and chemical standards laboratories. The chemical standards laboratory prepared control sample standards for the analytical laboratories in Buildings 371, 559, and 771 ${ }^{\mathrm{P} 061}$ The analytical laboratory provided analyses in support of plutonium operations. The types of analyses performed included. ${ }^{\mathrm{P} 66 \mathrm{I}, \mathrm{P0} 7}$

- X-Ray Fluorescence

- Alpha/Gamma Scintillation

- Atomic Absorption

- Laser Fluorimetry
- Spectrophotometry

- Calorimetry

- Gamma Spectroscopy

- Titrations

The laboratories used a variety of reagents and solvents including:

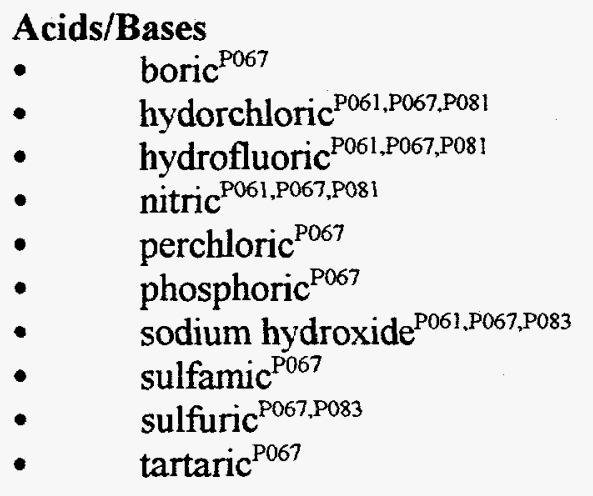

\section{Reagents}

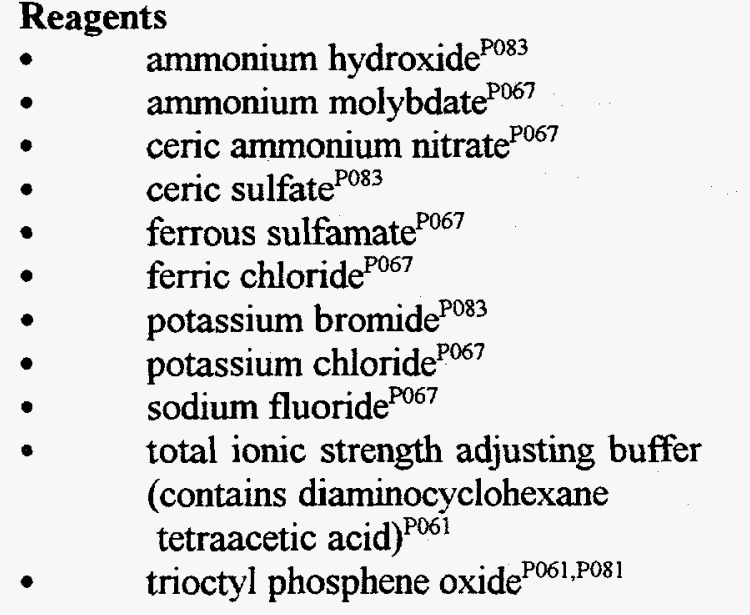

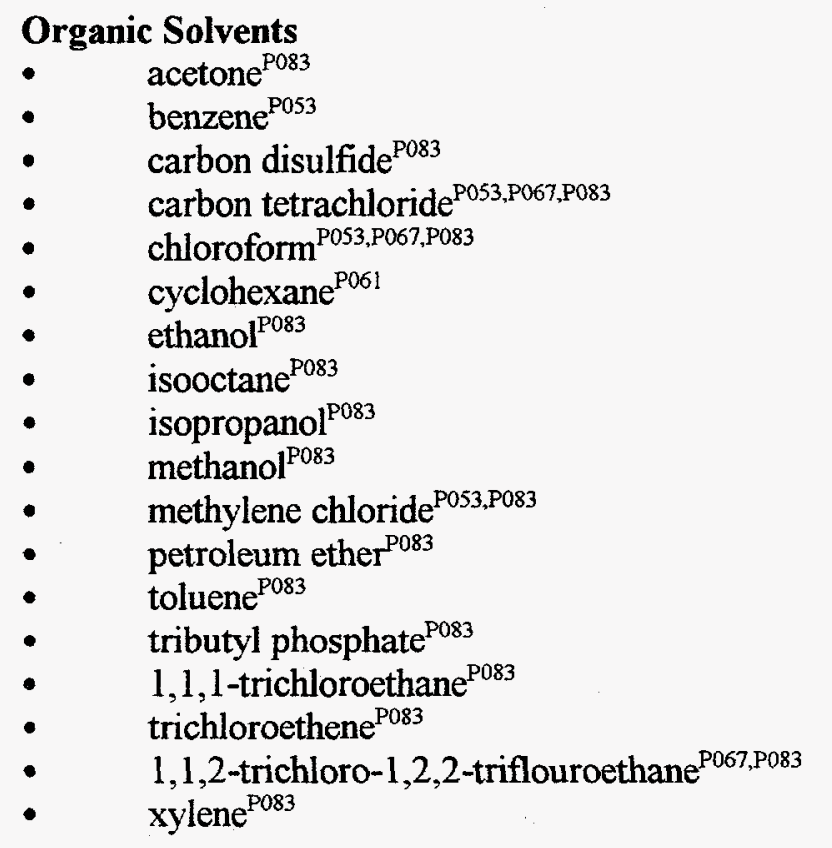




\subsubsection{Research and Development}

Research and Development (R\&D) included activities related to production, recovery, and purification as well as "special order" work. Building 779, which was built in 1965, housed much of the R\&D operations at the plant. Other areas at the plant supporting R\&D included Buildings 559, 771, 776, 777, and 881. ${ }^{\text {P053 }}$

The purpose of Building 779 was to gain more knowledge of the chemistry and metallurgy of plutonium and its interactions with other materials which might be used in plutonium operations. Other activities in Building 779 included developing improvements to the manufacturing process and finding new ways to recover plutonium and associated actinides. Another function was to develop a better understanding of the aging and shelf-life limitations of Rocky Flats products. Most of the materials used and wastes generated in this facility were the same as those in the production and recovery buildings, as much of the work conducted involved improvement of existing processes. ${ }^{P 053}$ However, processing of neptunium, curium, and cerium was also conducted. ${ }^{\mathrm{P} 053, \mathrm{U} 047}$

The plant conducted special order work for other facilities in the DOE complex, the DOD, or other federal departments or agencies. One example is the introduction of radionuclide tracers into pits destined for off-site test shots. This work took place in the 1960s and well into the 1970s. Materials such as americium240 , plutonium-238, neptunium, curium, and cerium were blended in with the regular component materials for the purpose of studying performance of the different weapon components based on post-test distribution of the rare tracers. These tracer materials were kept separate from the regular production material streams, and special recovery operations in Building 771 specialized in recovering these more exotic materials. ${ }^{\text {C072, P053 }}$

From approximately 1959 to the mid-1970s, Rocky Flats was involved in "Project Plowshare." The mission of the program was to develop technology for using nuclear explosives for peaceful applications such as excavation and uncovering of deep mineral deposits. Materials used in the manufacturing of these components were the same as those used in the production buildings. ${ }^{\text {P053 }}$

\subsubsection{Waste Treatment}

Waste processing at Rocky Flats has included both liquid and solid process wastes. Liquid waste treatment operations have had relatively few process changes over the years. When Building 774 was built in 1952 , its primary purpose was to treat radioactive aqueous waste from Building 771. Radionuclides were removed by precipitation, and the resulting slurry filtered. The solids removed from filters were combined with cement or other solidifying agents. The aqueous waste from this first stage goes through a second precipitation. ${ }^{\mathrm{P} 53}$ These processes used sodium hydroxide, ferric sulfate, magnesium sulfate, and calcium chloride. $^{\text {P109 }}$ See Section 23.0, Solidified Aqueous Sludge Building 774, for a detailed description of these processes.

Around 1965, an evaporator was installed in Building 774 to treat liquids from the second stage treatment and from the solar ponds. The concentrate from the evaporator was introduced into a steam-heated double-drum drier which produced a salt waste. The Building 774 evaporator was taken out in 1979 , and the liquids from the second stage treatment and solar ponds have since been transferred to Building 374 for additional treatment. ${ }^{\text {POS3 }}$

Building 774 also processed organic liquid wastes. Plutonium-contaminated organic liquids were generated from plutonium machining. ${ }^{\text {P053 }}$ The spent organic liquid was filtered and then mixed with a 
solidifying agent. The process was later changed to a one step process in which the organic liquid was mixed with Envirostone (Gypsum cement) and allowed to set up. ${ }^{\text {P109 }}$ See Section 25.0, Solidified Organic Waste for a detailed description of these processes.

Treatment of solid transuranic wastes was conducted in Buildings 771 and 776 . Building 771 processed wastes containing plutonium above the EDL while Building 776 processed wastes below the EDL.

Operations in Building 771 processed wastes including Raschig rings, HEPA filters, and sludges from the filter plenum and from process piping. Filters were disassembled to remove plutonium-contaminated dust. Process piping removed from service was cut up and cleaned of built-up sludge. Sludge from the process piping and from the filter plenum was dissolved in nitric acid to recover plutonium. Until 1984, plutonium was recovered from Raschig rings by nitric acid leaching. ${ }^{\mathrm{P} 06 \mathrm{l}}$

Size reduction in Building 776 removed materials from drums and sorted them in an airlock vault. Materials such as light metals, filters, glass, combustibles, and Raschig rings were then put into containers with like materials. Light metals and leaded gloves were washed in a ball mill. ${ }^{\text {P067 }}$

Advanced size reduction operations in Building 776 disassembled or cut plutonium-contaminated gloveboxes and miscellaneous large equipment into sizes that could be packaged in approved containers. ${ }^{P 110}$

The fluidized-bed incinerator in Building 776 received low-level plutonium-contaminated combustible solid and liquid wastes. ${ }^{\mathrm{P067}}$ Building 771 also housed an incinerator for processing combustible wastes. ${ }^{\text {P061,U047 }}$ See Section 14.0, Incinerator Waste, for a detailed description of the incineration processes.

\subsubsection{Routine Maintenance}

Routine maintenance at Rocky Flats included utilities; change-out of oils, coolants, filters, and Raschig rings; and other general maintenance activities.

Utility systems include HVAC systems, fume scrubbers, and process vacuum systems. The HVAC systems contain air supply units for filtering incoming air and plenums for filtering exhaust air. HVAC equipment was lubricated, generating waste oil and oily wipes. $\mathrm{KW}$ detergent was used for periodic maintenance inside and outside the plenums. Scrubbers housed in Buildings 371, 559, 771, and 779 used potassium or sodium hydroxide to neutralize acid fumes from various process off-gas streams and glovebox exhaust streams. Process vacuum systems provided an absolute pressure at a vacuum header which serves as a means to transfer fluids on demand by valving arrangements. ${ }^{\mathrm{P} 661, \mathrm{P} 067}$

Oils, coolants, filters, and Raschig rings were used in numerous processes and required periodic change out. During oil and coolant changes, wipes were generated from spill clean-up. During Raschig-ring removal, wipes, gloves, or other combustible materials may have been contaminated with oils, solvents, acids, or bases. Other general maintenance activities included repair or replacement of gloveboxes, tanks, valves, pumps, and pipes. $^{\text {P108,P061,P067,P109 }}$

\subsubsection{Non-Routine Operations}

Non-routine operations include spill clean up, strip-out operations, and activities associated with fires and other incidents. 
Occasionally, spills of various materials occurred due to leaks in tanks and piping or from material releases from gloveboxes. Tanks or pipes may have contained acids, bases, or solvents used during normal process operations. A paint stripper containing methylene chloride was often used for decontamination. Combustible and plastic wastes containing paint (possibly containing lead), paint stripping compound, and process solutions were generated from this type of activity. ${ }^{\text {P053,P067 }}$

Another nonroutine activity was the strip-out of glovebox lines, process piping, valves, and associated systems. Strip-out activities were performed when a glovebox line was scheduled to be replaced or during renovation. Solvents such as trichloroethene or 1,1,1-trichloroethane may have been used during this type of operation for decontamination. ${ }^{\mathrm{P} 67, \mathrm{P} 108}$

Other nonroutine activities, such as fires and other incidents, include:

- the 1969 fire which spread through combustible materials in several hundred inter-connected gloveboxes in Building 776/777; ${ }^{\text {P0s3 }}$

- the 1974 control valve release in Building 707 which allowed radioactive particulates to escape from an exhaust stack on the roof and into Module K.; ${ }^{\text {P0s3 }}$ and

- the tritium release in which tritium-contaminated plutonium was processed from April 9, 1973 through April 25, 1973 in Building 779 causing a tritium release to the atmosphere, as well as elevated tritium levels in surface waters, process wastes, equipment, gloveboxes, and exhaust plenums. ${ }^{\text {P053 }}$

\subsection{Waste Packaging}

Combustibles and plastic were double-bagged out of the glovebox or placed in polyethylene bottles and double-bagged out of the glovebox. ${ }^{\mathrm{P} 12}$

Depending on waste packaging requirements at the time, several combinations of bags and liners were used to prepare 55-gallon drums for shipment. From 1970 to 1972, waste drums were lined with one or two polyethylene drum bags. Cardboard liners might also have been used to line the inner drum bag. Use of the 90-mil rigid polyethylene liner began in 1972. ${ }^{\mathrm{P} 24}$ The rigid liner was placed in each drum and lined with one polyethylene round bottom drum liner or two polyethylene drum bags. ${ }^{\mathrm{P} 008, \mathrm{P} 012, \mathrm{P} 016, \mathrm{P} 024, \mathrm{P} 063 . \mathrm{P} 064}$ A polyvinyl chloride O-ring bag and a polyethylene bag were used if the drum was attached to the glovebox. ${ }^{\mathrm{PO} 16} \mathrm{~A}$ fiberboard liner and discs may also have been used between the waste packages and the drum liners. ${ }^{\mathrm{P} 008, \mathrm{P} 012, \mathrm{P} 016, \mathrm{P} 064}$ Lead drum liners were also used in some instances. ${ }^{\mathrm{P} 15, \mathrm{P} 024}$ When a drum was full, the drum liners were twisted and taped closed, the lid was secured with a bolted ring, and a tamper indicating device was attached to the drum. ${ }^{\mathrm{P} 12, \mathrm{P} 016, \mathrm{P} 024}$

After drums were inspected, one to two quarts of absorbent material (Oil-Dri) was placed on the top of the outer, sealed polyethylene drum bag. This procedure changed in February 1982 when vermiculite was used to fill the space between the outer, sealed polyethylene drum bag and the top of the 90 -mil rigid liner. The quantity of vermiculite varied from 3-12 pounds according to the amount of waste contained in each drum. ${ }^{\mathrm{P} 024}$

Waste management and inspection protocol allowed containers of wastes to contain up to 10 percent

of another IDC other than that assigned to the container. ${ }^{\mathrm{P} 016}$ Visual inspection of combustibles and plastic 
containers identified a variety of metal and glass items including Raschig rings, nails, cans, vials, bottles, lead sheeting, bolts, pipes, welding rods, batteries, tools, and wire. ${ }^{\mathrm{P} 15, \mathrm{P} 024}$

Wet combustibles were sorted from dry combustibles based on the criteria that wet combustibles contained a discernable amount of moisture. This definition was ambiguous and may have resulted in the misassignment of IDC 330 and IDC 336 in some cases. This observation is supported by inspections conducted on drums in inventory. Wastes assigned IDC 336 were found to be dry, while drums assigned IDC 330 were found to be wet or contain free liquids. ${ }^{\text {POos,P015 }}$

\subsection{Waste Characterization}

Combustibles and plastic are characterized based on knowledge of the material, knowledge of the processes generating the waste, RTR review of the waste, visual inspection, and headspace gas analysis. This section provides a RCRA hazardous waste determination for combustibles and plastic as well as radionuclide contaminants and potential complexing agents contained in the waste. This waste contains at least 50 percent (by volume) materials that meet the EPA LDR criteria for classification as debris, and is therefore a heterogeneous waste. ${ }^{\mathrm{P} 141}$

\subsubsection{Hazardous Waste Determination}

The material in this waste group does not qualify for any of the exclusions outlined in 40 CFR 260 or 261. The waste may exhibit the characteristics of ignitability due to cellulosic materials contaminated with nitrate salts, and corrosivity from the presence of corrosive free liquids. The waste may also exhibit the characteristic of toxicity for cadmium, chromium, lead, silver, and chloroform. The waste was mixed with halogenated- and nonhalogenated-solvents and electroplating wastes, and is therefore a F-listed hazardous waste. There is no evidence that combustibles and plastic exhibit any other characteristic of hazardous waste. ${ }^{\mathrm{C} 78}$ IDCs 330,336 , and 337 have been assessed as a single population due to the considerable amount of mixing of combustibles and plastic wastes. EPA Hazardous Waste Numbers applicable to some or all of the combustibles and plastic waste group are presented by IDC in Table 9-2. ${ }^{\text {P127 }}$ These conclusions are supported by the evaluation in Sections 9.3.1.1 and 9.3.1.2.

Table 9-2. Combustibles and Plastic Waste Characterization.

\begin{tabular}{lll}
\hline IDC & Title & \multicolumn{1}{c}{ EPA Hazardous Waste Numbers } \\
\hline 330 & Dry Combustibles & D001, D002, D006-D008, D011, D022, \\
& & F001-F003, F005-F007, and F009 \\
336 & Wet Combustibles & D001, D002, D006-D008, D011, D022, \\
& & F001-F003, F005-F007, and F009 \\
337 Plastic & D001, D002, D006-D008, D011, D022, \\
& F001-F003, F005-F007, and F009 \\
\hline
\end{tabular}




\subsubsection{Characteristic Waste}

The materials in this waste group may exhibit a characteristic of hazardous waste as defined in 40 CFR 261, Subpart C, as an ignitable waste (40 CFR 261.21), as a corrosive waste (40 CFR 261.22), and as a toxic waste ( 40 CFR 261.24). The materials do not exhibit the characteristic of reactivity (40 CFR 261.23). The origin of the characteristic hazardous waste numbers assigned to combustibles and plastic is provided in Table 9-3. The table includes only the hazardous waste numbers that are applicable to waste for which a specific source or time period was identified. The hazardous waste numbers are not applicable to waste generated from areas other than those listed in the table, or from those specific areas but during a different period of time.

Table 9-3. Origin of Characteristic Hazardous Waste Numbers.

\begin{tabular}{cll}
\hline IDC & \multicolumn{1}{c}{ EPA Hazardous Waste Numbers } & \multicolumn{1}{c}{ Areas or Dates of Generation } \\
\hline 330 & D001 and D002 & Waste generated before 1974 \\
& D006, D007, and D011 & Building 774 \\
& D022 & Analytical Laboratories-Buildings 371,559 , and 771 \\
336 & D001 and D002 & Waste generated before 1974 \\
& D006, D007, and D011 & Building 774 \\
& D022 & Analytical Laboratories-Buildings 371,559, and 771 \\
337 & D001 and D002 & Waste generated before 1974 \\
& D006, D007, and D011 & Building 774 \\
& D022 & Analytical Laboratories-Buildings 371,559, and 771 \\
\hline
\end{tabular}

Ignitability: The materials in this waste group meet the definition of ignitability as defined in 40 CFR 261.21 due to nitrate salt contamination. The materials are not liquid, and packaging procedures prohibited the addition of liquids to the containers. ${ }^{\mathrm{P} 016}$ In addition, absorbents were added to wastes having the potential of generating free liquids (i.e., wet combustibles or plastic bottles containing liquid) ${ }^{\mathrm{P} 12, \mathrm{P} 015, \mathrm{P} 024}$ Free liquids were identified in drums of combustibles and plastic (IDCs 330, 336, and 337); however, analysis of the liquids indicated that they were not ignitable. ${ }^{\mathrm{P} 15}$ The materials are not compressed gases, nor does the waste contain compressed gases. ${ }^{\mathrm{P} 012, \mathrm{P} 014, \mathrm{P} 015, \mathrm{P} 024}$ The materials are not capable of causing fire through friction or absorption of moisture. ${ }^{\mathrm{P} 012 \mathrm{P} 024}$ Prior to 1974 , nitric acid was not rinsed from combustibles prior to removal from the glovebox and a risk of spontaneous combustion has been identified. ${ }^{\mathrm{C} 76, \mathrm{P} 024, \mathrm{U} 060}$ Plastic (IDC 337) drums generated prior to 1974 may contain combustible wastes contaminated with nitrate salts. Therefore, EPA Hazardous Waste Number D001 is applicable to combustibles and plastic generated before 1974. ${ }^{\text {Ua60 }}$

Corrosivity: The materials in this waste group meet the definition of corrosivity as defined in 40 CFR 261.22 due to the presence of acidic or caustic solutions. The materials in this waste group are not liquid, and packaging procedures prohibited the addition of liquids to the containers. ${ }^{\mathrm{P} 16}$ In addition, absorbents were added to wastes having the potential of generating free liquids. ${ }^{\mathrm{P} 12, \mathrm{P} 015, \mathrm{P} 024}$ Free liquids were identified in drums of combustibles and plastic (IDCs 330, 336, and 337). Analysis of the liquids indicated $\mathrm{pH}$ values from 
5 to 12 which are not corrosive by definition. ${ }^{\mathrm{P} 15, \mathrm{U} 060}$ However, since combustibles were not rinsed prior to disposal before 1974, it is possible that any identified free liquids could have a $\mathrm{pH}$ less than 2.0 or greater than 12.5. Additionally, because free liquids were found in drums of plastics (IDC 337) as well, this IDC generated prior to 1974 may also contain corrosive free liquids. Therefore, EPA Hazardous Waste Number D002 is applicable to combustibles and plastic generated before $1974 .^{\mathrm{U} 060}$

Reactivity: The materials in this waste group do not meet the definition of reactivity as defined in 40 CFR 261.23. The materials are stable and will not undergo violent chemical change. The materials will not react violently with water, form potentially explosive mixtures with water, or generate toxic gases, vapors, or fumes when mixed with water. The materials do not contain cyanides or sulfides, and are not capable of detonation or explosive reaction. The materials are not forbidden explosives or Division 1.1, 1.2, or 1.3 (Class A or B) explosives as defined in 49 CFR 173, nor do the drums contain explosive materials. ${ }^{\mathrm{P} 012, \mathrm{P} 015, \mathrm{P} 024}$ Explosives were not handled or used around radioactive material. The materials in this waste group are therefore not reactive wastes (D003).

Toxicity: The materials in this waste group meet the definition of toxicity as defined in 40 CFR 261.24. The toxicity characteristic contaminants fall into one of two categories: metals and organics. Organic compounds include halogenated- and nonhalogenated-solvents, pesticides, herbicides, and other toxic compounds. This waste group may exhibit the characteristic of toxicity for cadmium, chromium, lead, and silver metals, and chloroform.

RTR has identified drums of combustibles and plastic waste containing lead items. Visual inspection of the waste revealed lead items such as glovebox gloves, tape, and sheeting. ${ }^{\mathrm{P} 15}$ Combustibles and plastic wastes from Building $\mathbf{7 7 4}$ may be contaminated with liquids or sludges containing cadmium, chromium, and silver from liquid waste treatment operations. ${ }^{\mathrm{C} 79}$ Combustibles and plastic may exhibit the characteristic of toxicity for these metals. Therefore, the materials in this waste group are assigned EPA Hazardous Waste Numbers D006, D007, D008, and D011 since a representative sample of this waste cannot be obtained for verification purposes.

There is no documentation indicating the presence or use of pesticides or herbicides in the areas or processes generating combustibles and plastic. Therefore, this waste group does not exhibit the characteristic of toxicity due to pesticides or herbicides (D012-D017).

Chloroform was used in laboratory operations and may be contained on combustibles and

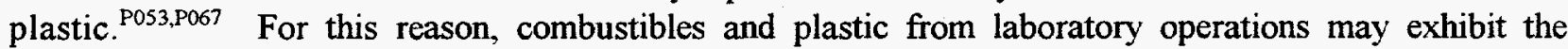
characteristic of toxicity for this compound. Therefore, combustibles and plastic from the laboratories are assigned EPA Hazardous Waste Number D022 since a representative sample of this waste cannot be obtained for verification purposes.

Carbon tetrachloride, tetrachloroethene, and trichloroethene were used for cleaning and degreasing. Benzene was used in laboratory analysis. Since these compounds were typically used as solvents, the waste is regulated as a listed hazardous waste and not a characteristic waste because these compounds are specifically addressed in the treatment standards for the listed hazardous waste ${ }^{\mathrm{P} 80}$ Since combustibles and plastic are characterized as listed hazardous wastes due to spent solvent contamination, the waste is not a toxic waste due to the presence of these organic compounds. 


\title{
9.3.1.2 Listed Hazardous Waste
}

The material in this waste group is a listed hazardous waste because it was mixed with a waste listed in 40 CFR 261, Subpart $D$ as a hazardous waste from non-specific sources (40 CFR 261.31). The material is not, or was not mixed with, a hazardous waste from specific sources (40 CFR 261.32), or a discarded commercial chemical product, an off-specification species, a container residue, or a spill residue thereof (40 CFR 261.33).

Tetrachloroethene, trichloroethene, methylene chloride, 1,1,1-trichloroethane, carbon tetrachloride, and 1,1,2-trichloro-1,2,2-trifluoroethane were used primarily in production, laboratory, and maintenance operations. Combustibles and plastic were mixed with these compounds, and are therefore assigned EPA Hazardous Waste Numbers F001 and F002.

Acetone, methanol, and xylene were used primarily in laboratory operations. Acetone may also have been used during production operations. Combustibles and plastic were mixed with these compounds, and are therefore assigned EPA Hazardous Waste Number F003.

There is no documentation indicating the presence or use of F004-listed solvents in the areas or processes generating combustibles and plastic. Therefore, this waste group is not a F004-listed hazardous waste.

Benzene, carbon disulfide, and toluene were used primarily in laboratory operations. Combustibles and plastic from laboratory operations were mixed with these compounds, and are therefore assigned EPA Hazardous Waste Number F005.

Headspace analysis performed on samples of combustibles and plastic obtained at INEEL confirms the presence of F-listed solvents. The detected F-listed compounds in which the 90 percent UCL is above the PRQL are provided. ${ }^{\mathrm{P} 33}$

carbon tetrachloride (IDCs 330 and
336 only)
chloroform (IDCs 336 and 337 only)
methylene chloride (IDCs 330 and
336 only)
tetrachloroethene (IDC 336 only)

toluene (IDC 336 only) 1,1,1-trichloroethane trichloroethene 1,1,2-trichloro-1,2,2-trifluoroethane (IDCs 330 and 336 only)

Additional F-listed solvents were detected in headspace samples of combustibles and plastic obtained Rocky Flats. The detected F-listed compounds in which the 90 percent UCL is above the PRQL are also provided. ${ }^{\text {U030 }}$

\footnotetext{
- 1-butanol (IDC 330 only)

- $\quad$ carbon tetrachloride (IDC 337)

- $\quad$ ethyl benzene (IDC 330 only)
}

\author{
- $\quad$ toluene (IDCs 330 and 337) \\ - $\quad$ o-xylene (IDC 330 only)
}

Aqueous waste treatment operations in Buildings 374 and 774 treated spent stripping, cleaning, and plating solutions and sludges from Building 444 electroplating operations. Combustibles and plastic from these 
operations may have been mixed with the electroplating wastes, and therefore are assigned EPA Hazardous Waste Numbers F006, F007, and F009.

The material in this waste group is not a hazardous waste from specific sources since it was not generated from any of the processes listed in 40 CFR 261.32. The material in this waste group is therefore not a K-listed hazardous waste.

The material in this waste group is not a discarded commercial chemical product, an off-specification species, a container residue, or a spill residue thereof (40 CFR 261.33). The material in this waste group is therefore not a P- or U-listed hazardous waste.

\subsubsection{Radionuclides}

This section identifies the radioisotopes potentially contained in the waste, as well as the chemical form of radionuclide contaminants and radioassay interferences. The primary radionuclides processed at Rocky Flats included weapons-grade plutonium, americium-241, enriched uranium, and depleted uranium. The isotopic compositions of weapons-grade plutonium, enriched uranium, and depleted uranium are specified in Section 3.0. Wastes from some of the processes described below may not be contained in the inventory based on the assigned prefixes. However, as explained in Section 9.3.2.6, it is assumed that repackaged drums could contain waste generated from any process.

\subsubsection{Plutonium Production}

Radionuclide contamination in waste from Building 707 will primarily consist of weapons-grade

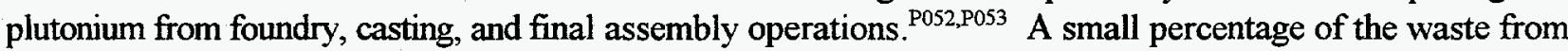
Building 707 may also contain americium-240, neptunium-237, and plutonium-238 from blending of these isotopes with weapons-grade plutonium for diagnostic tracers. ${ }^{\text {C171,C174,C184,C185,P053,P164,P167 }}$

Building 777 performed disassembly of site-return parts and fabrication operations including machining, briquetting, assembly, and production support processes (prefixes 04, 23, and 24). ${ }^{\text {C184,P052,U059,P079 }}$ Wastes from fabrication operations will be contaminated with weapons-grade plutonium and enriched uranium. Wastes generated by disassembly operations will be contaminated with site-return plutonium (higher americium-24l decay product) and enriched uranium. ${ }^{\text {C184,P079 }}$ Tritium may also be present from disassembly operations. $^{\text {P053 }}$

Buildings 707 and 777 handled actinides in metal or oxide form only. ${ }^{\mathrm{P} 060, \mathrm{P} 079}$ The actinide metals will likely have partially or completely oxidized because of the reaction with dry air, and some could possibly have formed a hydroxide layer from reaction with moist air. Radioassay interferences may include beryllium from Part V metal fabrication in Building 707, and calcium fluoride which was sprayed onto graphite molds in Building 707 prior to casting. ${ }^{\mathrm{Cl} 84, \mathrm{PO} 60}$ Other interfering waste contaminants include aluminum, beryllium, and stainless steel (chromium) which were machined in Building $777 .^{\text {P079 }}$

\subsubsection{Plutonium Recovery and Purification}

Waste from recovery operations in Building 371 will contain weapons-grade plutonium primarily from electrorefining. ${ }^{\text {C184.P067 }}$ A limited amount of the waste could also have been generated from aqueous recovery 
operations which only ran for a short time in 1982. Aqueous recovery operations were designed for recovering and purifying weapons-grade plutonium. ${ }^{\mathrm{C} 184, \mathrm{P} 164}$

The feed materials to the recovery and purification processes (prefixes 01 and 02 ) in Building 771 were impure plutonium residues which were processed to produce plutonium metal for use in the foundry and, therefore, wastes generated will be contaminated primarily with weapons-grade plutonium. ${ }^{\text {P052,P163,U059 }}$ Radionuclides from aqueous recovery operations will vary widely in chemical form depending on the specific process the waste originated, and because the majority of the aqueous processes were performed within one large MBA (prefixes 01 and 02), the specific process can not be determined. The different actinide forms are plutonium nitrate, plutonium chloride, plutonium peroxide, plutonium dioxide, plutonium tetrafluoride, and plutonium metal. Radioassay interferences may include aluminum nitrate from the dissolution process and beryllium which was removed during Part V leach. ${ }^{\text {P163 }}$

Wastes from the americium recovery glovebox lines (prefix 06) in Building 771, used for extraction of americium from site-return plutonium, will contain a significant amount of americium-241. ${ }^{\text {C184,P053,P164,U059 }}$ The americium was in a chloride, hydroxide, nitrate, oxalate, and oxide chemical form during different steps of the process. Prior to 1975 , ammonium thiocyanate was also used. ${ }^{\text {P053 }}$

The Oralloy leach process (prefix 74) in Building 771 chemically separated plutonium surface contamination from enriched uranium hemishells using nitric acid. The chemical form of the radionuclides will therefore be plutonium nitrate and uranyl nitrate. ${ }^{\mathrm{Cl} 84, \mathrm{P} 061, \mathrm{P} 163, \mathrm{U} 059}$

Wastes generated from Building 771 filter plenum maintenance were assigned prefix 09. ${ }^{\mathrm{C} 184, \mathrm{P} 052}$ It will be assumed that this waste could contain any of the radioisotopes processed in the building.

Site-return metal and other non-specification plutonium were processed by pyrochemical operations in Building 776 (prefix 03) to produce plutonium for use in the foundry. ${ }^{\mathrm{C} 184, \mathrm{P} 053, \mathrm{U} 059}$ The molten salt extraction process removed americium-24l from site-return and other non-specification plutonium. Electrorefining was used to purify plutonium metal that did not meet foundry specifications. Since metal was the feed and product to the MSE and electrorefining processes, wastes generated from these processes will be contaminated with actinide metals which now will probably have formed an oxide or hydroxide layer from reaction with dry and moist air. Direct oxide reduction was developed to convert plutonium dioxide to plutonium metal. ${ }^{\mathrm{P} 163, \mathrm{P} 175}$ MSE residue salts, which contain actinide chlorides, were the feed to the salt scrub process. Metal was the product of this process as well, so the radionuclide contaminants could be in a metal, oxide, and/or hydroxide form. Radioassay interferences may include chloride salts (i.e., sodium, potassium, magnesium, calcium, and zinc). ${ }^{\mathrm{P} 163}$

Hydride operations in Building 779 (prefix 55) recovered plutonium from various substrates by reacting plutonium metal with gaseous hydrogen in an argon-inerted glovebox. ${ }^{\text {P052,U059,P062,P163 }}$ Hydriding produced plutonium metal for use in the foundry or non-specification feed to pyrochemical operations, in addition to plutonium oxides sent for aqueous recovery. ${ }^{\mathrm{Cl} 44, \mathrm{P} 062}$ The hydriding process formed plutonium hydride which was converted to plutonium dioxide by oxidizing the material in an air atmosphere. ${ }^{\text {P163 }}$ 


\subsubsection{Laboratory}

The analytical laboratory in Building 371 (prefix 71) provided analytical support for process control and performed analyses on feed materials and residues from recovery operations in Building 371. ${ }^{\text {P053,U059,P081 }}$ The laboratory also analyzed samples from various operations at the site, but primarily from Building 374 . $^{\mathrm{P} 81}$ The Building 371 chemical standards laboratory prepared standards for various users and inspected standards that were used throughout plant site. ${ }^{\text {P053 }}$ Wastes from these laboratories will be contaminated with weaponsgrade plutonium and enriched and depleted uranium.

The Building 559 analytical laboratory (prefix 29) performed a variety of analyses, including plutonium, enriched and depleted uranium, americium, neptunium, and tritium content. ${ }^{\mathrm{P} 053, \mathrm{P} 067, \mathrm{P076,U059, \textrm {V } 0 7 3} \text { The }}$ primary mission of this laboratory was analysis of site-return and feed materials, in addition to recovery, purification, and foundry products. ${ }^{\mathrm{P} 03}$

The Building 771 analytical laboratory (prefix 37) received samples from recovery operations in the building as well as from the foundry. ${ }^{\mathrm{P} 067, \mathrm{U} 059}$ The samples included plutonium metal turnings, plutonium oxide, acidic plutonium solutions, and various process residues. ${ }^{\mathrm{P} 061}$ In addition, the analytical laboratory analyzed samples from R\&D laboratories in Buildings 771 and 779 (see Section 9.3.2.4). ${ }^{\text {P067,P061 The chemical standards }}$ laboratory (prefix 38) prepared uranium, plutonium, and americium nitrates used as control standards for the Buildings 371,559 , and 771 analytical laboratories. ${ }^{\mathrm{P} 67, \mathrm{P} 061}$ The laboratory also produced nondestructive assay standards used at drum counters and fluoride standards for chemical operations. ${ }^{\text {P061 }}$

The metallography laboratory (prefix 21) in Building 777 prepared and examined metallographic specimens in support of R\&D operations (plutonium metallography, nuclear and non-nuclear joining, quality engineering, and product physical chemistry) and, therefore, may contain any of the radionuclides used during R\&D activities (see Section 9.32.4). ${ }^{\text {C184,U059.P079 }}$ The Building 777 tritium surveillance laboratory analyzed solid, liquid, and gas samples from throughout the plant site for tritium content. ${ }^{\text {U078 }}$

Because the laboratories supported all phases of weapons production, the chemical form of the radionuclide contaminants and radioassay interferences will vary widely depending on the type of sample analyzed.

\subsubsection{Research and Development}

Projects using transuranic radionuclides were done in Buildings $771,776,777,779$, and 881 . Most of the documentation pertaining to R\&D activities does not specify locations in which the work was performed, and unless otherwise noted, it will be assumed that any of the radioisotopes could have been handled in the R\&D areas of any of these buildings. In addition to weapons-grade plutonium, americium-241, and enriched and depleted uranium, the following radioisotopes were processed during $R \& D$ activities: ${ }^{\mathrm{C} 134, \mathrm{C} 137, \mathrm{C} 185, \mathrm{P} 053, \mathrm{P} 164, \mathrm{P} 167, \mathrm{P} 189, \mathrm{P} 190, \mathrm{P} 194, \mathrm{P} 195, \mathrm{P} 198, \mathrm{P} 200, \mathrm{U} 064}$

- americium-240

- curium-244

- neptunium-237

- $\quad$ plutonium-238, $-240,-241$, and -242

- low NGS plutonium ( $\approx 3 \% \mathrm{Pu}-240)$

- $\quad$ power grade plutonium (up to $20 \% \mathrm{Pu}-240$ and $1 \% \mathrm{Pu}-241$ ) 
A summary of the projects and time periods that these and other radionuclides were used is presented in Section 3.0 .

In Building 771, special recovery anion exchange (prefix 45) separated plutonium from other materials that were not suitable for the regular recovery processes. ${ }^{\text {C154,P052,P061 }}$ Chemical technology (prefix 42) conducted aqueous R\&D activities while plutonium metallurgy operations (prefix 78) performed alloy preparation, heat

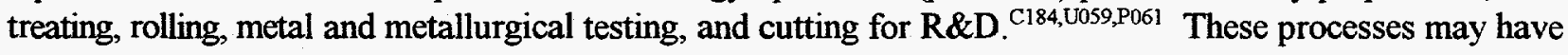
used numerous radioisotopes.

A pilot-scale fluidized-bed incinerator (prefix 75) was developed in Building 776 to treat low-level waste. ${ }^{\mathrm{C} 184, \mathrm{U} 059}$ The waste fed to the incinerator was contaminated with low levels of plutonium. ${ }^{\mathrm{P} 024}$

The coatings laboratory (prefix 16) in Building 777 developed various substrates to be coated with uranium or plutonium, including stainless steel, copper, chromium, aluminum, and beryllium. ${ }^{\text {P052,U059,P079 }}$ This research and development facility supported production processes. ${ }^{\mathrm{P} 52, \mathrm{P} 079}$ The special weapons area (prefix 66) in Building 777 was a research and development facility which assembled war reserve and other specially fabricated parts. ${ }^{\text {U059,P079 }}$ The process was also responsible for disassembly of surveillance (tracer) parts and drilling of parts for use in analytical testing. ${ }^{\text {P079 }}$

Pyrochemical technology (prefixes 10 and 52) in Building 779 involved the extraction and recovery of plutonium and americium in support of production operations. ${ }^{\text {P067,U059,P062 }}$ These processes included direct oxide reduction, molten salt extraction, electrorefining, salt scrub for MSE, salt scrub for electrorefining, pyrochemical salt recycle, anode alloy, and pyroredox. ${ }^{\mathrm{C} 182 \mathrm{P} 062}$. Most of the materials used in Building 779 were the same as those in the weapons-production areas and, therefore, will be contaminated primarily with weapons-grade plutonium and enriched uranium. ${ }^{\text {P053 }}$ However, other R\&D activities in the building may have used a variety of other radionuclides. ${ }^{\mathrm{C} 171, \mathrm{C} 184}$

\subsubsection{Liquid Waste Treatment}

Aqueous waste treatment operations in Buildings 374 and 774 received wastes from throughout plant site, including processes that generated low-level and nonradioactive liquid wastes. For this reason, wastes generated during treatment operations may contain any of the radioisotopes used at the plant. The most common radioactive materials handled were weapons-grade plutonium, americium-241, enriched uranium, and depleted uranium. Other radionuclides may also be found in the waste streams from R\&D, analytical, and special order work. ${ }^{\mathrm{P} 164}$ Radionuclide contaminants are removed from the aqueous wastes by precipitation using sodium hydroxide and, therefore, will be primarily in the form of hydroxides. ${ }^{\text {P163 }}$ Radioassay interferences may include magnesium sulfate and calcium chloride reagents used in the process. ${ }^{\text {P106,P163 }}$

Building 774 also processed organic liquid wastes. Organic wastes are comprised of a variety of oils and solvents. Most of the oils were from spent lathe coolant used in the plutonium machining area and lubricating oils used in machines throughout the plant. ${ }^{\mathrm{P} 164}$ The majority of the transuranic organic liquids were oils and solvents from plutonium machining and degreasing operations in Buildings 707 and 777 and, therefore, will be contaminated with actinide metals and oxides. ${ }^{\text {P052 }} \mathrm{A}$ more detailed discussion of the wastes treated in these buildings is provided in Sections 22.0 through 25.0 . 
A log entry from Building 774 indicates the presence of tritium in liquid received from Building 779. The liquid appears to have been cemented and then buried in a combustibles drum (RF074607832). ${ }^{\text {U043 }}$

\subsubsection{Size Reduction/Repackaging/Solid Waste Treatment}

Repack operations (prefix 76) in Building 371 involved the repackaging of residues for off-site shipment to other DOE facilities and the repackaging of wastes and residues for on-site storage. ${ }^{\text {P081,U059 }}$ Residues and wastes repacked for off-site shipment included plutonium oxides, incinerator ash, molten salt, electrorefining salt, cell scrape out, and anode heels. Wastes and residues were received from either the stacker/retriever (prefix 43) in Building 371 or from one of several 10- and 55-gallon drum storage areas within Building 371 . ${ }^{\text {Pos1.U059 }}$

The Size Reduction Vault (SRV) in Building 776 conducted solid waste treatment, repackaging, and size reduction operations. The SRV was divided into two sides. One side was the airlock (prefixes 25, 40, 41, and 57) where repackaging was done. The other side (prefixes 19 and 26) was a drybox atmosphere where size reduction and solid waste treatment activities took place. ${ }^{\mathrm{C} 175, \mathrm{C} 184, \mathrm{P} 067, \mathrm{U} 059}$ The repacked containers have the potential to contain contaminated materials from any of the processes within the transuranic waste generating buildings. ${ }^{\text {P067,U07 }}$ Size reduction included cutting up gloveboxes or ducting, and crushing HEPA filters. Solid waste treatment activities included washing leaded gloves and scrap metal with hot water in a ball-mill washer to recover plutonium. ${ }^{\mathrm{C} 053, \mathrm{P} 024, \mathrm{P} 067, \mathrm{P} 164}$

\subsubsection{Complexing Agents}

Because complexing agents can aid in the transport of transuranic radionuclides from the waste after disposal, the waste was assessed for potential complexing agents. This information may also be added to the chemical compatibility studies since limited information was available on these chemicals in the past.

EDTA represents a group of chelating compounds, such as ethenediaminetetraacetic acid, with similar molecular structures found in many soaps and detergents. Versene (a trade name for EDTA) and citric acid are known constituents of KW decontamination detergent. ${ }^{\mathrm{P} 24, \mathrm{P} 068} \mathrm{KW}$ was used during a variety of decontamination activities at the plant. A buffer solution (TISAB) containing diaminocyclohexane tetraacetic acid was used during specific ion electrode analysis in Building 559. ${ }^{\mathrm{P} 76}$ Oxalic acid and tetraphosphoric acid were used to etch plutonium and other metals. ${ }^{\mathrm{P} 62, \mathrm{P} 079, \mathrm{U} 043}$ Oxalic acid was also used for americium recovery. ${ }^{\mathrm{P} 113}$ Combustibles and plastic may be contaminated with minor quantities of these complexing agents. 


\subsection{FILTERS AND INSULATION}

This waste group consists of filters and insulation generated by the production, recovery, laboratory, treatment, maintenance, and research and development activities associated with plutonium operations. The waste was generated in Buildings 371, 374, 559, 707, 771, 774, 776, 777, and 779. ${ }^{\text {P001,P012,P016 }}$ Historic IDC descriptions and dates of generation for the INEEL accessible storage inventory are presented by IDC in Table 10-1. ${ }^{\text {P127 }}$

Table 10-1. Filters and Insulation Waste in the Accessible Storage Inventory.

\begin{tabular}{|c|c|c|}
\hline IDC & Title & Dates of Generation \\
\hline 328 & $\begin{array}{l}\text { Filters, Ful-Flo from Building } 771 \text { Incinerator }^{\mathrm{P} 032} \\
\text { Ful-Flo Filters }^{\mathrm{P} 061}\end{array}$ & April 1982-February 1983 \\
\hline 335 & $\begin{array}{l}\text { Filters Absolute } 8 \times 8^{\mathrm{C} 063} \\
\text { Absolute Drybox Filters }{ }^{\mathrm{C} 063} \\
\text { Absolute Drybox Filters, Not Acid Contaminated }\end{array}$ & January 1973-September 1985 \\
\hline 338 & $\begin{array}{l}\text { Insulation }{ }^{\mathrm{P} 014} \\
\text { Filter Media }^{\mathrm{P} 032} \\
\text { Insulation and Filter Media }^{\mathrm{P} 001}\end{array}$ & January 1973-May 1973 \\
\hline 360 & Insulation ${ }^{\mathrm{P} 024}$ & January 1973 \\
\hline 376 & $\begin{array}{l}\text { Cemented Insulation and Filter Media } \\
\text { Processed Filter Media } \\
\text { Pr2 }^{\mathrm{P} 2} \\
\text { Processed Insulation and Filter Media }^{\mathrm{P001}}\end{array}$ & April 1980-September 1988 \\
\hline 490 & $\begin{array}{l}\text { CWS Filters }{ }^{\mathrm{P} 024} \\
\text { HEPA Filters } \\
\text { HEPA Filters ( } 24 \text { X 24), Not Acid Contaminated }\end{array}$ & December 1972-July 1989 \\
\hline
\end{tabular}

Item Description Code 328, Filters, Ful-Flo from Building 771 Incinerator: This waste consists of Ful-Flo filters from the recovery incinerator in Building 771. Ful-Flo filters were in-line cartridge filters designed to remove particulates from liquid streams. ${ }^{\text {P01,P037.P052 }}$ The filters were one-piece, molded filters about 10 inches long by $31 / 2$ inches in diameter. Filter media consisted of a red fibrous material which filtered particulates greater than 5 microns. ${ }^{\text {P052 }} 5$ - and 1-micron fibrous polypropylene filters were also used. ${ }^{\text {P001,P052 }}$ Ful-Flo filters may contain caustic free liquids. ${ }^{\mathrm{P052}}$ Ful-Flo filters were processed as IDC $376 .^{\mathrm{P} 001}$

Item Description Code 335, Absolute Drybox Filters: This waste consists of glovebox air intake and exhaust HEPA filters. Filter sizes include $8 \times 8 \times 6$ inches, $8 \times 8 \times 4$ inches, and $12 \times 12 \times 6$ inches. Filter frames are constructed of either fire-retardant plywood or particle board and cadmium-plated or chromized carbon steel. The filter media is made of Nomex (glass and aromatic polyamide fibers), fiberglass, or asbestos. ${ }^{\text {POOL,P016,P024,P052 }}$ This waste includes acid-, nonacid-, and solvent-contaminated filters. ${ }^{\mathrm{C} 103}$ The waste may also contain limited amounts of combustible materials ${ }^{\text {P024 }}$ Beginning in approximately 1989 , acid- and nonacid-contaminated absolute drybox filters were sorted. IDC 335 was assigned to nonacid-contaminated filters, and acid-contaminated filters were assigned IDC 342 . Absolute filters contaminated with plutonium 
above the EDL were processed in Building 771 as IDC 338. Filters below the EDL, which were wet or had been exposed to corrosive fumes, were sent to Building 776 and processed as IDC $376 .{ }^{\text {P001,P016,P024 }}$

Item Description Code 338, Insulation and Filter Media: This waste consists primarily of filter media removed from various filters, but also includes asbestos or fiberglass pipe and furnace insulation, fire blankets, and asbestos gloves. ${ }^{\text {P043 }}$ Filter media that was wet or had been exposed to corrosive fumes was processed in Building 776 as IDC $376 .^{\mathrm{P} 001, \mathrm{P} 032, \mathrm{P} 043}$

Item Description Code 360, Insulation: This waste consists of asbestos-type pipe insulation, asbestos gloves and fire blankets, and fiberglass and asbestos prefilter and filter media. The waste may contain limited amounts of combustible materials such as surgical gloves. IDC 360 was replaced by IDC 338 in 1973 . $^{\text {P024 }}$

Item Description Code 376, Processed Insulation and Filter Media: This waste consists of Ful-Flo incinerator filters (IDC 328), absolute drybox filters (IDC 335), and insulation and filter media (IDC 338) that were wet or had been exposed to corrosive fumes. Beginning in approximately 1975 , filters and insulation were sent to size reduction in Building 776 where dry Portland cement was added to the waste. ${ }^{\mathrm{C} 103, \mathrm{P} 024}$ After adding cement, the waste was assigned IDC $376{ }^{\text {P001 }}$ Prior to 1979 , IDC 376 consisted primarily of filter media removed from various filters. Waste generated since 1979 consists of filter media and whole filters. ${ }^{\mathrm{P} 24}$ The waste also includes asbestos or fiberglass pipe and furnace insulation, fire blankets, and asbestos gloves. ${ }^{\text {P024.P032 }}$

Item Description Code 490, HEPA Filters: This waste consists primarily of $24 \times 24 \times 12$ inch HEPA filters from ventilation intake and exhaust filter plenums. The waste may also include various other sizes of plenum HEPA filters, prefilters, and glovebox HEPA filters. ${ }^{\text {P024,U009 }}$ Filter frames are constructed of either fireretardant plywood or particle board and cadmium-plated or chromized carbon steel. The filter media is made

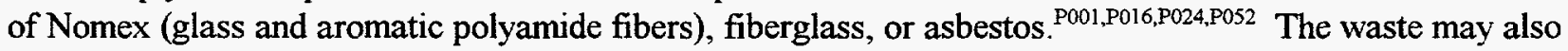
contain metal canister filters that were used for respiratory protection during chemical spill cleanup. At one time, IDC 490 was referred to as chemical warfare service (CWS) filters. ${ }^{\mathrm{C103}, \mathrm{Cl04}, \mathrm{P} 024}$ The waste included filters that had been potentially contaminated with acid vapors (acid-contaminated), solvent vapors (solventcontaminated), and filters that are not expected to have been contaminated with either acid or solvent vapors (nonacid-contaminated). In the mid-1980s, prefilters were sorted from HEPA filters and were assigned IDC 491. Beginning in approximately 1989 , acid- and nonacid-contaminated plenum HEPA filters were sorted. IDC 490 was assigned to nonacid-contaminated filters, and acid-contaminated filters were assigned IDC 492 . Prior to 1974, HEPA filters were packaged at each waste generating area ${ }^{\text {P24 }}$ HEPA filters contaminated with plutonium above the EDL were processed in Building 771 as IDC 338. Filters below the EDL, which were wet or had been exposed to corrosive fumes, were sent to Building 776 and processed as IDC 376. ${ }^{\mathrm{C} 104, \mathrm{P} 001, \mathrm{P} 016 . \mathrm{P} 024, \mathrm{U} 009}$

\subsection{Waste Generation}

Filters and insulation were generated by production, recovery, purification, laboratory, treatment, maintenance, and research and development activities associated with plutonium operations at the site.

\subsubsection{Plutonium Production}

Plutonium production consisted of operations directly associated with the manufacturing of plutonium metal parts including casting, rolling, forming, machining, and assembly processes. Buildings 707 and 777 
were the primary weapons components production facilities at the site after the construction of Building 707 in 1972. Building 707 was constructed after the 1969 fire in Building 776 which shut down foundry and machining operations in that building. ${ }^{\mathrm{P} 53}$

The foundry in Building 707 cast molten plutonium into classified components, subassemblies, and assemblies. Other parts were manufactured by rolling, forming, and machining plutonium ingots also cast in the foundry. Components were assembled using a number of welding and joining techniques in Buildings 707, 777, and 779. Production support operations in Buildings 707 and 777 included a variety of inspection, calibration, measurement, weighing, leak testing, and cleaning activities to assure that the parts met stringent specifications. Rejected plutonium parts, scraps, and turnings were returned to be recast. Small pieces of metal, fines, and sweepings were typically burned to oxide and sent to Building 771 to be recovered. ${ }^{\text {P052 }}$

Halogenated solvents were used in production operations to clean and degrease plutonium parts and metal. In addition, the solvents were used with cutting oils to cool plutonium parts during machining. Carbon tetrachloride, tetrachloroethene, 1,1,1-trichloroethane, 1,1,2-trichloro-1,2,2-trifluoroethane, trichloroethene, and methylene chloride were the primary solvents historically used during plutonium production. Tetrachloroethene was replaced by 1,1,1-trichloroethane for degreasing during the 1973 time frame. Several non-halogenated solvents were also used for cleaning and degreasing, primarily during efforts to reduce use of halogenated solvents. ${ }^{\text {P023,P052 }}$ These solvents included isopropyl alcohol, ethanol, and acetone. ${ }^{\text {P052,P053,P067 }}$ Building 777 housed the carbon tetrachloride and 1,1,1-trichloroethane systems that collected and filtered solvents generated during production operations. In addition to parts cleaning and degreasing, solvents were also used to clean plutonium operation glovebox lines. ${ }^{\mathrm{P} 023}$

\subsubsection{Plutonium Recovery and Purification}

Several operations at the plant were responsible for either the purification of non-specification plutonium metal or the recovery of plutonium from production waste and residues. Building 771 housed operations that recovered plutonium from waste materials and other sources. ${ }^{\text {P053 }}$ Plutonium purification was performed primarily in Buildings $371,771,776$, and $779 .{ }^{\text {POS2 }}$

Recovery operations in Building 771 used acid to dissolve solid materials containing plutonium. The resulting solutions were processed by a series of ion exchange, precipitation, calcination, fluorination, and reduction operations to produce purified plutonium metal to be recycled back into production operations. Potassium hydroxide, potassium fluoride, hydrogen peroxide, and nitric, hydrochloric, and hydrofluoric acids were the primary reagents used for plutonium recovery operations. ${ }^{\text {P053,P061,U047 }}$

Plutonium metal from returned parts and metal from other DOE facilities was purified at Rocky Flats. Plutonium-241 decays to americium-241 which decreases the effectiveness of the plutonium parts. Plutonium parts were disassembled in Building $777 .^{\text {P053,P113 }}$ Beginning in 1967, the molten salt extraction (MSE) process in Building 776 recovered americium from plutonium metal using sodium chloride, potassium chloride, and magnesium chloride. ${ }^{\text {P053 }}$ Americium was separated from the MSE residue salts using potassium hydroxide precipitation followed by an ammonium thiocyanate anion exchange process. In 1975, the process changed to cation exchange followed by anion exchange (no thiocyanate) and then precipitation using oxalic acid. ${ }^{\text {P113,U047 }}$ The process changed again the following year to the salt scrub process which used a magnesium/zinc or a magnesium/aluminum extractant. ${ }^{\mathrm{U} 047}$ The purified plutonium metal from MSE was either sent to the foundry in Building 707 or sent to the electrorefining (ER) process in Building 371 or Building 776 if the metal contained other impurities. ${ }^{\text {P053,U047 }}$ 
Spray leaching (Building 771) and hydride leaching (Building 779) also used acids to remove plutonium surface contamination from uranium metal and other metals or beryllium contamination from plutonium metal. These processes used nitric, hydrochloric, sulfuric, and sulfamic acids. ${ }^{\mathrm{P} 53, \mathrm{P} 061, \mathrm{P} 062}$

\subsubsection{Laboratory}

Buildings 371,559 , and 771 housed the main analytical laboratories at the site. The laboratories' primary function was to provide analytical support to production activities in addition to supporting recovery, purification, and liquid waste treatment operations. Each of the laboratories used numerous acids, bases, solvents, and other chemical reagents.

Building 371 had an analytical laboratory and a chemical standards laboratory. The chemical standards laboratory prepared standards for various users and inspects standards that have been used in the field. The analytical laboratory analyzed samples from various operations on site. ${ }^{\text {P081 }}$

Building 559 housed the Plutonium Analytical Laboratory responsible for spectrochemical, chemical, and mass spectrometric analyses of samples from plutonium production operations. Uranium, Raschig rings, solutions, and commercial product and gas samples were also analyzed in the laboratory. Plutonium production samples, including metal and oxide, were prepared and subdivided for analysis in the sample cutting process. ${ }^{\mathrm{P} 067}$

Building 771 housed analytical and chemical standards laboratories. The chemical standards laboratory prepared control sample standards for the analytical laboratories in Buildings 371, 559, and 771. ${ }^{\mathrm{P} 061}$ The analytical laboratory provided analyses in support of plutonium operations. ${ }^{\mathrm{P061,P067}}$

\subsubsection{Research and Development}

Research and Development (R\&D) included activities related to production, recovery, and purification as well as "special order" work. Building 779, which was built in 1965, housed much of the R\&D operations at the plant. Other areas at the plant supporting R\&D included Buildings $559,771,776,777$, and $881 .^{\mathrm{P} 053}$

The purpose of Building 779 was to gain more knowledge of the chemistry and metallurgy of plutonium and its interactions with other materials which might be used in plutonium operations. Other activities in Building 779 included developing improvements to the manufacturing process and finding new ways to recover plutonium and associated actinides. Another function was to develop a better understanding of the aging and shelf-life limitations of Rocky Flats products. Most of the materials used and wastes generated in this facility were the same as those in the production and recovery buildings, as much of the work conducted involved improvement of existing processes. ${ }^{\text {P053 }}$ However, processing of neptunium, curium, and cerium was also conducted. ${ }^{\mathrm{P} 053, \mathrm{U} 047}$

\subsubsection{Waste Treatment}

Waste processing at Rocky Flats has included both liquid and solid process wastes. Liquid waste treatment operations have had relatively few process changes over the years. When Building 774 was built in 1952 , its primary purpose was to treat radioactive aqueous waste from Building 771. Radionuclides were removed by precipitation, and the resulting slurry filtered. The solids removed from filters were combined with cement or other solidifying agents. The aqueous waste from this first stage goes through a second 
precipitation. ${ }^{\text {P053 }}$ These processes used sodium hydroxide, ferric sulfate, magnesium sulfate, and calcium chloride. ${ }^{\text {P109 }}$ See Section 23.0, Solidified Aqueous Sludge Building 774, for a detailed description of these processes.

Around 1965, an evaporator was installed in Building 774 to treat liquids from the second stage treatment and from the solar ponds. The concentrate from the evaporator was introduced into a steam-heated double-drum drier which produced a salt waste. The Building 774 evaporator was taken out in $1979 .{ }^{\text {P053 }}$ Beginning in 1985, the liquids from the second stage treatment and solar ponds were transferred to the Building 374 evaporator where a similar salt waste was produced ${ }^{\mathrm{P} 052, \mathrm{P} 053}$

In Building 374, liquids were concentrated by evaporation into a salt brine. The salt brine was introduced into a spray dryer producing small salt particles suspended in the air stream. The salt-laden air passed through a baghouse filter followed by HEPA filtration. ${ }^{\text {P106 }}$ Over time, a visible buildup of salt would form on the HEPA filters. ${ }^{\mathrm{P} 016}$

Building 774 also processed organic liquid wastes. Plutonium-contaminated organic liquids were generated from plutonium machining. ${ }^{\text {P053 }}$ The spent organic liquid was filtered and then mixed with a solidifying agent. The process was later changed to a one step process in which the organic liquid was mixed with Envirostone (Gypsum cement) and allowed to set up. The air from the process passed through a HEPA filtration system prior to being released ${ }^{\mathrm{P} 109}$. Filters from this process may have been contaminated with sludges containing oil and halogenated solvents. ${ }^{\text {P052 }}$ See Section 25.0, Solidified Organic Waste for a detailed description of these processes.

Treatment of solid transuranic wastes was conducted in Buildings 771 and 776 . Building 771 processed wastes containing plutonium above the EDL while Building 776 processed wastes below the EDL.

Operations in Building 771 processed wastes including Raschig rings, HEPA filters, and sludges from the filter plenum and from process piping. ${ }^{\text {P061 }}$ HEPA filters (IDC 490) removed from filter plenums were double bagged and placed in cardboard containers for assay. ${ }^{\text {P0OI }}$ Glovebox and plenum filters (IDCs 335 and 490) contaminated with plutonium above the EDL were processed in Building 771. Prior to disassembly, the filters were manually shaken to remove loose particulate. The particulate was sent for recovery. Filter frames were usually below the EDL and were disposed of as combustible or metal waste. Filter media were then repackaged as IDC 338. ${ }^{\text {P024,P061 }}$ HEPA filters (IDC 490) below the EDL were transferred to Building 776, removed from the cardboard container, and crushed in a press. ${ }^{\mathrm{P} 001, \mathrm{P} 016}$

Size reduction in Building 776 removed materials from drums and sorted them in an airlock vault. ${ }^{\mathrm{P} 067}$ Ful-Flo incinerator filters (IDC 328), absolute drybox filters (IDC 335), and insulation and filter media (IDC 338) were initially packed into drums by each waste-generating area and then assayed for plutonium content. Beginning in approximately 1975 , wastes contaminated with plutonium below the EDL were transported to size reduction in Building 776. ${ }^{\text {C103,P001,P124 }}$ Dry Portland cement was added to the waste as a precautionary measure to absorb moisture, neutralize any residual nitric acid that may be present, and reduce the potential for drum pressurization. Prior to 1979 , the waste was usually emptied from the original packaging (bottles, cans, or plastic bags) into a mortar box, mixed with dry Portland cement, and repackaged in a 15-gallon plastic bag. Since then, waste received at size reduction in cans or bottles was removed and repackaged in a 15-gallon polyethylene bag. A small quantity of Portland cement was added to each bag and the bag was shaken to disperse the cement. Waste received at size reduction in plastic bags was processed by cutting open the bag, 
pouring in a small quantity of Portland cement, and shaking the bag. ${ }^{\text {P024 }}$ After the waste was processed, it was assigned IDC $376^{\mathrm{P} 001, \mathrm{P} 024}$

Advanced size reduction operations in Building 776 disassembled or cut plutonium-contaminated gloveboxes and miscellaneous large equipment into sizes that could be packaged in approved containers. Glovebox HEPA filters in this area required periodic change-out. ${ }^{\mathrm{P} 110}$

The fluidized-bed incinerator in Building 776 received low-level plutonium-contaminated combustible solid and liquid wastes. ${ }^{\mathrm{P} 677}$ Building 771 also housed an incinerator for processing combustible wastes. ${ }^{\mathrm{P} 061, \mathrm{U} 047}$ Process flue gas from the Building 776 incinerator passes through cyclone separators, a sintered metal filter bank, and a HEPA filter bank, before being exhausted into the HEPA filter plenum of the building ventilation system. ${ }^{\mathrm{P} 067}$ Off-gases from the Building 771 incinerator passed through a caustic scrubber and the incinerator filter plenum before being combined with other glovebox exhaust gases in the main filter plenum. ${ }^{\text {P061.U047 }}$ The caustic scrubber solution (potassium hydroxide) passed through Ful-Flo filters to remove particulate matter. ${ }^{\mathrm{P} 052, \mathrm{P} 061}$ See Section 14.0, Incinerator Waste, for a detailed description of the incineration processes.

\subsubsection{Maintenance}

Routine and nonroutine maintenance at Rocky Flats includes utilities, filter testing and change-out, strip-out activities, and other general maintenance and cleanup activities.

Utility systems include HVAC systems, fume scrubbers, and process vacuum systems. The HVAC systems contain air supply units for filtering incoming air and plenums for filtering exhaust air. KW detergent was used periodically to wipe down filter frames. Scrubbers housed in Buildings 371, 559, 771, and 779 used potassium or sodium hydroxide to neutralize acid fumes from various process off-gas streams and glovebox exhaust streams. Process vacuum systems provided an absolute pressure at a vacuum header which serves as a means to transfer fluids on demand by valving arrangements. ${ }^{\mathrm{P} 061, \mathrm{P} 067}$

In-place testing of the plenum HEPA filters was initiated in response to a filter change, when there was visible damage to the filter or supporting framework, when plenum monitoring indicated there may be a problem, and when the routine testing schedule for that particular bank of filters dictated ${ }^{\text {P053 }}$ Dioctyl phthalate was used for testing filter efficiency, and $\mathrm{KW}$ detergent was used for wiping down filter frames. ${ }^{\mathrm{Cl} 05}$

The Building 776 fire in 1969 resulted in the removal of filters in the area and a high volume of filter waste was generated through 1972 because the plenums were rebuilt. To protect against a similar fire, several building filtering systems were upgraded which resulted in an increase in filter waste in 1973 and 1974. ${ }^{\text {P053,P090,U056 }}$

Other incidents generating filters included strip-out activities associated with a control valve release in Building 707 occurring in 1974 which allowed radioactive particulates to escape from an exhaust stack on the roof and into Module K. From April 9, 1973 through April 25, 1973, tritium-contaminated plutonium was processed in Building 779, causing a tritium release to the atmosphere and elevated tritium levels in surface waters, process wastes, equipment, gloveboxes, and exhaust plenums ${ }^{\mathrm{P} 053}$ 


\subsection{Waste Packaging}

Ful-Flo incinerator filters (IDC 328) were bagged out of the glovebox in one or two polyethylene bags. ${ }^{\text {P001,P015 }}$ The bagged filters may also be contained in an RPC (clamshell). ${ }^{\text {P015 }}$ Each bag or clamshell was placed in a 55-gallon drum. ${ }^{\mathrm{P} 01}$

Each absolute drybox filter (IDC 335) removed from a glovebox was double contained in plastic bags and sealed with tape. Oil-Dri was added to any bags containing damp filters. ${ }^{\mathrm{P} 001, \mathrm{P016}, \mathrm{P024}}$ Each bag containing a filter was assayed for plutonium content before placement in a 55-gallon drum. ${ }^{\mathrm{P} 024}$

HEPA filters (IDC 490) removed from filter plenums were double bagged and placed in cardboard cartons. The cardboard cartons were transferred to the drum counter for assay and then sent to Building 776 where the filter was removed from the carton for size reduction. The crushed filter was then placed into a waste box or a 55-gallon drum. The cardboard cartons used for transporting the filters were cut flat and may have been placed into the container as well. ${ }^{\mathrm{P} 001, \mathrm{P} 016}$ Drums of IDC 490 consist primarily of glovebox filters (rather than plenum filters) which were single or double bagged before being placed into the drum. ${ }^{\mathrm{P} 24}$

Filter media (IDC 338) was packaged by placing the media into a 1-gallon polyethylene bottle or in a polyethylene bag and double bagged out of the glovebox. Each bottle or bag was placed in a 55-gallon drum. ${ }^{\mathrm{P} 001}$

Insulation (IDC 360) was single- or double-bagged in polyvinyl chloride or polyethylene. ${ }^{\text {P015,P024 }}$ Each bag was sealed with tape and placed in a lined 55-gallon drum. Waste such as pipe insulation may have been wrapped with tape and placed directly into the drum. Wet insulation may have been dried in a clothes drier prior to packaging. ${ }^{\mathrm{P} 024}$

Processed insulation and filter media (IDC 376) consists of Ful-Flo incinerator filters, drybox filters, filter media, and insulation combined with dry Portland cement. IDCs 328, 335, and 338 were packaged as described above. After adding the cement, the bags of filters were placed in a 55-gallon drum for shipment. ${ }^{\mathrm{P} 016}$

Depending on waste packaging requirements at the time, several combinations of bags and liners were used to prepare 55-gallon drums for shipment. From 1970 to 1972, waste drums were lined with one or two polyethylene drum bags. Cardboard liners might also have been used to line the inner drum bag. Use of the 90-mil rigid polyethylene liner began in 1972. ${ }^{\mathrm{P} 24}$ The rigid liner was placed in each drum and lined with one

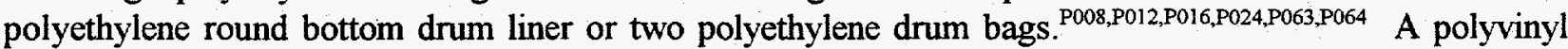
chloride O-ring bag and a polyethylene bag were used if the drum was attached to the glovebox. ${ }^{\text {P016 }} \mathrm{A}$ fiberboard liner and discs may also have been used between the waste packages and the drum liners. ${ }^{\mathrm{P} 088, \mathrm{P} 012, \mathrm{P} 016, \mathrm{P} 064}$ When a drum was full, the drum liners were twisted and taped closed, the lid was secured with a bolted ring, and a tamper indicating device was attached to the drum. ${ }^{\mathrm{P} 12, \mathrm{P} 016, \mathrm{P} 024}$

After drums were inspected, one to two quarts of absorbent material (Oil-Dri) was placed on the top of the outer, sealed polyethylene drum bag. This procedure changed in February 1982 when vermiculite was used to fill the space between the outer, sealed polyethylene drum bag and the top of the 90 -mil rigid liner. The quantity of vermiculite varied from 3-12 pounds according to the amount of waste contained in each drum. ${ }^{\mathrm{P} 024}$ 
Waste management and inspection protocol allowed containers of wastes to contain up to 10 percent of another IDC other than that assigned to the container. ${ }^{\mathrm{P} 16}$ Visual inspection of filters and insulation containers identified a variety of items including lead tape, nails, wood frames, rubber gaskets, and D-cell batteries. $^{\text {U011,U015,U028 }}$

\subsection{Waste Characterization}

Filters and insulation are characterized based on knowledge of the material, knowledge of the processes generating the waste, RTR review of the waste, visual inspection, and headspace gas analysis. This section provides a RCRA hazardous waste determination for filters and insulation as well as radionuclide contaminants and potential complexing agents contained in the waste. This waste contains at least 50 percent (by volume) materials that meet the EPA LDR criteria for classification as debris, and is therefore a heterogeneous waste. $^{\text {P141 }}$

\subsubsection{Hazardous Waste Determination}

The material in this waste group does not qualify for any of the exclusions outlined in 40 CFR 260 or 261. The waste may exhibit the characteristics of ignitability due to cellulosic materials contaminated with nitrate salts, and corrosivity from the presence of caustic free liquids. The waste may also exhibit the characteristic of toxicity for barium, chromium, lead, and silver. The waste was mixed with halogenated- and nonhalogenated-solvents and electroplating wastes, and is therefore a F-listed hazardous waste. There is no evidence that filters and insulation exhibit any other characteristic of hazardous waste. ${ }^{\mathrm{C} 107}$ EPA Hazardous Waste Numbers applicable to some or all of the filters and insulation waste group are presented by IDC in Table 10-2. ${ }^{\mathrm{P} 27}$ These conclusions are supported by the evaluation in Sections 10.3.1.1 and 10.3.1.2.

Table 10-2. Filters and Insulation Waste Characterization.

\begin{tabular}{lll}
\hline IDC & \multicolumn{1}{c}{ Title } & \multicolumn{1}{c}{ EPA Hazardous Waste Numbers } \\
\hline 328 & Filters, Ful-Flo from Building 771 Incinerator & $\begin{array}{l}\text { D002, D005, D007, D008, D01 1, F001, } \\
\text { F002, F003, and F005 }\end{array}$ \\
& \multirow{2}{*}{$\begin{array}{l}\text { Absolute Drybox Filters } \\
\text { D001, D005, D007, D008, D011, F001, } \\
\text { F002, F003, F005, F006, F007, and F009 }\end{array}$} \\
338 Insulation and Filter Media & $\begin{array}{l}\text { D001, D005, D007, D008, D011, F001, } \\
\text { and F002 }\end{array}$ \\
360 & Insulation & D005, D007, D008, D011, F001, and F002 \\
376 & Processed Insulation and Filter Media & D005, D007, D008, D011, F001, F002, \\
& & F003, F005, F006, F007, and F009 \\
490 & HEPA Filters & D001, D005, D007, D008, D011, F001, \\
& F002, F003, F005, F006, F007, and F009 \\
\hline
\end{tabular}




\subsubsection{Characteristic Waste}

The materials in this waste group may exhibit a characteristic of hazardous waste as defined in 40 CFR 261, Subpart C as an ignitable waste (40 CFR 261.21), as a corrosive waste (40 CFR 261.22), and as a toxic waste (40 CFR 261.24). The materials do not exhibit the characteristic of reactivity (40 CFR 261.23). The origin of the characteristic hazardous waste numbers assigned to filters and insulation is provided in Table 10-3. The table includes only the hazardous waste numbers that are applicable to waste for which a specific source and time period was identified. The hazardous waste numbers are not applicable to waste generated from areas other than those listed in the table, or from those specific areas but during a different period of time.

Table 10-3. Origin of Characteristic Hazardous Waste Numbers.

\begin{tabular}{ccc}
\hline IDC & EPA Hazardous Waste Numbers & \multicolumn{1}{c}{ Building } \\
\hline 335 & D001 & Building 374 generated after 1984 \\
338 & D001 & Building 374 generated after 1984 \\
490 & D001 & Building 374 generated after 1984 \\
\hline
\end{tabular}

Ignitability: Filters and insulation assigned IDCs 328, 360, and 376 do not meet the definition of ignitability as defined in 40 CFR 261.21. Filters assigned IDCs 335,338 , and 490 may meet the definition of ignitability due to nitrate salt contamination. The material in this waste group is not a liquid, and packaging procedures prohibited the addition of liquids to the containers. ${ }^{\mathrm{P} 016}$ In addition, absorbents were added to wastes having the potential of generating free liquids (i.e., filters used in acid glovebox lines). ${ }^{\text {P012.P015,P016,P024,U011,U015 }}$ Free liquids were identified in drums of Ful-Flo filters; however, the liquids were determined to be aqueous and are not ignitable. ${ }^{\mathrm{P} 015}$ The material is not a compressed gas, nor does the waste contain compressed gases. ${ }^{\mathrm{P} 12, \mathrm{PO} 15, \mathrm{P016}, \mathrm{P} 024, \mathrm{U} 011, \mathrm{U} 015}$ Filter and insulation wastes (IDCs 328, 360, and 376) are not DOT oxidizers as defined in 49 CFR 173, and are not capable of causing fire through friction, absorption of moisture, or spontaneous chemical change. ${ }^{\text {P012,P024 }}$ However, filters (IDCs 335 and 490) and associated filter media (IDC 338) used in conjunction with the generation of salt waste by Building 374 liquid waste treatment operations may have visible nitrate salt contamination. For this reason, a risk of spontaneous combustion has been identified. ${ }^{\text {P016,P052 }}$ Therefore, EPA Hazardous Waste Number D001 is applicable to filters (IDCs 335, 338 , and 490) from Building 374 generated after $1984 .^{\text {U060 }}$

Corrosivity: Filters and insulation assigned IDCs $335,338,360,376$, and 490 do not meet the definition of corrosivity as defined in 40 CFR 261.22. Ful-Flo filters (IDC 328) may meet the definition of corrosivity due to the presence of caustic free liquids. The material in this waste group is not a liquid, and packaging procedures prohibited the addition of liquids to the containers. ${ }^{\mathrm{P} 16}$ In addition, absorbents were added to wastes having the potential of generating free liquids. ${ }^{\mathrm{P} 12, \mathrm{P} 015, \mathrm{P} 024, \mathrm{U} 011, \mathrm{U} 015}$ However, free liquids were identified in drums of Ful-Flo filters (IDC 328) ${ }^{\text {P015 }}$ Since Ful-Flo filters were used in a caustic off-gas scrubber system, it is possible that free liquids could have a $\mathrm{pH}$ greater than 12.5 . Therefore, EPA Hazardous Waste Number D002 is assigned to Ful-Flo filters (IDC 328). ${ }^{\mathrm{U} 660}$

Reactivity: The materials in this waste group do not meet the definition of reactivity as defined in 40 CFR 261.23. The materials are stable and will not undergo violent chemical change. The materials will 
not react violently with water, form potentially explosive mixtures with water, or generate toxic gases, vapors, or fumes when mixed with water. The materials do not contain cyanides or sulfides, and are not capable of detonation or explosive reaction. The materials are not forbidden explosives or Division 1.1, 1.2, or 1.3 (Class A or B) explosives as defined in 49 CFR 173, nor do the drums contain explosive materials. ${ }^{\mathrm{P} 12, \mathrm{PO} 15, \mathrm{P} 024, \mathrm{U} 011, \mathrm{U1} 105}$ Explosives were not handled or used around radioactive material. The materials in this waste group are therefore not reactive wastes (D003).

Toxicity: The materials in this waste group meet the definition of toxicity as defined in 40 CFR 261.24. The toxicity characteristic contaminants fall into one of two categories: metals and organics. Organic compounds include halogenated- and nonhalogenated-solvents, pesticides, herbicides, and other toxic compounds. This waste group may exhibit the characteristic of toxicity for barium, chromium, lead, and silver metals.

Filters from the Building 771 incinerator plenum are contaminated with lead and barium. ${ }^{\mathrm{P} 016}$ RTR and visual inspection have identified drums of filters containing lead items such as lead tape ${ }^{\text {U011 }}$ In addition, emission spectroscopy data from plenum HEPA filter samples indicate the presence of several metals. ${ }^{\mathrm{U} 20}$

Table 10-4. Emission Spectroscopy Results for HEPA Filters.

\begin{tabular}{cc}
\hline Compound & Total Concentration (ppm) \\
\hline Barium & $>5,000$ \\
Chromium & 5 to 500 \\
Lead & $>5,000$ \\
Silver & 5 to 500 \\
\hline
\end{tabular}

Filters and insulation (IDCs 328, 335, 338, 360, 376, and 490) may exhibit the characteristic of toxicity for barium, chromium, lead, and silver. Therefore, the materials in this waste group are assigned EPA Hazardous Waste Numbers D005, D007, D008, and D011 since a representative sample of this waste cannot be obtained for verification purposes.

There is no documentation indicating the presence or use of pesticides or herbicides in the areas or processes generating filters and insulation. Therefore, this waste group does not exhibit the characteristic of toxicity due to pesticides or herbicides (D012-D017).

Carbon tetrachloride, tetrachloroethene, and trichloroethene were used for cleaning and degreasing. Benzene was used in laboratory analysis. Since these compounds were typically used as solvents, the waste is regulated as a listed hazardous waste and not a characteristic waste because these compounds are specifically addressed in the treatment standards for the listed hazardous waste. ${ }^{\mathrm{P} 80}$ Since filters and insulation are characterized as listed hazardous wastes due to spent solvent contamination, the waste is not a toxic waste due to the presence of these organic compounds.

Chloroform was used in laboratory operations, and glovebox filters from these operations may have been exposed to chloroform vapors. ${ }^{\text {P053,P067 }}$ However, this waste should not exhibit the characteristic of toxicity for chloroform because there is likely only trace quantities of chloroform on the filters. 


\subsubsection{Listed Hazardous Waste}

The material in this waste group is a listed hazardous waste because it was mixed with a waste listed in 40 CFR 261, Subpart $D$ as a hazardous waste from non-specific sources (40 CFR 261.31). The material is not, or was not mixed with, a hazardous waste from specific sources (40 CFR 261.32), or a discarded commercial chemical product, an off-specification species, a container residue, or a spill residue thereof (40 CFR 261.33). The origin of the listed hazardous waste numbers assigned to filters and insulation is provided in Table 10-5. The table includes only the hazardous waste numbers that are applicable to waste for which a specific source and time period was identified. Waste generated from areas other than those listed in the table, or from those specific areas but during a different period of time, are not assigned the hazardous waste numbers.

Table 10-5. Origin of Listed Hazardous Waste Numbers.

\begin{tabular}{cll}
\hline IDC & \multicolumn{1}{c}{ EPA Hazardous Waste Numbers } & \multicolumn{1}{c}{ Building } \\
\hline 335 & F001 and F002 & Building 774 \\
& F001, F002, F003, F005, F006, F007, and F009 & Building 374 generated after 1984 \\
338 & F001 and F002 & Building 774 \\
360 & F001 and F002 & Building 774 \\
376 & F001 and F002 & Building 774 \\
& F001, F002, F003, F005, F006, F007, and F009 & Building 374 generated after 1984 \\
490 & F001, F002, F003, F005, F006, F007, and F009 & Building 374 generated after 1984 \\
\hline
\end{tabular}

Combustible wastes fed to the recovery incinerator in Building 771 may have been contaminated with F001-, F002-, F003-, and F005-listed spent solvents. Ful-Flo filters (IDC 328) were used to filter particulate matter from the caustic solution used in the off-gas system of the incinerator. The Ful-Flo filters were derived from the treatment of a hazardous waste and are therefore assigned EPA Hazardous Waste Numbers F001, F002, F003, and F005. ${ }^{\text {P052 }}$

The Colorado Department of Public Health and Environment has stated that filters (except Ful-Flo) with no visible contamination can be excluded from characterization as a listed hazardous waste. ${ }^{\mathrm{Cl} 02}$ Based on this guidance, only filters used in conjunction with liquid waste treatment operations in Buildings 374 and 774 are characterized as listed hazardous wastes.

Waste oils and F001- and F002-listed spent solvents generated from machining and degreasing of plutonium metal were immobilized in Building 774. Absolute drybox filters would become contaminated with sludge containing oil and halogenated solvents from the organic liquid immobilization process. These filters (IDC 335) and the related filter media (IDCs 338, 360, and 376) from Building 774 were derived from the treatment of a hazardous waste and are therefore assigned EPA Hazardous Waste Numbers F001 and F002. ${ }^{\text {C102,P052 }}$ 
Liquid waste treatment operations in Building 374 treated aqueous wastes from numerous areas and processes that could have contained some F001-, F002-, F003-, or F005-listed spent solvents. Filters used in conjunction with the generation of salt waste in Building 374 (after 1984) may have visible nitrate salt contamination. Filters (IDCs 335, 376, and 490) were derived from the treatment of a hazardous waste, and therefore are assigned EPA Hazardous Waste Numbers F001, F002, F003, and F005. C102,P052

There is no documentation indicating the presence or use of F004-listed solvents in the areas or processes generating filters and insulation. Therefore, this waste group is not a F004-listed hazardous waste.

Headspace analysis performed on samples of filters and insulation obtained at INEEL and Rocky Flats confirms the presence of F-listed solvents. Headspace analysis results are not available for IDC 360 . The detected F-listed compounds in which the 90 percent UCL is above the PRQL are provided. ${ }^{\text {P033, U030 }}$

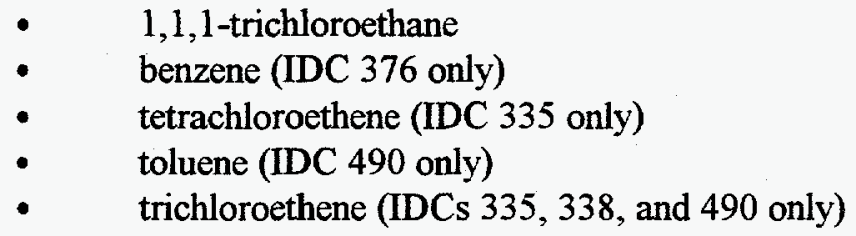

Additional F-listed solvents were detected in headspace samples of filters and insulation obtained Rocky Flats. The detected F-listed compounds in which the 90 percent UCL is above the PRQL are also provided. ${ }^{\mathrm{U} 030}$

- $\quad$ toluene (IDCs 335 and 376)

Aqueous waste treatment operations in Building 374 treated spent stripping, cleaning, and plating solutions and sludges from Building 444 electroplating operations after 1984. Filters used in conjunction with the generation of salt waste in Building 374 may have visible nitrate salt contamination. Filters (IDCs 335, 376 and 490) were derived from the treatment of a hazardous waste, and therefore are assigned EPA Hazardous Waste Numbers F006, F007, and F009. ${ }^{102, P 052}$

The inventory of filter and insulation (IDCs 338 and 360) were generated in 1973. ${ }^{\text {P127 }}$ Because the process in Building 374 that generated the salt waste was not in operation until approximately 1984 , these filter and insulation would not be contaminated with nitrate salts. ${ }^{\text {P052 }}$ Therefore, IDCs 338 and 360 are not assigned EPA Hazardous Waste Numbers F003, F005, F006, F007, or F009. ${ }^{\mathrm{Cl} 2}$

The material in this waste group is not a hazardous waste from specific sources since it was not generated from any of the processes listed in 40 CFR 261.32. The material in this waste group is therefore not a K-listed hazardous waste.

The material in this waste group is not a discarded commercial chemical product, an off-specification species, a container residue, or a spill residue thereof (40 CFR 261.33). The material in this waste group is therefore not a P-or U-listed hazardous waste. 


\subsubsection{Radionuclides}

This section identifies the radioisotopes potentially contained in the waste, as well as the chemical form of radionuclide contaminants and radioassay interferences. The primary radionuclides processed at Rocky Flats included weapons-grade plutonium, americium-241, enriched uranium, and depleted uranium. The isotopic compositions of weapons-grade plutonium, enriched uranium, and depleted uranium are specified in Section 3.0. Wastes from some of the processes described below may not be contained in the inventory based on the assigned prefixes. However, as explained in Section 10.3.2.6, it is assumed that repackaged drums could contain waste generated from any process.

Radioassay interferences may include polypropylene from Ful-Flo filters, cadmium or chromium from HEPA filter frames, aluminum foil used as a spacer between the folds of the filter media, and 5 to 7 weight percent Nomex which is a aromatic polyamide fiber used in HEPA filters. ${ }^{\text {P035.P052 }}$

\subsubsection{Plutonium Production}

Radionuclide contamination in waste from Building 707 will primarily consist of weapons-grade plutonium from foundry, casting, and final assembly operations. ${ }^{\text {P052,P053 }}$ A small percentage of the waste from Building 707 may also contain americium-240, neptunium-237, and plutonium-238 from blending of these isotopes with weapons-grade plutonium for diagnostic tracers. ${ }^{\text {C171,C174,C184,C185,P053,P164,P167 }}$

Building 777 performed disassembly of site-return parts and fabrication operations including machining, briquetting, assembly, and production support processes (prefixes 04, 23, and 24). ${ }^{\text {C184,P052,U059,P079 }}$ Wastes from fabrication operations will be contaminated with weapons-grade plutonium and enriched uranium. Wastes generated by disassembly operations will be contaminated with site-return plutonium (higher americium-241 decay product) and enriched uranium. ${ }^{\text {C184,P079 }}$ Tritium may also be present from disassembly operations. $^{\text {P053 }}$

Buildings 707 and 777 handled actinides in metal or oxide form only. ${ }^{\mathrm{P} 060, \mathrm{P} 079}$ The actinide metals will likely have partially or completely oxidized because of the reaction with dry air, and some could possibly have formed a hydroxide layer from reaction with moist air. Radioassay interferences may include beryllium from Part V metal fabrication in Building 707, and calcium fluoride which was sprayed onto graphite molds in Building 707 prior to casting. ${ }^{\mathrm{Cl} 84, \mathrm{P} 060}$ Other interfering waste contaminants include aluminum, beryllium, and stainless steel (chromium) which were machined in Building $777 .^{\text {P079 }}$

\subsubsection{Plutonium Recovery and Purification}

Waste from recovery operations in Building 371 will contain weapons-grade plutonium primarily from electrorefining. ${ }^{\text {C184,P067 }}$ A limited amount of the waste could also have been generated from aqueous recovery operations which only ran for a short time in 1982. Aqueous recovery operations were designed for recovering and purifying weapons-grade plutonium. ${ }^{\mathrm{C} 184, \mathrm{P} 164}$

The feed materials to the recovery and purification processes (prefixes 01 and 02) in Building 771 were impure plutonium residues which were processed to produce plutonium metal for use in the foundry and, therefore, wastes generated will be contaminated primarily with weapons-grade plutonium. ${ }^{\text {P052,P163,U059 }}$ Filters containing recoverable amounts of plutonium were processed in Building 771 by manually shaking the filter to remove loose particulate which was sent through recovery. ${ }^{\mathrm{P} 24, \mathrm{P} 061}$ Radionuclides from aqueous recovery 
operations will vary widely in chemical form depending on the specific process the waste originated, and because the majority of the aqueous processes were performed within one large MBA (prefixes 01 and 02), the specific process can not be determined. The different actinide forms are plutonium nitrate, plutonium chloride, plutonium peroxide, plutonium dioxide, plutonium tetrafluoride, and plutonium metal. Radioassay interferences may include aluminum nitrate from the dissolution process and beryllium which was removed during Part V leach. ${ }^{\text {P163 }}$

Wastes from the americium recovery glovebox lines (prefix 06) in Building 771, used for extraction of americium from site-return plutonium, will contain a significant amount of americium-241. ${ }^{\text {C184,P053,P164,U059 }}$ The americium was in a chloride, hydroxide, nitrate, oxalate, and oxide chemical form during different steps of the process. Prior to 1975 , ammonium thiocyanate was also used. ${ }^{\text {P053 }}$

The Oralloy leach process (prefix 74) in Building 771 chemically separated plutonium surface contamination from enriched uranium hemishells using nitric acid. The chemical form of the radionuclides will therefore be plutonium nitrate and uranyl nitrate. ${ }^{\text {C184,P061,P163,U059 }}$

Site-return metal and other non-specification plutonium were processed by pyrochemical operations

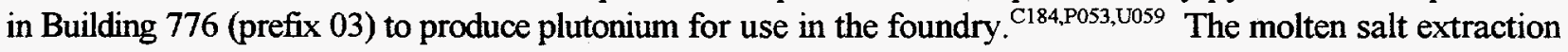
process removed americium-241 from site-return and other non-specification plutonium. Electrorefining was used to purify plutonium metal that did not meet foundry specifications. Since metal was the feed and product to the MSE and electrorefining processes, wastes generated from these processes will be contaminated with actinide metals which now will probably have formed an oxide or hydroxide layer from reaction with dry and moist air. Direct oxide reduction was developed to convert plutonium dioxide to plutonium metal. ${ }^{\text {P163.P175 }}$ MSE residue salts, which contain actinide chlorides, were the feed to the salt scrub process. Metal was the product of this process as well, so the radionuclide contaminants could be in a metal, oxide, and/or hydroxide form. Radioassay interferences may include chloride salts (i.e., sodium, potassium, magnesium, calcium, and zinc). ${ }^{\text {P163 }}$

Assay results for a drum of IDC 335 (RF000302881) from pyrochemical operations indicate a significant amount of uranium-235. ${ }^{\mathrm{P} 115}$ Although not confirmed, it is thought that the uranium from MSE and electrorefining salts may have concentrated in the filter. ${ }^{\mathrm{P} 175}$

Hydride operations in Building 779 (prefix 55) recovered plutonium from various substrates by reacting plutonium metal with gaseous hydrogen in an argon-inerted glovebox. ${ }^{\text {P052,U059,P062,P163 }}$ Hydriding produced plutonium metal for use in the foundry or non-specification feed to pyrochemical operations, in addition to plutonium oxides sent for aqueous recovery. ${ }^{\mathrm{C} 184, \mathrm{P} 062}$ The hydriding process formed plutonium hydride which was converted to plutonium dioxide by oxidizing the material in an air atmosphere. ${ }^{\text {P163 }}$

\subsubsection{Laboratory}

The analytical laboratory in Building 371 (prefix 71) provided analytical support for process control and performed analyses on feed materials and residues from recovery operations in Building 371. P053,0059,P081 The laboratory also analyzed samples from various operations at the site, but primarily from Building $374 .^{\text {P081 }}$ The Building 371 chemical standards laboratory prepared standards for various users and inspected standards that were used throughout plant site. ${ }^{\mathrm{P} 053}$ Wastes from these laboratories will be contaminated with weaponsgrade plutonium and enriched and depleted uranium. 
The Building 559 analytical laboratory (prefix 29) performed a variety of analyses, including plutonium, enriched and depleted uranium, americium, neptunium, and tritium content. ${ }^{\text {P053,P067,U059,U073 The }}$ primary mission of this laboratory was analysis of site-return and feed materials, in addition to recovery, purification, and foundry products. ${ }^{\text {P053 }}$

The Building 771 analytical laboratory (prefix 37 ) received samples from recovery operations in the building as well as from the foundry. ${ }^{\text {P067,U059 }}$ The samples included plutonium metal turnings, plutonium oxide, acidic plutonium solutions, and various process residues. ${ }^{\mathrm{P} 061}$ In addition, the analytical laboratory analyzed samples from R\&D laboratories in Buildings 771 and 779 (see Section 10.3.2.4). ${ }^{\mathrm{P} 067, \mathrm{P} 061}$ The chemical standards laboratory (prefix 38) prepared uranium, plutonium, and americium nitrates used as control standards for the Buildings 371,559 , and 771 analytical laboratories. ${ }^{\text {P067,P061 }}$ The laboratory also produced nondestructive assay standards used at drum counters and fluoride standards for chemical operations. ${ }^{\text {P06 } 1}$

The metallography laboratory (prefix 21) in Building 777 prepared and examined metallographic specimens in support of R\&D operations (plutonium metallography, nuclear and non-nuclear joining, quality engineering, and product physical chemistry) and, therefore, may contain any of the radionuclides used during

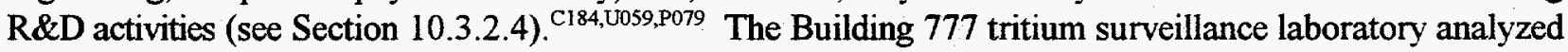
solid, liquid, and gas samples from throughout the plant site for tritium content. ${ }^{\mathrm{U} 078}$

Because the laboratories supported all phases of weapons production, the chemical form of the radionuclide contaminants and radioassay interferences will vary widely depending on the type of sample analyzed.

\subsubsection{Research and Development}

Projects using transuranic radionuclides were done in Buildings 771, 776, 777, 779, and 881. Most of the documentation pertaining to R\&D activities does not specify locations in which the work was performed, and unless otherwise noted, it will be assumed that any of the radioisotopes could have been handled in the R\&D areas of any of these buildings. In addition to weapons-grade plutonium, americium-241, and enriched and depleted uranium, the following radioisotopes were processed during R\&D activities. ${ }^{\mathrm{C134}, \mathrm{C137}, \mathrm{C1} 185, \mathrm{P} 053, \mathrm{P} 164, \mathrm{P} 167, \mathrm{P} 189, \mathrm{P} 190, \mathrm{P} 194, \mathrm{P} 195, \mathrm{P} 198, \mathrm{P} 200, \mathrm{U} 064}$

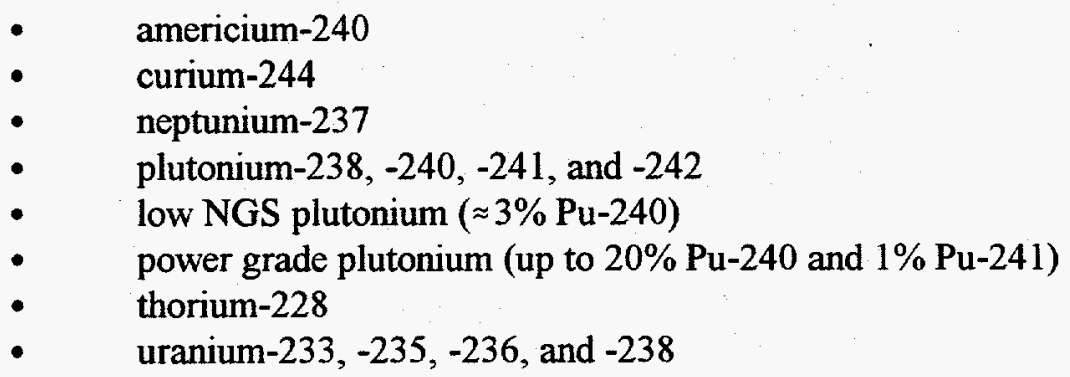

A summary of the projects and time periods that these and other radionuclides were used is presented in Section 3.0 .

In Building 771, special recovery anion exchange (prefix 45) separated plutonium from other materials that were not suitable for the regular recovery processes. ${ }^{\mathrm{C} 154, \mathrm{PO} 02 \mathrm{PO} 061}$ Chemical technology (prefix 42) conducted aqueous R\&D activities while plutonium metallurgy operations (prefix 78 ) performed alloy preparation, heat 
treating, rolling, metal and metallurgical testing, and cutting for R\&D. ${ }^{\text {C184,U059,P061 }}$ These processes may have used numerous radioisotopes.

A pilot-scale fluidized-bed incinerator (prefix 75) was developed in Building 776 to treat low-level waste. ${ }^{\mathrm{C} 184, \mathrm{U} 059}$ The waste fed to the incinerator was contaminated with low levels of plutonium. ${ }^{\mathrm{P} 024}$

The coatings laboratory (prefix 16) in Building 777 developed various substrates to be coated with uranium or plutonium, including stainless steel, copper, chromium, aluminum, and beryllium. ${ }^{\text {P052,U059,P079 }}$ This research and development facility supported production processes. ${ }^{\text {P052,P079 }}$ The special weapons area (prefix 66) in Building 777 was a research and development facility which assembled war reserve and other specially fabricated parts. ${ }^{\mathrm{U} 59, \mathrm{P} 079}$ The process was also responsible for disassembly of surveillance (tracer) parts and drilling of parts for use in analytical testing. ${ }^{\text {P079 }}$

Pyrochemical technology (prefixes 10 and 52) in Building 779 involved the extraction and recovery of plutonium and americium in support of production operations. ${ }^{\text {P067,U059,P062 }}$ These processes included direct oxide reduction, molten salt extraction, electrorefining, salt scrub for MSE, salt scrub for electrorefining, pyrochemical salt recycle, anode alloy, and pyroredox. ${ }^{\mathrm{C} 182 \mathrm{PO} 62}$ Most of the materials used in Building 779 were the same as those in the weapons-production areas and, therefore, will be contaminated primarily with weapons-grade plutonium and enriched uranium. ${ }^{\text {P053 }}$ However, other R\&D activities in the building may have used a variety of other radionuclides. ${ }^{\mathrm{Cl} 71, \mathrm{Cl} 84}$

\subsubsection{Liquid Waste Treatment}

Aqueous waste treatment operations in Buildings 374 and 774 received wastes from throughout plant site, including processes that generated low-level and nonradioactive liquid wastes. For this reason, wastes generated during treatment operations may contain any of the radioisotopes used at the plant. The most common radioactive materials handled were weapons-grade plutonium, americium-241, enriched uranium, and depleted uranium. Other radionuclides may also be found in the waste streams from R\&D, analytical, and

special order work. ${ }^{\mathrm{P} 64}$ Radionuclide contaminants are removed from the aqueous wastes by precipitation using sodium hydroxide and, therefore, will be primarily in the form of hydroxides. ${ }^{\text {P163 }}$ Radioassay interferences may include magnesium sulfate and calcium chloride reagents used in the process. ${ }^{\text {P106,P163 }}$

Building 774 also processed organic liquid wastes. Organic wastes are comprised of a variety of oils and solvents. Most of the oils were from spent lathe coolant used in the plutonium machining area and lubricating oils used in machines throughout the plant. ${ }^{\mathrm{P} 64}$ The majority of the transuranic organic liquids were oils and solvents from plutonium machining and degreasing operations in Buildings 707 and 777 and, therefore, will be contaminated with actinide metals and oxides. ${ }^{\mathrm{P}}{ }^{052} \mathrm{~A}$ more detailed discussion of the wastes treated in these buildings is provided in Sections 22.0 through 25.0 .

\subsubsection{Size Reduction/Repackaging/Solid Waste Treatment}

The Size Reduction Vault (SRV) in Building 776 conducted solid waste treatment, repackaging, and size reduction operations. The SRV was divided into two sides. One side was the airlock (prefixes 25, 40, 41, and 57) where repackaging was done. The other side (prefixes 19 and 26) was a drybox atmosphere where size

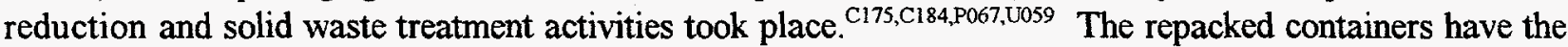
potential to contain contaminated materials from any of the processes within the transuranic waste generating buildings. ${ }^{\text {P067,U07 }}$ Size reduction included cutting up gloveboxes or ducting, and crushing HEPA filters. Solid 
waste treatment activities included washing leaded gloves and scrap metal with hot water in a ball-mill washer to recover plutonium. ${ }^{\text {C053.P067,P164 }}$

\subsubsection{Complexing Agents}

Because complexing agents can aid in the transport of transuranic radionuclides from the waste after disposal, the waste was assessed for potential complexing agents. This information may also be added to the chemical compatibility studies since limited information was available on these chemicals in the past.

EDTA represents a group of chelating compounds, such as ethenediaminetetraacetic acid, with similar molecular structures found in many soaps and detergents. Versene (a trade name for EDTA) and citric acid are known constituents of $\mathrm{KW}$ decontamination detergent. ${ }^{\mathrm{P} 24, \mathrm{P} 068} \mathrm{KW}$ was used during a variety of decontamination activities at the plant, including wiping down filter frames.. A buffer solution (TISAB) containing diaminocyclohexane tetraacetic acid was used during specific ion electrode analysis in Building 559. ${ }^{\mathrm{P} 076}$ Oxalic acid and tetraphosphoric acid were used to etch plutonium and other metals. ${ }^{\mathrm{P} 62, \mathrm{P} \text { P07, U043 }}$ Oxalic acid was also used for americium recovery. ${ }^{\mathrm{Pl13}}$ Filters and insulation may contain trace quantities of these complexing agents. 


\subsection{GLASS}

This waste group consists of glass materials generated by the production, recovery, laboratory, treatment, maintenance, and research and development activities associated with plutonium operations. The waste was generated in Buildings $371,374,559,707,771,774,776,777$, and 779 . $^{\text {O12,P083 }}$ Historic IDC descriptions and dates of generation for the INEEL accessible storage inventory are presented by IDC in Table 11-1. ${ }^{\mathrm{P} 127}$

Table 11-1. Glass Waste in the Accessible Storage Inventory.

\begin{tabular}{clc}
\hline IDC & \multicolumn{1}{c}{ Title } & \multicolumn{1}{c}{ Dates of Generation } \\
\hline 440 & $\begin{array}{l}\text { Glass }^{\mathrm{P} 012} \\
\text { Glass (except Raschig Rings) }\end{array}$ & November 1972-February 1988 \\
\hline
\end{tabular}

Item Description Code 440, Glass (except Raschig Rings): This waste consists of glass generated by plutonium production, recovery, treatment, laboratory, and maintenance operations in Buildings 371,374 , $559,707,771,774,776,777$, and $779 .^{\text {P012.P083 }}$ The waste consists of items such as bottles, vials, light bulbs, labware, glovebox windows, and process equipment. The materials may be glass, ceramic, leaded glass, or

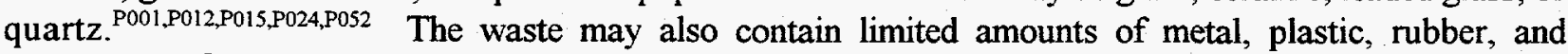
combustibles. ${ }^{\mathrm{P} 15, \mathrm{P} 024}$

\subsection{Waste Generation}

Glass was generated by production, recovery, purification, laboratory, treatment, maintenance, and research and development activities associated with plutonium operations at the site.

\subsubsection{Plutonium Production}

Plutonium production consisted of operations directly associated with the manufacturing of plutonium metal parts including casting, rolling, forming, machining, and assembly processes. Buildings 707 and 777 were the primary weapons components production facilities at the site after the construction of Building 707 in 1972. Building 707 was constructed after the 1969 fire in Building 776 which shut down foundry and machining operations in that building. ${ }^{\text {P053 }}$

The foundry in Building 707 cast molten plutonium into classified components, subassemblies, and assemblies. Other parts were manufactured by rolling, forming, and machining plutonium ingots also cast in the foundry. Components were assembled using a number of welding and joining techniques in Buildings 707 , 777, and 779. Production support operations in Buildings 707 and 777 included a variety of inspection, calibration, measurement, weighing, leak testing, and cleaning activities to assure that the parts met stringent specifications. Rejected plutonium parts, scraps, and turnings were returned to be recast. Small pieces of metal, fines, and sweepings were typically burned to oxide and sent to Building 771 to be recovered. ${ }^{\text {P052. P053 }}$ Glass waste generated by production operations consisted primarily of items such as bottles and sample vials. ${ }^{\mathrm{P} 033}$ 
Halogenated solvents were used in production operations to clean and degrease plutonium parts and metal. In addition, the solvents were used with cutting oils to cool plutonium parts during machining. Carbon tetrachloride, tetrachloroethene, 1,1,1-trichloroethane, 1,1,2-trichloro-1,2,2-trifluoroethane, trichloroethene, and methylene chloride were the primary solvents historically used during plutonium production. Tetrachloroethene was replaced by 1,1,1-trichloroethane for degreasing during the 1973 time frame. Several non-halogenated solvents were also used for cleaning and degreasing, primarily during efforts to reduce use of halogenated solvents. ${ }^{\text {P023,P053 }}$ These solvents included isopropyl alcohol, ethanol, and acetone. ${ }^{\text {P052,P053,P067 }}$ Building 777 housed the carbon tetrachloride and 1,1,1-trichloroethane systems that collected and filtered solvents generated during production operations. In addition to parts cleaning and degreasing, solvents were also used to clean plutonium operation glovebox lines. ${ }^{\mathrm{P} 53}$

\subsubsection{Plutonium Recovery and Purification}

Several operations at the plant were responsible for either the purification of non-specification plutonium metal or the recovery of plutonium from production waste and residues. Building 771 housed operations that recovered plutonium from waste materials and other sources. ${ }^{\text {P053 }}$ Plutonium purification was performed primarily in Buildings $371,771,776$, and 779. ${ }^{P 083}$

Recovery operations in Building 771 used acid to dissolve solid materials containing plutonium. The resulting solutions were processed by a series of ion exchange, precipitation, calcination, fluorination, and reduction operations to produce purified plutonium metal to be recycled back into production operations. Potassium hydroxide, potassium fluoride, hydrogen peroxide, and nitric, hydrochloric, and hydrofluoric acids were the primary reagents used for plutonium recovery operations. ${ }^{\text {P053,P061,P067,P083,U047 }}$

Plutonium metal from returned parts and metal from other DOE facilities was purified at Rocky Flats. Plutonium-24l decays to americium-241 which decreases the effectiveness of the plutonium parts. Plutonium parts were disassembled in Building 777. ${ }^{\text {P033,P113 }}$ Beginning in 1967, the molten salt extraction (MSE) process in Building 776 recovered americium from plutonium metal using sodium chloride, potassium chloride, and magnesium chloride. ${ }^{\mathrm{P} 53}$ Americium was separated from the MSE residue salts using potassium hydroxide precipitation followed by an ammonium thiocyanate anion exchange process. In 1975, the process changed to cation exchange followed by anion exchange (no thiocyanate) and then precipitation using oxalic acid. ${ }^{\text {P113, U047 }}$ The process changed again the following year to the salt scrub process which used a magnesium/zinc or a magnesium/aluminum extractant. ${ }^{\mathrm{U} 047}$ The purified plutonium metal from MSE was either sent to the foundry in Building 707 or sent to the electrorefining (ER) process in Building 371 or Building 776 if the metal contained other impurities. P053,U047 $^{2}$

Spray leaching (Building 771) and hydride leaching (Building 779) also used acids to remove plutonium surface contamination from uranium metal and other metals or beryllium contamination from plutonium metal. These processes used nitric, hydrochloric, sulfuric, and sulfamic acids. ${ }^{\text {P053,P061,P062 }}$

Glass waste generated by recovery operations included items such as bottles, condensers, ion columns, vessels, and vessel liners. ${ }^{\mathrm{P} 014, \mathrm{P} 083}$

\subsubsection{Laboratory}

Buildings 371,559 , and 771 housed the main analytical laboratories at the site. The laboratories' primary function was to provide analytical support to production activities in addition to supporting recovery, 
purification, and liquid waste treatment operations. Each of the laboratories used numerous acids, bases, solvents, and other chemical reagents.

Building 371 had an analytical laboratory and a chemical standards laboratory. The chemical standards laboratory prepared standards for various users and inspects standards that have been used in the field. The analytical laboratory analyzed samples from various operations on site. The types of analyses performed included. ${ }^{\text {081 }}$

- Total Alpha Activity

- Isotopic Analysis

- X-Ray Emission

- X-Ray Diffraction
- $\quad$ Plutonium, Uranium, and Americium

Content

- Corrosivity

- Ignitability

Building 559 housed the Plutonium Analytical Laboratory responsible for spectrochemical, chemical, and mass spectrometric analyses of samples from plutonium production operations. Uranium, Raschig rings, solutions, and commercial product and gas samples were also analyzed in the laboratory. Plutonium production samples, including metal and oxide, were prepared and subdivided for analysis in the sample cutting process. The types of analyses performed included. ${ }^{067}$

\section{- $\quad$ Emission Spectroscopy \\ - Atomic Absorption \\ - Infrared Analysis \\ - Gallium Analysis \\ - $\quad$ Plutonium Assay \\ - Carbon Analysis \\ - Uranium Analysis \\ - $\quad$ Raschig Ring Analysis}

$\begin{array}{ll}\text { - } & \text { Tritium Analyses } \\ \text { - } & \text { Nonroutine Chemical Analysis } \\ \text { - } & \text { Anion/Cation Solution Analysis } \\ \text { - } & \text { Thotopic Analysis } \\ \text { - } & \text { Gas Analysis } \\ \text { - } & \text { Xpark Source Mass Spectroscopy } \\ & \text { X-ray Analysis }\end{array}$

Building 771 housed analytical and chemical standards laboratories. The chemical standards laboratory prepared control sample standards for the analytical laboratories in Buildings 371, 559, and 771. ${ }^{\mathrm{P} 61}$ The analytical laboratory provided analyses in support of plutonium operations. The types of analyses performed included: ${ }^{\mathrm{P} 061, \mathrm{PO} 67}$

\begin{tabular}{|c|c|}
\hline $\begin{array}{l}\text { X-Ray Fluorescence } \\
\text { Alpha/Gamma Scintillation } \\
\text { Atomic Absorption } \\
\text { Laser Fluorimetry }\end{array}$ & $\begin{array}{ll}- & \text { Spectrophotometry } \\
\text { - } & \text { Calorimetry } \\
\text { - } & \text { Gamma Spectroscopy } \\
\text { Titrations }\end{array}$ \\
\hline
\end{tabular}

The laboratories used a variety of reagents and solvents including: 


\section{Acids/Bases}

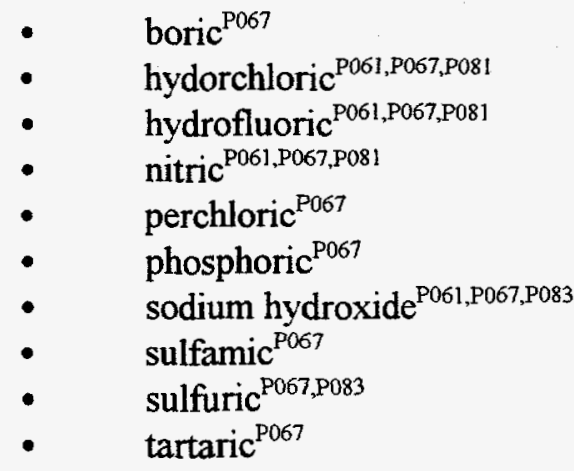

\section{Reagents}

\begin{tabular}{|c|}
\hline $\begin{array}{l}\text { ammonium hydroxide }{ }^{\mathrm{P} 083} \\
\text { ammonium molybdate }^{\mathrm{P} 067} \\
\text { ceric ammonium nitrate }^{\mathrm{P} 067} \\
\text { ceric sulfate } \\
\text { ferrous sulfamate }^{\mathrm{P} 063} \\
\text { ferric chloride }^{\mathrm{P} 067} \\
\text { potassium bromide } \\
\text { potassium chloride } \\
\text { sodium fluoride } \\
\text { total ionic strength adjusting buffer }^{\mathrm{P} 067} \\
\text { (contains diaminocyclohexane }^{\mathrm{P}} \\
\text { tetraacetic acid) } \\
\text { trioctyl phosphene oxide }^{\mathrm{P} 061, \mathrm{P} 081}\end{array}$ \\
\hline
\end{tabular}

\section{Organic Solvents}

- $\quad$ acetone $e^{\mathrm{P} 083}$

- benzene $e^{\mathrm{P} 053}$

- $\quad$ carbon disulfide ${ }^{\mathrm{P} 083}$

- $\quad$ carbon tetrachloride ${ }^{\mathrm{P} 053, \mathrm{P} 067, \mathrm{P} 083}$

- $\quad$ chloroform ${ }^{\text {P053,P067,P083 }}$

- cyclohexane $e^{\mathrm{P} 061}$

- ethanol $^{\mathrm{P083}}$

- $\quad$ isooctane $\mathrm{P}^{\mathrm{P} 03}$

- isopropanol $^{\mathrm{P} 083}$

- methanol ${ }^{\mathrm{P0} 3}$

- $\quad$ methylene chloride ${ }^{\mathrm{P} 053, \mathrm{P083}}$

- petroleum ether ${ }^{\mathrm{P} 083}$

- toluene $\mathrm{P}^{\mathrm{P083}}$

- $\quad$ tributyl phosphate ${ }^{\mathrm{P} 083}$

- 1,1,1-trichloroethane ${ }^{\mathrm{P} 083}$

- trichloroethene $\mathrm{P}^{\mathrm{0} 83}$

- 1,1,2-trichloro-1,2,2-triflouroethane $\mathrm{P}^{\mathrm{P067,P083}}$

- $\quad x y l e n e^{\mathrm{P083}}$

Laboratory operations generated a majority of the glass waste group. Laboratory operations generated items such as reagent bottles, vials, burettes, pipettes, ceramics, syringes, stirrers, watch glasses, funnels, beakers, flasks, sample cells, ampules, plasma torches, and other glass laboratory equipment and instruments. ${ }^{\mathrm{P} 83}$

\subsubsection{Research and Development}

Research and Development (R\&D) included activities related to production, recovery, and purification as well as "special order" work. Building 779 , which was built in 1965 , housed much of the R\&D operations at the plant. Other areas at the plant supporting $R \& D$ included Buildings $559,771,776,777$, and $881{ }^{\mathrm{P}}{ }^{053}$

The purpose of Building 779 was to gain more knowledge of the chemistry and metallurgy of plutonium and its interactions with other materials which might be used in plutonium operations. Other activities in Building 779 included developing improvements to the manufacturing process and finding new ways to recover plutonium and associated actinides. Another function was to develop a better understanding of the aging and shelf-life limitations of Rocky Flats products. Most of the materials used and wastes generated in this facility were the same as those in the production and recovery buildings, as much of the work conducted 
involved improvement of existing processes. ${ }^{\text {PO53 }}$ However, processing of neptunium, curium, and cerium was also conducted. ${ }^{\text {P053,U047 }}$

The plant conducted special order work for other facilities in the DOE complex, the DOD, or other federal departments or agencies. One example is the introduction of radionuclide tracers into pits destined for off-site test shots. This work took place in the 1960 s and well into the 1970 s. Materials such as americium240 , plutonium-238, neptunium, curium, and cerium were blended in with the regular component materials for the purpose of studying performance of the different weapon components based on post-test distribution of the rare tracers. These tracer materials were kept separate from the regular production material streams, and special recovery operations in Building 771 specialized in recovering these more exotic materials. ${ }^{\mathrm{C} 72, \mathrm{P} 053}$

From approximately 1959 to the mid-1970s, Rocky Flats was involved in "Project Plowshare." The mission of the program was to develop technology for using nuclear explosives for peaceful applications such as excavation and uncovering of deep mineral deposits. Materials used in the manufacturing of these components were the same as those used in the production buildings. ${ }^{\text {P053 }}$

Research and Development activities may have generated any of the glass items generated by similar production, recovery, and purification operations at the site.

\subsubsection{Waste Treatment}

Waste processing at Rocky Flats has included both liquid and solid process wastes. Liquid waste treatment operations have had relatively few process changes over the years. When Building 774 was built in 1952, its primary purpose was to treat radioactive aqueous waste from Building 771. Radionuclides were removed by precipitation, and the resulting slurry filtered. The solids removed from filters were combined with cement or other solidifying agents. The aqueous waste from this first stage goes through a second precipitation. ${ }^{\mathrm{P} 53}$ These processes use sodium hydroxide, ferric sulfate, magnesium sulfate, and calcium chloride. ${ }^{\text {P109 }}$ See Section 23.0, Solidified Aqueous Sludge Building 774, for a detailed description of these processes.

Around 1965, an evaporator was installed in Building 774 to treat liquids from the second stage treatment and from the solar ponds. The concentrate from the evaporator was introduced into a steam-heated double-drum drier which produced a salt waste. The Building 774 evaporator was taken out in 1979, and the liquids from the second stage treatment and solar ponds have since been transferred to Building 374 for additional treatment. ${ }^{\mathrm{P} 53}$

Building 774 also processed organic liquid wastes. Plutonium-contaminated organic liquids were generated from plutonium machining. ${ }^{\text {P053 }}$ The spent organic liquid was filtered and then mixed with a solidifying agent. The process was later changed to a one step process in which the organic liquid was mixed with Envirostone (Gypsum cement) and allowed to set up. ${ }^{\text {P109 }}$ See Section 25.0, Solidified Organic Waste for a detailed description of these processes.

Treatment of solid transuranic wastes was conducted in Buildings 771 and 776 . Building 771 processed wastes containing plutonium above the EDL while Building 776 processed wastes below the EDL.

Operations in Building 771 processed wastes including Raschig rings, HEPA filters, and sludges from the filter plenum and from process piping. Filters were disassembled to remove plutonium-contaminated dust. 
Process piping removed from service was cut up and cleaned of built-up sludge. Sludge from the process piping and from the filter plenum was dissolved in nitric acid to recover plutonium. Until 1984, plutonium was recovered from Raschig rings by nitric acid leaching. ${ }^{\text {P06l }}$

Size reduction in Building 776 removed materials from drums and sorted them in an airlock vault. Materials such as light metals, filters, glass, combustibles, and Raschig rings were then put into containers with like materials. Light metals and leaded gloves were washed in a ball mill. ${ }^{\text {P067 }}$

Advanced size reduction operations in Building 776 disassembled or cut plutonium-contaminated gloveboxes and miscellaneous large equipment into sizes that could be packaged in approved containers. ${ }^{\text {P067,P110 }}$

The fluidized-bed incinerator in Building 776 received low-level plutonium-contaminated combustible solid and liquid wastes. ${ }^{\mathrm{P} 67}$ Building 771 also housed an incinerator for processing combustible wastes. ${ }^{\text {P067,U047 }}$ See Section 14.0, Incinerator Waste, for a detailed description of the incineration processes.

Glass waste generated by waste treatment operations consisted primarily of items such as bottles and other broken containers. ${ }^{\mathrm{P} 083}$

\subsubsection{Routine Maintenance}

Routine maintenance at Rocky Flats included utilities; change out of oils, coolants, filters, and Raschig rings; and other general maintenance activities.

Utility systems include HVAC systems, fume scrubbers, and process vacuum systems. The HVAC systems contain air supply units for filtering incoming air and plenums for filtering exhaust air. KW detergent was used for periodic maintenance inside and outside the plenums. Scrubbers housed in Buildings 371, 559, 771 , and 779 used potassium or sodium hydroxide to neutralize acid fumes from various process off-gas streams and glovebox exhaust streams. Process vacuum systems provide an absolute pressure at a vacuum header which serves as a means to transfer fluids on demand by valving arrangements. ${ }^{\mathrm{P} 061, \mathrm{P} 067}$

Oils, coolants, filters, and Raschig rings were used in numerous processes and required periodic change out. Other general maintenance activities included repair or replacement of gloveboxes, tanks, valves, pumps, and pipes. ${ }^{\text {P108.P061,P067,P109 }}$

Glass waste generated by maintenance activities included leaded glass glovebox windows, scrubber vessels, inspection ports from fume scrubber towers, and fluorescent and incandescent light bulbs.

\subsubsection{Non-Routine Operations}

Non-routine operations include spill clean up, strip-out operations, and activities associated with fires and other incidents.

Occasionally, spills of various materials occur due to leaks in tanks and piping or from material releases from gloveboxes. Tanks or pipes may have contained acids, bases, or solvents used during normal process operations. A paint stripper containing methylene chloride was often used for decontamination. ${ }^{\text {P053,P067 }}$ 
Another nonroutine activity was the strip-out of glovebox lines, process piping, valves, and associated systems. Strip-out activities were performed when a glovebox line was scheduled to be replaced or during renovation. Solvents such as trichloroethene or 1,1,1-trichloroethane may have been used during this type of operation for decontamination. ${ }^{\text {P667.P108 }}$

Other nonroutine activities, such as fires and other incidents, include:

- the 1969 fire which spread through combustible materials in several hundred inter-connected gloveboxes in Building 776/777, ${ }^{\text {P053 }}$

- the 1974 control valve release in Building 707 which allowed radioactive particulates to escape from an exhaust stack on the roof and into Module $\mathrm{K} \cdot{ }^{\mathrm{P} 053}$ and

- the tritium release in which tritium-contaminated plutonium was processed from April 9, 1973 through April 25, 1973 in Building 779 causing a tritium release to the atmosphere, as well as elevated tritium levels in surface waters, process wastes, equipment, gloveboxes, and exhaust plenums. ${ }^{\text {P053 }}$

\subsection{Waste Packaging}

Glass was either loaded directly into a lined 55-gallon drum or double-bagged out of the glovebox line. To increase loading, many glass items were broken prior to packaging. Light bulbs may have been crushed prior to disposal. The waste may also have been collected in metal cans, polyethylene bottles, or Fibre-Paks prior to placement in a lined 55-gallon drum. ${ }^{\mathrm{P} 12, \mathrm{P} 024}$

Depending on waste packaging requirements at the time, several combinations of bags and liners were used to prepare 55-gallon drums for shipment. From 1970 to 1972, waste drums were lined with one or two polyethylene drum bags. Cardboard liners might also have been used to line the inner drum bag. Use of the 90-mil rigid polyethylene liner began in 1972. ${ }^{\mathrm{P} 024}$ The rigid liner was placed in each drum and lined with one polyethylene round bottom drum liner or one or two polyethylene drum bags. ${ }^{\mathrm{P} 008, \mathrm{P} 012, \mathrm{P016}, \mathrm{P024,P063,P064}} \mathrm{A}$ polyvinyl chloride O-ring bag and a polyethylene bag were used if the drum was attached to the glovebox. ${ }^{\text {P016 }} \mathrm{A}$ fiberboard liner and discs may also have been used between the waste packages and the drum liners for puncture protection. ${ }^{\mathrm{P} 008, \mathrm{PO} 12, \mathrm{P} 016, \mathrm{P} 063, \mathrm{P} 064}$ When a drum was full, the drum liners were twisted and taped closed, the lid was secured with a bolted ring, and a tamper indicating device was attached to the drum. ${ }^{\mathrm{P} 12, \mathrm{P} 016, \mathrm{P} 024}$

After drums were inspected, one to two quarts of absorbent material (Oil-Dri) was placed on the top of the outer, sealed polyethylene drum bag. This procedure changed in February 1982 when vermiculite was used to fill the space between the outer, sealed polyethylene drum bag and the top of the 90 -mil rigid liner. The quantity of vermiculite varied from 3-12 pounds according to the amount of waste contained in each drum. ${ }^{\mathrm{O} 24}$

Waste management and inspection protocol allowed containers of wastes to contain up to 10 percent of another IDC other than that assigned to the container. ${ }^{\mathrm{P} 016}$ Visual inspection of containers of glass waste identified plastic bottles, lead tape, rubber gaskets, and Raschig rings. ${ }^{\mathrm{P} 009, \mathrm{P} 015, \mathrm{P} 024}$ 


\subsection{Waste Characterization}

Glass is characterized based on knowledge of the material, knowledge of the processes generating the waste, RTR review of the waste, visual inspection, and headspace gas analysis. This section provides a RCRA hazardous waste determination for glass as well as radionuclide contaminants and potential complexing agents contained in the waste. This waste contains at least 50 percent by volume materials that meet the EPA LDR criteria for classification as debris, and is therefore a heterogeneous waste. ${ }^{\mathrm{P} 141}$

\subsubsection{Hazardous Waste Determination}

Some of the glass waste is not regulated as hazardous wastes as defined in 40 CFR 261.7 (empty container). Glass waste may exhibit the characteristic of ignitability due to the presence of ignitable free liquids. The waste may also exhibit the characteristic of toxicity for barium, lead, and mercury. The waste is not a listed hazardous waste, and there is no evidence that glass exhibits any other characteristic of hazardous waste. ${ }^{\mathrm{CO} 1, \mathrm{C} 094}$ EPA Hazardous Waste Numbers applicable to some or all of the glass waste group are presented by IDC in Table 11-2. These conclusions are supported by the evaluation in Sections 11.3.1.1 and 11.3.1.2.

Table 11-2. Glass Waste Characterization.

\begin{tabular}{ccc}
\hline IDC & Title & EPA Hazardous Waste Numbers \\
\hline 440 & Glass (except Raschig Rings) & D001, D005, D008, D009 \\
\hline
\end{tabular}

\subsubsection{Characteristic Waste}

The materials in this waste group may exhibit a characteristic of hazardous waste as defined in 40 CFR 261, Subpart C, as an ignitable waste (40 CFR 261.21) and as a toxic waste (40 CFR 261.24). The materials do not exhibit the characteristics of corrosivity (40 CFR 261.22) or reactivity (40 CFR 261.23).

Ignitability: The materials in this waste group may meet the definition of ignitability as defined in 40 CFR 261.21 due to the presence of ignitable free liquids. The materials are not liquid, and absorbents were added to wastes having the potential of generating free liquids (i.e., glass vials containing liquid). ${ }^{\mathrm{P} 012, \mathrm{P} 015, \mathrm{P} 024}$ Free liquids were identified in a few drums of glass waste. Headspace gas analysis of those drums indicates that the liquids contain cyclohexane which is an ignitable liquid. ${ }^{\mathrm{U} 005}$ The materials are not compressed gases, nor does the waste contain compressed gases. ${ }^{\mathrm{P} 12, \mathrm{PO} 14, \mathrm{PO} 15, \mathrm{P} 022, \mathrm{P} 024}$ The materials are not capable of causing fire through friction, absorption of moisture, or spontaneous chemical change. ${ }^{\mathrm{P} 012 \mathrm{P} 024}$ The materials are not DOT oxidizers as defined in 49 CFR 173. Therefore, EPA Hazardous Waste Number D001 may be applicable to drums of glass waste containing free liquids.

Corrosivity: The materials in this waste group do not meet the definition of corrosivity as defined in 40 CFR 261.22. The materials are not a liquid, and absorbents were added to wastes having the potential of generating free liquids (i.e., glass vials containing liquid). ${ }^{\mathrm{P} 12 \mathrm{P} 015, \mathrm{P} 024}$ Free liquids were identified in a few drums of glass waste; however, headspace gas analysis of those drums indicates that the liquids contain cyclohexane 
and 1,1,1-trichloroethane which are not corrosive liquids. ${ }^{\mathrm{U} 005}$ The materials in this waste group are therefore not corrosive wastes (D002).

Reactivity: The materials in this waste group do not meet the definition of reactivity as defined in 40 CFR 261.23. The materials are stable and will not undergo violent chemical change. The materials will not react violently with water, form potentially explosive mixtures with water, or generate toxic gases, vapors, or fumes when mixed with water. The materials do not contain cyanides or sulfides, and are not capable of detonation or explosive reaction. The materials are not forbidden explosives or Division $1.1,1.2$, or 1.3 (Class A or B) explosives as defined in 49 CFR 173, nor do the drums contain explosive materials. ${ }^{\text {P013,P015,P021,P022,P024 }}$ Explosives were not handled or used around radioactive material. The materials in this waste group are therefore not reactive wastes (D003).

Toxicity: The materials in this waste group may meet the definition of toxicity as defined in 40 CFR 261.24. The toxicity characteristic contaminants fall into one of two categories: metals and organics. Organic compounds include halogenated-and nonhalogenated-solvents, pesticides, herbicides, and other toxic compounds. This waste group may exhibit the characteristic of toxicity for barium, lead, and mercury metals.

Visual inspection of the glass waste revealed leaded glovebox windows and other lead items, as well as fluorescent bulbs. ${ }^{\mathrm{P} 15}$ Barium and lead are components of leaded glass, and fluorescent bulbs contain mercury. Prior to 1989 , leaded glass and fluorescent bulbs were not sorted from other glass waste. Glass waste may exhibit the characteristic of toxicity for these metals. Therefore, the materials in this waste group are assigned EPA Hazardous Waste Numbers D005, D008, and D009 since a representative sample of this waste cannot be obtained for verification purposes.

There is no documentation indicating the presence or use of pesticides or herbicides in the areas or processes generating glass. Therefore, this waste group does not exhibit the characteristic of toxicity due to pesticides or herbicides (D012-D017).

Carbon tetrachloride, tetrachloroethene, and trichloroethene were used for cleaning and degreasing. Benzene was used in laboratory analysis. Glass may have contacted these compounds during process operations. However, glass is a nonporous material and should not retain toxicity characteristic levels of organics. Therefore, this waste group does not exhibit the characteristic of toxicity due to organic compounds (D018-D043).

\subsubsection{Listed Hazardous Waste}

The material in this waste group is not, or was not mixed with, a waste listed in 40 CFR 261, Subpart D as a hazardous waste from non-specific sources (40 CFR 261.31), as a hazardous waste from specific sources (40 CFR 261.32), or as a discarded commercial chemical product, an off-specification species, a container residue, or a spill residue thereof (40 CFR 261.33).

Tetrachloroethene, trichloroethene, methylene chloride, 1,1,1-trichloroethane, carbon tetrachloride, and 1,1,2-trichloro-1,2,2-trifluoroethane were used in production, laboratory, and maintenance operations. Acetone, methanol, xylene, benzene, carbon disulfide, and toluene were used in laboratory operations. During process operations, glass may have come in contact with these compounds. However, much of the glass waste consists of empty containers which are not regulated as hazardous wastes as defined in 40 CFR 261.7. Also, glovebox windows while in place were part of a container-like apparatus, and are not a hazardous waste simply because 
solvents or other hazardous materials were used in the glovebox. Additionally, glass wastes such as labware that were wiped down with solvents for decontamination purposes are not regulated as listed hazardous wastes. This was clarified by the Colorado Department of Public Health and Environment. Therefore, this waste group is not a F001-, F002-, F003-, or F005-listed hazardous waste. ${ }^{\mathrm{C} 093}$

Raschig rings were identified in one drum of glass waste. Raschig rings removed from tanks that contained organic solvents are characterized as a F-listed waste. The drum of glass waste in question was generated in Building 371 where Raschig ring tanks did not contain solvents, and headspace gas analysis of this drum did not identify any organics. Since before 1970, it has been waste management practice to sort Raschig rings from other glass waste. ${ }^{\text {Co8, }, 0090 . P 015}$ Therefore, this waste group is not a F-listed hazardous waste due to the presence of Raschig rings.

There is no documentation indicating the presence or use of F004-listed solvents in the areas or processes generating glass. Therefore, this waste group is not a F004-listed hazardous waste.

Although this waste group is not a F-listed hazardous waste, headspace analysis performed on samples of glass obtained at INEEL confirms the presence of organic solvents. The detected compounds in which the 90 percent UCL is above the PRQL are provided. ${ }^{\text {033 }}$

\section{- 1,1,1-trichloroethane \\ - trichloroethene}

Additional F-listed solvents were detected in headspace samples of glass obtained Rocky Flats. The detected F-listed compounds in which the 90 percent UCL is above the PRQL are also provided. ${ }^{\mathrm{U} 030}$

\section{- methanol \\ - toluene}

The material in this waste group is not a hazardous waste from specific sources since it was not generated from any of the processes listed in 40 CFR 261.32. The material in this waste group is therefore not a K-listed hazardous waste.

The material in this waste group is not a discarded commercial chemical product, an off-specification species, a container residue, or a spill residue thereof (40 CFR 261.33). The material in this waste group is therefore not a P- or U-listed hazardous waste.

\subsubsection{Radionuclides}

This section identifies the radioisotopes potentially contained in the waste, as well as the chemical form of radionuclide contaminants and radioassay interferences. The primary radionuclides processed at Rocky Flats included weapons-grade plutonium, americium-24l, enriched uranium, and depleted uranium. The isotopic compositions of weapons-grade plutonium, enriched uranium, and depleted uranium are specified in Section 3.0. Wastes from some of the processes described below may not be contained in the inventory based on the assigned prefixes. However, as explained in Section 11.3.2.6, it is assumed that repackaged drums could contain waste generated from any process. 


\subsubsection{Plutonium Production}

Radionuclide contamination in waste from Building 707 will primarily consist of weapons-grade

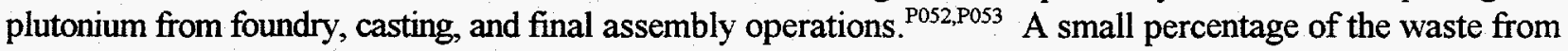
Building 707 may also contain americium-240, neptunium-237, and plutonium-238 from blending of these

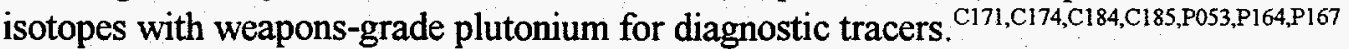

Building 777 performed disassembly of site-return parts and fabrication operations including machining, briquetting, assembly, and production support processes (prefixes 04, 23, and 24). ${ }^{\text {C184,P052,U059,P079 }}$ Wastes from fabrication operations will be contaminated with weapons-grade plutonium and enriched uranium. Wastes generated by disassembly operations will be contaminated with site-return plutonium (higher americium-241 decay product) and enriched uranium. ${ }^{\text {C184,P079 }}$ Tritium may also be present from disassembly operations. ${ }^{\mathrm{P} 53}$

Buildings 707 and 777 handled actinides in metal or oxide form only. P060.P079 The actinide metals will likely have partially or completely oxidized because of the reaction with dry air, and some could possibly have formed a hydroxide layer from reaction with moist air. Radioassay interferences may include beryllium from Part V metal fabrication in Building 707, and calcium fluoride which was sprayed onto graphite molds in Building 707 prior to casting. ${ }^{\mathrm{C} 184, \mathrm{P} 060}$ Other interfering waste contaminants include aluminum, beryllium, and stainless steel (chromium) which were machined in Building $777 .^{\text {P079 }}$

\subsubsection{Plutonium Recovery and Purification}

Waste from recovery operations in Building 371 will contain weapons-grade plutonium primarily from

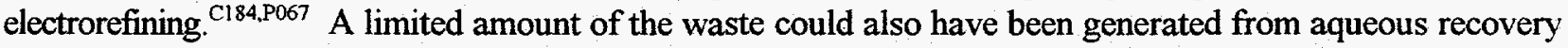
operations which only ran for a short time in 1982. Aqueous recovery operations were designed for recovering and purifying weapons-grade plutonium. ${ }^{\mathrm{Cl} 84, \mathrm{P} 164}$

The feed materials to the recovery and purification processes (prefixes 01 and 02 ) in Building 771 were impure plutonium residues which were processed to produce plutonium metal for use in the foundry and, therefore, wastes generated will be contaminated primarily with weapons-grade plutonium. ${ }^{\text {P052,P163,U059 }}$ Radionuclides from aqueous recovery operations will vary widely in chemical form depending on the specific process the waste originated, and because the majority of the aqueous processes were performed within one large MBA (prefixes 01 and 02), the specific process can not be determined. The different actinide forms are plutonium nitrate, plutonium chloride, plutonium peroxide, plutonium dioxide, plutonium tetrafluoride, and plutonium metal. Radioassay interferences may include aluminum nitrate from the dissolution process and beryllium which was removed during Part V leach. ${ }^{\text {P163 }}$

Wastes from the americium recovery glovebox lines (prefix 06) in Building 771, used for extraction of americium from site-return plutonium, will contain a significant amount of americium-241. ${ }^{\text {C184,P053,P164U059 }}$ The americium was in a chloride, hydroxide, nitrate, oxalate, and oxide chemical form during different steps of the process. Prior to 1975 , ammonium thiocyanate was also used. ${ }^{\mathrm{P}}{ }^{03}$.

The Oralloy leach process (prefix 74 ) in Building 771 chemically separated plutonium surface contamination from enriched uranium hemishells using nitric acid. The chemical form of the radionuclides will therefore be plutonium nitrate and uranyl nitrate. ${ }^{\mathrm{C} 184, \mathrm{PO} 061, \mathrm{P} 163, \mathrm{U} 059}$ 
Site-return metal and other non-specification plutonium were processed by pyrochemical operations in Building 776 (prefix 03) to produce plutonium for use in the foundry. ${ }^{\mathrm{C} 184, \mathrm{P} 053, \mathrm{U} 059}$ The molten salt extraction process removed americium-241 from site-return and other non-specification plutonium. Electrorefining was used to purify plutonium metal that did not meet foundry specifications. Since metal was the feed and product to the MSE and electrorefining processes, wastes generated from these processes will be contaminated with actinide metals which now will probably have formed an oxide or hydroxide layer from reaction with dry and moist air. Direct oxide reduction was developed to convert plutonium dioxide to plutonium metal ${ }^{\text {P163.P175 }}$ MSE residue salts, which contain actinide chlorides, were the feed to the salt scrub process. Metal was the product of this process as well, so the radionuclide contaminants could be in a metal, oxide, and/or hydroxide form. Radioassay interferences may include chloride salts (i.e., sodium, potassium, magnesium, calcium, and zinc). ${ }^{\mathrm{P} 163}$

Hydride operations in Building 779 (prefix 55) recovered plutonium from various substrates by reacting plutonium metal with gaseous hydrogen in an argon-inerted glovebox. ${ }^{\text {P052,U059,P062,P163 }}$ Hydriding produced plutonium metal for use in the foundry or non-specification feed to pyrochemical operations, in addition to plutonium oxides sent for aqueous recovery. ${ }^{\mathrm{C} 84, \mathrm{P} 062}$ The hydriding process formed plutonium hydride which was converted to plutonium dioxide by oxidizing the material in an air atmosphere. ${ }^{\text {P163 }}$

\subsubsection{Laboratory}

The analytical laboratory in Building 371 (prefix 71) provided analytical support for process control and performed analyses on feed materials and residues from recovery operations in Building 371. ${ }^{\text {P053,U059,P081 }}$ The laboratory also analyzed samples from various operations at the site, but primarily from Building $374{ }^{\text {P081 }}$ The Building 371 chemical standards laboratory prepared standards for various users and inspected standards that were used throughout plant site. ${ }^{\text {P053 }}$ Wastes from these laboratories will be contaminated with weaponsgrade plutonium and enriched and depleted uranium.

The Building 559 analytical laboratory (prefix 29) performed a variety of analyses, including plutonium, enriched and depleted uranium, americium, neptunium, and tritium content. ${ }^{\mathrm{P} 53, \mathrm{P} 067, \mathrm{U} 059, \mathrm{U} 073}$ The primary mission of this laboratory was analysis of site-return and feed materials, in addition to recovery, purification, and foundry products. ${ }^{\text {P053 }}$

The Building 771 analytical laboratory (prefix 37 ) received samples from recovery operations in the building as well as from the foundry. ${ }^{\mathrm{P} 067, \mathrm{U} 059}$ The samples included plutonium metal turnings, plutonium oxide, acidic plutonium solutions, and various process residues. ${ }^{\mathrm{P} 661}$ In addition, the analytical laboratory analyzed samples from R\&D laboratories in Buildings 771 and 779 (see Section 11.3.2.4). ${ }^{\mathrm{P} 067, \mathrm{P} 061}$ The chemical standards laboratory (prefix 38) prepared uranium, plutonium, and americium nitrates used as control standards for the Buildings 371, 559, and 771 analytical laboratories. ${ }^{\text {P067,P061 }}$ The laboratory also produced nondestructive assay standards used at drum counters and fluoride standards for chemical operations. ${ }^{\mathrm{P} 061}$

The metallography laboratory (prefix 21) in Building 777 prepared and examined metallographic specimens in support of R\&D operations (plutonium metallography, nuclear and non-nuclear joining, quality engineering, and product physical chemistry) and, therefore, may contain any of the radionuclides used during

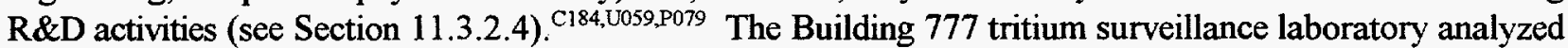
solid, liquid, and gas samples from throughout the plant site for tritium content. ${ }^{\mathrm{U}}{ }^{\mathrm{a}}$ 
Because the laboratories supported all phases of weapons production, the chemical form of the radionuclide contaminants and radioassay interferences will vary widely depending on the type of sample analyzed.

\subsubsection{Research and Development}

Projects using transuranic radionuclides were done in Buildings 771, 776, 777, 779, and 881. Most of the documentation pertaining to R\&D activities does not specify locations in which the work was performed, and unless otherwise noted, it will be assumed that any of the radioisotopes could have been handled in the $R \& D$ areas of any of these buildings. In addition to weapons-grade plutonium, americium-241, and enriched and depleted uranium, the following radioisotopes were processed during R\&D activities: $^{\text {C134,C137,C185,P053,P164,P167,P189,P190,P194,P195,P198,P200,U064 }}$

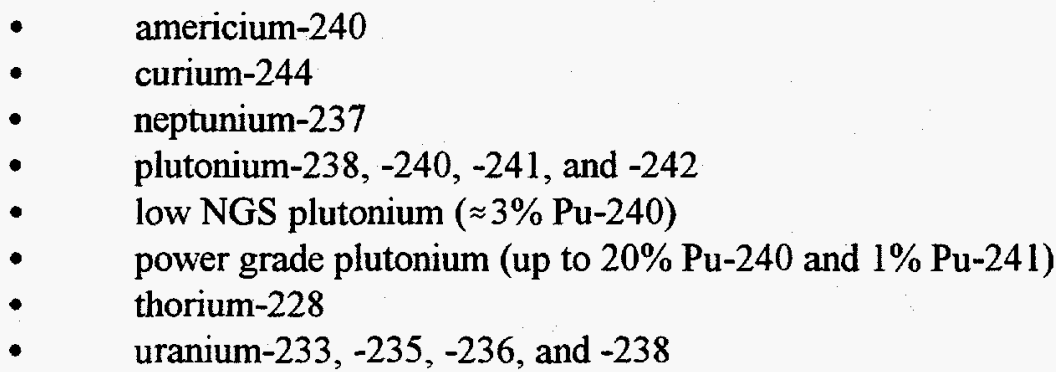

A summary of the projects and time periods that these and other radionuclides were used is presented in Section 3.0.

In Building 771, special recovery anion exchange (prefix 45) separated plutonium from other materials that were not suitable for the regular recovery processes. ${ }^{\mathrm{Cl} 54, \mathrm{PO5} 2 \mathrm{P} 061}$ Chemical technology (prefix 42) conducted aqueous R\&D activities while plutonium metallurgy operations (prefix 78) performed alloy preparation, heat treating, rolling, metal and metallurgical testing, and cutting for $R \& D .{ }^{\text {C184,U059,P061 }}$ These processes may have used numerous radioisotopes.

A pilot-scale fluidized-bed incinerator (prefix 75) was developed in Building 776 to treat low-level waste. ${ }^{\text {C184,U059 }}$ The waste fed to the incinerator was contaminated with low levels of plutonium. ${ }^{\mathrm{P} 024}$

The coatings laboratory (prefix 16) in Building 777 developed various substrates to be coated with uranium or plutonium, including stainless steel, copper, chromium, aluminum, and beryllium. ${ }^{\text {P052,U059,P079 }}$ This research and development facility supported production processes. ${ }^{\mathrm{P} 52, \mathrm{P} 079}$ The special weapons area (prefix 66) in Building 777 was a research and development facility which assembled war reserve and other specially fabricated parts. ${ }^{\text {U059.P079 }}$ The process was also responsible for disassembly of surveillance (tracer) parts and drilling of parts for use in analytical testing. ${ }^{\text {079 }}$

Pyrochemical technology (prefixes 10 and 52) in Building 779 involved the extraction and recovery of plutonium and americium in support of production operations. ${ }^{\text {P067,U059,P062 }}$ These processes included direct oxide reduction, molten salt extraction, electrorefining, salt scrub for MSE, salt scrub for electrorefining, pyrochemical salt recycle, anode alloy, and pyroredox. ${ }^{\text {C182.P062 }}$ Most of the materials used in Building 779 were the same as those in the weapons-production areas and, therefore, will be contaminated primarily with 
weapons-grade plutonium and enriched uranium. ${ }^{\mathrm{P} 53}$ However, other R\&D activities in the building may have used a variety of other radionuclides. ${ }^{\mathrm{C} 171, \mathrm{C} 184}$

\subsubsection{Liquid Waste Treatment}

Aqueous waste treatment operations in Buildings 374 and 774 received wastes from throughout plant site, including processes that generated low-level and nonradioactive liquid wastes. For this reason, wastes generated during treatment operations may contain any of the radioisotopes used at the plant. The most common radioactive materials handled were weapons-grade plutonium, americium-241, enriched uranium, and depleted uranium. Other radionuclides may also be found in the waste streams from R\&D, analytical, and special order work. ${ }^{\mathrm{P} 64}$ Radionuclide contaminants are removed from the aqueous wastes by precipitation using sodium hydroxide and, therefore, will be primarily in the form of hydroxides. ${ }^{\text {P163 }}$ Radioassay interferences may include magnesium sulfate and calcium chloride reagents used in the process. ${ }^{\text {P106,P163 }}$

Building 774 also processed organic liquid wastes. Organic wastes are comprised of a variety of oils and solvents. Most of the oils were from spent lathe coolant used in the plutonium machining area and lubricating oils used in machines throughout the plant. ${ }^{\mathrm{P} 64}$ The majority of the transuranic organic liquids were oils and solvents from plutonium machining and degreasing operations in Buildings 707 and 777 and, therefore, will be contaminated with actinide metals and oxides. ${ }^{\mathrm{P052}}$ A more detailed discussion of the wastes treated in these buildings is provided in Sections 22.0 through 25.0 .

\subsubsection{Size Reduction/Repackaging/Solid Waste Treatment}

Repack operations (prefix 76) in Building 371 involved the repackaging of residues for off-site shipment to other DOE facilities and the repackaging of wastes and residues for on-site storage. ${ }^{\text {P081.U05s }}$ Residues and wastes repacked for off-site shipment included plutonium oxides, incinerator ash, molten salt, electrorefining salt, cell scrape out, and anode heels. Wastes and residues were received from either the stacker/retriever (prefix 43) in Building 371 or from one of several 10-and 55-gallon drum storage areas within Building 371. ${ }^{\text {P081,U059 }}$

The Size Reduction Vault (SRV) in Building 776 conducted solid waste treatment, repackaging, and size reduction operations. The SRV was divided into two sides. One side was the airlock (prefixes $25,40,41$, and 57) where repackaging was done. The other side (prefixes 19 and 26) was a drybox atmosphere where size reduction and solid waste treatment activities took place. ${ }^{\mathrm{C} 175, \mathrm{C} 184, \mathrm{P} 067, \mathrm{U} 059}$ The repacked containers have the potential to contain contaminated materials from any of the processes within the transuranic waste generating

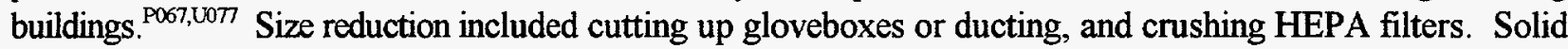
waste treatment activities included washing leaded gloves and scrap metal with hot water in a ball-mill washer to recover plutonium. ${ }^{\text {C053,P067,P164 }}$

\subsubsection{Complexing Agents}

Because complexing agents can aid in the transport of transuranic radionuclides from the waste after disposal, the waste was assessed for potential complexing agents. This information may also be added to the chemical compatibility studies since limited information was available on these chemicals in the past.

EDTA represents a group of chelating compounds, such as ethenediaminetetraacetic acid, with similar molecular structures found in many soaps and detergents. Versene (a trade name for EDTA) and citric acid 
are known constituents of $\mathrm{KW}$ decontamination detergent. ${ }^{\mathrm{P} 068} \mathrm{KW}$ was used during a variety of decontamination activities at the plant. A buffer solution (TISAB) containing diaminocyclohexane tetraacetic acid was used during specific ion electrode analysis in Building 559. ${ }^{\text {P076 }}$ Oxalic acid and tetraphosphoric acid were used to etch plutonium and other metals. ${ }^{\mathrm{PO} 2, \mathrm{U} 043}$ Oxalic acid was also used for americium recovery. ${ }^{\mathrm{P} 113}$ Glass may contain trace quantities of these complexing agents. 


\subsection{GRAPHITE}

This waste group consists of graphite generated by production, recovery, laboratory, size reduction, and research and development activities associated with plutonium operations. Graphite wastes include broken molds, furnace liners and spacers, graphite pieces ranging from chunks to pieces, and some laboratory equipment. ${ }^{\mathrm{P} 52, \mathrm{U} 032}$ The waste was generated in Buildings $371,559,707,771,776$, and 779. ${ }^{\mathrm{P} 12}$ Historic IDC descriptions and dates of generation for the INEEL accessible storage inventory are presented by IDC in Table 12-1. ${ }^{\mathrm{P} 127}$

Table 12-1. Graphite Waste in the Accessible Storage Inventory.

\begin{tabular}{|c|c|c|}
\hline IDC & Title & Dates of Generation \\
\hline 300 & Graphite Molds $^{\mathrm{P} 012}$ & November 1972-June 1988 \\
\hline 301 & $\begin{array}{l}\text { Classified Graphite Shapes } \\
\text { Graphite Cores }^{\mathrm{P} 014}\end{array}$ & April 1973-February 1985 \\
\hline 303 & Scarfed Graphite Chunks ${ }^{\mathrm{P} 012}$ & March 1985-April 1988 \\
\hline 310 & $\begin{array}{l}\text { Graphite Scarfings }{ }^{\mathrm{P} 024} \\
\text { Graphite, Pulverized or Fines }{ }^{\mathrm{P} 014} \\
\text { Graphite Scarfings and Fines }\end{array}$ & December 1983 \\
\hline 312 & Coarse Graphite ${ }^{\mathrm{P} 012}$ & November 1983-June 1984 \\
\hline
\end{tabular}

Item Description Code 300, Graphite Molds: This waste consists of graphite generated in Buildings 371, 559, 707, 771, and 776. Graphite items include molds from plutonium casting operations, spacers and liners used in high-temperature furnaces and ovens, electrodes, and pieces and chunks generated during mold cleaning. ${ }^{\mathrm{P} 12, \mathrm{PO} 77}$ Although the waste is primarily molds from plutonium casting operations in Building 707, limited amounts of graphite molds were periodically generated by various research and development projects. ${ }^{\mathrm{P} 16, \mathrm{P} 024, \mathrm{PO52}}$ IDC 300 may also include graphite electrodes from Building 559 laboratory operations. ${ }^{\mathrm{P} 667}$ Graphite contaminated with plutonium above the EDL was sent for recovery in Buildings 371 or 771. Some surgical gloves may also be included in the waste. ${ }^{\mathrm{P} 024}$

Item Description Code 301, Graphite Cores: This waste consists of graphite cores generated in Buildings 371,559 , and 707. ${ }^{\text {P24,P127,U059 }}$ Graphite cores were part of a classified shaped mold generated primarily by plutonium casting operations in Building $707 .{ }^{\mathrm{P} 24, \mathrm{P} 052, \mathrm{P} 060}$ During the casting of plutonium, classified shapes were sorted from unclassified shapes. Graphite cores contaminated with plutonium above the EDL were sent for plutonium recovery. ${ }^{\mathrm{P} 024}$ Prior to 1984, graphite cores were destroyed in Building 776 to render the material unclassified. ${ }^{\text {POS2 }}$ The pieces of graphite that remained after declassification were assigned IDC 310 or 312 . The graphite from Building 559 may be graphite electrodes which have been misidentified as IDC $301 .^{\text {C074 }}$ Classified waste should not have been shipped to the INEEL, and can be verified by RTR. $^{\text {C074,C077 }}$

Item Description Code 303, Scarfed Graphite Chunks: This waste consists of pieces of broken graphite mold generated from the mechanical cleaning (scarfing) of graphite molds and cores. Scarfing of the mold surface removed most of the mold coating (calcium fluoride) and plutonium contamination. ${ }^{\mathrm{P} 52}$ 
Item Description Code 310, Graphite Scarfing and Fines: This waste consists of graphite scarfings and fines generated from the mechanical cleaning (scarfing) of graphite molds. The small pieces and fines are coated with calcium fluoride and plutonium. ${ }^{\mathrm{P} 052}$ The fines were removed from larger chunks by screening. ${ }^{\mathrm{P} 060}$

Item Description Code 312, Coarse Graphite: This waste consists of odd sized and shaped chunks of graphite generated from the mechanical cleaning (scarfing) of graphite molds. ${ }^{\text {P038,P052 }}$ The graphite is coated with calcium fluoride and plutonium. ${ }^{\mathrm{P} 38}$

\subsection{Waste Generation}

Graphite molds and cores were generated primarily by plutonium production operations. Graphite materials were also generated from research and development activities and laboratory operations. Graphite contaminated with plutonium above the EDL was processed by recovery operations. Size reduction operations declassified materials, and performed waste repackaging or inspection activities. Figure 12-1 shows a general graphite generation flow diagram. Graphite waste generation by building is shown in Figure 12-2.

\subsubsection{Plutonium Production}

Plutonium production consisted of operations directly associated with the manufacturing of plutonium metal parts including casting, rolling, forming, machining, and assembly processes. Buildings 707 and 777 were the primary weapons components production facilities at the site after the construction of Building 707 in $1972{ }^{\text {P053 }}$

The foundry in Building 707 cast molten plutonium into classified components, subassemblies, and assemblies. Molds were cut from solid blocks, logs, or slabs of graphite which had high mechanical strength. The working surfaces of the mold were coated with calcium fluoride ${ }^{\mathrm{P} 016}$ Molten plutonium metal was cast in graphite molds as the initial step in weapons parts production. Plutonium metal was melted within a tantalum crucible and poured into the graphite mold. The castings were removed and allowed to cool, and the molds and castings were separated. If a mold was going to be reused, it was mechanically cleaned to remove the adhered plutonium which generated graphite scarfings. Once a mold had been used three times or was no longer usable, it was discarded as IDC 300 or $301 .^{\mathrm{P} 059, \mathrm{P} 060}$

\subsubsection{Research and Development}

Research and Development (R\&D) included activities related to production, recovery, and purification as well as "special order" work. Building 779 , which was built in 1965 , housed much of the R\&D operations at the plant. Other areas at the plant supporting R\&D included Buildings $559,771,776,777$, and $881 .^{\text {P053 }}$

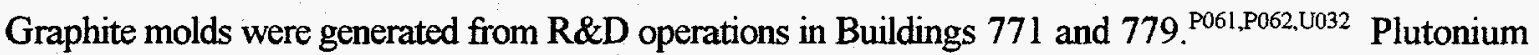
metallurgy in Building 771 cast plutonium alloys in furnaces using graphite crucibles. Solvents were not used in this process. ${ }^{\mathrm{P} 061}$ Experimental casting in Building 779 tested metal compatibilities with various substrates. Plutonium and non-nuclear metals were heated in a furnace and cast into graphite molds. Freon was used to clean the castings. ${ }^{\mathrm{P} 062}$ These operations simulated casting operations in Building 707. ${ }^{\text {P061,P062 }}$ 


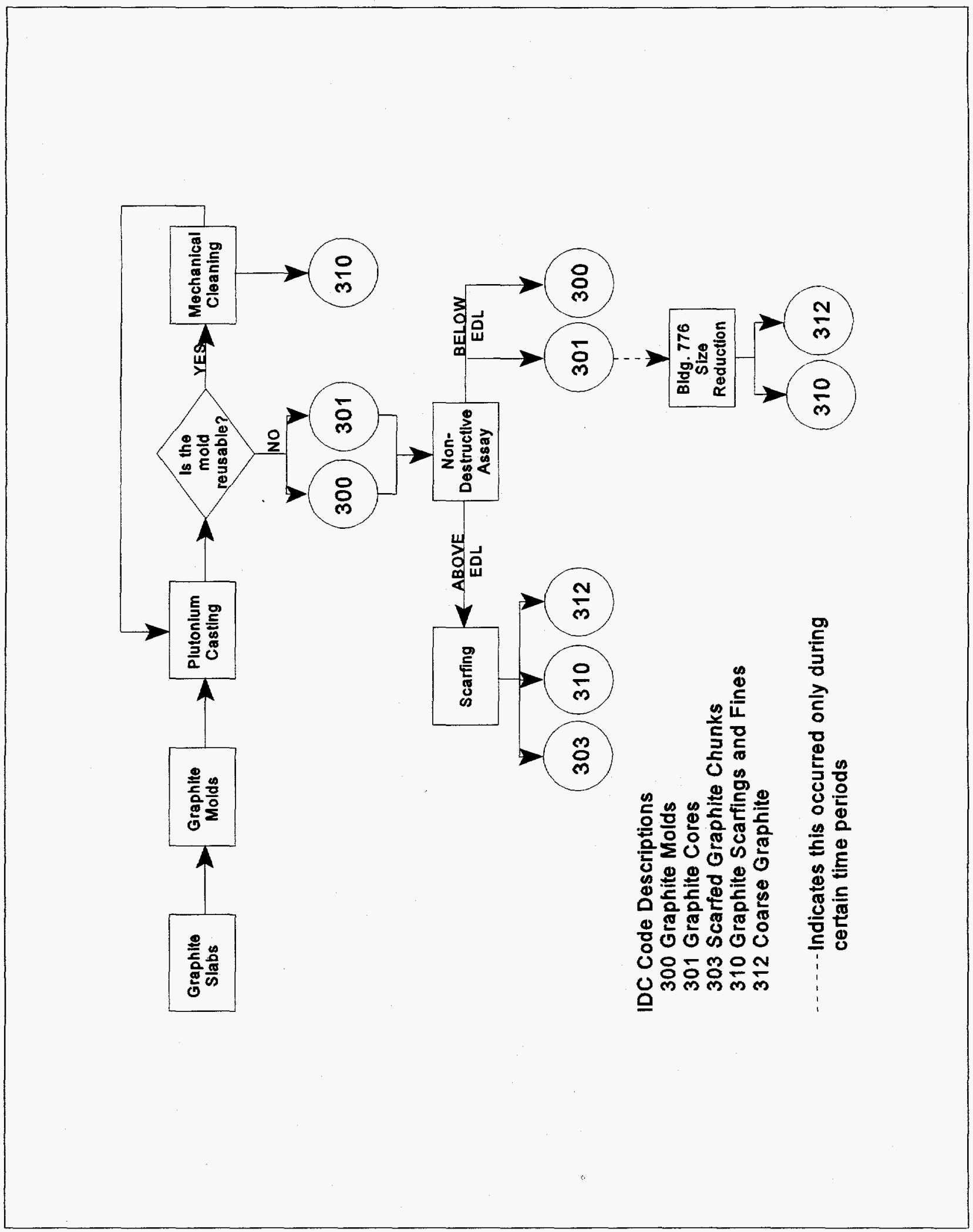

Figure 12-1. Graphite Waste Generation Flow Diagram. 


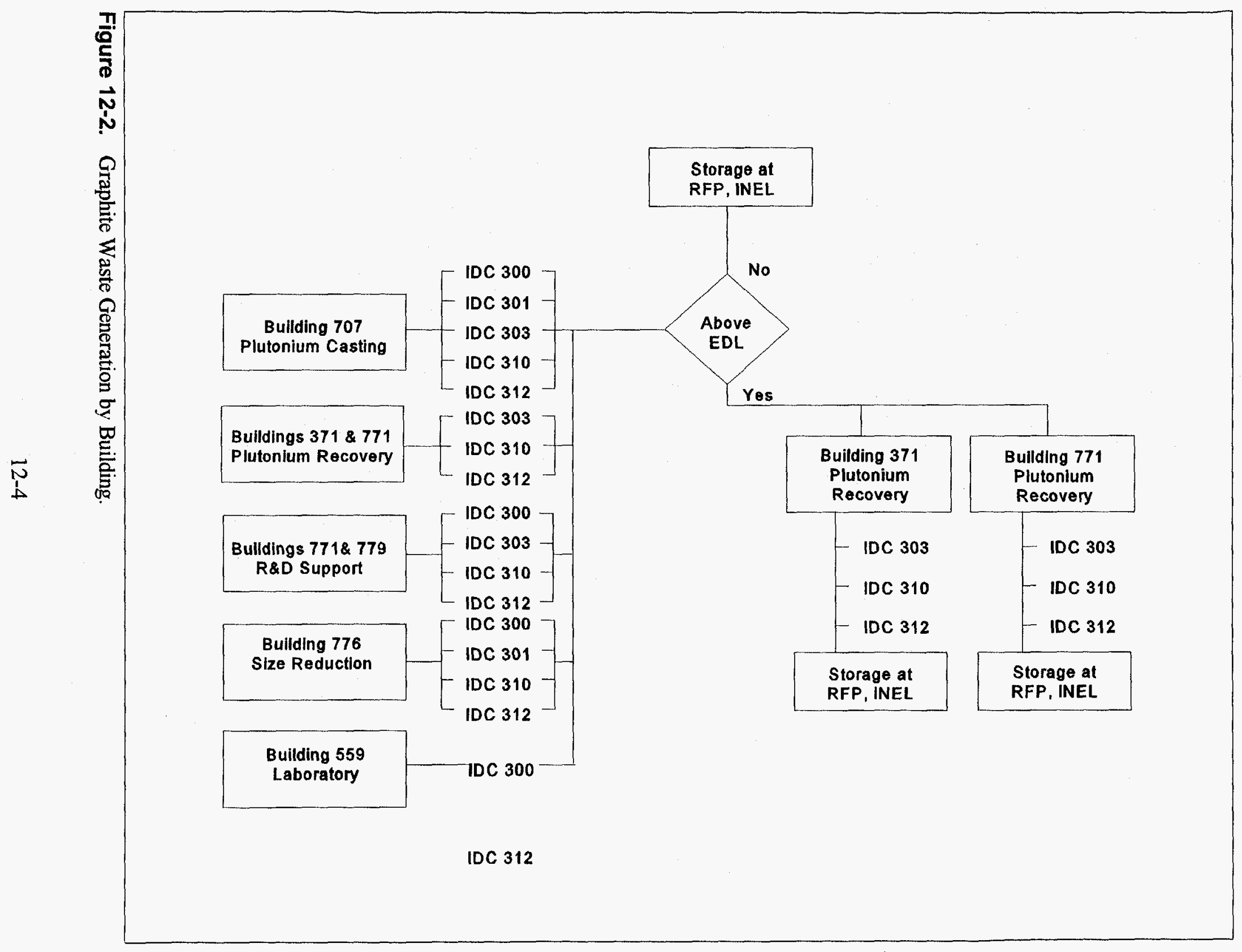




\subsubsection{Laboratory}

Building 559 housed the Plutonium Analytical Laboratory responsible for spectrochemical, chemical, and mass spectrometric analyses of samples from plutonium production operations. Uranium, Raschig rings, solutions, and commercial product and gas samples were also analyzed in the laboratory. Plutonium production samples, including metal and oxide, were prepared and subdivided for analysis in the sample cutting process. ${ }^{\text {P067 }}$

Emission spectroscopy was used for the determination of rare earth metals and impurities in various metal samples. The samples were leached in hydrochloric acid and dried in an oven to a low density oxide. The oxide was mixed with sodium fluoride and packed into a graphite electrode that was fired with an arc. The electrodes were removed from the spectrometer when their integrity was lost. Graphite electrodes were assigned IDC 300 P $^{\mathrm{P} 67}$

The Building 559 analytical laboratory also generated one drum (RF002900629) of graphite cores (IDC 301) in 1983. There were no operations in Building 559 that generate or process IDC 301 , and it is suspected that this drum may contain graphite electrodes from emission spectroscopy analysis. There are no classification issues with graphite electrodes. ${ }^{\mathrm{C} 067, \mathrm{C} 074}$

\subsubsection{Size Reduction}

Prior to 1984 , graphite cores were destroyed in Building 776 to render them unclassified ${ }^{\text {P052 }}$ The graphite cores were broken into pieces no larger than one inch. ${ }^{\mathrm{C} 066}$

After being assayed, drums containing plutonium below the EDL were sent to Building 776 for repackaging or inspection. A drum would have to be repackaged if the plutonium content was too high ( $>200$ grams) or if the net weight of the drum exceeded 200 pounds. ${ }^{\mathrm{P} 024}$ The declassified graphite cores were also repackaged. ${ }^{\mathrm{POO} 1}$ After repackaging, drums were identified as being generated from Building 776 . Therefore, Building 776 could be identified as the generation building for any of the graphite wastes.

\subsubsection{Plutonium Recovery}

Graphite molds containing plutonium above the EDL were cleaned by a mechanical scraping or "scarfing" to remove the plutonium metal which had adhered to the surface of the mold. This process also removed the calcium fluoride coating. Scarfing operations have occurred in Buildings 371, 707, 771, and 777. The process of scarfing generated IDCs 300, 301, 303, 310, and 312. Scarfed graphite chunks (IDC 303) were generated from the pieces of the mold remaining after the plutonium-contaminated surface had been scarfed. These pieces of graphite are typically one inch in diameter or larger. IDC 303 was created in early 1985 . $^{\text {Co0s }}$ Prior to this, scarfed graphite chunks were assigned IDC 300 or $301 .^{\mathrm{Cl} 77}$ The material which was mechanically removed from the mold was identified as IDC 310 or 312 depending on size. Graphite scarfing and fines (IDC 310 ) consisted of granular and fine graphite particles, and coarse graphite (IDC 312) consisted of pieces which were less than one inch in diameter but were larger than the fines. The graphite scarfings and fines were separated from the coarse graphite using a sifting screen. ${ }^{\text {C061,P035,P059,P097,P104 }}$ 


\subsection{Waste Packaging}

Graphite (IDCs 300 and 301) was placed directly into a lined 55-gallon drum or bagged out of the glovebox line in two polyvinyl chloride or polyethylene bags. Graphite pieces and chunks (IDCs 303 and 312) were typically placed in Fibre-Paks which were bagged out of the line ${ }^{\text {P012,P024 }}$ Graphite chunks (IDC 312) may have also been collected in $1 / 2$ - or 1 -gallon polyethylene bottles. ${ }^{\text {P015,P022 }}$ Graphite scarfings (IDC 310 ) were collected in 1-gallon polyethylene bottles before being bagged out of the glovebox line. ${ }^{\mathrm{P} 024}$ After removal from the glovebox, the waste was placed in a lined 55-gallon drum. ${ }^{\mathrm{P} 12, \mathrm{PO} 24}$

Depending on waste packaging requirements at the time, several combinations of bags and liners were used to prepare 55-gallon drums for shipment. From 1970 to 1972, waste drums were lined with one or two polyethylene drum bags. Cardboard liners might also have been used to line the inner drum bag. Use of the 90-mil rigid polyethylene liner began in 1972. ${ }^{\text {P024 }}$ The rigid liner was placed in each drum and lined with one polyethylene round bottom drum liner or two polyethylene drum bags. ${ }^{\mathrm{P} 008, \mathrm{P} 012, \mathrm{P} 016, \mathrm{P} 024 . \mathrm{P} 063 . \mathrm{P} 064} \mathrm{~A}$ polyvinyl chloride O-ring bag and a polyethylene bag were used if the drum was attached to the glovebox. ${ }^{\text {P016 }} \mathrm{A}$ fiberboard liner and discs may also have been used between the waste packages and the drum liners for puncture protection. ${ }^{\mathrm{P} 008, \mathrm{P} 012, \mathrm{P} 016, \mathrm{P} 063, \mathrm{P} 064}$ When a drum was full, the drum liners were twisted and taped closed, the lid was secured with a bolted ring, and a tamper indicating device was attached to the drum. ${ }^{\mathrm{P} 012, \mathrm{P} 016, \mathrm{P} 024}$

After drums were inspected, one to two quarts of absorbent material (Oil-Dri) was placed on the top of the outer, sealed polyethylene drum bag. This procedure changed in February 1982 when vermiculite was used to fill the space between the outer, sealed polyethylene drum bag and the top of the 90-mil rigid liner. The quantity of vermiculite varied from 3-12 pounds according to the amount of waste contained in each drum. ${ }^{\mathrm{P} 024}$

Waste management and inspection protocol allowed containers of wastes to contain up to 10 percent of another IDC other than that assigned to the container. ${ }^{\mathrm{P} 16}$ However, based on interviews with cognizant

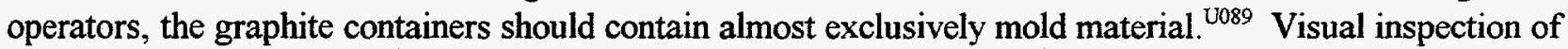
three graphite mold (IDC 300) containers identified paper clips, bungee cords, and blotter paper. ${ }^{\text {U011 }}$ One drum of graphite cores (IDC 301) contained a few metal bolts and some aluminum shavings. ${ }^{\text {P015 }}$

\subsection{Waste Characterization}

Graphite is characterized based on knowledge of the material, knowledge of the processes generating the waste, RTR review of the waste, visual inspection, and headspace gas analysis. This section provides a RCRA hazardous waste determination for graphite as well as radionuclide contaminants and potential complexing agents contained in the waste. Graphite wastes (IDCs 300, 301, 303, and 312) contain an estimated 80 percent or more (by volume), inorganic nonmetal debris that meet the EPA LDR criteria for classification as debris, and are classified as heterogeneous wastes. Graphite scarfings and fines (IDC 310) contain at least 50 percent (by volume) inorganic particulates, and are classified as homogeneous wastes. ${ }^{\text {P141 }}$

\subsubsection{Hazardous Waste Determination}

The material in this waste group does not qualify for any of the exclusions outlined in 40 CFR 260 or 261. Graphite was not mixed with a listed waste, nor does the waste exhibit a characteristic of hazardous waste. EPA Hazardous Waste Numbers applicable to some or all of the graphite waste group are presented by IDC in Table 12-2. These conclusions are supported by the evaluation in Sections 12.3.1.1 and 12.3.1.2. 
Table 12-2. Graphite Waste Characterization.

\begin{tabular}{clc}
\hline IDC & \multicolumn{1}{c}{ Title } & EPA Hazardous Waste Numbers \\
\hline 300 & Graphite Molds & None \\
301 & Graphite Cores & None \\
303 & Scarfed Graphite Chunks & None \\
310 & Graphite Scarfings and Fines & None \\
312 & Coarse Graphite & None \\
\hline
\end{tabular}

\subsubsection{Characteristic Waste}

The materials in this waste group do not exhibit a characteristic of hazardous waste as defined in 40 CFR 261, Subpart C as an ignitable waste (40 CFR 261.21), a corrosive waste (40 CFR 261.22), a reactive waste (40 CFR 261.23), or a toxic waste (40 CFR 261.24).

Ignitability: The material in this waste group does not meet the definition of ignitability as defined in 40 CFR 261.21. The material is not a liquid, and no free liquids have been identified in this waste. ${ }^{\mathrm{P} 015, \mathrm{P} 016, \mathrm{P} 017, \mathrm{P} 021, \mathrm{P} 022, \mathrm{U} 011}$ The material is not capable of causing fire through friction, absorption of moisture, or spontaneous chemical change. ${ }^{\mathrm{C} 064}$ The material is not a compressed gas, nor do the drums contain compressed gases. ${ }^{\mathrm{P} 15, \mathrm{P} 016, \mathrm{P} 017, \mathrm{P} 021, \mathrm{P} 022, \mathrm{U} 011}$ The material is not a DOT oxidizer as defined in 49 CFR 173. The materials in this waste group are therefore not ignitable wastes (D001).

Corrosivity: The material in this waste group does not meet the definition of corrosivity as defined in 40 CFR 261.22. The material is not a liquid, and no free liquids have been identified in this waste. ${ }^{\mathrm{P} 015, \mathrm{P} 016, \mathrm{P} 017, \mathrm{P} 021, \mathrm{P} 022, \mathrm{U} 011}$ The materials in this waste group are therefore not corrosive wastes (D002).

Reactivity: The materials in this waste group do not meet the definition of reactivity as defined in 40 CFR 261.23. The materials are stable and will not undergo violent chemical change. The materials will not react violently with water, form potentially explosive mixtures with water, or generate toxic gases, vapors, or fumes when mixed with water. The materials do not contain cyanides or sulfides, and are not capable of detonation or explosive reaction. The materials are not forbidden explosives or Division 1.1, 1.2, or 1.3 (Class A or B) explosives as defined in 49 CFR 173, nor do the drums contain explosive materials. ${ }^{\mathrm{P} 015, \mathrm{P} 016, \mathrm{P} 017, \mathrm{P} 021, \mathrm{P} 022, \mathrm{U} 011}$ Explosives were not handled or used around radioactive material. The materials in this waste group are therefore not reactive wastes (D003).

Toxicity: The materials in this waste group do not meet the definition of toxicity as defined in 40 CFR 261.24. The toxicity characteristic contaminants fall into one of two categories: metals and organics. Organic compounds include halogenated- and nonhalogenated-solvents, pesticides, herbicides, and other toxic compounds.

Toxicity characteristic metals were not used in the process which generated graphite waste. ${ }^{\text {P016,P035,P052,P060,P061,P062 }}$ Graphite bars or rods from Building 774 silver recovery were identified as IDC 312 and may contain cadmium and silver. This waste stream was a nonline-generated low-level waste stream 
and should not be in the INEEL inventory. ${ }^{\text {P109,0032 }}$ Analysis of a single sample of this waste stream indicates cadmium and silver below the regulatory level. ${ }^{\mathrm{C} 060, \mathrm{P} 052}$ Another reference also indicates that graphite exhibits the characteristic of toxicity for cadmium, and says that the source of cadmium was from salt residues. However, there is no information as to what process generated this waste. ${ }^{\text {P049 }}$ Since the majority of the available references indicate that graphite is nonhazardous, the silver recovery process in Building 774 is likely the source of the salt containing cadmium. An assessment of plutonium metal impurities concluded that the waste will not exhibit the characteristic of toxicity solely due to the plutonium. ${ }^{\text {U086 }}$ Therefore, this waste group does not exhibit the characteristic of toxicity (D004-D011).

There is no documentation indicating the presence or use of pesticides or herbicides in the areas or processes generating graphite. Therefore, this waste group does not exhibit the characteristic of toxicity due to pesticides or herbicides (D012-D017).

Carbon tetrachloride was used for cleaning plutonium parts in the Building 707 production area. However, carbon tetrachloride was used only to clean the gloveboxes and furnaces in the casting area. ${ }^{0087,0088,4089}$ The graphite molds from the process may contain trace quantities of this compound because cleaning was performed in the glovebox line. ${ }^{\mathrm{P} 060, \mathrm{P} 062}$ The carbon tetrachloride was not used to clean the molds, and the waste does not retain toxicity characteristic levels of this compound. ${ }^{\mathrm{U} 85}$ There is no documentation indicating the presence or use of any other toxicity characteristic organics in the areas or processes generating graphite. Therefore, this waste group does not exhibit the characteristic of toxicity due to organics (D018D043).

In addition to the above information, analysis of 27 samples of graphite fines and chunks (IDCs 310 and 312) generated between 1979 and 1989 verifies graphite does not exhibit the characteristic of toxicity for metal or organic compounds. ${ }^{\text {U085 }}$

\subsubsection{Listed Hazardous Waste}

The material in this waste group is not, or was not mixed with, a waste listed in 40 CFR 261, Subpart D as a hazardous waste from non-specific sources (40 CFR 261.31), as a hazardous waste from specific sources (40 CFR 261.32), or as a discarded commercial chemical product, an off-specification species, a container residue, or a spill residue thereof (40 CFR 261.33).

Carbon tetrachloride, 1,1,1-trichloroethane, and Freon (1,1,2-trichloro-1,2,2-trifluoroethane) were used for cleaning gloveboxes, equipment, and plutonium metal. The graphite molds may contain trace quantities of these compounds because cleaning was performed in the glovebox line. ${ }^{\text {P060.P062,U087 }}$ However, none of these solvents were used in conjunction with casting operations and did not come into direct contact with the molds and therefore are not F001- or F002-listed wastes. ${ }^{\text {U087 }}$

There is no documentation indicating the use of any other F-listed solvents in the areas or processes generating graphite. ${ }^{\text {U087,U088,U089 }}$ Therefore, this waste group is not a F003-, F004-, or F005-listed waste.

Although graphite is not a F-listed hazardous waste, headspace analysis performed on samples of graphite (IDCs 300, 303, and 3.12) obtained at INEEL indicates the presence of organic solvents in coarse graphite (IDC 312). The detected compounds in which the 90 percent UCL is above the PRQL are provided. ${ }^{\mathrm{P} 033}$ 


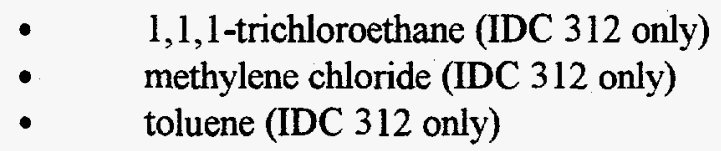

There is no documentation indicating the use of these solvents in graphite casting or scarfing operations. Therefore, this waste group is not a F001-, F002-, or F005-listed waste. Assessments of solvents detected in the headspace of graphite molds and solvent usage support these conclusions. ${ }^{\text {U087,U088, U089 }}$

The material in this waste group is not a hazardous waste from specific sources since it was not generated from any of the processes listed in 40 CFR 261.32. The material in this waste group is therefore not a K-listed hazardous waste.

The material in this waste group is not a discarded commercial chemical product, an off-specification species, a container residue, or a spill residue thereof (40 CFR 261.33). The material in this waste group is therefore not a P-or U-listed hazardous waste.

\subsubsection{Radionuclides}

This section identifies the radioisotopes potentially contained in the waste. In addition, Table 12-3 summarizes matrix and other physical parameters which could affect radioassay.

Radionuclide contamination in graphite waste from Building 707 will primarily consist of weaponsgrade plutonium from foundry, casting, and final assembly operations. ${ }^{\text {P052,P053 }}$ A small percentage of the waste from Building 707 may also contain americium-240, neptunium-237, and plutonium-238 from blending of these isotopes with weapons-grade plutonium for diagnostic tracers. Graphite molds used in plutonium production operations were also used for casting these plutonium alloys; however, processing of plutonium alloys was limited compared to plutonium. ${ }^{\mathrm{Cl} 11, \mathrm{C} 174, \mathrm{C} 184, \mathrm{C185,P} 053, \mathrm{P} 164, \mathrm{P} 167}$

Graphite waste from recovery operations in Buildings 371 and 771 was generated from scarfing operations. This graphite originated in Building 707 and, therefore, will contain primarily weapons-grade plutonium but could possibly contain the plutonium alloys. Graphite from R\&D activities in Building 771 (prefixes 42 and 78) will contain weapons-grade plutonium and could contain a variety of other radionuclides including neptunium-237, uranium-233, and plutonium-242. ${ }^{\mathrm{C} 185, \mathrm{U} 059}$

Graphite from Building 559 consist of electrodes from emission spectroscopy analysis. This process analyzed weapons-grade plutonium and enriched uranium metal and oxide samples from Building $707 .{ }^{\mathrm{U}}{ }^{073}$

The Size Reduction Vault (SRV) in Building 776 conducted solid waste treatment, repackaging, and size reduction operations. The SRV was divided into two sides. One side was the airlock (prefixes 25, 40, 41, and 57) where repackaging was done. The other side (prefixes 19 and 26) was a drybox atmosphere where size reduction and solid waste treatment activities took place. ${ }^{\text {C175,C184,P067,U059 }}$ The repacked graphite containers have the potential to contain contaminated materials from any of the processes which generated graphite waste. ${ }^{\text {P067,U077 }}$

U-235 was detected in two drums of IDC 300 from Building 707 and 6 drums of IDC 303 from Building 371. ${ }^{\mathrm{P} 115}$ Uranium was not cast in Building 707, however, on one occasion in the mid-1980s, metal 
chips from machining of plutonium and enriched uranium in Building 777 were mistakenly briquetted in Building 707. ${ }^{\mathrm{C} 184}$

Table 12-3. Waste Matrix Evaluation.

\begin{tabular}{|c|c|}
\hline Parameter & Results of Evaluation \\
\hline $\begin{array}{l}\text { Radionuclide Form, } \\
\text { Particle Size, and } \\
\text { Distribution }\end{array}$ & $\begin{array}{l}\text { Plutonium metal and oxide will be present in the graphite waste. }{ }^{P 035} \text { In general, } \\
\text { visible pieces of plutonium metal were removed from graphite molds prior to } \\
\text { packaging. }{ }^{\text {P104 }} \text { However, small pieces of plutonium metal were identified in } \\
\text { drums of graphite (IDC } 300 \text { ). }{ }^{\text {O015 }} \text { Review of RTR images of IDC } 300 \text { have } \\
\text { shown that drums contain either scarfed graphite or unscarfed graphite. } \\
\text { Source particle size in this waste with range from finely divided in the scarfed } \\
\text { graphite and impregnated on the surface of the molds to metal fines and } \\
\text { shavings dispersed in the waste. }\end{array}$ \\
\hline Hydrogen Content & $\begin{array}{l}\text { The primary sources for hydrogen in graphite waste include fiberboard, } \\
\text { polyvinyl chloride, and polyethylene liners, bags, and bottles (see section 12.2). } \\
\text { In addition, trace concentrations of hydrocarbons have been detected in the } \\
\text { headspace of graphite containers. }{ }^{\text {P033 }} \text { Moisture absorbtion should not be an } \\
\text { issue because neither graphite nor calcium fluoride (mold coating) are } \\
\text { hygroscopic. }\end{array}$ \\
\hline $\begin{array}{l}\text { Other Interfering Waste } \\
\text { Contaminants }\end{array}$ & $\begin{array}{l}\text { The graphite material itself is a moderating material and can bias radioassay. } \\
\text { Other contaminants include calcium fluoride mold coating, and magnesium } \\
\text { metal or oxide (plutonium impurity). }{ }^{\text {P035 }}\end{array}$ \\
\hline $\begin{array}{l}\text { Physical Matrix } \\
\text { Parameters }\end{array}$ & $\begin{array}{l}\text { If present in IDCs } 300 \text { or } 301 \text {, the calcium and magnesium metal or oxide will } \\
\text { be located on the inside mold surface; otherwise, the material is } \\
\text { homogeneous. }{ }^{\text {PO35 }} \text { Based on two samples of IDC } 310 \text {, the particle size } \\
\text { distribution of the graphite fines was less than } 0.7 \% \text { and } 0.5 \% \text { dispersible } \\
\text { fines. The material in both containers sampled was essentially } 100 \% \text { fines. }{ }^{\text {C186 }}\end{array}$ \\
\hline
\end{tabular}

\subsubsection{Complexing Agents}

Because complexing agents can aid in the transport of transuranic radionuclides from the waste after disposal, the waste was assessed for potential complexing agents. There is no documentation indicating the presence or use of complexing agents in the processes generating graphite. 


\subsection{GRIT}

This waste group consists primarily of iron fines, iron pellets, and aluminum oxide used in grit blasting operations in Building 707 and 771. Historic IDC descriptions and dates of generation for the INEEL accessible storage inventory are presented by IDC in Table 13-1. ${ }^{\mathrm{P} 27}$

Table 13-1. Grit Waste in the Accessible Storage Inventory.

\begin{tabular}{cccc}
\hline IDC & Title & Dates of Generation \\
\hline 372 & Grit $^{\mathrm{P} 024}$ & & November 1982- January 1984 \\
\hline
\end{tabular}

Item Description Code 372, Grit: This waste consists primarily of aluminum oxide and pin-head-size iron fines and pellets used in grit blasting operations. Grit blasting media such as walnut shells, glass beads, and ceramic beads may also be included. ${ }^{\mathrm{C} 120, \mathrm{P} 024, \mathrm{PO} 35}$

\subsection{Waste Generation}

The grit blasting process in Building 707 affixed serial numbers and part type identification to plutonium parts. Each part was mounted in a holding fixture along with a stencil indicating the serial number and part type. The part and stencil were placed in the grit blaster which etched the part through the stencil with aluminum oxide grit. Grit was recycled in the grit blaster and was infrequently replaced. ${ }^{\mathrm{P} 35, \mathrm{P} 060}$

Grit was also generated by plutonium recovery operations in Building 771. ${ }^{\text {P001,P024,P049 }}$ Pin-head-size iron fines or pellets, walnut shells, glass beads, or ceramic beads were used to grit blast various metal wastes such as molds contaminated with plutonium above the EDL. ${ }^{\text {Cl20,P024 }}$

\subsection{Waste Packaging}

Grit from plutonium recovery operations was packaged in one-gallon polyethylene bottles and doublebagged out of the glovebox in polyvinyl chloride and polyethylene bags. Each bag was sealed with tape before placement in a prepared 55-gallon drum. ${ }^{\mathrm{P} 024}$

Information on the exact packaging configuration of grit from Building 707 was not identified. However, standard glovebox bag-out operations (double-bagged in plastic) were most likely used when packaging this waste.

Depending on waste packaging requirements at the time, several combinations of bags and liners were used to prepare 55-gallon drums for shipment. Use of 90-mil rigid polyethylene liners began in $1972{ }^{{ }^{0024}}$ The rigid liner was placed in each drum and lined with one polyethylene round bottom drum liner or two polyethylene drum bags. ${ }^{\mathrm{P} 008, \mathrm{P} 024, \mathrm{P063}, \mathrm{P064}}$ A fiberboard liner and discs may also have been used between the waste and the drum liners. ${ }^{\mathrm{P} 008 \mathrm{P064}}$ When a drum was full, the drum liners were twisted and taped closed, the rigid liner lid was sealed on the rigid liner, and the drum lid and gasket were installed and secured with a lock-chine. ${ }^{\mathrm{P} 024}$ 
After drums were inspected, one to two quarts of absorbent material (Oil-Dri) was placed on top of the outer, sealed polyethylene drum bag. This procedure was changed in February 1982 when vermiculite was used to fill the space between the outer, sealed polyethylene drum bag and the top of the 90 -mil rigid liner. ${ }^{\mathrm{P} 24}$

\subsection{Waste Characterization}

Grit waste is characterized based on knowledge of the material and knowledge of the processes generating the waste. This section provides a RCRA hazardous waste determination for grit as well as radionuclide contaminants and potential complexing agents contained in the waste. This waste contains at least 50 percent (by volume) inorganic particulates, and is therefore a homogeneous waste. ${ }^{\mathrm{P} 141}$

\subsubsection{Hazardous Waste Determination}

The material in this waste group does not qualify for any of the exclusions outlined in 40 CFR 260 or 261. The waste was not mixed with a listed waste, nor does it exhibit any characteristics of hazardous waste. EPA Hazardous Waste Numbers applicable to the grit waste group are presented by IDC in Table 13-2. These conclusions are supported by the evaluation in Sections 13.3.1.1 and 13.3.1.2.

Table 13-2. Grit Waste Characterization.

\begin{tabular}{cccc}
\hline IDC & & Title & EPA Hazardous Waste Numbers \\
\hline 372 & Grit & & None \\
\hline
\end{tabular}

\subsubsection{Characteristic Waste}

The materials in this waste group do not exhibit a characteristic of hazardous waste as defined in 40 CFR 261, Subpart C as an ignitable waste (40 CFR 261.21), a corrosive waste (40 CFR 261.22), a reactive waste (40 CFR 261.23), or a toxic waste (40 CFR 261.24).

Ignitability: The material in this waste group does not meet the definition of ignitability as defined in 40 CFR 261.21. The material is not a liquid, and no free liquids have been identified in this waste. ${ }^{\mathrm{P} 24}$ The grit waste may contain iron fines, but are not divided finely enough to cause fire through friction, absorption of moisture, or spontaneous chemical change. ${ }^{\mathrm{P} 24}$ The material is not a compressed gas, and compressed gases have not been identified in this waste. ${ }^{\mathrm{P} 224}$ The material is not a DOT oxidizer as defined in 49 CFR 173. The materials in this waste group are therefore not ignitable wastes (D001).

Corrosivity: The material in this waste group does not meet the definition of corrosivity as defined in 40 CFR 261.22. The material is not a liquid, and no corrosive liquids have been identified in this waste. ${ }^{\mathrm{P} 024}$ The materials in this waste group are therefore not corrosive wastes (D002)

Reactivity: The materials in this waste group do not meet the definition of reactivity as defined in 40 CFR 261.23. The materials are stable and will not undergo violent chemical change. The materials will not react violently with water, form potentially explosive mixtures with water, or generate toxic gases, vapors, or fumes when mixed with water. The materials do not contain cyanides or sulfides, and are not capable of 
detonation or explosive reaction. The materials are not forbidden explosives or Division $1.1,1.2$, or 1.3 (Class A or B) explosives as defined in 49 CFR 173, nor do the drums contain explosive materials. ${ }^{\text {P024 }}$ Explosives were not handled or used around radioactive material. The materials in this waste group are therefore not reactive wastes (D003)

Toxicity: The materials in this waste group do not meet the definition of toxicity as defined in 40 CFR 261.24. The toxicity characteristic contaminants fall into one of two categories: metals and organics. Organic compounds include halogenated-and nonhalogenated-solvents, pesticides, herbicides, and other toxic compounds. Toxicity characteristic metals, organics, pesticides, and herbicides were not used in the process which generated this waste. Therefore, this waste group does not exhibit the characteristic of toxicity (D004-D043).

\subsubsection{Listed Hazardous Waste}

The material in this waste group is not, or was not mixed with, a waste listed in 40 CFR 261, Subpart D as a hazardous waste from non-specific sources (40 CFR 261.31), as a hazardous waste from specific sources (40 CFR 261.32), or as a discarded commercial chemical product, an off-specification species, a container residue, or a spill residue thereof (40 CFR 261.33).

1,1,1-trichloroethane was used in the grit blasting process in Building 707 for parts cleaning. However, parts cleaning was performed following grit blasting, and the grit will not be contaminated with the

solvent. No other solvents were identified with grit blasting operations. ${ }^{\mathrm{C} 120, \mathrm{P} 060}$ The material in this waste group is therefore not a listed hazardous waste.

The material in this waste group is not a hazardous waste from specific sources since it was not generated from any of the processes listed in 40 CFR 261.32. The material in this waste group is therefore not a K-listed hazardous waste.

The material in this waste group is not a discarded commercial chemical product, an off-specification species, or a container residue (40 CFR 261.33). It is uncertain if the waste was generated from cleanup of a commercial chemical product spill. However, it is highly unlikely that the cleanup of a commercial chemical product would result in the generation of TRU waste. Therefore, the material in this waste group is not a Por U-listed hazardous waste.

\subsubsection{Radionuclides}

Grit waste from Building 707 was generated from etching of plutonium parts and, therefore, radionuclide contamination will consist of weapons-grade plutonium. Grit from Building $\mathbf{7 7 1}$ was generated from recovery of plutonium from various metal surfaces. 
Table 13-3. Waste Matrix Evaluation.

\begin{tabular}{ll}
\hline \multicolumn{1}{c}{ Parameter } & \multicolumn{1}{c}{ Results of Evaluation } \\
\hline $\begin{array}{l}\text { Radionuclide Form, } \\
\text { Particle Size, and } \\
\text { Distribution }\end{array}$ & $\begin{array}{l}\text { Based on the process generating grit waste, the plutonium will most likely be in } \\
\text { an oxide form. No information on plutonium particle size or distribution was } \\
\text { identified. }\end{array}$ \\
$\begin{array}{l}\text { Hydrogen Content } \\
\text { The primary source of hydrogen is from plastic packaging material (see Section } \\
\text { 13.2). Walnut shells, which were used for grit blasting, are an organic } \\
\text { material. }\end{array}$ \\
$\begin{array}{l}\text { Other Interfering Waste } \\
\text { Contaminants } \\
\begin{array}{l}\text { Physical Matrix } \\
\text { Parameters }\end{array}\end{array}$ & $\begin{array}{l}\text { The majority of the grit waste is thought to be aluminum oxide. } \\
\text { The form of the material may range from fines to irregular particles. }\end{array}$ \\
\hline
\end{tabular}

\section{Complexing Agents}

Because complexing agents can aid in the transport of transuranic radionuclides from the waste after disposal, the waste was assessed for potential complexing agents. There is no documentation indicating the presence or use of complexing agents in the processes generating grit. 


\subsection{INCINERATOR WASTE}

This waste group includes sludge, firebrick, ash, soot, and cemented inorganic process solids generated by the low-specific activity (LSA) and high-specific activity (HSA) incinerators in Building 371, the plutonium recovery incinerator in Building 771, and the fluidized-bed incinerator (FBI) in Building 776. Historic IDC descriptions and dates of generation for the INEEL accessible storage inventory are presented by IDC in Table 14-1. ${ }^{\mathrm{P} 127}$

Table 14-1. Incinerator Waste in the Accessible Storage Inventory.

\begin{tabular}{rll}
\hline IDC & \multicolumn{1}{c}{ Title } & \multicolumn{1}{c}{ Dates of Generation } \\
\hline 292 & $\begin{array}{l}\text { Cemented Sludge } \\
\text { Incinerator Sludge }^{\mathrm{P} 001}\end{array}$ & May 1980-May 1986 \\
371 & Fire Brick $^{\mathrm{P} 001}$ & December 1972-May 1987 \\
377 & Coarse Fire Brick $^{\mathrm{P} 008}$ & March 1985-May 1987 \\
420 & Pulverized Incinerator Ash $^{\mathrm{P} 008}$ & December 1983-April 1984 \\
422 & Soot $^{\mathrm{P} 001}$ & March 1982-February 1986 \\
425 & Fluid Bed Ash $^{\mathrm{P} 014}$ & July 1981 \\
$807^{1}$ & Cemented Incinerator Sludge $^{\mathrm{P} 067}$ & November 1985-March 1987 \\
818 & Cemented Ash $^{\mathrm{P} 012}$ & October 1986 \\
820 & Cemented Soot $^{\mathrm{P} 012}$ & April 1986-October 1986 \\
\hline
\end{tabular}

Notes: 1. After March 1987, IDC 807 was used for Solidified Bypass Sludge from Liquid Waste Treatment in Building 374.

Item Description Code 292, Incinerator Sludge: This waste consists of sludge generated from the scrubber in the plutonium recovery incinerator in Building $771 .^{\mathrm{P} 014}$ The sludge consists of fly-ash and diatomite filter media. ${ }^{\mathrm{P} 16, \mathrm{P} 067}$ The sludge's consistency may range from a damp mass with a consistency of paste, to a mass that has been dried to some extent and may contain fines. ${ }^{\text {P035,P052 }}$ Portland cement was used as an absorbent for liquids in the sludge. ${ }^{\mathrm{P} 24}$

Item Description Code 371, Firebrick: This waste consists of firebrick which is an insulating material made of high-density refractory clay (primarily an alumina ceramic material) that was used to line plutonium processing furnaces and incinerators. ${ }^{\text {P001,P016,P032,P035 }}$ Drums of IDC 371 generated from 1971-1973 may contain pieces of construction bricks, cinder blocks, and firebrick from the plutonium recovery incinerator and from cleanup of the 1969 fire. The waste consists primarily of incinerator firebrick from the plutonium recovery incinerator, and may include firebrick from the LSA and HSA incinerators. ${ }^{\text {P037,P052 }}$

Item Description Code 377, Firebrick, Coarse: This waste consists of coarse firebrick which is firebrick larger than one-quarter inch in diameter and smaller than one-inch in diameter ${ }^{\text {P032 }}$ IDC 377 may also include cinder block and construction brick pieces of the same size. ${ }^{\mathrm{P} 24}$ 
Item Description Code 420, Pulverized Incinerator Ash: This waste consists of ash from the plutonium recovery incinerator, and is a mixture of coarse, granular, fine, and very fine particulate. The ash was jaw crushed and ball milled prior to removal from the glovebox. ${ }^{\mathrm{P} 14}$ The pulverized ash was assigned IDC 420. Drums of pulverized incinerator ash may contain some miscellaneous tramp metal, bits of unburned feed materials, and carbon from the incomplete oxidation of some feed materials. ${ }^{\text {P035.P052,U013 }}$ Ash from the LSA and HSA incinerators may also be included in IDC 420 ${ }^{\text {P052 }}$ Although not associated with an incinerator, IDC 420 may also include fire ash from the 1969 fire. ${ }^{\text {P058 }}$

Item Description Code 422, Soot: This waste consists of soot which is the airborne fly ash material that accumulated in the off-gas system of the plutonium recovery, LSA, and HSA incinerators. ${ }^{\mathrm{P} 14, \mathrm{P} 024, \mathrm{PO} 052, \mathrm{U} 013}$ Soot will contain most of the same constituents as the ash from which it was derived; however, the relative amounts of silica, carbon and minor components (the alumina, calcium, iron, and sodium oxides) will vary widely in the mixture. Soot generally contained a higher concentration of carbon and fine particulate than IDC 420 due to incomplete oxidation of some feed materials. ${ }^{\mathrm{P} 016, \mathrm{P} 035, \mathrm{P} 052}$

Item Description Code 425, Fluid-Bed Ash: This waste consists of fluid-bed ash which is a fine powder generated by the FBI. The ash is made up of approximately $10 \% \mathrm{NaCl}, 10 \% \mathrm{Na}_{2} \mathrm{CO}_{3}, 6 \%$ carbon, $30 \% \mathrm{Cr}_{2} \mathrm{O}_{3}$ (oxidation catalyst) on $\mathrm{Al}_{2} \mathrm{O}_{3}$, and $40 \%$ fly ash $\left(\mathrm{SiO}_{2}, \mathrm{Fe}_{2} \mathrm{O}_{3}, \mathrm{Al}_{2} \mathrm{O}_{3}\right)$. ${ }^{\text {P014,P052 }}$

Item Description Code 807, Cemented Incinerator Sludge: This waste consists of incinerator sludge (IDC 292) immobilized into a solid monolith with Portland cement. ${ }^{\text {P043,P063,P067,P098 }}$

Item Description Code 818, Cemented Ash: This waste consists of incinerator ash (IDC 420) immobilized into a solid monolith with Portland cement. The waste may contain miscellaneous tramp metal, bits of unburned feed material, and carbon from the incomplete oxidation of feed material. ${ }^{\mathrm{P} 16, \mathrm{P} 098}$

Item Description Code 820, Cemented Soot: This waste consists of soot (IDC 422) immobilized into a solid monolith with Portland cement. ${ }^{\mathrm{P} 016 \mathrm{P} 098}$

\subsection{Waste Generation}

TRU incinerator wastes were generated by the plutonium recovery incinerator in Building 771 , the Fluidized-Bed Incinerator (FBI) in Building 776, and test runs by the LSA and HSA incinerators in Building 371.

\subsubsection{Low-Specific Activity and High-Specific Activity Incinerators}

The LSA and HSA incinerators in Building 371 were developed as volume-reduction incinerators. The startup operation test program used nonhazardous materials during test runs. The test revealed design concerns, and the incinerators never became operational. Firebrick (IDCs 371 and 377), ash (IDC 420), and soot (IDC 422) wastes were generated during incinerator stripout operations. ${ }^{\text {PO16,P052 }}$

\subsubsection{Plutonium Recovery Incinerator}

The plutonium recovery incinerator in Building 771 was constructed for two main purposes. The first was to reduce the volume of solid combustible wastes to reduce storage costs. The second was to generate an 
ash from which actinides, primarily plutonium and americium, could be recovered. ${ }^{\text {U047 }}$ The incineration system was comprised of a multi-chamber, refractory-lined firebox; caustic scrubber system; dedicated vacuum system; heat exchangers; various tanks, pipes, and valves; and a filter plenum. ${ }^{\mathrm{P}}{ }^{\circ 1}$

Combustible wastes (primarily IDC's $330,331,336$, and 337 ) were received from production processes in Buildings 371, 707, 771, 776, 777, and 779. ${ }^{\text {O016.P052 }}$ Combustibles fed to the incinerator included paper, polyvinyl chloride and polystyrene bags, polypropylene and Ful-Flo filters, surgical gloves, polyvinyl chloride maintenance tents, and various types of sludge. The radioactively contaminated materials entered the glovebox from the drum hoist and bag-in area and were hand-sorted to segregate the combustibles. Noncombustibles, such as metal or glass wastes, were removed from the glovebox. ${ }^{\text {P052.P061 }}$

The incinerator was comprised of three chambers; a firebox where combustibles were initially introduced into the system, a main burner chamber where ashes that fell through the firebox grate continued to burn, and an afterburner section. ${ }^{\text {0047 }}$ Material was fed into the incinerator and was reduced by a 12-to-1 ratio, by weight. Incinerator ash was pulverized in the ball mill before being bagged out of the glovebox into drums. The pulverized ash was discarded as solid waste (IDC 420) if the plutonium was below the EDL or was sent for recovery if it contained plutonium above the EDL. ${ }^{\text {P061 }}$

Two air-to-gas heat exchangers drew in room air to help cool the incinerator off-gas before it passed through a caustic scrubber, and a venturi which increased the scrubbing efficiency of the potassium hydroxide $(\mathrm{KOH})$ caustic scrubber solution. After the off-gas passed through the scrubber, it was filtered through the incinerator filter plenum. Cooling air from the heat exchangers was filtered through the incinerator filter plenum and then through the main filter plenum where the gases were combined with other glovebox exhaust gases. $^{\text {P061 }}$

The $\mathrm{KOH}$ solution from the scrubber was processed through the drum filter where particulate matter (fly ash) was entrained on diatomite filter media. ${ }^{\mathrm{P} 67}$ Sludge, which consisted of fly ash and diatomite filter media, was discarded as solid waste (IDC 292) if the plutonium was below the EDL or was sent for recovery if the plutonium was above the EDL. ${ }^{\mathrm{P} 16, \mathrm{P} 061, \mathrm{U} 013}$

Firebrick (IDCs 371 and 377), which lined plutonium processing furnaces and incinerators, was generated during maintenance operations. After the firebrick was removed, it was subjected to a mechanical scarfing process to remove plutonium-bearing surface layers. ${ }^{\text {P016,P037,P } 117}$ Soot (IDC 422) was generated during routine filter change operations and when the off-gas system was disassembled and cleaned. ${ }^{\mathrm{P} 16 . \mathrm{P} 052}$ The plutonium recovery incineration process is presented in Figure 14.1. ${ }^{\text {P0S2 }}$

Beginning in 1985, incinerator sludge, ash, and soot wastes (IDCs 292, 420, and 422) were immobilized into a solid monolith with Portland cement and water ${ }^{\text {C050,P016 }}$ Portland cement and water were mixed, and incinerator sludge was gradually added to the mixture. The sludge, cement, and water mixture was poured into a 1-gallon polyethylene container mold and allowed to cure. The mold was removed from the solidified "puck" which was placed in a 55-gallon drum. Several "pucks" were placed in a drum. The same procedure was followed for cementation of incinerator ash and soot. ${ }^{\mathrm{P} 016, \mathrm{P} 043, \mathrm{P} 098}$ The cemented sludge, ash, and soot drums were assigned IDCs 807,818 , and 820 , respectively. ${ }^{\mathrm{P} 16, \mathrm{P} 043}$ 


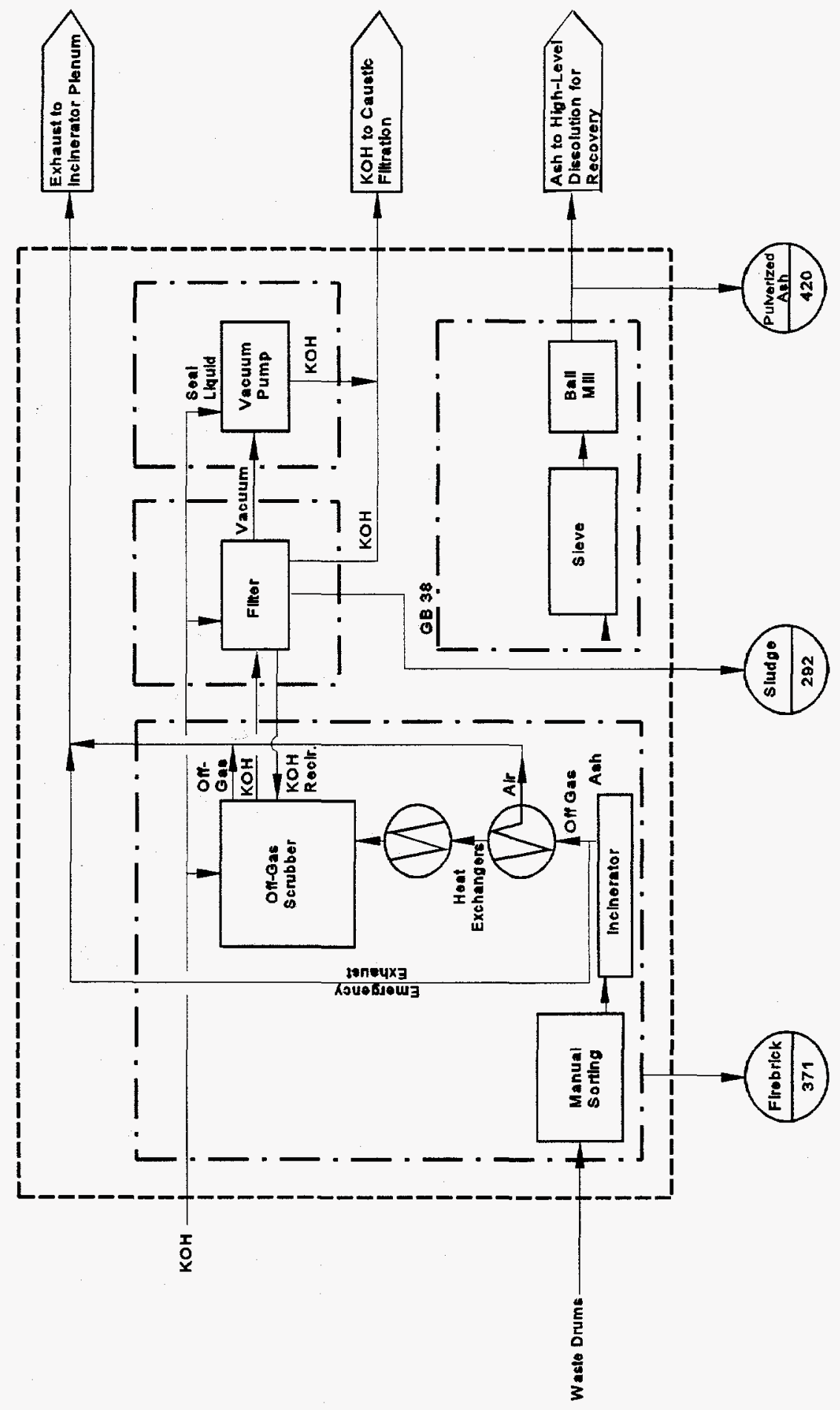

Figure 14-1. Plutonium Recovery Incineration Process. 


\subsubsection{Fluidized-Bed Incinerator}

The FBI received low-level plutonium-contaminated combustible solid and liquid wastes. The main purpose of the FBI program was to develop new technology to reduce volume and destroy volatile constituents prior to plutonium recovery operations. ${ }^{\text {P037,P052 }}$

The first runs of the FBI were made from 1971 to 1978 in a pilot-scale unit. Test materials introduced into the incinerator included polyvinyl chloride, polyethylene, and paper. After 1974, paint thinner, tributyl phosphate, kerosene, and hydrazine hydrate were burned. In 1978, polychlorinated biphenyls (PCB's), mixed as one part PCB to 4-5 parts diesel fuel or kerosene were burned. Waste burned in the pilot-scale unit was not considered a Toxic Substance Control Act (TSCA) waste because of the high efficiency of destruction achieved by this unit. ${ }^{\text {P052 }}$ Total PCBs analysis indicated concentrations of Aroclor-1254 from 24 to 27 parts per billion. ${ }^{\mathrm{P}} 2 \mathrm{~s}$

The first runs of the full-scale FBI occurred from 1978 to 1981 . These first runs used test materials such as newspaper, low-level waste from Building 776, combustible waste, kerosene, garage oil, and grease. Test runs conducted from 1985 to 1988 were conducted with methanol, diesel products, and nonradioactive surrogate combustibles (shredded coveralls, leather gloves, rolls of polyvinyl chloride plastic, wood, and paper). ${ }^{\mathrm{P} 52}$

Liquid wastes were pumped through filters into two incinerator feed tanks. From these tanks, the liquid was sprayed into the incinerator through nozzles. Solid wastes were transferred to a glovebox for hand-sorting where noncombustible materials such as metal and glass were removed. The combustible wastes were shredded and conveyed by screw feeder to the incinerator. ${ }^{\mathrm{P}}{ }^{67}$

The wastes were incinerated in fluidized beds of sodium carbonate and chromic oxide catalyst. The incinerator had a primary reactor and an afterburner. Process flue gases passed through two stages of cyclone separators, a stainless-steel sintered metal filter bank, and a one-stage HEPA filter, before being exhausted into the HEPA filter plenum of the building ventilation system. The ash (IDC 425) collected by the filters and cyclone separators was bagged out of the glovebox into drums. Even though the FBI processed low-level waste, both low-level and TRU ash were generated due to the concentrating of radionuclides from the feed material. The FBI process is illustrated by Figure 14-2. ${ }^{\text {P067 }}$

\subsection{Waste Packaging}

Incinerator sludge (IDC 292) packaged prior to 1977 was placed in a polyvinyl chloride bag and sealed with tape. The bag was then double-contained in plastic and placed in a 1-gallon metal paint can containing Portland cement. Additional cement was added to the top of the waste before the paint can lid was closed. Beginning in 1977, the sludge was collected in 2- or 4-liter Nalgene bottles. Portland cement was added in layers as the bottle filled with sludge. The sludge was capped with cement, the bottle lid was installed, and the bottle was double-bagged. ${ }^{\mathrm{P} 16 \mathrm{P} 024}$ The sludge may also be packaged in several plastic bags within the drum. ${ }^{\mathrm{P} 015}$ Each individual package was bagged out of the glovebox and placed in two plastic bags which were sealed with tape. The packages were assayed and placed into a 55-gallon drum. Up to 25 cans or 20 bottles were placed in a drum depending on assay. ${ }^{\mathrm{P} 016, \mathrm{P} 024}$ 


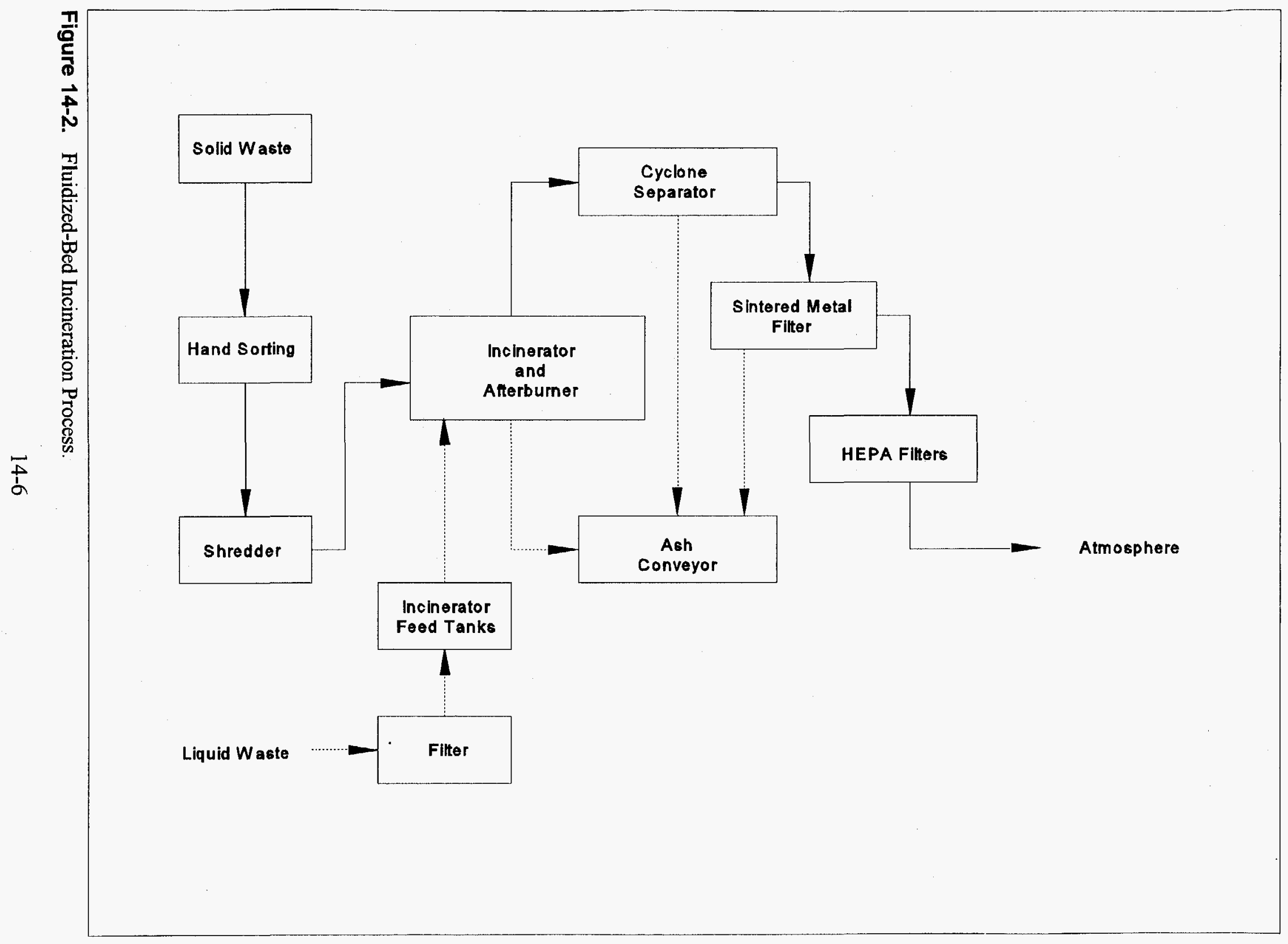


From 1971-1973, firebrick wastes (IDCs 371 and 377) were packaged by three different methods; double-bagged and placed into Fibre-Paks (two Fibre-Paks fit into a 55-gallon drum), double-bagged and placed into a 55-gallon drum, or placed directly into a 55-gallon drum. The plastic bags were sealed with tape prior to placement in a Fibre-Pak or drum. After 1973, firebrick was double-bagged and packaged in FibrePaks exclusively. Fibre-Packs were assayed before being placed in a 55-gallon drum. ${ }^{\mathrm{P} 12, \mathrm{P} 015, \mathrm{P} 024}$

Pulverized incinerator ash (IDC 420) was packaged in $1 / 2$ - or 1-gallon polyethylene bottles. The bottles were bagged out of the glovebox and placed in one or two polyethylene bags which were sealed with tape. The packages were assayed and placed into a 55-gallon drum. Up to 25 bottles were placed into a drum depending on assay. ${ }^{\mathrm{P}}{ }^{24}$

Soot (IDC 422) was packaged in 1- or 2-quart polyethylene bottles. The bottles were bagged out of the glovebox and placed in two polyethylene bags which were sealed with tape. The packages were assayed and placed into a 55 -gallon drum. Up to 50 bottles were placed into a drum depending on assay. ${ }^{\mathrm{P} 16, \mathrm{P} 024}$

Cemented ash pucks (IDC 818) were bagged out of the glovebox, double-bagged, and placed into a 55-gallon drum. Sludge and soot pucks (IDCs 807 and 820) were packaged in the same manner. ${ }^{\mathrm{P} 012, \mathrm{P} 016}$

FBI ash (IDC 425) was packaged in small plastic bags. Several bags were bagged out of the glovebox, placed in a polyvinyl chloride bag which was sealed with tape, and the bag was placed into a 55-gallon drum. ${ }^{\mathrm{P} 024}$

Depending on waste packaging requirements at the time, several combinations of bags and liners were used to prepare 55-gallon drums for shipment. From 1970 to 1972 , waste drums were lined with one or two polyethylene drum bags. Cardboard liners might have been used to line the inner drum bag. Use of 90-mil rigid polyethylene liners began in $1972 .{ }^{\mathrm{P} 24}$ A rigid liner was placed in each drum and lined with one

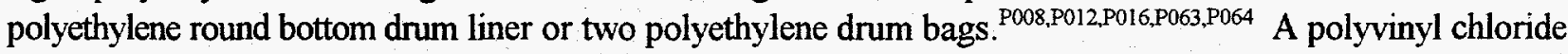
O-ring bag and a polyethylene bag placed inside the rigid liner was used if the drum was attached to a glovebox. ${ }^{\mathrm{P} 16}$ A fiberboard liner and discs may also have been used between the waste and the drum liners. ${ }^{\mathrm{P} 008, \mathrm{PO12}, \mathrm{P016}, \mathrm{PO} 33, \mathrm{PO} 64}$ In addition, drums of incinerator sludge (IDC 292) may be lead-lined. When a drum was full, the drum liners were twisted and taped closed, the lid was secured with a bolted ring, and a tamper indicating device was attached to the drum. ${ }^{\mathrm{P} 001, \mathrm{P} 016, \mathrm{P} 024, \mathrm{P} 043}$

After drums were inspected, one to two quarts of absorbent material (Oil-Dri) was placed on top of the outer, sealed polyethylene drum bag. This procedure was changed in February 1982 when vermiculite was used to fill the space between the outer, sealed polyethylene drum bag and the top of the 90 -mil rigid liner. The quantity of vermiculite varied from 3-12 pounds according to the amount of waste contained in each drum. ${ }^{\mathrm{P} 024}$

Waste management and inspection protocol allowed containers of incinerator wastes to contain up to 10 percent of another IDC other than that assigned to the container. Other wastes could include combustibles, glass, concrete, metal, leaded gloves, and plastics. ${ }^{\mathrm{P} 16}$ Visual inspection of some of the containers revealed several items. Ful-Flo filters laden with grease, empty cement bags, and unused polyethylene bags were identified in IDC 292 drums. Surgical gloves, asbestos insulation, foil, polyvinylchloride and polyethylene bags, and a thermocouple were found in IDC 371 drums. ${ }^{\mathrm{P} 15}$ 


\subsection{Waste Characterization}

Incinerator wastes have been characterized based on knowledge of the material, knowledge of the processes generating the waste, RTR review of the waste, visual inspection, waste analysis, and headspace gas analysis. This section provides a RCRA hazardous waste determination for incinerator wastes as well as radionuclide contaminants and potential complexing agents contained in the waste.

Incinerator ash (IDCs 420, 425, and 818) and soot (IDCs 422 and 820) are at least 50 percent (by volume) inorganic particulates, and incinerator sludge (IDCs 292 and 807) is at least 50 percent (by volume) inorganic sludge. These wastes are classified as homogeneous wastes. Firebrick (IDCs 371 and 377) is estimated to be 80 percent or more (by volume) inorganic nonmetal debris that meets the EPA LDR criteria for classification as debris, and is therefore a heterogeneous waste. ${ }^{\mathrm{P} 141}$

\subsubsection{Hazardous Waste Determination}

The material in this waste group does not qualify for any of the exclusions outlined in 40 CFR 260 or 261. The waste may exhibit the characteristic of corrosivity due to the presence of caustic free liquids. The waste may also exhibit the characteristic of toxicity for arsenic, barium, cadmium, chromium, lead, mercury, selenium, and silver. The waste was mixed with halogenated- and nonhalogenated-solvents, and is therefore a F-listed hazardous waste. There is no evidence that incinerator wastes exhibit any other characteristic of hazardous waste. ${ }^{\mathrm{C} 116}$ EPA Hazardous Waste Numbers applicable to some or all of the incinerator waste group are presented by IDC in Table 14-2. These conclusions are supported by the evaluation in Sections 14.3.1.1 and 14.3.1.2.

Characterization of FBI ash from Building 776 is supported by analytical data from samples of FBI ash taken from the Rocky Flats inventory. Samples were collected from drums of low-level ash waste. The FBI generated both TRU and low-level ash waste, and the analytical results should be applicable to the FBI ash in the INEEL inventory. ${ }^{\text {P125 }}$

Table 14-2. Incinerator Waste Characterization.

\begin{tabular}{lll}
\hline IDC & \multicolumn{1}{c}{ Title } & \multicolumn{1}{c}{ EPA Hazardous Waste Numbers } \\
\hline 292 & Incinerator Sludge & D002, D004-D01 1, F001, F002, F003, and F005 \\
371 & Fire Brick & D004-D011, F001, F002, F003, and F005 \\
377 & Coarse Fire Brick & D004-D011, F001, F002, F003, and F005 \\
420 & Pulverized Incinerator Ash & D004-D011, F001, F002, F003, and F005 \\
422 & Soot & D004-D011, F001, F002, F003, and F005 \\
425 & Fluid Bed Ash & D007, F003, and F005 \\
807 & Cemented Incinerator Sludge & D004-D01 1, F001, F002, F003, and F005 \\
818 & Cemented Ash & D004-D01 1, F001, F002, F003, and F005 \\
820 & Cemented Soot & D004-D011, F001, F002, F003, and F005 \\
\hline
\end{tabular}




\subsubsection{Characteristic Waste.}

The materials in this waste group may exhibit a characteristic of hazardous waste as defined in 40 CFR 261, Subpart C as a corrosive waste (40 CFR 261.22) and as a toxic waste (40 CFR 261.24). The materials do not exhibit the characteristics of ignitability (40 CFR 261.21) or reactivity (40 CFR 261.23). The origin of the characteristic hazardous waste numbers assigned to incinerator wastes is provided in Table 14-3. The table includes only the hazardous waste numbers that are applicable to waste for which a specific source was identified. The hazardous waste numbers are not applicable to waste generated from areas other than those listed in the table.

Table 14-3. Origin of Characteristic Hazardous Waste Numbers.

\begin{tabular}{ccl}
\hline IDC & EPA Hazardous Waste Numbers & \multicolumn{1}{c}{ Building/Area } \\
\hline 371 & None & Building 371 LSA and HSA Incinerators \\
& D004-D011 & Building 771 Plutonium Recovery Incinerator \\
377 & None & Building 371 LSA and HSA Incinerators \\
& D004-D011 & Building 771 Plutonium Recovery Incinerator \\
420 & None & Building 371 LSA and HSA Incinerators \\
& D004-D011 & Building 771 Plutonium Recovery Incinerator \\
422 & None & Building 371 LSA and HSA Incinerators \\
& D004-D011 & Building 771 Plutonium Recovery Incinerator \\
\hline
\end{tabular}

Ignitability: The material in this waste group does not meet the definition of ignitability as defined in 40 CFR 261.21. The material is not a liquid, and absorbents were added to wastes having the potential of generating free liquids. ${ }^{\mathrm{P} 24}$ RTR and visual inspection identified free liquids in several containers of incinerator sludge (IDC 292). However, sampling and analysis indicated that the liquids were aqueous with a $\mathrm{pH}$ of $12 .^{\mathrm{P} 015}$ The materials are not capable of causing fire through friction, absorption of moisture, or spontaneous chemical change. ${ }^{\mathrm{P} 012 \mathrm{P} 024}$ The material is not a compressed gas, nor do the drums contain compressed gases as confirmed by RTR and visual inspection. ${ }^{\mathrm{P} 013, \mathrm{P} 015}$ The material is not a DOT oxidizer as defined in 49 CFR 173.127. The materials in this waste group are therefore not ignitable wastes (D001).

Corrosivity: Incinerator sludge (IDC 292) may meet the definition of corrosivity as defined in 40 CFR 261.22. Other materials in this waste group do not meet the definition of corrosivity. The material is not a liquid, and absorbents were added to wastes having the potential of generating free liquids. ${ }^{\text {P024 }}$ RTR and visual inspection identified free liquids in several containers of incinerator sludge (IDC 292). Sampling and analysis indicated that the liquids were aqueous with a $\mathrm{pH}$ of $12 .^{\mathrm{P} 015}$ However, because the sludge was generated from filtering of caustic scrubber solution, other sludge drums could contain enough $\mathrm{KOH}$ content to exceed a pH of $12.5^{\text {P052,U060 }}$ Therefore, drums of incinerator sludge containing free liquids are assigned EPA Hazardous Waste Number D002. ${ }^{\text {U060 }}$ 
Reactivity: The materials in this waste group do not meet the definition of reactivity as defined in 40 CFR 261.23. The materials are stable and will not undergo violent chemical change. The materials will not react violently with water, form potentially explosive mixtures with water, or generate toxic gases, vapors, or fumes when mixed with water. The materials do not contain cyanides or sulfides, and are not capable of detonation or explosive reaction. The materials are not forbidden explosives or Division 1.1, 1.2, or 1.3 (Class A or B) explosives as defined in 49 CFR 173, nor do the drums contain explosive materials. ${ }^{\text {P013,P015 }}$ Explosives were not handled or used around radioactive material. The materials in this waste group are therefore not reactive wastes (D003).

Toxicity: The materials in this waste group meet the definition of toxicity as defined in 40 CFR 261.24. The toxicity characteristic contaminants fall into one of two categories: metals and organics. Organic compounds include halogenated- and nonhalogenated-solvents, pesticides, herbicides, and other toxic compounds. This waste group may exhibit the characteristic of toxicity for arsenic, barium, cadmium, chromium, lead, mercury, selenium, and silver metals.

Only nonhazardous materials were fed to the LSA and HSA incinerators in Building 371 . Therefore, wastes generated from these incinerators do not exhibit the characteristic of toxicty. ${ }^{\text {Pos2 }}$

Wastes contaminated with alcohols, glycols, solvents, and metals from numerous processes may have been fed to the plutonium recovery incinerator in Building 771. The incinerator could have accepted any of the combustible, plastic, or filter wastes that were generated during the time it was operational. Therefore, it is possible that wastes from the plutonium recovery incinerator exhibit the characteristic of toxicity for arsenic, barium, cadmium, chromium, lead, mercury, selenium, and silver and are assigned EPA Hazardous Waste Numbers D004-D011.

Toxicity characteristic metals were not fed to the FBI in Building 776. FBI ash contains chromium because wastes were incinerated in fluidized beds of sodium carbonate and chromic oxide catalyst. Table 14-4 presents total and TCLP metals results from analysis performed on FBI ash. Although the total concentrations show barium, cadmium, chromium, and lead, the TCLP only indicates chromium above the regulatory level. These results support the process knowledge that the ash contains chromium. Therefore, FBI ash (IDC 425) exhibits the characteristic of toxicity for chromium and is assigned EPA Hazardous Waste Number D007.

There is no documentation indicating the presence or use of pesticides or herbicides in the areas or processes generating wastes fed to the incinerators. Therefore, this waste group does not exhibit the characteristic of toxicity due to pesticides or herbicides (D012-D017).

Wastes fed to the plutonium recovery incinerator in Building 771 may be contaminated with organic compounds including tetrachloroethene, trichloroethene, and carbon tetrachloride. Since these compounds were typically used as solvents, the waste is regulated as a listed hazardous waste and not a characteristic waste because these compounds are specifically addressed in the treatment standards for the listed hazardous waste. ${ }^{\mathrm{P} 080}$ Since wastes from the Building 771 incinerator are characterized as listed hazardous wastes due to spent solvent contamination, the waste is not a toxic waste due to the presence of these organic compounds. 
Table 14-4. Metals Results for Fluid-Bed Ash. ${ }^{\text {Pl25 }}$

\begin{tabular}{lllc}
\hline \multirow{2}{*}{ Compound } & \multicolumn{2}{c}{ Concentration } & \multicolumn{1}{c}{$\begin{array}{c}\text { Regulatory Level } \\
\text { TCLP (mg/L) }\end{array}$} \\
\cline { 2 - 3 } & \multicolumn{1}{c}{ Total (mg/Kg) } & TCLP (mg/L) & 5.0 \\
\hline Arsenic & ND & ND-0.30 & 100.0 \\
Barium & $50.79-116.36$ & ND-4.67 & 1.0 \\
Cadmium & $20.03-29.54$ & ND & 5.0 \\
Chromium (Total) & $7,020.41-15,750.84$ & $89.0-113.96$ & - \\
Chromium & - & $100.00-850.00$ & \\
(Hexavalent) & - & & 5.0 \\
Lead & $1,527.87-6,167.23$ & ND-0.55 & 5.0 \\
Silver & ND & ND-0.16 & \\
\hline
\end{tabular}

Acronyms: ND Not Detected

$\mathrm{mg} / \mathrm{Kg}$ milligrams per kilogram (parts per million)

$\mathrm{mg} / \mathrm{L}$ milligrams per liter (parts per million)

Paint thinner was used as feed material for the FBI in Building 776. A common component of paint thinner was methyl ethyl ketone. TCLP analysis of FBI ash did not detect methyl ethyl ketone in the sample. TCLP analysis was also performed for vinyl chloride, 1,1-dichloroethene, chloroform, carbon tetrachloride, 1,2-dichloroethane, benzene, trichloroethene, tetrachloroethene, chlorobenzene, and 1,4-dichlorobenzene. None of these compound were detected in the sample. ${ }^{\mathrm{P} 125}$ Therefore, this waste group does not exhibit the characteristic of toxicity due to organic compounds (D018-D043).

Incinerator sludge, ash, and soot wastes will be randomly sampled and analyzed for toxicity characteristic constituents to verify their characterization. Firebrick wastes will not be sampled since they are heterogeneous wastes and a representative sample cannot be obtained. However, the results obtained from sampling Building 771 incinerator wastes should be applicable to firebrick wastes from this incinerator.

\subsubsection{Listed Hazardous Waste}

The material in this waste group was derived from the treatment of a waste listed in 40 CFR 261, Subpart D as a hazardous waste from non-specific sources (40 CFR 261.31). The waste is not, or was not derived from the treatment of, a hazardous waste from specific sources (40 CFR 261.32), or a discarded commercial chemical product, an off-specification species, a container residue, or a spill residue thereof (40 CFR 261.33). The origin of the listed hazardous waste numbers assigned to incinerator wastes are provided in Table 14-5. The table includes only the hazardous waste numbers that are applicable to waste for which a specific source was identified. The hazardous waste numbers are not applicable to waste generated from areas other than those listed in the table. 
Table 14-5. Origin of Listed Hazardous Waste Numbers.

\begin{tabular}{cll}
\hline IDC & \multicolumn{1}{c}{ EPA Hazardous Waste Numbers } & \multicolumn{1}{c}{ Building/Area } \\
\hline 371 & None & Building 371 LSA and HSA Incinerators \\
& F001, F002, F003, and F005 & Building 771 Plutonium Recovery Incinerator \\
377 & None & Building 371 LSA and HSA Incinerators \\
& F001, F002, F003, and F005 & Building 771 Plutonium Recovery Incinerator \\
420 & None & Building 371 LSA and HSA Incinerators \\
& F001, F002, F003, and F005 & Building 771 Plutonium Recovery Incinerator \\
422 & None & Building 371 LSA and HSA Incinerators \\
& F001, F002, F003, and F005 & Building 771 Plutonium Recovery Incinerator \\
\hline
\end{tabular}

Only nonhazardous materials were fed to the LSA and HSA incinerators in Building 371. Therefore, wastes generated from these incinerators are not listed hazardous wastes. ${ }^{\text {P052 }}$

Tetrachloroethene, trichloroethene, 1,1,1-trichloroethane, carbon tetrachloride, and 1,1,2-trichloro1,2,2-trifluoroethane were used for cleaning and degreasing. Methylene chloride was used primarily for paint removal. Wastes contaminated with these compounds may have been fed to the plutonium recovery incinerator in Building 771. The plutonium recovery incinerator wastes were derived from the treatment of a listed hazardous waste and are therefore assigned EPA Hazardous Waste Numbers F001 and F002. Since process knowledge indicates that halogenated solvents were not fed to the FBI, EPA Hazardous Waste Numbers F00 1 and F002 will not be applied to FBI ash.

Various processes that generated combustible wastes that fed the plutonium recovery incinerator may have used acetone, methanol, and xylene. Methanol was also used as feed material for the FBI. The plutonium recovery incinerator and FBI wastes were derived from the treatment of a listed hazardous waste and are therefore assigned EPA Hazardous Waste Number F003.

There is no documentation indicating the presence or use of F004-listed solvents in the areas or processes generating wastes fed to the incinerators. Therefore, this waste group is not a F004-listed hazardous waste.

Benzene and toluene were used as solvents in laboratory operations. The combustible wastes that fed the plutonium recovery incinerator may have been contaminated with these solvents. Paint thinner, which was fed to the FBI, may have contained toluene and methyl ethyl ketone (common components of paint thinner). The plutonium recovery incinerator and FBI wastes were derived from the treatment of a listed hazardous waste and are therefore assigned EPA Hazardous Waste Number F005.

Analysis of a single sample of FBI ash confirms the presence of listed solvents. Toluene and methyl ethyl ketone were detected at the highest concentrations in the waste. Several other organic solvents were detected in the ash, but at low concentrations (less than $0.2 \mathrm{mg} / \mathrm{kg}$ ). ${ }^{\mathrm{P} 125}$ 
Headspace analysis performed on samples of incinerator wastes (IDCs 292, 371, 422, and 818) obtained at INEEL confirms the presence of F-listed solvents. The detected F-listed compounds in which the calculated 90 percent UCL is above the PRQL are provided. ${ }^{\mathrm{P} 033}$

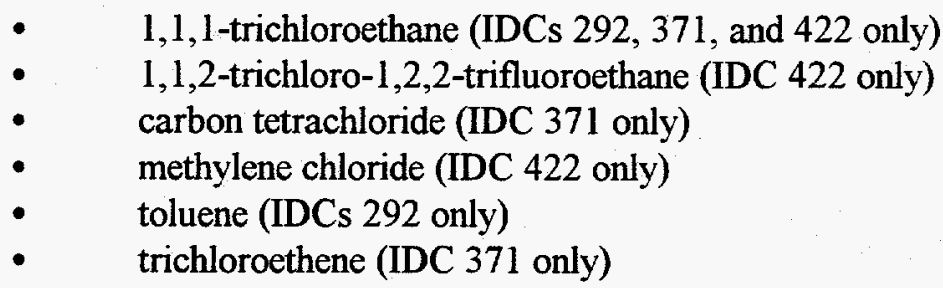

Toluene was also detected in the headspace of a single sample of coarse firebrick (IDC 377) obtained from Rocky Flats inventory.

The material in this waste group is not a hazardous waste from specific sources since it was not generated from any of the processes listed in 40 CFR 261.32. The material in this waste group is therefore not a K-listed hazardous waste.

The material in this waste group is not a discarded commercial chemical product, an off-specification species, a container residue, or a spill residue thereof (40 CFR 261.33). The material in this waste group is therefore not a P- or U-listed hazardous waste.

\subsubsection{Radionuclides}

The combustible wastes processed by the Building 771 incinerator were contaminated primarily with weapons-grade plutonium and americium-241. ${ }^{\text {P163 }}$ However, combustibles sent to the incinerator were generated by numerous production processes, and incinerator wastes will also be contaminated with enriched uranium. Documented assay results for IDC 377 confirm the presence of uranium-235. ${ }^{\mathrm{P} 16}$

Approximately 90 weight percent of the bulk is exhausted from the incinerator system as combustion product gases. All radionuclide contaminants remain behind after combustion resulting in an ash having a plutonium concentration of up to 10 weight percent. ${ }^{\mathrm{C180,P035,P163}}$ The sludge and soot removed from the off-gas system, and the firebrick incinerator liner removed during maintenance activities will contain most of the same constituents as the combustible feed material from which they were derived. ${ }^{\mathrm{P} 035}$

The pilot-scale fluidized-bed incinerator (prefix 75) was developed in Building 776 to treat low-level wastes. ${ }^{\mathrm{C} 184, \mathrm{U} 059}$ The wastes fed to the incinerator were contaminated with low-levels of plutonium. ${ }^{\mathrm{P} 024}$ Analysis indicates that the plutonium is weapons-grade. ${ }^{\mathrm{Pi} 25}$

It is not known where the wastes fed to the Building 371 incinerators originated. It is assumed that the combustible wastes originated from the same areas as those processed by the Building 771 incinerator and, therefore, could be contaminated with weapons-grade plutonium, americium-241, and enriched uranium. Since these incinerators never became operational, and ran only for the startup operation test program, only a small amount of waste would have been generated. 
In addition to the incinerators in Building 371, Building 371 immobilized residues in cement from plutonium recovery operations in preparation for shipment. Residues immobilized may include Building 771 incinerator sludge or other incinerator wastes. ${ }^{\mathrm{P} 067}$

The Size Reduction Vault (SRV) in Building 776 conducted solid waste treatment, repackaging, and size reduction operations. The SRV was divided into two sides. One side was the airlock (prefixes 25, 40, 4I, and 57) where repackaging was done. The other side (prefixes 19 and 26) was a drybox atmosphere where size reduction and solid waste treatment activities took place. ${ }^{\text {C175,C184,P067, } 0599}$ The repacked incinerator waste containers have the potential to contain contaminated materials from any of the incineration processes. ${ }^{\text {P067,U077 }}$

Table 14-6. Waste Matrix Evaluation.

\begin{tabular}{ll}
\hline \multicolumn{1}{c}{ Parameter } & \multicolumn{1}{c}{ Results of Evaluation } \\
\hline Radionuclide Form, Particle & IDC 292: Radionuclide contaminants will be in hydroxide form because \\
Size, and Distribution & IDC 292 sludge was produced from filtering potassium hydroxide scrubber \\
& solution. ${ }^{\text {P052,P061 }}$
\end{tabular}

Hydrogen Content

Other Interfering Waste

IDCs 371/377: The surface of the firebrick is contaminated with a "glaze" containing actinide oxides. ${ }^{\mathrm{P} 035}$

IDC 420: Radionuclides may be in the form of oxides or chlorides. ${ }^{\mathrm{P} 163}$ Analysis indicates $1.8-3.8 \mathrm{wt} \%$ plutonium oxide. ${ }^{\mathrm{C} 180}$

IDC 422: Contains most of the same constituents as IDC 420 . $^{\mathrm{P} 35}$

IDC 425: Radionuclides may be in the form of oxides or chlorides. ${ }^{\text {P052 }}$

IDC 292: Headspace gas analysis indicates $1.8-23.2 \mathrm{vol} \%$ hydrogen and an average of less than 0.5 vol\% hydrocarbons. ${ }^{\mathrm{P} 015}$

IDCs 371/377: Headspace gas analysis of IDC 371 indicates hydrogen from 17.1 vol $\%$ to none detected and an average of $0.35 \mathrm{vol} \%$ hydrocarbons. One sample of IDC 377 indicated $0.02 \mathrm{vol} \%$ hydrogen and 0.04 vol\% hydrocarbons. ${ }^{\mathrm{P} 015}$

IDC 420: Measured water content of 0.4 to $1.0 \mathrm{wt} \%$. Water and hydrocarbon content of ash could exceed $10 \mathrm{wt} \%$ based on water content and loss on ignition data. ${ }^{\mathrm{Cl} 80}$

IDC 422: Small quantities of hydrocarbons have been detected in headspace gas samples. ${ }^{\mathrm{P} 33}$

IDC 425: Analysis indicates $1.11 \%$ moisture content. ${ }^{\mathrm{P} 125}$

Contaminants

IDC 292: May contain trace amounts of beryllium and cadmium. ${ }^{\text {P035 }}$

IDCs 371/777: Typically comprised of $96 \%$ aluminum oxide. ${ }^{\mathrm{P} 024, \mathrm{P} 035}$

IDC 420: Analysis indicates $0.95-5.7 \mathrm{wt} \%$ aluminum oxide, $0.83-8.3 \mathrm{wt} \%$ magnesium oxide, and $0.44-0.88 \mathrm{wt} \%$ chromium(III) oxide. ${ }^{\mathrm{C} 180}$ An average of $0.6 \mathrm{wt} \%$ fluoride and $2.5 \mathrm{wt} \%$ chloride were also measured. ${ }^{\mathrm{P} 035}$

IDC 422: May contain minor amounts of aluminum oxide. ${ }^{\text {P035 }}$ 


\begin{tabular}{|c|c|}
\hline Parameter & Results of Evaluation \\
\hline \multirow{6}{*}{ Physical Matrix Parameters } & $\begin{array}{l}\text { IDC 425: Contains chromium oxide, aluminum oxide, and sodium } \\
\text { chloride. }{ }^{\mathrm{P} 052} \text { Analysis indicates } 4.1-9.5 \% \text { aluminum, } 208-342 \mathrm{ppm} \\
\text { magnesium, } 23-25 \mathrm{ppm} \text { boron, } 0.2-3.2 \% \text { chloride, and } 24-3600 \mathrm{ppm} \\
\text { fluoride. }{ }^{\mathrm{P} 125} \text { See Table } 14-4 \text { for cadmium and chromium concentrations. }\end{array}$ \\
\hline & $\begin{array}{l}\text { IDC 292: Damp mass with past consistency to a dryer mass containing } \\
\text { some fines. }{ }^{\text {P035 }}\end{array}$ \\
\hline & $\begin{array}{l}\text { IDCs } 371 / 377 \text { : The surface of the firebrick is contaminated with a "glaze" } \\
\text { containing various metal oxides. The density of firebrick is } 2.44 \mathrm{~g} / \mathrm{cm}^{3} \text {. P035 }\end{array}$ \\
\hline & $\begin{array}{l}\text { IDC 420: Mixture of coarse, granular, fine, and very fine (less than } 100 \\
\text { mesh) particulate. Ash will contain some metal and unburned feed } \\
\text { materials. }\end{array}$ \\
\hline & $\begin{array}{l}\text { IDC 422: Mixture of fine and very fine (less than } 100 \text { mesh) } \\
\text { particulate. }\end{array}$ \\
\hline & $\begin{array}{l}\text { IDC 425: Particle size data indicate } 52.6 \mathrm{wt} \% \text { is } 500-1000 \mu \mathrm{m}, 24.2 \mathrm{wt} \% \\
\text { is } 212-500 \mu \mathrm{m} \text {, and } 13.3 \mathrm{wt} \% \text { is greater than } 1000 \mu \mathrm{m} .\end{array}$ \\
\hline
\end{tabular}

\subsubsection{Complexing Agents}

Because complexing agents can aid in the transport of transuranic radionuclides from the waste after disposal, the waste was assessed for potential complexing agents. This information may also be added to the chemical compatibility studies since limited information was available on these chemicals in the past.

EDTA represents a group of chelating compounds, such as ethenediaminetetraacetic acid, with similar molecular structures found in many soaps and detergents. Versene (a trade name for EDTA) and citric acid are known constituents of $\mathrm{KW}$ decontamination detergent. ${ }^{\mathrm{P} 24, \mathrm{P} 068} \mathrm{KW}$ was used during a variety of decontamination activities at the plant, including wiping down filter frames. If combustibles fed to the incinerator were contaminated with these complexing agents, incinerator wastes may contain trace quantities of these compounds. 


\subsection{LEAD-CONTAINING WASTE}

This waste group consists of lead-containing wastes generated by the production, recovery, laboratory, treatment, maintenance, and research and development activities associated with plutonium operations. The waste was generated in Buildings $371,374,559,707,771,774,776,777$, and 779 , and consists primarily of heavy non-special source (non-SS) metal, lead, leaded rubber glovebox gloves, and leaded aprons. ${ }^{\text {P001,P012 }}$ Historic IDC descriptions and dates of generation for the INEEL accessible storage inventory are presented by IDC in Table 15-1. ${ }^{\text {P127 }}$.

Table 15-1. Lead-Containing Wastes in the Accessible Storage Inventory.

\begin{tabular}{clc}
\hline IDC & \multicolumn{1}{c}{ Title } & \multicolumn{1}{c}{ Dates of Generation } \\
\hline 320 & $\begin{array}{l}\text { Tantulum } \\
\text { Heavy Non-SS Metal }\end{array}$ & January 1973-June 1988 \\
321 & Lead $^{\mathrm{P} 012}$ & October 1987-November 1987 \\
339 & $\begin{array}{l}\text { Leaded Rubber Gloves and Aprons } \\
\text { Leaded Drybox Gloves and Other Leaded Rubber }{ }^{\mathrm{C} 063}\end{array}$ & February 1973-July 1988 \\
& Leaded Drybox Gloves, Not Acid Contaminated $^{\mathrm{P001}}$ & \\
\hline
\end{tabular}

Item Description Code 320, Heavy Non-SS Metal: This waste consists of heavy non-SS metals generated in Buildings $371,559,707,771,776,777$, and 779. ${ }^{\text {P016,P127, U059 }}$ Heavy non-SS metals include metals above copper on the periodic table. Tantalum items include crucibles, funnels, boats, process fixtures, pour rods, stir rods, and various other equipment that were used to handle molten plutonium. ${ }^{\mathrm{P} 001, \mathrm{P014,P016, \textrm {PO } 3} \text {, The }}$ waste consists primarily of tantalum but also includes metals such as tungsten, platinum, and depleted uranium. $^{\text {P083 }}$ In addition, prior to 1987 , the waste could contain lead materials such as bricks, tape, sheeting, and glovebox parts. IDC 321 was created in 1987 specifically for lead waste ${ }^{\mathrm{P} 016}$ IDC 320 was redefined from tantalum to heavy non-SS metal in 1985 to be more inclusive. ${ }^{\mathrm{C} 063}$

Item Description Code 321, Lead: This waste consists of primarily of radiation shielding in the form of lead bricks, tape, sheeting, and glovebox port covers. ${ }^{\mathrm{P} 16, \mathrm{P} 037, \mathrm{P} 049, \mathrm{P} 083, \mathrm{P} 116}$ The waste was generated by production operations in Building 707 and recovery, purification, and size reduction activities Building 776. ${ }^{\mathrm{P} 127, \mathrm{U} 059}$ IDC 321 was created in 1987 to sort lead waste from other heavy metals. ${ }^{\mathrm{C} 050, \mathrm{P} 016}$

Item Description Code 339, Leaded Drybox Gloves: This waste consists of leaded drybox (glovebox) gloves and leaded aprons generated in Buildings $371,374,559,707,771,774,776,777$, and 779. ${ }^{\mathrm{P} 049, \mathrm{P} 083}$ Leaded gloves were used in gloveboxes to reduce radiation exposure to personnel. IDC 339 also includes lead aprons that were also used to reduce radiation exposure. Leaded gloves were fabricated with three layers: a neoprene layer, a lead oxide layer, and a Hypalon layer. ${ }^{\mathrm{P} 35, \mathrm{P} 012}$ Two types of leaded gloves were used: S6 and S2P2. The only differences in these two types of gloves were the weight of the gloves and the thickness of the Hypalon layer ${ }^{\text {P016,C051 }}$ Prior to 1986 , all leaded glovebox gloves, both acid contaminated and not acid contaminated, were accumulated together as IDC 339. In 1986, IDC 341 was created to sort gloves that were generated in an environment where they may have been exposed to acid. ${ }^{\mathrm{C} 50, \mathrm{P} 035}$. The major concern was that 
nitric acid would react with the lead oxide layer of the gloves and form reactive lead nitrate, organic nitrates, or nitro-organic compounds. ${ }^{\mathrm{P} 016, \mathrm{P} 024, \mathrm{P} 120, \mathrm{C} 096}$

\subsection{Waste Generation}

Lead-containing wastes were generated by production, recovery, purification, laboratory, treatment, maintenance, and research and development activities associated with plutonium operations at the site.

\subsubsection{Plutonium Production}

Plutonium production consisted of operations directly associated with the manufacturing of plutonium metal parts including casting, rolling, forming, machining, and assembly processes. Buildings 707 and 777 were the primary weapons components production facilities at the site after the construction of Building 707 in 1972. Building 707 was constructed after the 1969 fire in Building 776 which shut down foundry and machining operations in that building. ${ }^{\text {Pos3 }}$

The foundry in Building 707 cast molten plutonium into classified components, subassemblies, and assemblies. Other parts were manufactured by rolling, forming, and machining plutonium ingots also cast in the foundry. Components were assembled using a number of welding and joining techniques in Buildings 707 , 777, and 7715. Production support operations in Buildings 707 and 777 included a variety of inspection, calibration, measurement, weighing, leak testing, and cleaning activities to assure that the parts met stringent specifications. Rejected plutonium parts, scraps, and turnings were returned to be recast. Small pieces of metal, fines, and sweepings were typically burned to oxide and sent to Building 771 to be recovered. ${ }^{\text {P052. P053 }}$

Plutonium metal was placed in tantalum crucibles and funnels and was heated inside a furnace vessel during the casting process. The used tantalum was oxidized and then returned to the furnace gloveboxes for reuse. Tantalum items to be discarded were processed by heating the items in a "burn-box" to convert adhering plutonium metal to plutonium oxide. After cooling, the tantalum items were scraped or brushed off to remove the plutonium oxide. ${ }^{\mathrm{P} 024}$

Halogenated solvents were used in production operations to clean and degrease plutonium parts and metal. In addition, the solvents were used with cutting oils to cool plutonium parts during machining. Carbon tetrachloride, tetrachloroethene, 1,1,1-trichloroethane, 1,1,2-trichloro-1,2,2-trifluoroethane, trichloroethene, and methylene chloride were the primary solvents historically used during plutonium production. Tetrachloroethene was replaced by 1,1,1-trichloroethane for degreasing during the 1973 time frame. Several non-halogenated solvents were also used for cleaning and degreasing, primarily during efforts to reduce use of halogenated solvents. ${ }^{\text {023,P052 }}$ These solvents included isopropyl alcohol, ethanol, and acetone. $^{\text {P052, P067, P053 }}$ Building 777 housed the carbon tetrachloride and 1,1,1-trichloroethane systems that collected and filtered solvents generated during production operations. In addition to parts cleaning and degreasing, solvents were also used to clean plutonium operation glovebox lines. ${ }^{\text {P053 }}$

\subsubsection{Plutonium Recovery and Purification}

Several operations at the plant were responsible for either the purification of non-specification plutonium metal or the recovery of plutonium from production waste and residues. Building 771 housed 
operations that recovered plutonium from waste materials and other sources. ${ }^{\text {P053 }}$ Plutonium purification was performed primarily in Buildings 371, 771, 776, and 7715. ${ }^{\mathrm{P} 052}$

Recovery operations in Building 771 used acid to dissolve solid materials containing plutonium. The resulting solutions were processed by a series of ion exchange, precipitation, calcination, fluorination, and reduction operations to produce purified plutonium metal to be recycled back into production operations. Potassium hydroxide, potassium fluoride, hydrogen peroxide, and nitric, hydrochloric, and hydrofluoric acids were the primary reagents used for plutonium recovery operations. ${ }^{\mathrm{P} 053, \mathrm{P} 061, \mathrm{P} 067, \mathrm{P083}, \mathrm{U} 047}$

Plutonium metal from returned parts and metal from other DOE facilities was purified at Rocky Flats. Plutonium-241 decays to americium-241 which decreases the effectiveness of the plutonium parts. Plutonium parts were disassembled in Building 777 ${ }^{\text {P053,P113 }}$ Beginning in 1967, the molten salt extraction (MSE) process in Building 776 recovered americium from plutonium metal using sodium chloride, potassium chloride, and magnesium chloride. ${ }^{\mathrm{P} 53}$ Americium was separated from the MSE residue salts using potassium hydroxide precipitation followed by an ammonium thiocyanate anion exchange process. In 1975, the process changed to cation exchange followed by anion exchange (no thiocyanate) and then precipitation using oxalic acid. ${ }^{\mathrm{P} 113, \mathrm{U} 047}$ The process changed again the following year to the salt scrub process which used a magnesium/zinc or a magnesium/aluminum extractant. ${ }^{\mathrm{U} 047}$ The purified plutonium metal from MSE was either sent to the foundry in Building 707 or sent to the electrorefining (ER) process in Building 371 or Building 776 if the metal contained other impurities. ${ }^{\mathrm{P} 53, \mathrm{U} 047}$

Spray leaching (Building 771) and hydride leaching (Building 779) also used acids to remove plutonium surface contamination from uranium metal and other metals or beryllium contamination from plutonium metal. ${ }^{\mathrm{P} 661 \mathrm{P} 062}$ From 1970 to 1975 , heavy non-SS metal contaminated with plutonium above the EDL was processed by spray leaching in Building 771. Starting in 1975, hydride leaching in Building 779 was used to remove recoverable amounts of plutonium from heavy non-SS metal. ${ }^{\text {P024,P058 }}$ These processes used nitric, hydrochloric, sulfuric, and sulfamic acids. ${ }^{\mathrm{P} 033, \mathrm{P} 061, \mathrm{P} 062}$

\subsubsection{Laboratory}

Buildings 371,559 , and 771 housed the main analytical laboratories at the site. The laboratories' primary function was to provide analytical support to production activities in addition to supporting recovery, purification, and liquid waste treatment operations. Each of the laboratories used numerous acids, bases, solvents, and other chemical reagents.

Building 371 had an analytical laboratory and a chemical standards laboratory. The chemical standards laboratory prepared standards for various users and inspects standards that have been used in the field. The analytical laboratory analyzed samples from various operations on site. The types of analyses performed included: ${ }^{\text {P081 }}$

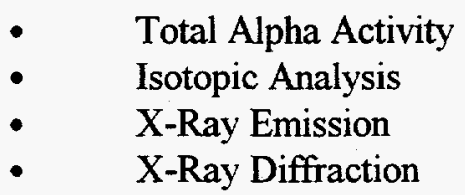

Building 559 housed the Plutonium Analytical Laboratory responsible for spectrochemical, chemical, and mass spectrometric analyses of samples from plutonium production operations. Uranium, Raschig rings, 
solutions, and commercial product and gas samples were also analyzed in the laboratory. Plutonium production samples, including metal and oxide, were prepared and subdivided for analysis in the sample cutting process. The types of analyses performed included: ${ }^{\mathrm{P} 07}$

$\begin{array}{ll}\text { - } & \text { Emission Spectroscopy } \\ \text { - } & \text { Atomic Absorption } \\ \text { - } & \text { Gallium Analysis } \\ \text { - } & \text { Plutonium Assay } \\ \text { - } & \text { Carbon Analysis } \\ \text { - } & \text { Raschium Analysis } \\ \end{array}$

$\begin{array}{ll}\text { - } & \text { Tritium Analyses } \\ \text { - } & \text { Nonroutine Chemical Analysis } \\ \text { - } & \text { Anion/Cation Solution Analysis } \\ \text { - } & \text { Thermal Analysis } \\ \text { - } & \text { Gas Analysis } \\ \text { - } & \text { Xpark Source Mass Spectroscopy Analysis }\end{array}$

Building 771 housed analytical and chemical standards laboratories. The chemical standards laboratory prepared control sample standards for the analytical laboratories in Buildings 371,559 , and 771 . $^{\mathrm{P}}{ }$ The analytical laboratory provided analyses in support of plutonium operations. The types of analyses performed included: ${ }^{061, P 067}$

$\begin{array}{ll}- & \text { X-Ray Fluorescence } \\ \text { - } & \text { Alpha/Gamma Scintillation } \\ \text { - } & \text { Atomic Absorption } \\ \text { Laser Fluorimetry }\end{array}$

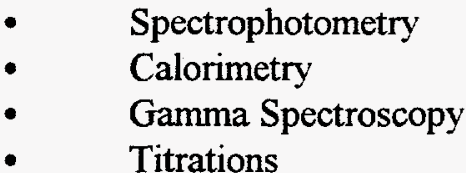

The laboratories used a variety of reagents and solvents including:

\begin{tabular}{|c|c|}
\hline & 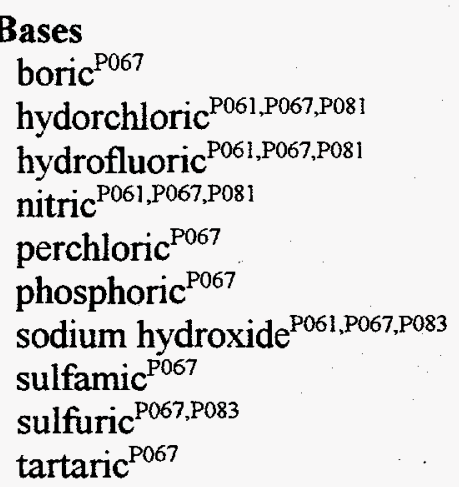 \\
\hline
\end{tabular}

\footnotetext{
Reagents

- $\quad$ ammonium hydroxide ${ }^{\mathrm{P} 083}$

- $\quad$ ammonium molybdate ${ }^{\mathrm{P} 067}$

- ceric ammonium nitrate ${ }^{\mathrm{P} 067}$

- $\quad$ ceric sulfate ${ }^{\mathrm{P} 083}$

- ferrous sulfamate ${ }^{\mathrm{P} 067}$

- ferric chloride ${ }^{\mathrm{P} 067}$

- potassium bromide ${ }^{\mathrm{P} 083}$

- potassium chloride $^{\mathrm{P} 067}$

- $\quad$ sodium fluoride ${ }^{\mathrm{P} 067}$
}

total ionic strength adjusting buffer (contains diaminocyclohexane tetraacetic acid) ${ }^{\mathrm{P} 061}$ trioctyl phosphene oxide ${ }^{\mathrm{P} 061 . \mathrm{P} 081}$

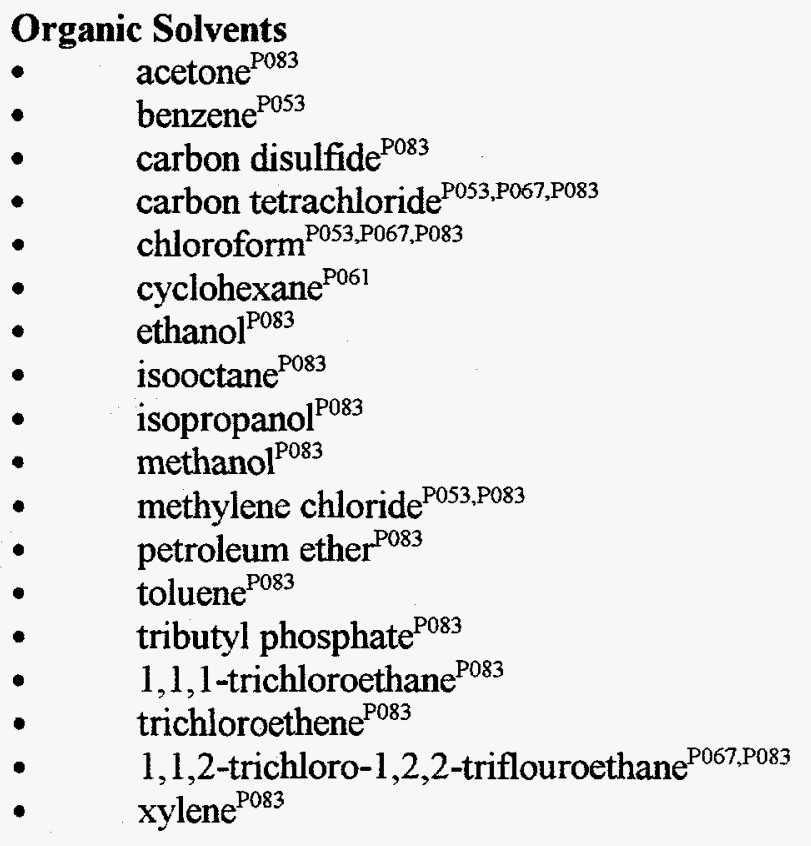




\subsubsection{Research and Development}

Research and Development (R\&D) included activities related to production, recovery, and purification as well as "special order" work. Building 779, which was built in 1965, housed much of the R\&D operations at the plant. Other areas at the plant supporting R\&D included Buildings $559,771,776,777$, and $881{ }^{\text {P053 }}$

The purpose of Building 779 was to gain more knowledge of the chemistry and metallurgy of plutonium and its interactions with other materials which might be used in plutonium operations. Other activities in Building 779 included developing improvements to the manufacturing process and finding new ways to recover plutonium and associated actinides. Another function was to develop a better understanding of the aging and shelf-life limitations of Rocky Flats products. Most of the materials used, and wastes generated, in this facility were the same as those in the production and recovery buildings, as much of the work conducted involved improvement of existing processes. ${ }^{\text {P053 }}$ However, processing of neptunium, curium, and cerium was also conducted. ${ }^{\mathrm{P} 053, \mathrm{U} 047}$

The plant conducted special order work for other facilities in the DOE complex, the DOD, or other federal departments or agencies. One example is the introduction of radionuclide tracers into pits destined for off-site test shots. This work took place in the 1960s and well into the 1970s. Materials such as americium240, plutonium-238, neptunium, curium, and cerium were blended in with the regular component materials for the purpose of studying performance of the different weapon components based on post-test distribution of the rare tracers. These tracer materials were kept separate from the regular production material streams, and special recovery operations in Building 771 specialized in recovering these more exotic materials. ${ }^{\mathrm{C}}{ }^{2}$, P053

From approximately 1959 to the mid-1970s, Rocky Flats was involved in "Project Plowshare." The mission of the program was to develop technology for using nuclear explosives for peaceful applications such as excavation and uncovering of deep mineral deposits. Materials used in the manufacturing of these components were the same as those used in the production buildings. ${ }^{\text {P053 }}$

\subsubsection{Waste Treatment}

Waste processing at Rocky Flats has included both liquid and solid process wastes. Liquid waste treatment operations have had relatively few process changes over the years. When Building 774 was built in 1952 , its primary purpose was to treat radioactive aqueous waste from Building 771 . Radionuclides were removed by precipitation, and the resulting slurry filtered. The solids removed from filters were combined with cement or other solidifying agents. The aqueous waste from this first stage goes through a second precipitation. $^{\text {P053 }}$ These processes use sodium hydroxide, ferric sulfate, magnesium sulfate, and calcium chloride. ${ }^{\text {P109 }}$ See Section 23.0, Solidified Aqueous Sludge Building 774, for a detailed description of these processes.

Around 1965, an evaporator was installed in Building 774 to treat liquids from the second stage treatment and from the solar ponds. The concentrate from the evaporator was introduced into a steam-heated double-drum drier which produced a salt waste. The Building 774 evaporator was taken out in 1979, and the liquids from the second stage treatment and solar ponds have since been transferred to Building 374 for additional treatment. ${ }^{\text {P053 }}$

Building 774 also processed organic liquid wastes. Plutonium-contaminated organic liquids were generated from plutonium machining. ${ }^{\text {P053 }}$ The spent organic liquid was filtered and then mixed with a 
solidifying agent. The process was later changed to a one step process in which the organic liquid was mixed with Envirostone (Gypsum cement) and allowed to set up. ${ }^{\text {P109 }}$ See Section 25.0, Solidified Organic Waste for a detailed description of these processes.

Treatment of solid transuranic wastes was conducted in Buildings 771 and 776 . Building 771 processed wastes containing plutonium above the EDL while Building 776 processed wastes below the EDL.

Operations in Building 771 processed wastes including Raschig rings, HEPA filters, and sludges from the filter plenum and from process piping. Filters were disassembled to remove plutonium-contaminated dust. Process piping removed from service was cut up and cleaned of built-up sludge. Sludge from the process piping and from the filter plenum was dissolved in nitric acid to recover plutonium. Until 1984, plutonium was recovered from Raschig rings by nitric acid leaching. ${ }^{\text {P061 }}$

Size reduction in Building 776 removed materials from drums and sorted them in an airlock vault. Materials such as light metals, filters, glass, combustibles, and Raschig rings were then put into containers with like materials. ${ }^{\mathrm{P} 67}$ From 1970 to 1973 , leaded gloves were packaged by each generating area. Acidcontaminated glovebox gloves may have been washed by hand prior to 1974; however, this has not been verified. ${ }^{\text {C99, } 1100, P 012}$ Beginning in 1974, acid-contaminated leaded gloves were sent to Building 776 where they were washed with hot water in a ball-mill prior to packaging. Later, nonacid-contaminated leaded gloves above the EDL were also washed in the ball-mill to remove radioactive surface contamination. ${ }^{\mathrm{P} 024}$ The ball-mill washing process was discontinued in 1989. ${ }^{\text {P052 }}$ However, any unwashed acid-contaminated leaded gloves generated since 1989 were assigned IDC 341 (not in INEEL inventory). ${ }^{\text {P024,P067 }}$

Advanced size reduction operations in Building 776 disassembled or cut plutonium-contaminated gloveboxes and miscellaneous large equipment into sizes that could be packaged in approved containers. ${ }^{\mathrm{P} 110}$

The fluidized-bed incinerator in Building 776 received low-level plutonium-contaminated combustible solid and liquid wastes. ${ }^{\mathrm{P} 067}$ Building 771 also housed an incinerator for processing combustible wastes. ${ }^{\text {P061,U047 }}$ See Section 14.0, Incinerator Waste, for a detailed description of the incineration processes.

\subsubsection{Maintenance}

Routine and nonroutine maintenance at Rocky Flats included utilities, strip-out operations, and other general maintenance and cleanup activities.

Utility systems include HVAC systems, fume scrubbers, and process vacuum systems. The HVAC systems contain air supply units for filtering incoming air and plenums for filtering exhaust air. Scrubbers housed in Buildings 371, 559, 771, and 779 used potassium or sodium hydroxide to neutralize acid fumes from various process off-gas streams and glovebox exhaust streams. Process vacuum systems provide an absolute pressure at a vacuum header which serves as a means to transfer fluids on demand by valving arrangements. ${ }^{\text {P061,P067 }}$

Another maintenance activity that may have generated lead-containing wastes was the strip-out of glovebox lines, process piping, valves, and associated systems. Strip-out activities were performed when a glovebox line was scheduled to be replaced or during renovation. Solvents such as trichloroethene or 1,1,1trichloroethane may have been used during this type of operation for decontamination. ${ }^{\mathrm{P} 67, \mathrm{P} 108}$ 
Leaded containing wastes may have also originated from cleanup of the 1969 fire which spread through combustible materials in several hundred inter-connected gloveboxes in Building 776. Another incident that may have generated lead containing wastes occurred when tritium-contaminated plutonium was processed from April 9, 1973 through April 25, 1973 in Building 779 causing a tritium release to the atmosphere and elevated tritium levels in surface waters, process wastes, equipment, gloveboxes, and exhaust plenums. ${ }^{\text {P024,P053 }}$

\subsection{Waste Packaging}

Heavy non-SS metal (IDC 320) and lead (IDC 321) were placed directly into a lined 55-gallon drum or double-bagged out of the glovebox line. After removal from the glovebox, the waste was placed in the drum or in Fibre-Paks which were then placed in the drum. Prior to packaging, sharp edges were taped to prevent puncturing of the liners. ${ }^{\mathrm{P} 12, \mathrm{P} 015, \mathrm{P} 024}$

Leaded drybox gloves (IDC 339) were placed directly into a lined 55-gallon drum or double-bagged out of the glovebox line in two polyvinyl chloride or polyethylene bags. ${ }^{\mathrm{P} 12, \mathrm{P} 015, \mathrm{P} 021, \mathrm{P} 024}$

Depending on waste packaging requirements at the time, several combinations of bags and liners were used to prepare 55-gallon drums for shipment. Use of the 90-mil rigid polyethylene liner began in $1972 .^{\mathrm{P} 024}$ The rigid liner was placed in each drum and lined with one polyethylene round bottom drum liner or one or two

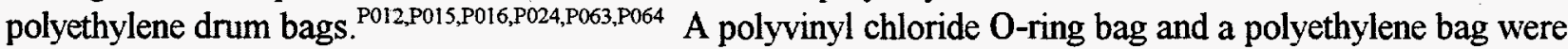
used if the drum was attached to the glovebox. ${ }^{\mathrm{P} 016} \mathrm{~A}$ fiberboard liner and discs may also have been used between the waste packages and the drum liners. ${ }^{\mathrm{P} 012, \mathrm{P016,P063,P064}}$ Lead drum liners placed between the drum and rigid liner were also used in some instances. ${ }^{\mathrm{P} 24}$ When a drum was full, the drum liners were twisted and taped closed, the lid was secured with a bolted ring, and a tamper indicating device was attached to the drum. ${ }^{\mathrm{P} 12, \mathrm{P} 016, \mathrm{P} 024}$

After drums were inspected, one to two quarts of absorbent material (Oil-Dri) was placed on the top of the outer, sealed polyethylene drum bag. This procedure changed in February 1982 when vermiculite was used to fill the space between the outer, sealed polyethylene drum bag and the top of the 90-mil rigid liner. The quantity of vermiculite varied from 3-12 pounds according to the amount of waste contained in each drum. ${ }^{\mathrm{P} 024}$

Waste management and inspection protocol allowed containers of wastes to contain up to 10 percent of another IDC other than that assigned to the container. ${ }^{\mathrm{P} 16}$ Visual inspection of drums of leaded gloves identified surgical gloves; rags; paper; cloth towels, booties, and glove liners; neoprene rubber sheets and window gaskets; a polyethylene bottle and skirting. ${ }^{\text {P015,U015 }}$ Visual examination of one heavy metal drum found cloth towels. $^{\text {volt }}$

\subsection{Waste Characterization}

Lead-containing wastes are characterized based on knowledge of the material, knowledge of the processes generating the waste, RTR review of the waste, visual inspection, and headspace gas analysis. This section provides a RCRA hazardous waste determination for lead-containing wastes as well as radionuclide contaminants and potential complexing agents contained in the waste. This waste contains at least 50 percent (by volume) materials that meet the EPA LDR criteria for classification as debris, and is therefore a heterogeneous waste. ${ }^{\mathrm{P} 141}$ 


\subsubsection{Hazardous Waste Determination}

Some heavy metal waste is not regulated as a hazardous waste as defined in 40 CFR 261.7 (empty container). Leaded gloves generated prior to 1974 may exhibit the characteristic of reactivity due to the reaction with nitric acid at elevated temperatures. Lead-containing wastes also exhibit the characteristic of toxicity for lead. There is no evidence that lead-containing wastes exhibit any other characteristic of hazardous waste. $^{\text {C101 }}$ EPA Hazardous Waste Numbers applicable to some or all of the lead-containing waste group are presented by IDC in Table 15-2. ${ }^{\text {P127 }}$ These conclusions are supported by the evaluation in Sections 15.3.1.1 and 15.3.1.2.

Table 15-2. Characterization of Lead-Containing Wastes.

\begin{tabular}{clc}
\hline IDC & \multicolumn{1}{c}{ Title } & EPA Hazardous Waste Numbers \\
\hline 320 & Heavy Non-SS Metal & D008 \\
321 & Lead & D008 \\
339 & Leaded Drybox Gloves & D003 and D008 \\
\hline
\end{tabular}

\subsubsection{Characteristic Waste}

The materials in this waste group may exhibit a characteristic of hazardous waste as defined in 40 CFR 261, Subpart C as a reactive waste (40 CFR 261.23), and as a toxic waste (40 CFR 261.24). The materials do not exhibit the characteristic of ignitability (40 CFR 261.21) or corrosivity (40 CFR 261.22).

Ignitability: The materials in this waste group do not meet the definition of ignitability as defined in

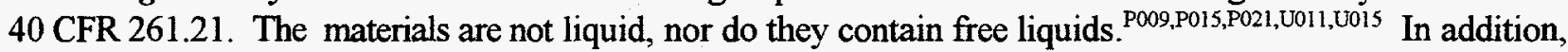
absorbents were added to wastes having the potential of generating free liquids (i.e. leaded gloves which had been washed). These materials are not capable of causing fire through friction, absorption of moisture, or spontaneous chemical change. ${ }^{\mathrm{PO} 2 \mathrm{P} 016 \mathrm{P} \mathrm{P} 24}$ The materials are not a compressed gas, nor do the containers contain compressed gases. ${ }^{\mathrm{P} 009, \mathrm{P} 015, \mathrm{P} 021, \mathrm{U} 011, \mathrm{U} 015}$ The materials are not DOT oxidizers as defined in 49 CFR 173. The materials in this waste group are therefore not ignitable wastes (D001).

Corrosivity: The materials in this waste group do not meet the definition of corrosivity as defined in

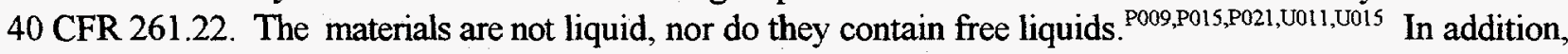
absorbents were added to wastes having the potential of generating free liquids (i.e. leaded gloves which had been washed). The materials in this waste group are therefore not corrosive wastes (D002).

Reactivity: Leaded drybox gloves and aprons (IDC 339) generated before 1974 may meet the definition of reactivity as defined in 40 CFR 261.23 due to explosive reaction with nitric acid at elevated temperatures. Leaded gloves and aprons (IDC 339) generated after 1974, heavy non-SS metal (IDC 320), and lead (IDC 321) do not meet the definition of reactivity. The materials in this waste group are stable and will not undergo violent chemical change. The materials will not react violently with water, form potentially explosive mixtures with water, or generate toxic gases, vapors, or fumes when mixed with water. The materials do not contain cyanides or sulfides. The materials are not forbidden explosives or Division 1.1, 1.2, or 1.3 (Class A or B) explosives as defined in 49 CFR 173. ${ }^{\text {P012,P015,P024 }}$ Explosives were not handled or used around radioactive 
material. However, some leaded drybox gloves and aprons were generated in an environment where they were exposed to nitric acid. Studies have shown that lead-impregnated neoprene (drybox gloves and aprons) reacts readily with nitric acid at elevated temperatures $\left(50-100^{\circ} \mathrm{C}\right)$ to form lead nitrate and nitro-organic compounds. The mixture of the lead nitrate and organics decomposes with a violent exothermic reaction under the proper conditions. ${ }^{\text {C096,P120 }}$ Prior to 1986 , acid- and nonacid-contaminated leaded drybox gloves and aprons were accumulated together as IDC 339. Beginning in 1974, leaded gloves and aprons were washed to remove the acid; however, it is uncertain whether they were washed prior to $1974 .{ }^{\mathrm{C} 099, \mathrm{Cl} 100}$ Therefore, EPA Hazardous Waste Number D003 is applicable to leaded drybox gloves and aprons (IDC 339) generated before 1974.

Toxicity: The materials in this waste group meet the definition of toxicity as defined in 40 CFR 261.24. The toxicity characteristic contaminants fall into one of two categories: metals and organics. Organic compounds include halogenated- and nonhalogenated-solvents, pesticides, herbicides, and other toxic compounds. This waste group may exhibit the characteristic of toxicity for lead metal.

IDC 321 was created specifically for lead waste. Prior to 1987, heavy non-SS (IDC 320) drums contained lead items. ${ }^{\mathrm{PO} 15}$ Analytical data indicate that unused leaded gloves (IDC 339) subjected to the TCLP test, leach lead at levels above the regulatory limit. Analytical data have not been obtained for used leaded gloves. ${ }^{\text {P016, } 095}$ Therefore, EPA Hazardous Waste Number D008 is assigned to the lead-containing waste group.

There is no documentation indicating the presence or use of pesticides or herbicides in the areas or processes generating lead-containing wastes. Therefore, this waste group does not exhibit the characteristic of toxicity due to pesticides or herbicides (D012-D017).

Carbon tetrachloride, tetrachloroethene, and trichloroethene were used for cleaning and degreasing. Chloroform was used in laboratory analysis. During process operations, lead-containing wastes may have come in contact with these organic compounds. Headspace gas analysis detected carbon tetrachloride, chloroform, and 1,1-dichloroethene in drums of leaded gloves (IDC 339) ${ }^{\text {P033,U030 }}$ However, because the leadcontaining wastes are not porous materials, there are likely only trace quantities of these organic compounds remaining on the wastes. Therefore, this waste group should not exhibit the characteristic of toxicity due to organic compounds (D018-D043).

\subsubsection{Listed Hazardous Waste}

The material in this waste group is not, or was not mixed with, a waste listed in 40 CFR 261, Subpart $D$ as a hazardous waste from non-specific sources (40 CFR 261.31), a hazardous waste from specific sources (40 CFR 261.32), or a discarded commercial chemical product, an off-specification species, a container residue, or a spill residue thereof (40 CFR 261.33).

Tetrachloroethene, trichloroethene, methylene chloride, 1,1,1-trichloroethane, carbon tetrachloride, and 1,1,2-trichloro-1,2,2-trifluoroethane were used in production, laboratory, and maintenance operations. Acetone, methanol, xylene, benzene, carbon disulfide, and toluene were used in laboratory operations. During process operations, lead-containing wastes may have come in contact with these compounds. However, some of the heavy metal waste consists of crucibles which, if empty, are not regulated as hazardous wastes as defined in 40 CFR 261.7. Leaded gloves in a glovebox are part of a container-like apparatus and, when discarded, are not a hazardous waste simply because solvents or other hazardous materials were used in the glovebox. Also, leaded gloves and heavy metal wastes such as labware that were wiped down with solvents for decontamination 
purposes are not regulated as listed hazardous wastes. This was clarified by the Colorado Department of Public Health and Environment. ${ }^{\mathrm{C} 93}$ Therefore, this waste group is not a F001-, F002-, F003-, or F005-listed hazardous waste.

There is no documentation indicating the presence or use of F004-listed solvents in the areas or processes generating lead-containing wastes. Therefore, this waste group is not a F004-listed hazardous waste.

Although this waste group is not a F-listed hazardous waste, headspace analysis performed on samples of heavy non-SS metal (IDC 320) and leaded gloves (IDC 339) obtained at INEEL confirms the presence of organic solvents. The detected compounds in which the 90 percent $\mathrm{UCL}$ is above the PRQL are provided. ${ }^{\mathrm{P} 33}$

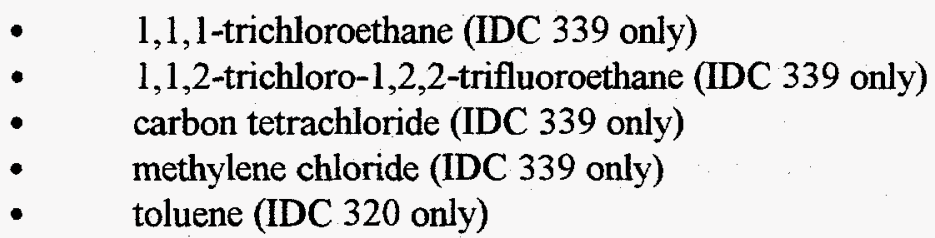

Additional F-listed solvents were detected in headspace samples of lead-containing wastes (IDCs 320, 321, and 339) obtained Rocky Flats. The detected F-listed compounds in which the 90 percent UCL is above the PRQL are also provided. ${ }^{\mathrm{U} 030}$

- 1,1,1-trichloroethane (IDCs 320 and 339)

- $\quad$ carbon tetrachloride (IDCs 320 and 339)

- $\quad$ toluene (IDC 339 only)

The material in this waste group is not a hazardous waste from specific sources since it was not generated from any of the processes listed in 40 CFR 261.32. The material in this waste group is therefore not a K-listed hazardous waste.

The material in this waste group is not a discarded commercial chemical product, an off-specification species, a container residue, or a spill residue thereof (40 CFR 261.33). The material in this waste group is therefore not a P- or U-listed hazardous waste.

\subsubsection{Radionuclides}

This section identifies the radioisotopes potentially contained in the waste, as well as the chemical form of radionuclide contaminants and radioassay interferences. The primary radionuclides processed at Rocky Flats included weapons-grade plutonium, americium-241, enriched uranium, and depleted uranium. The isotopic compositions of weapons-grade plutonium, enriched uranium, and depleted uranium are specified in Section 3.0. Wastes from some of the processes described below may not be contained in the inventory based on the assigned prefixes. However, as explained in Section 15.3.2.6, it is assumed that repackaged drums could contain waste generated from any process.

\subsubsection{Plutonium Production}

Radionuclide contamination in waste from Building 707 will primarily consist of weapons-grade

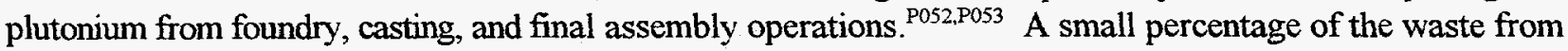


Building 707 may also contain americium-240, neptunium-237, and plutonium-238 from blending of these isotopes with weapons-grade plutonium for diagnostic tracers. ${ }^{\text {C171,C174,C184,C185,P053,P164,P167 }}$

Building 777 performed disassembly of site-return parts and fabrication operations including machining, briquetting, assembly, and production support processes (prefixes 04, 23, and 24). ${ }^{\mathrm{C184,P052,U059,P079}}$ Wastes from fabrication operations will be contaminated with weapons-grade plutonium and enriched uranium. Wastes generated by disassembly operations will be contaminated with site-return plutonium (higher americium-241 decay product) and enriched uranium. ${ }^{\text {C184,P079 }}$ Tritium may also be present from disassembly operations. ${ }^{\text {P053 }}$

Buildings 707 and 777 handled actinides in metal or oxide form only. ${ }^{\text {P060,P079 }}$ The actinide metals will likely have partially or completely oxidized because of the reaction with dry air, and some could possibly have formed a hydroxide layer from reaction with moist air. Radioassay interferences may include beryllium from Part V metal fabrication in Building 707, and calcium fluoride which was sprayed onto graphite molds in Building 707 prior to casting. ${ }^{\mathrm{C} 184, \mathrm{P} 060}$ Other interfering waste contaminants include aluminum, beryllium, and stainless steel (chromium) which were machined in Building 777 P079 $^{\text {Par }}$

\subsubsection{Plutonium Recovery and Purification}

Waste from recovery operations in Building 371 will contain weapons-grade plutonium primarily from electrorefining. ${ }^{\mathrm{C} 184, \mathrm{P} 067}$ A limited amount of the waste could also have been generated from aqueous recovery operations which only ran for a short time in 1982. Aqueous recovery operations were designed for recovering and purifying weapons-grade plutonium. ${ }^{\mathrm{C} 184, \mathrm{P} 164}$

The feed materials to the recovery and purification processes (prefixes 01 and 02 ) in Building 771 were impure plutonium residues which were processed to produce plutonium metal for use in the foundry and, therefore, wastes generated will be contaminated primarily with weapons-grade plutonium. ${ }^{\text {P052,P163,0059 }}$ Radionuclides from aqueous recovery operations will vary widely in chemical form depending on the specific process the waste originated, and because the majority of the aqueous processes were performed within one large MBA (prefixes 01 and 02), the specific process can not be determined. The different actinide forms are plutonium nitrate, plutonium chloride, plutonium peroxide, plutonium dioxide, plutonium tetrafluoride, and plutonium metal. Radioassay interferences may include aluminum nitrate from the dissolution process and beryllium which was removed during Part V leach. ${ }^{\text {P163 }}$

Wastes from the americium recovery glovebox lines (prefix 06) in Building 771, used for extraction of americium from site-return plutonium, will contain a significant amount of americium-241. C184,P053,P164,U059 The americium was in a chloride, hydroxide, nitrate, oxalate, and oxide chemical form during different steps of the process. Prior to 1975 , ammonium thiocyanate was also used. ${ }^{\text {Pos3 }}$

The Oralloy leach process (prefix 74) in Building 771 chemically separated plutonium surface contamination from enriched uranium hemishells using nitric acid. The chemical form of the radionuclides will therefore be plutonium nitrate and uranyl nitrate. ${ }^{\mathrm{Cl} 84, \mathrm{P} 061, \mathrm{P} 163, \mathrm{U} 059}$

Site-return metal and other non-specification plutonium were processed by pyrochemical operations in Building 776 (prefix 03) to produce plutonium for use in the foundry. ${ }^{\mathrm{Cl} 84, \mathrm{P} 053, \mathrm{U} 059}$ The molten salt extraction process removed americium-241 from site-return and other non-specification plutonium. Electrorefining was used to purify plutonium metal that did not meet foundry specifications. Since metal was the feed and product 
to the MSE and electrorefining processes, wastes generated from these processes will be contaminated with actinide metals which now will probably have formed an oxide or hydroxide layer from reaction with dry and moist air. Direct oxide reduction was developed to convert plutonium dioxide to plutonium metal. ${ }^{\text {P163,P175 }}$ MSE residue salts, which contain actinide chlorides, were the feed to the salt scrub process. Metal was the product of this process as well, so the radionuclide contaminants could be in a metal, oxide, and/or hydroxide form. Radioassay interferences may include chloride salts (i.e., sodium, potassium, magnesium, calcium, and zinc). ${ }^{\text {P163 }}$

Hydride operations in Building 779 (prefix 55) recovered plutonium from various substrates by reacting plutonium metal with gaseous hydrogen in an argon-inerted glovebox. ${ }^{\text {P052,U059,P062,P163 Hydriding }}$ produced plutonium metal for use in the foundry or non-specification feed to pyrochemical operations, in addition to plutonium oxides sent for aqueous recovery. ${ }^{\mathrm{C} 184, \mathrm{P} 062}$ The hydriding process formed plutonium hydride which was converted to plutonium dioxide by oxidizing the material in an air atmosphere. ${ }^{\text {P163 }}$

\subsubsection{Laboratory}

The analytical laboratory in Building 371 (prefix 71) provided analytical support for process control and performed analyses on feed materials and residues from recovery operations in Building 371 . $^{\text {P053,U059,P081 }}$ The laboratory also analyzed samples from various operations at the site, but primarily from Building $374{ }^{\mathrm{P} 081}$ The Building 371 chemical standards laboratory prepared standards for various users and inspected standards that were used throughout plant site. ${ }^{\mathrm{P} 53}$ Wastes from these laboratories will be contaminated with weaponsgrade plutonium and enriched and depleted uranium.

The Building 559 analytical laboratory (prefix 29) performed a variety of analyses, including plutonium, enriched and depleted uranium, americium, neptunium, and tritium content. ${ }^{\text {P053,P067,U059,U073 The }}$ primary mission of this laboratory was analysis of site-return and feed materials, in addition to recovery, purification, and foundry products. ${ }^{\text {P053 }}$

The Building 771 analytical laboratory (prefix 37) received samples from recovery operations in the building as well as from the foundry. ${ }^{\mathrm{P} 667,059}$ The samples included plutonium metal turnings, plutonium oxide, acidic plutonium solutions, and various process residues. ${ }^{\mathrm{P} 061}$ In addition, the analytical laboratory analyzed samples from R\&D laboratories in Buildings 771 and 779 (see Section 15.3.2.4). ${ }^{\mathrm{P} 67, \mathrm{P} 061}$ The chemical standards laboratory (prefix 38) prepared uranium, plutonium, and americium nitrates used as control standards for the Buildings 371, 559, and 771 analytical laboratories. ${ }^{\text {P067,P061 The laboratory also produced }}$ nondestructive assay standards used at drum counters and fluoride standards for chemical operations. ${ }^{\text {P061 }}$

The metallography laboratory (prefix 21) in Building 777 prepared and examined metallographic specimens in support of R\&D operations (plutonium metallography, nuclear and non-nuclear joining, quality engineering, and product physical chemistry) and, therefore, may contain any of the radionuclides used during R\&D activities (see Section 15.3.2.4). ${ }^{\text {C184,U059,P079 }}$ The Building 777 tritium surveillance laboratory analyzed solid, liquid, and gas samples from throughout the plant site for tritium content. ${ }^{\text {U078 }}$

Because the laboratories supported all phases of weapons production, the chemical form of the radionuclide contaminants and radioassay interferences will vary widely depending on the type of sample analyzed. 


\subsubsection{Research and Development}

Projects using transuranic radionuclides were done in Buildings $771,776,777,779$, and 881 . Most of the documentation pertaining to R\&D activities does not specify locations in which the work was performed, and unless otherwise noted, it will be assumed that any of the radioisotopes could have been handled in the $R \& D$ areas of any of these buildings. In addition to weapons-grade plutonium, americium-241, and enriched and depleted uranium, the following radioisotopes were processed during R\&D activities: ${ }^{.134, C 137, C 185, P 053, P 164, P 167, P 189, P 190, P 194, P 195, P 198, P 200, U 064 ~}$

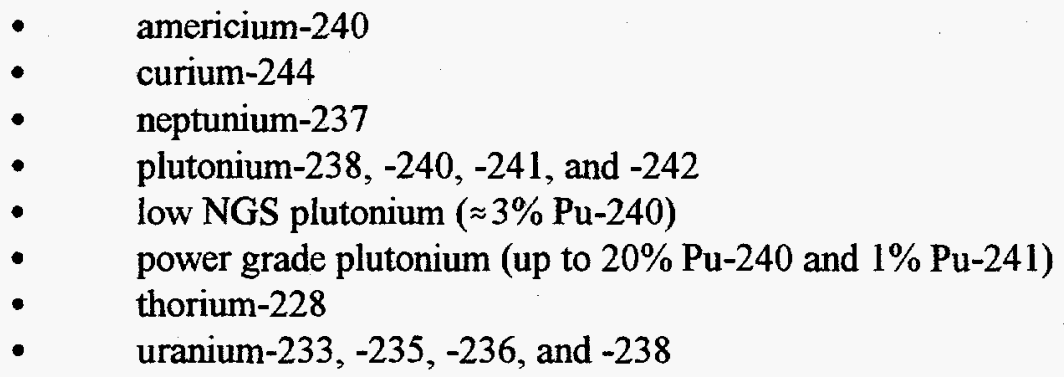

A summary of the projects and time periods that these and other radionuclides were used is presented in Section 3.0.

In Building 771, special recovery anion exchange (prefix 45) separated plutonium from other materials that were not suitable for the regular recovery processes. ${ }^{\text {C154.PO52P061 }}$ Chemical technology (prefix 42) conducted aqueous R\&D activities while plutonium metallurgy operations (prefix 78) performed alloy preparation, heat treating, rolling, metal and metallurgical testing, and cutting for R\&D. ${ }^{\text {C184,U059,P061 }}$ These processes may have used numerous radioisotopes.

A pilot-scale fluidized-bed incinerator (prefix 75) was developed in Building 776 to treat low-level waste. ${ }^{\mathrm{C} 184, \mathrm{U} 059}$ The waste fed to the incinerator was contaminated with low levels of plutonium. ${ }^{\mathrm{P} 024}$

The coatings laboratory (prefix 16) in Building 777 developed various substrates to be coated with uranium or plutonium, including stainless steel, copper, chromium, aluminum, and beryllium ${ }^{\text {P052,U059,P079 }}$ This research and development facility supported production processes. ${ }^{\text {P052.P079 }}$ The special weapons area (prefix 66 ) in Building 777 was a research and development facility which assembled war reserve and other specially fabricated parts. ${ }^{\text {U059,P079 }}$ The process was also responsible for disassembly of surveillance (tracer) parts and drilling of parts for use in analytical testing. ${ }^{\text {P079 }}$

Pyrochemical technology (prefixes 10 and 52) in Building 779 involved the extraction and recovery of plutonium and americium in support of production operations. ${ }^{\text {P067.U059,P062 }}$ These processes included direct oxide reduction, molten salt extraction, electrorefining, salt scrub for MSE, salt scrub for electrorefining, pyrochemical salt recycle, anode alloy, and pyroredox. ${ }^{\mathrm{Cl} 22 \mathrm{P062}}$ Most of the materials used in Building 779 were the same as those in the weapons-production areas and, therefore, will be contaminated primarily with weapons-grade plutonium and enriched uranium ${ }^{\text {P053 }}$ However, other R\&D activities in the building may have used a variety of other radionuclides. ${ }^{\mathrm{C} 171, \mathrm{C} 184}$ 


\subsubsection{Liquid Waste Treatment}

Aqueous waste treatment operations in Buildings 374 and 774 received wastes from throughout plant site, including processes that generated low-level and nonradioactive liquid wastes. For this reason, wastes generated during treatment operations may contain any of the radioisotopes used at the plant. The most common radioactive materials handled were weapons-grade plutonium, americium-241, enriched uranium, and depleted uranium. Other radionuclides may also be found in the waste streams from R\&D, analytical, and special order work. ${ }^{\mathrm{P} 164}$ Radionuclide contaminants are removed from the aqueous wastes by precipitation using sodium hydroxide and, therefore, will be primarily in the form of hydroxides. ${ }^{\mathrm{P} 163}$ Radioassay interferences may include magnesium sulfate and calcium chloride reagents used in the process. ${ }^{\text {P106,P163 }}$

Building 774 also processed organic liquid wastes. Organic wastes are comprised of a variety of oils and solvents. Most of the oils were from spent lathe coolant used in the plutonium machining area and lubricating oils used in machines throughout the plant. ${ }^{\mathrm{P} 164}$ The majority of the transuranic organic liquids were oils and solvents from plutonium machining and degreasing operations in Buildings 707 and 777 and, therefore, will be contaminated with actinide metals and oxides. ${ }^{\mathrm{P} 252}$ A more detailed discussion of the wastes treated in these buildings is provided in Sections 22.0 through 25.0 .

\subsubsection{Size Reduction/Repackaging/Solid Waste Treatment}

The Size Reduction Vault (SRV) in Building 776 conducted solid waste treatment, repackaging, and size reduction operations. The SRV was divided into two sides. One side was the airlock (prefixes 25, 40, 41, and 57) where repackaging was done. The other side (prefixes 19 and 26) was a drybox atmosphere where size

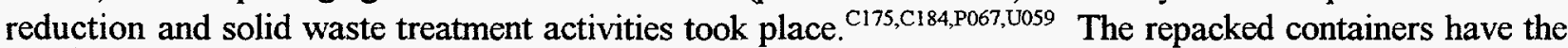
potential to contain contaminated materials from any of the processes within the transuranic waste generating

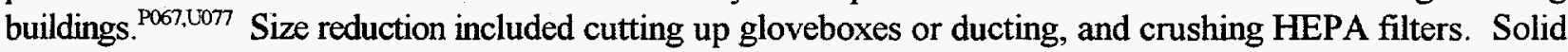
waste treatment activities included washing leaded gloves and scrap metal with hot water in a ball-mill washer to recover plutonium. ${ }^{\mathrm{C} 053, \mathrm{P} 067, \mathrm{P} 164}$

The full-scale fluidized bed incinerator (prefix 50) was designed to treat low-level waste. However, the waste generated from this incinerator is not likely transuranic. ${ }^{\mathrm{C} 184, \mathrm{P} 052}$

\subsubsection{Complexing Agents}

Because complexing agents can aid in the transport of transuranic radionuclides from the waste after disposal, the waste was assessed for potential complexing agents. This information may also be added to the chemical compatibility studies since limited information was available on these chemicals in the past.

EDTA represents a group of chelating compounds, such as ethenediaminetetraacetic acid, with similar molecular structures found in many soaps and detergents. Versene (a trade name for EDTA) and citric acid are known constituents of $\mathrm{KW}$ decontamination detergent. ${ }^{\mathrm{P} 024, \mathrm{P} 068} \mathrm{KW}$ was used during a variety of decontamination activities at the plant. A buffer solution (TISAB) containing diaminocyclohexane tetraacetic acid was used during specific ion electrode analysis in Building 559. ${ }^{\mathrm{P} 76}$ Oxalic acid and tetraphosphoric acid were used to etch plutonium and other metals. ${ }^{\text {P062,P079,0043 }}$ Oxalic acid was also used for americium recovery. ${ }^{\text {P113 }}$ Lead-containing wastes may be contaminated with trace quantities of these complexing agents. 


\subsection{LIGHT METAL}

This waste group consists of light metal generated by the production, recovery, laboratory, treatment, maintenance, and research and development activities associated with plutonium operations. Light metal includes copper and other metals and metal alloys below copper on the periodic table (heavy metals are discussed in Section 15.0, Lead-Containing Waste). The waste was generated in Buildings 371, 374, 559, 707, $771,774,776,777$, and $779 .^{\text {P012,P052 }}$ Historic IDC descriptions and dates of generation for the INEEL accessible storage inventory are presented by IDC in Table $16-1 .^{\mathrm{P} 127}$

Table 16-1. Light Metal Waste in the Accessible Storage Inventory.

\begin{tabular}{|c|c|c|}
\hline IDC & Title & Dates of Generation \\
\hline 480 & $\begin{array}{l}\text { Unleached Light Non-SS Metal } \\
\text { Light Non-SS Scrap Metal, Not Prepared for Leaching }^{\mathrm{P} 014} \\
\text { Metal Scrap (Non-SS) } \\
\text { Light Non-SS Metal, Not Prepared for Leach }^{\mathrm{C} 063} \\
\text { Non-Leached Light Metal }^{\mathrm{P} 063} \\
\text { Light Metal }^{\mathrm{P} 001}\end{array}$ & March 1972-July 1989 \\
\hline 481 & $\begin{array}{l}\text { Leached Non-SS Metal }^{\mathrm{P} 024} \\
\text { Light Non-SS Scrap Metal Prepared for Leaching }^{\mathrm{P} 014} \\
\text { Metal Leached (Non-SS) } \\
\text { Light Non-SS Metal Prepared for Leach } \\
\text { Leached Light Metal }^{\mathrm{C} 063}\end{array}$ & December 1972-October 1984 \\
\hline
\end{tabular}

Item Description Code 480, Light Metal: This waste consists of light metal generated by the plutonium production, recovery, treatment, laboratory, and maintenance operations in Buildings $371,374,559$, $707,771,774,776,777$, and 779. ${ }^{\text {P012.P052 }}$ Light metal includes iron, copper, aluminum, brass, bronze, galvanized metal, stainless steel, carbon steel, and other metal alloys. The metals consist of mechanical and electrical parts, tools, containers, scrap metals, piping, wire, cable, gauges, valves, foil, planchets, and a variety of other metal items. ${ }^{\text {P052 }}$ The metals may be contaminated with residual amounts of solvents, acids, bases, and other reagents used in the processes where they were generated. ${ }^{P 083}$ Solvent-contaminated metals were not sorted from nonsolvent-contaminated metals. ${ }^{\text {P114 }}$ Beryllium, pyrophoric metals, and heavy non-SS metal are excluded from IDC $480{ }^{\mathrm{P} 032}$ The waste may also contain limited amounts of combustible wastes. ${ }^{\mathrm{P} 024}$

Item Description Code 481, Leached Light Metal: This waste consists of light metal that was washed with hot water in Building 776 to remove radioactive surface contamination. Leached light metal consists of the same metals in IDC 480 and originated from the same buildings and processes as IDC $480 .^{\mathrm{P} 014, \mathrm{P} 024}$

\subsection{Waste Generation}

Light metal was generated by production, recovery, purification, laboratory, treatment, maintenance, and research and development activities associated with plutonium operations at the site. 


\subsubsection{Plutonium Production}

Plutonium production consisted of operations directly associated with the manufacturing of plutonium metal parts including casting, rolling, forming, machining, and assembly processes. Buildings 707 and 777 were the primary weapons components production facilities at the site after the construction of Building 707 in 1972. Building 707 was constructed after the 1969 fire in Building 776 which shut down foundry and machining operations in that building. ${ }^{\mathrm{P} 53}$

The foundry in Building 707 cast molten plutonium into classified components, subassemblies, and assemblies. Other parts were manufactured by rolling, forming, and machining plutonium ingots also cast in the foundry. Components were assembled using a number of welding and joining techniques in Buildings 707, 777, and 779. Production support operations in Buildings 707 and 777 included a variety of inspection, calibration, measurement, weighing, leak testing, and cleaning activities to assure that the parts met stringent specifications. Rejected plutonium parts, scraps, and turnings were returned to be recast. Small pieces of metal, fines, and sweepings were typically burned to oxide and sent to Building 771 to be recovered. ${ }^{\text {P052, P053 }}$ Typical light metal generated included chips, turnings, tools, and molds. ${ }^{\mathrm{P} 03}$

Halogenated solvents were used in production operations to clean and degrease plutonium parts and metal. In addition, the solvents were used with cutting oils to cool plutonium parts during machining. Carbon tetrachloride, tetrachloroethene, 1,1,1-trichloroethane, 1,1,2-trichloro-1,2,2-trifluoroethane, trichloroethene, and methylene chloride were the primary solvents historically used during plutonium production. Tetrachloroethene was replaced by 1,1,1-trichloroethane for degreasing during the 1973 time frame ${ }^{\mathrm{P} 023, \mathrm{P} 052}$ Several non-halogenated solvents were also used for cleaning and degreasing, primarily during efforts to reduce use of halogenated solvents. These solvents included isopropyl alcohol, ethanol, and acetone. ${ }^{\text {P052, P067, P053 }}$ Building 777 housed the carbon tetrachloride and 1,1,1-trichloroethane systems that collected and filtered solvents generated during production operations. In addition to parts cleaning and degreasing, solvents were also used to clean plutonium operation glovebox lines. ${ }^{\text {P053 }}$

\subsubsection{Plutonium Recovery and Purification}

Several operations at the plant were responsible for either the purification of non-specification plutonium metal or the recovery of plutonium from production waste and residues. Building 771 housed operations that recovered plutonium from waste materials and other sources. ${ }^{\text {P053 }}$ Plutonium purification was performed primarily in Buildings $371,771,776$, and $779 .{ }^{\text {P052 }}$

Recovery operations in Building 771 used acid to dissolve solid materials containing plutonium. The resulting solutions were processed by a series of ion exchange, precipitation, calcination, fluorination, and reduction operations to produce purified plutonium metal to be recycled back into production operations. ${ }^{\text {POS3 }}$ During normal glovebox operations, metal tools that were worn or broken were disposed of as light metal waste. ${ }^{\text {P083 }}$ Potassium hydroxide, potassium fluoride, hydrogen peroxide, and nitric, hydrochloric, and hydrofluoric acids were the primary reagents used for plutonium recovery operations. ${ }^{\text {P061,P067,P083,U047 }}$

Plutonium metal from returned parts and metal from other DOE facilities was purified at Rocky Flats. Plutonium-241 decays to americium-241 which decreases the effectiveness of the plutonium parts. Plutonium parts were disassembled in Building 777. ${ }^{\mathrm{P} 053, \mathrm{P} 113}$ Beginning in 1967, the molten salt extraction (MSE) process in Building 776 recovered americium from plutonium metal using sodium chloride, potassium chloride, and magnesium chloride. ${ }^{\text {POS } 3}$ Americium was separated from the MSE residue salts using potassium hydroxide 
precipitation followed by an ammonium thiocyanate anion exchange process. In 1975, the process changed to cation exchange followed by anion exchange (no thiocyanate) and then precipitation using oxalic acid. ${ }^{\text {P113,U047 }}$ The process changed again the following year to the salt scrub process which used a magnesium/zinc or a magnesium/aluminum extractant. ${ }^{\mathrm{U} 047}$ The purified plutonium metal from MSE was either sent to the foundry in Building 707 or sent to the electrorefining (ER) process in Building 371 or Building 776 if the metal contained other impurities. ${ }^{\text {P053,U047 }}$ Metal chips were generated from disassembly, and stainless steel and aluminum cans were generated from the MSE and ER processes. ${ }^{\mathrm{P} 083}$

Spray leaching (Building 771) and hydride leaching (Building 779) also used acids to remove plutonium surface contamination from uranium metal and other metals or beryllium contamination from plutonium metal. These processes used nitric, hydrochloric, sulfuric, and sulfamic acids. ${ }^{\text {P053,P061,P062 }}$

\subsubsection{Laboratory}

Buildings 371,559 , and 771 housed the main analytical laboratories at the site. The laboratories' primary functions were to provide analytical support to production activities in addition to supporting recovery, purification, and liquid waste treatment operations. Each of the laboratories used numerous acids, bases, solvents, and other chemical reagents.

Building 371 had an analytical laboratory and a chemical standards laboratory. The chemical standards laboratory prepared standards for various users and inspects standards that have been used in the field. The analytical laboratory analyzed samples from various operations on site. ${ }^{\mathrm{P} 081}$ The types of analyses performed included:

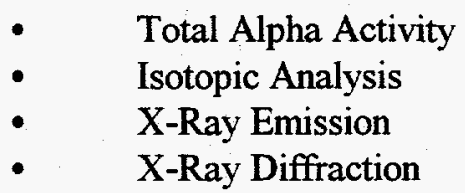

Building 559 housed the Plutonium Analytical Laboratory responsible for spectrochemical, chemical, and mass spectrometric analyses of samples from plutonium production operations. Uranium, Raschig rings, solutions, and commercial product and gas samples were also analyzed in the laboratory. Plutonium production samples, including metal and oxide, were prepared and subdivided for analysis in the sample cutting process. The types of analyses performed included: ${ }^{\mathrm{P} 067}$
- Plutonium, Uranium, and Americium

Content

- Corrosivity
Ignitability

$\begin{array}{ll}\text { - } & \text { Tritium Analyses } \\ \text { - } & \text { Nonroutine Chemical Analysis } \\ \text { - } & \text { Anion/Cation Solution Analysis } \\ \text { - } & \text { Thermal Analysis } \\ \text { - } & \text { Gas Analysis } \\ \text { - } \quad \text { X-ray Analysis }\end{array}$

- Tritium Analyses

Emission Spectroscopy

Atomic Absorption

Infrared Analysis

Gallium Analysis

Plutonium Assay

Carbon Analysis

Uranium Analysis

Raschig Ring Analysis

Building 771 housed analytical and chemical standards laboratories. The chemical standards laboratory prepared control sample standards for the analytical laboratories in Buildings 371,559 , and 771. ${ }^{\mathrm{P} 061}$ 
The analytical laboratory provided analyses in support of plutonium operations. The types of analyses performed included: ${ }^{\mathrm{P} 61, \mathrm{P} 067}$

- X-Ray Fluorescence

- Alpha/Gamma Scintillation

- Atomic Absorption

- Laser Fluorimetry

$\begin{array}{ll}\text { - } & \text { Spectrophotometry } \\ \text { - } & \text { Calorimetry } \\ \text { - } & \text { Tamma Spectroscopy } \\ & \text { Titrations }\end{array}$

The laboratories generated light metal wastes such as tools, planchets, and a variety of metal labware. Silver and lead solder and printed circuit boards containing cadmium, chromium, lead, and silver were also generated. ${ }^{\mathrm{P} 61}$ Many of these wastes may have contacted numerous reagents and solvents used in the laboratories including:

\section{Acids/Bases}

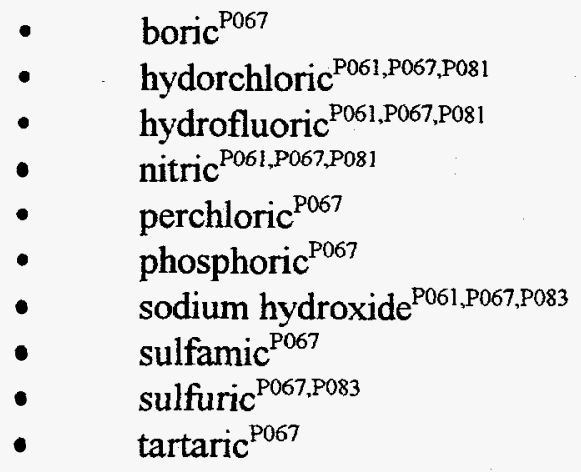

\section{Reagents}

- $\quad$ ammonium hydroxide ${ }^{\mathrm{P} 083}$

- $\quad$ ammonium molybdate $\mathrm{P}^{\mathrm{P} 67}$

- ceric ammonium nitrate ${ }^{\mathrm{P} 067}$

- $\quad$ ceric sulfate ${ }^{\mathrm{P} 083}$

- ferrous sulfamate ${ }^{\mathrm{P} 067}$

- ferric chloride $\mathrm{P}^{\mathrm{P} 67}$

- $\quad$ potassium bromide ${ }^{\mathrm{P} 083}$

- $\quad$ potassium chloride ${ }^{\mathrm{P} 067}$

- $\quad$ sodium fluoride ${ }^{\mathrm{P} 067}$

- total ionic strength adjusting buffer (contains diaminocyclohexane tetraacetic acid) $)^{\mathrm{P} 061}$

- trioctyl phosphene oxide ${ }^{\mathrm{P} 061, \mathrm{P} 081}$

\section{Organic Solvents}

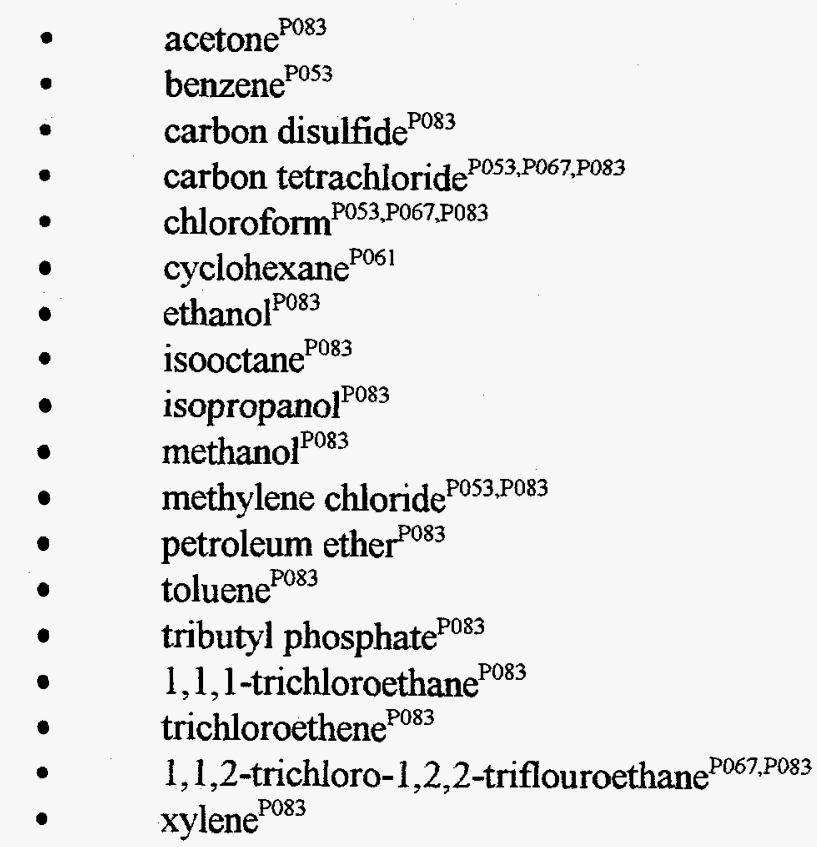

\subsubsection{Research and Development}

Research and Development (R\&D) included activities related to production, recovery, and purification as well as "special order" work. Building 779, which was built in 1965, housed much of the R\&D operations at the plant. Other areas at the plant supporting R\&D included Buildings 559, 771, 776, 777, and 881. ${ }^{\text {Pos }}$ 
The purpose of Building 779 was to gain more knowledge of the chemistry and metallurgy of plutonium and its interactions with other materials which might be used in plutonium operations. Other activities in Building 779 included developing improvements to the manufacturing process and finding new ways to recover plutonium and associated actinides. Another function was to develop a better understanding of the aging and shelf-life limitations of Rocky Flats products. Most of the materials used and wastes generated in this facility were the same as those in the production and recovery buildings, as much of the work conducted involved improvement of existing processes. ${ }^{\text {P053 }}$ However, processing of neptunium, curium, and cerium was also conducted. ${ }^{\mathrm{P} 53, \mathrm{U} 047}$

The plant has conducted special order work for other facilities in the DOE complex, the DOD, or other federal departments or agencies. One example is the introduction of radionuclide tracers into pits destined for off-site test shots. This work took place in the 1960 s and well into the $1970 \mathrm{~s}$. Materials such as americium240 , plutonium-238, neptunium, curium, and cerium were blended in with the regular component materials for the purpose of studying performance of the different weapon components based on post-test distribution of the rare tracers. These tracer materials were kept separate from the regular production material streams, and special recovery operations in Building 771 specialized in recovering these more exotic materials. ${ }^{\mathrm{C} 72, \mathrm{P} 053}$

From approximately 1959 to the mid-1970s, Rocky Flats was involved in "Project Plowshare." The mission of the program was to develop technology for using nuclear explosives for peaceful applications such as excavation and uncovering of deep mineral deposits. Materials used in the manufacturing of these components were the same as those used in the production buildings. ${ }^{\text {P053 }}$

\subsubsection{Waste Treatment}

Waste processing at Rocky Flats has included both liquid and solid process wastes. Liquid waste treatment operations have had relatively few process changes over the years. When Building 774 was built in 1952 , its primary purpose was to treat radioactive aqueous waste from Building 771. Radionuclides were removed by precipitation, and the resulting slurry filtered. The solids removed from filters were combined with cement or other solidifying agents. The aqueous waste from this first stage goes through a second precipitation. ${ }^{\text {P053 }}$ These processes use sodium hydroxide, ferric sulfate, magnesium sulfate, and calcium chloride. $^{\text {P109 }}$ See Section 23.0, Solidified Aqueous Sludge Building 774, for a detailed description of these processes.

Around 1965, an evaporator was installed in Building 774 to treat liquids from the second stage treatment and from the solar ponds. The concentrate from the evaporator was introduced into a steam-heated double-drum drier which produced a salt waste. The Building 774 evaporator was taken out in 1979, and the liquids from the second stage treatment and solar ponds have since been transferred to Building 374 for additional treatment. ${ }^{\mathrm{P} 53}$

Building 774 also processed organic liquid wastes. Plutonium-contaminated organic liquids were generated from plutonium machining. ${ }^{\text {P053 }}$ The spent organic liquid was filtered and then mixed with a solidifying agent. The process was later changed to a one step process in which the organic liquid was mixed with Envirostone (Gypsum cement) and allowed to set up. ${ }^{\text {P109 }}$ See Section 25.0, Solidified Organic Waste for a detailed description of these processes.

Treatment of solid transuranic wastes was conducted in Buildings 771 and 776 . Building 771 processed wastes containing plutonium above the EDL while Building 776 processed wastes below the EDL. 
Operations in Building 771 processed wastes including Raschig rings, HEPA filters, and sludges from the filter plenum and from process piping. Filters were disassembled to remove plutonium-contaminated dust. Process piping removed from service was cut up and discarded as light metal waste after it was cleaned of built-up sludge. Sludge from the process piping and from the filter plenum was dissolved in nitric acid to recover plutonium. Until 1984, plutonium was recovered from Raschig rings by nitric acid leaching. ${ }^{\text {P061 }}$

Size reduction in Building 776 removed materials from drums and sorted them in an airlock vault. Materials such as light metals, filters, glass, combustibles, and Raschig rings were then put into containers with like materials. ${ }^{\mathrm{P} 067}$ Light metal above the EDL was washed with hot water in an attempt to remove radioactive surface contamination, and then reassayed. ${ }^{\mathrm{C} 053, \mathrm{C} 082, \mathrm{P} 024}$ The metals were washed by hand from 1971 to 1973 , and a ball-mill washer was used from 1974 until the process was discontinued in 1989. ${ }^{\text {P024,P052 }}$ If washing reduced the assay to below the EDL, the metal was discarded as IDC $481{ }^{\text {C053,P024 }}$

Advanced size reduction operations in Building 776 disassembled or cut plutonium-contaminated gloveboxes and miscellaneous large equipment into sizes that could be packaged in approved containers. ${ }^{\text {P067,P } 110}$

The fluidized-bed incinerator in Building 776 received low-level plutonium-contaminated combustible solid and liquid wastes. ${ }^{\mathrm{P} 067}$ Building 771 also housed an incinerator for processing combustible wastes. ${ }^{\text {P061,U047 }}$ If drums of the solid combustible wastes contained any metal, it was removed prior to feeding the combustibles to the incinerator. ${ }^{\mathrm{P} 61, \mathrm{P} 067}$ See Section 14.0, Incinerator Waste, for a detailed description of the incineration processes.

\subsubsection{Maintenance}

Routine and nonroutine maintenance at Rocky Flats included utilities, change-out of oils and Raschig rings, equipment parts replacement, strip-out operations and other general maintenance and cleanup activities.

Utility systems include HVAC systems, fume scrubbers, and process vacuum systems. The HVAC systems contain air supply units for filtering incoming air and plenums for filtering exhaust air. ${ }^{\text {P061,P067,P081 }} \mathrm{KW}$ detergent was used for periodic maintenance inside and outside the plenums. ${ }^{\text {P083 }}$ Scrubbers housed in Buildings $371,559,771$, and 779 used potassium or sodium hydroxide to neutralize acid fumes from various process offgas streams and glovebox exhaust streams. Process vacuum systems provide an absolute pressure at a vacuum header which serves as a means to transfer fluids on demand by valving arrangements. ${ }^{\text {P061,P067,P081 }}$ Light metal parts and tools were generated from maintenance of motors, fans, and associated systems and circuits. ${ }^{\text {P061,P081 }}$

Oils and Raschig rings are used in numerous processes and require periodic change out. During oil changes, oil filters (possibly terne-plated) were replaced and discarded as light metal waste. During Raschig ring removal, broken bolts, part covers, tools, and other light metals were generated. Other general maintenance activities generating metal waste included repair of gloveboxes, tanks, valves, pumps, and piping. ${ }^{\mathrm{P} 61, \mathrm{P} 067, \mathrm{P} 083 . \mathrm{P} 109}$

Production, recovery, purification, treatment, $R \& D$, and laboratory operations required various types of machinery, instruments, and other equipment. Parts from the equipment were routinely changed due to normal wear and tear. The replaced parts were then discarded as light metal waste. Parts from Building 374 liquid waste treatment operations may have been contaminated with sludges containing cadmium and lead. ${ }^{\text {P052,P083 }}$ 
Another maintenance activity that may have generated light metal was the strip-out of glovebox lines, process piping, valves, and associated systems. Strip-out activities were performed when a glovebox line was scheduled to be replaced or during renovation. Solvents such as trichloroethene or 1,1,1-trichloroethane may have been used during this type of operation for decontamination. ${ }^{\text {P067.P108 }}$ Light metal such as piping from stripout operations may be contaminated with sludge containing chromium and lead. ${ }^{\text {P052 }}$

Light metal waste such as ducting and equipment may have also originated from cleanup of the 1969 fire which spread through combustible materials in several hundred inter-connected gloveboxes in Building 776. ${ }^{\mathrm{P} 24, \mathrm{P} 053}$

Other incidents that may have generated light metal resulting from strip-out activities include:

- the 1974 control valve release in Building 707 which allowed radioactive particulates to escape from an exhaust stack on the roof and into Module $\mathrm{K}^{\mathrm{P} 053}$ and

- the tritium release in which tritium-contaminated plutonium was processed from April 9, 1973 through April 25, 1973 in Building 779 causing a tritium release to the atmosphere, as well as elevated tritium levels in surface waters, process wastes, equipment, gloveboxes, and exhaust plenums. ${ }^{\text {P053 }}$

\subsection{Waste Packaging}

Light metal was placed directly into a lined 55-gallon drum or bagged out of the glovebox line in up to three plastic bags. Some metal may also be packaged in half-gallon or 1-gallon polyethylene bottles within the plastic bags. After removal from the glovebox, the waste was placed in the drum or in Fibre-Paks which were then placed in the drum. Prior to packaging, sharp edges were taped or wrapped with paper wipes to prevent puncturing of the liners. ${ }^{\mathrm{P} 012, \mathrm{P} 015, \mathrm{P} 024}$

Depending on waste packaging requirements at the time, several combinations of bags and liners were used to prepare 55-gallon drums for shipment. From 1970 to 1972 , waste drums were lined with one or two polyethylene drum bags. Cardboard liners might also have been used to line the inner drum bag. Use of the 90 -mil rigid polyethylene liner began in $1972 .^{\mathrm{P} 024}$ The rigid liner was placed in each drum and lined with one polyethylene round bottom drum liner or two polyethylene drum bags. ${ }^{\mathrm{P} 008, \mathrm{P} 012, \mathrm{P} 016, \mathrm{P} 024, \mathrm{P} 063, \mathrm{P} 064}$ A polyvinyl chloride O-ring bag and a polyethylene bag were used if the drum was attached to the glovebox. ${ }^{\text {P016 }} \mathrm{A}$ fiberboard liner and discs may also have been used between the waste packages and the drum liners for puncture protection. ${ }^{\mathrm{P} 12, \mathrm{P} 063, \mathrm{P} 064}$ Lead drum liners placed between the drum and rigid liner were also used in some instances. ${ }^{\mathrm{P} 01, \mathrm{P} 016, \mathrm{P} 024, \mathrm{P} 043}$ When a drum was full, the drum liners were twisted and taped closed, the lid was secured with a bolted ring, and a tamper indicating device was attached to the drum. ${ }^{\mathrm{P} 012, \mathrm{P} 016, \mathrm{P} 024}$

After drums were inspected, one to two quarts of absorbent material (Oil-Dri) was placed on the top of the outer, sealed polyethylene drum bag. This procedure changed in February 1982 when vermiculite was used to fill the space between the outer, sealed polyethylene drum bag and the top of the 90-mil rigid liner. The quantity of vermiculite varied from 3-12 pounds according to the amount of waste contained in each drum. ${ }^{\mathrm{P} 24}$

Waste management and inspection protocol allowed containers of wastes to contain up to 10 percent of another IDC other than that assigned to the container ${ }^{\mathrm{P} 16}$ Visual inspection of light metal containers identified a variety of combustible, glass, concrete, lead, and plastic items including wipes, surgical gloves, 
paper, Raschig rings, beakers, vials, fluorescent bulbs, leaded gloves, lead tape, scrap lead, rubber gaskets, plastic bags, containers, and tubing. Other items identified include tantalum crucibles, asbestos tie-wraps, aerosol cans, and lighting ballasts. ${ }^{\mathrm{P} 009, \mathrm{P} 015, \mathrm{P} 016, \mathrm{P} 017, \mathrm{P} 021, \mathrm{P} 022, \mathrm{P} 033, \mathrm{U} 011, \mathrm{U} 015}$

\subsection{Waste Characterization}

Light metal is characterized based on knowledge of the material, knowledge of the processes generating the waste, RTR review of the waste, visual inspection, and headspace gas analysis. This section provides a RCRA hazardous waste determination for light metal as well as radionuclide contaminants and potential complexing agents contained in the waste. This waste contains at least 50 percent (by volume) materials that meet the EPA LDR criteria for classification as debris, and is therefore a heterogeneous waste. ${ }^{\mathrm{P} 141}$

\subsubsection{Hazardous Waste Determination}

The material in this waste group does not qualify for any of the exclusions outlined in 40 CFR 260 or 261. Light metal (IDC 480) may exhibit the characteristic of ignitability due to the presence of free liquids and compressed gases. The waste may also exhibit the characteristic of toxicity for cadmium, chromium, lead, mercury, and silver. The waste was mixed with halogenated- and nonhalogenated-solvents and electroplating wastes, and is therefore a F-listed hazardous waste. There is no evidence that light metal exhibits any other characteristic of hazardous waste. ${ }^{\text {C081,C084 }}$ IDCs 480 and 481 have been characterized similarly due to the fact that the wastes originated from the same process operations. ${ }^{C 083}$ EPA Hazardous Waste Numbers applicable to some or all of the light metal waste group are presented by IDC in Table 16-2. These conclusions are supported by the evaluation in Sections 16.3.1.1 and 16.3.1.2.

Table 16-2. Light Metal Waste Characterization.

\begin{tabular}{cll}
\hline IDC & \multicolumn{1}{c}{ Title } & \multicolumn{1}{c}{ EPA Hazardous Waste Numbers } \\
\hline 480 & Light Metal & D001, D006, D007, D008, D011, \\
& & F001-F003, F005-F007, and F009 \\
481 & Leached Light Metal & D006, D007, D008, D011, F001-F003, \\
& & F005-F007, and F009 \\
\hline
\end{tabular}

\subsubsection{Characteristic Waste}

The materials in this waste group may exhibit a characteristic of hazardous waste as defined in 40 CFR 261, Subpart C, as an ignitable waste (40 CFR 261.21) and as a toxic waste (40 CFR 261.24). The materials do not exhibit the characteristics of corrosivity (40 CFR 261.22) or reactivity (40 CFR 261.23).

Ignitability: Light metal waste (IDC 480) may meet the definition of ignitability as defined in 40 CFR 261.21 due to the presence of ignitable free liquids or compressed gases. Leached light metal (IDC 481 ) should not exhibit the characteristic of ignitability because ignitable liquids or compressed gases have not been identified with this waste. ${ }^{\mathrm{P} 16, \mathrm{P} 024}$ The materials in this waste group are not liquid, and absorbents were added to wastes having the potential of generating free liquids. ${ }^{\mathrm{P} 12, \mathrm{P} 015, \mathrm{P} 024}$ However, a container of Dykem ${ }^{\circledR}$ Steel Blue, which has a flash point of $<25^{\circ} \mathrm{C}$, was found in one IDC 480 drum. ${ }^{\text {P015,P091 }}$ Another IDC 480 drum 
contained an 8 ounce can of xylene and methyl isobutyl ketone, which are both ignitable liquids. ${ }^{\text {U015 }}$ The materials are not compressed gases as defined by 49 CFR 173; however, an unpunctured aerosol can of WD-40 (which is likely to have an ignitable propellant) was found in a drum of light metal (IDC 480). The materials are not capable of causing fire through friction, absorption of moisture, or spontaneous chemical change. ${ }^{\mathrm{P} 12, \mathrm{P} 024}$ The materials are not DOT oxidizers as defined in 49 CFR 173. Therefore, EPA Hazardous Waste Number D001 may be applicable to drums of light metal (IDC 480) containing free liquids or compressed gases.

Corrosivity: The materials in this waste group do not meet the definition of corrosivity as defined in 40 CFR 261.22. The materials are not liquid, and absorbents were added to wastes having the potential of generating free liquids. ${ }^{\mathrm{P} 12, \mathrm{PO} 15, \mathrm{PO} 24}$ Small amounts of free liquids have been identified in some IDC 480 drums. However, analysis of the liquids has shown that the $\mathrm{pH}$ does not meet the definition of a corrosive waste. ${ }^{\text {P015 }}$ The materials in this waste group are therefore not corrosive wastes (D002).

Reactivity: The materials in this waste group do not meet the definition of reactivity as defined in 40 CFR 261.23. The materials are stable and will not undergo violent chemical change. The materials will not react violently with water, form potentially explosive mixtures with water, or generate toxic gases, vapors, or fumes when mixed with water. The materials do not contain cyanides or sulfides, and are not capable of detonation or explosive reaction. The materials are not forbidden explosives or Division 1.1, 1.2, or 1.3 (Class A or B) explosives as defined in 49 CFR 173, nor do the drums contain explosive materials. ${ }^{\mathrm{P} 12, \mathrm{P} 015, \mathrm{P} 024}$ Explosives were not handled or used around radioactive material. The materials in this waste group are therefore not reactive wastes (D003).

Toxicity: The materials in this waste group may meet the definition of toxicity as defined in 40 CFR 261.24. The toxicity characteristic contaminants fall into one of two categories: metals and organics. Organic compounds include halogenated-and nonhalogenated-solvents, pesticides, herbicides, and other toxic compounds. This waste group may exhibit the characteristic of toxicity for cadmium, chromium, lead; mercury, and silver metals.

RTR and visual inspection have identified drums of light metal waste containing lead items. Items in this waste group may also include lead and silver solder; fluorescent bulbs which contain mercury; circuit boards containing cadmium, chromium, lead, and silver; and terne-plated oil filters which contain lead. Additionally, light metal wastes from strip-out operations in Building 707 and liquid waste treatment operations in Building 374 may be contaminated with sludges containing cadmium, chromium, or lead. Light metal may exhibit the characteristic of toxicity for these metals. Therefore, the materials in this waste group are assigned EPA Hazardous Waste Numbers D006, D007, D008, and D011 since a representative sample of this waste cannot be obtained for verification purposes.

There is no documentation indicating the presence or use of pesticides or herbicides in the areas or processes generating light metal. Therefore, this waste group does not exhibit the characteristic of toxicity due to pesticides or herbicides (D012-D017).

Carbon tetrachloride, tetrachloroethene, and trichloroethene were used for cleaning and degreasing. Benzene was used in laboratory analysis. Since these compounds were typically used as solvents, the waste is regulated as a listed hazardous waste and not a characteristic waste because these compounds are specifically addressed in the treatment standards for the listed hazardous waste. ${ }^{\mathrm{P} 80}$ Since light metal is characterized as listed hazardous wastes due to spent solvent contamination, the waste is not a toxic waste due to the presence of these organic compounds. 


\subsubsection{Listed Hazardous Waste}

The material in this waste group is a listed hazardous waste because it was mixed with a waste listed in 40 CFR 261, Subpart $D$ as a hazardous waste from non-specific sources (40 CFR 261.31). The material is not, or was not mixed with, a hazardous waste from specific sources (40 CFR 261.32), or a discarded commercial chemical product, an off-specification species, a container residue, or a spill residue thereof (40 CFR 261.33).

Tetrachloroethene, trichloroethene, methylene chloride, 1,1,1-trichloroethane, carbon tetrachloride, and 1,1,2-trichloro-1,2,2-trifluoroethane were used in production, laboratory, and maintenance operations. Light metal may be contaminated with residual amounts of these spent solvents, and is therefore assigned EPA Hazardous Waste Numbers F001 and F002.

Acetone, methanol, and xylene were used in laboratory operations. Acetone may also have been used during production operations. In addition, a small container of xylene and methyl isobutyl ketone was found in a drum of light metal. Light metal may be contaminated with residual amounts of these spent solvents, and is therefore assigned EPA Hazardous Waste Number F003.

There is no documentation indicating the presence or use of F004-listed solvents in the areas or processes generating light metal. Therefore, this waste group is not a F004-listed hazardous waste.

Benzene, carbon disulfide, and toluene were used in laboratory operations. Light metal from laboratory operations may be contaminated with residual amounts of these spent solvents, and is therefore assigned EPA Hazardous Waste Number F005.

Headspace analysis performed on samples of light metal (IDCs 480 and 481 ) obtained at INEEL confirms the presence of F-listed solvents. The detected F-listed compounds in which the 90 percent UCL is above the PRQL are provided. ${ }^{\mathrm{P} 33}$

- $\quad$ methylene chloride (IDC 480 only)
- $\quad$ trichloroethene (IDC 480 only)

Additional F-listed solvents were detected in headspace samples of light metal (IDC 480) obtained Rocky Flats. The detected F-listed compounds in which the 90 percent UCL is above the PRQL are also provided. ${ }^{\text {U030 }}$

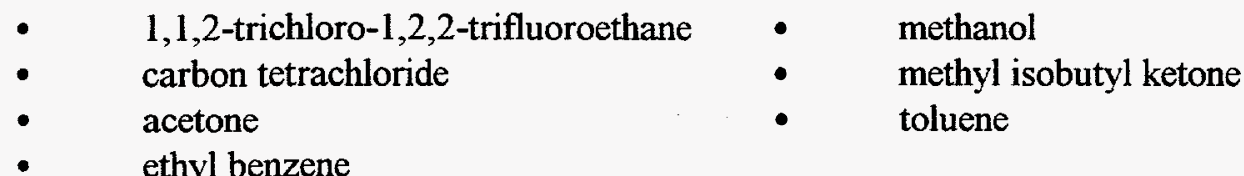

Aqueous waste treatment operations in Buildings 374 and 774 treated spent stripping, cleaning, and plating solutions and sludges from Building 444 electroplating operations. Light metal may be contaminated with residual amounts of the electroplating wastes, and therefore is assigned EPA Hazardous Waste Numbers F006, F007, and F009. 
The material in this waste group is not a hazardous waste from specific sources since it was not generated from any of the processes listed in 40 CFR 261.32. The material in this waste group is therefore not a K-listed hazardous waste.

The material in this waste group is not a discarded commercial chemical product, an off-specification species, a container residue, or a spill residue thereof (40 CFR 261.33). The material in this waste group is therefore not a P-or U-listed hazardous waste.

\subsubsection{Radionuclides}

This section identifies the radioisotopes potentially contained in the waste, as well as the chemical form of radionuclide contaminants and radioassay interferences. The primary radionuclides processed at Rocky Flats included weapons-grade plutonium, americium-241, enriched uranium, and depleted uranium. The isotopic compositions of weapons-grade plutonium, enriched uranium, and depleted uranium are specified in Section 3.0. Wastes from some of the processes described below may not be contained in the inventory based on the assigned prefixes. However, as explained in Section 16.3.2.6, it is assumed that repackaged drums could contain waste generated from any process.

\subsubsection{Plutonium Production}

Radionuclide contamination in waste from Building 707 will primarily consist of weapons-grade plutonium from foundry, casting, and final assembly operations. ${ }^{\text {P052,P053 }}$ A small percentage of the waste from Building 707 may also contain americium-240, neptunium-237, and plutonium-238 from blending of these isotopes with weapons-grade plutonium for diagnostic tracers. ${ }^{\text {C171,C174,C184,C185,P053,P164,P167 }}$

Building 777 performed disassembly of site-return parts and fabrication operations including machining, briquetting, assembly, and production support processes (prefixes 04, 23, and 24). ${ }^{\mathrm{C} 184, \mathrm{P} 052, \mathrm{U} 059, \mathrm{P} 079}$ Wastes from fabrication operations will be contaminated with weapons-grade plutonium and enriched uranium. Wastes generated by disassembly operations will be contaminated with site-return plutonium (higher americium-241 decay product) and enriched uranium. ${ }^{\text {C184,P079 }}$ Tritium may also be present from disassembly operations. ${ }^{\text {P053 }}$ There is documentation of five drums of IDC 480 containing tritium; however, it is not known if they were generated by this process, and the specific drum numbers and package dates are not known. ${ }^{\mathrm{U} 19}$

Buildings 707 and 777 handled actinides in metal or oxide form only. ${ }^{\mathrm{P} 060, \mathrm{P} 079}$ The actinide metals will likely have partially or completely oxidized because of the reaction with dry air, and some could possibly have formed a hydroxide layer from reaction with moist air. Radioassay interferences may include beryllium from Part V metal fabrication in Building 707, and calcium fluoride which was sprayed onto graphite molds in Building 707 prior to casting. ${ }^{\mathrm{C} 184, \mathrm{P} 060}$ Other interfering waste contaminants include aluminum, beryllium, and stainless steel (chromium) which were machined in Building 777. ${ }^{\text {P079 }}$

\subsubsection{Plutonium Recovery and Purification}

Waste from recovery operations in Building 371 will contain weapons-grade plutonium primarily from

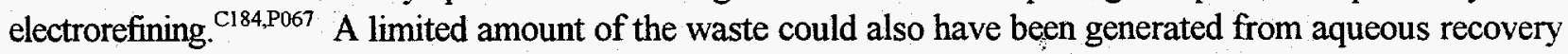
operations which only ran for a short time in 1982. Aqueous recovery operations were designed for recovering and purifying weapons-grade plutonium. ${ }^{\mathrm{C} 184, \mathrm{P} 164}$ 
The feed materials to the recovery and purification processes (prefixes 01 and 02) in Building 771 were impure plutonium residues which were processed to produce plutonium metal for use in the foundry and, therefore, wastes generated will be contaminated primarily with weapons-grade plutonium. ${ }^{\text {P052,P163,U059 }}$ Radionuclides from aqueous recovery operations will vary widely in chemical form depending on the specific process the waste originated, and because the majority of the aqueous processes were performed within one large MBA (prefixes 01 and 02), the specific process can not be determined. The different actinide forms are plutonium nitrate, plutonium chloride, plutonium peroxide, plutonium dioxide, plutonium tetrafluoride, and plutonium metal. Radioassay interferences may include aluminum nitrate from the dissolution process and beryllium which was removed during Part V leach. ${ }^{\mathrm{P} 163}$

Wastes from the americium recovery glovebox lines (prefix 06) in Building 771 , used for extraction of americium from site-return plutonium, will contain a significant amount of americium-241. C184,P053,P164,0059 The americium was in a chloride, hydroxide, nitrate, oxalate, and oxide chemical form during different steps of the process. Prior to 1975 , ammonium thiocyanate was also used. ${ }^{\mathrm{P} 53}$

The Oralloy leach process (prefix 74) in Building 771 chemically separated plutonium surface contamination from enriched uranium hemishells using nitric acid. The chemical form of the radionuclides will therefore be plutonium nitrate and uranyl nitrate. ${ }^{\mathrm{C184,P061,P163,0059}}$

Wastes generated from Building 771 filter plenum maintenance were assigned prefix 09. ${ }^{\mathrm{C} 184, \mathrm{P} 052}$ It will be assumed that this waste could contain any of the radioisotopes processed in the building.

Site-return metal and other non-specification plutonium were processed by pyrochemical operations in Building 776 (prefix 03) to produce plutonium for use in the foundry. ${ }^{\mathrm{C} 184, \mathrm{P} 053, \mathrm{U} 059}$ The molten salt extraction process removed americium-241 from site-return and other non-specification plutonium. Electrorefining was used to purify plutonium metal that did not meet foundry specifications. Since metal was the feed and product to the MSE and electrorefining processes, wastes generated from these processes will be contaminated with actinide metals which now will probably have formed an oxide or hydroxide layer from reaction with dry and moist air. Direct oxide reduction was developed to convert plutonium dioxide to plutonium metal ${ }^{\text {P163,P175 }}$ MSE residue salts, which contain actinide chlorides, were the feed to the salt scrub process. Metal was the product of this process as well, so the radionuclide contaminants could be in a metal, oxide, and/or hydroxide form. Radioassay interferences may include chloride salts (i.e., sodium, potassium, magnesium, calcium, and zinc). ${ }^{\text {P163 }}$

Hydride operations in Building 779 (prefix 55) recovered plutonium from various substrates by reacting plutonium metal with gaseous hydrogen in an argon-inerted glovebox. ${ }^{\text {P052,U059,P062,P163 }}$ Hydriding produced plutonium metal for use in the foundry or non-specification feed to pyrochemical operations, in addition to plutonium oxides sent for aqueous recovery. ${ }^{\mathrm{C} 184, \mathrm{P} 062}$ The hydriding process formed plutonium hydride which was converted to plutonium dioxide by oxidizing the material in an air atmosphere. ${ }^{\text {P163 }}$

\subsubsection{Laboratory}

The analytical laboratory in Building 371 (prefix 71) provided analytical support for process control and performed analyses on feed materials and residues from recovery operations in Building 371. ${ }^{\text {P053,U059,P081 }}$ The laboratory also analyzed samples from various operations at the site, but primarily from Building 374 . $^{\text {P01 }}$ The Building 371 chemical standards laboratory prepared standards for various users and inspected standards 
that were used throughout plant site. ${ }^{\text {P053 }}$ Wastes from these laboratories will be contaminated with weaponsgrade plutonium and enriched and depleted uranium.

The Building 559 analytical laboratory (prefix 29) performed a variety of analyses, including plutonium, enriched and depleted uranium, americium, neptunium, and tritium content. ${ }^{\text {P053,P067,U059,U073 }}$ The primary mission of this laboratory was analysis of site-return and feed materials, in addition to recovery, purification, and foundry products. ${ }^{\text {P053 }}$

The Building 771 analytical laboratory (prefix 37) received samples from recovery operations in the building as well as from the foundry. ${ }^{\text {P067,U059 }}$ The samples included plutonium metal turnings, plutonium oxide, acidic plutonium solutions, and various process residues. ${ }^{\mathrm{P} 061}$ In addition, the analytical laboratory analyzed samples from R\&D laboratories in Buildings 771 and 779 (see Section 16.3.2.4) ${ }^{\mathrm{P} 067, \mathrm{P} 061}$ The chemical standards laboratory (prefix 38) prepared uranium, plutonium, and americium nitrates used as control standards for the Buildings 371, 559, and 771 analytical laboratories. ${ }^{\text {P067.P061 }}$ The laboratory also produced nondestructive assay standards used at drum counters and fluoride standards for chemical operations. ${ }^{\text {P061 }}$

The metallography laboratory (prefix 21) in Building 777 prepared and examined metallographic specimens in support of R\&D operations (plutonium metallography, nuclear and non-nuclear joining, quality engineering, and product physical chemistry) and, therefore, may contain any of the radionuclides used during R\&D activities (see Section 16.3.2.4). ${ }^{\text {C184,U059,P079 }}$ The Building 777 tritium surveillance laboratory analyzed solid, liquid, and gas samples from throughout the plant site for tritium content. ${ }^{\mathrm{U} 78}$

Because the laboratories supported all phases of weapons production, the chemical form of the radionuclide contaminants and radioassay interferences will vary widely depending on the type of sample analyzed.

\subsubsection{Research and Development}

Projects using transuranic radionuclides were done in Buildings $771,776,777,779$, and 881 . Most of the documentation pertaining to $R \& D$ activities does not specify locations in which the work was performed, and unless otherwise noted, it will be assumed that any of the radioisotopes could have been handled in the $R \& D$ areas of any of these buildings. In addition to weapons-grade plutonium, americium- 241 , and enriched and depleted uranium, the following radioisotopes were processed during R\&D activities: ${ }^{\mathrm{C} 134, \mathrm{Cl} 137, \mathrm{C} 185, \mathrm{P053}, \mathrm{P} 164, \mathrm{P} 167, \mathrm{P} 189, \mathrm{P} 190, \mathrm{P} 194, \mathrm{P} 195, \mathrm{P} 198, \mathrm{P} 200, \mathrm{U} 064}$

- americium-240

- curium-244

- $\quad$ neptunium-237

- $\quad$ plutonium-238, $-240,-241$, and -242

- low NGS plutonium $(\approx 3 \% \mathrm{Pu}-240)$

- $\quad$ power grade plutonium (up to $20 \% \mathrm{Pu}-240$ and $1 \% \mathrm{Pu}-241$ )

- thorium-228

- uranium-233, $-235,-236$, and -238

A summary of the projects and time periods that these and other radionuclides were used is presented in Section 3.0. 
In Building 771, special recovery anion exchange (prefix 45) separated plutonium from other materials that were not suitable for the regular recovery processes. ${ }^{\text {Cl54,P052,P061 }}$ Chemical technology (prefix 42) conducted aqueous R\&D activities while plutonium metallurgy operations (prefix 78) performed alloy preparation, heat treating, rolling, metal and metallurgical testing, and cutting for R\&D. ${ }^{\text {C184,U059,P061 }}$ These processes may have used numerous radioisotopes.

A pilot-scale fluidized-bed incinerator (prefix 75) was developed in Building 776 to treat low-level waste. ${ }^{\text {C184,U059 }}$ The waste fed to the incinerator was contaminated with low levels of plutonium. ${ }^{\text {P024 }}$

The coatings laboratory (prefix 16) in Building 777 developed various substrates to be coated with uranium or plutonium, including stainless steel, copper, chromium, aluminum, and beryllium. ${ }^{\text {P052,U059,P079 This }}$ research and development facility supported production processes. ${ }^{\mathrm{P} 052, \mathrm{P} 039}$ The special weapons area (prefix 66) in Building 777 was a research and development facility which assembled war reserve and other specially fabricated parts. ${ }^{\text {U059,P079 }}$ The process was also responsible for disassembly of surveillance (tracer) parts and drilling of parts for use in analytical testing. ${ }^{\text {P079 }}$

Pyrochemical technology (prefixes 10 and 52) in Building 779 involved the extraction and recovery of plutonium and americium in support of production operations. ${ }^{\mathrm{P} 667, \mathrm{U} 059, \mathrm{P} 062}$ These processes included direct oxide reduction, molten salt extraction, electrorefining, salt scrub for MSE, salt scrub for electrorefining, pyrochemical salt recycle, anode alloy, and pyroredox. ${ }^{\mathrm{C} 182, \mathrm{P} 062}$ Most of the materials used in Building 779 were the same as those in the weapons-production areas and, therefore, will be contaminated primarily with weapons-grade plutonium and enriched uranium. ${ }^{\text {P053 }}$ However, other R\&D activities in the building may have used a variety of other radionuclides. ${ }^{\mathrm{Cl71}, \mathrm{Cl} 84}$

\subsubsection{Liquid Waste Treatment}

Aqueous waste treatment operations in Buildings 374 and 774 received wastes from throughout plant site, including processes that generated low-level and nonradioactive liquid wastes. For this reason, wastes generated during treatment operations may contain any of the radioisotopes used at the plant. The most common radioactive materials handled were weapons-grade plutonium, americium-241, enriched uranium, and depleted uranium. Other radionuclides may also be found in the waste streams from R\&D, analytical, and special order work. ${ }^{\mathrm{P} 64}$ Radionuclide contaminants are removed from the aqueous wastes by precipitation using sodium hydroxide and, therefore, will be primarily in the form of hydroxides. ${ }^{\mathrm{P} 163}$ Radioassay interferences may include magnesium sulfate and calcium chloride reagents used in the process. ${ }^{\text {P106.P163 }}$

Building 774 also processed organic liquid wastes. Organic wastes are comprised of a variety of oils and solvents. Most of the oils were from spent lathe coolant used in the plutonium machining area and lubricating oils used in machines throughout the plant. ${ }^{\mathrm{P} 64}$ The majority of the transuranic organic liquids were oils and solvents from plutonium machining and degreasing operations in Buildings 707 and 777 and, therefore, will be contaminated with actinide metals and oxides. ${ }^{\mathrm{P} 052} \mathrm{~A}$ more detailed discussion of the wastes treated in these buildings is provided in Sections 22.0 through 25.0.

\subsubsection{Size Reduction/Repackaging/Solid Waste Treatment}

Repack operations (prefix 76) in Building 371 involved the repackaging of residues for off-site shipment to other DOE facilities and the repackaging of wastes and residues for on-site storage. ${ }^{\text {P081,U059 }}$ Residues and wastes repacked for off-site shipment included plutonium oxides, incinerator ash, molten salt, 
electrorefining salt, cell scrape out, and anode heels. Wastes and residues were received from either the stacker/retriever (prefix 43) in Building 371 or from one of several 10- and 55-gallon drum storage areas within Building 371. ${ }^{\text {P081,U059 }}$

The Size Reduction Vault (SRV) in Building 776 conducted solid waste treatment, repackaging, and size reduction operations. The SRV was divided into two sides. One side was the airlock (prefixes 25, 40, 41, and 57) where repackaging was done. The other side (prefixes 19 and 26) was a drybox atmosphere where size reduction and solid waste treatment activities took place. ${ }^{\text {C175.C184.P067,U059 }}$ The repacked containers have the potential to contain contaminated materials from any of the processes within the transuranic waste generating buildings. ${ }^{\text {P067,U07 }}$ Size reduction included cutting up gloveboxes or ducting, and crushing HEPA filters. Solid waste treatment activities included washing leaded gloves and scrap metal with hot water in a ball-mill washer to recover plutonium. ${ }^{\mathrm{C} 053, \mathrm{P} 067, \mathrm{P} 164}$

\subsubsection{Complexing Agents}

Because complexing agents can aid in the transport of transuranic radionuclides from the waste after disposal, the waste was assessed for potential complexing agents. This information may also be added to the chemical compatibility studies since limited information was available on these chemicals in the past.

EDTA represents a group of chelating compounds, such as ethenediaminetetraacetic acid, with similar molecular structures found in many soaps and detergents. Versene (a trade name for EDTA) and citric acid are known constituents of $\mathrm{KW}$ decontamination detergent. ${ }^{\mathrm{P} 068} \mathrm{KW}$ was used during a variety of decontamination activities at the plant. A buffer solution (TISAB) containing diaminocyclohexane tetraacetic acid was used during specific ion electrode analysis in Building 559. ${ }^{\mathrm{P} 76}$ Oxalic acid and tetraphosphoric acid were used to etch plutonium and other metals. ${ }^{\mathrm{PO62,U}, \mathrm{U} 43}$ Oxalic acid was also used for americium recovery. ${ }^{\mathrm{P} 113}$ Light metal may be contaminated with trace quantities of these complexing agents. 


\subsection{MISCELLANEOUS CEMENTED WASTE}

This waste group includes various sludges, particulates, and heels that were cemented prior to disposal. Historic IDC descriptions and dates of generation for the INEEL accessible storage inventory are presented by IDC in Table $17-1 .^{\mathrm{P} 127}$

Table 17-1. Miscellaneous Cemented Waste in the Accessible Storage Inventory.

\begin{tabular}{cll}
\hline IDC & Title & \multicolumn{1}{c}{ Dates of Generation } \\
\hline \multirow{2}{8}{806} & Cemented Filter Sludge $^{\mathrm{P} 063}$ & April 1987-March 1988 \\
& Cemented Process Solids $^{\mathrm{P} 012}$ & \\
& Solidified Process Solids ${ }^{\mathrm{P} 001}$ & \\
823 & Cemented Miscellaneous Sludge $^{\mathrm{P} 063}$ & January 1987-March 1987 \\
\hline
\end{tabular}

Item Description Code 806, Solidified Process Solids: This waste consists of various sludges, particulates, and heels immobilized into a solid monolith with Portland cement. ${ }^{\text {P001,P039,P098 }}$ The sludges may have originated from filter plenums, Nash pumps, laboratories, the plutonium recovery incinerator, or the size reduction facility. Particulates and heels included graphite; incinerator ash, soot, and firebrick; and sand, slag, and crucible wastes. Additional particulate materials included ion-exchange resins, grit blasting media, and salt from clean-out of pyrochemical process lines. ${ }^{\text {P001,P039 }}$

Item Description Code 823, Cemented Miscellaneous Sludge: This waste consists of various wastes immobilized into a solid monolith with Portland cement. It is presumed that the generation source of the materials cemented is the same for both IDC 806 and IDC 823. ${ }^{\mathrm{P} 016}$

\subsection{Waste Generation}

Particulate- and sludge-type wastes were immobilized by mixing with Portland cement and water. ${ }^{\text {P0O1.P016 }}$ Some of the wastes to be immobilized were first washed with water to remove residual materials. Portland cement and water were mixed and the waste to be solidified was added to the mixture. The slurry was poured into a l-gallon polyethylene container mold. After the mixture cured, the cemented pucks were removed from the molds and placed in a 55-gallon drum. ${ }^{\text {P098 }}$ A brief description of the wastes that were immobilized are presented by IDC in Table 17-2. ${ }^{\text {P01,P039 }}$

Sludge wastes were cemented separately as were resin wastes. Particulate wastes, such as grit, ash, and heel, may have been mixed together prior to immobilization. ${ }^{\mathrm{P} 98}$ Even though the sludges and resins were cemented separately, no documentation was available to determine which drums contain the sludges or resins. ${ }^{\text {C044 }}$ Therefore, it will be assumed that miscellaneous cemented wastes (IDCs 806 and 823) may contain any of the wastes that were immobilized. 
Table 17-2. Description of Wastes that were Immobilized with Cement. ${ }^{\text {P001,P039 }}$

\begin{tabular}{|c|c|c|}
\hline IDC & Title & Description \\
\hline 159 & Screenings from Oxide & $\begin{array}{l}\text { Miscellaneous floor sweepings too large to sift } \\
\text { through a screen mesh. May contain fine } \\
\text { particles, metal, and glass. }\end{array}$ \\
\hline 290 & Filter Sludge & Sludge from filter plenums and Nash pumps. \\
\hline 291 & Dried Lab Waste Fluoride Sludge & $\begin{array}{l}\text { A more detailed description for this waste was } \\
\text { not identified. }\end{array}$ \\
\hline 292 & Incinerator Sludge & $\begin{array}{l}\text { Sludge collected from the recovery incinerator } \\
\text { in Building } 771 \text {. }\end{array}$ \\
\hline 310 & Graphite Scarfings and Fines & $\begin{array}{l}\text { Graphite particles below EDL produced from } \\
\text { mold cleaning and floor sweeping. }\end{array}$ \\
\hline 311 & Graphite Heels & $\begin{array}{l}\text { Insoluble components remaining after leaching } \\
\text { of graphite materials. }\end{array}$ \\
\hline 332 & Oily Sludge & $\begin{array}{l}\text { Sludge that contains oil and is not described by } \\
\text { another IDC. }\end{array}$ \\
\hline 340 & Sludge from Size Reduction Area & $\begin{array}{l}\text { Sludge recovered from cleanup of equipment } \\
\text { and clean-out of filter trap. }\end{array}$ \\
\hline 369 & Leco Heels & $\begin{array}{l}\text { Insoluble components remaining after leaching } \\
\text { of Leco materials. }\end{array}$ \\
\hline 372 & Grit & Grit blasting media in all forms. \\
\hline 373 & Firebrick Heel & $\begin{array}{l}\text { Insoluble components remaining after leaching } \\
\text { of incinerator firebrick. }\end{array}$ \\
\hline 378 & Firebrick, Pulverized or Fines & Particulate firebrick below EDL. \\
\hline 387 & $\begin{array}{l}\text { Reburned Sand, Slag, and Crucible } \\
\text { Sweepings }\end{array}$ & $\begin{array}{l}\text { Floor sweepings from button break-out, } \\
\text { calcined to neutralize reactive metals. }\end{array}$ \\
\hline 390 & Unpulverized Slag & $\begin{array}{l}\text { Unpulverized slag (calcium fluoride) from } \\
\text { button break-out. May contain calcium metal. }\end{array}$ \\
\hline 391 & Unpulverized Sand and Crucible & $\begin{array}{l}\text { Unpulverized magnesium oxide sand and } \\
\text { crucible from button break-out. May contain } \\
\text { calcium metal. }\end{array}$ \\
\hline 392 & Unpulverized Sand, Slag, and Crucible & $\begin{array}{l}\text { Unpulverized magnesium oxide sand and } \\
\text { crucible and calcium fluoride slag from button } \\
\text { break-out. May contain calcium metal. }\end{array}$ \\
\hline 393 & Sand, Slag, and Crucible Heel & $\begin{array}{l}\text { Insoluble components remaining after leaching } \\
\text { of sand, slag, and crucible. }\end{array}$ \\
\hline
\end{tabular}




\begin{tabular}{|c|c|c|}
\hline IDC & Title & Description \\
\hline 394 & Sand from Button Break-Out & $\begin{array}{l}\text { Magnesium oxide sand from button break-out. } \\
\text { May contain calcium metal. }\end{array}$ \\
\hline 395 & Unpulverized Slag and Crucible & $\begin{array}{l}\text { Unpulverized magnesium oxide crucible and } \\
\text { calcium fluoride slag from button break-out. } \\
\text { May contain calcium metal. }\end{array}$ \\
\hline 396 & Pulverized Slag & $\begin{array}{l}\text { Slag (IDC } 390 \text { ) that has been pulverized in a } \\
\text { jaw crusher and hammermill. }\end{array}$ \\
\hline 397 & Pulverized Sand and Crucible & $\begin{array}{l}\text { Sand and crucible (IDC 391) that has been } \\
\text { pulverized in a jaw crusher and hammermill. }\end{array}$ \\
\hline 398 & Pulverized Sand, Slag, and Crucible & $\begin{array}{l}\text { Sand, slag, and crucible (IDC } 392 \text { ) that has } \\
\text { been pulverized in a jaw crusher and } \\
\text { hammermill. }\end{array}$ \\
\hline 399 & Pulverized Slag and Crucible & $\begin{array}{l}\text { Slag and crucible (IDC 395) that has been } \\
\text { pulverized in a jaw crusher and hammermill. }\end{array}$ \\
\hline 413 & Impure Salt from Cell Clean-Out & $\begin{array}{l}\text { Salts generated from scraping and cleaning of } \\
\text { pyrochemical furnace cells. May contain } \\
\text { sodium, potassium, magnesium, and calcium } \\
\text { metals. }{ }^{\text {P52 } 2}\end{array}$ \\
\hline 420 & Pulverized Incinerator Ash & $\begin{array}{l}\text { Ash from the recovery incinerator in } \\
\text { Building } 771 \text { that has been pulverized in a ball } \\
\text { mill. }\end{array}$ \\
\hline 421 & Ash Heel & $\begin{array}{l}\text { Insoluble components remaining after leaching } \\
\text { of ash (IDC } 420 \text { ). }\end{array}$ \\
\hline 422 & Soot & $\begin{array}{l}\text { Airborne fly ash material that accumulated in } \\
\text { the off-gas system of the recovery incinerator } \\
\text { in Building } 771 \text {. }\end{array}$ \\
\hline 423 & Soot Heels & $\begin{array}{l}\text { Insoluble components remaining after leaching } \\
\text { of soot (IDC 422). }\end{array}$ \\
\hline 425 & Fluid Bed Ash & $\begin{array}{l}\text { Ash consisting of a fine powder generated by } \\
\text { the fluidized-bed incinerator in Building } 776 \text {. }\end{array}$ \\
\hline 431 & Resin, Leached & Ion-exchange column resin below EDL. \\
\hline
\end{tabular}

\subsection{Waste Packaging}

Individual containers of processed material were assayed by the in-line can counter. The solidified pucks were then bagged out of the glovebox, double-bagged, and placed into a 55-gallon drum. The individual assay values for containers solidified in a batch and placed in a drum were totaled to provide an assigned assay value for the drum. The drums may have been assayed on a SGS counter or a PADC to verify the assigned 
assay value. Drums that had not been PADC assayed and had SGS or in-line can counter assay values of 1 gram or less were assayed by PADC to verify that they were transuranic waste. ${ }^{\mathrm{P} 016}$

Depending on waste packaging requirements at the time, several combinations of bags and liners were used to prepare 55-gallon drums for shipment. Use of 90-mil rigid polyethylene liners began in 1972. A rigid liner was placed in each drum and lined with one polyethylene round bottom drum liner or two polyethylene drum bags. A polyvinyl chloride $\mathrm{O}$-ring bag and a polyethylene bag placed inside the rigid liner was used if the drum was attached to a glovebox. When a drum was full, the drum liners were twisted and taped closed, the lid was secured with a bolted ring, and a tamper indicating device was attached to the drum. ${ }^{\text {P001,P012,P016,P063,P064 }}$

\subsection{Waste Characterization}

Miscellaneous cemented wastes have been characterized based on knowledge of the material, knowledge of the processes generating the waste, and limited analytical data. This section provides a RCRA hazardous waste determination for miscellaneous cemented wastes as well as radionuclide contaminants and potential complexing agents contained in the waste. This waste does not meet the EPA LDR criteria for classification as debris, and is classified as a homogeneous waste. ${ }^{\mathrm{P} 141}$

\subsubsection{Hazardous Waste Determination}

The material in this waste group does not qualify for any of the exclusions outlined in 40 CFR 260 or 261. The waste may exhibit the characteristic of toxicity for arsenic, barium, cadmium, chromium, lead, mercury, selenium, and silver. The waste may have been mixed mixed with halogenated- and nonhalogenatedsolvents, and is therefore a F-listed hazardous waste. There is no evidence that miscellaneous cemented wastes exhibit any other characteristic of hazardous waste. EPA Hazardous Waste Numbers applicable to some or all of this waste group are presented by IDC in Table 17-3. These conclusions are supported by the evaluation in Sections 17.3.1.1 and 17.3.1.2.

The hazardous waste determination for the miscellaneous cemented waste group is based on the characterization of the wastes that were immobilized. Sections 12.0-14.0 and 21.0 of this document provide characterization information for IDCs $292,310,372,391,392,393,420,422$, and 425 . Limited analytical data are available for IDC $340 .{ }^{\text {C042 }}$ Constituent information on the remaining IDCs in Table 17-2 was not available.

Table 17-3. Miscellaneous Cemented Waste Characterization.

\begin{tabular}{cll}
\hline IDC & \multicolumn{1}{c}{ Title } & \multicolumn{1}{c}{ EPA Hazardous Waste Numbers } \\
\hline 806 & Solidified Process Solids & D004-D011, F001, F002, F003, and F005 \\
823 & Cemented Miscellaneous Sludge & D004-D011, F001, F002, F003, and F005 \\
\hline
\end{tabular}




\subsubsection{Characteristic Waste.}

The materials in this waste group may exhibit a characteristic of hazardous waste as defined in 40 CFR 261, Subpart $C$ as as a toxic waste (40 CFR 261.24). The materials do not exhibit the characteristics of ignitability (40 CFR 261.21), corrosivity (40 CFR 261.22), or reactivity (40 CFR 261.23).

Ignitability: The materials in this waste group do not meet the definition of ignitability as defined in 40 CFR 261.21. The material is not a liquid, and liquids were not normally associated with this waste. ${ }^{\mathrm{P}}{ }^{16}$ The wastes were inspected before placement in a drum to ensure there was no free liquid. ${ }^{\mathrm{P} 00 \mathrm{I}}$ The material is not capable of causing fire through friction, absorption of moisture, or spontaneous chemical change. The absence of pyrophoric materials was verified by the generating supervisor and periodic inspection. ${ }^{\mathrm{P} 016}$ In addition, pyrophoric materials would be rendered innocuous by the solidified cement matrix of this waste. ${ }^{\text {P0o1 }}$ The material is not a compressed gas, and compressed gases were prohibited by procedural control. The absence of compressed gases was verified by the generating supervisor, periodic inspection, and RTR examination. ${ }^{\text {P001.PO16 }}$ The material is not a DOT oxidizer as defined in 49 CFR 173. The materials in this waste group are therefore not ignitable wastes (D001).

Corrosivity: The materials in this waste group do not meet the definition of corrosivity as defined in 40 CFR 261.22. The material is not a liquid, and liquids were not normally associated with this waste. ${ }^{\text {P016 }}$ The wastes were inspected before placement in a drum to ensure there was no free liquid. ${ }^{\mathrm{P} 001}$ The materials in this waste group are therefore not corrosive wastes (D002).

Reactivity: The materials in this waste group do not meet the definition of reactivity as defined in 40 CFR 261.23. The materials are stable and will not undergo violent chemical change. The materials will not react violently with water, form potentially explosive mixtures with water, or generate toxic gases, vapors, or fumes when mixed with water. The materials do not contain cyanides or sulfides, and are not capable of detonation or explosive reaction. The materials are not forbidden explosives or Division $1.1,1.2$, or 1.3 (Class A or B) explosives as defined in 49 CFR 173, nor do the drums contain explosive materials. ${ }^{\text {P001,P016 }}$ Explosives were not handled or used around radioactive material. Reactive materials would be rendered innocuous by the solidified cement matrix of this waste. ${ }^{\mathrm{P} 001}$ The materials in this waste group are therefore not reactive wastes $(\mathrm{D} 003)$.

Toxicity: The materials in this waste group may meet the definition of toxicity as defined in 40 CFR 261.24. The toxicity characteristic contaminants fall into one of two categories: metals and organics. Organic compounds include halogenated- and nonhalogenated-solvents, pesticides, herbicides, and other toxic compounds. This waste group may exhibit the characteristic of toxicity for arsenic, barium, cadmium, chromium, lead, mercury, selenium, and silver metals.

The wastes that were cemented may have been contaminated with any of the toxicity characteristic metals. The purpose of the immobilization was to meet the particulate requirements for waste certification. It is uncertain if immobilization of these wastes removed the toxicity characteristic. Therefore, materials in this waste group are assigned EPA Hazardous Waste Numbers D004-D011. A representative sample of this waste will be obtained for verification purposes.

There is no documentation indicating the presence or use of pesticides or herbicides in the areas or processes generating the wastes that were cemented by this process, nor were they used in the cementation 
process. Therefore, this waste group does not exhibit the characteristic of toxicity due to pesticides or herbicides (D012-D017).

The immobilized wastes may have been contaminated with organic compounds, such as tetrachloroethene, trichloroethene, carbon tetrachloride, and methyl ethyl ketone, which were commonly used at Rocky Flats. ${ }^{\text {P023.P053 }}$ However, since these compounds were typically used as solvents, the waste is regulated as a listed hazardous waste and not a characteristic waste because these compounds are specifically addressed in the treatment standards for the listed hazardous waste. ${ }^{\mathrm{P} 80}$ Since miscellaneous cemented wastes are listed hazardous wastes due to the presence of spent solvents, the waste is not a toxic waste due to the presence of these organic compounds.

\subsubsection{Listed Hazardous Waste.}

The material in this waste group may have been mixed with a waste listed in 40 CFR 261, Subpart $D$ as a hazardous waste from non-specific sources (40 CFR 261.31). The waste is not, or was not mixed with, a hazardous waste from specific sources (40 CFR 261.32), or a discarded commercial chemical product, an off-specification species, a container residue, or a spill residue thereof (40 CFR 261.33).

Tetrachloroethene, trichloroethene, 1,1,1-trichloroethane, and carbon tetrachloride were used commonly for cleaning and degreasing. Methylene chloride was used primarily for paint removal. ${ }^{\text {P023,P053 }}$ The wastes immobilized by the cementation process may have been contaminated with these spent solvents. Miscellaneous cemented wastes were derived from the treatment of a listed hazardous waste and therefore, are assigned EPA Hazardous Waste Numbers F001 and F002.

Acetone, methanol, and xylene were common solvents used at Rocky Flats. The wastes immobilized by the cementation process may have been contaminated with these spent solvents. Miscellaneous cemented wastes were derived from the treatment of a listed hazardous waste and therefore, are assigned EPA Hazardous Waste Number F003.

There is no documentation indicating the presence or use of F004-listed solvents in the areas or processes generating the wastes immobilized by the cementation process, nor were these solvents used in the cementation process. Therefore, this waste group is not a F004-listed hazardous waste.

Toluene and methyl ethyl ketone were common solvents used at Rocky Flats. The wastes immobilized by the cementation process may have been contaminated with these spent solvents. Miscellaneous cemented wastes were derived from the treatment of a listed hazardous waste and therefore, are assigned EPA Hazardous Waste Number F005.

The material in this waste group is not a hazardous waste from specific sources since it was not generated from any of the processes listed in 40 CFR 261.32. The material in this waste group is therefore not a K-listed hazardous waste.

The material in this waste group is not a discarded commercial chemical product, an off-specification species, a container residue, or a spill residue thereof (40 CFR 261.33). The material in this waste group is therefore not a P- or U-listed hazardous waste. 


\subsubsection{Radionuclides}

Radionuclide contamination in IDC 806/823 is based on the generating process for the wastes that were immobilized. Several of the wastes, such as graphite (IDCs 310 and 311 ), grit (IDC 372), resin (IDC 431), and sand, slag, and crucible (IDCs 387 and 390-399) will be contaminated primarily with weapons-grade plutonium. Building 771 incinerator wastes (IDCs 292, 373, 378, and 420-423) and pyrochemical salts (IDC 413) may be contaminated with weapons-grade plutonium, americium-241, and enriched uranium. A more detailed description of the processes generating these wastes is provided in Sections 12.0, 13.0, 14.0, 18.0, 20.0 , and 21.0 .

Additionally, a single drum of IDC 806 was generated by hydride operations (prefix 55) in Building 779. The hydriding process recovered plutonium from various substrates. ${ }^{\text {P062,P163,U059 }}$ These processes produced plutonium metal for use in the foundry or non-specification feed to pyrochemical operations, in addition to plutonium oxides sent for aqueous recovery. ${ }^{\text {P062,P163 }}$

The Size Reduction Vault in Building 776 conducted repackaging in an airlock (prefix 25) ${ }^{\text {P078,U059 }}$ The repacked containers could have been generated from any of the processes that generated miscellaneous cemented wastes. $^{\mathrm{P} 078}$

Table 17-4. Waste Matrix Evaluation.

\begin{tabular}{|c|c|}
\hline Parameter & Results of Evaluation \\
\hline $\begin{array}{l}\text { Radionuclide Form, } \\
\text { Particle Size, and } \\
\text { Distribution }\end{array}$ & $\begin{array}{l}\text { Radionuclide contaminants may be in several forms. As specified in Table 17- } \\
2 \text {, screenings from oxide and fluoride sludge are two of the wastes that may } \\
\text { have been solidified. Actinide metals and oxides may be present from sand, } \\
\text { slag, and crucible (see Section } 21.0 \text { ), hydroxides, oxides, and chlorides from } \\
\text { incinerator wastes (see Section } 14.0 \text { ), and nitrates and chlorides from ion } \\
\text { exchange resins (see Section } 20.0 \text { ). Distribution of actinides should be } \\
\text { relatively well distributed throughout the waste, based on the cementing } \\
\text { procedure. }\end{array}$ \\
\hline Hydrogen Content & $\begin{array}{l}\text { Each solidified "puck" contains } 600 \mathrm{ml} \text { of water. }{ }^{\mathrm{P} 098} \text { Hydrocarbons may be } \\
\text { present due to oily sludge (IDC } 332 \text { ) and resin (IDC } 431 \text { ) and as contaminants } \\
\text { in other wastes that were cemented (see Table 17-2). }\end{array}$ \\
\hline $\begin{array}{l}\text { Other Interfering Waste } \\
\text { Contaminants }\end{array}$ & $\begin{array}{l}\text { Other interferences may include fluoride sludge (see Table 17-2), graphite (see } \\
\text { Section 12.0), aluminum oxide grit and firebrick (see Sections } 13.0 \text { and 14.0), } \\
\text { magnesium oxide sand and crucible, and calcium fluoride slag (see Section } \\
21.0 \text { ). }\end{array}$ \\
\hline $\begin{array}{l}\text { Physical Matrix } \\
\text { Parameters }\end{array}$ & $\begin{array}{l}\text { Distribution of waste and waste contaminants should be relatively well } \\
\text { distributed throughout the waste, based on the cementing procedure. }\end{array}$ \\
\hline
\end{tabular}




\subsubsection{Complexing Agents}

Because complexing agents can aid in the transport of transuranic radionuclides from the waste after disposal, the waste was assessed for potential complexing agents. This information may also be added to the chemical compatibility studies since limited information was available on these chemicals in the past.

EDTA represents a group of chelating compounds, such as ethenediaminetetraacetic acid, with similar molecular structures found in many soaps and detergents. Versene (a trade name for EDTA) and citric acid are known constituents of $\mathrm{KW}$ decontamination detergent. ${ }^{\mathrm{P} 24, \mathrm{P} 068} \mathrm{KW}$ was used during a variety of decontamination activities at the plant. Wastes fed to the recovery incinerator may have contained EDTA (See Section 14.0). Aluminum nitrate was used as a fluoride complexing agent for leaching of materials including graphite, incinerator ash, and sand, slag, and crucible wastes. ${ }^{\text {061 }}$ Therefore, trace quantities of these compounds may be present in miscellaneous cemented wastes. 


\subsection{PYROCHEMICAL WASTE}

This waste group includes spent salts and zinc-magnesium alloy metal generated by production and experimental pyrochemical operations used to recover and purify plutonium metal. The salts were generated by molten salt extraction, direct oxide reduction, and electrorefining processes in Buildings 371, 776, and 779. ${ }^{\text {P038 }}$ The zinc magnesium metal (one drum) was generated by an experimental salt cleanup project in Building 779. ${ }^{\text {P24.P127,U059 }}$ Historic IDC descriptions and dates of generation for the INEEL accessible storage inventory are presented by IDC in Table $18-1 .^{\text {P127 }}$

Table 18-1. Pyrochemical Waste in the Accessible Storage Inventory.

\begin{tabular}{cll}
\hline IDC & \multicolumn{1}{c}{ Title } & \multicolumn{1}{c}{ Dates of Generation } \\
\hline 409 & Molten Salt-30\% Unpulverized $^{\mathrm{P} 038}$ & September 1982-January 1986 \\
411 & $\begin{array}{l}\text { Electrorefining Salt } \\
\text { Electrorefining Salt, Final Disposition }^{\mathrm{P} 001}\end{array}$ & April 1982-August 1986 \\
412 & Gibson Salts $^{\mathrm{P} 12}$ & August 1980 \\
414 & $\begin{array}{l}\text { Direct Oxide Reduction Salt } \\
\text { Direct Oxide Reduction Salt-Unoxidized Ca }\end{array}$ & May 1982-August 1985 \\
416 & $\begin{array}{l}\text { Zinc Magnesium Alloy } \\
\text { Zinc }\end{array}$ & June 1980 \\
\hline
\end{tabular}

Item Description Code 409, Molten Salt-30\% Unpulverized: This waste consists of spent salt generated by the molten salt extraction process used to extract americium contamination from plutonium metal. The MSE process that generated IDC 409 used a 30 mole percent of magnesium chloride salt during the extraction. The spent salt is composed primarily of sodium chloride, potassium chloride, residual magnesium chloride, entrained magnesium metal, and various plutonium and americium compounds. IDC 409 consists of unpulverized fused chunks of salt. ${ }^{\mathrm{P} 38, \mathrm{P} 139}$

Item Description Code 411, Electrorefining Salt: This waste consists of spent salt generated by electrorefining operations used to purify plutonium metal that did not meet foundry specifications. The salt is composed primarily of sodium chloride, potassium chloride, magnesium chloride, entrained magnesium metal, and various plutonium coumpounds. ${ }^{\mathrm{P} 139}$ The salt is a mixture of chunks, granular, and fine particles. ${ }^{\mathrm{P} 038}$ This salt may also contain sodium and potassium metal produced during electrolysis of the molten salt mixture. ${ }^{\text {P052,P139 }}$

Item Description Code 412, Gibson Salts: This waste consists of a single drum of spent salt generated by an experimental pyroredox process that was being developed to extract impurities from plutonium metal. The salt is composed primarily of sodium chloride, potassium chloride, calcium chloride, zinc chloride, entrained zinc and calcium metal, and various plutonium and americium compounds. ${ }^{\mathrm{P} 139}$ The dry, fused salt chunks may also contain sodium and potassium metal resulting from the reduction of sodium chloride and magnesium chloride by the excess calcium metal. ${ }^{\mathrm{P} 038, \mathrm{P} 139}$ 
Item Description Code 414, Direct Oxide Reduction Salt: This waste consists of spent salt generated by the direct oxide reduction process used to reduce plutonium oxide to plutonium metal buttons. The salt is composed primarily of calcium chloride, calcium oxide, entrained calcium metal, calcium metal buttons, and various plutonium compounds. ${ }^{\mathrm{P} 39}$ The salt is in the form of chunks and fines. ${ }^{\mathrm{P} 38}$

Item Description Code 416, Zinc-Magnesium Alloy Metal: This waste consists of single drum of metal billets or ingots generated by a research and development project being developed to cleanup pyrochemical salts. The weight percent of magnesium in the alloy ranged from 10 to 30 percent. ${ }^{\text {P052 }}$ This IDC was generated during pyroredox development efforts and could consist of zinc/magnesium, calcium/magnesium/zinc, or calcium/zinc alloy. ${ }^{\mathrm{C} 182}$

\subsection{Waste Generation}

Pyrochemical wastes were generated by molten salt processes associated with plutonium recovery and purification operations in Buildings 371, 776, and 779. With the exception of a drum of zinc-magnesium alloy (IDC 416), the pyrochemical waste consists of spent salts used during molten salt extraction, electrorefining, and direct oxide reduction operations. Electrorefining was conducted in Buildings 371, 776, and 779. Molten salt extraction and direct oxide reduction were performed in Building 776 . Building 779 supported technology development and experimental scale operations for the pyrochemical processes. ${ }^{\mathrm{P}}{ }^{2} 8 \mathrm{P}$ The zinc-magnesium alloy was generated in Building 779 during an experimental salt cleanup project. ${ }^{\text {P052,P127 }}$

\subsubsection{Molten Salt Extraction}

Molten salt extraction technology was used to remove americium from salvaged plutonium metal. The process that generated IDC 409 was primarily conducted in the twelve stationary furnaces in Building 776. However, these salts were also generated by experimental operations in Building $779 .{ }^{\mathrm{P} 038}$

Plutonium metal containing unacceptable levels of americium was combined with an equimolar mixture of sodium chloride and potassium chloride with magnesium chloride. The metal and salts were placed in a tantalum crucible. The crucible and contents were placed in a furnace and heated until the mixture was molten. The molten salt and metals were then mixed by stirring. While in the molten state, the magnesium chloride oxidized most of the americium and some of the plutonium. The oxidized actinides migrated from the metal to the salt phase. As the mixture cooled, the extremely dense plutonium metal separated from the salt and settled at the bottom of the crucible. The metal and salt were removed from the crucible and separated. Depending on the purity of the plutonium, it was either sent to the foundry or it was further purified in the electrorefining process. ${ }^{\text {P139 }}$ The spent salt (IDC 409) was sent to Building 771 for plutonium assay. Salt above the EDL was stored on site for recovery. Drums of waste salt below the EDL were sent to Building 776 for inspection and sealing. ${ }^{\mathrm{P} 24}$

\subsubsection{Electrorefining}

Electrorefining was used to purify plutonium metal from molten salt extraction and other recovery operations that did not meet foundry specifications. The processes that generated IDC 411 were conducted in the tilt-pour furnaces in Building 371 and the stationary furnaces in Buildings 776 and $779 .{ }^{038}$ 
Non-specification plutonium metal, cast as an anode, was combined with magnesium chloride and an equimolar mixture of sodium chloride and potassium chloride in a magnesium oxide crucible. The crucible and contents were heated in a furnace until the mixture was molten. A cathode and an anode/stirrer were then lowered into the molten mixture. A current was applied to the anode/stirrer which flowed through the mixture to the cathode. Plutonium ions migrated through the salt to the cathode and were reduced to purified metal. After the cathode and anode were removed, the crucible was allowed to cool before it was removed from the furnace. The crucible was broken and the purified plutonium metal was separated from the salt and anode heel. The plutonium was analyzed then sent to the foundry for production. ${ }^{\mathrm{P} 139}$. The spent salt was sent to Building 771 for plutonium assay. Salt above the EDL was stored on site for recovery. Drums of waste salt below the EDL were sent to Building 776 for inspection and sealing. ${ }^{\mathrm{P} 24}$

\subsubsection{Direct Oxide Reduction}

Direct oxide reduction technology was developed to reduce plutonium oxide to metal. The process that generated IDC 414 was conducted on a production scale in Building 776 and development work was done in Building 779. ${ }^{\mathrm{P} 38}$

Calcined plutonium oxide was placed into a magnesium-oxide crucible with calcium chloride and calcium metal. The crucible and contents was placed in a furnace and heated until the contents were molten. The molten mixture was stirred until the reduction was complete. After the mixture cooled, the contents were removed and the plutonium metal was separated from the salt phase. Depending on the purity of the plutonium, it was either sent to the foundry or it was further purified in the electrorefining process. ${ }^{\text {P139 }}$ The spent salt was sent to the in-line can counter for plutonium assay. Salt above the EDL was stored for recovery. Drums of waste salt below the EDL were sent to Building 776 for inspection and sealing. ${ }^{\text {P24 }}$

\subsubsection{Pyroredox}

Gibson salts (IDC 412) and zinc-magnesium alloy (IDC 416) were generated during a pyroredox process development effort in Building 779 in the late 1970s. ${ }^{\text {P038,P052 }}$ In general, the pyroredox process was a three-step process to purify plutonium. The first step involved the oxidation of impure plutonium in a calcium chloride/potassium chloride molten salt matrix using zinc chloride as the oxidant. Plutonium metal was reduced out of the resulting plutonium rich salt using calcium metal. The remaining salt was assigned IDC 412 . The reduced plutonium contained impurities such as calcium and zinc. A calcium/zinc alloy (IDC 416) was produced when these metals were volatilized and condensed from the plutonium. Different feed materials or reductants (i.e. magnesium) would also produce zinc/magnesium or calcium/magnesium/zinc alloys assigned IDC $416^{\mathrm{C} 182, \mathrm{C} 187}$

\subsection{Waste Packaging}

A variety of container and liner configurations were used to package pyrochemical wastes. In general, the salts were placed directly into stainless steel cans or produce cans with rolled seam lids. ${ }^{\text {P001,P038 }}$ Electrorefining salts were also placed in one-gallon paint cans wrapped in lead. Direct oxide reduction salts may be contained in 4-liter Nalgene bottles. The individual packages were assayed by the in-line can counter to determine if the salt was above or below the EDL. ${ }^{\mathrm{P} 001}$ The container was then double-bagged and removed from the glovebox line or placed in another stainless steel can that was double bagged and remove from the glovebox. ${ }^{\mathrm{P} 12}$ Packages removed from the glovebox were either placed into another package such as lead-lined 
Fiber-Paks ${ }^{\mathrm{P} 015}$, stainless steel containers ${ }^{\mathrm{P} 024}$, or Process Residue Containers (clamshells) ${ }^{\mathrm{U} 061}$ or placed directly into prepared drums. ${ }^{\mathrm{P} 12}$

Depending on waste packaging requirements at the time, several combinations of bags and liners were used to prepare 55-gallon drums for shipment. A 90-mil rigid polyethylene liner was placed in each drum and lined with one polyethylene round bottom drum liner or two polyethylene drum bags. A PVC O-ring bag and a polyethylene bag were used if the drum was attached to the glovebox. ${ }^{\mathrm{P} 016} \mathrm{~A}$ fiberboard liner and discs may also have been used between the waste packages and the drum liners. When a drum was full, the drum liners were twisted and taped closed, the lid was secured with a bolted ring, and a tamper indicating device was attached to the drum. ${ }^{\mathrm{P} 038}$

After drums were inspected, one to two quarts of absorbent material (Oil-Dri) was placed on top of the outer, sealed polyethylene drum bag. This procedure was changed in February 1982 when vermiculite was used to fill the space between the outer, sealed polyethylene drum bag and the top of the 90 -mil rigid liner. The quantity of vermiculite varied from 3-12 pounds according to the amount of waste contained in each drum. ${ }^{\text {P024 }}$

Waste management and inspection protocol allowed containers of wastes to contain up to 10 percent of another IDC other than that assigned to the container ${ }^{\mathrm{P} 16}$ Visual inspection of a drum of direct oxide reduction salt (IDC 414) identified ceramic items in the packages. ${ }^{\mathrm{P} 15}$

\subsection{Waste Characterization}

Pyrochemical wastes have been characterized based on knowledge of the material, knowledge of the processes generating the waste, visual inspection, sampling and analysis, and headspace gas analysis. This section provides a RCRA hazardous waste determination for pyrochemical wastes as well as radionuclide contaminants and potential complexing agents contained in the waste. Zinc magnesium alloy (IDC 416) contains an estimated 80 percent or more (by volume), metal debris material that meet the EPA LDR criteria for classification as debris, and is classified as a heterogeneous waste. Pyrochemical salts (IDCs 409, 411, 412 , and 414 ) contain at least 50 percent (by volume) salts, and are classified as homogeneous wastes. ${ }^{\text {P141 }}$

\subsubsection{Hazardous Waste Determination}

The material in this waste group does not qualify for any of the exclusions outlined in 40 CFR 260 or 261. Pyrochemical wastes were not mixed with a listed waste, nor does the waste exhibit a characteristic of hazardous waste. EPA Hazardous Waste Numbers applicable to some or all of the pyrochemical waste group are presented by IDC in Table 18-2. These conclusions are supported by the evaluation in Sections 18.3.1.1 and 18.3.1.2.

The characterization of pyrochemical salts has changed dramatically over the years. Many of the pyrochemical salts were initially determined to be hazardous for the characteristics of corrosivity (D002), reactivity (D003), and toxicity for chromium (D007). Due to numerous waste and surrogate sampling activities, studies, and regulatory interpretations, it was determined that the pyrochemical salts do not exhibit any characteristics of hazardous waste. ${ }^{\text {C117,C119,P139,U062 }}$ 
Table 18-2. Pyrochemical Waste Characterization.

\begin{tabular}{cll}
\hline IDC & \multicolumn{1}{c}{ Title } & EPA Hazardous Waste Numbers \\
\hline 409 & Molten Salt-30\% Unpulverized & None \\
411 & Electrorefining Salt & None \\
412 & Gibson Salts & None \\
414 & Direct Oxide Reduction Salt & None \\
416 & Zinc Magnesium Alloy & None \\
\hline
\end{tabular}

\subsubsection{Characteristic Waste}

The materials in this waste group do not exhibit a characteristic of hazardous waste as defined in 40 CFR 261, Subpart C as an ignitable waste (40 CFR 261.21), a corrosive waste (40 CFR 261.22), a reactive waste (40 CFR 261.23), or a toxic waste (40 CFR 261.24).

Ignitability: The material in this waste group does not meet the definition of ignitability as defined in 40 CFR 261.21. The material was generated in furnaces during molten salt recovery and purification operations and packaged in a dry environment. The material is dry when packaged and does not contain free liquids. ${ }^{\mathrm{P} 24}$ The absence of free liquids has been confirmed by RTR and visual examination of the packages. ${ }^{\mathrm{P} 12, \mathrm{PO} 15, \mathrm{P} 021}$ Due to the hygroscopic nature of some of the salts, it is possible that free liquids could form by absorption of moisture from the atmosphere. ${ }^{\text {P140 }}$ Even if this was to occur, the liquid formed would be aqueous and not ignitible, and the reaction with metals such as sodium and calcium entrained in the salt would not be violent or rapid. ${ }^{\mathrm{P} 052}$ The material is not capable of causing fire through friction or spontaneous chemical change. The material is not a compressed gas, and inspections will be performed to certify that the drums do not contain compressed gases. The material is not a DOT oxidizer as defined in 49 CFR 173 . The materials in this waste group are therefore not ignitable wastes (D001).

Corrosivity: The materials in this waste group do not meet the definition of corrosivity as defined in 40 CFR 261.22. The material is dry when packaged and does not contain free liquids. ${ }^{\mathrm{P} 24}$ The absence of free liquids has been confirmed by RTR and visual examination of the packages. ${ }^{\text {P012,P015,P021 }}$ Gibson salts (IDC 412) contain hygroscopic calcium chloride and zinc chloride salts. As a result, these salts have the potential of producing free liquid. Testing has demonstrated that the $\mathrm{pH}$ of a surrogate sample composed of a saturated solution containing these chloride salts was greater than 3 . In addition, results of corrosion testing on stainless steel were less than 0.25 inches per year. ${ }^{\text {P052, } \mathrm{Cl} 17}$ The materials in this waste group are therefore not corrosive wastes (D002). ${ }^{\mathrm{C} 119}$

Reactivity: The materials in this waste group are stable and will not undergo violent chemical change. The salts in this waste group may contain sodium, calcium, magnesium, zinc, and potassium metals. These metals all react with water to a varying degree; however, based on analytical data and regulatory interpretations by the Colorado Department of Public Health and Environment (CDPHE), the metals do not meet the definition of reactivity as defined in 40 CFR 261.23. Testing has demonstrated that the reaction of the pyrochemical salts in water is not violent or rapid. ${ }^{\mathrm{P} 139, \mathrm{P} 052, \mathrm{P} 140}$ Even though the reaction of salts containing calcium (IDC 414) in water may be more significant than other pyrochemical salts, CDPHE has clearly stated that the salts do not 
exhibit the RCRA characteristic of reactivitiy. ${ }^{\mathrm{Cl1}}$ The material does not contain cyanides or sulfides and is not capable of detonation. The material is not a forbidden explosive or a Division 1.1, 1.2, or 1.3 (Class A or B) explosive as defined in 49 CFR 173. Explosives were not handled or used around radioactive material. The absence of explosives and compressed gases was verified by the generating supervisor and periodically inspectections. ${ }^{\mathrm{P} 16, \mathrm{C} 119}$ The materials in this waste group are therefore not reactive wastes (D003)

Toxicity: The materials in this waste group do not meet the definition of toxicity as defined in 40 CFR 261.24. The toxicity characteristic contaminants fall into one of two categories: metals and organics. Organic compounds include halogenated- and nonhalogenated-solvents, pesticides, herbicides, and other toxic compounds.

There is no documentation indicating that this waste group came into contact with any of the toxicity characteristic metals except for chromium, which was a contaminant of the plutonium metal. Thermodynamic calculations performed at Rocky Flats concluded that chromium would be present at insignificant concentrations in the salts, because the chromium alloyed with the plutonium which was removed from the salt after the pyrochemical reactions. ${ }^{\text {P052,U062.C119 }}$

There is no documentation indicating the presence or use of pesticides or herbicides in the areas or processes generating pyrochemical wastes. Therefore, this waste group does not exhibit the characteristic of toxicity due to pesticides or herbicides (D012-D017).

Carbon tetrachloride was used for cleaning the glovebox lines used for pyrochemical operations, but was not used in the process generating pyrochemical wastes. ${ }^{\mathrm{C} 123}$ Carbon tetrachloride was detected in the headspace of drums containing molten salt extraction (IDC 409) and direct oxide reduction (IDC 414) spent salts. ${ }^{\text {P033 }}$ However, the waste should not contain toxicity characteristic levels of carbon tetrachloride since it was used only for glovebox cleaning and not in pyrochemical operations. There is no documentation indicating the presence or use of any other toxicity characteristic organics in the areas or processes generating pyrochemical wastes. Therefore, this waste group does not exhibit the characteristic of toxicity due to organics (D018-D043).

\subsubsection{Listed Hazardous Waste}

The material in this waste group is not, or was not mixed with, a waste listed in 40 CFR 261, Subpart D as a hazardous waste from non-specific sources (40 CFR 261.31), as a hazardous waste from specific sources (40 CFR 261.32), or as a discarded commercial chemical product, an off-specification species, a container residue, or a spill residue thereof (40 CFR 261.33).

Carbon tetrachloride and 1,1,1-trichloroethane were used for cleaning the glovebox lines used for pyrochemical operations, but were not used in the process generating pyrochemical wastes. ${ }^{\mathrm{C} 123}$ Carbon tetrachloride and 1,1,1-trichloroethane were detected in the headspace of drums containing molten salt extraction (IDC 409) and direct oxide reduction (IDC 414) spent salts. ${ }^{\text {P033 }}$ However, since these compounds were used only for glovebox cleaning and not in pyrochemical operations, pyrochemical wastes are not F001or F002-listed wastes.

There is no documentation indicating the use of any other F-listed solvents in the areas or processes generating pyrochemical wastes. Therefore, this waste group is not a F003-, F004-, or F005-listed waste. 
Although pyrochemical wastes are not F-listed hazardous wastes, headspace analysis performed on samples of pyrochemical salts (IDCs 409,411 , and 414) obtained at INEEL indicates the presence of organic solvents. The detected compounds in which the 90 percent UCL is above the PRQL are provided. ${ }^{\text {P033 }}$

- 1,1,1-trichloroethane (IDCs 409 and 414 only)

- $\quad$ carbon tetrachloride (IDC 414 only)

The material in this waste group is not a hazardous waste from specific sources since it was not generated from any of the processes listed in 40 CFR 261.32. The material in this waste group is therefore not a K-listed hazardous waste.

The material in this waste group is not a discarded commercial chemical product, an off-specification species, a container residue, or a spill residue thereof (40 CFR 261.33). The material in this waste group is therefore not a P-or U-listed hazardous waste.

\subsubsection{Radionuclides}

This section identifies the radioisotopes potentially contained in the waste. In addition, Table 18-3 summarizes matrix and other physical parameters which could affect radioassay.

The MSE process removed the americium-241 decay product from site-return metal and other nonspecification plutonium. ${ }^{\text {P163 }}$ Mass balance calculations for MSE residues (IDC 409) estimate these salts contain 22.6 percent plutonium, $46,400 \mathrm{ppm}$ americium, and $200 \mathrm{ppm}$ uranium. ${ }^{\mathrm{P} 175}$ The composition of sitereturn metal and the isotopic make-up of weapons-grade plutonium and enriched uranium are provided in Section 3.0.

The electrorefining process purified plutonium metal from MSE or other operations for use in the foundry. ${ }^{\text {P163 }}$ Mass balance calculations for electrorefining residues (IDC 411) estimate these salts contain 10 percent plutonium, $66.5 \mathrm{ppm}$ americium, and $617 \mathrm{ppm}$ uranium. ${ }^{\mathrm{P} 175}$

The direct oxide reduction process produced plutonium metal directly from foundry generated plutonium oxide and, therefore, will only contain impurity levels of americium and uranium. ${ }^{\text {P163 }}$ Mass balance calculations for direct oxide reduction residues (IDC 414) estimate these salts contain 4,540 ppm plutonium, $10.1 \mathrm{ppm}$ americium, and $1.1 \mathrm{ppm}$ uranium. ${ }^{\mathrm{P} 175}$

The experimental pyroredox process was for purification of plutonium metal from MSE residues or other sources of impure plutonium metal. Since MSE residue salts were one of the possible feed sources to this process, the Gibson salts (IDC 412) and magnesium/zinc alloy (IDC 416) may contain plutonium, americium, and uranium. ${ }^{\mathrm{Cl} 22}$ The levels of americium and uranium are possible present as impurities only. In addition, impurity levels of neptunium may also be present. ${ }^{\mathrm{P} 35}$ 
Table 18-3. Waste Matrix Evaluation.

\begin{tabular}{|c|c|}
\hline Parameter & Results of Evaluation \\
\hline \multirow[t]{2}{*}{$\begin{array}{l}\text { Radionuclide Form, } \\
\text { Particle Size, and } \\
\text { Distribution }\end{array}$} & $\begin{array}{l}\text { IDC 409: Primarily plutonium chloride and americium chloride with trace } \\
\text { amounts of uranium chloride. }{ }^{\mathrm{P} 75} \text { Plutonium metal beads ranging from } 0.1 \text { to } \\
1.0 \text { millimeters have been observed in the salts. }{ }^{\mathrm{P} 140}\end{array}$ \\
\hline & $\begin{array}{l}\text { IDC 411: Primarily plutonium chloride and plutonium metal with trace } \\
\text { amounts of uranium metal and americium chloride. }{ }^{\mathrm{P} 175} \text { Trace amounts of } \\
\text { plutonium oxide, } \mathrm{PuOCl} \text {, and } \mathrm{K}_{2} \mathrm{PuCl}_{5} \text { have also been observed in samples of } \\
\text { the salts. }{ }^{\mathrm{C} 186, \mathrm{Cl} 77} \text { Plutonium metal beads ranging from } 0.1 \text { to } 1.0 \text { millimeters } \\
\text { have also been observed in the salts. }{ }^{\mathrm{P} 40}\end{array}$ \\
\hline
\end{tabular}

IDC 412: Gibson salt will contain plutonium chloride, and possibly americium chloride, uranium chloride, and neptunium chloride. ${ }^{\mathrm{P} 35}$

IDC 414: Primarily plutonium oxide with trace amounts of uranium oxide and americium oxide. ${ }^{\mathrm{P} 175}$ Plutonium metal beads ranging from 0.1 to 1.0 millimeters have been observed in the salts. ${ }^{\mathrm{P} 140}$

IDC 416: The chemical form should be metal since IDC 416 is a metal alloy.

Hydrogen Content The primary sources for hydrogen in pyrochemical salt waste include fiberboard, polyvinyl chloride, and polyethylene liners, bags, and bottles (see Section 18.2). In addition, trace amounts of hydrocarbons have been detected in waste samples and headspace gas samples. ${ }^{\mathrm{C} 87, \mathrm{P} 033}$ Based on studies conducted at Rocky Flats, the pyrochemical salts may hydrate from exposure to water in the atmosphere during processing or storage. The amount of this hydration will vary depending on IDC, time in storage, and the amount of plutonium in the salt. ${ }^{\mathrm{C} 178, \mathrm{C} 179}$ Observations from recent sampling activities indicate minimal weight gain that could be attributed to hydration during storage. ${ }^{\mathrm{Cl} 86}$

Other Interfering Waste Contaminants

IDC 409: Primarily sodium chloride and potassium chloride, residual magnesium chloride, and entrained magnesium metal. ${ }^{\mathrm{P} 39, \mathrm{P} 175}$

IDC 411: Primarily sodium chloride and potassium chloride, residual magnesium chloride and magnesium oxide (from crucibles), and entrained magnesium metal. ${ }^{\text {P139,C186,C187P175 }}$ Analyses of these salts detected trace amounts of chromium (below TCLP limits). ${ }^{\mathrm{C} 186, \mathrm{Cl} 187}$

IDC 412: Sodium chloride, potassium chloride, calcium chloride, and residual zinc chloride. ${ }^{\mathrm{C} 182, \mathrm{P} 139}$ May also contain chromium chloride and small amounts of aluminum. ${ }^{\mathrm{P} 035}$

IDC 414: Calcium chloride and magnesium oxide (from crucibles). ${ }^{\mathrm{P} 139, \mathrm{P} 175}$

IDC 416: $X$-ray diffraction analysis indicated a magnesium/zinc alloy and trace quantities of sodium chloride, potassium chloride, and magnesium oxide. Analysis also detected trace amounts of cadmium and chromium (below TCLP limits). ${ }^{\mathrm{C} 187}$ 


\begin{tabular}{ll}
\hline \multicolumn{1}{c}{ Parameter } & \multicolumn{1}{c}{ Results of Evaluation } \\
\hline Physical Matrix & IDC 409: Consists of dry, fused salts in the form of chunks and some \\
Parameters & dispersible fines. The particle sizes will not be evenly distributed. ${ }^{\text {P035 }}$ \\
IDC 411: Observed salt particle sizes ranging from greater than 6 inches to \\
very fine dispersible powder. The percentage of the different particle sizes \\
varied from drum to drum and will not be evenly distributed. ${ }^{\text {C187.P035 }}$ \\
IDC 412: Consists of dry, fused salts in the form of chunks and some \\
dispersible fines. The particle sizes will not be evenly distributed. ${ }^{\text {P038 }}$ \\
IDC 414: Consists of salts in the form of chunks and fines. The particle sizes \\
will not be evenly distributed. ${ }^{\text {P035 }}$. Large calcium metal beads may also be \\
present throughout the salt as well as the presence of a calcium button. ${ }^{\text {P139.P140 }}$ \\
IDC 416: Observed particle sizes ranged from powder, slivers, and chips to \\
large spherical chunks. ${ }^{\text {C187 }}$
\end{tabular}

\subsubsection{Complexing Agents}

Because complexing agents can aid in the transport of transuranic radionuclides from the waste after disposal, the waste was assessed for potential complexing agents. There is no documentation indicating the presence or use of complexing agents in the areas or processes generating pyrochemical wastes. 


\subsection{RASCHIG RINGS}

This waste group consists of Raschig rings generated by the production, recovery, laboratory, treatment, and maintenance activities associated with plutonium operations. The waste was generated in Buildings $371,559,707,771,776$, and 777. ${ }^{\mathrm{P} 024, \mathrm{P} 052, \mathrm{P} 076}$ Historic IDC descriptions and dates of generation for the INEEL accessible storage inventory are presented by IDC in Table 19-1. ${ }^{\mathrm{PI} 27}$

Table 19-1. Raschig Ring Waste in the Accessible Storage Inventory.

\begin{tabular}{rll}
\hline IDC & \multicolumn{1}{c}{ Title } & Dates of Generation \\
\hline 441 & Unleached Raschig Rings $^{\mathrm{P} 001}$ & April 1973-July 1986 \\
442 & Leached Raschig Rings $^{\mathrm{P001}}$ & April 1979-June 1988 \\
\hline
\end{tabular}

Item Description Code 441, Unleached Raschig Rings: This waste consists of Raschig rings which are borosilicate glass rings used to maintain subcritical conditions in fissile solution storage tanks that were not safe by dimension. The boron in the rings is a neutron poison, an element that absorbs neutrons. The volume of the ring displaces a proportionate volume of solution and, in combination with the boron, creates a critically safe configuration. When the rings were replaced, they were assayed. If the plutonium content was below the EDL, they were assigned IDC $441 .{ }^{\text {P0s2 }}$ In 1989 , IDC 443 was created for sorting of solventcontaminated Raschig rings from nonsolvent-contaminated Raschig rings. ${ }^{\mathrm{C} 69}$

Item Description Code 442, Leached Raschig Rings: This waste consists of Raschig rings (IDC 441) that were contaminated with plutonium above the EDL. ${ }^{\mathrm{P} 052}$ The rings were leached in nitric acid to remove the contamination and repackaged as IDC $442 .^{\text {P012 }}$

\subsection{Waste Generation}

Raschig rings were contained in tanks used by plutonium production, recovery, purification, and treatment operations at the site. Over time, Raschig rings would become broken or otherwise damaged and were replaced. The rings were also replaced if the assay of the tank exceeded acceptable limits. ${ }^{\text {P052 }}$

\subsubsection{Plutonium Production}

Plutonium production consisted of operations directly associated with the manufacturing of plutonium metal parts including casting, rolling, forming, machining, and assembly processes. Buildings 707 and 777 were the primary weapons components production facilities at the site after the construction of Building 707 in 1972. Building 707 was constructed after the 1969 fire in Building 776 which shut down foundry and machining operations in that building. ${ }^{\mathrm{P} 053}$

The foundry in Building 707 cast molten plutonium into classified components, subassemblies, and assemblies. Other parts were manufactured by rolling, forming, and machining plutonium ingots also cast in the foundry. Components were assembled using a number of welding and joining techniques in Buildings 707, 777, and 779. Production support operations in Buildings 707 and 777 included a variety of inspection, calibration, measurement, weighing, leak testing, and cleaning activities to assure that the parts met stringent 
specifications. Rejected plutonium parts, scraps, and turnings were returned to be recast. Small pieces of metal, fines, and sweepings were typically burned to oxide and sent to Building 771 to be recovered. ${ }^{\text {Pos } 2}$

Halogenated solvents were used in production operations to clean and degrease plutonium parts and metal. In addition, the solvents were used with cutting oils to cool plutonium parts during machining. At one time, Raschig ring-filled storage tanks in Building 707 were used to collect 1,1,1-trichloroethane and carbon tetrachloride. The carbon tetrachloride also contained Freon and various oils. These organic liquids were sent to Building 777 to be filtered. ${ }^{\text {035,P060 }}$

Building 777 contained two organic solvent collection and filtration systems which used Raschig ringfilled tanks. The carbon tetrachloride system collected, filtered, and distributed waste carbon tetrachloride for eventual treatment in Building 774, and employed three Raschig ring-filled tanks. Other contaminates which could be in the system included Freon TF (1,1,2-trichloro-1,2,2-trifluoroethane), coolant oils, vacuum pump oil, and sight gauge oil. The 1,1,1-trichloroethane filtration system collected and filtered 1,1,1-trichloroethane from several ultrasonic wash tanks and employed two Raschig ring-filled tanks. ${ }^{\text {P052,P079 }}$

\subsubsection{Plutonium Recovery and Purification}

Several operations at the plant were responsible for either the purification of non-specification plutonium metal or the recovery of plutonium from production waste and residues. Building 771 housed operations that recovered plutonium from waste materials and other sources. ${ }^{\text {P053 }}$ Plutonium purification was performed primarily in Buildings $371,771,776$, and $779 .{ }^{\text {P052 }}$

Recovery operations in Building 771 used acid to dissolve solid materials containing plutonium. The resulting solutions were processed by a series of ion exchange, precipitation, calcination, fluorination, and reduction operations to produce purified plutonium metal to be recycled back into production operations. Potassium hydroxide, potassium fluoride, hydrogen peroxide, and nitric, hydrochloric, and hydrofluoric acids were the primary reagents used for plutonium recovery operations. ${ }^{\text {P053,P061,P067,U047 Raschig ring-filled tanks }}$ containing acid or caustic were used in these processes. ${ }^{\text {P052 }}$

\subsubsection{Waste Treatment}

Operations in Building 771 processed wastes including Raschig rings, HEPA filters, and sludges from the filter plenum and from process piping. Until 1984, plutonium was recovered from Raschig rings by acid

leaching. ${ }^{\text {P61 }}$ Raschig rings containing plutonium above the EDL were leached with hot nitric acid. After leaching, the rings were rinsed with water and air-dried before packaging. ${ }^{\text {P016 }}$

Size reduction in Building 776 removed materials from drums and sorted them in an airlock vault. Materials such as light metals, filters, glass, combustibles, and Raschig rings were then put into containers with like materials. Water and KW detergent were used to wash the vault floor. The waste water was filtered and then stored in Raschig ring-filled tanks in Building 776 for eventual treatment. ${ }^{\text {P052.P078 }}$

\subsubsection{Laboratory}

Building 559 housed the Plutonium Analytical Laboratory responsible for spectrochemical, chemical, and mass spectrometric analyses of samples from plutonium production operations. Uranium, Raschig rings, solutions, and commercial product and gas samples were also analyzed in the laboratory. Plutonium 
production samples, including metal and oxide, were prepared and subdivided for analysis in the sample cutting process. $^{\text {P067 }}$

New and used Raschig rings were tested at the Building 559 laboratory to ensure integrity and specification compliance. Used Raschig rings were removed as samples from various tanks and were typically contaminated with plutonium, uranium, and occasionally sludge. Neutron absorption, chemical resistance, and durability and strength tests were performed on the rings. Nitric acid and sodium hydroxide were used for chemical compatibility testing. The rings were rinsed and dried before disposal. ${ }^{\mathrm{P} 076}$

\subsubsection{Maintenance}

The majority of the Raschig ring waste was generated by changing out Raschig rings from production, recovery, purification, and waste treatment process tanks. Raschig ring change out was a routine maintenance operation in which rings were sampled, removed, and replaced.

Process tanks were inspected periodically and the rings were replaced if the assay of the tank exceeded acceptable limits. Change out would also occur when the Raschig rings reached the end of their useful life (about 5 years), or became broken or otherwise damaged. This was determined by sampling and analysis or by visual inspection. The Raschig rings were replaced when the sampling showed wall thinning in the rings due to corrosion, loss of boron in the rings, or buildup of solid material in the tank. Raschig rings were also replaced if rings could no longer be sampled. ${ }^{\mathrm{P} 014, \mathrm{P} 035, \mathrm{P} 052}$

During the change out process, the tank was drained and flushed with a compatible solution. For example, tanks containing nitric acid were flushed with nitric acid, tanks containing oil and carbon tetrachloride were flushed with carbon tetrachloride. ${ }^{\mathrm{P} 024}$

Raschig rings were also generated when Raschig ring tanks were removed and replaced with equipment which is safe by geometric design (e.g., annular tanks). ${ }^{\mathrm{P} 035}$

Utility systems include HVAC systems, fume scrubbers, and process vacuum systems. Scrubbers used potassium or sodium hydroxide to neutralize acid fumes from various process off-gas streams and glovebox exhaust streams. Process vacuum systems provide an absolute pressure at a vacuum header which serves as

a means to transfer fluids on demand by valving arrangements. Scrubber tanks and vacuum traps and receivers contained Raschig rings. ${ }^{\text {P052,P055 }}$

\subsection{Waste Packaging}

After removal from a tank, Raschig rings were contained in up to three polyvinyl chloride or polyethylene bags which were placed in a Fibre-Pak. ${ }^{\mathrm{P} 012, \mathrm{P} 024}$ Raschig rings were bagged out of the leaching glovebox line in two plastic bags and were also placed in a Fibre-Pak. Two Fibre-Paks were placed in a prepared 55-gallon drum. Raschig rings from the laboratory were broken into $1 / 4$-inch diameter fragments for analysis. After analysis, the fragments were placed in 4-liter polyethylene bottles, double-bagged out of the glovebox, and placed in a prepared 55-gallon drum. ${ }^{\mathrm{P} 024}$

Depending on waste packaging requirements at the time, several combinations of bags and liners were used to prepare 55-gallon drums for shipment. Use of the 90-mil rigid polyethylene liner began in $1972{ }^{\text {P024 }}$ 
The rigid liner was placed in each drum and lined with one polyethylene round bottom drum liner or two polyethylene drum bags. ${ }^{\mathrm{P} 008, \mathrm{P} 012, \mathrm{P} 016, \mathrm{P} 024, \mathrm{P} 063, \mathrm{P} 064}$ A polyvinyl chloride $\mathrm{O}$-ring bag and a polyethylene bag were used if the drum was attached to the glovebox. ${ }^{016}$ A fiberboard liner and discs may also have been used

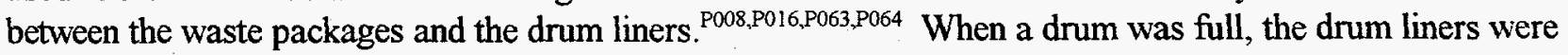
twisted and taped closed, the lid was secured with a bolted ring, and a tamper indicating device was attached to the drum. ${ }^{\mathrm{P} 12, \mathrm{P} 016, \mathrm{P} 024}$

After drums were inspected, one to two quarts of absorbent material (Oil-Dri) was placed on the top of the outer, sealed polyethylene drum bag. This procedure changed in February 1982 when vermiculite was used to fill the space between the outer, sealed polyethylene drum bag and the top of the 90 -mil rigid liner. The quantity of vermiculite varied from 3-12 pounds according to the amount of waste contained in each drum. ${ }^{\mathrm{P} 024}$

\subsection{Waste Characterization}

Raschig rings are characterized based on knowledge of the material, knowledge of the processes generating the waste, RTR review of the waste, visual inspection, waste analysis, and headspace gas analysis. This section provides a RCRA hazardous waste determination for Raschig rings as well as radionuclide contaminants and potential complexing agents contained in the waste.

Currently, Rashcig rings are classified as a homogeneous waste in the WIPP Transuranic Waste Baseline Inventory Report ${ }^{\mathrm{P} 141}$ However, this waste contains at least 50 percent by volume materials that meet the EPA LDR criteria for classification as debris, and should be considered a heterogeneous waste. In discussions with WIPP, it is understood that this classification change will be made.

\subsubsection{Hazardous Waste Determination}

The material in this waste group does not qualify for any of the exclusions outlined in 40 CFR 260 or 261. The waste may exhibit the characteristic of corrosivity from the presence of acidic or caustic free liquids. The waste was mixed with halogenated-solvents, and is therefore a F-listed hazardous waste. There is no evidence that Raschig rings exhibit any other characteristic of hazardous waste. EPA Hazardous Waste Numbers applicable to some or all of the Raschig rings waste group are presented by IDC in Table 19-2. ${ }^{\text {P127 }}$ These conclusions are supported by the evaluation in Sections 19.3.1.1 and 19.3.1.2.

Table 19-2. Raschig Rings Waste Characterization.

\begin{tabular}{lcc}
\hline IDC & Title & EPA Hazardous Waste Numbers \\
\hline 441 & Unleached Raschig Rings & D002, F001, and F002 \\
442 & Leached Raschig Rings & F001 and F002 \\
\hline
\end{tabular}

\subsubsection{Characteristic Waste}

The materials in this waste group may exhibit a characteristic of hazardous waste as defined in 40 CFR 261, Subpart C as a corrosive waste (40 CFR 261.22). The materials do not exhibit the characteristics of ignitability (40 CFR 261.21), reactivity (40 CFR 261.23), or toxicity (40 CFR 261.24). 
Ignitability: The material in this waste group does not meet the definition of ignitability as defined in 40 CFR 261.21. The material is not a liquid, nor does it contain free liquids. In addition, absorbents were added to wastes having the potential of generating free liquids. ${ }^{\mathrm{P} 009, \mathrm{P} 012, \mathrm{P} 014, \mathrm{P} 015, \mathrm{PO} 17, \mathrm{P} 022, \mathrm{U} 005, \mathrm{U} 011}$ The material is not capable of causing fire through friction, absorption of moisture, or spontaneous chemical change. ${ }^{\mathrm{P} 12, \mathrm{P} 016, \mathrm{P} 024}$ The material is not a compressed gas, nor do the containers contain compressed gases. ${ }^{\mathrm{P} 012, \mathrm{P} 014, \mathrm{P} 015, \mathrm{P} 017, \mathrm{P} 022, \mathrm{U} 005, \mathrm{U} 011}$ The material is not a DOT oxidizer as defined in 49 CFR 173. The materials in this waste group are therefore not ignitable (D001).

Corrosivity: Leached Raschig rings (IDC 442) do not meet the definition of corrosivity as defined in 40 CFR 261.22. Unleached Raschig rings (IDC 441) may meet the definition of corrosivity due to the presence of acidic or caustic free liquids. The material in this waste group is not a liquid, and absorbents were added to wastes having the potential of generating free liquids. ${ }^{\text {P009,P012,P014,P015,P017,P022,U005,U011 However, unleached }}$ Raschig rings removed from tanks that contained acids or bases, could potentially contain corrosive free liquids. If free liquids are identified in leached Raschig ring (IDC 442) drums, the liquid should not be corrosive because the rings were rinsed with water after the leaching process. Therefore, EPA Hazardous Waste Number D002 is assigned to drums of unleached Raschig rings (IDC 441) containing free liquids. ${ }^{\text {U060 }}$

Reactivity: The materials in this waste group do not meet the definition of reactivity as defined in 40 CFR 261.23. The materials are stable and will not undergo violent chemical change. The materials will not react violently with water, form potentially explosive mixtures with water, or generate toxic gases, vapors, or fumes when mixed with water. The materials do not contain cyanides or sulfides, and are not capable of detonation or explosive reaction. The materials are not forbidden explosives or Division 1.1, 1.2, or 1.3 (Class A or B) explosives as defined in 49 CFR 173, nor do the drums contain explosive materials. ${ }^{\mathrm{P} 12, \mathrm{P} 014, \mathrm{P} 015, \mathrm{P} 022, \mathrm{P} 024, \mathrm{U} 005, \mathrm{U} 011}$ Explosives were not handled or used around radioactive material. The materials in this waste group are therefore not reactive wastes (D003).

Toxicity: The materials in this waste group do not meet the definition of toxicity as defined in 40 CFR 261.24. The toxicity characteristic contaminants fall into one of two categories: metals and organics. Organic compounds include halogenated- and nonhalogenated-solvents, pesticides, herbicides, and other toxic compounds.

There is no documentation indicating the presence or use of RCRA-regulated metals in the areas or processes generating Raschig rings. In addition, TCLP analysis of unused Raschig rings indicate concentrations of barium, cadmium, chromium, lead, and silver well below the regulated levels. ${ }^{\text {C070,P052 }}$ Therefore, this waste group does not exhibit the characteristic of toxicity due to metals (D004-D011).

There is no documentation indicating the presence or use of pesticides or herbicides in the areas or processes generating Raschig rings. Therefore, this waste group does not exhibit the characteristic of toxicity due to pesticides or herbicides (D012-D017).

Carbon tetrachloride was used for cleaning and degreasing, and was stored in Raschig ring tanks. When the Raschig rings were changed out, carbon tetrachloride was used to flush out the tanks. Since this compound was used as a solvent, the waste is regulated as a listed hazardous waste and not a characteristic waste because this compound is specifically addressed in the treatment standards for the listed hazardous waste. ${ }^{\mathrm{P} 080}$ Since Raschig rings are characterized as listed hazardous wastes due to spent solvent contamination, the waste is not a toxic waste due to the presence of this organic compound. There is no documentation 
indicating the presence or use of any other toxicity characteristic organics in the areas or processes generating Raschig rings.

\subsubsection{Listed Hazardous Waste}

The material in this waste group is a listed hazardous waste because it was mixed with a waste listed in 40 CFR 261, Subpart D as a hazardous waste from non-specific sources (40 CFR 261.31). The material is not, or was not mixed with, a hazardous waste from specific sources (40 CFR 261.32), or a discarded commercial chemical product, an off-specification species, a container residue, or a spill residue thereof (40 CFR 261.33). The origin of the listed hazardous waste numbers assigned to Raschig rings is provided in Table 19-3. The table includes only the hazardous waste numbers that are applicable to waste for which a specific source was identified. The hazardous waste numbers are not applicable to waste generated from areas other than those listed in the table.

Table 19-3. Origin of Characteristic Hazardous Waste Numbers.

\begin{tabular}{clc}
\hline IDC & EPA Hazardous Waste Numbers & Building \\
\hline 441 & F001 and F002 & Buildings 707 and 777 \\
442 & F001 and F002 & Buildings 707 and 777 \\
\hline
\end{tabular}

Waste oils containing carbon tetrachloride and 1,1,2-trichloro-1,2,2-trifluoroethane spent solvents and 1,1,1-trichloroethane were used for machining and degreasing of plutonium metal. When the Raschig rings were changed out, these solvents were used to flush out the tanks. Therefore, this waste group is assigned EPA Hazardous Waste Numbers F001 and F002.

There is no documentation indicating the use of F003-, F004-, or F005-listed solvents in the areas or processes generating Raschig rings. Therefore, this waste group is not a F003-, F004-, or F005-listed hazardous waste.

Headspace analysis performed on samples of Raschig rings obtained at INEEL confirms the presence of F-listed solvents. The detected F-listed compounds in which the 90 percent UCL is above the PRQL are provided. $^{\text {P033 }}$

\footnotetext{
- 1,1,1-trichloroethane

- carbon tetrachloride (IDC 441 only)

- tetrachloroethene (IDC 441 only)

- trichloroethene (IDC 44l only)

- methanol (IDC 441 only)
}

Although methanol was detected in the headspace, there is no documentation indicating that this compound was associated with Raschig rings. 
The material in this waste group is not a hazardous waste from specific sources since it was not generated from any of the processes listed in 40 CFR 261.32. The material in this waste group is therefore not a K-listed hazardous waste.

The material in this waste group is not a discarded commercial chemical product, an off-specification species, a container residue, or a spill residue thereof (40 CFR 261.33). The material in this waste group is therefore not a P- or U-listed hazardous waste.

\subsubsection{Radionuclides}

This section identifies the radioisotopes potentially contained in the waste, as well as the chemical form of radionuclide contaminants and radioassay interferences. The primary radionuclides processed at Rocky Flats included weapons-grade plutonium, americium-241, enriched uranium, and depleted uranium. The isotopic compositions of weapons-grade plutonium, enriched uranium, and depleted uranium are specified in Section 3.0. Wastes from some of the processes described below may not be contained in the inventory based on the assigned prefixes. However, as explained in Section 19.3.2.5, it is assumed that repackaged drums could contain waste generated from any process.

Radioassay interference in all Raschig rings will be caused by the boron content which is a neutron absorber ${ }^{\text {POS2 }}$ The rings contain 11.8 to 13.8 weight percent boron oxide with an isotopic content of ${ }^{10} \mathrm{~B} /{ }^{11} \mathrm{~B}$ of not less than 0.24 . The borosilicate type glass used has a density of not less than $2.2 \mathrm{~g} / \mathrm{cm}^{3}{ }^{3024}$

\subsubsection{Plutonium Production}

Radionuclide contamination in waste from Building 707 will primarily consist of weapons-grade

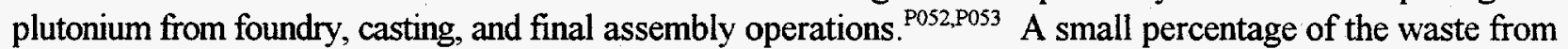
Building 707 may also contain americium-240, neptunium-237, and plutonium-238 from blending of these isotopes with weapons-grade plutonium for diagnostic tracers. ${ }^{\text {C171,C174,C184,C185,P053,P164,P167 }}$

Building 777 performed disassembly of site-return parts and fabrication operations including machining, briquetting, assembly, and production support processes (prefixes 04, 23, and 24). ${ }^{\text {C184,P052,U059,P079 }}$ Wastes from fabrication operations will be contaminated with weapons-grade plutonium and enriched uranium. Wastes generated by disassembly operations will be contaminated with site-return plutonium (higher americium-241 decay product) and enriched uranium. ${ }^{\text {C184,P079 }}$ Tritium may also be present from disassembly operations. ${ }^{\text {P053 }}$

Buildings 707 and 777 handled actinides in metal or oxide form only. ${ }^{\text {P060,P079 The actinide metals will }}$ likely have partially or completely oxidized because of the reaction with dry air, and some could possibly have formed a hydroxide layer from reaction with moist air. Radioassay interferences may include beryllium from Part V metal fabrication in Building 707, and calcium fluoride which was sprayed onto graphite molds in Building 707 prior to casting. ${ }^{\mathrm{C} 184 . \mathrm{P} 060}$ Other interfering waste contaminants include aluminum, beryllium, and stainless steel (chromium) which were machined in Building $777 .{ }^{\text {P079 }}$

\subsubsection{Plutonium Recovery and Purification}

Waste from recovery operations in Building 371 will contain weapons-grade plutonium primarily from electrorefining. ${ }^{\mathrm{C} 84, \mathrm{P} 067}$ A limited amount of the waste could also have been generated from aqueous recovery 
operations which only ran for a short time in 1982. Aqueous recovery operations were designed for recovering and purifying weapons-grade plutonium. ${ }^{\mathrm{C} 184, \mathrm{P} 164}$

The feed materials to the recovery and purification processes (prefixes 01 and 02) in Building 771 were impure plutonium residues which were processed to produce plutonium metal for use in the foundry and, therefore, wastes generated will be contaminated primarily with weapons-grade plutonium. ${ }^{\text {P052.P163,U059 }}$ Radionuclides from aqueous recovery operations will vary widely in chemical form depending on the specific process the waste originated, and because the majority of the aqueous processes were performed within one large MBA (prefixes 01 and 02), the specific process can not be determined. The different actinide forms are plutonium nitrate, plutonium chloride, plutonium peroxide, plutonium dioxide, plutonium tetrafluoride, and plutonium metal. Radioassay interferences may include aluminum nitrate from the dissolution process and beryllium which was removed during Part V leach. ${ }^{\mathrm{P} 63}$

Wastes from the americium recovery glovebox lines (prefix 06) in Building 771, used for extraction of americium from site-return plutonium, will contain a significant amount of americium-241. ${ }^{\text {C184,P053,P164,U059 }}$ The americium was in a chloride, hydroxide, nitrate, oxalate, and oxide chemical form during different steps of the process. Prior to 1975, ammonium thiocyanate was also used. ${ }^{\text {P053 }}$

The Oralloy leach process (prefix 74) in Building 771 chemically separated plutonium surface contamination from enriched uranium hemishells using nitric acid. The chemical form of the radionuclides will therefore be plutonium nitrate and uranyl nitrate. ${ }^{\mathrm{C} 184, \mathrm{P} 061, \mathrm{P} 163, \mathrm{U} 059}$

\subsubsection{Laboratory}

The analytical laboratory in Building 371 (prefix 71) provided analytical support for process control and performed analyses on feed materials and residues from recovery operations in Building 371. ${ }^{\text {P053.U059.P081 }}$ The laboratory also analyzed samples from various operations at the site, but primarily from Building $374 .^{\mathrm{P} 081}$ The Building 371 chemical standards laboratory prepared standards for various users and inspected standards that were used throughout plant site. ${ }^{\mathrm{P} 053}$ Wastes from these laboratories will be contaminated with weaponsgrade plutonium and enriched and depleted uranium.

The Building 559 analytical laboratory (prefix 29) performed a variety of analyses, including plutonium, enriched and depleted uranium, americium, neptunium, and tritium content. ${ }^{\mathrm{P} 053, \mathrm{P} 067, \mathrm{P} 076, \mathrm{U} 059, \mathrm{U} 073}$ The primary mission of this laboratory was analysis of site-return and feed materials, in addition to recovery, purification, and foundry products. ${ }^{\text {P053 }}$

The Building 771 analytical laboratory (prefix 37) received samples from recovery operations in the building as well as from the foundry. ${ }^{\mathrm{P} 667, \mathrm{U} 059}$ The samples included plutonium metal turnings, plutonium oxide, acidic plutonium solutions, and various process residues. ${ }^{\mathrm{P} 61}$ In addition, the analytical laboratory analyzed samples from R\&D laboratories in Buildings 771 and 779 (see Section 19.3.2.4). ${ }^{\mathrm{P} 067, \mathrm{P} 061}$ The chemical standards laboratory (prefix 38) prepared uranium, plutonium, and americium nitrates used as control standards for the Buildings 371,559 , and 771 analytical laboratories. ${ }^{\text {P067,P061 }}$ The laboratory also produced nondestructive assay standards used at drum counters and fluoride standards for chemical operations. ${ }^{\mathrm{P}}{ }^{\mathrm{G} 1}$ 


\subsubsection{Research and Development}

Projects using transuranic radionuclides were done in Buildings 771, 776, 777, 779, and 881. Most of the documentation pertaining to R\&D activities does not specify locations in which the work was performed, and unless otherwise noted, it will be assumed that any of the radioisotopes could have been handled in the R\&D areas of any of these buildings. In addition to weapons-grade plutonium, americium- 241 , and enriched and depleted uranium, the following radioisotopes were processed during R\&D

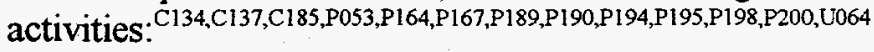

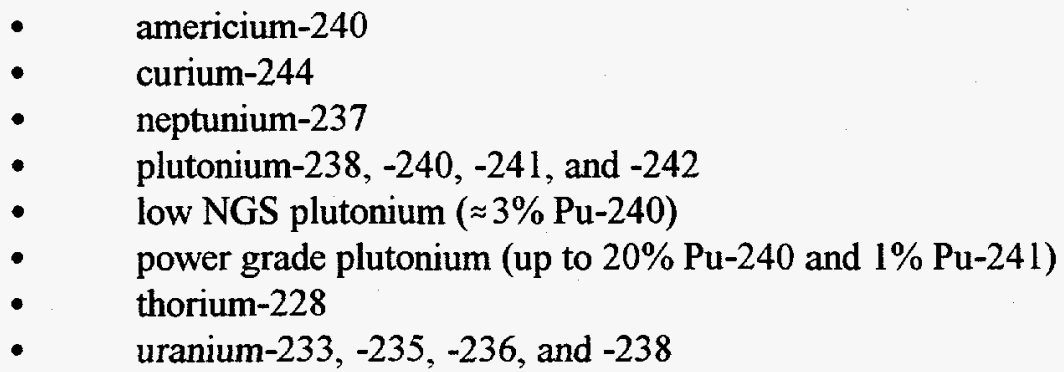

A summary of the projects and time periods that these and other radionuclides were used is presented in Section 3.0.

In Building 771, special recovery anion exchange (prefix 45) separated plutonium from other materials that were not suitable for the regular recovery processes. C154,P052P061 Chemical technology (prefix 42) conducted aqueous R\&D activities while plutonium metallurgy operations (prefix 78) performed alloy preparation, heat treating, rolling, metal and metallurgical testing, and cutting for R\&D. ${ }^{\text {C184,U059,P061 }}$ These processes may have used numerous radioisotopes.

The coatings laboratory (prefix 16) in Building 777 developed various substrates to be coated with uranium or plutonium, including stainless steel, copper, chromium, aluminum, and beryllium. ${ }^{\text {P052,U059,P079 }}$ This research and development facility supported production processes. ${ }^{\text {P052,P079 }}$ The special weapons area (prefix 66 ) in Building 777 was a research and development facility which assembled war reserve and other specially fabricated parts. ${ }^{059,0079}$ The process was also responsible for disassembly of surveillance (tracer) parts and drilling of parts for use in analytical testing. ${ }^{\mathrm{P} 079}$

Pyrochemical technology (prefixes 10 and 52) in Building 779 involved the extraction and recovery of plutonium and americium in support of production operations. ${ }^{\text {P067,U059,P062 }}$ These processes included direct oxide reduction, molten salt extraction, electrorefining, salt scrub for MSE, salt scrub for electrorefining, pyrochemical salt recycle, anode alloy, and pyroredox. ${ }^{\mathrm{C} 182 \mathrm{P} 062}$ Most of the materials used in Building 779 were the same as those in the weapons-production areas and, therefore, will be contaminated primarily with weapons-grade plutonium and enriched uranium. ${ }^{\mathrm{P} 53}$ However, other R\&D activities in the building may have used a variety of other radionuclides. ${ }^{\mathrm{C} 171, \mathrm{C} 184}$

\subsubsection{Size Reduction/Repackaging/Solid Waste Treatment}

The Size Reduction Vault (SRV) in Building 776 conducted solid waste treatment, repackaging, and size reduction operations. The SRV was divided into two sides. One side was the airlock (prefixes $25,40,41$, and 57) where repackaging was done. The other side (prefixes 19 and 26) was a drybox atmosphere where size 


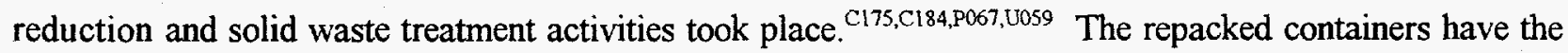
potential to contain contaminated materials from any of the processes within the transuranic waste generating buildings. ${ }^{\text {P067, U077 }}$

\subsubsection{Complexing Agents}

Because complexing agents can aid in the transport of transuranic radionuclides from the waste after disposal, the waste was assessed for potential complexing agents. This information may also be added to the chemical compatibility studies since limited information was available on these chemicals in the past.

EDTA represents a group of chelating compounds, such as ethenediaminetetraacetic acid, with similar molecular structures found in many soaps and detergents. Versene (a trade name for EDTA) and citric acid are known constituents of $\mathrm{KW}$ decontamination detergent. ${ }^{\mathrm{P} 068}$ A solution of water and $\mathrm{KW}$ was used to clean the size reduction vault in Building 776. The waste water was stored in Raschig ring tanks. ${ }^{\text {P052,P078 }}$ Raschig rings may contain trace quantities of these complexing agents. 


\subsection{RESIN}

This waste group consists of spent anion and cation exchange resins that have been cemented. The majority of this waste was generated by plutonium recovery operations in Building $771{ }^{\text {P012 }}$ Smaller amounts of ion exchange resin were generated from americium recovery and R\&D operations in Building 771 , and from laboratory analysis. Historic IDC descriptions and dates of generation for the INEEL accessible storage inventory are presented by IDC in Table 20-1. ${ }^{\mathrm{P} 127}$

Table 20-1. Resin Waste in the Accessible Storage Inventory.

\begin{tabular}{clc}
\hline IDC & \multicolumn{1}{c}{ Title } & Dates of Generation \\
\hline 432 & $\begin{array}{l}\text { Cemented Resin } \\
\text { Resin, Leached and Cemented }\end{array}$ & January 1972-August 1986 \\
822 & $\begin{array}{l}\text { Cemented Resin } \\
\text { P012 }\end{array}$ & January 1986-February 1987 \\
\hline
\end{tabular}

Item Description Code 432, Cemented Resin: This waste consists of leached, spent anion and cation exchange resins that were cemented by mixing Portland cement, water, and washed resin into a slurry. The slurry was poured into a polyethylene bottle or metal can. ${ }^{\mathrm{U} 11 . \mathrm{P} 024}$

Item Description Code 822, Cemented Resin: This waste consists of washed, spent anion and cation exchange resins that were coated with cement with a mixer in a metal bowl. The resin was slurried with Portland cement and water. The slurried resin was poured into a polyethylene residue container mold and allowed to solidify. ${ }^{\mathrm{P} 43, \mathrm{P} 098}$

\subsection{Waste Generation}

Ion exchange resins were generated by the recovery, purification, laboratory, and research and development activities associated with plutonium operations. Spent ion exchange resins were washed or leached and cemented prior to disposal.

\subsection{1 lon Exchange Processes}

Ion exchange processes were important to the plutonium purification processes at Rocky Flats. Anion exchange resin was part of the main plutonium recovery operation in Building 771. Plutonium-contaminated materials were often dissolved in nitric acid and processed through ion exchange. The dissolution process created plutonium nitrate solution. The ion exchange resin contained in a glass cylinder was loaded with plutonium by passing the plutonium nitrate solution through the column. Americium and other impurities passed through the column without being loaded on the resins. Ferrous sulfamate and aluminum nitrate were added to the plutonium nitrate solution to aid in the sorption of the plutonium on the resin. The plutonium was then eluted from the resin by passing a dilute nitric acid solution through the column. The resin was replaced when the efficiency was reduced through repeated use. The ion exchange resin used at Rocky Flats was generally small polystyrene plastic beads in which long-chain organic compounds with an activated group are imbedded. ${ }^{\text {P052,P061 }}$ 
Four ion exchange processes within Building 771 may have generated resin included in IDCs 432 and 822. These processes were anion exchange for plutonium recovery operations, cation exchange for plutonium purification from chloride solutions, special recovery anion exchange for plutonium and neptunium separation, and ammonium thiocyanate anion/cation exchange for americium purification. ${ }^{\text {P061,P095,P096,P102,P105 }}$

The anion exchange processes used for plutonium recovery operations and special recovery operations operated in a similar manner. The major differences between the two processes were (1) flow rate of the solution; (2) the special recovery process was used to separate plutonium and neptunium from impurities or plutonium from enriched uranium; and, (3) small amounts of hydrofluoric acid and sodium nitrite were used as needed in the special recovery process. ${ }^{\mathrm{P} 061, \mathrm{P} 095, \mathrm{P} 096, \mathrm{P} 102, \mathrm{P} 105}$

The cation exchange process for plutonium purification used the same general steps as anion exchiange, but with a different type of resin. In addition, the plutonium was loaded onto the resin with a hydrochloric acid solution and removed with nitric acid. ${ }^{\text {P052,P061 }}$

Prior to 1975 , a combination anion and cation exchange process was used to purify americium from plutonium and other metals as part of the americium recovery process. The americium and plutonium were loaded onto a hydrogen form cation exchange resin with a nitric acid solution. The resin was water washed to remove any residual nitric acid. A weak ammonium thiocyanate solution was trickled through the resin to remove iron and other impurities. A stronger ammonium thiocyanate solution was then trickled through the resin to remove the americium and plutonium. The resin was washed again to remove residual ammonium thiocyanate solution prior to repeating the nitric acid loading process. ${ }^{\mathrm{P} 113}$

The americium and plutonium solution from the initial cation exchange purification was trickled through chloride form anion exchange resin columns. A strong ammonium thiocyanate solution was trickled through the resin to remove cerium, yttrium, and other rare earth metals. Residual ammonium thiocyanate was removed using vacuum. The americium and plutonium were removed with a hydrochloric acid solution. Impurities such as chromium, nickel, lead, and iron remained on the resin. The anion exchange resin was replaced after each use. ${ }^{\text {P113 }}$

The solution from the anion exchange purification was concentrated through use of another cation exchange step. Plutonium and americium were separated in a final anion exchange step. A small amount of nitric acid added to the americium and plutonium solution caused the plutonium to load on the chloride form resin and the purified americium would pass through the column to the next americium recovery step. The plutonium was removed from the column with water and returned to the main plutonium recovery process. ${ }^{\text {PI } 13}$

The laboratories located in Buildings 559 and 779 generated small amounts of anion exchange resins. Two processes in Building 559 used anion exchange to prepare plutonium samples for isotopic analysis. Building 779 evaluated ion exchange resins for efficiency in support of Building 771 plutonium recovery operations. All of these three processes operated in a manner similar to Building 771 plutonium recovery operations anion exchange and special recovery anion exchange but on a much smaller scale. ${ }^{\text {P062,P076 }}$

\subsubsection{Resin Washing and Cementation}

Operating procedures required that the ion exchange resin was to be washed twice with water prior to removal from the glovebox. The washing was performed to remove any residual acid from the resin. Resin was removed from the gloveboxes in six-inch diameter plastic-covered Kraft tubes or polyethylene bottles. The 
containers were assayed to determine if the resin was waste or if it contained recoverable amounts of plutonium. ${ }^{\mathrm{P} 024, \mathrm{P} 096, \mathrm{P} 102, \mathrm{P} 105}$ Once the resin was determined to be waste, it was sent to Building 371 or 771 for cementation. IDCs 432 and 822 are both cemented resins. IDC 822 replaced IDC 432 in the mid-1980s. The change in IDCs is a reflection of a change in the cementation process, not a change in the processes generating the resins. The two cementation processes are summarized below.

Item Description Code 432, Cemented Resin: Leached, spent anion and cation exchange resins were cemented by mixing 1 liter of Portland cement, 500 milliliters of water, and 1 liter of washed resin into a slurry. The slurry was poured into a polyethylene bottle or metal can. One-half inch of dry Portland cement was added to the bottle before the slurry was added and after the slurry had solidified. ${ }^{\mathrm{U} 011, \mathrm{P} 024}$

Item Description Code 822, Cemented Resin: Washed, spent anion and cation exchange resins were coated with cement with a mixer in a metal bowl. One liter of resin was slurried with 1200 milliliters of Portland cement and 600 milliliters of water. The slurried resin was poured into a polyethylene residue container mold and allowed to solidify. Americium resin required lead shielding on the mixer and plastic container. ${ }^{\text {P043,P098 }}$

\subsection{Waste Packaging}

The bottles or cans of cemented resin (IDC 432) were double-bagged out of the glovebox line in polyvinyl chloride or polyethylene bags. ${ }^{\mathrm{P} 15, \mathrm{P} 024}$ The cemented blocks of americium resin were placed in leadwrapped plastic residue containers after solidification and before removal from the glovebox. ${ }^{\text {P098 }}$ The waste was then placed in a prepared 55-gallon drum. ${ }^{\mathrm{P} 012, \mathrm{P} 015, \mathrm{P} 024}$

The polyethylene containers of cemented resin (IDC 822) were contained in plastic and then doublebagged out of the glovebox line in polyvinyl chloride or polyethylene bags. ${ }^{\text {P012.P098 }}$ The waste was then placed in a prepared 55-gallon drum. ${ }^{\text {P012.PO15.PO24 }}$

Depending on waste packaging requirements at the time, several combinations of bags and liners were used to prepare 55-gallon drums for shipment. From 1970 to 1972, waste drums were lined with one or two polyethylene drum bags. Cardboard liners might also have been used to line the inner drum bag. Use of the 90-mil rigid polyethylene liner began in 1972. ${ }^{\text {P024 }}$ The rigid liner was placed in each drum and lined with one

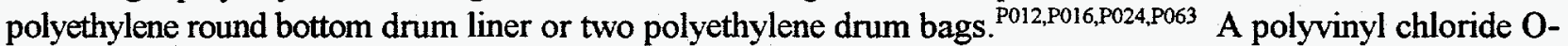
ring bag and a polyethylene bag were used if the drum was attached to the glovebox. ${ }^{\mathrm{P} 16}$ Lead drum liners placed between the drum and rigid liner were usually used for cemented resin from the americium recovery line. ${ }^{\mathrm{P} 24}$ When a drum was full, the drum liners were twisted and taped closed, the lid was secured with a bolted ring, and a tamper indicating device was attached to the drum. ${ }^{\mathrm{PO} 2, \mathrm{P} 016, \mathrm{P} 024}$

After drums were inspected, one to two quarts of absorbent material (Oil-Dri) was placed on top of the outer, sealed polyethylene drum bag. This procedure was changed in February 1982 when vermiculite was used to fill the space between the outer, sealed polyethylene drum bag and the top of the 90 -mil rigid liner. The quantity of vermiculite varied from 3-12 pounds according to the amount of waste contained in each drum. ${ }^{\mathrm{P} 24}$

Waste management and inspection protocol allowed containers of wastes to contain up to 10 percent of another IDC other than that assigned to the container. ${ }^{\mathrm{P} 016}$ Visual inspection of cemented resin containers 
identified a variety of items including a bag of dry Portland cement, white powder in a 1-gallon paint can, a cloth towel, tools, a grease pencil, and paper. ${ }^{\mathrm{P} 015, \mathrm{U} 011}$

\subsection{Waste Characterization}

Resin is characterized based on knowledge of the material, knowledge of the processes generating the waste, RTR reviews of the waste, visual inspection, and headspace analysis. This section provides a RCRA hazardous waste determination for resin as well as radionuclide contaminants and potential complexing agents contained in the waste. This waste is at least 50 percent (by volume) organic particulates, and is classified as a homogeneous waste. ${ }^{\text {P14l }}$

\subsubsection{Hazardous Waste Determination}

The material in this waste group does not qualify for any of the exclusions outlined in 40 CFR 260 or 261. Resin may exhibit the characteristic of toxicity for chromium and lead. The waste was not mixed with a listed hazardous waste. There is no evidence that resin exhibits any other characteristic of hazardous waste. ${ }^{\mathrm{U} 060}$ EPA Hazardous Waste Numbers applicable to some or all of the resin waste group are presented by IDC in Table 20-2. These conclusions are supported by the evaluation in Sections 20.3.1.1 and 20.3.1.2.

Table 20-2. Resin Waste Characterization.

\begin{tabular}{ccc}
\hline IDC & Title & EPA Hazardous Waste Numbers \\
\hline 432 & Cemented Resin & D007 and D008 \\
822 & Cemented Resin & None \\
\hline
\end{tabular}

\subsubsection{Characteristic Waste}

The materials in this waste group may exhibit a characteristic of hazardous waste as defined in 40 CFR 261, Subpart C as as a toxic waste (40 CFR 261.24). The materials do not exhibit the characteristics of ignitability (40 CFR 261.21), corrosivity (40 CFR 261.22), or reactivity (40 CFR 261.23). The origin of the characteristic hazardous waste numbers assigned to resin is provided in Table 20-3. The table includes only the hazardous waste numbers that are applicable to waste for which a specific source and time period was identified. The hazardous waste numbers are not applicable to waste generated from areas other than those listed in the table.

Table 20-3. Origin of Characteristic Hazardous Waste Numbers.

\begin{tabular}{ccc}
\hline IDC & EPA Hazardous Waste Numbers & Building and Date of Generation \\
\hline 432 & D007 and D008 & Generated in Building 771 before 1975 \\
\hline
\end{tabular}

Ignitability: The materials in this waste group do not meet the definition of ignitability as defined in 40 CFR 261.21. The material is not a liquid, nor does it contain free liquids. ${ }^{\mathrm{P} 15, \mathrm{P} 021, \mathrm{U} 011}$ The material is not 
capable of causing fire through friction, absorption of moisture, or spontaneous chemical change. The material is not a compressed gas, nor do the drums contain compressed gases. ${ }^{\mathrm{P} 15, \mathrm{P} 021, \mathrm{U} 011}$ Although nitrates were associated with the anion exchange process, the resin washing and cementation process would remove the oxidizer property. The resultant material is therefore, not a DOT oxidizer as defined in 49 CFR 173 . The materials in this waste group are therefore not ignitable wastes (D001).

Corrosivity: The materials in this waste group do not meet the definition of corrosivity as defined in 40 CFR 261.22. The material is not a liquid, nor does it contain free liquids. ${ }^{\text {P015,P021,U011 }}$ The materials in this waste group are therefore not corrosive wastes (D002).

Reactivity: The materials in this waste group do not meet the definition of reactivity as defined in 40 CFR 261.23. The materials are stable and will not undergo violent chemical change. The materials will not react violently with water, form potentially explosive mixtures with water, or generate toxic gases, vapors, or fumes when mixed with water. The materials do not contain sulfides, and are not capable of detonation or explosive reaction. The materials are not forbidden explosives or Division 1.1, 1.2, or 1.3 (Class A or B) explosives as defined in 49 CFR 173, nor do the drums contain explosive materials. ${ }^{\text {P015.P021,U011 }}$ Explosives were not handled or used around radioactive material. The resin from the thiocyanate anion exchange process should not contain reactive levels of cyanide because the resin was washed with water and nitric acid before and after contact with thiocyanate solution. ${ }^{\text {P113 }}$ The nitric acid would liberate any reactive cyanide at that time. The materials in this waste group are therefore not reactive wastes (D003).

Toxicity: The materials in this waste group may meet the definition of toxicity as defined in 40 CFR 261.24. The toxicity characteristic contaminants fall into one of two categories: metals and organics. Organic compounds include halogenated- and nonhalogenated-solvents, pesticides, herbicides, and other toxic compounds. This waste group may exhibit the characteristic of toxicity for chromium and lead metals.

The resin from the ammonium thiocyanate ion exchange process in Building 771 , which operated until 1975, retained impurities such as chromium, nickel, lead, and iron. ${ }^{\text {Pl } 13}$. The resins from the other ion exchange processes were used to selectively remove plutonium or other radionuclides and let other metals pass on in the liquid effluent. Therefore, cemented resin (IDC 432) generated in Building 771 prior to 1975 is assigned EPA Hazardous Waste Numbers D007 and D008. A representative sample of this waste will be obtained for verification purposes.

There is no documentation indicating the presence or use of pesticides or herbicides in the areas or processes generating resin. Therefore, this waste group does not exhibit the characteristic of toxicity due to pesticides or herbicides (D012-D017).

There is no documentation indicating toxicity characteristic organics were used in the ion exchange processes generating resin. Headspace analysis detected trichloroethene and 1,1-dichloroethene in cemented resin (IDC 432). ${ }^{\text {P033 }}$ Trichloroethene was commonly used for cleaning, and could have been used to clean gloveboxes used in the various ion exchange processes. ${ }^{\mathrm{P} 023, \mathrm{P} 053}$ The source of 1,1-dichloroethene may be from the radiolysis of 1,1,1-trichloroethane. ${ }^{\mathrm{PIS1}}$ Since trichloroethene and 1,1-dichloroethene were not used in the ion exchange processes, the resin should not contain toxicity characteristic levels of these compounds. Therefore, this waste group does not exhibit the characteristic of toxicity due to organics (D018-D043). A representative sample of this waste will be obtained for verification purposes. 


\subsubsection{Listed Hazardous Waste}

The material in this waste group is not, or was not mixed with, a waste listed in 40 CFR 261, Subpart D as a hazardous waste from non-specific sources (40 CFR 261.31), as a hazardous waste from specific sources (40 CFR 261.32), or as a discarded commercial chemical product, an off-specification species, a container residue, or a spill residue thereof (40 CFR 261.33).

There is no documentation indicating the presence or use of F003- or F004-listed solvents in the areas or processes generating resin. Therefore, this waste group is not a F003- or F004-listed hazardous waste.

Organic solvents may have been used for cleaning the glovebox lines used in the various ion exchange processes. ${ }^{\mathrm{P} 023, \mathrm{P} 053}$ However, there is no documentation indicating that listed solvents were used in the processes generating resin. Therefore, this waste group is not a F001-, F002-, or F005-listed hazardous waste.

Although this waste is not a F-listed hazardous waste, headspace analysis performed on samples of resin (IDCs 432 and 822) obtained at INEEL confirms the presence of organic solvents in IDC 432 . The detected compounds in which the 90 percent UCL is above the PRQL are provided. ${ }^{\text {P33 }}$

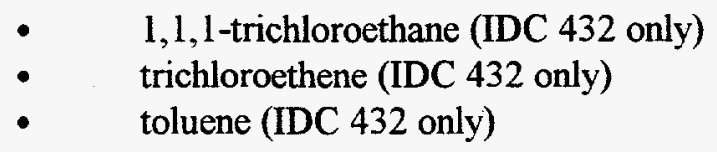

The material in this waste group is not a hazardous waste from specific sources since it was not generated from any of the processes listed in 40 CFR 261.32. The material in this waste group is therefore not a K-listed hazardous waste.

The material in this waste group is not a discarded commercial chemical product, an off-specification species, a container residue, or a spill residue thereof (40 CFR 261.33). The material in this waste group is therefore not a P-or U-listed hazardous waste.

\subsubsection{Radionuclides}

Radionuclide contamination in anion and cation ion exchange resins from plutonium recovery operations in Buildings 371 and 771 will consist primarily of plutonium because americium and other impurities remained in the acid solution while the plutonium loaded onto the resin. ${ }^{\mathrm{P}}{ }^{2}$ Resin from the americium recovery and purification process will be contaminated with higher levels of americium since both plutonium and americium were loaded onto the resins. ${ }^{\text {P113 }}$ Limited amounts of resin were generated in Building 559 and the special recovery area of Building 77 land may be contaminated with neptunium, plutonium, americium, and uranium-235. ${ }^{\mathrm{P} 076, \mathrm{P} 095, \mathrm{P} 096}$

Buildings 371 and 771 cemented resins in preparation for shipment and, therefore, resins from both buildings potentially could have originated from any ion exchange processes. ${ }^{\mathrm{P} 024, \mathrm{P} 067}$ The Size Reduction Vault in Building 776 conducted repackaging operations, and the repacked containers have the potential to contain resins from any of the ion exchange processes. ${ }^{\mathrm{Cl75,P078}}$ 
Table 20-4. Waste Matrix Evaluation.

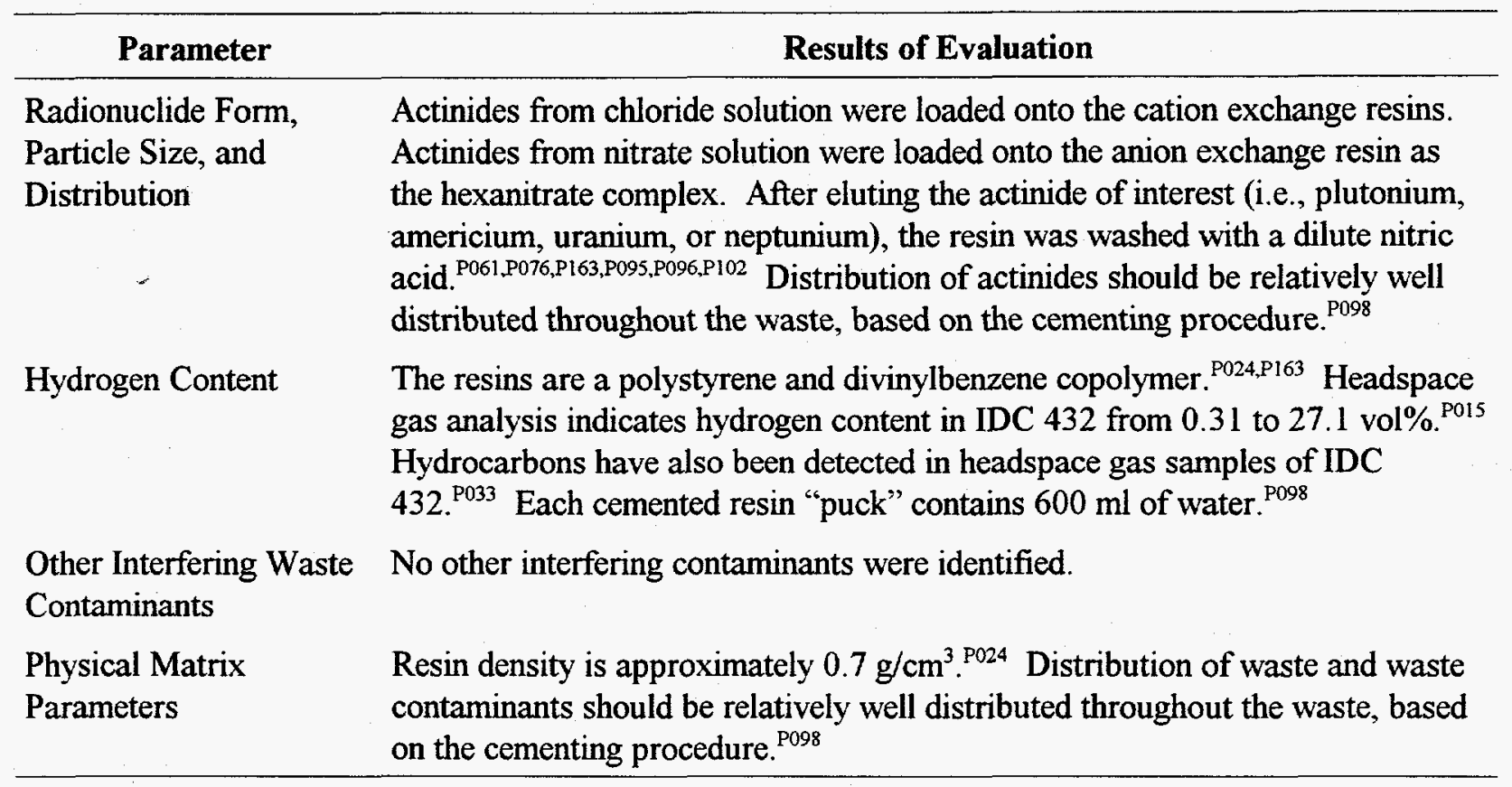

\subsubsection{Complexing Agents}

Because complexing agents can aid in the transport of transuranic radionuclides from the waste after disposal, the waste was assessed for potential complexing agents. This information may also be added to the chemical compatibility studies since limited information was available on these chemicals in the past.

Oxalic acid was used in the americium recovery line. However, it was used for a precipitation process that followed the ion exchange processes, and therefore, should not be contained in resin. ${ }^{\mathrm{P} 13}$ There is no documentation indicating the presence or use of any other complexing agents in the areas or processes generating resin. 


\subsection{SAND, SLAG AND CRUCIBLE}

This waste group includes sand, slag, and crucible wastes generated by laboratory operations in Buildings 559 and 771, plutonium recovery operations in Building 771, and research and development activities in Building 779. Historic IDC descriptions and dates of generation for the INEEL accessible storage inventory are presented by IDC in Table $21-1 .{ }^{\text {P127 }}$

Table 21-1. Sand, Slag, and Crucible Waste in the Accessible Storage Inventory.

\begin{tabular}{|c|c|c|}
\hline IDC & Title & Dates of Generation \\
\hline 370 & Leco Crucibles ${ }^{\mathrm{C} 063}$ & October 1980-June 1982 \\
\hline 391 & $\begin{array}{l}\text { Crucible and Sand } \\
\text { Unpulverized Sand and Crucible }\end{array}$ & June 1980-February 1984 \\
\hline 392 & $\begin{array}{l}\text { Sand, Slag, and Crucibles }{ }^{\mathrm{C} 063} \\
\text { Unpulverized Sand, Slag, and Crucible }\end{array}$ & July 1981 \\
\hline 393 & Sand, Slag, and Crucible Heels ${ }^{\mathrm{C} 063}$ & August 1980-October 1985 \\
\hline 817 & Cemented Sand, Slag, and Crucible Heels ${ }^{\mathrm{C} 063}$ & October 1986-January 1987 \\
\hline
\end{tabular}

Item Description Code 370, Leco Crucibles: This waste consists of aluminum silicate-based ceramic crucibles with approximately 0.5 percent chromium, and ranging from 4 -inch long by $3 / 4$-inch square to 1 -inch high by 1-inch diameter. ${ }^{\mathrm{P} 012, \mathrm{P} 035}$ Used Leco crucibles contained a spent accelerator metal (copper, iron, tungsten, or tin). Plutonium and an accelerating metal were fused into the Leco crucible. The crucibles may be intact or in pieces. Leco crucibles were segregated into unused (blank) crucibles and used (fused) crucibles. Only blank crucibles were shipped to INEEL. ${ }^{\text {P024,P035,P052 }}$

Item Description Code 391, Unpulverized Sand and Crucible: This waste consists of magnesium oxide crucibles and limited amounts of magnesium oxide sand. ${ }^{\mathrm{P} 024}$ The crucibles will range from half to three quarters the length and diameter of the original crucible to pieces approximately the size of the larger grains of sand. This waste may also contain small beads of magnesium metal condensed from magnesium metal vapor. The vapor was produced by the action of excess calcium metal on magnesium oxide. ${ }^{\text {P035 }}$

Item Description Code 392, Unpulverized Sand, Slag, and Crucible: This waste consists of magnesium oxide crucibles, calcium fluoride slag, and limited amounts of magnesium oxide sand. The crucibles will range from half to three quarters the length and diameter of the original crucible to pieces approximately the size of the larger grains of sand. The slag consists primarily of calcium fluoride contaminated with uncoalesced plutonium, some residual calcium metal or calcium salt, magnesium metal, and trace amounts of the reduction pyrotechnic initiator (powdered magnesium, sodium peroxide, and potassium iodate). ${ }^{\mathrm{P} 035, \mathrm{P} 061}$

Item Description Code 393, Sand, Slag, and Crucible Heels: This waste consists of undissolved or precipitated calcium fluoride (slag) and undissolved magnesium oxide sand and crucible remaining after pulverizing and leaching of sand, slag, and crucible (IDC 392). ${ }^{\mathrm{P} 16, \mathrm{P} 024, \mathrm{P} 061}$ The waste may also contain trace 
amounts of aluminum nitrate and aluminum fluoride. The actinides remaining in the heel will be in the form of fluorides and oxides; predominantly fluorides. ${ }^{\mathrm{P} 035}$

Item Description Code 817, Cemented Sand, Slag, and Crucible Heels: This waste consists of sand, slag, and crucible heels (IDC 393) mixed with Portland cement and water in 1-gallon molds. The cured "pucks" (IDC 817) were removed from the molds in the form of a solid monolith. ${ }^{\text {Pol }}$

\subsection{Waste Generation}

The laboratories in Buildings 559 and 771 generated Leco crucibles. Sand, slag, and crucible wastes were generated from plutonium recovery operations in Building 771 and from research and development activities in Building 779. ${ }^{\mathrm{P} 24, \mathrm{P} 052, \mathrm{P} 127, \mathrm{U} 059}$

\subsubsection{Leco Crucible Generation}

The laboratories in Buildings 559 and 771 generated Leco crucible waste (ID 370). Leco crucibles were used for carbon analyses of plutonium metals and oxides. Stainless-steel pins were also heated in the crucibles for calibration purposes. ${ }^{\text {Pos2 }}$

Samples of metals, oxides, or stainless-steel pins were placed in a Leco crucible with an accelerator metal (typically copper, iron, tungsten, or tin) and heated. The heating caused the carbon in the sample to react, forming carbon dioxide. The carbon dioxide was measured to determine the carbon content of the sample. Figure $21-1$ shows the carbon analysis process. ${ }^{\mathrm{P} 052}$

\subsubsection{Sand, Slag, and Crucible Generation}

A magnesium oxide crucible was placed in a stainless-steel reduction vessel, and the void between the crucible and the vessel was filled with magnesium oxide sand. Plutonium tetrafluoride from the hydrofluorination process was mixed with calcium metal and a pyrotechnic initiator (magnesium metal, sodium peroxide, and potassium iodate) and placed in the crucible. The vessel was sealed, placed in an induction furnace, purged with argon, and heated. The resulting reaction reduced the plutonium tetrafluoride to plutonium metal, and oxidized the calcium metal to form calcium fluoride (slag). The purified plutonium metal "button" was separated from the crucible and reaction by-products. ${ }^{\text {P061 }}$ Unpulverized sand and crucible (IDC 391) was generated when the sand and crucible residues were separated from the slag. Unpulverized sand, slag, and crucible (IDC 393) was generated when the crucible and reaction by-products were not separated prior to disposal. ${ }^{\text {P052 }}$ Plutonium metal meeting purity requirements was sent to the foundry in Building 707 . The plutonium metal containing unacceptable impurities was sent for electrorefining. ${ }^{\mathrm{U} 13}$ The reduction and button break-out process is illustrated in Figure 21-2. ${ }^{\mathrm{P} 52}$

Unpulverized sand, slag, and crucibles from the reduction and button break-out process were pulverized using a jaw crusher and a hammermill and sent to the residue dissolution process for plutonium recovery. ${ }^{\text {P061,P103 }}$ The pulverized sand, slag, and crucibles were leached with heated nitric acid. Aluminum nitrate was added as a fluoride complexing agent to prevent corrosion of downstream process equipment. The plutonium nitrate solution flowed to a R-6 filter for removal of undissolved solids and through a 1-micron filter for final particulate removal. Water was used for washing the undissolved solids on a secondary R- 6 filter. The undissolved solids (heels) were dried on a hot plate and then assayed for plutonium content. Heels above 


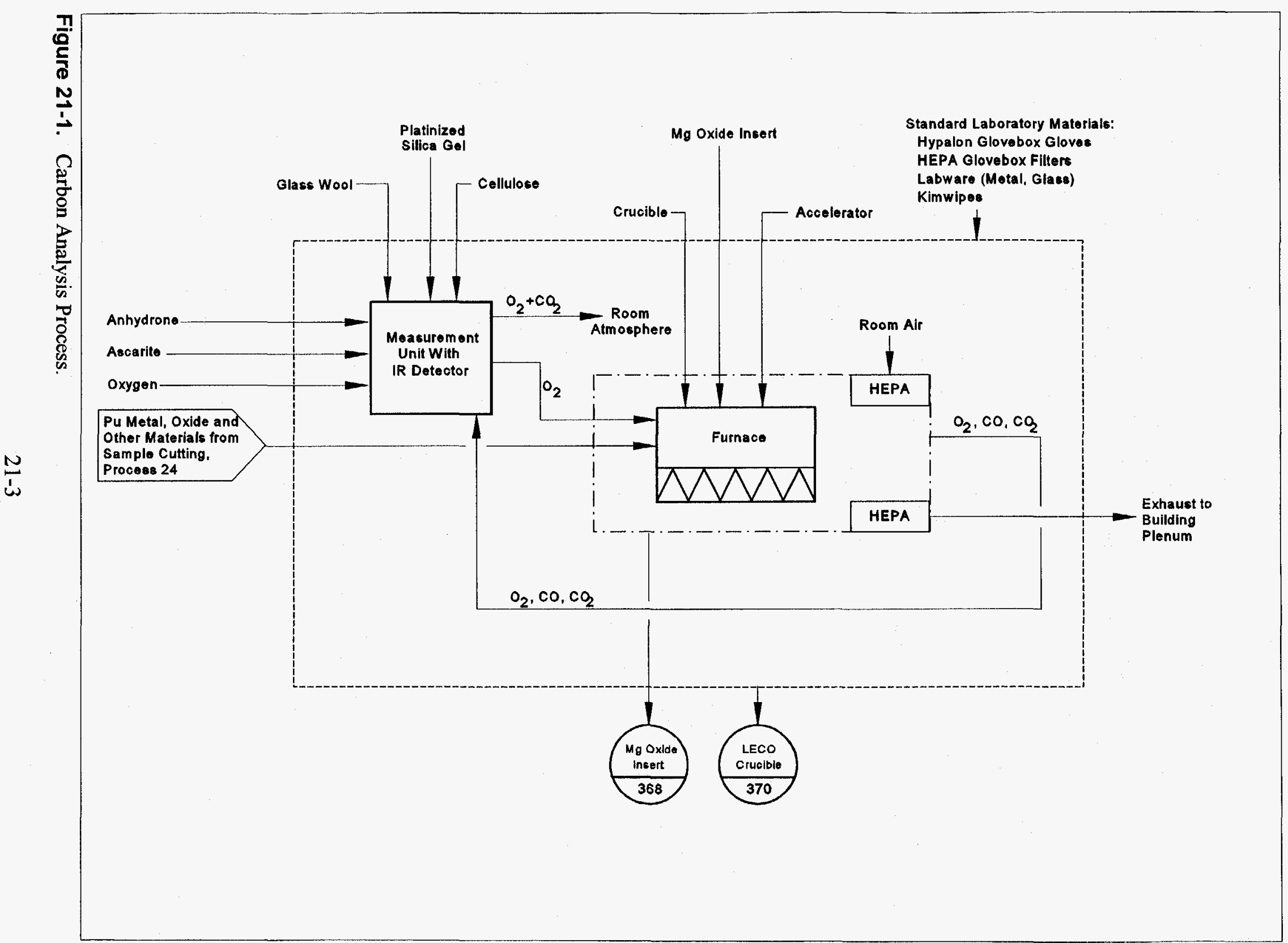




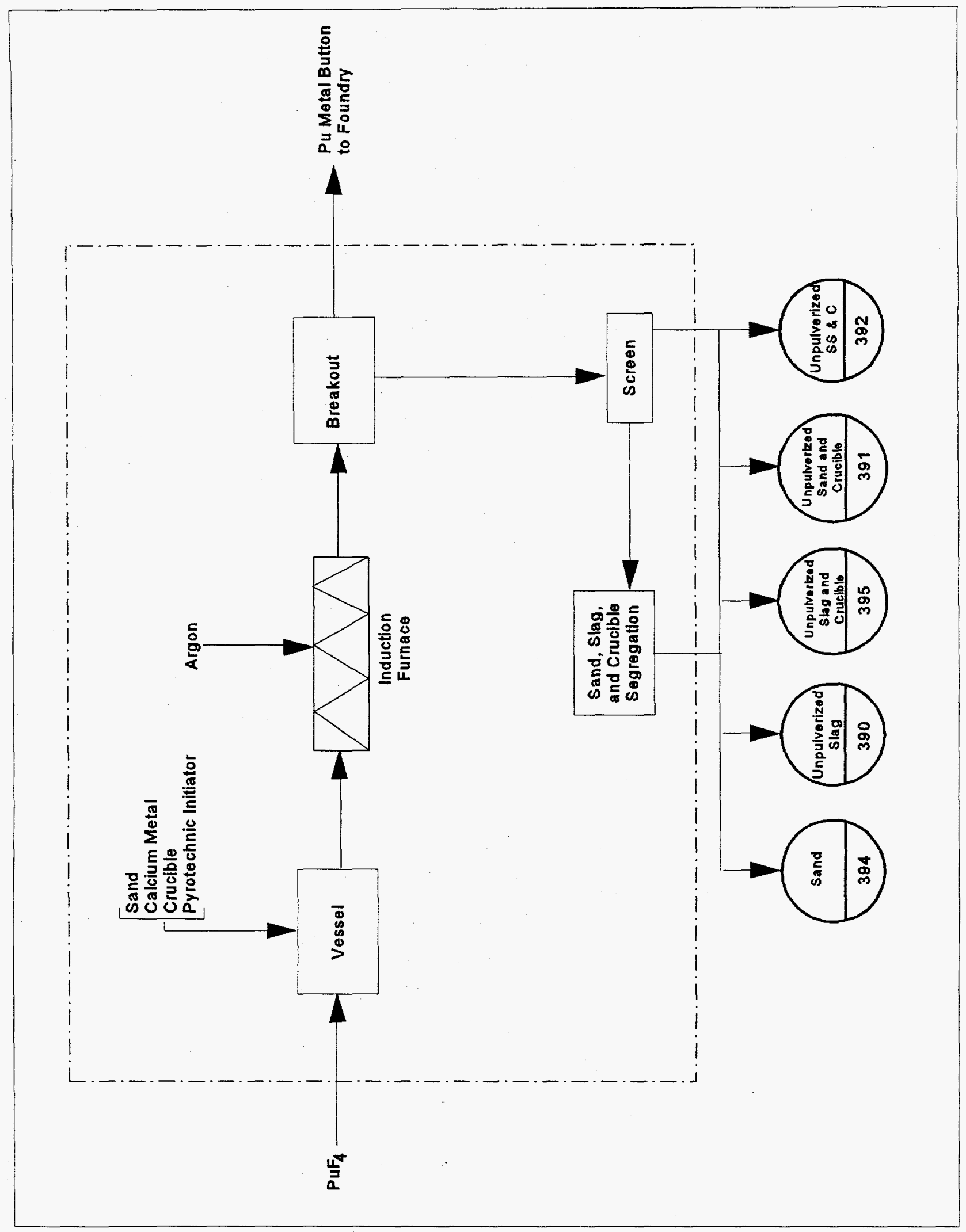

Figure 21-2. Reduction and Button Break-Out Process.

$$
21-4
$$




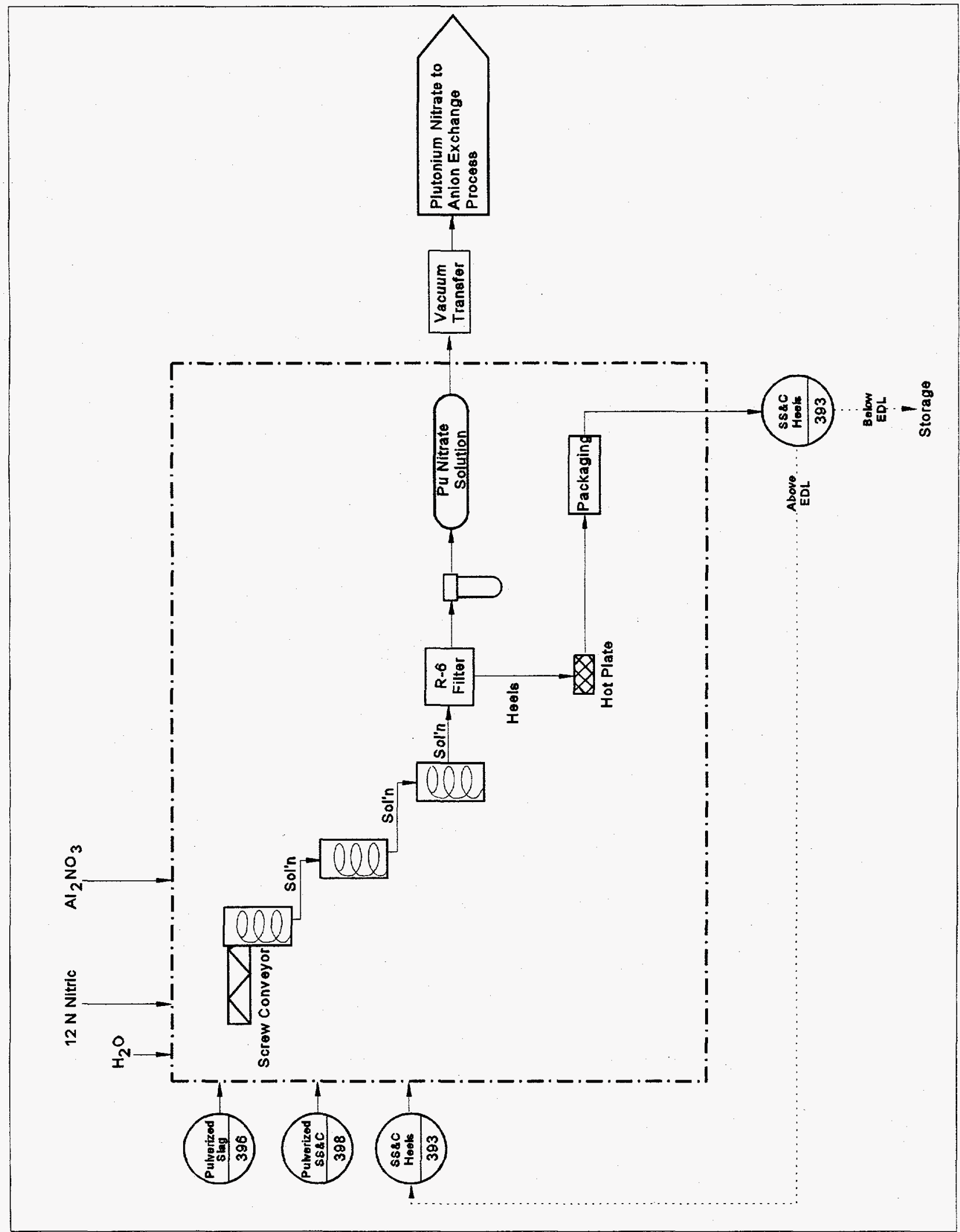

Figure 21-3. Residue Dissolution Process. 
the EDL were sent back through the residue dissolution process. Heels (IDC 393) below the EDL were placed in storage. ${ }^{\mathrm{P} 16}$ Figure 21-3 shows the residue dissolution process. ${ }^{\text {P061.P092 }}$

Beginning in 1985, sand, slag, and crucible heels (IDC 393) were immobilized into a solid monolith with Portland cement and water. ${ }^{\mathrm{C} 50, \mathrm{PO} 16}$ Portland cement and water were mixed, and approximately one liter of the heel material was mixed in until completely coated with cement. The heels, cement, and water mixture was poured into a 1-gallon polyethylene container mold and allowed to cure. After being removed from the mold, the solidified puck was placed in a 55-gallon drum. Several pucks were placed in a drum. ${ }^{\text {P016.P098 }}$ The cemented sand, slag, and crucible heels were assigned IDC $817 .^{\mathrm{P} 16}$

Unpulverized sand and crucible (IDC 391) was also generated during research and development activities in Building 779. ${ }^{\mathrm{P} 127}$ Documentation pertaining to the specific operation which generated this waste was not identified. However, operations may have been conducted in Building 779 for the development or improvement of the Building $\mathbf{7 7 1}$ recovery processes that generated sand, slag, and crucible wastes. The materials used in the research and development operations are not known, but were likely similar to those used in the recovery processes in Building $771 .^{\mathrm{C} 118, \mathrm{P} 067}$

\subsection{Waste Packaging}

Leco crucibles (IDC 370) were placed in 1-gallon metal paint cans. Unpulverized sand and crucible (IDC 391) was packaged in l-gallon paint cans or polyethylene bottles. Sand, slag, and crucible heels (IDC 393) were packaged in $1 / 2$ - and 1-gallon polyethylene bottles. Documentation was not identified for the packaging configuration of unpulverized sand, slag, and crucibles (IDC 392). It is assumed that IDC 392 was packaged like IDC 391 because they were generated by the same process. ${ }^{\text {P012.P024 }}$

The paint cans or polyethylene bottles were double-bagged out of the glovebox in PVC or polyethylene bags which were sealed with tape. Each can or bottle was assayed for plutonium content. The packages were then placed in a 55-gallon drum. Approximately 15 to 25 one-gallon containers and up to 30 half-gallon containers were placed in a drum depending on assay. ${ }^{\mathrm{P} 12, \mathrm{P} 024}$

Cemented sand, slag, and crucible heels (IDC 817) were bagged out of the glovebox, double-bagged, and placed into a 55-gallon drum. ${ }^{\text {P016 }}$

Depending on waste packaging requirements at the time, several combinations of bags and liners were used to prepare 55-gallon drums for shipment. From 1970 to 1972, waste drums were lined with one or two polyethylene drum bags. Cardboard liners might have been used to line the inner drum bag. Use of 90-mil rigid polyethylene liners began in 1972 . $^{\mathrm{P} 24}$ The rigid liner was placed in each drum and lined with one polyethylene round bottom drum liner or two polyethylene drum bags. ${ }^{\mathrm{P} 008, \mathrm{P} 012, \mathrm{P016}, \mathrm{P} 024, \mathrm{P} 063, \mathrm{P} 064}$ A PVC O-ring bag and a polyethylene bag placed inside the rigid liner was used if the drum was attached to a glovebox. ${ }^{\text {P016 }} \mathrm{A}$ fiberboard liner and discs may also have been used between the waste and the drum liners. ${ }^{\text {P008,P012,P016,P064 When }}$ a drum was full, the drum liners were twisted and taped closed, the lid was secured with a bolted ring, and a tamper indicating device was attached to the drum. ${ }^{\mathrm{P} 12, \mathrm{P} 016, \mathrm{P} 024}$

After drums were inspected, one to two quarts of absorbent material (Oil-Dri) was placed on top of the outer, sealed polyethylene drum bag. This procedure was changed in February 1982 when vermiculite was 
used to fill the space between the outer, sealed polyethylene drum bag and the top of the 90 -mil rigid liner. The quantity of vermiculite varied from 3-12 pounds according to the amount of waste contained in each drum. ${ }^{\mathrm{P}}{ }^{\mathrm{P}}$

\subsection{Waste Characterization}

Sand, slag, and crucible wastes have been characterized based on knowledge of the material and knowledge of the processes generating the waste. This section provides a RCRA hazardous waste determination for sand, slag, and crucible as well as radionuclide contaminants and potential complexing agents contained in the waste. This waste is at least 50 percent (by volume) inorganic particulates, and is classified as a homogeneous waste. ${ }^{\mathrm{Pl}} 41$

\subsubsection{Hazardous Waste Determination}

The material in this waste group does not qualify for any of the exclusions outlined in 40 CFR 260 or 261. Sand, slag, and crucible may exhibit the characteristic of toxicity for chromium. The waste was not mixed with a listed hazardous waste. There is no evidence that sand, slag, and crucible exhibits any other characteristic of hazardous waste. ${ }^{\text {C117 }}$ EPA Hazardous Waste Numbers applicable to some or all of the sand, slag, and crucible waste group are presented by IDC in Table 21-2. These conclusions are supported by the evaluation in Sections 21.3.1.1 and 21.3.1.2.

Table 21-2. Sand, Slag, and Crucible Waste Characterization.

\begin{tabular}{lll}
\hline IDC & \multicolumn{1}{c}{ Title } & EPA Hazardous Waste Numbers \\
\hline 370 & Leco Crucibles & None \\
391 & Unpulverized Sand and Crucible & None \\
392 & Unpulverized Sand, Slag, and Crucible & None \\
393 & Sand, Slag, and Crucible Heels & D007 \\
817 & Cemented Sand, Slag, and Crucible Heels & D007 \\
\hline
\end{tabular}

\subsubsection{Characteristic Waste.}

The materials in this waste group may exhibit a characteristic of hazardous waste as defined in 40 CFR 261, Subpart C as as a toxic waste (40 CFR 261.24). The materials do not exhibit the characteristics of ignitability (40 CFR 261.21), corrosivity (40 CFR 261.22), or reactivity (40 CFR 261.23).

Ignitability: The material in this waste group does not meet the definition of ignitability as defined in 40 CFR 261.21. The material is not a liquid, and should not contain free liquids because the waste was dry when packaged. ${ }^{\mathrm{P} 12, \mathrm{P} 016, \mathrm{P} 024, \mathrm{P} 043}$ The material is not capable of causing fire through friction or spontaneous chemical change. Even though sand, slag, and crucible wastes (IDCs 391 and 392) may contain calcium metal, they are not capable of causing fire from absorption of moisture. ${ }^{\text {P052 }}$ The material is not a compressed gas, and compressed gases have not been identified in this waste. ${ }^{\mathrm{P} 012, \mathrm{PO16}, \mathrm{P} 024, \mathrm{P} 043}$. The material is not a DOT oxidizer as defined in 49 CFR 173. Documentation verifying the absence of free liquids and compressed gases in IDC 392 
containers was not identified; however, it is assumed that the same procedural controls applied to this waste. The materials in this waste group are therefore not ignitable wastes (D001).

Corrosivity: The material in this waste group does not meet the definition of corrosivity as defined in 40 CFR 261.22. The material is not a liquid, and should not contain free liquids because the waste was dry when packaged. ${ }^{\mathrm{P} 12, \mathrm{PO} 16, \mathrm{P} 024, \mathrm{PO} 43}$ Documentation verifying the absence of free liquids in IDC 392 containers was not identified; however, it is assumed that the same procedural controls applied to this waste. The materials in this waste group are therefore not corrosive wastes (D002).

Reactivity: The materials in this waste group are stable and will not undergo violent chemical change. The materials will not form potentially explosive mixtures with water, or generate toxic gases, vapors, or fumes when mixed with water. Sand, slag, and crucible wastes (IDCs 391 and 392) may contain calcium metal which reacts with water. Based on regulatory intepretations by the Colorado Department of Public Health and Environment (CDPHE), calcium-containing pyrochemical salts do not meet the definition of reactivity as defined in 40 CFR 261.23. This interpretation is applicable to IDCs 391 and 392. C117.C119.P052 The material does not contain cyanides or sulfides and is not capable of detonation or explosive reaction. The material is not a forbidden explosive or a Division 1.1, 1.2, or 1.3 (Class A or B) explosive as defined in 49 CFR 173, nor do the drums contain explosive materials. ${ }^{\mathrm{P} 016, \mathrm{P} 024}$ Explosives were not handled or used around radioactive material. Documentation concerning the absence of explosives in IDC 392 containers was not identified; however, it is assumed that the same procedural controls applied to this waste. The materials in this waste group are therefore not reactive wastes (D003).

Toxicity: The materials in this waste group may meet the definition of toxicity as defined in 40 CFR 261.24. The toxicity characteristic contaminants fall into one of two categories: metals and organics. Organic compounds include halogenated- and nonhalogenated-solvents, pesticides, herbicides, and other toxic compounds. This waste group may exhibit the characteristic of toxicity for chromium metal.

Toxicity characteristic metals were not fired with Leco crucibles. The only source of toxicity characteristic metals was the chromium which is present in the crucible itself, and the fused stainless-steel on used Leco crucibles. Analysis of nonradioactive Leco crucibles indicates that chromium does not leach. Therefore, Leco crucibles (IDC 370) do not exhibit the characteristic of toxicity for chromium. ${ }^{\mathrm{P} 52}$

Chromium was a contaminant of plutonium tetrafluoride which was the feed material for the reduction and button break-out process. Plutonium recovery analysis records of the plutonium metal indicate that the chromium remained with the plutonium metal after the reduction was performed. Therefore, sand, slag, and crucible wastes (IDCs 391 and 392) do not exhibit the characteristic of toxicity for chromium. ${ }^{\text {P052 }}$

Chromium may have been added to sand, slag, and crucible heels from the corrosion of the stainlesssteel in the dissolution process area. The level of chromium contamination in unknown. Therefore, sand, slag, and crucible heels (IDCs 393 and 817) are assigned EPA Hazardous Waste Number D007. ${ }^{\text {P0s }}$ A representative sample of this waste will be obtained for verification purposes.

There is no documentation indicating the presence or use of pesticides, herbicides, or other organic compounds in the areas or processes generating sand, slag, and crucible. Therefore, this waste group does not exhibit the characteristic of toxicity due to organic compounds (D012-D043). 


\subsubsection{Listed Hazardous Waste.}

The material in this waste group is not, or was not mixed with, a waste listed in 40 CFR 261, Subpart D as a hazardous waste from non-specific sources (40 CFR 261.31), as a hazardous waste from specific sources (40 CFR 261.32), or as a discarded commercial chemical product, an off-specification species, a container residue, or a spill residue thereof (40 CFR 261.33).

The compounds listed in 40 CFR 261.31 were not used in the processes which generated this waste, nor was this waste mixed with any of these compounds. The material in this waste group is therefore not a F-listed hazardous waste.

The material in this waste group is not a hazardous waste from specific sources since it was not generated from any of the processes listed in 40 CFR 261.32. The material in this waste group is therefore not a K-listed hazardous waste.

The material in this waste group is not a discarded commercial chemical product, an off-specification species, a container residue, or a spill residue thereof (40 CFR 261.33). The material in this waste group is therefore not a P- or U-listed hazardous waste.

\subsubsection{Radionuclides}

This section identifies the radioisotopes potentially contained in the waste. In addition, Table 21-3 summarizes matrix and other physical parameters which could affect radioassay.

Leco crucibles (IDC 370) were generated from carbon analysis of plutonium metal and oxide samples. ${ }^{\text {P052 }}$ Sand, slag, and crucible (IDCs 391 and 392) were generated during the final step of aqueous plutonium recovery processing where plutonium tetrafluoride was reduced to plutonium metal for use in weapons production. Heels (IDCs 393 and 817) were generated from recovery of plutonium from sand, slag, and crucible wastes. ${ }^{\text {P035.P052 }}$ Therefore, radionuclide contamination will consist of weapons-grade plutonium only. The isotopic composition of weapons-grade plutonium is provided in Section 3.0.

Table 21-3. Waste Matrix Evaluation.

\begin{tabular}{ll}
\hline \multicolumn{1}{c}{ Parameter } & \multicolumn{1}{c}{ Results of Evaluation } \\
\hline $\begin{array}{l}\text { Radionuclide Form, } \\
\text { Particle Size, and } \\
\text { Distribution }\end{array}$ & IDC 370: Plutonium metal and oxide. ${ }^{\text {POS2 }}$ \\
& $\begin{array}{l}\text { IDC 391: Plutonium metal and trace amounts of unreacted plutonium fluoride } \\
\text { located toward the bottom of the crucible. The sand could contain plutonium } \\
\text { metal and fluoride. }\end{array}$ \\
& IDC 35 \\
& located toward the bottom of the crucible. The mid-section of the crucible will \\
primarily contain the calcium fluoride slag which will be contaminated with \\
plutonium metal. The sand could contain plutonium metal and fluoride.
\end{tabular}

IDCs 393/817: Plutonium fluoride and oxide; predominantly fluoride. ${ }^{\mathrm{P} 35}$ 


\begin{tabular}{|c|c|}
\hline Parameter & Results of Evaluation \\
\hline Hydrogen Content & $\begin{array}{l}\text { The primary sources for hydrogen in this waste includes fiberboard, polyvinyl } \\
\text { chloride, and polyethylene liners, bags, and bottles (see Section } 21.2 \text { ). } \\
\text { Analysis of IDC } 398 \text { (pulverized IDC 392) indicates trace amounts of } \\
\text { hydrocarbons (less than } 10 \mathrm{ppm} \text { ) which may have been produced from the } \\
\text { degradation of the plastic packaging material. }{ }^{C 186} \text { IDC } 393 \text { may contain an } \\
\text { appreciable amount of moisture because there were no controls on the moisture } \\
\text { content of the dried heels. } \text {. }^{81}\end{array}$ \\
\hline \multirow[t]{4}{*}{$\begin{array}{l}\text { Other Interfering Waste } \\
\text { Contaminants }\end{array}$} & $\begin{array}{l}\text { IDC 370: Leco crucibles are an aluminum silicate-based ceramic with } \\
\text { approximately } 0.5 \% \text { chromium. The waste may also contain stainless-steel } \\
\text { which was melted in the crucible for calibration purposes. }\end{array}$ \\
\hline & $\begin{array}{l}\text { IDC 391: The sand and crucible are composed of magnesium oxide. The } \\
\text { waste may also contain small beads of magnesium metal. }{ }^{\text {Po35 }}\end{array}$ \\
\hline & $\begin{array}{l}\text { IDC 392: The sand and crucible are composed of magnesium oxide. The } \\
\text { waste may also contain small beads of magnesium metal. The calcium fluoride } \\
\text { slag will contain trace amounts of the pyrotechnic initiator (powdered } \\
\text { magnesium and potassium iodate). }\end{array}$ \\
\hline & $\begin{array}{l}\text { IDC 393/817: Undissolved or precipitated calcium fluoride (slag) and } \\
\text { undissolved magnesium oxide sand and crucible remaining after the waste had } \\
\text { been pulverized and leached. The waste may also contain trace amounts of } \\
\text { aluminum nitrate and aluminum fluoride. }\end{array}$ \\
\hline \multirow[t]{2}{*}{$\begin{array}{l}\text { Physical Matrix } \\
\text { Parameters }\end{array}$} & $\begin{array}{l}\text { IDC 391: The small beads of magnesium metal will be located in the free } \\
\text { board area of the crucible. }{ }^{\text {P035 }}\end{array}$ \\
\hline & $\begin{array}{l}\text { IDC 392: The small beads of magnesium metal will be located in the free } \\
\text { board area of the crucible, and the slag and pyrotechnic initiator will be located } \\
\text { in the mid-section of the crucible. }\end{array}$ \\
\hline
\end{tabular}

\subsubsection{Complexing Agents}

Because complexing agents can aid in the transport of transuranic radionuclides from the waste after disposal, the waste was assessed for potential complexing agents. This information may also be added to the chemical compatibility studies since limited information was available on these chemicals in the past.

Aluminum nitrate was used in the residue dissolution process as a fluoride complexing agent. Trace quantities of this compound may be present in sand slag, and crucible heels (IDCs 393 and 817). ${ }^{\text {P061 }}$ 


\subsection{SOLIDIFIED AQUEOUS WASTE-BUILDING 374}

This waste group consists of aqueous sludges generated by liquid waste treatment operations in Building 374 at the Rocky Flats Plant. Aqueous wastes from numerous buildings and processes at the plant were received in Building 374 where they were treated to remove radioactive and chemical contaminants. Chemical contaminants were removed using evaporation. Radioactive contaminants were removed using neutralization, precipitation, flocculation, and clarification techniques. The slurry containing the radioactive contaminants was filtered producing a moist sludge. The sludge was either (1) dried, (2) mixed with an absorbent material, or (3) dried and mixed with cement and water. Historic IDC descriptions and dates of generation for the INEEL accessible storage inventory are presented by IDC in Table 22-1. ${ }^{\text {P127 }}$

Table 22-1. Solidified Aqueous Waste-Building 374 in the Accessible Storage Inventory.

\begin{tabular}{|c|c|c|}
\hline IDC & Title & Dates of Generation \\
\hline 007 & $\begin{array}{l}\text { Dried Sludge }{ }^{\mathrm{P} 014} \\
\text { Bldg. } 374 \text { Dry Sludge }{ }^{\mathrm{C} 063} \\
\text { Wet Sludge-Bldg. } 374^{\mathrm{C} 063}\end{array}$ & December 1982-March 1987 \\
\hline 803 & $\begin{array}{l}\text { Wet Sludge-Cemented } \\
\text { Solidified Sludge Bldg. } 374 \text { (DCP) }{ }^{\mathrm{C} 031}\end{array}$ & April 1986-May 1987 \\
\hline 807 & Solidified By-pass Sludge-Bldg. $374^{\mathrm{C} 031}$ & March 1987-July 1988 \\
\hline
\end{tabular}

Item Description Code 007; Wet Sludge-Bldg. 374: This waste consists of either a sludge that has been dried in a dryer, or a moist sludge mixed with Portland cement or a diatomite and Portland cement mixture. The dried sludge was produced from January 1981 to October 1982, and may not be included in the INEEL inventory based on the package dates for IDC 007 in storage. The moist sludge was produced from 1982 to 1987 . $^{\text {P052 }}$

Item Description Code 803, Solidified Sludge Bldg. 374 (DCP): This waste consists of sludge dried in a dryer, and mixed with Portland cement and water, which cured to form a solid monolith. IDC 803 was only generated for about a year. ${ }^{\mathrm{P} 52}$

Item Description Code 807, Solidified By-pass Sludge-Bldg. 374: This waste consists of sludge that bypassed the dryer, and was mixed with diatomite and Portland cement. IDC 807 sludge is the same as the IDC 007 sludge generated using the bypass system. IDC 807 was generated from March 1987 to 1991 . $^{\text {P052.P127 }}$ Prior to 1987 , IDC 807 was assigned to cemented incinerator sludge from Building 771. ${ }^{\text {C010,C063,C114,P043 See }}$ Section 14.0, Incinerator Waste, for a description of this waste.

\subsection{Waste Generation}

Rocky Flats has treated both liquid and solid process wastes. Liquid waste treatment operations have had relatively few process changes over the years. Building 374 went into operation in 1980 as an integral part of the new plutonium recovery facility, Building 371. It was designed to handle primarily the wastes generated by Building 371, but also helped to relieve the demand on Building $774{ }^{\text {P053 }}$ Only aqueous waste that contained 
plutonium below the EDL was processed in Building 374. ${ }^{\mathrm{P} 001}$ Aqueous treatment operations included radioactive decontamination, evaporation, acid neutralization, and sludge solidification. ${ }^{\text {P052.P106.P113 }}$

\subsubsection{Radioactive Decontamination}

Aqueous wastes containing greater than $13,500 \mathrm{pCi} / \mathrm{L}$ alpha contamination were treated in the radioactive decontamination process. The wastes were received by pipeline from Buildings $371,444,559$, $707,774,776,779,865,881,883$, and $889 .{ }^{\text {C087,U049 }}$ The treatment process involved three separate stages of precipitation, flocculation, and clarification.

The first stage feed tank, D-812, received supernatant from the sludge solidification process and basic waste solutions from Building 371. If needed, the $\mathrm{pH}$ of the solutions was adjusted to 10.5 or greater with potassium hydroxide. The basic solutions were pumped to a reactor tank where reagents, including magnesium sulfate, calcium chloride, and ferric sulfate, were added, which attracted and combined with the radioactive isotopes. The reactor contents were mixed with an agitator and flowed continuously by gravity to a flocculator tank. A flocculent was added to aid in agglomeration of the precipitate. The contents were mixed with an agitator and continuously overflowed to a clarifier. A rake at the bottom of the clarifier slowly moved the solids to the center where they were drawn off the bottom of the tank into the feed tanks, D824 A and B, for the sludge solidification process. ${ }^{\mathrm{P} 04, \mathrm{P} 106, \mathrm{P} 113}$

The first-stage clarifier liquids flowed over a weir and were pumped to the second-stage feed tank. The second-stage feed tank also received third-stage clarifier effluent, steam condensate and decontamination wastewater from Building 371, wastes from Building 444, and from the 500, 700, and 800 areas. ${ }^{\mathrm{C} 87, \mathrm{C} 121, \mathrm{U} 045, \mathrm{U} 049, \mathrm{U} 051}$ The second- and third-stage reactors, flocculators, and clarifiers functioned exactly as the first stage. ${ }^{\mathrm{P} 004, \mathrm{P} 106, \mathrm{P} 113}$ Figure 22.1 shows the radioactive decontamination process. ${ }^{\mathrm{P} 052}$

\subsubsection{Evaporation}

The evaporation process concentrated soluble materials from low-level desaltable aqueous wastes. Aqueous wastes were received from Buildings 122, 123, 443, 444, 447, 460, 559, 561, and 566. Clarifier effluent from the radioactive decontamination process, solar pond water, and aqueous wastes from buildings in the 700 and 800 areas were also sent to the evaporator. ${ }^{\text {P052,U045 }}$ The aqueous wastes were pumped to the evaporator where they were continuously circulated and heated by steam producing a concentrated salt brine and steam. The steam was condensed for use by the boiler plant and cooling tower. The salt brine was dried and immobilized with cement. Periodically, a nitric and phosphoric acid descaling solution was used to flush the evaporator heat exchangers. This solution was then sent to the sludge immobilization process. ${ }^{\text {P106 }}$ The evaporation process is shown in Figure 22.1. ${ }^{\mathrm{P} 052}$ 



\subsubsection{Acid Neutralization}

Nitric acid wastes from plutonium recovery operations in Building 371 were received in Building 374 by pipeline. Acid wastes were also received as packaged materials in 55-gallon drums from Buildings 123, $444,460,559,774,865,881$, and $8833^{\text {U045 }}$ The acid wastes were continuously mixed by an agitator in Tank D-808, and by circulation through a heat exchanger. The heat exchanger removed heat generated during the process. As the the liquid circulated, a $\mathrm{pH}$ analyzer regulated the amount of neutralization solution, containing $46 \%$ potassium hydroxide that was fed to the tank to maintain a pH of $12.5 .^{\mathrm{Cl21}, \mathrm{P} 106, \mathrm{P} 113}$ Neutralized acid waste was piped to Tanks D-824 A and B for eventual treatment by the sludge solidification process. ${ }^{\text {P106,P113 }}$ The acid neutralization process is shown in Figure 22.2. ${ }^{\text {P052 }}$

\subsubsection{Sludge Solidification}

Liquid wastes treated by the acid neutralization, radioactive decontamination, and evaporation processes were transferred to the sludge solidification process. The waste streams that were treated in the sludge solidification process are described in Table 22-2. ${ }^{\text {P052,P106 }}$

Table 22-2. Waste Streams Treated in the Sludge Solidification Process.

\begin{tabular}{|c|c|c|}
\hline Waste Streams & Source Buildings & Contaminants \\
\hline $\begin{array}{l}\text { Tank D-808: } \\
\text { Packaged Acid Wastes and } \\
\text { Building } 371 \text { Nitric Acid } \\
\text { Wastes }\end{array}$ & $\begin{array}{l}\text { Buildings } 123,371 \text {, } \\
444,460,559,774, \\
865,881 \text {, and } 883\end{array}$ & Acid Wastes \\
\hline $\begin{array}{l}\text { Tanks D-815, D-819, D-823: } \\
\text { Radioactive Decontamination } \\
\text { Process Effluent }\end{array}$ & $\begin{array}{l}\text { Buildings } 371 \text { and } \\
559 \text {, and } 700 \text { and } 800 \\
\text { Areas }\end{array}$ & $\begin{array}{l}\text { Acids, bases, arsenic, barium, beryllium, } \\
\text { cadmium, chromium, lead, mercury, } \\
\text { selenium, silver, Trim Sol } \mathrm{P}^{\mathrm{P} 130} \text {, Oakite } \\
\text { Cleaner }{ }^{\mathrm{P} 91} \text {, Ox Out } 536^{\mathrm{P} 129} \text {, acetone, ethyl } \\
\text { alcohol, hexane, methanol, MEK, methylene } \\
\text { chloride, eutectic salts, photo } \\
\text { developer }^{\mathrm{P} 144, \mathrm{P} 146, \mathrm{P} 150} \text {, and photo stop bath }\end{array}$ \\
\hline $\begin{array}{l}\text { Tank D-845: } \\
\text { Evaporation Process } \\
\text { Descaling Solution (nitric } \\
\text { and phosphoric acid) }\end{array}$ & $\begin{array}{l}\text { Buildings } 122,123 \text {, } \\
443,444,447,460, \\
559,561,566,700 \\
\text { and } 800 \text { Areas, and } \\
\text { Solar Ponds }\end{array}$ & $\begin{array}{l}\text { Radioactive decontamination process } \\
\text { effluent contaminants, solar pond water } \\
\text { constituents, demineralization salts, water } \\
\text { softeners, chemical indicators, } 1,1,2- \\
\text { trichloro-1,2,2-trifluoroethane, toluene, } \\
\text { penetrant oils, isopropanol, ethylene glycol, } \\
\text { Mariko }{ }^{\mathrm{P} 128} \text {, diamond paste, spent } \\
\text { emulsifier }^{\text {149, }} \text {, spent developer }\end{array}$ \\
\hline
\end{tabular}

The slurry from radioactive decontamination, spent descaling solution from the evaporator, and wastes from acid neutralization were fed into the filter feed tanks, D-824 A and B. Supernatant from the filter feed tanks was decanted to the radioactive decontamination process. The slurry from the feed tanks was pumped to the radioactively contaminated solids on the surface of the filter media. An advancing blade continuously removed rotary drum vacuum filter. The filter drum was coated with a mixture of diatomite and water or the 


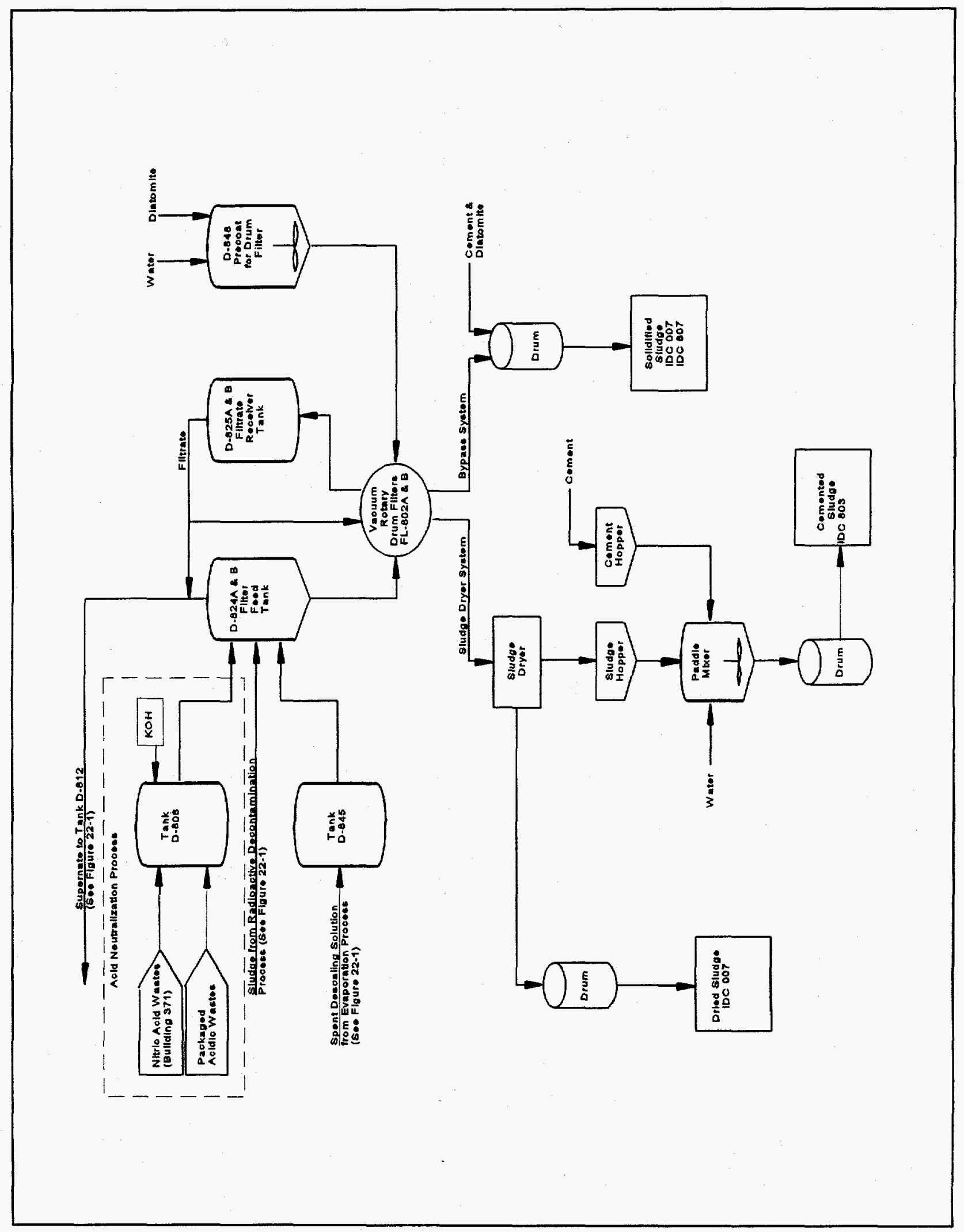

Figure 22-2. Building 374 Acid Neutralization and Sludge Immobilization Processes. 
filtrate. The slurry was fed into the filter pan, and the filtrate was drawn through the precoat by a vacuum, leaving the radioactively contaminated solids on the surface of the filter media. An advancing blade continuously removed the sludge and a thin layer of precoat. The filtrate from the rotary drum filter was transferred back to the radioactive decontamination process. ${ }^{\mathrm{P} 047, \mathrm{P} 106, \mathrm{P} 113}$

The sludge from the rotary drum filter was immobilized using either the sludge dryer system or the bypass system. In the sludge dryer system, the sludge from the vacuum filters was fed to the dryer feed hopper then conveyed through the dryer in heated flights. The dried sludge was transferred directly into a 55 -gallon drum. The resulting waste was assigned IDC 007 and consisted of dispersible fines. ${ }^{\text {P052P106 }}$

The process was modified in October 1982 to bypass the dryer. The bypass system used a series of two conveyor belts to transfer the moist sludge exiting the vacuum filter directly into a 55-gallon drum. Before 1986, cement was placed into the drum in layers with the sludge and tamped down during the metering process. This waste was also assigned IDC 007. After April 1986, diatomite and cement in a 1-to-1 ratio were metered into the drum with the sludge. ${ }^{\mathrm{P} 13, \mathrm{P} 015, \mathrm{P} 016}$ IDC 007 was discontinued in 1987 and replaced by IDC 807. ${ }^{\mathrm{P} 52}$ The process that generated IDC 807 was the same as IDC 007. ${ }^{\text {P052.P106 }}$

Use of the sludge drier resumed in 1985. The sludge from the vacuum filter was dried in the same manner as the sludge generated prior to October 1982. However, the dried sludge was cemented in the direct cementation process (DCP). The dried sludge overflowed directly into the DCP sludge hopper, and cement and water were mixed in using a paddle mixer. The sludge, cement, and water mixture was deposited into a 55 gallon drum and allowed to solidify. ${ }^{\text {P047,P052,P106 }}$ DCP sludge was assigned IDC 803 . Due to mechanical problems, the DCP was only in operation for about a year. ${ }^{\text {P052 }}$ Figure 22.2 illustrates the sludge immobilization processes.

\subsection{Waste Packaging}

Depending on the type of sludge and waste packaging requirements at the time, several combinations of bags and liners were used to prepare 55-gallon drums for shipment. A 90-mil rigid polyethylene liner was placed in the empty drum. Either a polyethylene drum bag or a round-bottom polyethylene drum bag was placed inside the rigid liner. A PVC O-ring bag was placed inside the polyethylene liner. ${ }^{\text {P012,P013,P016,P022,P026,P047 }}$

Sludge generated using the sludge dryer system (IDC 007) was placed directly into lined 55-gallon drums. ${ }^{\text {POS2 }}$ Until 1986, sludge generated using the bypass system (IDC 007) was placed into a drum and mixed with cement. The resulting mixture of sludge and cement was tamped down during the metering process. Free liquids have been identified in many of the bypass sludge drums generated during this time period. ${ }^{\mathrm{P} 013 . P 015, P 016}$

For bypass sludge generated after April 1986 (IDC 007/807), one pound of diatomite was placed in the bottom of the rigid liner and another pound inside the polyethylene drum bag. The PVC O-ring bag was placed inside the polyethylene drum bag, and the excess top of the bag was folded down over the outside of the drum. The bag was doubled back up to form a tuck, and two pounds of diatomite were evenly distributed into the tucked portion of the $\mathrm{O}$-ring bag. Two pounds of diatomite were also placed in the bottom of the O-ring bag. Diatomite and Portland cement were metered into the lined drum with the moist sludge. The cement and diatomite mixture was determined to be a better absorbent, and no free liquids or condensation have been found in the drums generated after April 1986. ${ }^{\mathrm{P} 016}$ A 7-to-1 ratio of sludge to the cement and diatomite mixture was used. ${ }^{\mathrm{C} 13, \mathrm{C} 015}$ As the drum was filled, the waste was periodically tamped down using a tamping tool. The 
diatomite in the tucked portion of the 0 -ring bag capped off the top of the sludge when the bag was twisted and taped closed. ${ }^{\text {047,P052 }}$

For IDC 803, one liter of Oil Dri was placed in the bottom of the O-ring bag. The sludge, cement, and water mixture was placed into the $\mathrm{O}$-ring bag, and the $\mathrm{O}$-ring bag was twisted and taped closed. One liter of Oil Dri was placed on top of the O-ring bag inside the polyethylene drum bag. ${ }^{\mathrm{P} 47}$

Once a drum was full, the drum bags were twisted and taped closed, and the waste was allowed to cure. The rigid liner was closed with a plastic lid, the drum lid was secured with a bolted ring, and a tamper indicating device was attached to the drum. ${ }^{\text {P01.POS2 }}$

\subsection{Waste Characterization}

Building 374 solidified aqueous waste is characterized based on knowledge of the material, knowledge of the processes generating the waste, RTR review of the waste, visual inspection, waste analysis, and headspace gas analysis. This section provides a RCRA hazardous waste determination for Building 374 solidified aqueous waste as well as radionuclide contaminants and potential complexing agents contained in the waste. This waste is at least 50 percent (by volume) inorganic solids and is classified as a homogeneous waste. ${ }^{\mathrm{P} 141}$

\subsubsection{Hazardous Waste Determination}

The material in this waste group does not qualify for any of the exclusions outlined in 40 CFR 260 or 261. The waste may exhibit the characteristic of corrosivity due to the presence of caustic free liquids. The waste may also exhibit the characteristic of toxicity for chromium and selenium. The waste was derived from the treatment of electroplating wastes and aqueous wastes containing halogenated- and nonhalogenatedsolvents, and is therefore a F-listed hazardous waste. There is no evidence that the waste exhibits any other characteristic of hazardous waste. EPA Hazardous Waste Numbers applicable to some or all of the Building 374 solidified aqueous waste group are presented by IDC in Table 22-3. These conclusions are supported by the evaluation in Sections 22.3.1.1 and 22.3.1.2.

Table 22-3. Building 374 Solidified Aqueous Waste Characterization.

\begin{tabular}{lll}
\hline IDC & \multicolumn{1}{c}{ Title } & \multicolumn{1}{c}{ EPA Hazardous Waste Numbers } \\
\hline 007 & Wet Sludge-Bldg. 374 & D002, D007, D010, F001, F002, F003, F005, F006, \\
& & F007, and F009 \\
803 & Solidified Sludge Bldg. 374 (DCP) & $\begin{array}{l}\text { D002, D007, D010, F001, F002, F003, F005, F006, } \\
\text { F007, and F009 }\end{array}$ \\
& & D002, D007, D010, F001, F002, F003, F005, F006, \\
807 Solidified By-pass Sludge Bldg. 374 & F007, and F009 \\
\hline
\end{tabular}




\subsubsection{Characteristic Waste}

The materials in this waste group may exhibit a characteristic of hazardous waste as defined in 40 CFR 261, Subpart C as a corrosive waste (40 CFR 261.22) and as a toxic waste (40 CFR 261.24). The materials do not exhibit the characteristics of ignitability (40 CFR 261.21) or reactivity (40 CFR 261.23).

Ignitability: The materials in this waste group do not meet the definition of ignitability as defined in 40 CFR 261.21. These materials are not liquid, but RTR and visual inspection have identified free liquids in some sludge drums. However, the liquids are aqueous and are not ignitable. ${ }^{\text {P013.P015.U060 }}$ These materials are not capable of causing fire through friction, absorption of moisture, or spontaneous chemical change. These materials are not compressed gases, nor do the containers contain compressed gases. ${ }^{\mathrm{P} 013 . \mathrm{P} 015, \mathrm{P} 022}$ These materials are not DOT oxidizers as defined in 49 CFR 173. The materials in this waste group are therefore not ignitable wastes (D001).

Corrosivity: The materials in this waste group may meet the definition of corrosivity as defined in 40 CFR 261.22 due to the presence of caustic free liquids. The materials are not liquid, but it is suspected that bypass sludge (IDC 007) generated before April 1986 may have dewatered. In addition, DCP sludge (IDC 803) may also have dewatered. ${ }^{\mathrm{C} 121}$ After April 1986, a mixture of Portland cement and diatomite was mixed with the sludge (IDCs 007 and 807) which may help prevent the waste from dewatering. Visual inspection of a few bypass sludge (IDC 007) generated after April 1986 did not identify free liquids. ${ }^{\text {P013,P015 }}$ Free liquids were however, identified in four sludge drums (IDC 007) generated prior to this date. Analysis of the liquids indicate a pH range of 7 to 12 . Although the $\mathrm{pH}$ of the liquids does not meet the definition of corrosivity, these results are limited and may not be representative of the entire inventory. According to generator knowledge and Building 374 liquid waste treatment $\log$ books, the $\mathrm{pH}$ of liquids treated was as high as 14, and was consistently above 12.5 . ${ }^{\text {C121.U049.U050 }}$ Therefore, drums of Building 374 solidified aqueous waste containing free liquid are assigned EPA Hazardous Waste Number D002.

Reactivity: The materials in this waste group do not meet the definition of reactivity as defined in 40 CFR 261.23. The materials are stable and will not undergo violent chemical change. The materials will not react violently with water, form potentially explosive mixtures with water, or generate toxic gases, vapors, or fumes when mixed with water. The materials do not contain sulfides, and are not capable of detonation or explosive reaction. The materials are not forbidden explosives or Division 1.1, 1.2, or 1.3 (Class A or B) explosives as defined in 49 CFR 173, nor do the drums contain explosive materials. ${ }^{\text {P013,P015,P022 }}$ Explosives were not handled or used around radioactive material. The waste may contain cyanide from treatment of electroplating wastes. Analysis of bypass sludge indicates a maximum total cyanide concentration $8.2 \mathrm{mg} / \mathrm{kg}$, and a maximum reactive cyanide concentration of $5.36 \mathrm{mg} / \mathrm{kg}$. These cyanide levels will not cause the waste to be reactive. ${ }^{\mathrm{C} 111, \mathrm{Cl13}}$ The materials in this waste group are therefore not reactive wastes (D003).

Toxicity: The materials in this waste group may meet the definition of toxicity as defined in 40 CFR 261.24. The toxicity characteristic contaminants fall into one of two categories: metals and organics. Organic compounds include halogenated-and nonhalogenated-solvents, pesticides, herbicides, and other toxic compounds. This waste group may exhibit the characteristic of toxicity for chromium and selenium metals.

TCLP results from Building 374 bypass sludge samples collected in 1995 are provided in Table 22$4{ }^{\mathrm{Cl} 22}$ Table 22-5 shows TCLP results for bypass sludge samples obtained in 1989 and 1990 . $^{\text {P052 }}$ The 1995 results indicate that the waste does not contain toxicity characteristic levels of metals. The waste may however, exhibit the characteristic of toxicity for selenium based on the data from 1990. The results from 1989 indicate 
that the waste may also exhibit the characteristic of toxicity for chromium. Even though the results are only for bypass sludge samples, they may apply to all of the Building 374 sludge wastes since they were derived from the treatment of the same aqueous wastes. Therefore, the Building 374 solidified aqueous waste group is assigned EPA Hazardous Waste Numbers D007 and D010.

Table 22-4. TCLP Metals Results for By-pass Sludge from 1995 . $^{\mathrm{C} 22}$

\begin{tabular}{lccc}
\hline \multicolumn{1}{c}{ Constituent } & TCLP Limit (mg/l) & Sample Size & Concentration (mg/l) \\
\hline Arsenic & 5.0 & 7 & Not detected \\
Barium & 100.0 & 7 & $0.10-0.86$ \\
Cadmium & 1.0 & 7 & Not detected \\
Chromium & 5.0 & 7 & $0.24-0.55$ \\
Lead & 5.0 & 7 & Not detected \\
Selenium & 1.0 & 7 & Not detected-0.12 \\
Silver & 5.0 & 7 & Not detected \\
\hline
\end{tabular}

Table 22-5. TCLP Metals Results for By-pass Sludge from 1989 and $19900^{\text {P0s2 }}$

\begin{tabular}{lcccc}
\hline \multicolumn{1}{c}{ Constituent } & TCLP Limit (mg/l) & Sample Size & Mean (mg/l) & $\begin{array}{c}\text { Upper 90-Percent } \\
\text { Confidence Limit }\end{array}$ \\
\hline Arsenic $^{2}$ & 5.0 & 7 & 0.6876 & 0.9085 \\
Barium $^{2}$ & 100.0 & 7 & 0.924 & 0.1118 \\
Cadmium $^{5}$ & 1.0 & 14 & 0.0448 & 0.0608 \\
Chromium $^{1,2}$ & 5.0 & 7 & 2.3743 & 4.1724 \\
Chromium $^{1,3}$ & 5.0 & 7 & 12.260 & 15.2886 \\
Lead $^{5}$ & 5.0 & 14 & 0.7304 & 1.1503 \\
Mercury $^{2}$ & 0.2 & 6 & 0.0022 & 0.0042 \\
Nickel $^{2}$ & N/A & 7 & 0.7414 & -4 \\
Selenium $^{2}$ & 1.0 & 7 & 0.9391 & 1.3900 \\
Silver $^{5}$ & 5.0 & 14 & 0.7282 & 0.7414 \\
\hline
\end{tabular}

Notes: 1. Chromium analyses in 1989 and 1990 used different analytical methods.

2. May 1990 data.

3. November 1989 data.

4. Not calculated in reference number P052.

5. Combined 1989 and 1990 data. 
There is no documentation indicating the presence or use of pesticides or herbicides in the areas or processes that generated the aqueous waste from which Building 374 solidified aqueous waste was derived. Therefore, this waste group does not exhibit the characteristic of toxicity due to pesticides or herbicides (D012-D017).

Analytical results for the toxicity characteristic organic compounds detected in Building 374 sludge samples are shown in Tables 22-6. Analyses were performed on total or TCLP extracts. Other than the compounds listed in Table $22-6$, most of the toxicity characteristic organics were analyzed for and were not detected in the TCLP extract. ${ }^{\mathrm{Cl1} 1, \mathrm{Cl1} 2, \mathrm{Cl13}, \mathrm{Cl} 22, \mathrm{U} 029}$

Table 22-6. Volatile Organic Results for Building 374 Sludge Wastes.

\begin{tabular}{lccc}
\hline \multicolumn{1}{c}{ Constituent } & $\begin{array}{c}\text { TCLP Limit } \\
(\mathbf{m g} / \mathbf{l})\end{array}$ & $\begin{array}{c}\text { TCLP Concentrations } \\
(\mathbf{m g} / \mathbf{k g})\end{array}$ & $\begin{array}{c}\text { Total Concentration } \\
(\mathbf{m g} / \mathbf{k g})\end{array}$ \\
\hline Benzene & 0.5 & $0.13-0.14$ & 2.0 \\
Carbon Tetrachloride & 0.5 & $--^{1}$ & 13.0 \\
Chloroform & 6.0 & $-042-2.9$ & 0.2 \\
Methyl Ethyl Ketone & 200.0 & -1 & 1.0 \\
Tetrachloroethene & 0.7 & $--^{1}$ & 1.4 \\
Trichloroethene & 0.5 & & 16.0 \\
\hline
\end{tabular}

Notes: $1 . \quad$ TCLP analysis not performed.

Based on these data, the waste may exhibit the characteristic of toxicity for carbon tetrachloride and tetrachloroethene. However, because these compounds were used as solvents for cleaning and degreasing, the waste is regulated as a listed hazardous waste and not a characteristic waste because these compounds are specifically addressed in the treatment standards for the listed hazardous waste. ${ }^{\mathrm{P} 080}$ Since Building 374 solidified aqueous waste is characterized as a listed hazardous wastes due to spent solvent contamination, the waste is not a toxic waste due to the presence of these organic compounds.

\subsubsection{Listed Hazardous Waste}

The material in this waste group was derived from the treatment of a waste listed in 40 CFR 261, Subpart D as a hazardous waste from non-specific sources (40 CFR 261.31). The waste is not, or was not derived from the treatment of, a hazardous waste from specific sources (40 CFR 261.32), or a discarded commercial chemical product, an off-specification species, a container residue, or a spill residue thereof (40 CFR 261.33).

Tetrachloroethene, trichloroethene, 1,1,1-trichloroethane, carbon tetrachloride, and 1,1,2-trichloro1,2,2-trifluoroethane were commonly used for cleaning and degreasing. Methylene chloride was used primarily for paint removal. The aqueous waste transferred to Building 374 for treatment may have contained small amounts of these spent solvents. Building 374 solidified aqueous waste was derived from the treatment of a listed hazardous waste and is therefore assigned EPA Hazardous Waste Numbers F001 and F002. 
Acetone, methanol, and xylene were used primarily as solvents in laboratory operations. The aqueous waste transferred to Building 374 for treatment may have contained small amounts of these spent solvents. Building 374 solidified aqueous waste was derived from the treatment of a listed hazardous waste and is therefore assigned EPA Hazardous Waste Number F003.

There is no documentation indicating the presence or use of F004-listed solvents in the areas or processes that generated the aqueous waste from which Building 374 solidified aqueous waste was derived. Therefore, this waste group is not a F004-listed hazardous waste.

Benzene and toluene were used as solvents in laboratory operations. The aqueous waste transferred to Building 374 for treatment may have contained small amounts of these spent solvents. Building 374 solidified aqueous waste was derived from the treatment of a listed hazardous waste and is therefore assigned EPA Hazardous Waste Number F005.

Analysis of Building 374 sludge confirms the presence of F-listed solvents. The analytical results are presented in Table 22-7. C111,C112,C113.C122.U029

Table 22-7. Volatile Organic Results for Building 374 Sludge Wastes.

\begin{tabular}{lcc}
\hline \multicolumn{1}{c}{ Constituent } & $\begin{array}{c}\text { TCLP Concentrations } \\
(\mathbf{m g} / \mathbf{k g})\end{array}$ & $\begin{array}{c}\text { Total Concentrations } \\
(\mathbf{m g} / \mathbf{k g})\end{array}$ \\
\hline Tetrachloroethene & -1 & 1.4 \\
Trichloroethene & -1 & 16.0 \\
1,1,1-trichloroethane & -1 & 41.1 \\
Methylene Chloride & $0.56-4.0$ & 27.0 \\
Carbon Tetrachloride & -1 & 13.0 \\
Total Xylenes & -1 & 11.0 \\
Acetone & $0.004-1.6$ & -2 \\
Ethyl Benzene & $-{ }^{1}$ & $0.3-6.0$ \\
n-Butyl Alcohol & $0.065-0.17$ & $--^{2}$ \\
Methanol & 6.2 & $-^{2}$ \\
Toluene & $0.0087-1.6$ & 7.0 \\
Methyl Ethyl Ketone & $0.042-2.9$ & 1.0 \\
Methyl Isobutyl Ketone & 0.051 & $-^{2}$ \\
Benzene & $0.13-0.14$ & 2.0 \\
\hline
\end{tabular}

Notes: $\quad$ 1. TCLP analysis not performed.

2. Totals analysis not performed. 
Headspace analysis was performed on samples of Building 374 aqueous sludge wastes (IDCs 007, 803, and 807) obtained at INEEL. The detected F-listed compounds in which the 90 percent UCL is above the PRQL are provided: ${ }^{\mathrm{P} 33}$

- $\quad$ methylene chloride (IDC 007 only)

- 1,1,1-trichloroethane (IDC 007 only)

Additional F-listed solvents were detected in headspace samples of sludge (IDCs 803 and 807) obtained at Rocky Flats. The detected F-listed compounds in which the 90 percent UCL is above the PRQL are also provided. ${ }^{\text {0030 }}$

- 1,1,2-trichloro-1,2,2-trifluoroethane (IDC 803 only)

- $\quad$ methylene chloride (IDC 803 only)

- 1,1,1-trichloroethane (IDC 803 only)

At one time, the evaporator in Building 374 treated spent stripping, cleaning, and plating solutions from electroplating operations in Building 444 in which cyanides were used. The Building 374 sludges were derived from the treatment of spent descaling solution from the evaporator, and therefore are assigned EPA Hazardous Waste Numbers F006, F007, and F009.

The material in this waste group is not a hazardous waste from specific sources since it was not generated from any of the processes listed in 40 CFR 261.32. The material in this waste group is therefore not a K-listed hazardous waste.

The material in this waste group is not a discarded commercial chemical product, an off-specification species, a container residue, or a spill residue thereof ( 40 CFR 261.33). The material in this waste group is therefore not a P-or U-listed hazardous waste.

Analytical results for Building 374 sludge samples detected several other organic compounds which are provided in Table 22-8 for informational purposes. ${ }^{\mathrm{Cl} 12, \mathrm{U} 029}$

Table 22-8. Organic Results for Building 374 Sludge Wastes.

\begin{tabular}{lc}
\hline \multicolumn{1}{c}{ Constituent } & Total Concentrations $(\mathbf{m g} / \mathbf{k g})$ \\
\hline 1,2-dichloroethene & 5.7 \\
Trans-1,3-dichloropropene & 24.0 \\
1,1,2,2-tetrachloroethane & 26.0 \\
Styrene & 10.0 \\
\hline
\end{tabular}

\subsubsection{Radionuclides}

This section identifies the radioisotopes potentially contained in the waste. In addition, Table 22-9 summarizes matrix and other physical parameters which could affect radioassay. 
Aqueous waste treatment operations in Building 374 receive wastes from throughout plant site, including processes that generated low-level and nonradioactive liquid wastes. For this reason, wastes generated during treatment operations may contain any of the radioisotopes used at the plant. The most common radioactive materials handled were weapons-grade plutonium, americium-241, enriched uranium, and depleted uranium ${ }^{\mathrm{P} 164}$ The isotopic compositions of weapons-grade plutonium, enriched uranium, and depleted uranium are provided in Section 3.0.

Production and production support processes in Buildings 371, 559, 707, 771 (Building 774 effluent), 776,777 , and 779 generated wastes contaminated with weapons-grade plutonium, americium-241, and enriched uranium which were treated in Building 374. Production and production support processes in Buildings 444, 447,865 , and 883 generated wastes contaminated with depleted uranium which were treated in Building $374{ }^{\text {P053,U053 }}$ Other radionuclides may also be found in Building 374 wastes from R\&D, analytical, and special

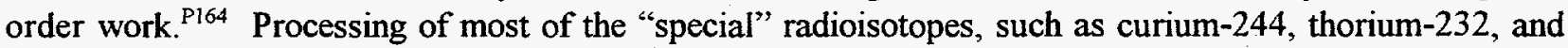
uranium-236, was performed until the early- to mid-1970s. ${ }^{\text {C154,P164,P189,P194 }}$ However, these isotopes will not be contained in the sludge waste because Building 374 was not in operation until 1980. Neptunium-237 was processed until 1985 or 1986 , and uranium- 233 was handled until about 1982 and, therefore, are potentially

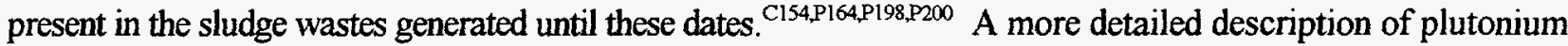
and uranium production operations and R\&D operations is provided in Section 3.0.

The Size Reduction Vault in Building 776 conducted repackaging operations (prefixes 19, 25, and

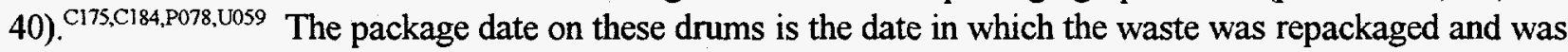
originally generated some time prior to this date. Therefore, it is assumed that the repacked IDC 007 sludge containers could potentially contain any of the above radioisotopes. IDC 803 should not contain uranium-233 because this waste was not generated until about 1985 .

Table 22-9. Waste Matrix Evaluation.

\begin{tabular}{|c|c|}
\hline Parameter & Results of Evaluation \\
\hline $\begin{array}{l}\text { Radionuclide Form, } \\
\text { Particle Size, and } \\
\text { Distribution }\end{array}$ & $\begin{array}{l}\text { The sludges were produced by a carrier precipitation process in which ferric } \\
\text { sulfate, calcium chloride, magnesium sulfate, and a flocculant were used to } \\
\text { form a floc that coprecipitated with the radioactive contaminants. }{ }^{\text {P004.P164 }} \text { Based } \\
\text { on the generation process, the distribution of actinides in waste should be } \\
\text { relatively homogeneous. }\end{array}$ \\
\hline Hydrogen Content & $\begin{array}{l}\text { Sources of hydrogen may include plastic packaging material (see Section } 22.2 \text { ) } \\
\text { and trace amounts of hydrocarbons (see Section } 22.3 .1 \text { ). Based on visual } \\
\text { inspection, some of the waste is damp or contains free liquid. }{ }^{\text {P013.P015.P022 }}\end{array}$ \\
\hline $\begin{array}{l}\text { Other Interfering Waste } \\
\text { Contaminants }\end{array}$ & $\begin{array}{l}\text { Magnesium and chromium were detected in waste samples. }{ }^{\mathrm{C} 122} \text { The major } \\
\text { anions and cations in Building } 774 \text { sludges include aluminum, magnesium, } \\
\text { fluoride, and chloride. It could be assumed that these contaminants are in } \\
\text { sludges from Building } 374 \text { as well because the wastes treated originated from } \\
\text { most of the same buildings and processes. }\end{array}$ \\
\hline $\begin{array}{l}\text { Physical Matrix } \\
\text { Parameters }\end{array}$ & $\begin{array}{l}\text { Documentation on the distribution of contaminants was not identified but, } \\
\text { based on the generation process, should be relatively homogeneous. Measured } \\
\text { sludge density and void space information was not identified. }\end{array}$ \\
\hline
\end{tabular}




\subsubsection{Complexing Agents}

Because complexing agents can aid in the transport of transuranic radionuclides from the waste after disposal, the waste was assessed for potential complexing agents. This information may also be added to the chemical compatibility studies since limited information was available on these chemicals in the past.

EDTA represents a group of chelating compounds, such as ethenediaminetetraacetic acid, with similar molecular structures found in many soaps and detergents. Versene (a trade name for EDTA) and citric acid are known constituents of KW decontamination detergent. ${ }^{\mathrm{P} 24, \mathrm{P0} 68} \mathrm{KW}$ was used during a variety of decontamination activities at the plant. A buffer solution (TISAB) containing diaminocyclohexane tetraacetic acid was used during specific ion electrode analysis in Building 559. ${ }^{\mathrm{P} 76}$ Oxalic acid and tetraphosphoric acid were used to etch plutonium and other metals. ${ }^{\mathrm{PO} 2 \mathrm{P079,0043}}$ Oxalic acid was also used for americium recovery. ${ }^{\mathrm{P} 113}$ Because complexing agents interfered with the aqueous waste treatment system, wastes sent to Building 374 for treatment should have had only trace quantities of these compounds. Therefore, the solidified aqueous waste should only have trace quantities of complexing agents. 


\subsection{SOLIDIFIED AQUEOUS WASTE-BUILDING 774}

This waste group consists of aqueous sludges generated by liquid waste treatment operations in Building 774 at Rocky Flats Plant. Aqueous wastes from numerous buildings and processes at the plant were received in Building 774 where they were treated to remove radioactive and chemical contaminants, and converted to a solid for disposal. A wet sludge containing the contaminants was filtered followed by the addition of cement or diatomite. Historic IDC descriptions and dates of generation for the INEEL accessible storage inventory are presented by IDC in Table $23-1 .^{\text {P127 }}$

Table 23-1. Building 774 Solidified Aqueous Waste in the Accessible Storage Inventory.

\begin{tabular}{|c|c|c|}
\hline IDC & Title & Dates of Generation \\
\hline 001 & $\begin{array}{l}\text { First-Stage Sludge }{ }^{\mathrm{C} 063} \\
\text { First-Stage Sludge (prefix 741) } \text { ) }^{\mathrm{P} 024} \\
\text { First-Stage Sludge-Bldg. } 774^{\mathrm{C} 063} \\
\text { Combined Sludge (prefix 7412) } \\
\text { First- and Second-Stage Sludge } \\
\text { P014 }\end{array}$ & January 1972-August 1986 \\
\hline 002 & $\begin{array}{l}\text { Second-Stage Sludge }{ }^{\mathrm{C} 063} \\
\text { Second-Stage Sludge (prefix 742) }\end{array}$ & August 1972-July 1985 \\
\hline 800 & $\begin{array}{l}\text { "7412-series" Sludge }{ }^{\mathrm{P} 004} \\
\text { Solidified Sludge-Bldg. } 774^{\mathrm{C} 031}\end{array}$ & December 1985-September 1988 \\
\hline
\end{tabular}

Item Description Code 001, First-Stage Sludge: This waste consists of immobilized materials generated from first-stage treatment operations in Building 774. Aqueous liquids coming into the process originated from Building 771 recovery operations. The liquids were made basic with sodium hydroxide to precipitate iron, magnesium, etc., which also carried down the relatively small precipitate of plutonium and americium hydrated oxides. The precipitate was filtered to produce a sludge (IDC 001) which was placed in a drum with Portland cement. Beginning in 1979 , sludge waste from second-stage treatment was combined with first-stage sludge. The combined sludges were also assigned IDC 001 . IDC 001 was discontinued in 1986 when the immobilization process changed, and has since been assigned IDC 800 . ${ }^{\mathrm{P} 04, \mathrm{P} 015, \mathrm{P} 016, \mathrm{P} 052, \mathrm{P} 113}$

Item Description Code 002, Second-Stage Sludge: This waste consists of immobilized materials generated from second-stage treatment operations in Building 774. Aqueous liquids to be treated originated from first-stage treatment and from numerous buildings on plant site. The liquids were treated in the same manner as the liquids from the first-stage, and the resulting sludge (IDC 002) was placed into a drum with Portland cement. Prior to 1973, second-stage sludge may contain miscellaneous debris. ${ }^{\text {P004,P024,P042,P052,P109,P124 }}$

Item Description Code 800, Solidified Sludge-Bldg. 774: The process that produced solidified sludge from Building 774 (IDC 800) was very similar to IDC 001 . The difference between the two IDCs was the immobilization process. For IDC 800, the sludge was co-fed into a drum with a diatomite and Portland cement mixture which formed a solid monolith after curing. IDC 800 was generated from 1986 until March 1991. ${ }^{\text {P001,P016,P052,P109 }}$ 


\subsection{Waste Generation}

Waste processing at Rocky Flats has included both liquid and solid process wastes. Liquid waste treatment operations have had relatively few process changes over the years. When Building 774 was built in 1952 , its primary purpose was to treat radioactive aqueous waste from Building 771 . Later, aqueous wastes from numerous buildings on plant site were treated in Building 774. Aqueous treatment operations included neutralization, precipitation, filtration, flocculation, clarification, immobilization, and evaporation. ${ }^{\text {P052,P053,P113 }}$ The evaporation process did not generate aqueous sludge and is not discussed. A flow diagram of the Building 774 aqueous waste treatment system is shown in Figure 23.2 (evaporation not shown). ${ }^{\text {P052 }}$

\subsubsection{First-Stage Treatment}

Most aqueous wastes from plutonium recovery operations in Building 771 entered the first-stage of the Building 774 liquid waste processing facility by vacuum transfer through the process waste system. The most common waste streams that entered first-stage treatment were: ${ }^{\mathrm{P} 01, \mathrm{Pl} 13, \mathrm{P} 124}$

- $\quad$ Plutonium ion column effluent

- Americium ion column effluent

- Thiocyanate waste solution

- $\quad$ Caustic scrubber solution

- $\quad$ Part V waste solutions (nitric, sulfuric, and hydrofluoric acids)

- $\quad$ Nitric acid distillate from feed evaporator

- Water distillate from peroxide precipitation filtrate evaporator

- Steam condensate

The following compounds were used during recovery operations in Building 771 and may be present in aqueous sludges from first-stage treatment: ${ }^{\text {0661,U047 }}$

- $\quad$ Nitric acid

- Aluminum nitrate

- Calcium fluoride

- $\quad$ Potassium hydroxide

- Ferrous sulfamate

- $\quad$ Sulfuric acid

- Hydrogen peroxide

- Calcium

- Magnesium oxide
- Magnesium

- Sodium peroxide

- Potassium iodate

- Hydrogen fluoride

- Sodium nitrate

- Hydrochloric acid

- Hydrofluoric acid

- Sodium hypochlorite

- $\quad$ Potassium fluoride

In general, there were three initial treatment processes in Building 774 for aqueous wastes which did not contain complexing agents. Complexing agents were handled separately and were not mixed these aqueous waste streams (see Section 24.0, Solidified Laboratory Waste). There were initial treatment processes for: 1) acids with large quantities of cations in solution; 2) acids or bases with small quantities of cations or solids; and 3) basic or neutral solutions that were relatively free of solids. Treatment techniques consisted of neutralization, precipitation, flocculation, and clarification. Sodium hydroxide, ferric sulfate, calcium chloride, and a flocculating agent (Purifloc A23) ${ }^{\mathrm{P} 065}$ were used in these treatment processes. The high nitrate liquid from 


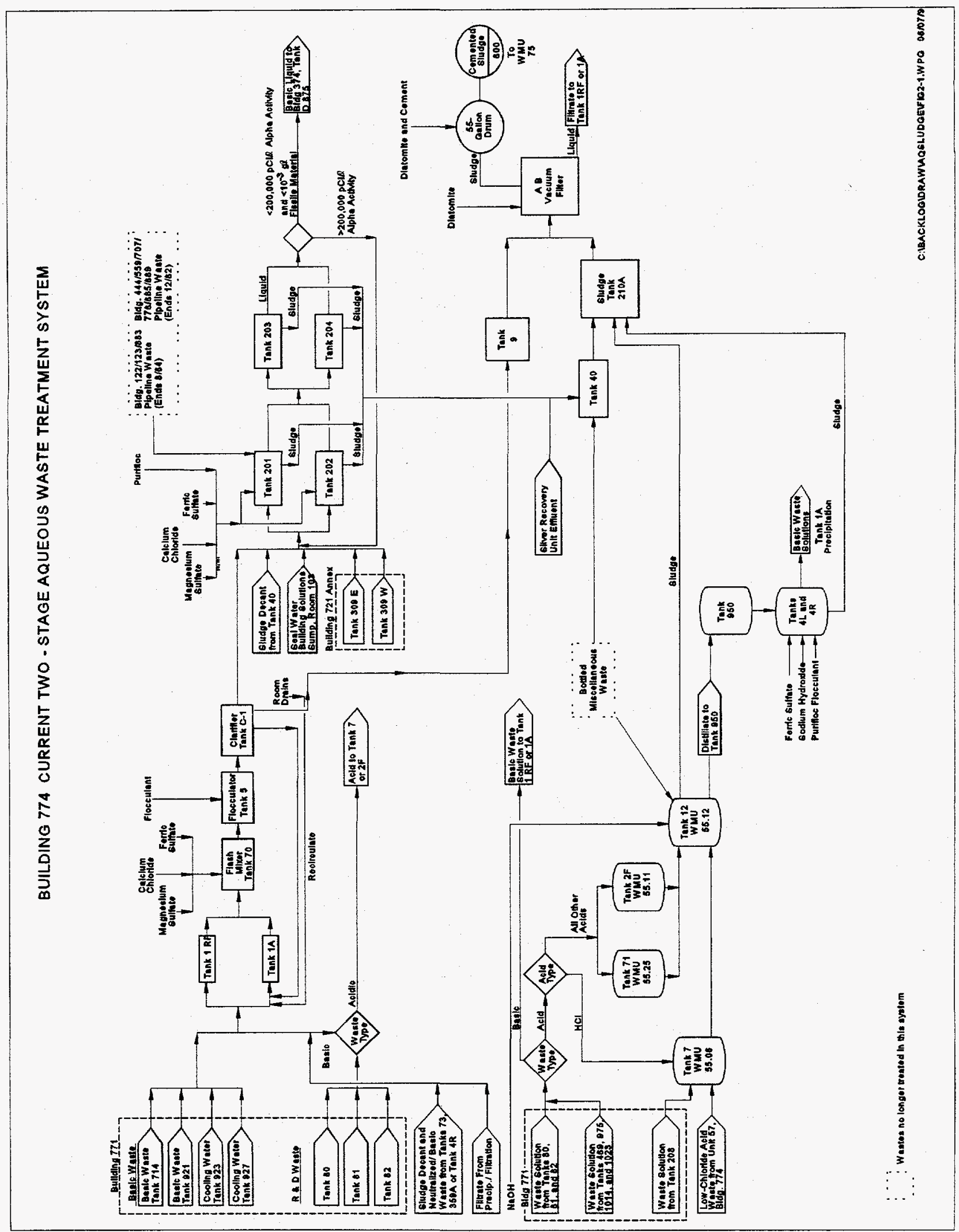

Figure 23-1. Building 774 Aqueous Waste Treatment Process. 
the clarifier tank was used as feed for second-stage treatment. ${ }^{\mathrm{P} 13}$ Treatment of the slurry, which resulted from each of these initial treatment processes, is described in Section 23.1.3.

\subsubsection{Second-Stage Treatment}

Second-stage treatment handled liquids that were treated by first-stage treatment, decanted liquids from Tank 40 (slurry holding tank), and low-level or nonradioactive aqueous process wastes from numerous buildings on plant site. The buildings of generation and the types of wastes that were transferred to secondstage treatment (by truck or the process waste system) are provided in Table 23-2. Most of the wastes transferred to second-stage treatment by the process waste system were only accepted until August 1984 when the precipitation process in Building 374 went on line. After that time, the wastes from Buildings 771 and 774 given below continued to be transferred to Building 774 second-stage treatment through the process waste system. Wastes from the remaining buildings also continued to be sent to Building 774 by tanker after August 1984. ${ }^{\mathrm{P} 052, \mathrm{P} 061, \mathrm{P} 109, \mathrm{P} 126, \mathrm{U} 043}$

Table 23-2. Waste Streams Feeding Second-Stage Treatment

\begin{tabular}{cl}
$\begin{array}{c}\text { Source } \\
\text { Buildings }\end{array}$ & \\
\hline 111 & Process liquid waste \\
122 & Medical decontamination washdown \\
123 & Acidic solutions, process waste water, and standards and sample waste \\
331 & Filter sludge and antifreeze solution \\
334 & Ammonium persulfate, copper sulfate, etchants, and cleaners \\
371 & Ammonia hydroxide, potassium hydroxide, and process waste water \\
443 & Lithium chloride solution and water treatment additives \\
444 & Process waste water (acidic), waste plating acid \\
447 & Process waste water \\
460 & Process waste water (acidic) \\
551 & 35\% hydrogen peroxide, high tin content \\
553 & Sulfuric acid, baking soda, calcium chloride \\
559 & Standards, caustic scrubber solution, acid wastes, and process waste water \\
690 & Acid solutions \\
705 & Ox-Out (water, ammonium bifluoride, and nitric acid) \\
707 & Calcium fluoride solution and acid solutions \\
750 & Hydrochloric acid and trisodium phosphate \\
771 & Process waste water (residual chemicals, blowdown water, decon water) \\
774 & Floor washdown and silver recovery effluent \\
776 & Ammonia hydroxide, ethanol, hexane, acid solutions, and process waste water \\
&
\end{tabular}




\begin{tabular}{cl}
$\begin{array}{c}\text { Source } \\
\text { Buildings }\end{array}$ & \multicolumn{1}{c}{ Materials } \\
\hline 778 & Laundry waste water, Suma cleaner, and rinse water/battery acid ${ }^{\text {U084 }}$ \\
779 & Acidic and basic solutions and process waste water \\
865 & Acid solutions, scrubber effluent, polishing solution, and process waste water \\
\hline 881 & Acid solutions, standards, samples, ammonium chloride, and process waste water \\
883 & Acid solutions, Ox-Out, and process waste water \\
886 & Ferric chloride, detergents, and process waste water \\
889 & Equipment decontamination water \\
991 & Acidic and basic solutions and water samples \\
\hline
\end{tabular}

The second-stage process included two separate radioactive decontamination systems: (1) A batchprecipitation system used to remove radioactive materials from wastes in which both the radioactive and chemical contaminants exceeded the standards, and (2) A continuous-precipitation system used to remove radioactive materials from wastes meeting the standards for chemical, but not radioactive contaminants. Both processes used the ferric hydroxide carrier-precipitation method of decontamination. The treated liquids from the batch process were stored in asphalt-lined ponds or sent to Building 374 for further treatment. Liquids from the continuous process were stored in unlined earthen ponds. ${ }^{\mathrm{P} 113}$

\subsubsection{Sludge Treatment}

Slurry from first-stage treatment was drawn through diatomite filter media by a vacuum inside a rotating filter drum. The filter media and trapped solids were continually scraped off the drum filter and fed into a 55-gallon drum. ${ }^{\text {P001 }}$ Portland cement was added to the bottom of the drum prior to placing the sludge in the drum. Portland cement may also have been added on top of the sludge. The sludge was assigned IDC $001{ }^{\text {P016 }}$ The slurry from the second-stage was kept separate from the first-stage slurry. Second-stage sludge was assigned IDC 002 . $^{\text {P052 }}$

Beginning in 1979, slurry from first- and second-stage treatment was combined prior to filtration. The sludge was still assigned IDC $001{ }^{\text {P024 }}$ In 1986 , the immobilization process changed and IDC 001 was discontinued. The process of pulling the combined slurry through diatomite filter media remained the same. ${ }^{\mathrm{P} 001}$ However, as the sludge was scraped off the drum filter, it was co-fed into a drum with a diatomite and Portland cement mixture which formed a solid monolith after curing. This waste was assigned IDC 800 and was generated until March 1991. ${ }^{\mathrm{P} 016, \mathrm{P} 052}$

\subsection{Waste Packaging}

Depending on the type of sludge (first-stage, second-stage, or combined) and waste packaging requirements at the time, several types and combinations of bags and liners were used to prepare 55-gallon drums for shipment. 
From 1970 to 1972,3 to 5 pounds of Portland cement was placed in the bottom of an unlined drum. A polyethylene drum bag was then used to line the drum, and another 3 to 5 pounds of cement was placed at the bottom of the bag. A PVC O-ring bag (first-stage sludge) or a plastic bag (second-stage sludge) was put in the drum. The PVC O-ring bag was attached to the glovebox. Approximately 30 pounds of cement was placed in the bottom of the PVC O-ring bag. First-stage sludge was put in the drum and the bag was twisted and taped closed. For second-stage sludge, another 3 to 5 pounds of cement was placed at the bottom of the plastic bag. Second-stage sludge was put in the drum in several layers with 3 to 5 pounds of cement between each layer. Another 3 to 5 pounds of cement was placed on the last sludge layer before the bag was twisted and taped closed. Approximately 5 pounds of cement was placed on the top of the PVC O-ring bag (first-stage sludge) or plastic bag (second-stage sludge) inside the polyethylene liner and the liner was twisted and taped closed. ${ }^{\mathrm{P} 024}$

Use of the 90-mil rigid polyethylene liners began in 1972. From 1972 to 1979 , the rigid liner was placed in the empty drum with Portland cement being placed in the bottom of the rigid liner. The remaining packaging configuration, including cement layering, was the same as it was before 1972. However, in some cases, second-stage sludge was contained in a single round-bottom polyethylene liner within the rigid liner. ${ }^{\mathrm{P} 012, \mathrm{P} 013, \mathrm{P} 015, \mathrm{P} 022, \mathrm{PO} 24}$

Beginning in 1979, first- and second-stage sludges were combined prior to filtration and subsequent packaging. ${ }^{\mathrm{P} 24}$ As before, the drum was lined with a 90 -mil rigid liner with Portland cement placed in the bottom. The rest of the packaging configuration was the same as it was for first-stage sludge since 1970 . The one exception is that, beginning in 1983, an additional 3 to 5 pound layer of cement may have been placed on top of the sludge inside the O-ring bag before it was closed. Although not required until 1989, a polyethylene round bottom drum liner may have been placed between the rigid liner and O-ring bag as early as 1973. ${ }^{\mathrm{P} 012, \mathrm{P} 013, \mathrm{P} 015, \mathrm{PO} 16, \mathrm{P} 022}$

First-stage sludge drums may have been lead-lined to reduce radiation levels. Lead-lining may be in the form of lead sheeting used to line the inside of the drum or, after 1972, lead tape may have been used to wrap the outside of the rigid liner. Increased radiation levels are usually associated with high americium concentrations in the sludge. ${ }^{\mathrm{P} 24}$

Once the drums were full, and the liners were twisted and taped closed, the drum lids were secured with a bolted ring, and tamper indicating devices were attached to the drums. For IDC 800, the drum was closed after the sludge, diatomite, and cement mixture was allowed to cure. ${ }^{\mathrm{P} 01, \mathrm{PO} 43}$

After drums were inspected, 1 to 2 quarts of Oil Dri were placed on the top of the outer, sealed polyethylene drum bag. This procedure changed in 1982 when vermiculite was used to fill the space between the outer, sealed polyethylene drum bag and the top of the rigid liner. ${ }^{\mathrm{P} 024, \mathrm{P} 043}$

Waste management and inspection protocol allowed containers of aqueous sludge waste to contain up to ten percent of another IDC other than that assigned to the container ${ }^{\text {PO16 }}$ The other IDCs could be those for combustibles, concrete, metal, and plastics. Inspection of the containers have identified a variety of items including Kimwipes, leaded gloves, rubber gloves, and bottles. Prior to 1973, second-stage sludge may contain items such as electric motors, bottles of chemical wastes (usually liquid), mercury and lithium batteries, and small amounts of contaminated mercury in pint bottles. Radioactive sources may also be included with secondstage sludge through 1979. ${ }^{\mathrm{P} 013, \mathrm{P} 015, \mathrm{P} 022, \mathrm{P} 024}$ 


\subsection{Waste Characterization}

Building 774 solidified aqueous wastes are characterized based on knowledge of the material, knowledge of the processes generating the waste, RTR review of the waste, visual inspection, waste analysis, and headspace gas analysis. This section provides a RCRA hazardous waste determination for Building 774 solidified aqueous waste as well as radionuclide contaminants and potential complexing agents contained in the waste. This waste is at least 50 percent (by volume) inorganic sludge and is classified as a homogeneous waste. $^{\text {P141 }}$

\subsubsection{Hazardous Waste Determination}

The material in this waste group does not qualify for any of the exclusions outlined in 40 CFR 260 or 261. The waste may exhibit the characteristic of corrosivity due to the presence of caustic free liquids. The waste may also exhibit the characteristic of toxicity for arsenic, barium, cadmium, chromium, lead, mercury, selenium, and silver. The waste was derived from the treatment of aqueous electroplating wastes, and aqueous wastes containing small quantities of halogenated- and nonhalogenated-solvents, and is therefore a F-listed hazardous waste. There is no evidence that the waste exhibits any other characteristic of hazardous waste. EPA Hazardous Waste Numbers applicable to some or all of the Building 774 solidified aqueous waste group are presented by IDC in Table 23-3. These conclusions are supported by the evaluation in Sections 23.3.1.1 and 23.3.1.2.

Table 23-3. Building 774 Solidified Aqueous Waste Characterization.

\begin{tabular}{lll}
\hline IDC & \multicolumn{1}{c}{ Title } & \multicolumn{1}{c}{ EPA Hazardous Waste Numbers } \\
\hline 001 & First-Stage Sludge & D002, D004-D01 1, F001, F002, F003, F005, F006, F007, and \\
& & F009 \\
002 & Second-Stage Sludge & D002, D004-D011, F001, F002, F003, F005, F006, F007, and \\
& & F009 \\
800 & Solidified Sludge-Bldg. 774 & D002, D004-D011, F001, F002, F003, F005, F006, F007, and \\
& & F009 \\
\hline
\end{tabular}

\subsubsection{Characteristic Waste}

The materials in this waste group may exhibit a characteristic of hazardous waste as defined in 40 CFR 261, Subpart $C$ as a corrosive waste (40 CFR 261.22) and as a toxic waste (40 CFR 261.24). The materials do not exhibit the characteristics of ignitability ( 40 CFR 261.21) or reactivity (40 CFR 261.23). The origin of the characteristic hazardous waste numbers assigned to IDC 001 is provided in Table 23-4. The table includes only the hazardous waste numbers that are applicable to waste for which a specific time period was identified. 
Table 23-4. Origin of Characteristic Hazardous Waste Numbers.

\begin{tabular}{ccc}
\hline IDC & EPA Hazardous Waste Numbers & Date of Generation \\
\hline 001 & D005-D008 & Generated before 1979 \\
& D004-D011 & Generated after 1979 \\
\hline
\end{tabular}

Ignitability: The materials in this waste group do not meet the definition of ignitability as defined in 40 CFR 261.21. These materials are not liquid, but RTR and visual inspection have identified free liquids in some sludge drums. However, the liquids are aqueous and are not ignitable. ${ }^{\mathrm{P} 013, \mathrm{P} 015, \mathrm{P} 022, \mathrm{U} 060}$ The materials are not capable of causing fire through friction, absorption of moisture, or spontaneous chemical change. ${ }^{\mathrm{P} 012, \mathrm{P} 016, \mathrm{P} 024}$ The materials are not compressed gases, nor do the containers contain compressed gases. ${ }^{\mathrm{P} 013, \mathrm{P} 015, \mathrm{P} 022}$ The materials are not DOT oxidizers as defined in 49 CFR 173. The materials in this waste group are therefore not ignitable wastes (D001).

Corrosivity: The materials in this waste group may meet the definition of corrosivity as defined in 40 CFR 261.22 due to the presence of caustic free liquids. The materials are not liquid, but free liquids were identified in some sludge drums. ${ }^{\mathrm{P} 13, \mathrm{P} 015, \mathrm{P} 022}$ Analysis of the liquids indicate a $\mathrm{pH}$ range of 8 to 12 . Although the $\mathrm{pH}$ of the liquids does not meet the definition of corrosivity, these results are limited and may not be representative of the entire inventory. According to Building 774 second-stage liquid waste treatment log books, the liquids treated were consistently above $12.5 .{ }^{\mathrm{C} 037}$ In addition, Building 771 waste streams transferred to first-stage treatment were characterized as corrosive. Therefore, EPA Hazardous Waste Number D002 may be applicable to drums of Building 774 solidified aqueous waste containing free liquid.

Reactivity: The materials in this waste group do not meet the definition of reactivity as defined in 40 CFR 261.23. The materials are stable and will not undergo violent chemical change. The materials will not react violently with water, form potentially explosive mixtures with water, or generate toxic gases, vapors, or fumes when mixed with water. The materials do not contain sulfides, and are not capable of detonation or explosive reaction. The materials are not forbidden explosives or Division 1.1, 1.2, or 1.3 (Class A or B) explosives as defined in 49 CFR 173, nor do the drums contain explosive materials. ${ }^{\text {P013,P015,P022 }}$ Explosives were not handled or used around radioactive material. The waste may contain cyanide from treatment of electroplating wastes. However, the cyanide concentrations in the sludge should be relatively low and should not cause the waste to be reactive. ${ }^{\text {C065,P124 }}$ Second-stage sludge generated before 1973 may contain lithium batteries. Lithium metal, which is highly reactive with water, was used as the anode in lithium alkaline batteries. As the battery discharges, the lithium metal is converted to lithium oxide which is not reactive. ${ }^{\text {P024,U060 }}$ The materials in this waste group are therefore not reactive wastes (D003).

Toxicity: The materials in this waste group may meet the definition of toxicity as defined in 40 CFR 261.24. The toxicity characteristic contaminants fall into one of two categories: metals and organics. Organic compounds include halogenated-and nonhalogenated-solvents, pesticides, herbicides, and other toxic compounds. This waste group may exhibit the characteristic of toxicity for arsenic, barium, cadmium, chromium, lead, mercury, selenium, and silver metals. Since this waste is a homogeneous solid, it will be randomly sampled and analyzed for the toxicity characteristic contaminants for verification purposes. 
Aqueous wastes from recovery operations in Building 771 may contain chromium above the regulatory level. ${ }^{\text {P052 }}$ However, analytical data for acid solutions from recovery operations indicate barium, cadmium, chromium, and lead above toxicity characteristics levels. ${ }^{\mathrm{P} 125}$ Following plutonium recovery, these solutions were transferred to Building 774 first-stage treatment. Prior to 1979 , recovery operations were the only source of waste entering first-stage treatment. Therefore, first-stage sludges (IDC 001) generated before 1979 are assigned EPA Hazardous Waste Numbers D005-D008.

Since 1979, first- and second-stage sludges were combined. Wastes from the several other sources were sent to second-stage treatment (see Table 23-2). The waste streams entering second-stage treatment contained arsenic, barium, cadmium, chromium, lead, mercury, selenium, and silver, or a combination of these metals. ${ }^{\text {Po52 }}$ In addition, leaded gloves were identified in some sludge drums, and prior to 1973, bottles of liquid mercury may have been placed into second-stage sludges. Therefore, IDC 001 generated after 1979, and all of IDCs 800 and 002 are assigned EPA Hazardous Waste Numbers D004-D011.

Emission spectroscopy data from two Building 774 sludge samples are shown in Table $23-5$. $^{\mathrm{P} 122}$. The data confirm the presence of toxicity characteristic metals, and indicate that the waste could exhibit the characteristic of toxicity for cadmium, chromium, lead, and silver.

Table 23-5. Total Metals Results for Building 774 Aqueous Sludge

\begin{tabular}{cc}
\hline Compound & Total Concentration (ppm) \\
\hline Arsenic & $<10$ \\
Barium & 20 to 50 \\
Cadmium & 50 to 500 \\
Chromium & 5 to 100 \\
Lead & 1,000 to 5,000 \\
Mercury & $<5$ \\
Silver & 200 \\
\hline
\end{tabular}

There is no documentation indicating the presence or use of pesticides or herbicides in the areas or processes that generated the aqueous waste from which Building 774 solidified aqueous waste was derived. Therefore, this waste group does not exhibit the characteristic of toxicity due to pesticides or herbicides (D012-D017).

Tetrachloroethylene, trichloroethylene, and carbon tetrachloride were used primarily for cleaning and degreasing, and small quantities of these solvents may be present in Building 774 solidified aqueous wastes. Since these compounds were typically used as solvents, the waste is regulated as a listed hazardous waste and not a characteristic waste because these compounds are specifically addressed in the treatment standards for the listed hazardous waste. ${ }^{P 080}$ Since Building 774 solidified aqueous wastes are characterized as listed hazardous wastes due to spent solvent contamination, the waste is not a toxic waste due to the presence of these organic compounds. 
Volatile organics analysis of a single sample of Building 774 sludge show a total concentration of 4.4 ppm chlorobenzene which is significantly less than the regulatory level for this compound. ${ }^{\text {U029 }}$ None of the references indicate a source for chlorobenzene. Therefore, this waste group does not exhibit the characteristic of toxicity for chlorobenzene (D021).

\subsubsection{Listed Hazardous Waste}

The material in this waste group was derived from the treatment of a waste listed in 40 CFR 261, Subpart D as a hazardous waste from non-specific sources (40 CFR 261.31). The waste is not, or was not derived from the treatment of, a hazardous waste from specific sources ( 40 CFR 261.32), or a discarded commercial chemical product, an off-specification species, a container residue, or a spill residue thereof (40 CFR 261.33).

Tetrachloroethylene, trichloroethylene, 1,1,1-trichloroethane, carbon tetrachloride, and 1,1,2-trichloro1,2,2-trifluoroethane were commonly used for cleaning and degreasing. Methylene chloride was used primarily for paint removal. Acetone, methanol, xylene, benzene, and toluene were used as solvents primarily in laboratory operations. The aqueous waste transferred to Building 774 second-stage treatment may have contained small quantities of these spent solvents. In addition, the liquid from the vacuum filter was processed back through first-stage treatment. Building 774 solidified aqueous wastes were derived from the treatment of a listed hazardous waste and are therefore assigned EPA Hazardous Waste Numbers F001, F002, F003, and F005.

There is no documentation indicating the presence or use of F004-listed solvents in the areas or processes that generated the aqueous waste from which Building 774 solidified aqueous waste was derived. Therefore, this waste group is not a F004-listed hazardous waste.

Analysis of a single sample of Building 774 sludge confirms the presence of F-listed solvents. The analytical results are presented in Table $23-6 .{ }^{\text {U029 }}$

Table 23-6. Total Volatiles Results for Building 774 Aqueous Sludge.

\begin{tabular}{cc}
\hline Compound & Total Concentration (ppm) \\
\hline Methylene Chloride & 0.2 \\
Trichloroethene & 0.3 \\
1,1,2-trichloroethane & 3.6 \\
Toluene & 1.1 \\
Chlorobenzene & 4.4 \\
Ethylbenzene & 62.0 \\
Total Xylenes & 96.6 \\
\hline
\end{tabular}

Headspace analysis was performed on samples of Building 774 solidified aqueous wastes (IDCs 001 , 002, and 800) obtained at INEEL. The detected F-listed compounds in which the 90 percent UCL was above the PRQL are provided: ${ }^{\text {P033 }}$ 
- carbon tetrachloride (IDCs 001 and 002 only)

- 1,1,1-trichloroethane (IDCs 001 and 002 only)

- 1,1,2-trichloro-1,2,2-trifluoroethane (IDC 001 only)

- trichloroethylene (IDCs 001 and 002 only)

Additional F-listed solvents were detected in headspace samples of sludge (IDC 800) obtained at Rocky Flats. The detected F-listed compounds in which the 90 percent UCL is above the PRQL are also provided. ${ }^{\text {U030 }}$

- carbon tetrachloride

- toluene

- 1,1,1-trichloroethane

At one time, Building 774 treated spent stripping, cleaning, and plating solutions from electroplating operations in which cyanides were used. Building 774 solidified aqueous wastes were derived from the treatment of the hazardous electroplating wastes, and therefore are assigned EPA Hazardous Waste Numbers F006, F007, and F009.

The material in this waste group is not a hazardous waste from specific sources since it was not generated from any of the processes listed in 40 CFR 261.32. The material in this waste group is therefore not a K-listed hazardous waste.

The material in this waste group is not a discarded commercial chemical product, an off-specification species, a container residue, or a spill residue thereof ( 40 CFR 261.33). The material in this waste group is therefore not a P-or U-listed hazardous waste.

\subsubsection{Radionuclides}

This section identifies the radioisotopes potentially contained in the waste. In addition, Table 23-7 summarizes matrix and other physical parameters which could affect radioassay.

Aqueous waste treatment operations in Building 774 receive wastes from throughout plant site, including processes that generated low-level and nonradioactive liquid wastes. For this reason, wastes generated during treatment operations may contain any of the radioisotopes used at the plant. The most common radioactive materials handled were weapons-grade plutonium, americium-24l, enriched uranium, and depleted uranium. ${ }^{\mathrm{P} 64}$ The isotopic compositions of weapons-grade plutonium, enriched uranium, and depleted uranium are provided in Section 3.0.

Production and production support processes in Buildings 371, 559, 707, 771, 776, 777, and 779 generated wastes contaminated with weapons-grade plutonium, americium-241, and enriched uranium which were treated in Building 774. Production and production support processes in Buildings 444, 447, 865, and 883 generated wastes contaminated with depleted uranium which were treated in Building $774 .{ }^{\text {P053,U053 }}$ Other radionuclides may also be found in Building 774 wastes from R\&D, analytical, and special order work. ${ }^{\text {P164 }}$ Processing of most of the "special" radioisotopes, such as curium-244, thorium-232, and uranium-236, was performed until the early- to mid-1970s. ${ }^{\text {C154.P164,P189.P194 }}$ Neptunium-237 was processed until 1985 or 1986, and

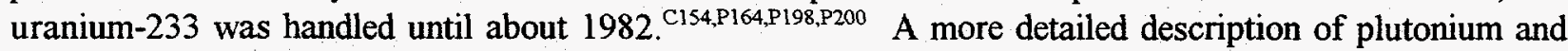
uranium production operations and $R \& D$ operations is provided in Section 3.0. 
The Size Reduction Vault in Building 776 conducted repackaging operations (prefixes 19, 25, and 40). ${ }^{\mathrm{C} 175, \mathrm{C184}, \mathrm{P} 078, \mathrm{U} 059}$ The package date on these drums is the date in which the waste was repackaged and was originally generated some time prior to this date. Therefore, it is assumed that the repacked sludge containers could potentially contain any of the above radioisotopes. IDC 800 should not contain uranium-233 because this waste was not generated until about 1986.

Table 23.7 Waste Matrix Evaluation.

\begin{tabular}{|c|c|}
\hline Parameter & Results of Evaluation \\
\hline $\begin{array}{l}\text { Radionuclide Form, } \\
\text { Particle Size, and } \\
\text { Distribution }\end{array}$ & $\begin{array}{l}\text { The sludges were produced by a carrier precipitation process in which ferric } \\
\text { sulfate, calcium chloride, magnesium sulfate, and a coagulating agent were } \\
\text { used to form a floc that coprecipitated with the radioactive } \\
\text { contaminants. }{ }^{\text {P004.P164 }} \text { Based on the generation process, the distribution of } \\
\text { actinides in waste should be relatively homogeneous. However, as specified in } \\
\text { Section } 23.2 \text {, radioactive sources may have been mixed in second-stage sludges } \\
\text { (IDC 002) prior to } 1980 \text {. }\end{array}$ \\
\hline Hydrogen Content & $\begin{array}{l}\text { Sources of hydrogen may include plastic packaging material (see Section } 23.2 \text { ) } \\
\text { and trace amounts of hydrocarbons (see Section } 23.3 .1 .2 \text { ). Based on visual } \\
\text { inspection, several of the IDC } 800 \text { sludges are damp or contain free liquid. }{ }^{\mathrm{P} 13} \\
\text { Nearly all of the IDC } 001 \text { and } 002 \text { sludges examined were damp and several } \\
\text { contained free liquid. }{ }^{\mathrm{P} 015, \mathrm{P} 022}\end{array}$ \\
\hline $\begin{array}{l}\text { Other Interfering Waste } \\
\text { Contaminants }\end{array}$ & $\begin{array}{l}\text { Documentation indicates that the major anions and cations include aluminum, } \\
\text { magnesium, fluoride, and chloride. }{ }^{\mathrm{Pl} 64} \text { Waste analysis confirms the presence of } \\
\text { aluminum ( } 1 \% \text { ) and magnesium }(0.5 \text { and } 3 \%) \text {. The analysis also detected } \\
\text { boron }(10 \text { and } 50 \mathrm{ppm}) \text {, beryllium }(100 \text { and } 200 \mathrm{ppm}) \text {, cadmium ( } 50 \text { and } 500 \\
\text { ppm), and chromium }(5 \text { and } 100 \mathrm{ppm}) .{ }^{\mathrm{P} 122}\end{array}$ \\
\hline $\begin{array}{l}\text { Physical Matrix } \\
\text { Parameters }\end{array}$ & $\begin{array}{l}\text { Measured sludge density information was not identified; however, average bulk } \\
\text { densities were calculated for } 13, \mathrm{IDC} 001 \text { and } 5, \text { IDC } 002 \text { sludges. The } \\
\text { average density was calculated as } 1261 \mathrm{~kg} / \mathrm{m}^{3} \text {. C196 Documentation on the } \\
\text { distribution of contaminants was not identified but, based on the generation } \\
\text { process, should be relatively homogeneous. }\end{array}$ \\
\hline
\end{tabular}

\subsubsection{Complexing Agents}

Because complexing agents can aid in the transport of transuranic radionuclides from the waste after disposal, the waste was assessed for potential complexing agents. This information may also be added to the chemical compatibility studies since limited information was available on these chemicals in the past.

EDTA represents a group of chelating compounds, such as ethylenediaminetetraacetic acid, with similar molecular structures found in many soaps and detergents. Versene (a trade name for EDTA) and citric acid are known constituents of KW decontamination detergent. ${ }^{\mathrm{P} 24, \mathrm{P} 068} \mathrm{KW}$ was used during a variety of decontamination activities at the plant. A buffer solution (TISAB) containing diaminocyclohexane tetraacetic 
acid was used during specific ion electrode analysis in Building 559. ${ }^{\text {P076 }}$ Oxalic acid and tetraphosphoric acid were used to etch plutonium and other metals. ${ }^{\mathrm{P} 62 \mathrm{P} 079, \mathrm{U} 043}$ Oxalic acid was also used for americium recovery. ${ }^{\mathrm{U} 047}$

Aqueous wastes that were known to contain complexing agents were isolated and prepared separately. Because complexing agents were not compatible with the aqueous waste treatment system, Building 774 solidified aqueous waste should only have trace quantities of complexing agents. ${ }^{\mathrm{P} 004}$ 


\subsection{SOLIDIFIED LABORATORY WASTE}

This waste group consists of solidified liquid wastes that were not compatible with the primary aqueous waste treatment system, such as complexing agents, strong acids, and strong bases. The liquids were neutralized and solidified in Building 774. ${ }^{\text {O012 }}$ The liquid wastes, which were generated in numerous buildings on plant site, were treated to produce IDCs 004 and 802. ${ }^{\mathrm{V} 043}$ Historic IDC descriptions and dates of generation for the INEEL accessible storage inventory are presented by IDC in Table 24-1. ${ }^{\text {Pl27 }}$

Table 24-1. Solidified Laboratory Waste in the Accessible Storage Inventory.

\begin{tabular}{cll}
\hline IDC & \multicolumn{1}{c}{ Title } & \multicolumn{1}{c}{ Dates of Generation } \\
\hline 004 & Special Setups-Building $774^{\mathrm{P} 016}$ & December 1972-November 1986 \\
802 & Solidified Laboratory Waste-Building $774^{\mathrm{P} 016}$ & June 1986-April 1988 \\
\hline
\end{tabular}

Item Description Code 004, Special Setups-Building 774: This waste consists of liquids primarily from laboratory operations throughout plant site that were neutralized and solidified in Building 774. A mixture of Portland cement and insulation cement was placed in a lined 55-gallon drum. The liquid waste was neutralized and then added to the cement mixture which cured to form a solid monolith. Some drums may contain polyethylene bottles of solidified waste. ${ }^{\mathrm{P} 24}$

Item Description Code 802, Solidified Laboratory Waste-Building 774: The cementation process for IDC 802 was similar to IDC 004 . IDC 802 replaced IDC 004 in approximately 1986 . $^{\mathrm{P} 27}$ The IDC was changed to designate containers of solidified laboratory waste that were certified for disposal. ${ }^{\mathrm{c} 008}$

\subsection{Waste Generation}

Liquid wastes that were not compatible with the primary aqueous waste treatment system were solidified in Building 774. The liquids, which include complexing agents, strong acids, and strong bases, were generated primarily from the analytical laboratories, research and development laboratories, and maintenance shops. ${ }^{\mathrm{P} 16, \mathrm{P} 24}$ Specifically, the liquid wastes originated in Buildings $122,123,126,371,444,559,705,707$, $750,771,777,779,865,881,883,886$, and $991 .{ }^{\text {U043 }}$ The liquids generated in the analytical laboratories in Buildings 371,559 , and 771 were sent to Building 771 for recovery if they contained plutonium above the EDL. ${ }^{\text {P067 }}$ Following recovery, the liquids were transferred to Building 774 where they were immobilized in cement. Liquid wastes from the other buildings and processes were below the EDL and were also solidified in Building 774. ${ }^{\mathrm{P} 16, \mathrm{P} 024}$

\subsubsection{Neutralization and Solidification Process}

Packaged waste received in plastic bottles was entered into the glovebox. The bottles containing acid waste were transferred into Tank T-7, the receiver and neutralizer tank adjacent to the glovebox. After sodium hydroxide was added to Tank T-7, pH paper was used to ensure the acid waste had been neutralized. Basic liquid waste received were not neutralized prior to solidification. ${ }^{\mathrm{P} 70}$ 
A mixture of approximately $250-300$ pounds of Portland type I/II cement and 100-150 pounds of insulation cement were placed in a lined 55-gallon drum that was attached to the glovebox. ${ }^{\mathrm{P} 73}$ Approximately 80-100 liters of the basic waste or neutralized liquid waste was added to the cement mixture and placed on a drum roller to ensure mixing of the contents. ${ }^{\text {P024,P073 }}$ The cement mixture in the drum reacted with the waste solution to form a solid monolith. ${ }^{\text {P070 }}$

Periodically, polyethylene bottles were filled with the cement mixture and sent to the small quantity waste generators on plant site for addition of the liquid waste. ${ }^{\mathrm{P} 224}$

\subsubsection{Liquid waste generation}

A setup log book was used in Building 774 to record the types of waste and generation source of IDCs 004 and 802. The date of treatment, generation location, waste description, and treatment process were entered in the log book. ${ }^{\mathrm{U} 43}$ All wastes with treatment entries indicated as "bottle box" or "setup in bottle box" were those treated by this process. If the entry was "setup" with no indicated treatment process, it was assumed to be included in IDC 004 and 802 except large volumes ( $>1$ drum) of organic liquids. There are numerous entries for less than 10 liters of organic waste treated in the bottle box system. A large volume of organic waste is not compatible with the bottle box solidification system and would most likely have been treated in the solidified organic waste system (see Section 25.0, Solidified Organic Waste).

A description of the liquid wastes treated by this process including generation buildings is presented in Table 24-2. ${ }^{\text {U043 }}$ Information in parentheses does not appear in the log book but is provided as clarification.

Table 24-2. Liquid Wastes Included In IDCs 004 and 802.

\begin{tabular}{|c|c|}
\hline $\begin{array}{l}\text { Generation } \\
\text { Building }\end{array}$ & Waste Description \\
\hline 122 & $\mathrm{Pu}^{239}, \mathrm{Pu}^{239}$, and $\mathrm{Fe}^{55}$ (assumed to be sources) \\
\hline 123 & $\begin{array}{l}\text { Anion \& cation resin, glass wool, hydrochloric acid, and nitric acid; lab waste; } \\
\text { liquid bromine; } \mathrm{NH}_{4} \mathrm{Cl} ; \mathrm{Ba}^{133} \text { (assumed to be a source); enriched uranium, } \mathrm{Np}^{237} \text {, } \\
\mathrm{Sr}^{90} \text {, and tritium sources; small amount of liquid apparently had been a standard }\end{array}$ \\
\hline 126 & Isotopes (assumed to be sources) \\
\hline 371 & DCHP (dicesium hexachloroplutonate); effluent waste; lab waste \\
\hline 444 & $\begin{array}{l}\text { Ox-out } / 5.5 \% \text { nitric acid }(\mathrm{Ox} \text {-out is a water solution of nitric acid and ammonium } \\
\left.\text { bifluoride }{ }^{\mathrm{PO} 91}\right) \text {; phosphoric acid; chromic acid; sodium lignosulfonate; Versene } \\
\text { (Versene is a trade name EDTA product }^{\mathrm{P} 024} \text { ) }\end{array}$ \\
\hline 447 & $\begin{array}{l}\text { Contaminated Turco bath (Turco is a trade name for a series of cleaners with } \\
\text { various combinations of acids, complexing agents, and surfactants }{ }^{\mathrm{P} 091} \text { ) }\end{array}$ \\
\hline 559 & $\begin{array}{l}5-15 \% \text { phosphoric acid; basic lab waste; beryllium chloride salts; electroetch } \\
\text { solution; inorganic waste; m-phenylenediamine; scrubber waste; tritium } \\
\text { scintillation cocktail contains toluene; tritium analytical waste }\end{array}$ \\
\hline 705 & $\mathrm{Ox}$-out (Ox-out is a water solution of nitric acid and ammonium bifluoride ${ }^{\mathrm{P} 091}$ ) \\
\hline
\end{tabular}




\begin{tabular}{|c|c|}
\hline $\begin{array}{l}\text { Generation } \\
\text { Building }\end{array}$ & Waste Description \\
\hline 707 & Coolant water; dist. water \\
\hline 750 & Absorber - no contamination \\
\hline 771 & $\begin{array}{l}\text { Acid solution; acrylonitrile; americium oxalate filtrate; basic cyanide waste; basic } \\
\text { lab waste; boilout solution; cadmium nitrate; caustic; } \mathrm{Cl} \text { and } \mathrm{SCN} \text { waste; citric } \\
\text { solution - Am. citrate solution; } \mathrm{Cl}-\mathrm{NO}_{3} \text { waste; } \mathrm{Cl}_{2} \text { waste } \mathrm{HF} \text { trapping solvent; } \\
\text { cooling water; depleted uranium in nitric acid; distillate water and detergent; } \\
\text { ethylene glycol; filter solution; floor sweepings (oxide waste); } \mathrm{HCl} \text { dissolns.; } \mathrm{HF} \\
\text { fluoride solution; hydrofluoric, oxalic, and ascorbic acid with stannous chloride; } \\
\text { magnesium, potassium, and sodium (assumed to be in solution, the waste volume } \\
\text { is reported in liters); met lab waste; nitrate, borate, chromate, and oxalate; } \mathrm{OH} \\
\text { filtrate; phosphoric acid, 2-ethoxyethanol, oxalic acid, ethylene glycol, water, and } \\
\text { ethyl alcohol; potassium hydroxide; } \mathrm{Pu-Cm} \mathrm{sludge;} \mathrm{slurried} \mathrm{cement;} \mathrm{SST} \\
\text { (assumed to be stainless steel) capsules - depleted uranium; tetraphosphoric acid; } \\
\text { titanium tetrachloride; U-233 in oil; U-233 plating solution; } \mathrm{U}-233 \text { filtrate } \\
\text { solution; U-238 acid waste; solid cerium; wash solution; waste acid nickel plating; } \\
\text { waste etching solution; waste solution; water from compactor; Metex solution } \\
\text { (Metex is a trade name for a series of inorganic and organic acids or salts }{ }^{\mathrm{Pl1}} \text {; } \text { ) }\end{array}$ \\
\hline 777 & Dist. water \\
\hline 779 & $\begin{array}{l}75 \% \text { sulfuric acid; americium solution; contaminated soil; } \mathrm{Cs} / \mathrm{Na} / \mathrm{K} / \mathrm{NaCl} \text { salts; } \\
\text { depleted uranium; etchant solution; tetraphosphoric; etching solution; perchloric } \\
\text { acid; hydrochloric acid solution; low level waste; metal } \mathrm{X} \text { and } \mathrm{B} 273 \text { (no reference } \\
\text { was found to identify the constituents of this material); nitric acid; oil; phosphoric } \\
\text { acid and ethylene glycol; plutonium oxide and sodium hydroxide; propylene } \\
\text { carbonate; waste solution; water etching solution }\end{array}$ \\
\hline 865 & 700 gram picric acid - reacted with $\mathrm{Na}_{2} \mathrm{~S} \mathrm{NaOH}\left(\mathrm{NH}_{4}\right)$ 2s \\
\hline 865 & Aqueous cut-off wheel solution \\
\hline 881 & $\begin{array}{l}\text { Acid solution } \mathrm{Pu}, \mathrm{Am}, \mathrm{U} \text {; aqueous; chlorophenol; } \mathrm{ECM} \text { (electrochemical milling) } \\
\text { sludge; hot waste solution } \mathrm{Pu}, \mathrm{Np}, \mathrm{Am}, \mathrm{Th}, \mathrm{U} \text {; lab waste solution-high in tritium; } \\
\text { liquid from vacuum trap; low-level waste } \mathrm{Np}, \mathrm{U}-235, \mathrm{Pu}, \mathrm{Am} \text {; nitrate and chloride } \\
\text { salts; tributyl phosphate; tritiated water; tritium }\end{array}$ \\
\hline 883 & Grinder coolant, machine coolant \\
\hline 886 & Kepro developer (Kepro developer contains 1,1,1-trichloroethane ${ }^{\mathrm{P} 091}$ ) \\
\hline 991 & $\begin{array}{l}\text { Ox-out containing beryllium ( } \mathrm{Ox} \text {-out is a water solution of nitric acid and } \\
\text { ammonium bifluoride }{ }^{\mathrm{P091}} \text { ) }\end{array}$ \\
\hline
\end{tabular}




\subsection{Waste Packaging}

Solidified laboratory waste was contained by an O-ring bag inside a prepared 55-gallon drum attached to the glovebox. ${ }^{\mathrm{P} 15 \mathrm{P} 021}$ Approximately 10 to 15 pounds of Portland cement were added on top of the cemented laboratory waste before the $\mathrm{O}$-ring bag was sealed. The solidified waste may also be contained in polyethylene bottles inside the lined 55-gallon drum. ${ }^{\mathrm{P} 24}$

Depending on waste packaging requirements at the time, several combinations of bags and liners were used to prepare 55-gallon drums for shipment. From 1970 to 1972 , waste drums were lined with a polyethylene drum bag. Three to five pounds of Portland cement was placed in the bottom of the drum and in the drum bag. Use of the 90-mil rigid polyethylene liner began in 1972. ${ }^{\mathrm{P} 024}$ The rigid liner was placed in each drum and lined with a polyethylene round bottom drum liner. ${ }^{\text {P016.P024,P063,P064 }}$ Three to five pounds of Portland cement was placed in the bottom of the rigid liner and in the round bottom liner. When a drum was full, the drum liners were twisted and taped closed, the lid was secured with a bolted ring, and a tamper indicating device was attached to the drum. ${ }^{\mathrm{PO} 12, \mathrm{PO} 16, \mathrm{P} 024}$

After drums were inspected, one to two quarts of absorbent material (Oil-Dri) was placed on the top of the outer, sealed polyethylene drum bag. This procedure changed in February 1982 when vermiculite was used to fill the space between the outer, sealed polyethylene drum bag and the top of the 90 -mil rigid liner. The quantity of vermiculite varied from 3-12 pounds according to the amount of waste contained in each drum. ${ }^{\mathrm{P} 024}$

\subsection{Waste Characterization}

Solidified laboratory waste is characterized based on knowledge of the material, knowledge of the processes generating the waste, RTR review of the waste, visual inspection, surrogate waste analysis, and headspace gas analysis. This section provides a RCRA hazardous waste determination for solidified laboratory waste as well as radionuclide contaminants and complexing agents contained in the waste. This waste is at least 50 percent (by volume) inorganic solids and is classified as a homogeneous waste. ${ }^{\text {141 }}$

\subsubsection{Hazardous Waste Determination}

The material in this waste group does not qualify for any of the exclusions outlined in 40 CFR 260 or 261. The waste was mixed with halogenated-and nonhalogenated-solvents and is therefore a listed waste. The waste does not exhibit a characteristic of hazardous waste. EPA Hazardous Waste Numbers applicable to some or all of the solidified laboratory waste group are presented by IDC in Table 24-3. ${ }^{\text {P127 }}$ These conclusions are supported by the evaluation in Sections 24.3.1.1 and 24.3.1.2.

Table 24-3. Solidified Laboratory Waste Characterization.

\begin{tabular}{ccc}
\hline IDC & \multicolumn{1}{c}{ Title } & EPA Hazardous Waste Numbers \\
\hline 004 & Special Setups-Building 774 & F001, F002, F003, and F005 \\
802 & Solidified Laboratory Waste-Building 774 & F001, F002, F003, and F005 \\
\hline
\end{tabular}




\subsubsection{Characteristic Waste.}

The materials in this waste group do not exhibit a characteristic of hazardous waste as defined in 40 CFR 261, Subpart C, as an ignitable waste (40 CFR 261.21), as a corrosive waste (40 CFR 261.22), as a reactive waste (40 CFR 261.23), or as a toxic waste (40 CFR 261.24).

Ignitability: The material in this waste group does not meet the definition of ignitability as defined in 40 CFR 261.21. The material is not a liquid, and free liquids are not normally associated with this waste. ${ }^{\mathrm{P} 16}$ In addition, absorbents were added to wastes having the potential of generating free liquids (i.e., dewatering of cemented wastes). ${ }^{\mathrm{P} 015, \mathrm{PO} 21 . \mathrm{P} 024}$ Visual inspection identified one drum containing 20 milliliters of liquid on the outside of the rigid liner. The liquid appeared to be water or condensation and would not be ignitable. ${ }^{\mathrm{P} 015}$ The material is not a compressed gas, nor does the waste contain compressed gases. ${ }^{\text {P012.P013,P015,P016,P021,P024 Even }}$ though oxidizers were added to solidified laboratory waste for treatment, the cementation process would remove the oxidizer property. Therefore, the resultant material is not a DOT oxidizer as defined in 49 CFR 173. The material is not capable of causing fire through friction, absorption of moisture, or spontaneous chemical change. ${ }^{\mathrm{P} 12, \mathrm{P} 016, \mathrm{P} 024}$ The materials in this waste group are therefore not ignitable wastes (D001).

Corrosivity: The material in this waste group does not meet the definition of corrosivity as defined in 40 CFR 261.22. The material is not a liquid, and free liquids are not normally associated with this waste. ${ }^{\mathrm{P} 016}$ In addition, absorbents were added to wastes having the potential of generating free liquids (i.e., dewatering of cemented wastes). ${ }^{\mathrm{P} 15, \mathrm{PO} 21, \mathrm{P} 024}$ Visual inspection identified one drum containing 20 milliliters of liquid on the outside of the rigid liner. The liquid appeared to be water or condensation and would not be corrosive. ${ }^{\mathrm{P} 015}$ The materials in this waste group are therefore not corrosive wastes (D002). ${ }^{\mathrm{U} 060}$

Reactivity: The material in this waste group does not meet the definition of reactivity as defined in 40 CFR 261.23. The material is stable and will not undergo violent chemical change. The material will not react violently with water, form potentially explosive mixtures with water, or generate toxic gases, vapors, or fumes when mixed with water. The material is not capable of detonation or explosive reaction. The material is not a forbidden explosive or Division 1.1,1.2, or 1.3 (Class A or B) explosive as defined in 49 CFR 173, nor do the drums contain explosive materials. ${ }^{\text {P012,P013,P015,P016,P021,P024 Explosives were not handled }}$ or used around radioactive material. ${ }^{\mathrm{P} 12}$ Small volumes of cyanide, acrylonitrile (vinyl cyanide), thiocyanate, and sodium sulfide solution were added to the solidified laboratory waste stream on five occasions $(11 / 13 / 73$, $9 / 11 / 74,2 / 2 / 78,2 / 21 / 78$, and 10/14/80). ${ }^{\mathrm{U} 043}$ However, due to the solidified matrix of this waste, if exposed to $\mathrm{pH}$ conditions between 2 and 12.5, it should not generated toxic gases, vapors, or fumes in a quantity sufficient to present a danger to human health or the environment. The materials in this waste group are therefore not reactive wastes (D003).

Toxicity: The material in this waste group does not meet the definition of toxicity as defined in 40 CFR 261.24. The toxicity characteristic contaminants fall into one of two categories: metals and organics. Organic compounds include halogenated- and nonhalogenated-solvents, pesticides, herbicides, and other toxic compounds.

Surrogate laboratory waste was spiked with various concentrations of barium, cadmium, chromium, lead, and silver. Sampling and TCLP analysis of the resultant solidified waste form indicated that the surrogate sample did not exhibit the characteristic of toxicity for these metal compounds. ${ }^{\text {U054 }}$ Although arsenic and mercury were not tested, there is no documentation indicating that these compounds were solidified in the rocess. ${ }^{\mathrm{U} 43}$ Therefore, this waste group does not exhibit the characteristic of toxicity due metals (D004-D011). 
There is no documentation indicating the presence or use of pesticides or herbicides in the areas or processes generating filters and insulation. Therefore, this waste group does not exhibit the characteristic of toxicity due to pesticides or herbicides (D012-D017).

Carbon tetrachloride and trichloroethene were used in the laboratory as well as many other operations on plant site. Since these compounds were typically used as solvents, the waste is regulated as a listed hazardous waste and not a characteristic waste because these compounds are specifically addressed in the treatment standards for the listed hazardous waste. ${ }^{\text {P080 }}$ Since solidified laboratory waste is characterized as listed hazardous wastes due to spent solvent contamination, the waste is not a toxic waste due to the presence of these organic compounds.

\subsubsection{Listed Hazardous Waste}

The material in this waste group is a listed hazardous waste because it was mixed with a waste listed in 40 CFR 261, Subpart D as a hazardous waste from non-specific sources (40 CFR 261.31). The material is not, or was not mixed with, a hazardous waste from specific sources (40 CFR 261.32), or a discarded commercial chemical product, an off-specification species, a container residue, or a spill residue thereof ( 40 CFR 261.33).

Solvents including carbon tetrachloride and Freon were used in laboratory analysis but were separated from the aqueous phase of the wastes prior to treatment. ${ }^{\text {P107 }}$ The aqueous phase would not be considered a spent solvent. ${ }^{\text {C085 }}$ Although Kepro developer (contains 1,1,1-trichloroethane) was added to solidified laboratory waste, a developer is not used as a solvent. ${ }^{\mathrm{P} 091, \mathrm{U} 043}$ However, organic compounds such as 1,1,1-trichloroethane, carbon tetrachloride, and trichloroethene were commonly used for various cleaning activities on plant site. ${ }^{\text {P053 }}$ Since maintenance shops also generated liquid wastes that were added to solidified laboratory waste, it is possible that some amount of spent solvent was introduced into the solidification process. ${ }^{\mathrm{P} 016}$ Therefore, solidified laboratory waste is assigned EPA Hazardous Waste Numbers F001 and F002.

Solvents such as methanol and xylene were also used in laboratory analysis. ${ }^{\text {P107 }}$ There is no documentation indicating that these solvents were added to solidified laboratory waste. However, if the solvents were separated from the aqueous phase after analysis, the aqueous phase would not be considered a spent solvent. ${ }^{C 085}$ Solidification of aqueous waste containing these solvents has not been verified. Headspace gas analysis of solidified laboratory waste (see below) detected these solvents and also detected ethyl benzene. $^{\mathrm{P} 033}$ The source of ethyl benzene has not been identified, and it is assumed that ethyl benzene could have been introduced into the solidification process as a spent solvent. Therefore, solidified laboratory waste is assigned EPA Hazardous Waste Numbers F003.

There is no documentation indicating the presence or use of F004-listed solvents in the areas or processes generating filters and insulation. Therefore, this waste group is not a F004-listed hazardous waste.

Large volumes of organic waste were not compatible with the bottle box solidification system which produced solidified laboratory waste. However, small amounts (4-8 liters) of organic solvents were added to the waste on several occasions. Spent solvent wastes included electropolishing solution containing 2ethoxyethanol from metallography laboratories and scintillation cocktail containing toluene from tritium analysis. ${ }^{0043}$ Solidified laboratory waste was derived from the treatment of these spent solvent wastes, and is therefore assigned EPA Hazardous Waste Number F005. 
Headspace analysis performed on samples of solidified laboratory waste obtained at INEEL confirms the presence of F-listed solvents. The detected F-listed compounds in which the 90 percent UCL is above the PRQL are provided. ${ }^{\text {P033 }}$

$\begin{array}{lll}\text { - } & \text { 1,1,1-trichloroethane (IDC } 004 \text { only) } & \text { ethyl benzene (IDC } 004 \text { only) } \\ \text { carbon tetrachloride (IDC } 004 \text { only) } & \text { - } & \text { methanol } \\ \text { trichloroethene (IDC } 004 \text { only) } & -\quad \text { xylene (IDC } 004 \text { only) }\end{array}$

The material in this waste group is not a hazardous waste from specific sources since it was not generated from any of the processes listed in 40 CFR 261.32. The material in this waste group is therefore not a K-listed hazardous waste.

The material in this waste group is not a discarded commercial chemical product, an off-specification species, a container residue, or a spill residue thereof (40 CFR 261.33). The material in this waste group is therefore not a P- or U-listed hazardous waste.

\subsubsection{Radionuclides}

This section identifies the radioisotopes potentially contained in the waste. In addition, Table 24-4 summarizes matrix and other physical parameters which could affect radioassay.

Aqueous waste treatment operations in Building 774 receive wastes from throughout plant site, including processes that generated low-level and nonradioactive liquid wastes. For this reason, wastes generated during treatment operations may contain any of the radioisotopes used at the plant. The most common radioactive materials handled were weapons-grade plutonium, americium-241, enriched uranium, and depleted uranium. The isotopic compositions of weapons grade plutonium, enriched uranium, and depleted uranium are provided in Section 3.0. The solidified laboratory waste will also contain other radioisotopes that were undesirable in the regular aqueous waste treatment system. ${ }^{\mathrm{P} 164}$

As was specified in Table 24-2, tritium, plutonium, americium, depleted uranium, enriched uranium, uranium-233, iron-55, neptunium-237, barium-133, strontium-90, and curium (no isotope specified) were introduced into the solidification process in liquid received or as sources from various buildings. In addition, one $\log$ book entry for waste from Building 126 , which is a radioisotope storage area, is simply "isotopes" with no further detail. ${ }^{\mathrm{U} 043}$

The Size Reduction Vault in Building 776 conducted repackaging operations (prefixes 19 and 25). ${ }^{\mathrm{C} 175, \mathrm{Cl} 184, \mathrm{P} 078, \mathrm{U} 059}$ The package date on these drums is the date in which the waste was repackaged and was originally generated some time prior to this date. Therefore, it is assumed that the repacked containers could potentially contain any of the above radioisotopes. IDC 802 should not contain uranium- 233 because uranium233 was only handled until about 1982 , and IDC 802 was not generated until about $1986 .{ }^{\mathrm{P} 198}$ 
Table 24.4 Waste Matrix Evaluation.

\begin{tabular}{|c|c|}
\hline Parameter & Results of Evaluation \\
\hline $\begin{array}{l}\text { Radionuclide Form, } \\
\text { Particle Size, and } \\
\text { Distribution }\end{array}$ & $\begin{array}{l}\text { Radionuclides will primarily be in the form of hydroxides because sodium } \\
\text { hydroxide was used to neutralize the waste solution prior to solidification. }{ }^{\text {P070 }} \\
\text { Other radionuclide forms may include oxalate, citrate, and oxide (see Table } \\
24-2 \text { ). }\end{array}$ \\
\hline Hydrogen Content & $\begin{array}{l}\text { Sources of hydrogen may include plastic packaging material (see Section 24.2) } \\
\text { and small amounts of hydrocarbons (see Table 24-2). A few drums may } \\
\text { contain free liquid or unhardened sludge. }\end{array}$ \\
\hline $\begin{array}{l}\text { Other Interfering Waste } \\
\text { Contaminants }\end{array}$ & $\begin{array}{l}\text { Radioassay interferences may include bromine, ammonium bifluoride, } \\
\text { hydrofluoric acid, chromic acid, beryllium chloride, hydrochloric acid, } \\
\text { cadmium nitrate, magnesium, and borate (see Table 24-2). }\end{array}$ \\
\hline $\begin{array}{l}\text { Physical Matrix } \\
\text { Parameters }\end{array}$ & $\begin{array}{l}\text { The distribution of waste contaminants should be relatively homogeneous } \\
\text { because after the liquid was added to the cement mixture, it was placed on a } \\
\text { drum roller to ensure mixing of the contents. }{ }^{\text {P024 }}\end{array}$ \\
\hline
\end{tabular}

\subsubsection{Complexing Agents}

Because complexing agents can aid in the transport of transuranic radionuclides from the waste after disposal, the waste was assessed for potential complexing agents. This information may also be added to the chemical compatibility studies since limited information was available on these chemicals in the past.

Liquid wastes containing complexing agents were treated in the process producing solidified laboratory waste. Complexing agents interfered with the first and second stage aqueous waste treatment systems in Building 774. ${ }^{\mathrm{C} 73}$ The complexing agents in the solidified laboratory waste include Versene (a trade name for ethenediaminetetraacetic acid), tetraphosphoric acid, tributyl phosphate, citrate, oxalic acid, sodium lignosulfonate, and americium oxalate. ${ }^{\mathrm{P} 024, \mathrm{U} 043}$ 


\subsection{SOLIDIFIED ORGANIC WASTE}

This waste group consists of organic liquid wastes that were solidified in Building 774 . The liquid wastes were generated in numerous buildings on plant site, but originated primarily from Buildings 707 and 777. The majority of the liquids were oil and chlorinated solvents generated from machining and degreasing of plutonium metal. ${ }^{\text {P016,P024,P052 }}$ Historic IDC descriptions and dates of generation for the INEEL accessible storage inventory are presented by IDC in Table $25-1 .^{\mathrm{P} 127}$

Table 25-1. Solidified Organic Waste in the Accessible Storage Inventory.

\begin{tabular}{rll}
\hline IDC & \multicolumn{1}{c}{ Title } & \multicolumn{1}{c}{ Dates of Generation } \\
\hline 003 & $\begin{array}{l}\text { Organic Set Ups, Oil Solids }{ }^{\mathrm{C} 063} \\
\text { Grease-Bldg. 774 }\end{array}$ & August 1972-March 1986 \\
& $\begin{array}{l}\text { Organic Setups }{ }^{\mathrm{P} 12} \\
\text { Solidified Organics }\end{array}$ & \\
700 & OASIS Waste $^{\mathrm{P} 12}$ & March 1986-May 1986 \\
801 & Cemented Grease (OASIS) $^{\mathrm{P} 063}$ & January 1986-September 1988 \\
\hline
\end{tabular}

Item Description Code 003, Organic Setups: This waste consists of various organic liquids that were transferred to Building 774 where they were mixed with Microcel-E (a synthetic calcium silicate) to form a grease or paste-like material. ${ }^{\mathrm{PO} 2}, \mathrm{PO} 24$ The organic liquids were primarily oil and chlorinated solvents generated from machining and degreasing of plutonium metal in Buildings 707 and 777, ${ }^{\text {P016,P024,P052 }}$ Small amounts of Oil-Dri were sometimes added to the mixture as well. ${ }^{\mathrm{P} 024}$ The process generating this waste operated until November 1985 . $^{\text {P52 }}$

Item Description Code 700, OASIS Waste: This waste consists of various organic liquids cemented to form a solid monolith. IDC 700 was assigned to the waste generated by the experimental prototype Organic and Sludge Immobilization System (OASIS) process in Building 774 that would later generate IDC 801. The organic liquids solidified as well as the solidifying agents should be the same for IDCs 700 and $801{ }^{\text {P016 }}$ The OASIS process began operation in November 1985. ${ }^{\mathrm{P} 16, \mathrm{P} 052}$ See the description for IDC 801 for more information about this waste.

Item Description Code 801, Solidified Organics: This waste consists of various organic liquids immobilized into a solid monolith in the OASIS process in Building 774. Oils and chlorinated solvents from machining and degreasing of plutonium metal in Buildings 707 and 777 were the primary liquids treated by the OASIS process. ${ }^{\mathrm{P} 016, \mathrm{P} 052}$ The OASIS process also treated organic liquids from Buildings $334,371,443,444$, $447,559,771,776,778,779,865,881,883$, and $991 .{ }^{\text {U040, } 0043}$ The organic liquids were immobilized by mixing with water, ENVIROSTONE emulsifier, accelerator, and gypsum cement. The emulsifier was a polyethylene glycol ether, and the accelerator contained gypsum and potassium sulfate. ${ }^{\mathrm{P} 66}$ 


\subsection{Waste Generation}

Solidified organic waste was produced by mixing organic liquids with a solidification material. ${ }^{\mathrm{P} 02}$ The liquids were transferred to Building 774 by pipeline or in containers. The organic liquids were generated in Buildings $334,371,443,444,447,559,707,771,776,777,778,779,865,881,883$, and 991 . U040, 043 In 1985 , it appears as if the organic wastes were segregated into either the low-level or transuranic tank systems. Prior to this, both low-level and transuranic liquids may have been included in the solidified organic waste. ${ }^{\text {U040 }}$

\subsubsection{Solidification Process}

Organic setups (IDC 003) were produced by mixing the organic liquid with Microcel-E which was a synthetic calcium silicate. ${ }^{\mathrm{P} 022}$ Small amounts of Oil-Dri were sometimes added to the mixture as well. ${ }^{\mathrm{P} 024}$ The amounts of materials added to the mixture were not metered. However, the operator would adjust the composition if the outgoing mixture did not have a paste-like consistency. The mixture would then drop into an O-ring bag contained in a 55-gallon drum. ${ }^{\mathrm{P} 016}$ The composition of organic setups was approximately 30 gallons of liquid organic waste to 100 pounds of Microcel-E. ${ }^{\mathrm{P} 24}$ Figure 25-1 represents the flow of organic liquid waste into IDC 003 drums. ${ }^{\text {P052 }}$

Solidified organics (IDC 801) and OASIS waste (IDC 700) were produced by the OASIS process. IDC 700 was assigned to the waste generated by the experimental prototype OASIS process in Building 774 that would later generate IDC 801. OASIS is a batch type process generating one drum per run. Waste oils were pumped into an O-ring bag contained in a 55-gallon drum attached to the bottom of the OASIS glovebox. ENVIROSTONE emulsifier, gypsum cement, and accelerator were also metered into the bag. House water (water which had not been used in any other processes) was added to the mixture as well. ${ }^{\mathrm{P} 16}$ The typical composition of solidified organic waste was 170 pounds of organic liquid waste, 250 pounds of cement, 25 pounds of emulsifier, 10 pounds of accelerator, and 42 pounds of water. ${ }^{\text {ViO }}$ After all of the materials were added, a lightning mixer was lowered into the drum. The amount of materials added to the mixture was computer controlled. ${ }^{\mathrm{P} 16}$ Figure 25-2 represents the flow of organic liquid waste into IDCs 700 and 801 drums. ${ }^{\text {P052 }}$ 


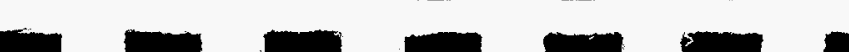
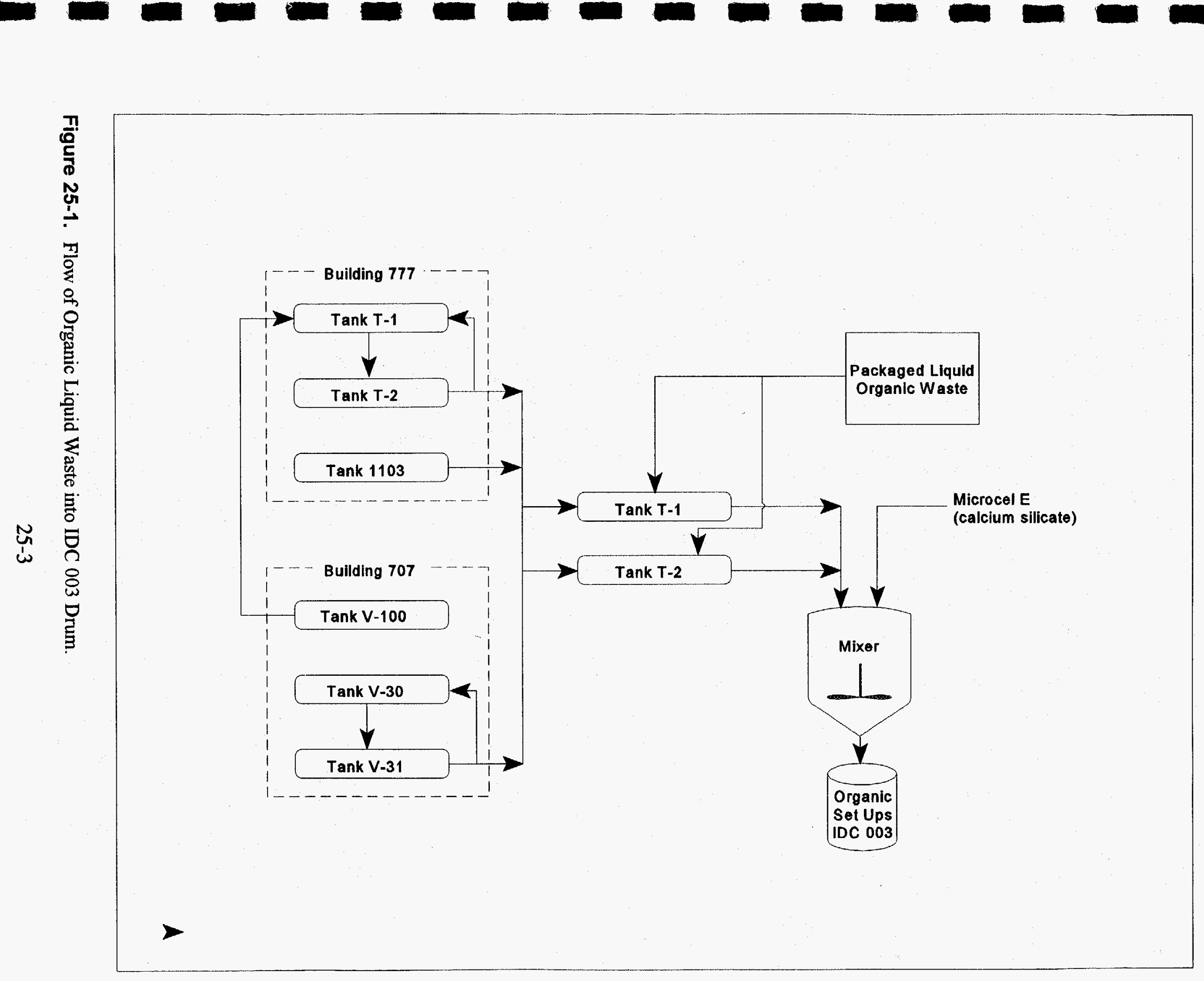


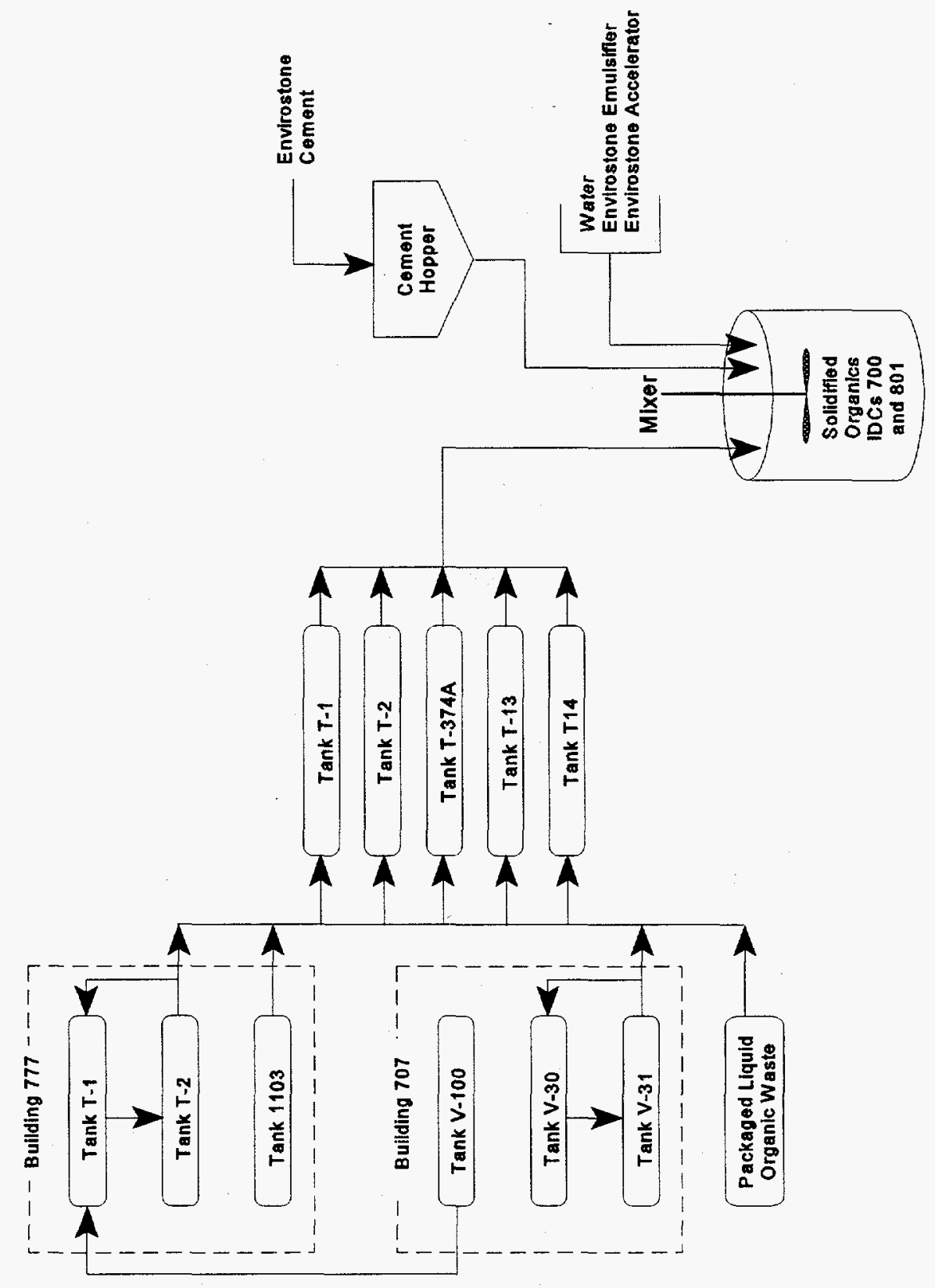

Figure 25-2. Flow of Organic Liquid Waste into IDCs 700 and 801 Drums. 


\subsubsection{Liquid Waste Generation}

Solidified waste oils and solvents were generated primarily in Buildings 707 and 777 . Solventcontaminated (carbon tetrachloride and 1,1,2-trichloro-1,2,2-trifluoroethane) wastes were generated by plutonium machining and tool degreasing. Ultrasonic cleaner baths consisting of 1,1,1-trichloroethane were used to clean parts. Metal turnings and scrap were cleaned in carbon tetrachloride baths before forming the turnings into briquettes. ${ }^{\text {P052 }}$ Trichloroethane began replacing trichloroethene for vapor degreasing of parts in plutonium areas beginning around 1973. By the end of 1974, trichloroethene remained in use in only one plutonium operation, and by February 1975 was used only in research and analytical activities. ${ }^{\text {P023 }}$ Since 1985 , the solidified organic waste was derived almost exclusively from Buildings 707 and $777 .{ }^{040}$

Trace amounts of miscellaneous laboratory wastes including organophosphates and nitrobenzene were also introduced into the solidification process. In addition, PCB contaminated oils were processed until 1979. ${ }^{\text {P024 }}$ Two documented cases $(8 / 27 / 76$ and $1 / 26 / 78)$ indicate PCB contaminated oils from Building 334 were processed. ${ }^{\mathrm{U} 40}$

A log book was used in Building 774 to record the types of organic waste and generation source of the liquids that made up IDCs 003,700 , and 801 . The date of treatment, generation location, waste description, and volume of waste were entered in the log book. A description of the organic liquids included in IDCs 003, 700 , and 801 , the buildings from which they were generated, and the buildings function is presented in

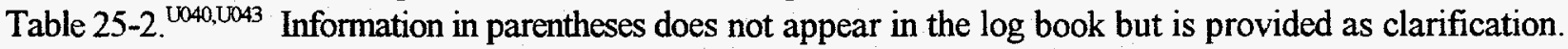

Table 25-2. Organic Liquid Wastes Included In IDCs 003, 700, and 801.

\begin{tabular}{|c|c|c|}
\hline Building & Building Function & Organic Liquid Waste Description \\
\hline 334 & Maintenance shops & $\begin{array}{l}\text { waste oil, PCBs, Zyglo (Zyglo is a dye penetrant compound } \\
\text { containing fluoranthene, petroleum distillates, and } \\
\text { kerosene) }\end{array}$ \\
\hline 371 & Plutonium recovery & oil \\
\hline 443 & Power plant & oil \\
\hline 444 & $\begin{array}{l}\text { Depleted uranium casting } \\
\text { and machining, beryllium } \\
\text { machining }\end{array}$ & oil, trichlor (assumed to be 1,1,1-trichloroethane), Freon \\
\hline 447 & Building 444 support & oil \\
\hline 559 & $\begin{array}{l}\text { Production support } \\
\text { laboratories }\end{array}$ & $\begin{array}{l}\text { pump oil, oil, toluene/ } \mathrm{H}_{3} \text { (assumed to be tritium), silicon oil, } \\
\text { organic waste (xylene/DHDECMP) }\end{array}$ \\
\hline 707 & $\begin{array}{l}\text { Plutonium component } \\
\text { manufacturing }\end{array}$ & oil samples, hydraulic oil \\
\hline 771 & Plutonium recovery & $\begin{array}{l}\text { oil, etch solution, Freon oil, oil/ } \mathrm{CCl}_{4} \text {, mixed organics, } \\
\text { halocarbon oil, TBP (assumed to be tributyl phosphate), } \\
\text { organic extract, Chlorothene (Chlorothene is a trade name for } \\
1,1,1 \text {-trichloroethane) }\end{array}$ \\
\hline
\end{tabular}




\begin{tabular}{|c|c|c|}
\hline Building & Building Function & Organic Liquid Waste Description \\
\hline 776 & $\begin{array}{l}\text { Pyrochemistry and waste } \\
\text { operations }\end{array}$ & engine oil, lube oil, lathe cutting oil \\
\hline 777 & $\begin{array}{l}\text { Plutonium component } \\
\text { manufacturing and } \\
\text { research }\end{array}$ & $\begin{array}{l}\text { coolant oil/ } \mathrm{CCl}_{4} \text {, perc (assumed to be tetrachloroethene), or } \\
\text { trichloroethene }\end{array}$ \\
\hline 778 & Maintenance & $\begin{array}{l}\text { oil, Pydraul oil (Pydraul products are hydraulic oils containing } \\
\text { triphenyl phosphate, trialkylphenyl phosphates, and alkyl aryl } \\
\text { phosphates) }\end{array}$ \\
\hline 779 & Plutonium research & $\begin{array}{l}\text { hydraulic oil, equipment oil, } \mathrm{H}_{3} \text { (assumed to be } \\
\text { tritium)/toluene, Freon }\end{array}$ \\
\hline 865 & $\begin{array}{l}\text { Depleted uranium and } \\
\text { beryllium metallurgy } \\
\text { research }\end{array}$ & beryllium waste oil \\
\hline 881 & $\begin{array}{l}\text { Laboratories and } \\
\text { maintenance }\end{array}$ & $\begin{array}{l}\text { oil, machine coolant, perchlor (assumed to be } \\
\text { tetrachloroethene), waste cocktail (assumed to be scintillation } \\
\text { cocktail), Varsol oil (Varsol is a trade name petroleum solvent } \\
\text { containing primarily saturated hydrocarbons and less than } 2 \% \\
\text { toluene, xylene, and ethyl benzene) } \\
\text { P084 }\end{array}$ \\
\hline 883 & $\begin{array}{l}\text { Depleted uranium rolling } \\
\text { and forming }\end{array}$ & $\begin{array}{l}\text { oil, cooling solvent, D-38 (depleted uranium) oil, oil and perk } \\
\text { (assumed to tetrachloroethene) }\end{array}$ \\
\hline 991 & Product warehouse & coolant, band saw coolant \\
\hline
\end{tabular}

\subsection{Waste Packaging}

Depending on waste packaging requirements at the time, several combinations of bags and liners were used to prepare 55-gallon drums for shipment. From 1970 to 1972, waste drums were lined with two polyethylene drum bags. About four pounds of Oil-Dri was placed in the bottom of the drum and in the bottom of each drum bag. Organic setup (IDC 003) waste was then placed in the the drum. Use of the 90-mil rigid polyethylene liner began in $1972{ }^{\text {P024 }}$ The rigid liner was placed in each drum and lined with one polyethylene

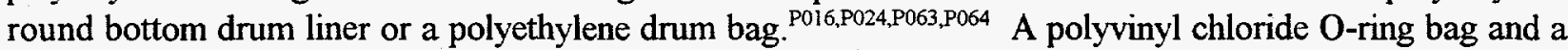
polyethylene bag were used if the drum was attached to the glovebox. About four pounds of Oil-Dri was placed in the bottom of the rigid liner, the round bottom liner or drum bag, and the O-ring bag. The organic liquids were then place in the $\mathrm{O}$-ring bag along with the solidifying agents. When a drum was full, the drum liners were twisted and taped closed, the lid was secured with a bolted ring, and a tamper indicating device was attached to the drum. ${ }^{\mathrm{P} 12, \mathrm{P} 016, \mathrm{P} 024}$

Prior to 1972, absorbent material (Oil-Dri) may have been added to the top of the sealed drum bag which contained the organic setup waste (IDC 003). Since approximately 1972, after drums were inspected, one to two quarts of Oil-Dri was placed on the top of the outer, sealed polyethylene drum bag. This procedure changed in February 1982 when vermiculite was used to fill the space between the outer, sealed polyethylene 
drum bag and the top of the 90-mil rigid liner. The quantity of vermiculite varied from 3-12 pounds according to the amount of waste contained in each drum. ${ }^{\mathrm{P} 24}$

\subsection{Waste Characterization}

Solidified organic waste is characterized based on knowledge of the material, knowledge of the processes generating the waste, RTR review of the waste, visual inspection, and headspace gas analysis. This section provides a RCRA hazardous waste determination for solidified organic waste as well as radionuclide contaminants and potential complexing agents contained in the waste. This waste is at least 50 percent (by volume) inorganic particulates and is classified as a homogeneous waste. ${ }^{\mathrm{P} 141}$

\subsubsection{Hazardous Waste Determination}

The material in this waste group does not qualify for any of the exclusions outlined in 40 CFR 260 or 261. The waste was mixed with halogenated- and nonhalogenated-solvents and is therefore a listed waste. The waste may exhibit the characteristic of toxicity for chloroform, 1,1-dichloroethene, and nitrobenzene. EPA Hazardous Waste Numbers applicable to some or all of the solidified organic waste group are presented by IDC in Table 25-3. These conclusions are supported by the evaluation in Sections 25.3.1.1 and 25.3.1.2.

Table 25-3. Solidified Organic Waste Characterization.

\begin{tabular}{clc}
\hline IDC & \multicolumn{1}{c}{ Title } & EPA Hazardous Waste Numbers \\
\hline 003 & Organic Setups & D022, D029, D036, F001, F002, and F003 \\
700 & OASIS Waste & D022, F001, F002, and F003 \\
801 & Solidified Organics & D022, F001, F002, and F003 \\
\hline
\end{tabular}

\subsubsection{Characteristic Waste}

The materials in this waste group may exhibit a characteristic of hazardous waste as defined in 40 CFR 261, Subpart C as a toxic waste (40 CFR 261.24). The materials do not exhibit the characteristics of ignitability (40 CFR 261.21), corrosivity (40 CFR 261.22), or reactivity (40 CFR 261.23).

Ignitability: The material in this waste group does not meet the definition of ignitability as defined in 40 CFR 261.21. The material is not a liquid but may contain some free liquids. ${ }^{\text {P015 }}$ Absorbents were added to wastes having the potential of generating free liquids (i.e., dewatering of wastes). ${ }^{\mathrm{P} 15, \mathrm{P} 024}$ Visual inspection identified drums of organic setup waste (IDC 003) containing free liquid. However, analysis of the liquids did not identify any ignitable compounds. ${ }^{\text {P015 }}$ The material is not capable of causing fire through friction, absorption of moisture, or spontaneous chemical change. ${ }^{\mathrm{P} 012, \mathrm{P} 016, \mathrm{P} 024}$ The material is not a compressed gas, nor does the waste contain compressed gases. ${ }^{\mathrm{P} 012, \mathrm{P013}, \mathrm{P} 015, \mathrm{P} 016, \mathrm{P} 022, \mathrm{P} 024}$ The material is not a DOT oxidizer as defined in 49 CFR 173. The materials in this waste group are therefore not ignitable wastes (D001).

Corrosivity: The material in this waste group does not meet the definition of corrosivity as defined in 40 CFR 261.22. The material is not a liquid but may contain some free liquids. ${ }^{\text {PO1s }}$ Absorbents were added 
to wastes having the potential of generating free liquids (i.e., dewatering of wastes) ${ }^{\mathrm{P} 015, \mathrm{P} 024}$ Visual inspection identified drums of organic setup waste (IDC 003) containing free liquid. However, analysis indicated that the $\mathrm{pH}$ of the liquids did not meet the definition of a corrosive waste. ${ }^{\text {P015 }}$ The materials in this waste group are therefore not corrosive wastes (D002).

Reactivity: The material in this waste group does not meet the definition of reactivity as defined in 40 CFR 261.23. The material is stable and will not undergo violent chemical change. The material will not react violently with water, form potentially explosive mixtures with water, or generate toxic gases, vapors, or fumes when mixed with water. The material does not contain cyanides or sulfides, and is not capable of detonation or explosive reaction. The material is not a forbidden explosive or a Division 1.1, 1.2, or 1.3 (Class A or B) explosive as defined in 49 CFR 173, nor do the drums contain any explosives. ${ }^{\mathrm{P} 12, \mathrm{P} 013, \mathrm{P} 015, \mathrm{P} 016, \mathrm{P} 022, \mathrm{P} 024}$ Explosives were not handled or used around radioactive material. The materials in this waste group are therefore not reactive wastes (D003).

Toxicity: The material in this waste group meets the definition of toxicity as defined in 40 CFR 261.24. The toxicity characteristic contaminants fall into one of two categories: metals and organics. Organic compounds include halogenated- and nonhalogenated-solvents, pesticides, herbicides, and other toxic compounds. This waste group may exhibit the characteristic of toxicity for the organic compounds chloroform, 1,1-dichloroethene, and nitrobenzene.

There is no documentation indicating the presence or use of metals in the areas or processes generating solidified organic waste. Therefore, this waste group should not exhibit the characteristic of toxicity due to metals (D004-D011).

There is no documentation indicating the presence or use of pesticides or herbicides in the areas or processes generating solidified organic waste. Therefore, this waste group does not exhibit the characteristic of toxicity due to pesticides or herbicides (D012-D017).

Carbon tetrachloride, tetrachloroethene, and trichloroethene, which were used for cleaning and degreasing, are in solidified organic waste. Since these compounds were used as solvents, the waste is regulated as a listed hazardous waste and not a characteristic waste because these compounds are specifically addressed in the treatment standards for the listed hazardous waste. ${ }^{\text {P080 }}$ Since solidified organic waste is characterized as listed hazardous wastes due to spent solvent contamination, the waste is not a toxic waste due to the presence of these organic compounds.

Chloroform was used in laboratory analysis and as a solvent for joining plastics. ${ }^{\text {P053 }}$ There is no documentation indicating that chloroform was introduced into the organic solidification process. However, chloroform was detected in headspace gas samples. Of the 42 drums of organic setups (IDC 003) sampled, 15 had chloroform in the headspace. Only 3 drums of solidified organics (IDC 801) were sampled, and one contained chloroform in the headspace. ${ }^{\mathrm{P} 033}$ Although there is not a direct correlation between the concentration of a compound in the headspace gas versus the waste, it is possible that the waste exhibits the characteristic of toxicity for chloroform. Therefore, EPA Hazardous Waste Number D022 is assigned to this waste group. A representative sample of this waste will be collected for verification purposes.

There is no documentation indicating the use of 1,1-dichloroethene in the areas or processes generating organic liquid waste, or that it was introduced into the organic solidification process. However, 1,1-dichloroethene was detected in headspace gas samples. Of the 42 drums of organic setups (IDC 003) 
sampled, one had 1,1-dichloroethene in the headspace. This single detection was at a high enough concentration to cause the $90 \%$ UCL to exceed the PRQL for that compound ${ }^{\mathrm{PO} 33}$ It is possible that the organic setup waste (IDC 003) exhibits the characteristic of toxicity for 1,1-dichloroethene, and therefore is assigned EPA Hazardous Waste Number D029. A representative sample of this waste will be collected for verification purposes.

Nitrobenzene was a contaminant in nonroutine laboratory waste, and small amounts of this compound were introduced into five or fewer drums of organic setups (IDC 003). There is no documentation specifying the individual drums or time frame; however, the source of this information was from a document published in October 1982. ${ }^{\text {P024,P052 }}$ There is no indication that nitrobenzene was ever used as an F004 solvent at Rocky Flats. Therefore, organic setup waste (IDC 003) generated before October 1982 may exhibit the characteristic of toxicity for nitrobenzene and is assigned EPA Hazardous Waste Number D036. A representative sample of this waste will be collected for verification purposes

\subsubsection{Listed Hazardous Waste}

The material in this waste group is a listed hazardous waste because it was mixed with a waste listed in 40 CFR 261, Subpart D as a hazardous waste from non-specific sources (40 CFR 261.31). The material is not, or was not mixed with, a hazardous waste from specific sources (40 CFR 261.32), or a discarded commercial chemical product, an off-specification species, a container residue, or a spill residue thereof (40 CFR 261.33).

Carbon tetrachloride, 1,1,2-trichloro-1,2,2-trifluoroethane, 1,1,1-trichloroethane, trichloroethene, and tetrachloroethene spent solvents were mixed with solidified organic waste. Therefore, solidified organic waste is assigned EPA Hazardous Waste Numbers F001 and F002.

Methylene chloride was present in paints and paint strippers and was used in several laboratories and process areas for sample preparation and analysis. ${ }^{\mathrm{P} 053}$ There is no documentation indicating that methylene chloride was mixed with solidified organic waste. However, methylene chloride was detected in headspace gas samples of organic setups (IDC 003) ${ }^{\mathrm{P} 033}$ If methylene chloride was mixed with organic setups, the characterization does not change because methylene chloride is a F001- or F002-listed solvent.

Solvents such as methanol and xylene were used in laboratory analysis. ${ }^{\mathrm{P} 107}$ Documentation indicates one drum (RF074318283) of solidified organics (IDC 801) containing 7.6 liters of solidified xylene waste. There is no documentation indicating that xylene (spent solvent) was mixed with organic setups (IDC 003). However, headspace gas analysis of organic setups detected xylene. ${ }^{\mathrm{P} 033}$. There is no documentation indicating that methanol was mixed with solidified organic waste, yet headspace gas analysis of solidified organic waste (IDC 801) detected methanol. ${ }^{\text {P033 }}$ Therefore, solidified organic waste is assigned EPA Hazardous Waste Number F003.

Organic setups (IDC 003) may contain trace concentrations of nitrobenzene. ${ }^{\mathrm{P} 024}$ There is no indication that nitrobenzene was ever used as a solvent, nor is there documentation indicating the presence or use of any other F004-listed solvents in the areas or processes generating solidified organic waste. Therefore, this waste group is not a F004-listed hazardous waste.

There is documentation that a tritium/toluene mixture was twice added to organic setups (IDC 003) in the 1970 s. The toluene is described as a constituent of scintillation cocktail. ${ }^{\text {U043 }}$ Scintillation cocktail is not 
used as a solvent. Varsol oil, which contains toluene, was mixed with solidified organic waste. However, Varsol oil contains less than a half of a percent toluene. Therefore, this waste group is not a F005-listed waste.

Headspace analysis performed on samples of solidified organic waste obtained at INEEL confirms the presence of F-listed solvents. The detected F-listed compounds in which the 90 percent UCL is above the PRQL are provided. ${ }^{\text {P033 }}$

$\begin{array}{lll}\text { - } & \text { 1,1,1-trichloroethane } & \text { trichloroethene } \\ \text { 1,1,2-trichloro-1,2,2-trifluoroethane (IDC } 003 \text { only) } & \text { - } & \text { methanol (IDC } 801 \text { only) } \\ \text { carbon tetrachloride } & \text { xylene (IDC } 003 \text { only) } \\ \text { methylene chloride (IDC } 003 \text { only) } & -\quad & \text { toluene (IDC } 003 \text { only) } \\ \text { tetrachloroethane (IDC } 003 \text { only) } & & \end{array}$

The material in this waste group is not a hazardous waste from specific sources since it was not generated from any of the processes listed in 40 CFR 261.32. The material in this waste group is therefore not a K-listed hazardous waste.

The material in this waste group is not a discarded commercial chemical product, an off-specification species, a container residue, or a spill residue thereof (40 CFR 261.33). The material in this waste group is therefore not a P- or U-listed hazardous waste.

\subsubsection{Radionuclides}

Assay values for waste drums were obtained from radiochemical analyses of batch treatments or analysis results of individual bottles and drums that were received for processing. Average values were usually assigned to waste drums. ${ }^{\mathrm{P} 16, \mathrm{P} 024}$ Documented assay results and treatment log book descriptions for solidified organic waste drums indicate the presence of plutonium, americium-241, tritium, uranium-235, and uranium$238{ }^{\mathrm{P} 016, \mathrm{P} 024, \mathrm{P} 033, \mathrm{U} 040}$ The processes that generated waste oils and solvents contaminated with these and potentially other radioisotopes is presented below. In addition, Table 25-4 summarizes matrix and other physical parameters which could affect radioassay.

Transuranic waste oils and solvents were generated primarily in Buildings 707 and 777 . Radionuclide contamination in waste from Building 707 will primarily consist of weapons-grade plutonium from foundry, casting, and final assembly operations. ${ }^{\text {P052.POS3 }}$ Building 777 performed disassembly of site-return parts and fabrication operations, including machining, briquetting, assembly, and production support processes. ${ }^{\text {C184.P052P079 }}$ Waste from fabrication operations will be contaminated with weapons-grade plutonium and enriched uranium. Wastes generated by disassembly operations will be contaminated with site-return plutonium (higher americium-241 decay product) and enriched uranium. ${ }^{\text {C184.P079 }}$ Tritium may also be present from disassembly operations. ${ }^{\text {P0s3 }}$ The isotopic compositions of weapons-grade plutonium and enriched uranium are presented in Section 3.0.

Waste oils or solvents contaminated with depleted uranium were generated from casting, machining, and other metal working processes in Buildings $444,447,865$, and 883 . $^{\text {P053 }}$ Although these oils have been segregated from transuranic oils since 1985, there is documentation that indicates waste oil 238 (assumed to be uranium-238) from Building 771 was introduced into solidified organic waste in 1986. ${ }^{\text {U040 }}$ Therefore, there is a potential for depleted uranium contamination in all solidified organic waste. The isotopic composition of depleted uranium is presented in Section 3.0. 
Research and development operations also generated waste oils and solvents from casting, machining,

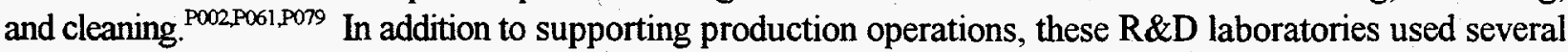
other radioisotopes. Processing of most of the "special" radioisotopes, such as curium-244, thorium-232, and

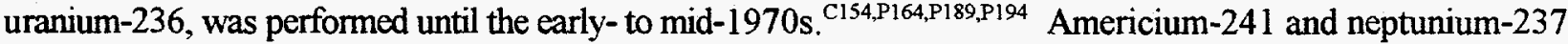
were processed until 1985 or 1986 , and uranium-233 was handled until about 1982. ${ }^{\text {C154,P164,P198,P200 A more }}$ detailed description of plutonium and uranium production operations and R\&D operations is provided in Section 3.0.

The Size Reduction Vault in Building 776 conducted repackaging operations (prefixes 19 and 25). ${ }^{\mathrm{C} 175, \mathrm{C1} 184, \mathrm{P} 078, \mathrm{U} 059}$ The package date on these drums is the date in which the waste was repackaged and was originally generated some time prior to this date. Therefore, it is assumed that the repacked containers could potentially contain any of the above radioisotopes. IDCs 700 and 801 will not contain uranium-233 because this waste was not generated until about 1986.

Table 25-4. Waste Matrix Evaluation.

\begin{tabular}{|c|c|}
\hline Parameter & Results of Evaluation \\
\hline $\begin{array}{l}\text { Radionuclide Form, } \\
\text { Particle Size, and } \\
\text { Distribution }\end{array}$ & $\begin{array}{l}\text { Because the oils and solvents originated from metal fabrication operations, the } \\
\text { radionuclides will likely be in the form of metals and oxides. The radioactive } \\
\text { contaminants should be evenly distributed throughout the waste because IDC } \\
003 \text { was blended in a continuous mixer, and IDC } 801 \text { was agitated for a set } \\
\text { period of time to allow for proper mixing. } \text { P002,P024 }^{\text {. }}\end{array}$ \\
\hline Hydrogen Content & $\begin{array}{l}\text { IDC } 003 \text { contains no water and approximately } 30 \text { gallons of organic liquid. }{ }^{\mathrm{P} 024} \\
\text { IDC } 801 \text { contains about } 15 \mathrm{wt} \% \text { water and } 35 \% \text { organic liquids. }{ }^{\mathrm{P} 002, \mathrm{U} 010}\end{array}$ \\
\hline $\begin{array}{l}\text { Other Interfering Waste } \\
\text { Contaminants }\end{array}$ & $\begin{array}{l}\text { Interfering waste contaminants may include aluminum, beryllium, and stainless } \\
\text { steel (chromium) which were machined in Building } 7777^{\text {P079 }} \text { Beryllium will also } \\
\text { be present from degreasing solvents generated in Building } 444 .^{\text {P024 }}\end{array}$ \\
\hline $\begin{array}{l}\text { Physical Matrix } \\
\text { Parameters }\end{array}$ & $\begin{array}{l}\text { IDC } 003 \text { is a paste-like material, and IDC } 801 \text { is a solid monolith. The waste } \\
\text { contaminants should be evenly distributed throughout the waste. }\end{array}$ \\
\hline
\end{tabular}

\subsubsection{Complexing Agents}

Because complexing agents can aid in the transport of transuranic radionuclides from the waste after disposal, the waste was assessed for potential complexing agents. This information may also be added to the chemical compatibility studies since limited information was available on these chemicals in the past.

There are two documented cases of complexing agents included in the solidified organic waste. In 1983, 54 liters of tributyl phosphate were processed into a drum or organic setup waste (IDC 003). ${ }^{\mathrm{U} 040}$ In 1988, 7.6 liters of a xylene and dihexl-n,n-diethylcarbamoyl methylphosphonate (DHDECMP) mixture were included in a drum (RF074318283) of solidified organics (IDC 801). ${ }^{\mathrm{C} 027, \mathrm{C} 032, \mathrm{C} 086, \mathrm{U} 040}$ 


\subsection{0-SERIES WASTE}

This waste group includes plastic, paper, wood, metal, glass, concrete, and asphalt wastes generated in Buildings 771 and 774 and the 904 Pad. Historic IDC descriptions and dates of generation for the INEEL accessible storage inventory are presented by IDC in Table 26-1. ${ }^{\mathrm{P} 127}$

Table 26-1. 900-Series Waste in the Accessible Storage Inventory.

\begin{tabular}{lll}
\hline IDC & \multicolumn{1}{c}{ Title } & \multicolumn{1}{c}{ Dates of Generation } \\
\hline 900 & $\begin{array}{l}\text { LSA Plastics, Paper, etc. }{ }^{\mathrm{P} 024} \\
\text { Plastic, Paper, etc. }{ }^{\text {O12 }}\end{array}$ & December 1972-May 1973 \\
950 & LSA Metal, Glass, etc. ${ }^{\text {P024 }}$ & December 1972 \\
960 & Concrete, Asphalt, etc. $^{\text {P024 }}$ & January 1972-May 1973 \\
970 & Wood $^{\mathrm{P} 024}$ & January 1973 \\
\hline
\end{tabular}

Item Description Code 900, Plastic, Paper, etc: This waste consists primarily of combustible wastes such as plastics, paper, wipes, empty polyethylene bottles, booties, filter paper, and surgical gloves. The waste

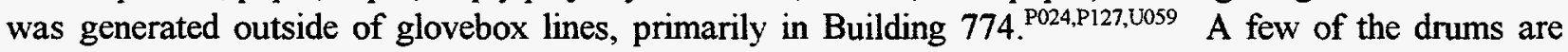
contaminated with depleted uranium and originated from a non-plutonium area. The waste may be dry or damp. Up to 15 pounds of Portland cement was added to drums containing damp waste. Limited amounts of non-combustible waste may also be included. IDC 900 was replaced by IDC 330 , dry combustibles, in $1974{ }^{\text {P024 }}$

Item Description Code 950, Metal, Glass, etc.: This waste consists primarily of non-combustible wastes such as electrical conduit, water and steam pipes, tools, control panels, electronic instrumentation, light bulbs, windows, office equipment, lead shielding, and structural metal ${ }^{\mathrm{P} 024}$ The waste was generated primarily outside of glovebox lines in Building 774. ${ }^{\text {P024,P127,U059 }} \mathrm{A}$ few drums of this waste may be non-plutonium contaminated. The waste may also include some combustible wastes. Wastes generated inside the glovebox lines in Building 774 may also be included. IDC 950 has not been used since $1974 .^{\text {P024 }}$ Metal and glass wastes have since been segregated.

Item Description Code 960, Concrete, Asphalt, etc.: This waste consists primarily of concrete and asphalt, but may also include limited amounts of dirt and combustible wastes. ${ }^{\mathrm{P} 24}$ The wastes were generated in Buildings 771 and 774 and the 904 Pad. $^{\text {P127,U059 }}$ IDC 960 was replaced in 1973 by IDC 374; blacktop, concrete, dirt, and sand.

Item Description Code 970, Wood: This waste consists of lumber, plywood sheeting, filter frames, and ladders. Combustible wastes such as plastic sheeting and wipes, and non-combustible wastes including nails and sheetrock may also be present in the waste. ${ }^{\mathrm{P} 024}$ The wastes were generated in Building 771 and the $904 \mathrm{Pad}^{\text {P127.U059 }}$ IDC 970 was discontinued in 1978, and is now included in IDC 330, dry combustibles. ${ }^{\text {P024 }}$ 


\subsection{Waste Generation}

The entire inventory of paper, plastic, glass, and metal wastes (IDCs 900 and 950) and a portion of the concrete and asphalt waste (IDC 960), was generated by liquid waste treatment operations in Building 774 . Wood waste (IDC 970) and the remainder of the concrete and asphalt wastes (IDC 960) were generated by aqueous recovery operations in Building 771 and from the 904 Pad. $^{\text {P127,U059 }}$

\subsubsection{Paper, Plastic, Etc.}

Paper and plastic wastes (IDC 900) were primarily nonline-generated combustibles from routine liquid waste treatment operations in Building $774 .^{\text {P024,P127,U059 }}$ When Building 774 was built in 1952, its primary purpose was for the treatment of radioactive aqueous waste from Building 771. Radionuclides were removed by precipitation, and the resulting slurry was filtered. The solids removed from the filters were combined with cement or another solidifying agent. The aqueous waste from this first stage went through a second stage which was essentially the same process. ${ }^{\mathrm{P} O 53}$ These processes used sodium hydroxide, ferric sulfate, magnesium sulfate, and calcium chloride. ${ }^{\mathrm{P} 109}$

Around 1965, an evaporator was installed in Building 774 to treat liquids from the second stage treatment and from the solar ponds. The concentrate from the evaporator was dried which resulted in a salt waste. The evaporator was taken out in 1979, and the liquids from the second stage treatment and solar ponds have since been transferred to Building 374. ${ }^{\mathrm{P} 53}$ A more detailed description of wastes treated by these processes is presented in Section 23.0, Solidified Aqueous Sludge Building 774.

Liquid wastes from laboratory operations throughout Rocky Flats that were not compatible with the primary aqueous treatment system were treated separately from other liquid wastes. These wastes, which include complexing agents, strong acids, or strong bases, were treated by mixing with cement and water to form a solid monolith. Prior to treatment, the acids were neutralized with sodium hydroxide. ${ }^{\mathrm{P} 070}$ See Section 24.0, Solidified Laboratory Waste, for more information on the wastes treated by this process.

Building 774 also processes organic liquid wastes. Plutonium-contaminated oil and chlorinated-solvent mixtures were generated from plutonium machining. The spent organic liquid was filtered and then mixed with Microcel-E solidifying agent which was a synthetic calcium silicate. ${ }^{\text {P002,P053 }}$ Wastes treated by this process are described in greater detail in Section 25.0, Solidified Organic Waste.

\subsubsection{Metal, Glass, Etc.}

Metal and glass wastes (IDC 950) were primarily nonline-generated noncombustibles from liquid waste treatment operations in Building $774{ }^{\text {P127,U059 }}$ The wastes generated from liquid waste treatment were usually associated with maintenance activities.

Building 774 liquid waste treatment operations required various types of machinery, instruments, and other equipment. Parts from the equipment were routinely changed due to normal wear and tear. ${ }^{\text {P052 }}$ Another maintenance activity that generated metal waste was the strip-out of glovebox lines, process piping, tanks, and associated systems. Methylene chloride was sometimes used for paint removal during cleanup. Other solvents such as trichloroethylene or 1,1,1-trichloroethane may also have been used during strip-out activities for 
decontamination. Maintenance activities also generated glass wastes including glovebox windows and light bulbs. ${ }^{\mathrm{P} 035, \mathrm{P} 049, \mathrm{P} 053}$

\subsubsection{Concrete, Asphalt, Etc.}

Concrete and asphalt wastes (IDC 960) are primarily nonline-generated wastes that originated from cleanup of spills, decontamination activities, and maintenance operations in Buildings 771, 774, and the 904 Pad. The waste may contain any chemicals or compounds that were used in these areas.

Asphalt waste was generated from the cleanup of a spill in Building 771. The source or composition of the spill could not be identified. Concrete pieces, chips, and fines were also generated in Building 771 from removal of concrete blocks used to support Nash pumps. Also in Building 771, concrete walls were cut out for doorways. In Building 774, concrete pieces and fines were generated from the removal of reinforced concrete treatment tanks. ${ }^{\mathrm{P} 24}$ Concrete and asphalt waste was also generated at the $904 \mathrm{Pad}^{\text {P127,U059 }}$ The 904 Pad was a waste storage area for containers generated at any area of the plant site.

Nitric acid, hydrochloric acid, potassium hydroxide, potassium fluoride, and hydrogen peroxide were the primary reagents used in Building 771 recovery operations. Carbon tetrachloride, tetrachloroethylene, 1,1,1-trichloroethane, 1,1,2-trichloro-1,2,2-trifluoroethane, trichloroethylene, and methylene chloride were the primary solvents used during plutonium operations. Common chemicals used for decontamination activities include 1,1,1-trichloroethane, trichloroethene, and paint thinner (toluene and methyl ethyl ketone) for cleaning, and methylene chloride for paint removal. ${ }^{\mathrm{P} 23, \mathrm{P} 053}$

Information regarding metal contaminants in asphalt and concrete waste is limited. The waste from Building 774 may be contaminated with sludge from liquid waste treatment operations. These sludges contain various toxic metals. Mercury was used in instruments such as barometers, thermometers, plant machinery, and mercury switches. ${ }^{\text {P53 }}$ Lead-based paint which may have been used to paint concrete floors and walls is another source of metal contamination.

\subsubsection{Wood}

Wood waste (IDC 970) was generated primarily in Building 771 from the removal of wood filter frames from absolute filters. Filters contaminated with plutonium above the EDL were manually shaken to remove loose particulate which was sent for recovery. Filter frames were usually below the EDL and were discarded. ${ }^{\mathrm{P} 024, \mathrm{P} 061}$

Wood waste was also generated at the 904 Pad. $^{\text {PI27.U059 }}$ It is speculated that the wood may be used waste boxes that were cut up. ${ }^{\mathrm{P} 24}$ However, the source of this waste was not verified.

\subsection{Waste Packaging}

The 900-series wastes may be single- or double-bagged in polyvinyl chloride or polyethylene, or placed directly into a lined 55-gallon drum. The individual packages within a drum may or may not be sealed with tape. Concrete and asphalt waste (IDC 960) may also be contained in Fibre-Paks. Up to 15 pounds of Portland cement may have been added to IDC 900 drums containing damp waste. ${ }^{\text {P012,P015,P024 }}$ 
Depending on waste packaging requirements at the time, several combinations of bags and liners were used to prepare 55-gallon drums for shipment. From 1970 to 1972, waste drums were lined with one or two polyethylene drum bags. Cardboard liners might have been used to line the inner drum bag. Use of 90 -mil rigid polyethylene liners began in 1972. A rigid liner was placed in each drum and lined with one polyethylene round bottom drum liner or two polyethylene drum bags. A polyvinyl chloride $\mathrm{O}$-ring bag and a polyethylene bag placed inside the rigid liner was used if the drum was attached to a glovebox. A fiberboard liner and discs may also have been used between the waste and the drum liners for puncture protection. When a drum was full, the drum liners were twisted and taped closed, the rigid liner lid was sealed on the rigid liner, and the drum lid and gasket were installed and secured with a lock-chine. ${ }^{\mathrm{P} 012, \mathrm{P} 015, \mathrm{P} 024}$

Since approximately 1972, drums have been inspected for free liquids, proper packaging, and use of proper IDC. Rejected drums were returned to the generator for correction. After inspection, one to two quarts of absorbent material (Oil-Dri) was placed on top of the outer, sealed polyethylene drum bag. ${ }^{\mathrm{P} 024}$

Visual inspection of paper and plastic (IDC 900) drums identified a variety of items other than combustibles including metal shims, welding rods, steel pipe, nuts, bolts, an electric motor and cord, a flashlight, concrete chunks, brushes, and lumber. Visual examination of one drum of asphalt and concrete (IDC 960) revealed only cinder blocks. Drums of wood (IDC 970) from Building 771 contained only filter frames. ${ }^{\text {P015 }}$ Visual inspection records were not identified for drums of IDC 950.

\subsection{Waste Characterization}

The 900-series wastes are characterized based on knowledge of the material, knowledge of the processes generating the waste, general chemical usage at Rocky Flats, and headspace gas analysis. This section provides a RCRA hazardous waste determination for 900 -series wastes as well as radionuclide contaminants and potential complexing agents contained in the waste. This waste is at least 50 percent (by volume) materials that meet the EPA LDR criteria for classification as debris, and is classified as a heterogeneous waste. ${ }^{\text {Pl41 }}$

\subsubsection{Hazardous Waste Determination}

The material in this waste group does not qualify for any of the exclusions outlined in 40 CFR 260 or 261. The waste may exhibit the characteristic of toxicity for arsenic, barium, cadmium, chromium, lead, mercury, selenium, silver, and 1,1-dichloroethene. The waste may have been mixed mixed with halogenatedand nonhalogenated-solvents, and is therefore a F-listed hazardous waste. There is no evidence that 900-series wastes exhibit any other characteristic of hazardous waste. EPA Hazardous Waste Numbers applicable to some or all of this waste group are presented by IDC in Table 26-2. These conclusions are supported by the evaluation in Sections 26.3.1.1 and 26.3.1.2. 
Table 26-2. 900-Series Waste Characterization.

\begin{tabular}{rll}
\hline IDC & \multicolumn{1}{c}{ Title } & \multicolumn{1}{c}{ EPA Hazardous Waste Numbers } \\
\hline 900 & Plastic, Paper, etc. & D004-D011, D029, F001, F002, and F005 \\
950 & Metal, Glass, etc. & D004-D011, F001, F002, and F005 \\
960 & Concrete, Asphalt, etc. & D004-D011, F001, F002, and F005 \\
970 & Wood & F001, F002, and F005 \\
\hline
\end{tabular}

\subsubsection{Characteristic Waste.}

The materials in this waste group may exhibit a characteristic of hazardous waste as defined in 40 CFR 261, Subpart $C$ as as a toxic waste (40 CFR 261.24). The materials do not exhibit the characteristics of ignitability (40 CFR 261.21), corrosivity (40 CFR 261.22), or reactivity (40 CFR 261.23). The origin of the characteristic hazardous waste numbers assigned to 900 -series wastes is provided in Table 26-3. The table includes only the hazardous waste numbers that are applicable to waste for which a specific source was identified.

Table 26-3. Origin of Characteristic Hazardous Waste Numbers.

\begin{tabular}{cll}
\hline IDC & \multicolumn{1}{c}{ EPA Hazardous Waste Numbers } & \multicolumn{1}{c}{ Building of Generation } \\
\hline 960 & D008 and D009 & Generated in Building 771 \\
& D004-D011 & Generated in Building 774 or the 904 Pad \\
\hline
\end{tabular}

Ignitability: The materials in this waste group do not meet the definition of ignitability as defined in 40 CFR 261.21. The materials are not liquid, and an absorbent material was added to drums if moisture was

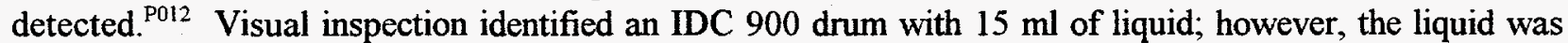
identified as primarily water, silicates, and carbonates and is not ignitable. ${ }^{\text {P015 }}$ The materials are not compressed gases, and no compressed gases have been identified in this waste group. ${ }^{\mathrm{P} 012, \mathrm{P} 024}$ The materials are not capable of causing fire through friction, absorption of moisture, or spontaneous chemical change. The materials are not DOT oxidizers as defined in 49 CFR 173. The materials in this waste group are therefore not ignitable wastes (D001).

Corrosivity: The materials in this waste group do not meet the definition of corrosivity as defined in 40 CFR 261.22. The materials are not liquid, and an absorbent material was added to drums if moisture was detected. $^{\text {P012 }}$ Visual inspection identified an IDC 900 drum with $15 \mathrm{ml}$ of liquid; however, the liquid was identified as primarily water, silicates, and carbonates with a pH of 12 which is not corrosive by definition. ${ }^{\mathrm{P} 015}$ The materials in this waste group are therefore not corrosive wastes (D002).

Reactivity: The materials in this waste group are stable and will not undergo violent chemical change. The materials will not react violently with water, form potentially explosive mixtures with water, or generate toxic gases, vapors, or fumes when mixed with water. The materials do not contain cyanides or sulfides, and 
are not capable of detonation or explosive reaction. The materials are not forbidden explosives or Division 1.1, 1.2 , or 1.3 (Class A or B) explosives as defined in 49 CFR 173. Explosives were not handled or used around radioactive material. The materials in this waste group are therefore not reactive wastes (D003).

Toxicity: The materials in this waste group may meet the definition of toxicity as defined in 40 CFR 261.24. The toxicity characteristic contaminants fall into one of two categories: metals and organics. Organic compounds include halogenated- and nonhalogenated-solvents, pesticides, herbicides, and other toxic compounds. This waste group may exhibit the characteristic of toxicity for arsenic, barium, cadmium, chromium, lead, mercury, selenium, and silver metals, as well as 1,1-dichloroethene.

The entire inventory of plastic and paper (IDC 900) and glass and metal (IDC 950) were generated by Building 774 liquid waste treatment operations. Aqueous wastes treated in Building 774 may have contained all of the toxicity characteristic metals (See Section 23.0, Solidified Aqueous Sludge Building 774), and it is possible that these wastes may contain waste water treatment sludge. Glass and metal (IDC 950) may also include leaded glovebox windows which contain barium and lead, fluorescent bulbs and instruments containing mercury, and lead shielding. ${ }^{\text {P024.P053 }}$ Therefore, IDCs 900 and 950 are assigned EPA Hazardous Waste Numbers D004-D011 since a representative sample of this waste cannot be obtained for verification purposes.

A portion of the concrete and asphalt (IDC 960) inventory was also generated by Building 774 liquid waste treatment operations. The remaining inventory of concrete and asphalt was generated by recovery operations in Building 771 and the $904 \mathrm{Pad}$. Since the $904 \mathrm{Pad}$ is a waste storage area, the waste from this area could have originated from anywhere on plant site and may contain any of the toxicity characteristic metals. Lead-based paint, which may have been used to paint floors and walls, is a possible source of metal contamination in asphalt and concrete waste from Building 771 , as well as other areas. In addition, concrete and asphalt could have been generated from spill cleanup of mercury containing instruments. Therefore, IDC 960 from Building 771 is assigned EPA Hazardous Waste Numbers D008 and D009, and IDC 960 from Building 774 and the 904 Pad is assigned EPA Hazardous Waste Numbers D004-D011 since a representative sample of this waste cannot be obtained for verification purposes.

Wood (IDC 970) consists primarily of filter frames from Building 771 recovery operations. Wood (possibly cardboard boxes) was also generated from the $904 \mathrm{Pad}$. There is no documentation that indicates a possible source for metal contamination on wood. Therefore, wood (IDC 970) does not exhibit the characteristic of toxicity due to metals (D004-D011).

There is no documentation indicating the presence or use of pesticides or herbicides in the areas or processes generating 900 -series wastes. Therefore, this waste group does not exhibit the characteristic of toxicity due to pesticides or herbicides (D012-D017).

Tetrachloroethylene, trichloroethylene, carbon tetrachloride, and methyl ethyl ketone (common component of paint thinner) were used during production operations or decontamination activities. The 900series wastes could potentially be contaminated with these solvents. However, since these compounds were typically used as solvents, the wastes are regulated as listed hazardous wastes and not characteristic wastes because these compounds are specifically addressed in the treatment standards for the listed hazardous waste. ${ }^{\text {P080 }}$ Since the 900 -series wastes will be considered a listed hazardous waste due to the presence of spent solvents, the wastes are not toxicity characteristic wastes due to the presence of these compounds. 
1,1-dichloroethene was detected in headspace samples of paper and plastic (IDC 900) and wood (IDC 900). ${ }^{\text {P033 }}$ The only possible source identified for this compound is from radiolysis of 1,1,1-trichlorothane. ${ }^{\mathrm{P} 151}$ It is possible that toxicity characteristic levels of 1,1-dichloroethene may be present in paper and plastic (IDC 900). However, it is unlikely that this is the case for wood (IDC 970) based on the waste matrix. Therefore, IDC 900 is assigned EPA Hazardous Waste Number D029 since a representative sample of this waste cannot be obtained for verification purposes.

\subsubsection{Listed hazardous waste.}

The material in this waste group may have been mixed with a waste listed in 40 CFR 261, Subpart $D$ as a hazardous waste from non-specific sources (40 CFR 261.31). The waste is not, or was not mixed with, a hazardous waste from specific sources (40 CFR 261.32), or a discarded commercial chemical product, an off-specification species, a container residue, or a spill residue thereof (40 CFR 261.33).

Solvents such as carbon tetrachloride, tetrachloroethene, 1,1,1-trichloroethane, trichloroethene, 1,1,2-trichloro-1,2,2-trifluoroethane, and methylene chloride, were used during production operations and decontamination activities. The 900 -series wastes may be contaminated with these spent solvents, and are therefore assigned EPA Hazardous Waste Numbers F001 and F002.

There is no documentation indicating the presence or use of F004-listed solvents in the areas or processes generating 900 -series wastes. Therefore, this waste group is not a F004-listed hazardous waste.

Toluene and methyl ethyl ketone were common components of paint and lacquer thinners which were commonly used for cleaning. The 900 -series wastes may be contaminated with these spent solvents, and are therefore assigned EPA Hazardous Waste Number F005.

Headspace analysis performed on samples of 900-series wastes (IDCs 900, 960, and 970) obtained at INEEL confirms the presence of F-listed solvents. Headspace analysis results are not available for IDC 950. The detected F-listed compounds in which the 90 percent UCL is above the PRQL are provided. Only 2 to 4 samples were collected for each IDC which resulted in undetected compounds being statistically above the PRQL. This was a result of using half the detection limit when calculating the 90 percent UCL. In cases where this occurred, the compounds are not provided below. ${ }^{\mathrm{P} 033}$

- 1,1,1-trichloroethane

- $\quad$ carbon tetrachloride (IDCs 900 and 970 only)

- $\quad$ tetrachloroethene (IDC 900 only)

- $\quad$ toluene (IDCs 900 and 970 only)

- trichloroethene

At one time, Building 774 treated spent stripping, cleaning, and plating solutions and sludges from Building 444 electroplating operations. Research and development electroplating operations in Building 444 started in approximately 1973 or 1974 , and production scale in $1981 .^{\text {C048,P053 }}$ However, the 900 -series wastes were generated before electroplating operations began. Therefore, the materials in this waste group are not F006-, F007-, and F009-listed hazardous wastes. 
The material in this waste group is not a hazardous waste from specific sources since it was not generated from any of the processes listed in 40 CFR 261.32. The material in this waste group is therefore not a K-listed hazardous waste.

The material in this waste group is not a discarded commercial chemical product, an off-specification species, a container residue, or a spill residue thereof (40 CFR 261.33). The material in this waste group is therefore not a P- or U-listed hazardous waste.

\subsubsection{Radionuclides}

The feed materials to the recovery and purification processes (prefix 01) in Building 771 were impure plutonium residues which were processed to produce plutonium metal for use in the foundry and, therefore, wastes generated will be contaminated primarily with weapons-grade plutonium. ${ }^{\text {P052,P163,U059 Radionuclides from }}$ aqueous recovery operations will vary widely in chemical form depending on the specific process the waste originated, and because the majority of the aqueous processes were performed within one large MBA (prefix 01 ), the specific process can not be determined. The different actinide forms are plutonium nitrate, plutonium chloride, plutonium peroxide, plutonium dioxide, plutonium tetrafluoride, and plutonium metal. Radioassay interferences may include aluminum nitrate from the dissolution process and beryllium which was removed during Part V leach. ${ }^{\mathrm{P} 163}$

Aqueous waste treatment operations in Buildings 374 and 774 receive wastes from throughout plant site, including processes that generated low-level and nonradioactive liquid wastes. For this reason, wastes generated during treatment operations may contain any of the radioisotopes used at the plant. The most common radioactive materials handled were weapons-grade plutonium, americium-241, enriched uranium, and depleted uranium. Other radionuclides may also be found in the waste streams from $R \& D$, analytical, and special order work. ${ }^{\mathrm{Pl} 64}$ Radionuclide contaminants are removed from the aqueous wastes by precipitation using sodium hydroxide and, therefore, will be primarily in the form of hydroxides. ${ }^{\mathrm{P} 163}$ Radioassay interferences may include magnesium sulfate and calcium chloride reagents used in the process. ${ }^{\text {P106.P163 }}$

Building 774 also processed organic liquid wastes. Organic wastes are comprised of a variety of oils and solvents. Most of the oils were from spent lathe coolant used in the plutonium machining area and lubricating oils used in machines throughout the plant. ${ }^{\text {P164 }}$ The majority of the transuranic organic liquids were oils and solvents from plutonium machining and degreasing operations in Buildings 707 and 777 and, therefore, will be contaminated with actinide metals and oxides. ${ }^{\text {P052 }}$ A more detailed discussion of the wastes treated in these buildings is provided in Sections 22.0 through 25.0.

\subsubsection{Complexing Agents}

Because complexing agents can aid in the transport of transuranic radionuclides from the waste after disposal, the waste was assessed for potential complexing agents. This information may also be added to the chemical compatibility studies since limited information was available on these chemicals in the past.

EDTA represents a group of chelating compounds, such as ethylenediaminetetraacetic acid, with similar molecular structures found in many soaps and detergents. Versene (a trade name for EDTA) and citric acid are known constituents of $\mathrm{KW}$ decontamination detergent. ${ }^{\text {P024,P068 }} \mathrm{KW}$ was used during a variety of decontamination activities at the plant, including wiping down filter frames. A buffer solution (TISAB) containing diaminocyclohexane tetraacetic acid was used during specific ion electrode analysis in Building 
559. ${ }^{\text {P076 }}$ Oxalic acid and tetraphosphoric acid were used to etch plutonium and other metals. ${ }^{\text {P062,U043 }}$ Oxalic acid was also used for americium recovery. ${ }^{\mathrm{P} 113}$ The 900 -series wastes may contain trace quantities of these complexing agents. 


\begin{tabular}{|l|l|l|l|}
\hline REF \# & TITLE & SUMMARY & DATE \\
\hline \hline
\end{tabular}

\begin{tabular}{|c|c|c|c|}
\hline $\mathrm{Co01}$ & $\begin{array}{l}\text { Internal correspondence from T. L. Clements, } \\
\text { Jr. to distribution. "Content Code } 7 \text { Waste." } \\
\text { TLC-1-83. }\end{array}$ & $\begin{array}{l}\text { Summary of discussion between Tom } \\
\text { Clements and Chuck Wickland about content } \\
\text { code } 7 \text { sludge. }\end{array}$ & $\begin{array}{c}1983 . \\
\text { January } 17 .\end{array}$ \\
\hline $\mathrm{COO2}$ & $\begin{array}{l}\text { Internal correspondence from D. L. Zielger to } \\
\text { C. E. Wickland. "P-Ci Calculations for WG } \\
\text { Pu." }\end{array}$ & $\begin{array}{l}\text { Weight \%, specific activity, alpha activity, and } \\
\text { equivalent plutonium curie activity for typical } \\
\text { RFP transuranic waste. }\end{array}$ & $\begin{array}{c}1983 . \\
\text { November } 30\end{array}$ \\
\hline $\mathrm{C003}$ & $\begin{array}{l}\text { External letter with attachments from W. D. } \\
\text { Reinhart to Albert E. Whiteman, DOE/RFAO. } \\
\text { "Rockwell Discussions with EG\&G Idaho, } \\
\text { Inc." (certification statements and data } \\
\text { package deficiencies). 86-RF-1518. }\end{array}$ & $\begin{array}{l}\text { Actions required by RFP to correct deficiencies } \\
\text { on transuranic waste sent to INEL. }\end{array}$ & $\begin{array}{l}1985 . \\
\text { May } 8 .\end{array}$ \\
\hline $\operatorname{co04}$ & $\begin{array}{l}\text { Memorandum from Joseph M. McGough to J. } \\
\text { R. Nicks, Area Manager, RFAO. } \\
\text { "Rockwell WIPP-WAC Nonconforming } \\
\text { Sludge and Other Waste Management } \\
\text { Concerns." }\end{array}$ & $\begin{array}{l}\text { Letter from WIPP to RF that itemizes the } \\
\text { nonconforming wastes from Rocky Flats. The } \\
\text { letter provides status of treatment operations in } \\
\text { the first quarter of FY85. }\end{array}$ & $\begin{array}{c}1985 . \\
\text { January } 14 .\end{array}$ \\
\hline $\mathrm{C} 005$ & $\begin{array}{l}\text { Internal correspondence from T. L. Clements, } \\
\text { Jr. to L. A. Cook. "Addition of Content Code } \\
303 \text { to the Certifiable Waste Categories." } \\
\text { TLC-11-86. }\end{array}$ & Scarfed graphite chunks information. & $\begin{array}{c}1986 . \\
\text { January } 23 .\end{array}$ \\
\hline $\operatorname{co06}$ & $\begin{array}{l}\text { Internal correspondence from A. C. Ficklin to } \\
\text { Distribution. "Box and Drum Identification to } \\
\text { meeting WIPP Requirements." }\end{array}$ & $\begin{array}{l}\text { Proposed changes for drum and box } \\
\text { identification at RFP to meet WIPP } \\
\text { requirements. }\end{array}$ & $\begin{array}{l}1986 . \\
\text { February } 4 .\end{array}$ \\
\hline $\mathrm{Co07}$ & $\begin{array}{l}\text { External letter from J. D. Wells to Ann } \\
\text { Ficklin, Manager Solid Waste Operations, } \\
\text { Rockwell International. "Item Description } \\
\text { Codes." JDW-08-86. }\end{array}$ & $\begin{array}{l}\text { Letter from INEL to RF accepting IDCs } 368 \text {, } \\
700,701, \text { and } 702 .\end{array}$ & $\begin{array}{c}1986 . \\
\text { March } 27 .\end{array}$ \\
\hline $\operatorname{co08}$ & $\begin{array}{l}\text { Internal correspondence from G. F. Jaskot to } \\
\text { Distribution. "Certification Waste } \\
\text { Documentation." }\end{array}$ & $\begin{array}{l}\text { The letter contains information on IDCs that will } \\
\text { be certified to the WIPP criteria. }\end{array}$ & $\begin{array}{l}1986 . \\
\text { May } 9 .\end{array}$ \\
\hline $\operatorname{co09}$ & $\begin{array}{l}\text { Internal correspondence from T. L. Clements, } \\
\text { Jr. to J. M. Bower. "Addition of Content } \\
\text { Codes } 312 \text { and } 377 \text { to the Certifiable Waste } \\
\text { Category." TLC-40-86. }\end{array}$ & $\begin{array}{l}\text { IDCs } 312 \text { (coarse graphite) and } 377 \text { (coarse } \\
\text { firebrick) are added to the list of certifiable } \\
\text { wastes stored at the RWMC. }\end{array}$ & $\begin{array}{c}1986 . \\
\text { May } 19 .\end{array}$ \\
\hline $\mathrm{Co10}$ & $\begin{array}{l}\text { External letter from J. D. Wells to W. D. } \\
\text { Reinhart, Manager Waste Certification, } \\
\text { Rockwell International. "Nonstandard } \\
\text { Shipment Approval." JDW-14-86. }\end{array}$ & $\begin{array}{l}\text { Listing of approved } 800 \text {-series cemented } \\
\text { wastes approved for shipment to the INEL. }\end{array}$ & $\begin{array}{l}1986 . \\
\text { June } 19 .\end{array}$ \\
\hline Co11 & $\begin{array}{l}\text { Letter from G. F. Jaskot to Distribution. } \\
\text { "TRU Waste Determination." }\end{array}$ & $\begin{array}{l}\text { Information on specific activity associated with } \\
\mathrm{Pu}, \mathrm{Am} \text {, and U-235. }\end{array}$ & $\begin{array}{c}1986 . \\
\text { October } 21 .\end{array}$ \\
\hline $\mathrm{C} 012$ & $\begin{array}{l}\text { Internal Correspondence from D. Vigil and } \\
\text { W. A. Meisner to G. L. Hickle. "Diatomite- } \\
\text { Cement-Sludge Mixture." }\end{array}$ & $\begin{array}{l}\text { Information on the ratio of cement/diatomite to } \\
\text { sludge for Building } 374 \text {. }\end{array}$ & $\begin{array}{l}1986 . \\
\text { December } 15\end{array}$ \\
\hline $\mathrm{CO13}$ & $\begin{array}{l}\text { Letter from William F. Kane to Distribution. } \\
\text { "TRU/LLW Determination for Waste to meet } \\
\text { the WIPP-WAC." }\end{array}$ & $\begin{array}{l}\text { Discussion of sludge picocuries/gram for final } \\
\text { waste form TRU/LLW determination in IDC } \\
007 / 803 \text { sludges. }\end{array}$ & $\begin{array}{l}1987 . \\
\text { February } 18 .\end{array}$ \\
\hline $\mathrm{C} 014$ & $\begin{array}{l}\text { Internal correspondence from G. F. Jaskot to } \\
\text { B. C. Barrett. "IDC and WFN Revision." }\end{array}$ & $\begin{array}{l}\text { Information to correlate IDCs to WIPP waste } \\
\text { form numbers. }\end{array}$ & $\begin{array}{c}1987 . \\
\text { March } 24 .\end{array}$ \\
\hline $\mathrm{C} 015$ & $\begin{array}{l}\text { Internal correspondence from G. F. Jaskot to } \\
\text { B. C. Barrett. "Certified IDC Update." }\end{array}$ & $\begin{array}{l}\text { Information on certification of IDCs } 335 \text { and } \\
490 \text {. Also, data on production of Building } 374 \\
\text { sludge drums. }\end{array}$ & $\begin{array}{c}1987 . \\
\text { April } 15\end{array}$ \\
\hline $\mathrm{C} 016$ & $\begin{array}{l}\text { Internal correspondence from R. P. Brugger } \\
\text { to Waste Review Board. "Waste Container } \\
\text { Tare Weights." }\end{array}$ & Documentation of container tare weights. & $\begin{array}{l}1987 . \\
\text { April } 20 .\end{array}$ \\
\hline
\end{tabular}




\begin{tabular}{|l|l|l|l|l|}
\hline REF \# & TITLE & SUMMARY & & DATE \\
\hline \hline
\end{tabular}

\begin{tabular}{|c|c|c|c|}
\hline $\mathrm{C} 017$ & $\begin{array}{l}\text { Internal letter from C. D. Bretzke to B. A. } \\
\text { Reynolds. "Solid Waste Information } \\
\text { Management System Data Package." }\end{array}$ & $\begin{array}{l}\text { Letter regarding assignment of } 0.2 \mathrm{~g} \mathrm{Pu} \text { to } \\
\text { grams assayed as zero } \mathrm{g} \mathrm{Pu} \text {. }\end{array}$ & $\begin{array}{l}1987 . \\
\text { May } 6 .\end{array}$ \\
\hline $\mathrm{C} 018$ & $\begin{array}{l}\text { Internal letter from L. A. Abila to W. D. } \\
\text { Reinhart. "Guidelines for Repackaging Waste } \\
\text { at Size Reduction." }\end{array}$ & $\begin{array}{l}\text { Guidelines for repackaging Drums of } \\
\text { combustibles and metal into metal boxes at } \\
\text { Size Reduction. }\end{array}$ & $\begin{array}{l}1987 . \\
\text { June } 2 \text {. }\end{array}$ \\
\hline $\mathrm{C} 019$ & $\begin{array}{l}\text { Internal correspondence from L. A. Bearly to } \\
\text { R. P. Brugger. "Drum Paint Requirements." }\end{array}$ & $\begin{array}{l}\text { Response to WIPP request for painting waste } \\
\text { drums the same as waste boxes. }\end{array}$ & $\begin{array}{l}1987 . \\
\text { July } 6 .\end{array}$ \\
\hline $\mathrm{C} 020$ & $\begin{array}{l}\text { Facsimile transmission from Jeff Paynter to } \\
\text { Al Morgan, NMC. "Drums to be shipped as } \\
\text { TRU Mixed Waste to } 664 . "\end{array}$ & List of lead drums for shipment. & $\begin{array}{c}1987 . \\
\text { September } 22 .\end{array}$ \\
\hline $\mathrm{C} 021$ & $\begin{array}{l}\text { Internal correspondence from J. K. Paynter to } \\
\text { R. D. Mullet. "RCRA Mixed Waste IDCs." }\end{array}$ & $\begin{array}{l}\text { Description of new and revised IDCs for mixed } \\
\text { waste. }\end{array}$ & $\begin{array}{c}1987 . \\
\text { October } 5\end{array}$ \\
\hline $\mathrm{C} 022$ & $\begin{array}{l}\text { Internal correspondence from C. D. Bretzke } \\
\text { to All Supervision. "New and Revised Waste } \\
\text { Item Description Codes (IDCs)." }\end{array}$ & $\begin{array}{l}\text { Description of new and revised IDCs for mixed } \\
\text { IDCs and combustibles. }\end{array}$ & $\begin{array}{c}1987 . \\
\text { November } 30\end{array}$ \\
\hline $\mathrm{CO} 23$ & $\begin{array}{l}\text { Internal correspondence from C. D. Bretzke } \\
\text { to W. D. Reinhart. "Funding EG\&G } \\
\text { Evaluation of Sludge Processing } \\
\text { Techniques." }\end{array}$ & $\begin{array}{l}\text { Several memos regarding evaluation of free } \\
\text { liquids in RFP sludge waste. }\end{array}$ & $\begin{array}{l}1988 . \\
\text { February } 11 .\end{array}$ \\
\hline $\mathrm{CO} 24$ & $\begin{array}{l}\text { Internal correspondence from C. D. Bretzke, } \\
\text { et. al. to Distribution. "Waste IDCs for } \\
\text { Combustibles." }\end{array}$ & $\begin{array}{l}\text { Description of IDCs used to segregate } \\
\text { combustibles. IDCs } 322,323 \text {, and } 324 \text { were } \\
\text { deleted. }\end{array}$ & $\begin{array}{l}1988 . \\
\text { February } 19 .\end{array}$ \\
\hline $\mathrm{CO25}$ & $\begin{array}{l}\text { Internal correspondence from C. L. Fox } x \text { to } \\
\text { B. T. Reich. "Air Sparging to Eliminate } \\
\text { Pyrophoric Sodium." }\end{array}$ & $\begin{array}{l}\text { Description of air sparged pyrochemical salts } \\
\text { from LANL. }\end{array}$ & $\begin{array}{c}1988 . \\
\text { February } 25 .\end{array}$ \\
\hline $\mathrm{C} 026$ & $\begin{array}{l}\text { External letter from T. L. Clements, Jr. to Jeff } \\
\text { Paynter, Rocky Flats Plant. "Content Code } \\
\text { Description Data for TRUPACT II Payload } \\
\text { Compliance Plan." TLC-22-88. }\end{array}$ & $\begin{array}{l}\text { Information about INEL's program to verify } \\
\text { content code descriptions. }\end{array}$ & $\begin{array}{l}1988 . \\
\text { April } 4 .\end{array}$ \\
\hline $\mathrm{CO} 27$ & $\begin{array}{l}\text { Internal correspondence to E. A. Dicarlo from } \\
\text { J. A. Hayden. "Disposal of Organic Lab } \\
\text { Waste (DHDECMP in Xylene) from the } \\
\text { Plutonium Lab, Bldg. } 559 . "\end{array}$ & $\begin{array}{l}\text { Information regarding generation and possible } \\
\text { disposal for DHDECMP in xylene lab waste. }\end{array}$ & $\begin{array}{l}1988 . \\
\text { April } 18 .\end{array}$ \\
\hline $\mathrm{C} 028$ & $\begin{array}{l}\text { External letter from Jeff Harrison to Sheila } \\
\text { Hailey, LMITCO. "Comments on EDF } \\
\text { RWMC-942, Rev 0; INELINT-97-00214, Rev } \\
\text { 0." }\end{array}$ & $\begin{array}{l}\text { A review of the assignments of D001 and D002 } \\
\text { to combustible and plastic wastes and D003 to } \\
\text { leaded rubber. }\end{array}$ & $\begin{array}{c}1997 . \\
\text { November } 14 .\end{array}$ \\
\hline $\mathrm{CO} 29$ & $\begin{array}{l}\text { Internal correspondence from H. K. Fry to G. } \\
\text { L. Aguero. "Counting IDCs } 800 \text { through } 823 \\
\text { on Segmented Drum Counters." }\end{array}$ & $\begin{array}{l}\text { Procedural steps for assay of IDCs } 800-823 \\
\text { materials on SGS counters. }\end{array}$ & $\begin{array}{l}1988 . \\
\text { April } 29 .\end{array}$ \\
\hline $\mathrm{CO30}$ & $\begin{array}{l}\text { Internal correspondence from C. D. Bretzke } \\
\text { to Distribution. "Item Description Codes } \\
\text { (IDCs) for Non-PSZ Combustibles and } \\
\text { Depleted Uranium Oxide." }\end{array}$ & $\begin{array}{l}\text { Description of new IDCs for combustibles and } \\
\text { D-38 oxide. }\end{array}$ & $\begin{array}{c}1988 . \\
\text { May } 12 .\end{array}$ \\
\hline $\mathrm{C} 031$ & $\begin{array}{l}\text { Internal correspondence from R. T. Scott to } \\
\text { Distribution. "Line Generated Waste Drum } \\
\text { Inspection." }\end{array}$ & List of IDCs requiring inspection. & $\begin{array}{c}1988 . \\
\text { August } 24 \text {. }\end{array}$ \\
\hline $\mathrm{CO} 32$ & $\begin{array}{l}\text { External letter from J. K. Paynter to J. N. } \\
\text { Davis, Idaho National Engineering } \\
\text { Laboratory. "Data Package Information } \\
\text { Change for Drum D40197-0743-18283." 88- } \\
\text { RF-2813. }\end{array}$ & $\begin{array}{l}\text { Description of one drum (IDC 801) containing } \\
\text { xylene. }\end{array}$ & $\begin{array}{c}1988 . \\
\text { September } 9 .\end{array}$ \\
\hline
\end{tabular}




\begin{tabular}{|l|l|l|l|}
\hline REF \# & TITLE & SUMMARY & DATE \\
\hline
\end{tabular}

\begin{tabular}{|c|c|c|c|}
\hline $\operatorname{co33}$ & $\begin{array}{l}\text { External letter from D. M. Hartley to J. } \\
\text { Paynter, Rockwell International. } \\
\text { "Content Code 700." DMH-1-88. } \\
\end{array}$ & $\begin{array}{l}\text { Letter from INEL requesting certification } \\
\text { information on IDC } 700 \text { drums. }\end{array}$ & $\begin{array}{c}1988 . \\
\text { December } 22 .\end{array}$ \\
\hline $\operatorname{co34}$ & $\begin{array}{l}\text { Memorandum from E. K. Hunter to A. E. } \\
\text { Whiteman, Area Manager, RFAO. } \\
\text { "RFP Certification and QA Plan Formal } \\
\text { Approvals and Reaudit." }\end{array}$ & $\begin{array}{l}\text { Requested topics for WIPP-WACCC audit in } \\
\text { January } 1989 .\end{array}$ & $\begin{array}{c}1988 . \\
\text { December } 20 .\end{array}$ \\
\hline C035 & $\begin{array}{l}\text { External letter from J. K. Paynter to Marilyn } \\
\text { Warrant, Sandia National Laboratories. } \\
\text { "Assay Information for Current Content Code } \\
\text { Assessment." 89-RF-0195. }\end{array}$ & $\begin{array}{l}\text { Responses to questions raised about RFP } \\
\text { assay. }\end{array}$ & $\begin{array}{c}1989 . \\
\text { January } 18 .\end{array}$ \\
\hline $\mathrm{C036}$ & $\begin{array}{l}\text { Internal correspondence from F. G. Trevino } \\
\text { to Distribution. "Random Surveillance } \\
\text { Implementation." }\end{array}$ & $\begin{array}{l}\text { Random surveillance of waste program } \\
\text { implemented on } 2 / 6 / 89 \text {. }\end{array}$ & $\begin{array}{c}1989 . \\
\text { January } 30 .\end{array}$ \\
\hline $\mathrm{co37}$ & $\begin{array}{l}\text { Internal correspondence from C. D. Bretzke, } \\
\text { et al. to Distribution. "New IDCs." WCP7-28. }\end{array}$ & Description of IDCs $809,854,855$, and 856 . & $\begin{array}{c}1989 . \\
\text { February } 8 .\end{array}$ \\
\hline $\mathrm{C038}$ & $\begin{array}{l}\text { Internal correspondence from C. D. Bretzke } \\
\text { to C. E. Trump. "Deviation from WO-4034, } \\
\text { 'Waste Packaging Requirements."' } \\
\text { WCP7-29. }\end{array}$ & $\begin{array}{l}\text { Description of new requirements for IDCs } 338 \\
\text { and } 342 .\end{array}$ & $\begin{array}{l}1989 . \\
\text { February } 8 .\end{array}$ \\
\hline C039 & $\begin{array}{l}\text { Internal correspondence from J. K. Paynter to } \\
\text { B. C. Barrett. "Radionuclide Information } \\
\text { Required for TRUPACT II Shipments." } \\
\text { WCP8-20. }\end{array}$ & $\begin{array}{l}\text { Documentation of RFP isotopic distribution, } \\
\text { decay heat, specific activity, and alpha curies } \\
\text { for WR plutonium. }\end{array}$ & $\begin{array}{l}1989 . \\
\text { March } 23 .\end{array}$ \\
\hline $\mathrm{CO40}$ & $\begin{array}{l}\text { Internal correspondence from F. G. Trevino } \\
\text { to Distribution. "Changes to Random } \\
\text { Surveillance Program." }\end{array}$ & $\begin{array}{l}\text { Change in procedures for issuing waste boxes } \\
\text { to waste generators. }\end{array}$ & $\begin{array}{l}1989 . \\
\text { April } 10 .\end{array}$ \\
\hline C041 & $\begin{array}{l}\text { External letter from T. L. Clements; Jr. to C. } \\
\text { D. Bretzke, Rocky Flats Plant. "Transuranic } \\
\text { Waste Stream Profile Statements." } \\
\text { TLC-65-89. }\end{array}$ & $\begin{array}{l}\text { INEL acceptance of IDCs } 338,342,809,854 \text {, } \\
855 \text {, and } 856 \text {. }\end{array}$ & $\begin{array}{l}1989 . \\
\text { May } 8 .\end{array}$ \\
\hline $\mathrm{CO42}$ & $\begin{array}{l}\text { Internal correspondence from C. D. Bretzke } \\
\text { to R. C. Lerche. "Hazardous Constituent } \\
\text { Information." WCP8-85. }\end{array}$ & Characterization of IDCs 340,333 , and 331 . & $\begin{array}{l}1989 . \\
\text { May } 30 .\end{array}$ \\
\hline $\mathrm{CO43}$ & $\begin{array}{l}\text { Internal correspondence from J. A. } \\
\text { Detamore, et al. to Distribution. "New } \\
\text { IDC/Revised IDCs." }\end{array}$ & $\begin{array}{l}\text { Descriptions for IDCs } 860,443 \text {, and } 444 \text {. IDCs } \\
855 \text { and } 856 \text { were deleted. }\end{array}$ & $\begin{array}{l}1989 . \\
\text { July } 3 .\end{array}$ \\
\hline $\mathrm{CO44}$ & $\begin{array}{l}\text { External letter from C. D. Bretzke to Dale } \\
\text { Wells, EG\&G Idaho, Inc. "Information } \\
\text { Request Concerning New IDCs and Resin in } \\
\text { IDC 806." }\end{array}$ & $\begin{array}{l}\text { WFN assignments for IDCs } 809,854,855, \text { and } \\
856 \text {. Reply to INEL regarding resin in IDC } 806 \\
\text { drums. }\end{array}$ & $\begin{array}{l}1989 . \\
\text { July } 8\end{array}$ \\
\hline $\mathrm{C} 045$ & $\begin{array}{l}\text { Internal correspondence from J. K. Paynter to } \\
\text { J. A. Detamore. "TRUPACT II Waste } \\
\text { Requirements." PT-76. }\end{array}$ & $\begin{array}{l}\text { Requirements to be implemented for TRU } \\
\text { waste to meet TRUPACT II shipping } \\
\text { requirements. }\end{array}$ & $\begin{array}{c}1989 . \\
\text { July } 25 .\end{array}$ \\
\hline $\mathrm{CO46}$ & $\begin{array}{l}\text { Use of the Passive-Active Drum Counter. } \\
\text { Presentation given by Dr. McKamy of the } \\
\text { Safeguards Measurements Group, Rockwell } \\
\text { International, Rocky Flats Plant. }\end{array}$ & Three presentations on various assay topics. & 1988. \\
\hline $\mathrm{C} 047$ & $\begin{array}{l}\text { Interview Record and associated } \\
\text { documentation of William V. Conner by } T \text {. } \\
\text { Widner and J. Lamb. }\end{array}$ & $\begin{array}{l}\text { Interview with good details on historical } \\
\text { information on } \mathrm{Pu} \mathrm{lab} \text { and Am recovery. }\end{array}$ & $\begin{array}{c}1991 . \\
\text { August } 13 .\end{array}$ \\
\hline $\mathrm{CO48}$ & $\begin{array}{l}\text { Interview Record of Mike Simmons by T. } \\
\text { Widner and D. Herrick. }\end{array}$ & Information on Building 444 operations. & $\begin{array}{c}1991 . \\
\text { August } 6 .\end{array}$ \\
\hline
\end{tabular}




\begin{tabular}{|l|l|l|l|}
\hline REF \# & TITLE & SUMMARY & DATE \\
\hline
\end{tabular}

\begin{tabular}{|c|c|c|c|}
\hline $\operatorname{co49}$ & $\begin{array}{l}\text { Interview Record of Ronald P. Teel by T. } \\
\text { Widner and D. Herrick. }\end{array}$ & $\begin{array}{l}\text { Historical information on liquid waste } \\
\text { processing. }\end{array}$ & $\begin{array}{c}1991 . \\
\text { August } 7 .\end{array}$ \\
\hline $\mathrm{C050}$ & $\begin{array}{l}\text { Informal memorandum from J. K. Paynter to } \\
\text { Al Morgan, EG\&G Rocky Flats, Inc. } \\
\text { "Creation and deletion dates of IDCs." }\end{array}$ & $\begin{array}{l}\text { Creation and deletion dates from the } \\
\text { Safeguards Accountability Network (SAN). }\end{array}$ & $\begin{array}{l}1994 . \\
\text { June } 16 .\end{array}$ \\
\hline C051 & $\begin{array}{l}\text { Telecon between Jeff Paynter and Dick Saiki, } \\
\text { EG\&G RFP. "Composition of Rocky Flats } \\
\text { Leaded Gloves." }\end{array}$ & $\begin{array}{l}\text { Construction and usage information for RFP } \\
\text { leaded gloves. }\end{array}$ & $\begin{array}{c}1994 . \\
\text { July } 19 .\end{array}$ \\
\hline $\mathrm{C} 052$ & $\begin{array}{l}\text { Telecon between Jeff Paynter and Gary } \\
\text { Dinghman, EG\&G RFP. "RTR Acceptance of } \\
\text { Mixed IDCs." }\end{array}$ & $\begin{array}{l}\text { Information on acceptance of mixed IDCs by } \\
\text { RTR inspection in the } 1980 \mathrm{~s} \text {. }\end{array}$ & $\begin{array}{l}1994 . \\
\text { July } 27 .\end{array}$ \\
\hline C053 & $\begin{array}{l}\text { Telecon between Jeff Paynter and AI Morgan, } \\
\text { EG\&G RFP. "Usage of IDC 481." }\end{array}$ & $\begin{array}{l}\text { Information on usage of IDCs } 480 \text { and } 481 \\
\text { relative to metal washing. }\end{array}$ & $\begin{array}{c}1995 . \\
\text { January } 23 .\end{array}$ \\
\hline $\cos 4$ & $\begin{array}{l}\text { Internal correspondence from Sheila M. } \\
\text { Hailey to Distribution. "Oakridge pH } \\
\text { analysis." }\end{array}$ & pH data for inorganic sludges. & $\begin{array}{c}1996 . \\
\text { February } 1 .\end{array}$ \\
\hline C055 & $\begin{array}{l}\text { Internal correspondence from Mary L. } \\
\text { Adamic to John Krsul. "pH Determination of } \\
\text { Drum Free Liquids." ED-AL-(MLA)-96-005. }\end{array}$ & pH data for inorganic sludges. & $\begin{array}{l}1996 . \\
\text { February } 16 .\end{array}$ \\
\hline $\mathrm{C} 056$ & $\begin{array}{l}\text { Telecon between Jeff Paynter and Jim } \\
\text { Docktor, SafeSites. "Resolution of Solvent } \\
\text { Usage with Graphite." }\end{array}$ & $\begin{array}{l}\text { Solvent usage questions and answers for } \\
\text { graphite waste generated by the Building } 707 \\
\text { Foundry. }\end{array}$ & $\begin{array}{c}1996 . \\
\text { March } 25 .\end{array}$ \\
\hline $\operatorname{co57}$ & $\begin{array}{l}\text { Drum, gasket, liner usage at RFP compiled } \\
\text { by Larry Bearly. }\end{array}$ & $\begin{array}{l}\text { Usage dates for drums, gaskets, and liners. } \\
\text { Compiled for WIPP information request. }\end{array}$ & 1989. \\
\hline C058 & $\begin{array}{l}\text { Informal notes from Jeff Paynter regarding } \\
\text { HEPA and Drum Repackaging at the Size } \\
\text { Reduction Facility. }\end{array}$ & $\begin{array}{l}\text { Notes on HEPA filters and drum repackaging at } \\
\text { Size Reduction. }\end{array}$ & Undated. \\
\hline $\operatorname{co59}$ & $\begin{array}{l}\text { Excerpt from Rocky Flats Plant Quality } \\
\text { Report August 1986. "Transuranic and Low } \\
\text { Level Waste 1985-1986." }\end{array}$ & $\begin{array}{l}\text { Information on rejected low-level and } \\
\text { transuranic wastes. }\end{array}$ & 1986. \\
\hline $\mathrm{Co60}$ & $\begin{array}{l}\text { Memorandum to File from L. S. Hendrickson. } \\
\text { "Discrepancy Report on Graphite Waste } \\
\text { Group." }\end{array}$ & $\begin{array}{l}\text { resolution of metal-contaminated graphite } \\
\text { information. Results from nonline-generated } \\
\text { graphite electrodes in Building } 774 \text {. }\end{array}$ & $\begin{array}{l}1996 . \\
\text { April } 2 .\end{array}$ \\
\hline C061 & $\begin{array}{l}\text { Memorandum to File from Jeff Paynter. } \\
\text { "Graphite Process Procedure from Building } \\
\text { 707." }\end{array}$ & $\begin{array}{l}\text { Justification for usage of procedure FO-0015 as } \\
\text { a reference for historical graphite process } \\
\text { operations. }\end{array}$ & $\begin{array}{l}1996 . \\
\text { April } 1 .\end{array}$ \\
\hline $\mathrm{C} 062$ & $\begin{array}{l}\text { External letter from Jacqueline W. Sales to } \\
\text { Frank Czigler, S\&W Waste Inc. }\end{array}$ & Application of F001 - F005 solvent codes. & $\begin{array}{c}1987 . \\
\text { May } 20 .\end{array}$ \\
\hline $\mathrm{C} 063$ & $\begin{array}{l}\text { External letter from J. D. Wells to Ann } \\
\text { Ficklin, Rockwell International Corporation. } \\
\text { "Content Code Reconciliation." }\end{array}$ & $\begin{array}{l}\text { Letter from INEL to RFP to reconcile changes } \\
\text { and deletions of IDCs. }\end{array}$ & $\begin{array}{l}1985 . \\
\text { November } 8\end{array}$ \\
\hline C064 & $\begin{array}{l}\text { Internal correspondence from D. E. Kudera to } \\
\text { T. L. Clements, Jr. "Combustibility of } \\
\text { Graphite." DEK-10-86. }\end{array}$ & $\begin{array}{l}\text { An assessment of the combustibility of graphite } \\
\text { per WIPP criteria. }\end{array}$ & $\begin{array}{c}1986 . \\
\text { December } 2\end{array}$ \\
\hline $\mathrm{C} 065$ & $\begin{array}{l}\text { Telecon between Jeff Paynter and Mike } \\
\text { Simmons, SMC. "Plating Wastes." }\end{array}$ & $\begin{array}{l}\text { Information about cyanide plating waste } \\
\text { transferred to Building } 774 \text {. }\end{array}$ & $\begin{array}{l}1996 . \\
\text { April } 8 .\end{array}$ \\
\hline C066 & $\begin{array}{l}\text { Telecon between Jeff Paynter and Steve } \\
\text { Cunningham, WorldWide Security. } \\
\text { "Declassification of Graphite Molds." }\end{array}$ & $\begin{array}{l}\text { History of graphite declassification and } \\
\text { declassification criteria. }\end{array}$ & $\begin{array}{c}1996 . \\
\text { April } 23 .\end{array}$ \\
\hline $\mathrm{C} 067$ & $\begin{array}{l}\text { Telecon between Jeff Paynter and John } \\
\text { Collins, RMRS. "IDC } 301 \text { Drums from } \\
\text { Buildings } 371 \text { and } 559 . "\end{array}$ & $\begin{array}{l}\text { Possible graphite waste generation points for } \\
\text { Buildings } 371 \text { and } 559 \text {. }\end{array}$ & $\begin{array}{c}1996 . \\
\text { April } 24 .\end{array}$ \\
\hline
\end{tabular}




\begin{tabular}{|l|l|l|l|}
\hline REF \# & TITLE & SUMMARY & DATE \\
\hline
\end{tabular}

\begin{tabular}{|c|c|c|c|}
\hline C068 & $\begin{array}{l}\text { Memorandum from Jeff Paynter and Linda } \\
\text { Hendrickson. "WSRIC Processes that Began } \\
\text { after 1989." }\end{array}$ & $\begin{array}{l}\text { Documentation that supercompaction and duct } \\
\text { remediation began after } 1989 \text {. }\end{array}$ & $\begin{array}{c}1996 . \\
\text { April } 25 .\end{array}$ \\
\hline $\mathrm{C} 069$ & This is a duplicate of $\mathrm{C} 043$. & & \\
\hline $\mathrm{co70}$ & $\begin{array}{l}\text { Internal correspondence from R. D. Thiel to } \\
\text { A. M. Faucette. "TCLP Analysis of Raschig } \\
\text { Rings." }\end{array}$ & TCLP metals analysis of Raschig rings. & $\begin{array}{l}1994 . \\
\text { February } 24 .\end{array}$ \\
\hline $\mathrm{C} 071$ & $\begin{array}{l}\text { Rocky Flats Personnel Interview of John } \\
\text { Morrison by Flack and Herrick. }\end{array}$ & Information on Pu and Am recovery. & $\begin{array}{c}1991 . \\
\text { August } 14 .\end{array}$ \\
\hline $\mathrm{C} 072$ & $\begin{array}{l}\text { Record of Conversation of Rod Hoffman, } \\
\text { recorded by Doug Herrick and Jennifer Lamb. }\end{array}$ & Special isotope information. & $\begin{array}{c}1991 . \\
\text { September } 4 .\end{array}$ \\
\hline $\mathrm{Co73}$ & $\begin{array}{l}\text { Record of Conversation of Maurie Maas, } \\
\text { recorded by Doug Herrick and Jennifer Lamb. }\end{array}$ & Liquid waste treatment information. & $\begin{array}{l}1991 . \\
\text { September } 4 .\end{array}$ \\
\hline $\mathrm{CO74}$ & $\begin{array}{l}\text { External correspondence from Jeff Paynter to } \\
\text { Don Kudera, Lockheed Idaho Technologies } \\
\text { Company. "Information regarding Three IDC } \\
\text { 301 Drums." }\end{array}$ & $\begin{array}{l}\text { Process knowledge for three specific drums of } \\
\text { IDC } 301 \text {. In addition, characterization guidance } \\
\text { for broken molds is included. }\end{array}$ & $\begin{array}{c}1996 . \\
\text { April } 24 .\end{array}$ \\
\hline C075 & $\begin{array}{l}\text { Telecon between Jeff Paynter and Don } \\
\text { Kudera, Lockheed Idaho Technologies } \\
\text { Company. "Prefixes for Organic Sludges." }\end{array}$ & Verification of organic sludge prefixes at INEL. & $\begin{array}{l}1996 . \\
\text { May } 1\end{array}$ \\
\hline $\mathrm{co76}$ & $\begin{array}{l}\text { Internal Memorandum to File from Jeff } \\
\text { Harrison. "Combustibles and Plastic } \\
\text { Characterization." }\end{array}$ & $\begin{array}{l}\text { Resolution of EPA Code discrepancies from } \\
\text { references used for the Acceptance Knowledge } \\
\text { document. }\end{array}$ & $\begin{array}{c}1996 . \\
\text { May } 23 .\end{array}$ \\
\hline $\operatorname{co77}$ & $\begin{array}{l}\text { External Memorandum from R. B. Hoffman to } \\
\text { K. C. Gerard, Lockheed Idaho Technology } \\
\text { Company. "Classification Waste." }\end{array}$ & $\begin{array}{l}\text { Classified waste input from the DOE-RFFO } \\
\text { Classification Officer. }\end{array}$ & $\begin{array}{c}1996 . \\
\text { April } 24 .\end{array}$ \\
\hline $\operatorname{co78}$ & $\begin{array}{l}\text { Internal Memorandum to File from Jeff } \\
\text { Harrison. "Combustibles and Plastic } \\
\text { Characterization." }\end{array}$ & $\begin{array}{l}\text { Resolution of discrepancies between two } \\
\text { characterization references. }\end{array}$ & $\begin{array}{c}1996 . \\
\text { May } 30 .\end{array}$ \\
\hline $\operatorname{co79}$ & $\begin{array}{l}\text { Telecon between Wynn Eakins and Karlan } \\
\text { Richards, EG\&G Rocky Flats, Inc. } \\
\text { "Characteristic Codes for B774 Wastes." }\end{array}$ & $\begin{array}{l}\text { Use of characteristic EPA codes on Building } \\
774 \text { combustibles. }\end{array}$ & $\begin{array}{c}1994 . \\
\text { September } 8 .\end{array}$ \\
\hline $\mathrm{C} 080$ & $\begin{array}{l}\text { Telecon between Wynn Eakins and Pam } \\
\text { Edrich, EG\&G Rocky Flats, Inc. } \\
\text { "Characterization of Combustible Laboratory } \\
\text { Waste.". }\end{array}$ & $\begin{array}{l}\text { Characterization guidance used during the } \\
1994 \text { BWR for laboratory-generated } \\
\text { combustibles. }\end{array}$ & $\begin{array}{c}1994 . \\
\text { September } 9 .\end{array}$ \\
\hline $\mathrm{C} 081$ & $\begin{array}{l}\text { Memorandum to File from Jeff Harrison. } \\
\text { "Light Metal Characterization." }\end{array}$ & $\begin{array}{l}\text { Resolution of characterization reference } \\
\text { discrepancies for IDCs } 480 \text { and } 481 .\end{array}$ & $\begin{array}{c}1996 . \\
\text { May } 29 .\end{array}$ \\
\hline $\mathrm{Co82}$ & $\begin{array}{l}\text { Telecon between Jeff Harrison and Al } \\
\text { Morgan of SafeSites of Colorado. } \\
\text { "Generation of Leached Light Metal (IDC } \\
\text { 481)." }\end{array}$ & Resolution of IDC 481 description discrepancy. & $\begin{array}{c}1996 . \\
\text { May } 28 .\end{array}$ \\
\hline $\mathrm{C} 083$ & $\begin{array}{l}\text { Memorandum to File from Jeff Harrison. } \\
\text { "Light Metal Characterization." }\end{array}$ & $\begin{array}{l}\text { Logic for assigning IDCs } 480 \text { and } 481 \text { with the } \\
\text { same EPA codes. }\end{array}$ & $\begin{array}{c}1996 . \\
\text { May } 29 .\end{array}$ \\
\hline $\cos 4$ & $\begin{array}{l}\text { Memorandum to File from Jeff Harrison. } \\
\text { "Light Metal (IDC } 480 \text { ) Generated in Building } \\
371 \text { Analytical Laboratory." }\end{array}$ & $\begin{array}{l}\text { Disposition of EPA codes assigned to IDC } 480 \\
\text { wastes from the Building } 371 \text { analytical } \\
\text { laboratory. }\end{array}$ & $\begin{array}{l}1996 . \\
\text { May } 29 .\end{array}$ \\
\hline $\operatorname{cos5}$ & $\begin{array}{l}\text { Memorandum from Thom Putney. } \\
\text { "Historical Constituents of IDC } 800 / 801 . "\end{array}$ & $\begin{array}{l}\text { Documentation of interviews concerning listed } \\
\text { solvents in aqueous laboratory wastes from } \\
\text { Buildings } 559 \text { and } 779 \text {. }\end{array}$ & $\begin{array}{l}1993 . \\
\text { November } 8 .\end{array}$ \\
\hline $\mathrm{C} 086$ & $\begin{array}{l}\text { Memorandum from Jeff Paynter to Pamela of } \\
\text { IT Corporation. "Use of the Complexing } \\
\text { Agent DHDECMP." }\end{array}$ & $\begin{array}{l}\text { Information on the use of DHDECMP and mass } \\
\text { of crates loaded with combustible waste. }\end{array}$ & $\begin{array}{c}1989 . \\
\text { February } 7 .\end{array}$ \\
\hline
\end{tabular}




\begin{tabular}{|l|l|l|l|l|}
\hline REF \# & TITLE & SUMMARY & DATE \\
\hline
\end{tabular}

\begin{tabular}{|c|c|c|c|}
\hline $\mathrm{C} 087$ & $\begin{array}{l}\text { Telecon between Jeff Paynter and Carrie } \\
\text { Wesley of RMRS. "Process Wastes Treated } \\
\text { in Building } 374 . "\end{array}$ & $\begin{array}{l}\text { Supplementary information on wastes treated } \\
\text { in the Building } 374 \text { precipitation process. }\end{array}$ & $\begin{array}{l}1996 . \\
\text { May } 29 .\end{array}$ \\
\hline C088 & $\begin{array}{l}\text { Telecon between Jeff Paynter and Rod } \\
\text { Hoffman/Bob Riddle of DOE RFFO } \\
\text { Classification/SAIC. "Composition of "Grip" } \\
\text { and ZPPR Fuel Elements." }\end{array}$ & $\begin{array}{l}\text { Unclassified description of "Grip" and } \\
\text { classification guidance for ZPPR fuel elements. }\end{array}$ & $\begin{array}{l}1996 . \\
\text { May } 29 .\end{array}$ \\
\hline C089 & $\begin{array}{l}\text { Telecon between Jeff Harrison and Al } \\
\text { Morgan of SafeSites of Colorado. "Creation } \\
\text { of IDCs } 440,441,442,444 \text {, and } 855 . "\end{array}$ & $\begin{array}{l}\text { Summary of discussion with Al Morgan about } \\
\text { the creation of glass IDCs. }\end{array}$ & $\begin{array}{l}1996 . \\
\text { June } 3 .\end{array}$ \\
\hline $\mathrm{C} 090$ & $\begin{array}{l}\text { Telecon between Jeff Harrison and Ron } \\
\text { Bowen of SafeSites of Colorado. } \\
\text { "Raschig Ring Tanks in Building 371." }\end{array}$ & $\begin{array}{l}\text { Summary of discussion with Ron Bowen about } \\
\text { solvents in Raschig ring tank in B371. }\end{array}$ & $\begin{array}{l}1996 . \\
\text { June } 3 .\end{array}$ \\
\hline Co91 & $\begin{array}{l}\text { Memorandum to File from Jeff Harrison. } \\
\text { "Glass Characterization." }\end{array}$ & $\begin{array}{l}\text { Memo summarizing the characterization of } \mathrm{LL} \\
\text { glass that would not have been sent to INEL. }\end{array}$ & $\begin{array}{l}1996 . \\
\text { June } 3 .\end{array}$ \\
\hline $\mathrm{Cog} 2$ & $\begin{array}{l}\text { Memorandum to File from Jeff Paynter. } \\
\text { "Resolution of Conflicting Characterization } \\
\text { Information for Waste Group \#4." }\end{array}$ & $\begin{array}{l}\text { Resolution to conflicting characterization of IDC } \\
802 \text {. }\end{array}$ & $\begin{array}{l}1996 . \\
\text { June } 4 .\end{array}$ \\
\hline Co93 & $\begin{array}{l}\text { Letter assumed to have been written by } \\
\text { David P. Simonson to Fred Dowsett of the } \\
\text { Colorado Department of Health, and } \\
\text { corresponding response letter. Discussion re. } \\
\text { Definition of Hazardous Waste as defined by } \\
\text { Colorado Hazardous Waste Regulations. }\end{array}$ & $\begin{array}{l}\text { Characterization of wipes (corrosivity and U- } \\
\text { listed), solvent carryover on metals, and } \\
\text { glovebox (decommissioned) material } \\
\text { characterization. }\end{array}$ & $\begin{array}{c}1989 . \\
\text { November } 9 \text {. }\end{array}$ \\
\hline $\mathrm{Cog4}$ & $\begin{array}{l}\text { DOE RFO Contact Record from David } \\
\text { Maxwell to Ken Niswonger of Colorado } \\
\text { Department of Health. "Confirm regulatory } \\
\text { interpretation that listed waste codes on lab } \\
\text { samples do not carry over to the waste } \\
\text { generated from the analysis of the sample." }\end{array}$ & $\begin{array}{l}\text { Lab waste characterization. Not listed if } \\
\text { analyzing listed samples. }\end{array}$ & $\begin{array}{c}1994 . \\
\text { September } 9 .\end{array}$ \\
\hline $\operatorname{cog} 5$ & $\begin{array}{l}\text { Internal memorandum from E. E. Ericson to } \\
\text { L. C. Baaso. "Leaded Glovebox Gloves." }\end{array}$ & $\begin{array}{l}\text { TCLP results and conclusions for lead in leaded } \\
\text { gloves. }\end{array}$ & $\begin{array}{l}1993 . \\
\text { June } 9 .\end{array}$ \\
\hline C096 & $\begin{array}{l}\text { External Letter from K. J. Grossaint to J. L. } \\
\text { Long. "Identification and Thermal Studies of } \\
\text { the Residue from Nitric Acid Reaction with } \\
\text { Leaded Neoprene Gloves." }\end{array}$ & $\begin{array}{l}\text { Results of a study of the reaction of nitric acid } \\
\text { with Neoprene leaded gloves. }\end{array}$ & $\begin{array}{l}1973 . \\
\text { March } 30 .\end{array}$ \\
\hline$C 097$ & $\begin{array}{l}\text { External Letter from Frederick R. Dowsett to } \\
\text { Michael S. Karol of DOE Rocky Flats Office. } \\
\text { Discussion re. reclassification of certain } \\
\text { waste streams formerly classified as subject } \\
\text { to Land Disposal Restrictions." }\end{array}$ & $\begin{array}{l}\text { Reassessment of Rocky Flats "carryover" } \\
\text { characterization policy for insulation, metal, } \\
\text { and filter waste. }\end{array}$ & $\begin{array}{c}1993 . \\
\text { August } 11 \text {. }\end{array}$ \\
\hline $\mathrm{Cog8}$ & $\begin{array}{l}\text { Memorandum to File from Jeff Paynter. } \\
\text { "Justification for not including DCHP in } \\
\text { Building } 371 \text {." }\end{array}$ & $\begin{array}{l}\text { Justification for not including DCHP in Building } \\
371 \text {. }\end{array}$ & $\begin{array}{l}1996 . \\
\text { June } 7 .\end{array}$ \\
\hline $\operatorname{Cog9}$ & $\begin{array}{l}\text { Memorandum to File from Jeff Harrison. } \\
\text { "Discrepancy with Washing of Leaded Gloves } \\
\text { and Aprons." }\end{array}$ & $\begin{array}{l}\text { Washing of acid-contaminated leaded gloves } \\
\text { prior to } 1974 \text {. }\end{array}$ & $\begin{array}{l}1996 . \\
\text { June } 13 .\end{array}$ \\
\hline $\mathrm{C} 100$ & $\begin{array}{l}\text { Telecon between Jeff Harrison and Al } \\
\text { Morgan of SafeSites of Colorado. } \\
\text { "Washing of Leaded Gloves." }\end{array}$ & $\begin{array}{l}\text { Washing of acid-contaminated leaded gloves } \\
\text { prior to } 1974 \text {. }\end{array}$ & $\begin{array}{l}1996 . \\
\text { June } 13 .\end{array}$ \\
\hline C101 & $\begin{array}{l}\text { Memorandum to File from Jeff Harrison. } \\
\text { "Characterization of Lead Containing Waste } \\
\text { (IDCs } 320 \text { and } 339 \text { )." }\end{array}$ & $\begin{array}{l}\text { Resolution of characterization discrepancies } \\
\text { with IDCs } 320 \text { and } 339 \text {. }\end{array}$ & $\begin{array}{l}1996 . \\
\text { June } 17 .\end{array}$ \\
\hline
\end{tabular}




\begin{tabular}{|l|l|l|l|l|}
\hline REF \# & TITLE & SUMMARY & DATE \\
\hline
\end{tabular}

\begin{tabular}{|c|c|c|c|}
\hline C102 & $\begin{array}{l}\text { Letter from Frederick R. Dowset (Colorado } \\
\text { Department of Health) to Michael S. Karol } \\
\text { (DOE/Rocky Flats) }\end{array}$ & $\begin{array}{l}\text { Characterization of Insulation, filter, and metal } \\
\text { waste relating to solvent carry-over }\end{array}$ & $\begin{array}{c}1993 . \\
\text { August } 11 .\end{array}$ \\
\hline C103 & $\begin{array}{l}\text { Telecon between Jeff Harrison and Al } \\
\text { Morgan of SafeSites of Colorado. } \\
\text { "Creation of Filter IDCs." }\end{array}$ & $\begin{array}{l}\text { Creation dates for IDCs } 328,331,335,342, \\
490,492,491,338, \text { and } 376 .\end{array}$ & $\begin{array}{l}1996 . \\
\text { June } 6 .\end{array}$ \\
\hline C104 & $\begin{array}{l}\text { Telecon between Jeff Harrison and Jack } \\
\text { Weaver of SafeSites of Colorado. } \\
\text { "CWS Filters." }\end{array}$ & CWS Filters. & $\begin{array}{l}1996 . \\
\text { June } 18 .\end{array}$ \\
\hline C105 & $\begin{array}{l}\text { Interview Record of John Milner, Jr. by T. } \\
\text { Widner and S. Flack. }\end{array}$ & $\begin{array}{l}\text { Historical information on filter testing and } \\
\text { contamination. }\end{array}$ & $\begin{array}{c}1991 \\
\text { August } 20\end{array}$ \\
\hline C106 & $\begin{array}{l}\text { Telecon between Jeff Harrison and Al } \\
\text { Morgan of SafeSites of Colorado. } \\
\text { "CWS Filters." }\end{array}$ & $\begin{array}{l}\text { Creation dates for IDCs } 328,331,335,342 \\
490,492,491,338, \text { and } 376 .\end{array}$ & $\begin{array}{l}1996 . \\
\text { June } 18 .\end{array}$ \\
\hline C107 & $\begin{array}{l}\text { Memorandum to file from Jeff Harrison and } \\
\text { Al Morgan of SafeSites of Colorado. } \\
\text { "CWS Filters." }\end{array}$ & Resolution of characterization discrepancies. & $\begin{array}{l}1996 . \\
\text { June } 21 .\end{array}$ \\
\hline C108 & $\begin{array}{l}\text { Letter to R. E. Yoder from E. Vejvoda. } \\
\text { "Tritium Balance for Buildings } 771 \text { and } 774 \\
\text { Processing." }\end{array}$ & $\begin{array}{l}\text { Description of tritium disposition at Rocky } \\
\text { Flats. }\end{array}$ & $\begin{array}{c}1976 . \\
\text { August } 6 .\end{array}$ \\
\hline C109 & $\begin{array}{l}\text { Letter to W. C. Bright, Rocky Flats, from B. } \\
\text { L. Kelchner, DOW. "Emission of Carbon } \\
\text { Tetrachloride Vapor from Building } 774 \text {. }\end{array}$ & $\begin{array}{l}\text { Questions the hazardous characteristic of } \\
\text { discharged carbon tetrachloride vapor. }\end{array}$ & $\begin{array}{l}1971 . \\
\text { February } 5 .\end{array}$ \\
\hline C110 & $\begin{array}{l}\text { Personnel interview of Dick Del Pizzo by } \\
\text { Herrick \& Flack. }\end{array}$ & & $\begin{array}{c}1992 . \\
\text { January } 21 .\end{array}$ \\
\hline C111 & $\begin{array}{l}\text { Letter from Lisa A Leehy, Envirodyne, to Peg } \\
\text { Beatty, Weston. }\end{array}$ & Soil samples. & $\begin{array}{c}1990 . \\
\text { January } 3 .\end{array}$ \\
\hline C112 & $\begin{array}{l}\text { Letter from E. L. D'Amico, Rocky Flats, to } \\
\text { Cal Ozaki. }\end{array}$ & Analytical data. & $\begin{array}{l}1988 . \\
\text { May } 6 .\end{array}$ \\
\hline C113 & $\begin{array}{l}\text { Interoffice Correspondence from M.T. Saba } \\
\text { to S.A. Anderson. }\end{array}$ & $\begin{array}{l}\text { Evaluation of analytical data for by-pass sludge } \\
\text { sampled May, } 1990 \text {. }\end{array}$ & $\begin{array}{c}1990 . \\
\text { October } 3 .\end{array}$ \\
\hline C114 & $\begin{array}{l}\text { Memorandum to File from Jeff Harrison. } \\
\text { Historical Use of IDC } 807 .\end{array}$ & $\begin{array}{l}\text { Discussion of IDC } 807 \text { that was used for } \\
\text { cemented incinerator sludge and for solidified } \\
\text { bypass sludge. }\end{array}$ & $\begin{array}{l}1996 . \\
\text { July } 18\end{array}$ \\
\hline C115 & $\begin{array}{l}\text { Telecon between Jeff Harrison and Bill } \\
\text { Connor of Kaiser-Hill LATO. "Generation of } \\
\text { Americium Process Residue (IDC 241)." }\end{array}$ & Creation and processing of IDC 241 . & $\begin{array}{l}1996 \\
\text { July } 29\end{array}$ \\
\hline C116 & $\begin{array}{l}\text { Memorandum to file from Jeff Harrison. } \\
\text { "Resolution of Incinerator Waste } \\
\text { Characterization Discrepancy." }\end{array}$ & Clarification of EPA codes for incinerator waste. & $\begin{array}{c}1996 . \\
\text { August } 2 .\end{array}$ \\
\hline C117 & $\begin{array}{l}\text { Miscellaneous Correspondence and Draft } \\
\text { Correspondence about Pyrochemical Salts. }\end{array}$ & $\begin{array}{l}\text { Correspondence relating to the } \mathrm{D} 003 \text { and } \mathrm{D} 007 \\
\text { characterization of pyrochemical salts. }\end{array}$ & $1993-1995$ \\
\hline C118 & $\begin{array}{l}\text { Telecon between Jeff Harrison and Bill } \\
\text { Connor of Kaiser-Hill LATO. "R\&D Activities } \\
\text { Generating Sand, Slag, and Crucible (SS\&C) } \\
\text { Wastes (IDCs } 391 \text { and 393)." }\end{array}$ & Creation and processing of IDCs 391 and 393. & $\begin{array}{c}1996 . \\
\text { August } 13 .\end{array}$ \\
\hline C119 & $\begin{array}{l}\text { Discrepancy Report. "Evolution of the } \\
\text { Characterization of Pyrochemical Salts and } \\
\text { SS\&C." }\end{array}$ & $\begin{array}{l}\text { Discussion of the evolution of the pyrochemical } \\
\text { salt and SS\&C waste characterization, } \\
\text { including D002, D003, and D007 } \\
\text { determinations.. }\end{array}$ & $\begin{array}{c}1996 . \\
\text { August } 14 .\end{array}$ \\
\hline C120 & $\begin{array}{l}\text { Telecon between Jeff Harrison and Bill } \\
\text { Connor of Kaiser-Hill LATO. "Grit Blasting in } \\
\text { Building } 771 . "\end{array}$ & $\begin{array}{l}\text { Information about grit blasting process in } \\
\text { Building } 771 \text {. }\end{array}$ & $\begin{array}{c}1996 . \\
\text { August } 15 .\end{array}$ \\
\hline
\end{tabular}




\begin{tabular}{|l|l|l|l|}
\hline REF \# & TITLE & SUMMARY & DATE \\
\hline
\end{tabular}

\begin{tabular}{|c|c|c|c|}
\hline C121 & $\begin{array}{l}\text { Telecon between Jeff Harrison and Carrie } \\
\text { Wesley, RMRS. "Information on Building } 374 \\
\text { Aqueous Waste Treatment." }\end{array}$ & $\begin{array}{l}\text { Information about liquid waste treatment } \\
\text { operations. }\end{array}$ & $\begin{array}{c}1996 . \\
\text { September } 12 .\end{array}$ \\
\hline $\mathrm{C} 122$ & $\begin{array}{l}\text { Memorandum to A.M. Faucette, Safe Sites, } \\
\text { from Y.B. Mazza and D.L. Remmington, Safe } \\
\text { Sites. "Analysis of Cemented Bypass Sludge } \\
\text { Samples for TCLP Extract Elements by ICP } \\
\text { AES and GC/MS." }\end{array}$ & Building 374 Bypass Sludge analytical data. & $\begin{array}{c}1995 . \\
\text { September } 12 .\end{array}$ \\
\hline C123 & $\begin{array}{l}\text { Telecon between Jeff Harrison and Bud } \\
\text { Nannie, Rocky Flats Plant-retired. } \\
\text { "Use of Carbon Tetrachloride and 1,1,1- } \\
\text { Trichloroethane in Pyrochemical Operations." }\end{array}$ & $\begin{array}{l}\text { Information about pyrochemical processing and } \\
\text { solvents. }\end{array}$ & $\begin{array}{c}1996 . \\
\text { September } 19 .\end{array}$ \\
\hline $\mathrm{C} 124$ & $\begin{array}{l}\text { Interoffice Correspondence from A.L. } \\
\text { Schubert to Distribution. "Management of } \\
\text { Spent Fluorescent Light Tubes." } \\
\text { ALS-328-91. }\end{array}$ & $\begin{array}{l}\text { Guidance for the hazardous waste } \\
\text { management of fluorescent light bulbs. }\end{array}$ & $\begin{array}{c}1994 . \\
\text { October } 8 .\end{array}$ \\
\hline C125 & $\begin{array}{l}\text { Interoffice Correspondence from John Hill of } \\
\text { Kaiser Hill, LLC Rocky Flats to Distribution. } \\
\text { "Environmental Compliance Directive No. 1: } \\
\text { Spent Incandescent Bulbs to be Collected for } \\
\text { Recycling." JAH-009-95. }\end{array}$ & Management of incandescent light bulbs. & $\begin{array}{c}1995 . \\
\text { August } 4 .\end{array}$ \\
\hline C126 & $\begin{array}{l}\text { Battery Characterization. Attachment } 8 \text { - } \\
\text { Mercury Batteries. }\end{array}$ & $\begin{array}{l}\text { RCRA characterization and constituent } \\
\text { information for mercury batteries. }\end{array}$ & $\begin{array}{c}1996 . \\
\text { November } 12 .\end{array}$ \\
\hline C127 & $\begin{array}{l}\text { Telecon between Norm Cypher of RMRS- } \\
\text { Rocky Flats and Ann Quinn. }\end{array}$ & $\begin{array}{l}\text { Corrosivity of Aggregate Feed Streams to } \\
\text { Building } 374 \text { Treatment Process. }\end{array}$ & $\begin{array}{c}1996 . \\
\text { November } 13 .\end{array}$ \\
\hline C128 & $\begin{array}{l}\text { Telecon between Paul Pigion of RTG and } \\
\text { Ann Quinn. }\end{array}$ & Permit status for Building 374 . & $\begin{array}{c}1996 . \\
\text { November } 13 .\end{array}$ \\
\hline C129 & $\begin{array}{l}\text { Informal memorandum from Jack Templeton } \\
\text { of SAIC to Briand Wu and others. } \\
\text { Evaluation of ITS Water and Recommended } \\
\text { Discharge Options. ER-95-195. } \\
\end{array}$ & Summary of ITS water data from 1989 to 1995 . & $\begin{array}{c}1996 . \\
\text { October } 6 \text {. }\end{array}$ \\
\hline C130 & $\begin{array}{l}\text { Fax from Steve Cunningham, Rocky Flats, to } \\
\text { Jeff Paynter. Rocky Flats Plutonium Isotopic } \\
\text { Levels. }\end{array}$ & $\begin{array}{l}\text { Plutonium isotopic levels at Rocky Flats for } \\
1959 \text { through } 1974 .\end{array}$ & $\begin{array}{c}1992 . \\
\text { February } 18 .\end{array}$ \\
\hline C131 & $\begin{array}{l}\text { Telecon between Andy Leford of RMRS- } \\
\text { Rocky Flats and Ann Quinn. }\end{array}$ & $\begin{array}{l}\text { WSRIC Building Book } 774 \text {-upcoming changes } \\
\text { to process } 10 \text {. }\end{array}$ & $\begin{array}{c}1997 . \\
\text { January } 15 .\end{array}$ \\
\hline C132 & $\begin{array}{l}\text { Telecon between Karlan Richards of RMRS- } \\
\text { Rocky Flats and Ann Quinn. }\end{array}$ & $\begin{array}{l}\text { WSRIC Building Book } 774 \text { Upcoming changes } \\
\text { for LDR Assessment. }\end{array}$ & $\begin{array}{c}1997 . \\
\text { January } 13 .\end{array}$ \\
\hline C133 & $\begin{array}{l}\text { Telecon between Jim Hahn of Rocky Flats } \\
\text { and Jeff Harrison. }\end{array}$ & $\begin{array}{l}\text { Mercury Contaminated Combustibles from } \\
\text { Building } 125 .\end{array}$ & $\begin{array}{l}1997 . \\
\text { January } 28 .\end{array}$ \\
\hline C134 & $\begin{array}{l}\text { Interview Record and associated } \\
\text { documentation of several former Rocky Flats } \\
\text { employees. }\end{array}$ & $\begin{array}{l}\text { Interview with information about general Rocky } \\
\text { Flats history. }\end{array}$ & Unknown. \\
\hline C135 & $\begin{array}{l}\text { Interview Record of Mike Simmons by } T \text {. } \\
\text { Widner and D. Herrick. }\end{array}$ & $\begin{array}{l}\text { Interview with information about B444 } \\
\text { operations. }\end{array}$ & $\begin{array}{c}1991 . \\
\text { August } 6 .\end{array}$ \\
\hline C136 & $\begin{array}{l}\text { Interview Record of Joe Risinger by } \mathrm{T} \text {. } \\
\text { Widner and D. Herrick. }\end{array}$ & $\begin{array}{l}\text { Interview with information about B776 } \\
\text { electrorefining, B771 incinerators, and B444. }\end{array}$ & $\begin{array}{c}1991 . \\
\text { August } 29 .\end{array}$ \\
\hline C137 & $\begin{array}{l}\text { Interview Record of E. Putzier and E. } \\
\text { Vejvoda by D. Herrick and J. Lamb. }\end{array}$ & $\begin{array}{l}\text { Interview with information about historical } \\
\text { process changes, historical air/water effluent } \\
\text { monitoring and waste disposal practice, and } \\
\text { plutonium types and usage. }\end{array}$ & $\begin{array}{c}1991 . \\
\text { September } 5 .\end{array}$ \\
\hline C138 & $\begin{array}{l}\text { Interview Record of Joe Aldrich by Flack and } \\
\text { Herrick. }\end{array}$ & $\begin{array}{l}\text { Interview with information about historical } \\
\text { process changes to } B 886, B 881 \text {, and } B 444 \text {. }\end{array}$ & $\begin{array}{c}1991 . \\
\text { August } 22 .\end{array}$ \\
\hline
\end{tabular}




\begin{tabular}{|l|l|l|l|}
\hline REF \# & TITLE & SUMMARY & DATE \\
\hline
\end{tabular}

\begin{tabular}{|c|c|c|c|}
\hline C139 & Interview Record of C. Barrick by D. Herrick. & $\begin{array}{l}\text { Interview with information about sensitivity of } \\
\text { Th233 information. }\end{array}$ & $\begin{array}{c}1990 . \\
\text { December } 14 .\end{array}$ \\
\hline C140 & Interview Record of N. Clark by D. Herrick. & $\begin{array}{l}\text { Interview with information about historical } \\
\text { process changes to B883 and relationship to } \\
\text { changes in quantity of chemicals used in B883. }\end{array}$ & $\begin{array}{c}1991 . \\
\text { December } 13 .\end{array}$ \\
\hline C141 & $\begin{array}{l}\text { Interview Record of L.R. Crisler by T Widner } \\
\text { and D. Herrick. }\end{array}$ & $\begin{array}{l}\text { Interview with information about B771 } \\
\text { operations and chemicals used, with references } \\
\text { to historical documents written by L.R. Crisler. }\end{array}$ & $\begin{array}{c}1991 . \\
\text { August } 27 .\end{array}$ \\
\hline C142 & Interview Record of N. Cypher by D. Herrick. & $\begin{array}{l}\text { Interview with information about B774 } \\
\text { evaporator, B883 classified project, chemicals } \\
\text { in B374, incidents in B374 and B866. }\end{array}$ & $\begin{array}{c}1991 . \\
\text { August } 13 .\end{array}$ \\
\hline C143 & $\begin{array}{l}\text { Interview Record of R. Greinetz by D. } \\
\text { Herrick. }\end{array}$ & $\begin{array}{l}\text { Interview of Ph.D. chemist who worked at } \\
\text { Rocky Flats. }\end{array}$ & $\begin{array}{c}1992 . \\
\text { January } 7 .\end{array}$ \\
\hline C144 & $\begin{array}{l}\text { Interview Record of M. Maas by D. Herrick } \\
\text { and J. Lamb. }\end{array}$ & $\begin{array}{l}\text { Interview with information about B774 } \\
\text { functions. }\end{array}$ & $\begin{array}{c}1991 . \\
\text { September } 4 .\end{array}$ \\
\hline C145 & $\begin{array}{l}\text { Interview Record D. Del Pizzo by D. Herrick } \\
\text { and Flack. }\end{array}$ & $\begin{array}{l}\text { Interview with information about } \cup 233 \text { use at } \\
\text { Rocky Flats and the ZPPR project. }\end{array}$ & $\begin{array}{c}1992 . \\
\text { January } 21 .\end{array}$ \\
\hline C146 & $\begin{array}{l}\text { Interview Record of S. DeWitt by Flack and } \\
\text { Herrick. }\end{array}$ & $\begin{array}{l}\text { Interview with information about } B 771 \text {; } \\
\text { structural. }\end{array}$ & $\begin{array}{c}1991 . \\
\text { August } 15 .\end{array}$ \\
\hline C147 & $\begin{array}{l}\text { Interview Record of V. Dingman by } T \text {. Widner } \\
\text { and D. Herrick. }\end{array}$ & $\begin{array}{l}\text { Interview with information about } B 777 \text { and } \\
\text { B707 chemicals, uranium processing. }\end{array}$ & $\begin{array}{c}1991 . \\
\text { August } 14 .\end{array}$ \\
\hline C148 & Interview Record of J. Dorr by D. Herrick. & $\begin{array}{l}\text { Interview with information about ZPPR Project } \\
\text { and coating studies. }\end{array}$ & $\begin{array}{c}1992 . \\
\text { January } 22 .\end{array}$ \\
\hline C149 & $\begin{array}{l}\text { Interview Record of M.W. Beranek by T. } \\
\text { Widner and D. Herrick. }\end{array}$ & $\begin{array}{l}\text { Interview with information about B771 Am } \\
\text { processing, filter system, and incinerator. }\end{array}$ & $\begin{array}{c}1991 . \\
\text { August } 7 .\end{array}$ \\
\hline C150 & $\begin{array}{l}\text { Interview Record of C. Forrey by D. Herrick } \\
\text { and J. Lamb. }\end{array}$ & $\begin{array}{l}\text { Interview with information about B771 fume } \\
\text { scrubber, cooling tower, filter plenum, and } \\
\text { caustic scrubber. }\end{array}$ & $\begin{array}{c}1991 . \\
\text { August } 23\end{array}$ \\
\hline $\mathrm{C} 151$ & Interview Record of J. Hebert by D. Herrick. & $\begin{array}{l}\text { Interview with information about } \mathrm{B} 771 \mathrm{Pu} \\
\text { metallurgy and fluorinator, the } \mathrm{B} 447 \text { chip } \\
\text { roaster, and } \mathrm{B} 460 \text { waste from } \mathrm{B} 881 \text {. }\end{array}$ & $\begin{array}{c}1991 . \\
\text { August } 6 .\end{array}$ \\
\hline C152 & $\begin{array}{l}\text { Interview Record of F. McMenus by } T \text {. } \\
\text { Widner and } D \text {. Herrick. }\end{array}$ & $\begin{array}{l}\text { Interview with information about waste transfer } \\
\text { system, cleanup of solar ponds, OASIS, B774 } \\
\text { vacuum filter, B771 incinerator, and B374 } \\
\text { holding ponds. }\end{array}$ & $\begin{array}{c}1991 . \\
\text { August } 7 .\end{array}$ \\
\hline C153 & $\begin{array}{l}\text { Interview Record of J. Morrison by D. Herrick } \\
\text { and Flack. }\end{array}$ & $\begin{array}{l}\text { Interview with information about Pu recovery } \\
\text { process and Am recovery process. }\end{array}$ & $\begin{array}{c}1991 . \\
\text { August } 14 .\end{array}$ \\
\hline C154 & $\begin{array}{l}\text { Interview Record of W.V. Conner by T. } \\
\text { Widner and D. Lamb. }\end{array}$ & $\begin{array}{l}\text { Interview with information about several B771 } \\
\text { operations, Am purification, Np work, } \\
\text { chemicals used, and fume scrubber. }\end{array}$ & $\begin{array}{c}1991 . \\
\text { August } 13 .\end{array}$ \\
\hline C155 & $\begin{array}{l}\text { Interview Record of J.D. Weaver by T. } \\
\text { Widner and J. Lamb. }\end{array}$ & $\begin{array}{l}\text { Interview with information about } \mathrm{B} 771 \\
\text { operations, including dissolution process, } \\
\text { leached } \mathrm{Pu} \text {, and ammonium thiocyanate } \\
\text { process; and } \mathrm{B} 371 \text { construction and operation. }\end{array}$ & $\begin{array}{l}1991 . \\
\text { August } 15 .\end{array}$ \\
\hline C156 & $\begin{array}{l}\text { Interview Record of R. Jackson by T. Widner } \\
\text { and J. Lamb. }\end{array}$ & $\begin{array}{l}\text { Interview with information about } B 883 \\
\text { production. }\end{array}$ & $\begin{array}{c}1991 . \\
\text { August } 13 .\end{array}$ \\
\hline C157 & $\begin{array}{l}\text { Interview Record of R. Gisler by T. Widner } \\
\text { and Flack. }\end{array}$ & $\begin{array}{l}\text { Interview with information about Room 114, } \\
\text { B } 771 \text { and chemicals used. }\end{array}$ & $\begin{array}{l}1991 . \\
\text { August } 20 .\end{array}$ \\
\hline C158 & Interview Record of R. Simmons by S. Flack. & $\begin{array}{l}\text { Interview with information about health physics, } \\
\text { some beryllium. }\end{array}$ & $\begin{array}{c}1991 . \\
\text { November } 21 .\end{array}$ \\
\hline
\end{tabular}




\begin{tabular}{|l|l|l|l|}
\hline REF \# & TITLE & SUMMARY & DATE \\
\hline
\end{tabular}

\begin{tabular}{|c|c|c|c|}
\hline C159 & $\begin{array}{l}\text { Interview Record of R. Hoffman by D. Herrick } \\
\text { and J. Lamb. }\end{array}$ & $\begin{array}{l}\text { Interview with information about SOW and } \\
\text { U233 use, nickel carbonyl, and limited ZPPR } \\
\text { information. }\end{array}$ & $\begin{array}{l}1991 . \\
\text { September } 4 .\end{array}$ \\
\hline C160 & $\begin{array}{l}\text { Interview Record of M. Delhierro by D. } \\
\text { Herrick. }\end{array}$ & $\begin{array}{l}\text { Interview with information about pyrochemistry } \\
\text { in B371. }\end{array}$ & $\begin{array}{c}1991 \\
\text { August } 13 .\end{array}$ \\
\hline C161 & Interview Record of K. Freiberg by D. Herrick. & $\begin{array}{l}\text { Interview with information about } \mathrm{Th}^{233} \text { and } \\
\mathrm{Cu}^{244} \text {. }\end{array}$ & $\begin{array}{r}1991 . \\
\text { May } 9 .\end{array}$ \\
\hline C162 & Interview Record of R. Hilbig by D. Herrick. & $\begin{array}{l}\text { Interview with information about Freon in } B 460 \text {, } \\
\text { composition of nitrad, and some solvents and } \\
\text { chemicals used at Rocky Flats. }\end{array}$ & $\begin{array}{l}1991 \\
\text { August } 13 .\end{array}$ \\
\hline C163 & $\begin{array}{l}\text { Interview Record of G. Ideker by T. Widner } \\
\text { and S. Flack. }\end{array}$ & $\begin{array}{l}\text { Interview with information about } B 881 \text { stainless } \\
\text { steel operations and } B 460 \text { operations. }\end{array}$ & $\begin{array}{c}1991 . \\
\text { August } 14 .\end{array}$ \\
\hline C164 & $\begin{array}{l}\text { Interview Record of B. Kelchner by D. Herrick } \\
\text { and J. Lamb. }\end{array}$ & $\begin{array}{l}\text { Interview with information about } U \text { operations } \\
\text { and chemicals used in } B 881 \text {. }\end{array}$ & $\begin{array}{c}1991 . \\
\text { September } 6 .\end{array}$ \\
\hline C165 & $\begin{array}{l}\text { Interview Record of L. Martella by T. Widner } \\
\text { and D. Herrick. }\end{array}$ & $\begin{array}{l}\text { Interview with information about } \mathrm{Np}, \mathrm{Am} \\
\text { recovery, and } \mathrm{U} \text { "special recovery". }\end{array}$ & $\begin{array}{c}1991 . \\
\text { August } 7 .\end{array}$ \\
\hline C166 & Interview Record of L. Martella by D. Herrick. & $\begin{array}{l}\text { Interview with information about } \mathrm{Np} \text {, and } \mathrm{Am} \\
\text { recovery. }\end{array}$ & $\begin{array}{c}1991 . \\
\text { August } 7 .\end{array}$ \\
\hline C167 & $\begin{array}{l}\text { Interview Record of J. Merriman by D. } \\
\text { Herrick and J. Lamb. }\end{array}$ & $\begin{array}{l}\text { Interview with information about } \mathrm{B} 559 \\
\text { ventilation upgrade and radionuclide emissions. }\end{array}$ & $\begin{array}{c}1991 . \\
\text { August } 20 .\end{array}$ \\
\hline C168 & $\begin{array}{l}\text { Interview Record of J.D. Morrison by T. } \\
\text { Widner and D. Herrick. }\end{array}$ & $\begin{array}{l}\text { Interview with information about B771 and } \\
\text { B774 Ops, a little bit about ZPPR, and } \\
\text { chemical list attached. }\end{array}$ & $\begin{array}{l}1991 . \\
\text { August } 29 \text {. }\end{array}$ \\
\hline C169 & $\begin{array}{l}\text { Telecon between Al Morgan of Rocky Flats } \\
\text { (retired) and Jeff Harrison. }\end{array}$ & $\begin{array}{l}\text { Information regarding drum prefix usage and } \\
\text { plutonium isotopic composition. }\end{array}$ & $\begin{array}{c}1997 . \\
\text { January } 9 .\end{array}$ \\
\hline $\mathrm{C} 170$ & $\begin{array}{l}\text { Telecon between Al Morgan of Rocky Flats } \\
\text { (retired) and Jeff Harrison. }\end{array}$ & $\begin{array}{l}\text { Information regarding drum prefix usage prior } \\
\text { to WEMS. }\end{array}$ & $\begin{array}{c}1997 . \\
\text { February } 17 .\end{array}$ \\
\hline C171 & $\begin{array}{l}\text { Telecon between Bill Connor of Kaiser-Hill } \\
\text { LATO and Jeff Harrison. }\end{array}$ & Nonroutine radionuclide work. & $\begin{array}{c}1997 . \\
\text { February } 13 .\end{array}$ \\
\hline $\mathrm{C} 172$ & $\begin{array}{l}\text { Interoffice correspondence between L.C. } \\
\text { Basso and J.R. Ryan of RFETS. }\end{array}$ & $\begin{array}{l}\text { Review of data for tar; the interpretation of the } \\
\text { data is incorrect. }\end{array}$ & $\begin{array}{c}1994 . \\
\text { May } 10 .\end{array}$ \\
\hline C173 & $\begin{array}{l}\text { Telecon between Rick Wagner of RFETS and } \\
\text { Jeff Harrison. }\end{array}$ & Graphite from drum prefix 0743. & $\begin{array}{c}1997 . \\
\text { February } 28 .\end{array}$ \\
\hline $\mathrm{C} 174$ & $\begin{array}{l}\text { Telecon between Bob Fiore of RFETS and } \\
\text { Jeff Harrison. }\end{array}$ & Building 707 Operations. & $\begin{array}{l}1997 . \\
\text { February } 28 .\end{array}$ \\
\hline C175 & $\begin{array}{l}\text { Telecon between Al Morgan of Rocky Flats } \\
\text { (retired) and Jeff Harrison. }\end{array}$ & Building 776 Size Reduction Area. & $\begin{array}{l}1997 . \\
\text { February } 27 .\end{array}$ \\
\hline C176 & $\begin{array}{l}\text { Telecon between Bill Connor of Kaiser-Hill } \\
\text { LATO and Jeff Harrison. }\end{array}$ & Nonroutine and R\&D Operations. & $\begin{array}{l}1997 . \\
\text { February } 27 .\end{array}$ \\
\hline $\mathrm{c} 177$ & $\begin{array}{l}\text { Telecon between Al Morgan of Rocky Flats } \\
\text { (retired) and Jeff Harrison. }\end{array}$ & Graphite scarfing. & $\begin{array}{c}1997 . \\
\text { February } 26 .\end{array}$ \\
\hline C178 & $\begin{array}{l}\text { Interoffice Memorandum to A.J. Holifield of } \\
\text { Safe Sites from A.M. Murray of Kaiser-Hill. } \\
\text { KAP-006-96, Attachment } 1 .\end{array}$ & $\begin{array}{l}\text { Review of six item description codes with } \\
\text { respect to potential water content - AMM-002- } \\
96 .\end{array}$ & $\begin{array}{c}1996 . \\
\text { January } 10 .\end{array}$ \\
\hline C179 & $\begin{array}{l}\text { Interoffice Memorandum to R.E. Wilson from } \\
\text { A.M. Murray of Kaiser-Hill. } \\
\text { KAP-006-96, Attachment } 2 \text {. }\end{array}$ & $\begin{array}{l}\text { Moisture content in pyrochemical salt residues } \\
\text { with respect to considering them "wet" by } \\
\text { nuclear material safety limits - AMM-014-96. }\end{array}$ & $\begin{array}{l}1996 . \\
\text { March } 19 .\end{array}$ \\
\hline C180 & $\begin{array}{l}\text { Informal Memorandum to J.M. Ball of SSOC } \\
\text { from W.V. Connor of Kaiser-Hill. } \\
\text { KAP-006-96, Attachment 3. }\end{array}$ & $\begin{array}{l}\text { Moisture content of non-salt residue IDCs } \\
\text { (WVC-96-6). }\end{array}$ & $\begin{array}{l}1996 . \\
\text { March } 20 .\end{array}$ \\
\hline
\end{tabular}




\begin{tabular}{|c|c|c|c|}
\hline REF \# & TITLE & SUMMARY & DATE \\
\hline C181 & $\begin{array}{l}\text { Informal Memorandum to J.M. Ball of SSOC } \\
\text { from W.V. Conner of Kaiser-Hill. } \\
\text { KAP-006-96, Attachment } 4 \text {. }\end{array}$ & $\begin{array}{l}\text { Moisture content of all non-salt residue IDCs } \\
\text { (WVC-96-7). }\end{array}$ & $\begin{array}{l}1996 . \\
\text { April } 4 .\end{array}$ \\
\hline $\mathrm{C}_{182}$ & $\begin{array}{l}\text { Interoffice Correspondence to K.A. Phillips } \\
\text { from A.M. Murray. }\end{array}$ & $\begin{array}{l}\text { Information regarding item description code } \\
\text { (IDC) } 416 \text { - AMM-019-96. }\end{array}$ & $\begin{array}{l}1996 . \\
\text { April } 16 .\end{array}$ \\
\hline C183 & $\begin{array}{l}\text { Telecon between Mike West of LATO, Lynn } \\
\text { McCurry of WI (ORNL), and Kevin Peters. }\end{array}$ & $\begin{array}{l}\text { Composition of MSE Salt, IDC } 409 \text { (drawing } \\
\text { attached). }\end{array}$ & $\begin{array}{c}1997 . \\
\text { March } 11 .\end{array}$ \\
\hline C184 & $\begin{array}{l}\text { Interview Record of Al Morgan by Jeff } \\
\text { Harrison. }\end{array}$ & $\begin{array}{l}\text { Historical Rocky Flats Operations with } \\
\text { emphasis on radionuclides. }\end{array}$ & $\begin{array}{l}1997 . \\
\text { March } 19 .\end{array}$ \\
\hline $\mathrm{C} 185$ & $\begin{array}{l}\text { Telecon between Bill Connor of LAPO and } \\
\text { Jeff Harrison. }\end{array}$ & Special isotopes used in R\&D Operations. & $\begin{array}{c}1997 . \\
\text { March } 20 .\end{array}$ \\
\hline $\mathrm{C} 186$ & $\begin{array}{l}\text { Interoffice Correspondence from K. Phillips of } \\
\text { SSOC to J. Ball, SSOC. }\end{array}$ & $\begin{array}{l}\text { Interim Residue Characterization Status Report } \\
\text { KAP-017-96. }\end{array}$ & $\begin{array}{c}1996 . \\
\text { December } 31\end{array}$ \\
\hline C187 & $\begin{array}{l}\text { Interoffice Correspondence from K. Phillips of } \\
\text { SSOC to J. Ball, SSOC. }\end{array}$ & $\begin{array}{l}\text { Interim Residue Characterization Status Report } \\
\text { KAP-012-96. }\end{array}$ & $\begin{array}{c}1996 . \\
\text { July } 22 . \\
\end{array}$ \\
\hline $\mathrm{C} 188$ & $\begin{array}{l}\text { Telecon between Bill Conner of LAPO and } \\
\text { Jeff Harrison. }\end{array}$ & Defense Versus Non-Defense Related Projects. & $\begin{array}{l}1997 . \\
\text { April } 3 .\end{array}$ \\
\hline C189 & $\begin{array}{l}\text { Telecon between Al Morgan of Rocky Flats } \\
\text { (retired) and Jeff Harrison. }\end{array}$ & Americium Recovery and Purification. & $\begin{array}{l}1997 \\
\text { April } 3 .\end{array}$ \\
\hline C190 & $\begin{array}{l}\text { Telecon between Bill Conner of Rocky Flats } \\
\text { and Jeff Harrison. }\end{array}$ & Defense and Non-Defense Activities. & $\begin{array}{c}1997 \\
\text { May } 20 .\end{array}$ \\
\hline C191 & $\begin{array}{l}\text { Memorandum from DOE CAO to J. M. } \\
\text { Roberson, RFFO and J. M. Wilcynski, } \\
\text { INEEL. }\end{array}$ & $\begin{array}{l}\text { Identification of Defense Waste Streams } \\
\text { Generated at Rocky Flats.. Also identifies that } \\
\text { the wastes were not associated with nuclear } \\
\text { fuels or high-level waste. }\end{array}$ & $\begin{array}{c}1997 \\
\text { May } 20 .\end{array}$ \\
\hline C192 & $\begin{array}{l}\text { Letter from E. R. Naimon, Manager Waste } \\
\text { Operations, to Albert E. Whiteman, Area } \\
\text { Manager DOE, RFAO. "Classified Waste } \\
\text { Characterization." 88-RF-0409. }\end{array}$ & $\begin{array}{l}\text { List of classified waste IDCs that are not RCRA } \\
\text { hazardous waste. }\end{array}$ & $\begin{array}{l}1988 . \\
\text { February } 10 .\end{array}$ \\
\hline C193 & $\begin{array}{l}\text { Facsimile Memorandum from Jeff Paynter to } \\
\text { Jeff Harrison, WASTREN. "Info on 1518-4 } \\
\text { Containers." }\end{array}$ & $\begin{array}{l}\text { Unclassified description for retired weapons } \\
\text { components stored at the Nevada Test Site. }\end{array}$ & $\begin{array}{l}1997 . \\
\text { July } 10 .\end{array}$ \\
\hline C194 & $\begin{array}{l}\text { Telecon between Jeff Harrison and Jeff } \\
\text { Paynter, M. H. Chew \& Associates. } \\
\text { "General Discussion of NTS Inventory of } \\
\text { Rocky Flats Waste." }\end{array}$ & Descriptions of classified waste IDCs. & $\begin{array}{l}1997 . \\
\text { July } 10 .\end{array}$ \\
\hline C195 & $\begin{array}{l}\text { Telecon between Jeff Harrison and Jeff } \\
\text { Paynter, M. H. Chew \& Associates. } \\
\text { "Relation of Processes Generating Classified } \\
\text { IDCs." }\end{array}$ & $\begin{array}{l}\text { Description of how processes that generated } \\
\text { classified waste IDCs are related. }\end{array}$ & $\begin{array}{l}1997 . \\
\text { July } 17 .\end{array}$ \\
\hline C196 & $\begin{array}{l}\text { Facsimile Transmission from Pat Arnold to } \\
\text { Jeff Harrison, WASTREN. Density of Sludge } \\
\text { Drums. }\end{array}$ & $\begin{array}{l}\text { Sludge density calculations for IDC } 800 \\
\text { performed by Pat Arnold. }\end{array}$ & $\begin{array}{c}1997 . \\
\text { March } 18 .\end{array}$ \\
\hline C197 & Memorandum from Jeff Harrison to File. & $\begin{array}{l}\text { Summary of drum prefix discrepancies for } \\
\text { INEEL Accessible Storage TRU Waste } \\
\text { Inventory-Rocky Flats Waste. }\end{array}$ & $\begin{array}{c}1997 . \\
\text { August } 12 .\end{array}$ \\
\hline P001 & $\begin{array}{l}\text { TRU Waste Compliance Program for WIPP- } \\
\text { WAC (U). WO-4500-H. }\end{array}$ & $\begin{array}{l}\text { A procedure that described the WIPP-certified } \\
\text { transuranic waste generation process at Rocky } \\
\text { Flats. The WIPP-WACCC audited RFP to this } \\
\text { procedure to assure the waste met current } \\
\text { WIPP requirements. }\end{array}$ & 1989. \\
\hline $\mathrm{P} 002$ & $\begin{array}{l}\text { Organic and S/udge Immobilization System. } \\
\text { RFP-4095. }\end{array}$ & $\begin{array}{l}\text { Description of the development and operation } \\
\text { of the OASIS process (IDCs } 700 \text { and 801). }\end{array}$ & 1987. \\
\hline
\end{tabular}




\begin{tabular}{|l|l|l|l|l|}
\hline REF \# & TITLE & SUMMARY & DATE \\
\hline
\end{tabular}

\begin{tabular}{|c|c|c|c|}
\hline P003 & $\begin{array}{l}\text { Quality Assurance Program for TRU Waste } \\
\text { Certification. WC-4500-D. }\end{array}$ & $\begin{array}{l}\text { Companion procedure to WO- } 4500 \text { specific to } \\
\text { certification procedures used by Rocky Flats to } \\
\text { pre-certify Transuranic waste shipped to INEL. }\end{array}$ & 1988. \\
\hline P004 & $\begin{array}{l}\text { Rocky Flats Plant Waste Management Site } \\
\text { Plan. }\end{array}$ & $\begin{array}{l}\text { Description of waste activities at Rocky Flats } \\
\text { emphasizing solid and liquid waste treatment. }\end{array}$ & 1987. \\
\hline P005 & $\begin{array}{l}\text { Procedure for Labeling and Marking } \\
\text { Unclassified TRU Waste Containers for } \\
\text { Shipment to INEL. Traffic 300-1. }\end{array}$ & $\begin{array}{l}\text { Traffic Department Procedure for labeling and } \\
\text { marking containers of transuranic waste } \\
\text { transported via ATMX rail car to INEL. }\end{array}$ & 1988. \\
\hline P006 & $\begin{array}{l}\text { Gas Generation Results and Venting Study } \\
\text { for Transuranic Waste Drums. RFP-3739. }\end{array}$ & $\begin{array}{l}\text { Gas generation measurements from IDCs } 001 \text {, } \\
003,330,336,337 \text {, and } 339 \text { wastes. }\end{array}$ & 1985. \\
\hline P007 & $\begin{array}{l}\text { Waste Operations internal Document Control } \\
\text { for Documents Pertaining to the WIPP-WAC. } \\
\text { WO-4000-A. }\end{array}$ & $\begin{array}{l}\text { Procedure listing holders of controlled copies of } \\
\text { procedures pertaining to generation of WIPP- } \\
\text { certified waste. }\end{array}$ & 1989. \\
\hline P008 & $\begin{array}{l}\text { Packaging and Handling Line- and Nonline- } \\
\text { Generated Materials (U). } 1-1002-\mathrm{C} / 0 \text {. }\end{array}$ & $\begin{array}{l}\text { Packaging procedure stating general } \\
\text { requirements for nonline- and line-generated } \\
\text { waste. This procedure also includes IDC- } \\
\text { specific packaging requirements. }\end{array}$ & 1988. \\
\hline P009 & $\begin{array}{l}\text { Characterization and Categorization Study of } \\
\text { TRU Waste for EG\&G. CSE 80-0017. }\end{array}$ & $\begin{array}{l}\text { Description of drums destructively examined for } \\
\text { EG\&G Idaho. IDCs included are } 330,336,480 \text {, } \\
481,442,339 \text {, and } 440 \text {. }\end{array}$ & Undated \\
\hline P010 & Solid Waste Inspection. WC-4003-I. & $\begin{array}{l}\text { Procedure for waste inspectors reviewing low- } \\
\text { level waste and transuranic waste containers. } \\
\text { (Page } 9 \text { has OASIS [IDC } 801 / 700 \text { ] recipe } \\
\text { requirements.) IDC descriptions are included in } \\
\text { the back of the procedures. }\end{array}$ & 1989. \\
\hline P011 & FY-1987 Waste Operations Operating Plan. & $\begin{array}{l}\text { Describes manpower, budget, and waste } \\
\text { operations for RFP during FY } 1987 .\end{array}$ & Undated \\
\hline P012 & $\begin{array}{l}\text { TRUPACT-/l Content Codes (TRUCON). } \\
89-004 .\end{array}$ & $\begin{array}{l}\text { Content code descriptions (roll-up of IDCs) for } \\
\text { transportation. Descriptions include generation } \\
\text { area, short process write-up assay, and } \\
\text { packaging configurations. }\end{array}$ & 1992. \\
\hline P013 & $\begin{array}{l}\text { EG\&G Sampling Program Results FY1987. } \\
\text { PSD87-059. }\end{array}$ & $\begin{array}{l}\text { Results from Destructive Examination of IDCs } \\
292,411,440,1,3,4 \text {, and } 7 \text { wastes. }\end{array}$ & 1987. \\
\hline P014 & $\begin{array}{l}\text { TRU Waste Certification Program for WIPP. } \\
\text { WAC (U). CO-4500-A. }\end{array}$ & $\begin{array}{l}\text { Forerunner to WO-4500. First procedure to } \\
\text { describe the WIPP certification program at } \\
\text { RFP. }\end{array}$ & 1983. \\
\hline P015 & $\begin{array}{l}\text { TRU Waste Sampling Program: Volume 1- } \\
\text { Waste Characterization. EGG-WM-6503. }\end{array}$ & $\begin{array}{l}\text { Destructive Examination and gas sampling of } \\
\text { transuranic wastes. A large number of IDCs } \\
\text { from RFP and LANL are represented. }\end{array}$ & 1985. \\
\hline P016 & $\begin{array}{l}\text { Idaho National Engineering Laboratory Code } \\
\text { Assessment of the Rocky Flats Transuranic } \\
\text { Waste. INEL-95/0281. }\end{array}$ & $\begin{array}{l}\text { Description of each IDC shipped to INEL from } \\
\text { RFP from } 1985 \text { until } 1989 .\end{array}$ & 1995. \\
\hline P017 & $\begin{array}{l}\text { Preliminary Assessment of Real-Time } \\
\text { Radiography and Visual Characterization for } \\
\text { Selected Waste Categories. RFP-4604. }\end{array}$ & $\begin{array}{l}\text { A variety of transuranic wastes in drums were } \\
\text { examined by RTR then destructively examined } \\
\text { in the Size Reduction unit. This project report } \\
\text { details the accuracy of the RTR examination } \\
\text { compared to usual examination and weighing } \\
\text { of contents. }\end{array}$ & 1993. \\
\hline P018 & $\begin{array}{l}\text { Waste Drum Gas Generation Sampling } \\
\text { Program at Rocky Flats during FY } 1988 . \\
\text { RFP-4311. }\end{array}$ & $\begin{array}{l}\text { Inorganic and organic sludges, Raschig rings, } \\
\text { and combustibles drums were evaluated for } \\
\text { gas generation rate, gas composition, and } \\
\text { physical contents in } 1988 \text {. }\end{array}$ & 1991. \\
\hline
\end{tabular}




\begin{tabular}{|l|l|l|l|}
\hline REF \# & TITLE & SUMMARY & DATE \\
\hline
\end{tabular}

\begin{tabular}{|c|c|c|c|}
\hline P019 & $\begin{array}{l}\text { HEPA Filter Optimization/lmplementation. } \\
\text { RFP-4171. }\end{array}$ & $\begin{array}{l}\text { Describes efforts to reduce IDC } 490 \text { waste } \\
\text { volume by using prefilters. Describes the } \\
\text { Building } 771 \text { plenums. }\end{array}$ & 1988. \\
\hline $\mathrm{P} 020$ & $\begin{array}{l}\text { Characteristics of Transuranic Waste at } \\
\text { Department of Energy Sites. RFP-3357. }\end{array}$ & $\begin{array}{l}\text { Inventory data (D1981) for transuranic wastes } \\
\text { at DOE facilities. No specific process } \\
\text { information; rather, inventory data, i.e., } \\
\text { radionuclide content, volume, weight, etc. }\end{array}$ & 1983 \\
\hline P021 & $\begin{array}{l}\text { EG\&G Drum Sampling Program Results } \\
\text { FY1986. PSD86-061. }\end{array}$ & $\begin{array}{l}\text { Physical evaluation of drum contents for IDC } \\
300,303,320,339,411,432,440 \text {, and } 004 \text {. } \\
\text { Drums originally generated at Rocky Flats, sent } \\
\text { to Rocky Flats from INEL for examination, and } \\
\text { then returned to INEL. }\end{array}$ & 1986 \\
\hline P022 & $\begin{array}{l}\text { EG\&G Sampling Program Results FY1989. } \\
\text { PSD89-011. }\end{array}$ & $\begin{array}{l}\text { Visual examination results for IDCs } 003,312 \text {, } \\
300,007,001,440,442,337 \text {, and } 480 \text {. Waste } \\
\text { originally generated at Rocky Flats, then } \\
\text { returned to Rocky Flats from INEL for } \\
\text { examination. }\end{array}$ & 1989 \\
\hline P023 & $\begin{array}{l}\text { (Task } 5 \text { Draft Report) Estimating Historical } \\
\text { Emissions from Rocky Flats. }\end{array}$ & Chemical usage information at RFP. & 1992. \\
\hline P024 & $\begin{array}{l}\text { Content Code Assessments for INEL } \\
\text { Contact-Handled Stored Transuranic Wastes. } \\
\text { WM-F1-82-021. }\end{array}$ & $\begin{array}{l}\text { Assessment, by content code, of transuranic } \\
\text { wastes stored at INEL in } 1981 \text {. Process, } \\
\text { packaging, radionuclide, and certification } \\
\text { information by content code is included. }\end{array}$ & 1982 \\
\hline P025 & $\begin{array}{l}\text { Standard for DOT-17C } 55 \text { Gal. Drum. } \\
\text { Rocky Flats Plant STD No. SX-200 (formerly } \\
\text { P.E. No. P12413). }\end{array}$ & $\begin{array}{l}\text { Procurement standard for white 55-gallon } \\
\text { drums used for waste packaging. }\end{array}$ & 1977. \\
\hline P026 & $\begin{array}{l}\text { Transuranic Solid Waste Inspection }(U) \text {. } \\
\text { WC-4003-A. }\end{array}$ & $\begin{array}{l}\text { Procedure for inspector's examination of solid } \\
\text { waste including paperwork, physical } \\
\text { examination, and packaging. }\end{array}$ & 1985 \\
\hline $\mathrm{P} 027$ & $\begin{array}{l}\text { TRU Waste Acceptance Criteria for the } \\
\text { Waste Isolation Pilot Plant. WIPPIDOE-069. }\end{array}$ & $\begin{array}{l}\text { Waste acceptance requirements for transuranic } \\
\text { waste stored at the WIPP site. }\end{array}$ & 1989 \\
\hline P028 & $\begin{array}{l}\text { TRU Waste Certification Compliance } \\
\text { Requirements for Acceptance of Newly } \\
\text { Generated Contact-Handled Wastes to be } \\
\text { Shipped to the Waste Isolation Pilot Plant. } \\
\text { WIPP-DOE-114. }\end{array}$ & $\begin{array}{l}\text { Discussion of WIPPNWAC criterion, intent, } \\
\text { controlled properties, and compliance } \\
\text { requirements. }\end{array}$ & 1989 \\
\hline P029 & $\begin{array}{l}\text { Safety Analysis Report for Packaging - } \\
\text { Corrugated Steel Container (SAND Box) for } \\
\text { DOE Specification 7A Packaging. RFP-3345. }\end{array}$ & $\begin{array}{l}\text { This report details the Type A testing performed } \\
\text { on the SAND Box. }\end{array}$ & 1983. \\
\hline P030 & $\begin{array}{l}\text { Drop Test of DOT Specification 7A Type A } \\
\text { Metal Corrugated Box (SANDbox) with a 3/4" } \\
\text { Plywood Liner. WPS 89-001. }\end{array}$ & $\begin{array}{l}\text { This report details the testing of the wooden } \\
\text { liner for metal wastes placed in the SANDbox. }\end{array}$ & 1989 \\
\hline P031 & $\begin{array}{l}\text { Full-Scale Drop-Impact Tests with DOT } \\
\text { Specification 7A Waste Containers. } \\
\text { WPS } 88-001 .\end{array}$ & $\begin{array}{l}\text { Details on testing of } 55 \text {-gallon drums and } \\
\text { SAND boxes for the revised ATMX SAR. }\end{array}$ & 1988 \\
\hline P032 & $\begin{array}{l}\text { Waste Item Description Code Manual. } \\
\text { WC-4004-A. }\end{array}$ & $\begin{array}{l}1987 \text { procedure that provides IDC definitions } \\
\text { and certification status for each IDC. }\end{array}$ & 1987 \\
\hline P033 & $\begin{array}{l}\text { Summary of Transuranic Waste } \\
\text { Characterization Programs at the INEL } \\
\text { (1979-Present). INEL-95/0397. }\end{array}$ & $\begin{array}{l}\text { This document describes the transuranic waste } \\
\text { characterization programs to date including } \\
\text { results of RTR examinations, visual } \\
\text { examinations, headspace gas analysis, solid } \\
\text { sample analysis, and radioassay. }\end{array}$ & 1995 \\
\hline
\end{tabular}




\begin{tabular}{|ll|l|l|l|l|l|l|}
\hline REF \# & TITLE & SUMMARY & \\
\hline
\end{tabular}

\begin{tabular}{|c|c|c|c|}
\hline P034 & $\begin{array}{l}\text { Health, Safety \& Environment Manual. } \\
\text { Disposal of Excess Chemicals, Waste Oils, } \\
\text { and Organic Solvents. HSE 21.01. }\end{array}$ & $\begin{array}{l}\text { This procedure applies to the disposal of } \\
\text { excess chemicals, waste oils, and organic } \\
\text { solvents. }\end{array}$ & 1982. \\
\hline P035 & $\begin{array}{l}\text { Backlog Residues at the DOE Rocky Flats } \\
\text { Plant: Residue IDC Descriptions. }\end{array}$ & $\begin{array}{l}\text { Document generated by the Residue } \\
\text { Elimination project. The document describes } \\
\text { the residue, IDC by IDC, with regard to form, } \\
\text { plutonium content, RCRA characterization, and } \\
\text { shipment information. }\end{array}$ & 1993. \\
\hline P036 & $\begin{array}{l}\text { Radioactive Waste Package Development at } \\
\text { the Rocky Flats Plant. IAEA-SR-10/26. }\end{array}$ & $\begin{array}{l}\text { Development of rigid liners for transuranic } \\
\text { waste drums. }\end{array}$ & \\
\hline P037 & $\begin{array}{l}\text { Rocky Flats Environmental Technology Site } \\
1995 \text { Annual Land Disposal Restriction } \\
\text { Progress Report. }\end{array}$ & $\begin{array}{l}\text { Characterization information for LDR wastes. } \\
\text { This document uses BWR as the primary } \\
\text { characterization reference. }\end{array}$ & 1995. \\
\hline P038 & Residue Analysis Study. CE-010-001. & $\begin{array}{l}\text { This document includes extracts of complete } \\
\text { data/details for individual IDCs when required } \\
\text { for analysis or discussion. General information } \\
\text { on the scope, assumptions made, and } \\
\text { methodologies used can be found in Chapters I } \\
\text { through IV of the Study. }\end{array}$ & 1992. \\
\hline P039 & $\begin{array}{l}\text { Rocky Flats Plant Radioactive Waste } \\
\text { Packaging Requirements. 1-M12-WO-4034. }\end{array}$ & $\begin{array}{l}\text { Waste packaging requirements for low-level } \\
\text { and transuranic waste. }\end{array}$ & 1994. \\
\hline P040 & $\begin{array}{l}\text { Operating the Building } 771 \text { Waste Collection } \\
\text { System (Decontamination Shower and } \\
\text { Process Sinks }(U) \text {. CO-4017-F. }\end{array}$ & $\begin{array}{l}\text { Operating procedure for Building } 771 \text { process } \\
\text { waste (2nd stage treatment). }\end{array}$ & 1984. \\
\hline P041 & $\begin{array}{l}\text { Waste Receiving and Transferring, Second } \\
\text { Stage Tanks (U). WO-4026-AVO. }\end{array}$ & $\begin{array}{l}\text { Operating procedure for } 2 \text { nd stage treatment } \\
\text { tanks in Building } 774 \text {. }\end{array}$ & 1987. \\
\hline P042 & $\begin{array}{l}\text { Liquid Waste Processing (Second Stage }(U) \text {. } \\
\text { WO-4004-A. }\end{array}$ & $\begin{array}{l}\text { Operating procedure for } 2 \text { nd stage precipitation } \\
\text { in Building } 774 \text {. }\end{array}$ & 1987. \\
\hline P043 & $\begin{array}{l}\text { TRU Waste Compliance Program for WIPP- } \\
\text { WAC (U). WO-4500-F. }\end{array}$ & $\begin{array}{l}\text { Procedure that RF was audited to for WIPP } \\
\text { certified waste (pre-certified waste to INEL). } \\
\text { Process descriptions for individual waste forms } \\
\text { are located as appendices in the back. }\end{array}$ & 1987. \\
\hline P044 & $\begin{array}{l}\text { Evaluation of RFP TRU/TRU-Mixed Inventory } \\
\text { for Compliance with Selected WIPP and } \\
\text { TRAMPAC Requirements. 94-RF-06806. }\end{array}$ & $\begin{array}{l}\text { Comparison of RF transuranic wastes to WIPP } \\
\text { waste acceptance and transportation } \\
\text { requirements. }\end{array}$ & 1994. \\
\hline P045 & $\begin{array}{l}\text { Standard for Corrugated Metal Waste } \\
\text { Container (Steel Box). Rocky Flats Plant } \\
\text { STD No. SX-231. }\end{array}$ & $\begin{array}{l}\text { Procurement standard for corrugated metal } \\
\text { boxes (also known as a } 4 \times 4 \times 7 \text { metal box or } \\
\text { SAND Box). }\end{array}$ & 1983. \\
\hline P046 & $\begin{array}{l}\text { ATMX-600 Rail Car Safety Analysis Report. } \\
\text { RFP-2444 (Draft). }\end{array}$ & $\begin{array}{l}\text { Provides details on the ATMX-600 rail car } \\
\text { construction, operation, and safety features. } \\
\text { The ATMX-600 was used to transport waste } \\
\text { from RFP to INEL. }\end{array}$ & 1985. \\
\hline P047 & $\begin{array}{l}\text { Filtering, Drying, Conveying, Cementing, and } \\
\text { Packaging Sludge (U). WO-5014-AV1. }\end{array}$ & Procedure for waste treatment in Building 374. & 1987. \\
\hline P048 & Waste Operations Supplies. WO-4040. & $\begin{array}{l}\text { Document provides details on proper handling, } \\
\text { storage, and preparation of waste supplies } \\
\text { (empty containers, pallets, liners). }\end{array}$ & 1989. \\
\hline P049 & $\begin{array}{l}\text { Annual Land Disposal Restriction Progress } \\
\text { Report. Rocky Flats Plant. }\end{array}$ & $\begin{array}{l}\text { This document provides current (at the time of } \\
\text { publishing) information on inventory and } \\
\text { treatment development. }\end{array}$ & 1994. \\
\hline P050 & $\begin{array}{l}\text { Waste Acceptance Criteria for the Waste } \\
\text { Isolation Pilot Plant. WIPP-DOE-069. }\end{array}$ & $\begin{array}{l}\text { Waste acceptance requirements for transuranic } \\
\text { waste at the WIPP site. }\end{array}$ & 1991. \\
\hline
\end{tabular}




\begin{tabular}{|c|c|c|c|}
\hline REF \# & TITLE & SUMMARY & DATE \\
\hline $\mathrm{P} 051$ & $\begin{array}{l}\text { Rocky Flats Environmental Technology Site } \\
\text { Proposed Site Treatment Plan. } \\
\text { Background Volume and Compliance Plan } \\
\text { Volume. }\end{array}$ & Plan for treatment of RFP mixed wastes. & 1995. \\
\hline P052 & $\begin{array}{l}\text { Backlog Waste Reassessment Baseline } \\
\text { Book. }\end{array}$ & $\begin{array}{l}\text { The Backlog Baseline Book provides RCRA } \\
\text { characterizations and associated rationales for } \\
\text { wastes stored at RF. Good source of process } \\
\text { descriptions. }\end{array}$ & 1995. \\
\hline P053 & $\begin{array}{l}\text { (Tasks } 3 \text { \& } 4 \text { Final Draft Report) } \\
\text { Reconstruction of Historical Rocky Flats } \\
\text { Operations and ldentification of Release } \\
\text { Points. }\end{array}$ & $\begin{array}{l}\text { Excellent historical description of Rocky Flats } \\
\text { operations. }\end{array}$ & 1992. \\
\hline P054 & $\begin{array}{l}\text { Handling Miscellaneous Wastes in Size } \\
\text { Reduction, Building } 776 \text {. WO-4016-E. }\end{array}$ & $\begin{array}{l}\text { Describes wastes treated in Size Reduction and } \\
\text { secondary wastes generated from the waste } \\
\text { treatment activities. }\end{array}$ & 1988. \\
\hline P055 & $\begin{array}{l}\text { Inspection of Raschig Rings in Contaminated } \\
\text { Tanks }(U) \text {. CO-3002. }\end{array}$ & $\begin{array}{l}\text { Procedural requirements for inspecting Raschig } \\
\text { rings including taking ring samples. }\end{array}$ & 1988. \\
\hline P056 & $\begin{array}{l}\text { Removal and Replacement of Raschig Rings } \\
\text { (U). CO-3001. }\end{array}$ & $\begin{array}{l}\text { Procedural requirements for removal of } \\
\text { Raschig rings from tanks. }\end{array}$ & 1989. \\
\hline P057 & $\begin{array}{l}\text { Operational Safety Analysis (OSA). } \\
\text { Raschig Ring Inspection, Removal, and } \\
\text { Replacement. } 771.037 \text {. }\end{array}$ & $\begin{array}{l}\text { Operational safety analysis for Raschig ring } \\
\text { inspection, removal, and replacement. }\end{array}$ & 1989. \\
\hline P058 & $\begin{array}{l}\text { Rocky Flats Plant Hazardous Waste } \\
\text { Determination Status Report No. } 2 .\end{array}$ & $\begin{array}{l}\text { Preliminary characterization data for residues. } \\
\text { Published in } 1991 .\end{array}$ & 1991. \\
\hline P059 & $\begin{array}{l}\text { Graphite Process Operations in Building } 707 . \\
\text { FO-0015. }\end{array}$ & Description of used graphite mold processing. & 1991. \\
\hline P060 & $\begin{array}{l}\text { Waste Stream and Residue Identification and } \\
\text { Characterization Building } 707.707-V_{3} .2 \text {. }\end{array}$ & $\begin{array}{l}\text { Process description, flow diagrams, and } \\
\text { descriptions for process outputs generated in } \\
\text { Building } 707 \text {. }\end{array}$ & 1992. \\
\hline P061 & $\begin{array}{l}\text { Waste Stream and Residue Identification and } \\
\text { Characterization Building } 771.771-\mathrm{V} 3.2 \text {. }\end{array}$ & $\begin{array}{l}\text { Process description, flow diagrams, and } \\
\text { descriptions for process outputs generated in } \\
\text { Building } 771 \text {. }\end{array}$ & 1992. \\
\hline P062 & $\begin{array}{l}\text { Waste Stream and Residue Identification and } \\
\text { Characterization Building } 779.779-\mathrm{V} 3.2 \text {. }\end{array}$ & $\begin{array}{l}\text { Process description, flow diagrams, and } \\
\text { descriptions for process outputs for Building } \\
779 \text {. }\end{array}$ & 1991. \\
\hline P063 & $\begin{array}{l}\text { Packaging Wastes for Shipment Offsite }(U) \text {. } \\
\text { WO-4034-C. }\end{array}$ & $\begin{array}{l}\text { Packaging requirements for transuranic and } \\
\text { low-level wastes at RFP. }\end{array}$ & 1986. \\
\hline P064 & $\begin{array}{l}\text { Waste Packaging Requirements. } \\
\text { Wo-4034-F. }\end{array}$ & $\begin{array}{l}\text { Packaging requirements for transuranic and } \\
\text { low-level wastes at RFP. }\end{array}$ & 1988. \\
\hline P065 & $\begin{array}{l}\text { Material Safety Data Sheet for Purifloc }(R) \\
\text { A23 Flocculant. }\end{array}$ & $\begin{array}{l}\text { Composition of precipitation flocculant used in } \\
\text { Building } 774 \text {. }\end{array}$ & $\begin{array}{c}1985 . \\
\text { March } 1 .\end{array}$ \\
\hline P066 & $\begin{array}{l}\text { Material Safety Data Sheet for } \\
\text { ENVIROSTONE (and related data). }\end{array}$ & $\begin{array}{l}\text { Composition of Envirostone products used in } \\
\text { the OASIS process. }\end{array}$ & $\begin{array}{r}1986 . \\
\text { May } 12 .\end{array}$ \\
\hline P067 & $\begin{array}{l}\text { Waste Stream Identification and } \\
\text { Characterization. }\end{array}$ & $\begin{array}{l}\text { Descriptions of Rocky Flats waste streams and } \\
\text { processes. }\end{array}$ & 1987. \\
\hline P068 & Chemical Safety Bulletins Building 81 - 83 . & $\begin{array}{l}\text { MSDS-like composition information for } \\
\text { chemicals at RFP. }\end{array}$ & 1962. \\
\hline P069 & $\begin{array}{l}\text { Nuclear Materials Control Elements printout. } \\
\text { SAN Database. Report No. 6016-01. }\end{array}$ & $\begin{array}{l}\text { Element coding in SAN for accountable nuclear } \\
\text { material. }\end{array}$ & $\begin{array}{l}1984 . \\
\text { Query date } \\
\text { June } 1 .\end{array}$ \\
\hline P070 & $\begin{array}{l}\text { Operational Safety Analysis (OSA). } \\
\text { Waste Receipt and Processing No. } 774.001 .\end{array}$ & $\begin{array}{l}\text { Contains treatment process descriptions from } \\
\text { Building } 774 \text {. }\end{array}$ & 1995. \\
\hline
\end{tabular}




\begin{tabular}{|l|l|l|l|l|}
\hline REF \# & TITLE & SUMMARY & DATE \\
\hline
\end{tabular}

\begin{tabular}{|c|c|c|c|}
\hline P071 & $\begin{array}{l}\text { Waste Receiving and Transferring, (Second } \\
\text { Stage) Bldg. } 774 \text {. WO-2026. }\end{array}$ & $\begin{array}{l}\text { Operating procedure for tanks associated with } \\
\text { 2nd stage treatment in Building } 774 \text {. }\end{array}$ & 1990. \\
\hline P072 & $\begin{array}{l}\text { EG\&G Rocky Flats Plant Waste Operations } \\
\text { Procedures Nuclear Safety Related Category } \\
\text { 3. TRU Organic Waste Sampling and } \\
\text { Transferring, Buildings } 707 \text { and } 777 \text {. } \\
\text { WO-2010. }\end{array}$ & $\begin{array}{l}\text { Operating procedure for pipeline transfers of } \\
\text { organic waste to Building } 774 \text {. }\end{array}$ & 1991. \\
\hline P073 & $\begin{array}{l}\text { Process Qualification Report for } \\
\text { Miscellaneous Waste Handling and } \\
\text { Solidification (Bottlebox) Building } 774 . \\
\text { A-008-LWTO. }\end{array}$ & $\begin{array}{l}\text { Process development information for IDC } \\
004 / 802 \text { waste. }\end{array}$ & 1993. \\
\hline P074 & $\begin{array}{l}\text { Plutonium Recovery Waste Collection } \\
\text { System, Building } 771 \text {. WO-4007-B. }\end{array}$ & $\begin{array}{l}\text { Information on collection and treatment of liquid } \\
\text { wastes from Building } 771 .\end{array}$ & 1988. \\
\hline P075 & $\begin{array}{l}\text { Liquid Waste Processing (First Stage). } \\
\text { WO-4001-A. }\end{array}$ & $\begin{array}{l}\text { Operating procedure for } 1 \text { st stage waste } \\
\text { treatment. }\end{array}$ & 1988. \\
\hline P076 & $\begin{array}{l}\text { Waste Stream Residue Identification and } \\
\text { Characterization Building 559. 559-V3.2. }\end{array}$ & $\begin{array}{l}\text { Process description, flow diagrams, and } \\
\text { descriptions for process outputs generated in } \\
\text { Building } 559 \text {. }\end{array}$ & 1991. \\
\hline P077 & $\begin{array}{l}\text { Waste Stream Residue Identification and } \\
\text { Characterization Building 774. 774-V3.2. }\end{array}$ & $\begin{array}{l}\text { Process description, flow diagrams, and } \\
\text { descriptions for process outputs generated in } \\
\text { Building } 774 \text {. }\end{array}$ & 1992. \\
\hline P078 & $\begin{array}{l}\text { Waste Stream Residue Identification and } \\
\text { Characterization Building 776. 776-V3.2. }\end{array}$ & $\begin{array}{l}\text { Process description, flow diagrams, and } \\
\text { descriptions for process outputs generated in } \\
\text { Building } 776 .\end{array}$ & 1992. \\
\hline P079 & $\begin{array}{l}\text { Waste Stream Residue Identification and } \\
\text { Characterization Building } 777.777-V 3.2 \text {. }\end{array}$ & $\begin{array}{l}\text { Process description, flow diagrams, and } \\
\text { descriptions for process outputs generated in } \\
\text { Building } 777 \text {. }\end{array}$ & 1992. \\
\hline P080 & $\begin{array}{l}\text { RCRA Land Disposal Restrictions: A Guide } \\
\text { to Compliance. } 1995 \text { Edition. The Hazardous } \\
\text { Waste Consultant. Vol. 12, Issue } 6 \text {. ISSN } \\
0738-0232 \text {. }\end{array}$ & $\begin{array}{l}\text { The document is a guidance and interpretation } \\
\text { book on RCRA regulations. Specifically, the } \\
\text { book provides guidance on assigning EPA } \\
\text { hazardous waste numbers and the applicability } \\
\text { of the land disposal restrictions. }\end{array}$ & $\begin{array}{c}1994 . \\
\text { October/November. }\end{array}$ \\
\hline P081 & $\begin{array}{l}\text { Waste Stream Residue Identification and } \\
\text { Characterization Building 371. } 371-\mathrm{V} 3.2 \text {. }\end{array}$ & $\begin{array}{l}\text { Process description, flow diagrams, and } \\
\text { descriptions for process outputs generated in } \\
\text { Building } 371 \text {. }\end{array}$ & 1992. \\
\hline P082 & $\begin{array}{l}\text { Waste Stream Residue Identification and } \\
\text { Characterization Building 374. } 374-\sqrt{ } 3.2 \text {. }\end{array}$ & $\begin{array}{l}\text { Process description, flow diagrams, and } \\
\text { descriptions for process outputs generated in } \\
\text { Building } 374 \text {. }\end{array}$ & 1992. \\
\hline P083 & $\begin{array}{l}\text { Waste Stream and Residue Identification and } \\
\text { Characterization Database. }\end{array}$ & $\begin{array}{l}\text { Rocky Flats waste stream information. } \\
\text { Originally gathered in } 1989-1990 .\end{array}$ & 1996. \\
\hline P084 & Material Safety Data Sheet for Varsol 1. & $\begin{array}{l}\text { Varsol is a trade name petroleum solvent or } \\
\text { Stoddard solvent. }\end{array}$ & $\begin{array}{c}1986 . \\
\text { August } 25 .\end{array}$ \\
\hline P085 & $\begin{array}{l}\text { Waste Systems Progress Report March } 1983 \\
\text { through February 1984. RFP-3682. }\end{array}$ & $\begin{array}{l}\text { Summary of waste treatment technology } \\
\text { development for transuranic wastes. }\end{array}$ & 1984. \\
\hline P086 & $\begin{array}{l}\text { Neptunium Processing at the Rocky Flats } \\
\text { Plant. RFP-2899. }\end{array}$ & $\begin{array}{l}\text { Summary of neptunium- } 237 \text { processing at } \\
\text { Rocky Flats. }\end{array}$ & 1981. \\
\hline P087 & $\begin{array}{l}\text { Nondestructive Radioassay for Waste } \\
\text { Management - An Assessment. RFP-3256. }\end{array}$ & $\begin{array}{l}\text { History of waste radioassay at Rocky Flats } \\
\text { from } 1964 \text { to } 1981 .\end{array}$ & 1981. \\
\hline P088 & Glovebox Window Materials. RFP-1424. & $\begin{array}{l}\text { Information regarding glovebox window and } \\
\text { window adhesive materials used at Rocky Flats } \\
\text { in } 1970 .\end{array}$ & 1970. \\
\hline
\end{tabular}




\begin{tabular}{|c|c|c|c|}
\hline REF \# & TITLE & SUMMARY & DATE \\
\hline P089 & $\begin{array}{l}\text { Waste Systems Progress Report March } 1984 \\
\text { through February 1985. RFP-3871. }\end{array}$ & $\begin{array}{l}\text { Summary of waste treatment technology } \\
\text { development for transuranic waste. }\end{array}$ & 1986. \\
\hline P090 & $\begin{array}{l}\text { History of Rocky Flats Waste Streams. } \\
\text { RFP-3186. }\end{array}$ & $\begin{array}{l}\text { History of Rocky Flats waste shipped to the } \\
\text { INEL from } 1971 \text { to } 1979 .\end{array}$ & 1982. \\
\hline P091 & Materials Hazards Manual. & $\begin{array}{l}\text { Hazards and composition of chemicals used at } \\
\text { Rocky Flats. }\end{array}$ & 1976. \\
\hline P092 & $\begin{array}{l}\text { Residue Dissolution (Lines } 23 \text { and 25) (U). } \\
\text { CO-1026-T/0. }\end{array}$ & $\begin{array}{l}\text { Process procedure for dissolution of pulverized } \\
\text { incinerator ash, graphite, sand, slag, and } \\
\text { crucible, along with the resultant heels. }\end{array}$ & 1988. \\
\hline $\mathrm{P} 093$ & $\begin{array}{l}\text { Residue Dissolution, Gloveboxes } 1500 \mathrm{~A}, \\
1500 \mathrm{~B} \text {, and 1515, Building } 371(\mathrm{U}) \\
\mathrm{CO}-1130-\mathrm{B} / 0 .\end{array}$ & $\begin{array}{l}\text { Process procedure for dissolution of incinerator } \\
\text { ash in Building } 371 .\end{array}$ & 1988. \\
\hline P094 & $\begin{array}{l}\text { Special Recovery Operation General } \\
\text { Procedures }(U) \text {. CO-2018-E/O. }\end{array}$ & $\begin{array}{l}\text { General procedures for tank and powder } \\
\text { sampling in the Special Recovery area of } \\
\text { Building } 771 .\end{array}$ & 1988. \\
\hline P095 & $\begin{array}{l}\text { Plutonium-Neptunium Separation }(U) \text {. } \\
\text { CO-2017-B/0. }\end{array}$ & $\begin{array}{l}\text { Procedures for processing plutonium- } \\
\text { neptunium mixtures including oxide dissolution, } \\
\text { feed preparation, wash preparation, ion column } \\
\text { operations, and product evaporation. }\end{array}$ & 1987. \\
\hline P096 & $\begin{array}{l}\text { Operating the lon Columns (Special } \\
\text { Recovery, Line MT-4) (U). CO-2010. }\end{array}$ & $\begin{array}{l}\text { Operating procedures for the Special Recovery } \\
\text { ion column system. }\end{array}$ & 1989. \\
\hline P097 & $\begin{array}{l}\text { HSA Incineration System Scarfing and } \\
\text { Grinding }(U) \text {. CO-6017-C. }\end{array}$ & $\begin{array}{l}\text { Procedures for scarfing of graphite and } \\
\text { firebrick in Building } 371 .\end{array}$ & 1984. \\
\hline P098 & Resin Cementing Line $2(U)$. CO-1027. & $\begin{array}{l}\text { Operating procedures for the cementation of } \\
\text { resin, sludge, grit, ash, and heel in Building } \\
771 \text {. }\end{array}$ & 1988. \\
\hline P099 & $\begin{array}{l}\text { Molten Salt (8\%) Residue Process (Line 30) } \\
\text { (U). CO-1012-G. }\end{array}$ & $\begin{array}{l}\text { Operational procedure for dissolution of } 8 \% \\
\text { magnesium chloride molten salt in Building } \\
771 \text {. }\end{array}$ & 1978. \\
\hline P100 & $\begin{array}{l}\text { Leaching Tantalum Fixtures and Inserts (Line } \\
\text { 5) (U). CO-1019-KNo. }\end{array}$ & $\begin{array}{l}\text { Operating procedure for acid leaching to } \\
\text { remove plutonium from tantalum fixtures in } \\
\text { Building } 771 \text {. }\end{array}$ & 1988. \\
\hline P101 & $\begin{array}{l}\text { Modified Purex Solvent Extraction Process } \\
\text { (Special Recovery; Lines MT-3, MT-7) (U). } \\
\text { CO-2005-KO. }\end{array}$ & $\begin{array}{l}\text { Operational procedure for organic/aqueous } \\
\text { solvent extraction of uranium from plutonium in } \\
\text { the special recovery area of Building } 771 \text {. }\end{array}$ & 1988. \\
\hline $\mathrm{P} 102$ & $\begin{array}{l}\text { Anion Exchange (Lines } 42 \text { and } 43 D \text { ) (U). } \\
\text { CO-1033-AAV. }\end{array}$ & $\begin{array}{l}\text { Operating procedure for plutonium nitrate } \\
\text { solution purification using anion exchange resin } \\
\text { in Building } 771 \text {. }\end{array}$ & 1988. \\
\hline P103 & $\begin{array}{l}\text { Sand, Slag, and Crucible Size Reduction, } \\
\text { Lines } 43 A \text { and } C(U) \text {. CO-1005-J/0. }\end{array}$ & $\begin{array}{l}\text { Operating procedure for crushing and grinding } \\
\text { sand, slag, and crucible generated in the } \\
\text { reduction process during plutonium metal } \\
\text { production. }\end{array}$ & 1988. \\
\hline P104 & $\begin{array}{l}\text { Scarfing Graphite (Line 43A) (U). } \\
\text { CO-1076-D. }\end{array}$ & $\begin{array}{l}\text { Operating procedure for scarfing graphite in } \\
\text { Building } 771 \text {. }\end{array}$ & 1988. \\
\hline P105 & $\begin{array}{l}\text { Operational Safety Analysis (OSA). } \\
\text { Special Recovery lon Exchange. } 771.047 .\end{array}$ & $\begin{array}{l}\text { Operational safety analysis for ion exchange } \\
\text { separation of actinides in the Special Recovery } \\
\text { area of Building } 771 .\end{array}$ & 1989. \\
\hline P106 & $\begin{array}{l}\text { Waste Stream Residue Identification and } \\
\text { Characterization Building 374. 374-V5.0. }\end{array}$ & $\begin{array}{l}\text { Process description, flow diagrams, and } \\
\text { descriptions for process outputs generated in } \\
\text { Building } 374 \text {. }\end{array}$ & 1993. \\
\hline P107 & $\begin{array}{l}\text { Waste Stream Residue Identification and } \\
\text { Characterization Building 559. 559-V5.0. }\end{array}$ & $\begin{array}{l}\text { Process description, flow diagrams, and } \\
\text { descriptions for process outputs generated in } \\
\text { Building } 559 \text {. }\end{array}$ & 1993. \\
\hline
\end{tabular}




\begin{tabular}{|l|l|l|l|l|}
\hline REF \# & TITLE & SUMMARY & DATE \\
\hline
\end{tabular}

\begin{tabular}{|c|c|c|c|}
\hline P108 & $\begin{array}{l}\text { Waste Stream and Residue Identification and } \\
\text { Characterization Building 707. 707-V5.0. }\end{array}$ & $\begin{array}{l}\text { Process description, flow diagrams, and } \\
\text { descriptions for process outputs generated in } \\
\text { Building } 707 \text {. }\end{array}$ & 1995. \\
\hline P109 & $\begin{array}{l}\text { Waste Stream Residue Identification and } \\
\text { Characterization Building 774. 774-V5.0. }\end{array}$ & $\begin{array}{l}\text { Process description, flow diagrams, and } \\
\text { descriptions for process outputs generated in } \\
\text { Building } 774 \text {. }\end{array}$ & 1993. \\
\hline P110 & $\begin{array}{l}\text { Waste Stream Residue Identification and } \\
\text { Characterization Building 776. 776-V5.0. }\end{array}$ & $\begin{array}{l}\text { Process description, flow diagrams, and } \\
\text { descriptions for process outputs generated in . } \\
\text { Building } 776 \text {. }\end{array}$ & 1993. \\
\hline P111 & $\begin{array}{l}\text { Waste Stream Residue Identification and } \\
\text { Characterization Building } 777.777-V 5.0 \text {. }\end{array}$ & $\begin{array}{l}\text { Process description, flow diagrams, and } \\
\text { descriptions for process outputs generated in } \\
\text { Building } 777 \text {. }\end{array}$ & 1992. \\
\hline P112 & $\begin{array}{l}\text { Waste Stream and Residue Identification and } \\
\text { Characterization Building 779. } 779 \text {-V5.0. }\end{array}$ & $\begin{array}{l}\text { Process description, flow diagrams, and } \\
\text { descriptions for process outputs for Building } \\
779 \text {. }\end{array}$ & 1991. \\
\hline P113 & Actinide Processing at Rocky Flats. & $\begin{array}{l}\text { Detailed description of actinide recovery and } \\
\text { waste treatment at Rocky Flats }\end{array}$ & 1991. \\
\hline P114 & $\begin{array}{l}\text { Federal Facilities Compliance Agreement } \\
\text { Compliant Order Storage Report. }\end{array}$ & $\begin{array}{l}\text { Information on Rocky Flats LDR wastes as } \\
\text { compiled in } 1989 \text { and } 1990 \text { including process } \\
\text { descriptions and inventories. }\end{array}$ & 1990. \\
\hline P115 & $\begin{array}{l}\text { Solid Waste Information Management } \\
\text { System Database. }\end{array}$ & $\begin{array}{l}\text { Container information for transuranic waste } \\
\text { shipped to INEL from Rocky Flats } 1985 \text { through } \\
1989 .\end{array}$ & \\
\hline P116 & $\begin{array}{l}\text { Federal Facilities Compliance } \\
\text { Agreement/Compliance Order Inventory } \\
\text { Report. }\end{array}$ & $\begin{array}{l}\text { Process descriptions and inventories for Rocky } \\
\text { Flats mixed waste that was not LDR in } 1989 .\end{array}$ & 1989. \\
\hline P117 & $\begin{array}{l}\text { Sorting and Scarfing Firebrick (Line 48) (U). } \\
\text { CO-1039-D. }\end{array}$ & $\begin{array}{l}\text { Operating procedure for sorting and scarfing } \\
\text { firebrick from the Building } 771 \text { incinerator. }\end{array}$ & 1988. \\
\hline P118 & $\begin{array}{l}\text { Material Safety Data Sheet for Supertemp } \\
\text { 1900/Ramcote } 1200 \text {. }\end{array}$ & $\begin{array}{l}\text { MSDS for cement referred to as pipe insulation } \\
\text { or magnesia cement. }\end{array}$ & $\begin{array}{c}1991 . \\
\text { January. }\end{array}$ \\
\hline P119 & $\begin{array}{l}\text { Material Safety Data Sheet for Metex } \\
\text { Chemicals. }\end{array}$ & $\begin{array}{l}\text { Composition of Metex-series chemicals used at } \\
\text { Rocky Flats. Metex solution is referenced in the } \\
\text { Building } 774 \text { setup log book (U043). It is } \\
\text { unclear which Metex product was treated. }\end{array}$ & $1985-1986$ \\
\hline P120 & $\begin{array}{l}\text { Flammability of Leaded Dry-Box Gloves. } \\
\text { RFP-1354. }\end{array}$ & $\begin{array}{l}\text { Results of a study of the reaction of nitric acid } \\
\text { with neoprene and Hypalon leaded gloves. }\end{array}$ & 1969. \\
\hline P121 & $\begin{array}{l}\text { Waste Characterization Report Heavy } \\
\text { Metals. Item Description Code } 320 \text {. }\end{array}$ & $\begin{array}{l}\text { Description of the heavy metal inventory (IDC } \\
\text { 320) of Rocky Flats. }\end{array}$ & 1993. \\
\hline P122 & $\begin{array}{l}\text { Document title unknown. Exhibit } 1 \text { excerpt. } \\
\text { RFP-2487. }\end{array}$ & $\begin{array}{l}\text { Excerpt from RFP-4148-results of the analysis } \\
\text { of } 774 \text { sludge samples. }\end{array}$ & Date unknown \\
\hline P123 & $\begin{array}{l}\text { Packaging Rocky Flats Waste. Radioactive } \\
\text { Waste. RFP } 2487 .\end{array}$ & $\begin{array}{l}\text { Packaging of liquid and solid treated wastes at } \\
\text { Rocky Flats. }\end{array}$ & $\begin{array}{c}1976 . \\
\text { May } 17 .\end{array}$ \\
\hline P124 & $\begin{array}{l}\text { A Survey of the Rocky Flats Division Waste } \\
\text { Streams. CRDL-950351-009. }\end{array}$ & $\begin{array}{l}\text { Source, volume, composition, and disposition } \\
\text { of aqueous and solid waste streams and air } \\
\text { emissions from Rocky Flats Plant. }\end{array}$ & $\begin{array}{l}1972 . \\
\text { June } 30 .\end{array}$ \\
\hline $\mathrm{P} 125$ & $\begin{array}{l}\text { Waste Stream and Residue Identification and } \\
\text { Characterization Sampling and Analysis } \\
\text { Database. }\end{array}$ & $\begin{array}{l}\text { Analytical data from WSRIC waste stream } \\
\text { sampling and sampling of Rocky Flats } \\
\text { inventory waste. }\end{array}$ & 1992. \\
\hline P126 & $\begin{array}{l}\text { Waste Stream and Residue Identification and } \\
\text { Characterization Building Valve Vaults. }\end{array}$ & $\begin{array}{l}\text { Describes the aqueous process wastes from } \\
\text { various buildings on plant site that are sent to } \\
\text { Building } 374 \text { through the process waste transfer } \\
\text { system. }\end{array}$ & 1993. \\
\hline
\end{tabular}




\begin{tabular}{|l|l|l|l|}
\hline REF \# & TITLE & SUMMARY & DATE \\
\hline
\end{tabular}

\begin{tabular}{|c|c|c|c|}
\hline P127 & INEL SWEPP Track Accessible Database. & $\begin{array}{l}\text { INEL accessible drum storage data for Rocky } \\
\text { Flats inventory, including number of containers } \\
\text { and dates of generation. }\end{array}$ & 1996. \\
\hline P128 & Material Safety Data Sheet for Mariko. & & $\begin{array}{c}1986 . \\
\text { September } 11 .\end{array}$ \\
\hline $\mathrm{P} 129$ & Material Safety Data Sheet for OX-Out 536. & & $\begin{array}{r}1986 . \\
\text { May } 5 . \\
\end{array}$ \\
\hline P130 & Material Safety Data Sheet for TRIM SOL. & & $\begin{array}{c}1992 . \\
\text { February } 27 .\end{array}$ \\
\hline P131 & $\begin{array}{l}\text { Waste Analysis At Facilities That Generate, } \\
\text { Treat, Store, and Dispose of Hazardous } \\
\text { Wastes. A Guidance Manual. PB94-963603. } \\
\text { OSWER 9938.4-03 }\end{array}$ & $\begin{array}{l}\text { EPA Guidance for Waste Analysis and when } \\
\text { acceptable knowledge should be used. }\end{array}$ & $\begin{array}{l}1994 . \\
\text { April. }\end{array}$ \\
\hline $\mathrm{P} 132$ & $\begin{array}{l}\text { Predecisional Draft Transuranic Waste } \\
\text { Characterization Acceptable Knowledge } \\
\text { Guidance Document. R-6078 } \\
\end{array}$ & $\begin{array}{l}\text { Guidance document for the use of acceptable } \\
\text { knowledge. }\end{array}$ & $\begin{array}{l}1995 . \\
\text { August. }\end{array}$ \\
\hline P133 & $\begin{array}{l}\text { Quality Assurance Program Description. } \\
\text { CAO-94-1012 }\end{array}$ & $\begin{array}{l}\text { Quality management document which identifies } \\
\text { federal and industry quality requirements } \\
\text { applicable to the CAO quality assurance } \\
\text { program. }\end{array}$ & $\begin{array}{l}1994 . \\
\text { June. }\end{array}$ \\
\hline $\mathrm{P} 134$ & $\begin{array}{l}\text { Waste Isolation Pilot Plant RCRA Part B } \\
\text { Permit Application. Appendix C9, TRU Waste } \\
\text { Characterization Using Acceptable } \\
\text { Knowledge. DOEMIPP 91-005. }\end{array}$ & $\begin{array}{l}\text { Methodology for the use of Acceptable } \\
\text { Knowledge. }\end{array}$ & $\begin{array}{c}1996 . \\
\text { January } 15 .\end{array}$ \\
\hline P135 & $\begin{array}{l}\text { Guidance For Preparing Transuranic Waste } \\
\text { Sampling Plans (Draft). R-6157 }\end{array}$ & $\begin{array}{l}\text { Guidance on how to develop site-specific } \\
\text { sampling plans. }\end{array}$ & $\begin{array}{c}1995 . \\
\text { November. }\end{array}$ \\
\hline $\mathrm{P} 136$ & $\begin{array}{l}\text { Guidance For Preparing Transuranic Waste } \\
\text { Sampling Plans. R-6157 }\end{array}$ & $\begin{array}{l}\text { Guidance on how to develop site-specific } \\
\text { sampling plans. }\end{array}$ & $\begin{array}{c}1996 . \\
\text { February. }\end{array}$ \\
\hline $\mathrm{P} 137$ & $\begin{array}{l}\text { Transuranic Waste Characterization Quality } \\
\text { Assurance Program Plan. CAO-94-1010. }\end{array}$ & $\begin{array}{l}\text { Identifies the quality of data necessary and } \\
\text { techniques designed to attain and ensure the } \\
\text { required quality to meet WIPP-DQOs. }\end{array}$ & $\begin{array}{l}1995 . \\
\text { April } 30 .\end{array}$ \\
\hline P137A & $\begin{array}{l}\text { Transuranic Waste Characterization Quality } \\
\text { Assurance Program Plan. CAO-94-1010. }\end{array}$ & $\begin{array}{l}\text { Identifies the quality of data necessary and } \\
\text { techniques designed to attain and ensure the } \\
\text { required quality to meet WIPP-DQOs. }\end{array}$ & $\begin{array}{c}1996 . \\
\text { November } 15 .\end{array}$ \\
\hline P138 & $\begin{array}{l}\text { Waste Acceptance Criteria For The Waste } \\
\text { Isolation Pilot Plant. DOEMVIPP-069 }\end{array}$ & Waste acceptance criteria for WIPP. & $\begin{array}{c}1996 . \\
\text { January. }\end{array}$ \\
\hline P139 & $\begin{array}{l}\text { Reactivity of Pyrochemical Salts at Rocky } \\
\text { Flats Plant. 14-RF-04701. }\end{array}$ & $\begin{array}{l}\text { Review of the reactivity characterization of } \\
\text { pyrochemical salts. }\end{array}$ & $\begin{array}{l}1994 . \\
\text { April. }\end{array}$ \\
\hline P140 & $\begin{array}{l}\text { Analytical Methods for Determining the } \\
\text { Reactivity of Pyrochemical Salts. } \\
\text { TDR-94-011. }\end{array}$ & $\begin{array}{l}\text { Methods developed to analyze pyrochemical } \\
\text { salts for reactivity; includes description of } \\
\text { metals in pyrochemical salts. }\end{array}$ & 1994. \\
\hline P141 & $\begin{array}{l}\text { Engineering Design File. Matrix Parameter } \\
\text { Category Groups (MPCG). } \\
\text { RWMC-805/INEL-95/029. } \\
\end{array}$ & $\begin{array}{l}\text { Groups the waste streams stored in the } \\
\text { Transuranic Storage Area at the Radioactive } \\
\text { Waste Management Complex into MPCGs. }\end{array}$ & 1994. \\
\hline P142 & $\begin{array}{l}\text { Material Safety Data Sheet for } Z L-22 A \text { Zyglo } \\
\text { Penetrant. }\end{array}$ & Zyglo Penetrant MSDS. & $\begin{array}{c}1993 . \\
\text { June } 14 .\end{array}$ \\
\hline P143 & $\begin{array}{l}\text { Material Safety Data Sheet for Developer } \\
\text { Fluid Contained in Film Pod. }\end{array}$ & Developer Fluid contained in film pod MSDS. & $\begin{array}{c}1986 . \\
\text { February } 10 .\end{array}$ \\
\hline P144 & $\begin{array}{l}\text { Material Safety Data Sheet for KODAK } \\
\text { Developer D-19. CAT } 1464593 \text {, } \\
\text { CAT } 1946045 .\end{array}$ & Kodak Developer D-19 MSDS. & $\begin{array}{c}1984 . \\
\text { March } 14 .\end{array}$ \\
\hline
\end{tabular}




\begin{tabular}{|l|l|l|l|}
\hline REF \# & TITLE & SUMMARY & DATE \\
\hline
\end{tabular}

\begin{tabular}{|c|c|c|c|}
\hline P145 & $\begin{array}{l}\text { Material Safety Data Sheet for KODAK } \\
\text { INDUSTREX Developer Replenisher, Part A. } \\
\text { CAT } 1397215 .\end{array}$ & Kodak INDUSTREX Replenisher MSDS. & $\begin{array}{c}1985 . \\
\text { January } 3 .\end{array}$ \\
\hline P146 & $\begin{array}{l}\text { Material Safety Data Sheet for KODAK } \\
\text { INDUSTREX Developer Starter. } \\
\text { CAT } 1628528 .\end{array}$ & Kodak INDUSTREX Starter MSDS. & $\begin{array}{l}1984 . \\
\text { August } 27 .\end{array}$ \\
\hline $\mathrm{P} 147$ & $\begin{array}{l}\text { Material Safety Data Sheet for KODAK HRP } \\
\text { Developer. CAT } 1401306 .\end{array}$ & Kodak HRP Developer MSDS. & $\begin{array}{c}1984 . \\
\text { June } 25 .\end{array}$ \\
\hline P148 & $\begin{array}{l}\text { Material Safety Data Sheet for KODAK RP X- } \\
\text { OMAT Developer Replenisher. }\end{array}$ & Kodak RP X-OMAT MSDS. & $\begin{array}{c}1985 . \\
\text { December } 31 .\end{array}$ \\
\hline P149 & $\begin{array}{l}\text { Material Safety Data Sheet for ZE-3 Zyglo } \\
\text { Emulsifier. }\end{array}$ & Zyglo Emulsifier MSDS. & $\begin{array}{c}1991 . \\
\text { December } 5 .\end{array}$ \\
\hline $\mathrm{P} 150$ & $\begin{array}{l}\text { Material Safety Data Sheet for ZP-5 Zyglo } \\
\text { Aqueous Developer. }\end{array}$ & Zyglo Aqueous Developer MSDS. & $\begin{array}{c}1991 . \\
\text { December } 5 .\end{array}$ \\
\hline P151 & $\begin{array}{l}\text { Safety Analysis Report for the TRUPACT-II } \\
\text { Shipping Package. Appendix C, Volume } 4 .\end{array}$ & $\begin{array}{l}\text { Appendix } 3.6 .8 \text { - radiolytic } G \text { values for waste } \\
\text { materials. }\end{array}$ & $\begin{array}{c}1994 . \\
\text { October. }\end{array}$ \\
\hline $\mathrm{P} 152$ & $\begin{array}{l}\text { "Plutonium Metal Feed Specification for Use } \\
\text { in the Weapons Program." Volume I. }\end{array}$ & $\begin{array}{l}\text { Metallurgical, chemical, and isotopic } \\
\text { specifications for Rocky Flats WR Plutonium } \\
\text { (nonspecification plutonium definition). }\end{array}$ & $\begin{array}{l}1985 . \\
\text { March } 22 .\end{array}$ \\
\hline P153 & $\begin{array}{l}\text { Analytical Requirement Review of Saltcrete. } \\
\text { Item Description Code } 804 . \\
\text { 96-RMRS-SSOC-0004. }\end{array}$ & $\begin{array}{l}\text { Analytical requirements for saltcrete for LDR } \\
\text { regulations. }\end{array}$ & $\begin{array}{c}1996 . \\
\text { February } 20 .\end{array}$ \\
\hline P154 & $\begin{array}{l}\text { Uncertainty Analysis of the SWEPP Drum } \\
\text { Assay System for Graphite. } \\
\text { Content Code } 300 \text {. INEL-95/0475. }\end{array}$ & $\begin{array}{l}\text { Describes the methodology for determining the } \\
\text { total uncertainty of the SWEPP drum assay } \\
\text { system for graphite content code } 300 \text {. }\end{array}$ & $\begin{array}{l}1995 . \\
\text { September. }\end{array}$ \\
\hline P155 & $\begin{array}{l}\text { Uncertainty Analysis of the SWEPP PAN } \\
\text { Assay. System for Glass Waste. } \\
\text { Content Codes } 440,441 \text {, and } 442 . \\
\text { INEL-96/0343. }\end{array}$ & $\begin{array}{l}\text { Describes the methodology for determining the } \\
\text { total uncertainty of the SWEPP drum assay } \\
\text { system for glass waste, content codes } 440 \text {, } \\
441 \text {, and } 442 \text {. }\end{array}$ & $\begin{array}{c}1996 . \\
\text { October. }\end{array}$ \\
\hline P156 & $\begin{array}{l}\text { Uncertainty Analysis of the SWEPP PAN } \\
\text { Assay System for Combustible Waste. } \\
\text { Content Codes } 330 \text { and } 336 \text {. INEL-96/0257. }\end{array}$ & $\begin{array}{l}\text { Describes the methodology for determining the } \\
\text { total uncertainty of the SWEPP drum assay } \\
\text { system for combustible waste, content codes } \\
330 \text { and } 336 \text {. }\end{array}$ & $\begin{array}{l}1996 . \\
\text { August. }\end{array}$ \\
\hline P157 & $\begin{array}{l}\text { Proceedings of the Non-Destructive Assay } \\
\text { and Non-Destructive Examination Waste } \\
\text { Characterization Conference. } \\
\text { CONF-940216. }\end{array}$ & $\begin{array}{l}\text { Experience gained from Passive/Active Neutron } \\
\text { (PAN) assay managements on } 12,600 \text { TRU } \\
\text { waste drums at INEL LV East, G.K. Becker; } \\
\text { Second Generation PAN. }\end{array}$ & $\begin{array}{l}1994 . \\
\text { February. }\end{array}$ \\
\hline P158 & $\begin{array}{l}\text { Matrix Effects in TRU Assays using the } \\
\text { SWEPP PAN Assay System. } \\
\text { EGG-PHY-9204. }\end{array}$ & $\begin{array}{l}\text { DAS (Drum Assay System) study of DAN } \\
\text { system results of } 50,000 \text { drums of TRU waste } \\
\text { from RFP. Active assay matrix dependent } \\
\text { correlation factors for many IDCs. }\end{array}$ & $\begin{array}{l}1990 . \\
\text { August. }\end{array}$ \\
\hline P159 & $\begin{array}{l}\text { SWEPP Non-Destructive Assay (NDA) } \\
\text { Methodology for Waste Entrained Uranium. } \\
\text { RWMC-657. }\end{array}$ & $\begin{array}{l}\text { Describes the process used to quantify } \mathrm{U}^{238} \text { in } \\
\text { waste using PAN. }\end{array}$ & $\begin{array}{c}1993 . \\
\text { September } 1 .\end{array}$ \\
\hline P160 & $\begin{array}{l}\text { Relative Isotopic Mass Ratio Gamma } \\
\text { Measurements. RWMC-EDF-533. }\end{array}$ & $\begin{array}{l}\text { Describes the technique used for radionuclide } \\
\text { identification and the determination of relative } \\
\text { isotopic mass ratios in wastes in SWEPP. }\end{array}$ & $\begin{array}{l}1994 . \\
\text { June } 28 .\end{array}$ \\
\hline P161 & $\begin{array}{l}\text { Dose Reconstruction Project Task } 5 . \\
\text { Estimating Historical Emissions from Rocky } \\
\text { Flats. }\end{array}$ & $\begin{array}{l}\text { Development of estimates for routine } \\
\text { radioactive airborne emissions, routine } \\
\text { nonradioactive airborne emissions, routine } \\
\text { surface-water-borne emissions, and Nonroutine } \\
\text { contaminant releases. }\end{array}$ & $\begin{array}{l}1992 . \\
\text { November. }\end{array}$ \\
\hline
\end{tabular}




\begin{tabular}{|l|l|l|l|}
\hline REF \# & TITLE & SUMMARY & DATE \\
\hline
\end{tabular}

\begin{tabular}{|c|c|c|c|}
\hline P162 & $\begin{array}{l}\text { Dose Reconstruction Project Task } 1 . \\
\text { Identification of Chemicals and } \\
\text { Radionuclides Used at Rocky Flats, Draft } \\
\text { Report. }\end{array}$ & $\begin{array}{l}\text { Preparation of a list of the radionuclides and } \\
\text { chemicals that have been used or produced at } \\
\text { Rocky Flats since } 1952 \text {. }\end{array}$ & $\begin{array}{l}1991 . \\
\text { January. }\end{array}$ \\
\hline P163 & $\begin{array}{l}\text { Rocky Flats Plant Plutonium Recovery } \\
\text { Reference Process. (Including Historical } \\
\text { References } 1952 \text { to 1991). RT92-002 }\end{array}$ & Plutonium recovery at Rocky Flats. & $\begin{array}{l}1992 . \\
\text { February } 3 .\end{array}$ \\
\hline P164 & $\begin{array}{l}\text { A History of the Rocky Flats } \\
\text { Plutonium/Actinide Recovery Plant, 1952- } \\
\text { 1991. RT92-003 }\end{array}$ & $\begin{array}{l}\text { Actinide recovery at Rocky Flats; includes } \\
\text { plutonium, americium, uranium, neptunium, } \\
\text { and curium processes. }\end{array}$ & $\begin{array}{c}1992 . \\
\text { February } 3 .\end{array}$ \\
\hline P165 & $\begin{array}{l}\text { A Comprehensive History of the Rocky Flats } \\
\text { Plutonium/Actinide Recovery Operations. } \\
\text { 1952-1991 (Draft). }\end{array}$ & $\begin{array}{l}\text { A more comprehensive version of "A History of } \\
\text { the Rocky Flats Plutonium/Actinide Recovery } \\
\text { Plant". }\end{array}$ & Unknown. \\
\hline P166 & $\begin{array}{l}\text { Rocky Flats Risk Assessment Guide. } \\
\text { RF/03/00/85/0/5 }\end{array}$ & $\begin{array}{l}\text { Methodologies used to determine risk of } \\
\text { facilities and operations at the Rocky Flats } \\
\text { Plant. }\end{array}$ & $\begin{array}{l}1985 . \\
\text { March. }\end{array}$ \\
\hline P167 & $\begin{array}{l}\text { Neptunium Processing at the Rocky Flats } \\
\text { Plant. RFP-2899 }\end{array}$ & $\begin{array}{l}\text { Processes used at Rocky Flats to recover and } \\
\text { purify neptunium and processes used for } \\
\text { conversion to metal for casting and rolling. }\end{array}$ & $\begin{array}{c}1981 . \\
\text { September } 20 .\end{array}$ \\
\hline P168 & $\begin{array}{l}\text { Status of Americium-241 Recovery at Rocky } \\
\text { Flats Plant. RFP-3061. }\end{array}$ & Extraction of americium 241 by MSE. & $\begin{array}{c}1981 . \\
\text { March } 18 .\end{array}$ \\
\hline P169 & Plutonium Isotopic Ratios at Rocky Flats. & $\begin{array}{l}\text { Inventory of plutonium fallout from mass } \\
\text { spectroscopic analysis of plutonium recovered } \\
\text { from soil around Rocky Flats. }\end{array}$ & $\begin{array}{c}1990 . \\
\text { November } 16 .\end{array}$ \\
\hline P170 & $\begin{array}{l}\text { The Past } 30 \text { Years at Rocky Flats Plant. } \\
\text { HS371. }\end{array}$ & $\begin{array}{l}\text { A summary of experiences and observations at } \\
\text { Rocky Flats Plant over the past } 30 \text { years with } \\
\text { an emphasis on health and safety. }\end{array}$ & $\begin{array}{l}1982 . \\
\text { November. }\end{array}$ \\
\hline P171 & $\begin{array}{l}\text { Evaluation of Residue Drum Storage Safety } \\
\text { Risks. RFP-4826, UC-721, DOE/OSTI-4500. }\end{array}$ & $\begin{array}{l}\text { Potential safety problems of packaged drums at } \\
\text { Rocky Flats. }\end{array}$ & $\begin{array}{l}1994 . \\
\text { June } 17 .\end{array}$ \\
\hline P172 & $\begin{array}{l}\text { Standard for Cylindrical HEPA Filters. } \\
\text { SMU-404. }\end{array}$ & $\begin{array}{l}\text { Standard for cylindrical shaped, fire resistant, } \\
\text { water resistant, high efficiency particulate air } \\
\text { (HEPA) filter units. }\end{array}$ & $\begin{array}{c}1974 . \\
\text { February } 1 .\end{array}$ \\
\hline P173 & $\begin{array}{l}\text { Standard for HEPA Filters, General Purpose. } \\
\text { SMU-401. }\end{array}$ & $\begin{array}{l}\text { Standard for square and rectangular shaped, } \\
\text { fire resistant, water resistant, high efficiency } \\
\text { particulate air (HEPA) filter units.. }\end{array}$ & $\begin{array}{l}1974 . \\
\text { February. }\end{array}$ \\
\hline P174 & Building 374 Evaporator Feed Streams. & $\begin{array}{l}\text { Identifies waste that is treated in the } \\
\text { evaporation process at Building } 374 \text {. Drawings } \\
\text { referenced in the table are not included. }\end{array}$ & $\begin{array}{l}1992 . \\
\text { April } 21 .\end{array}$ \\
\hline P175 & $\begin{array}{l}\text { Conceptual Design Report - Plutonium } \\
\text { Recovery Project. Volume II Part } 3 \text { - } \\
\text { Technical Appendix. Specifications and } \\
\text { Drawings. } 87-R F-1817 \text {. } \\
\end{array}$ & $\begin{array}{l}\text { Specifications and drawings for the conceptual } \\
\text { design of the plutonium recovery processes in } \\
\text { Building } 371 \text {. }\end{array}$ & $\begin{array}{c}1987 . \\
\text { March } 16 .\end{array}$ \\
\hline P176 & $\begin{array}{l}\text { Project Plan for Inspection, Sampling, and } \\
\text { Characterization of Solid Residues. } \\
\text { SRM-012-022. }\end{array}$ & $\begin{array}{l}\text { Detailed chemical and physical analysis of a } \\
\text { representative sampling of the residues. }\end{array}$ & $\begin{array}{c}1995 . \\
\text { December } 13 .\end{array}$ \\
\hline P177 & $\begin{array}{l}\text { (Task } 2 \text { Final Report) Selection of the } \\
\text { Chemicals and Radionuclides of Concern. }\end{array}$ & $\begin{array}{l}\text { Excellent historical description of Rocky Flats } \\
\text { operations. }\end{array}$ & $\begin{array}{l}1991 . \\
\text { June. }\end{array}$ \\
\hline P178 & $\begin{array}{l}\text { Research and Development Quarterly } \\
\text { Progress Report. October, November, and } \\
\text { December 1968. RFP-1311-A. }\end{array}$ & $\begin{array}{l}\text { Reports summarizing special order, research } \\
\text { and development, analytical development, } \\
\text { production support (recovery development). }\end{array}$ & $\begin{array}{c}1969 . \\
\text { January } 31 .\end{array}$ \\
\hline
\end{tabular}




\begin{tabular}{|l|l|l|l|}
\hline REF \# & TITLE & SUMMARY & DATE \\
\hline
\end{tabular}

\begin{tabular}{|c|c|c|c|}
\hline P179 & $\begin{array}{l}\text { Research and Development Quarterly } \\
\text { Progress Report. April, May, and June } 1969 . \\
\text { RFP-1406-A. }\end{array}$ & $\begin{array}{l}\text { Reports summarizing special order, research } \\
\text { and development, analytical development, } \\
\text { production support (recovery development). }\end{array}$ & $\begin{array}{c}1969 . \\
\text { July } 31 .\end{array}$ \\
\hline P180 & $\begin{array}{l}\text { Research and Development Quarterly } \\
\text { Progress Report. July, August, and } \\
\text { September 1969. RFP-1436-A. }\end{array}$ & $\begin{array}{l}\text { Reports summarizing special order, research } \\
\text { and development, analytical development, } \\
\text { production support (recovery development). }\end{array}$ & $\begin{array}{c}1969 . \\
\text { October } 31 .\end{array}$ \\
\hline P181 & $\begin{array}{l}\text { Research and Development Quarterly } \\
\text { Progress Report. January, February, and } \\
\text { March } 1970 \text {. RFP-1519-A. }\end{array}$ & $\begin{array}{l}\text { Reports summarizing special order, research } \\
\text { and development, analytical development, } \\
\text { production support (recovery development). }\end{array}$ & $\begin{array}{c}1970 . \\
\text { April } 30 .\end{array}$ \\
\hline P182 & $\begin{array}{l}\text { Research and Development Quarterly } \\
\text { Progress Report. April, May, and June } 1970 . \\
\text { RFP-1579-A. }\end{array}$ & $\begin{array}{l}\text { Reports summarizing special order, research } \\
\text { and development, analytical development, } \\
\text { production support (recovery development). }\end{array}$ & $\begin{array}{c}1970 . \\
\text { September } 16\end{array}$ \\
\hline P183 & $\begin{array}{l}\text { Research and Development Quarterly. } \\
\text { Progress Report. July, August, and } \\
\text { September 1970. RFP-1602-A. }\end{array}$ & $\begin{array}{l}\text { Reports summarizing special order, research } \\
\text { and development, analytical development, } \\
\text { production support (recovery development). }\end{array}$ & $\begin{array}{c}1970 . \\
\text { October } 30 .\end{array}$ \\
\hline P184 & $\begin{array}{l}\text { Research and Development Quarterly } \\
\text { Progress Report. October, November, and } \\
\text { December 1970. RFP-1638-A. }\end{array}$ & $\begin{array}{l}\text { Reports summarizing special order, research } \\
\text { and development, analytical development, } \\
\text { production support (recovery development). }\end{array}$ & $\begin{array}{c}1971 . \\
\text { January } 31 .\end{array}$ \\
\hline P185 & $\begin{array}{l}\text { Research and Development Quarterly } \\
\text { Progress Report. January, February, and } \\
\text { March 1971. RFP-1691-A. }\end{array}$ & $\begin{array}{l}\text { Reports summarizing special order, research } \\
\text { and development, analytical development, } \\
\text { production support (recovery development). }\end{array}$ & $\begin{array}{c}1971 . \\
\text { April } 30 .\end{array}$ \\
\hline P186 & $\begin{array}{l}\text { Research and Development Quarterly } \\
\text { Progress Report. April, May, and June } 1971 . \\
\text { RFP-1748-A. }\end{array}$ & $\begin{array}{l}\text { Reports summarizing special order, research } \\
\text { and development, analytical development, } \\
\text { production support (recovery development). }\end{array}$ & $\begin{array}{c}1971 . \\
\text { July } 30 .\end{array}$ \\
\hline P187 & $\begin{array}{l}\text { Research and Development Quarterly } \\
\text { Progress Report. July, August, and } \\
\text { September 1971. RFP-1790-A. }\end{array}$ & $\begin{array}{l}\text { Reports summarizing special order, research } \\
\text { and development, analytical development, } \\
\text { production support (recovery development). }\end{array}$ & $\begin{array}{c}1971 . \\
\text { October } 29 .\end{array}$ \\
\hline P188 & $\begin{array}{l}\text { Research and Ecology Annual Report. } \\
\text { Chemistry Research and Development. } \\
\text { (Published 4/14/72). RFP-1837-A. }\end{array}$ & $\begin{array}{l}\text { Reports summarizing special order, research } \\
\text { and development, analytical development, } \\
\text { production support (recovery development). }\end{array}$ & $\begin{array}{l}1972 . \\
\text { April } 14 .\end{array}$ \\
\hline P189 & $\begin{array}{l}\text { Research and Ecology Semi-Annual Progress } \\
\text { Report. Chemistry Research and } \\
\text { Development. January-June 1972. RFP- } \\
\text { 1921-A. }\end{array}$ & $\begin{array}{l}\text { Reports summarizing special order, research } \\
\text { and development, analytical development, } \\
\text { production support (recovery development). }\end{array}$ & $\begin{array}{c}1972 . \\
\text { August } 30 .\end{array}$ \\
\hline P190 & $\begin{array}{l}\text { Research and Ecology Semi-Annual Progress } \\
\text { Report. Chemistry Research and } \\
\text { Development. July through December } 1972 . \\
\text { RFP-2004-A. }\end{array}$ & $\begin{array}{l}\text { Reports summarizing special order, research } \\
\text { and development, analytical development, } \\
\text { production support (recovery development). }\end{array}$ & $\begin{array}{c}1973 . \\
\text { May } 16 .\end{array}$ \\
\hline P191 & $\begin{array}{l}\text { Research and Ecology Semi-Annual Progress } \\
\text { Report. Chemistry Research and } \\
\text { Development. January-June 1973. RFP- } \\
\text { 2102-A. }\end{array}$ & $\begin{array}{l}\text { Reports summarizing special order, research } \\
\text { and development, analytical development, } \\
\text { production support (recovery development). }\end{array}$ & $\begin{array}{c}1973 . \\
\text { August } 13 .\end{array}$ \\
\hline P192 & $\begin{array}{l}\text { Research and Ecology Semi-Annual Progress } \\
\text { Report. Chemistry Research and } \\
\text { Development. July-December } 1973 \text {. RFP- } \\
2200-A .\end{array}$ & $\begin{array}{l}\text { Reports summarizing special order, research } \\
\text { and development, analytical development, } \\
\text { production support (recovery development). }\end{array}$ & $\begin{array}{c}1974 . \\
\text { March } 18 .\end{array}$ \\
\hline P193 & $\begin{array}{l}\text { Research and Development Semi-Annual } \\
\text { Progress Report for July through December } \\
\text { 1994. RFP-2360-A. }\end{array}$ & $\begin{array}{l}\text { Reports summarizing special order, research } \\
\text { and development, analytical development, } \\
\text { production support (recovery development). }\end{array}$ & $\begin{array}{c}1975 . \\
\text { February } 24 .\end{array}$ \\
\hline P194 & $\begin{array}{l}\text { Research and Development Semi-Annual } \\
\text { Progress Report for January through June } \\
\text { 1975. RFP-2417-A. }\end{array}$ & $\begin{array}{l}\text { Reports summarizing special order, research } \\
\text { and development, analytical development, } \\
\text { production support (recovery development). }\end{array}$ & $\begin{array}{c}1975 . \\
\text { August } 29 .\end{array}$ \\
\hline
\end{tabular}




\begin{tabular}{|c|c|c|c|}
\hline REF \# & TITLE & SUMMARY & DATE \\
\hline
\end{tabular}

\begin{tabular}{|c|c|c|c|}
\hline P195 & $\begin{array}{l}\text { Research and Development Semi-Annual } \\
\text { Progress Report for January through June } \\
\text { 1977. RFP-2680-A. }\end{array}$ & $\begin{array}{l}\text { Reports summarizing special order, research } \\
\text { and development, analytical development, } \\
\text { production support (recovery development). }\end{array}$ & $\begin{array}{c}1977 . \\
\text { October } 21 .\end{array}$ \\
\hline P196 & $\begin{array}{l}\text { Chemistry Research and Development } \\
\text { Annual Progress Report. November 1, } 1979 \\
\text { to October 31, 1980. RFP-3180. }\end{array}$ & $\begin{array}{l}\text { Reports summarizing special order, research } \\
\text { and development, analytical development, } \\
\text { production support (recovery development). }\end{array}$ & $\begin{array}{c}1981 . \\
\text { August } 4 .\end{array}$ \\
\hline P197 & $\begin{array}{l}\text { Chemistry Research and Development } \\
\text { Annual Progress Report. November 1,1980 } \\
\text { to September } 30,1981 \text {. RFP-3324. }\end{array}$ & $\begin{array}{l}\text { Reports summarizing special order, research } \\
\text { and development, analytical development, } \\
\text { production support (recovery development). }\end{array}$ & $\begin{array}{c}1982 . \\
\text { August } 11 .\end{array}$ \\
\hline P198 & $\begin{array}{l}\text { Chemistry Research and Development } \\
\text { Annual Progress Report. October 1, } 1981 \text { to } \\
\text { September 30, 1982. RFP-3511. }\end{array}$ & $\begin{array}{l}\text { Reports summarizing special order, research } \\
\text { and development, analytical development, } \\
\text { production support (recovery development). }\end{array}$ & $\begin{array}{c}1983 . \\
\text { September } 16 .\end{array}$ \\
\hline P199 & $\begin{array}{l}\text { Chemistry Research and Development } \\
\text { Annual Progress Report. October 1, } 1982 \text { to } \\
\text { September } 30,1983 \text {. RFP-3654. }\end{array}$ & $\begin{array}{l}\text { Reports summarizing special order, research } \\
\text { and development, analytical development, } \\
\text { production support (recovery development). }\end{array}$ & $\begin{array}{c}1984 . \\
\text { September } 24 .\end{array}$ \\
\hline P200 & $\begin{array}{l}\text { Chemistry Research and Development } \\
\text { Annual Progress Report. October } 1,1983 \text { to } \\
\text { September } 30,1984 \text {. RFP-3825. }\end{array}$ & $\begin{array}{l}\text { Reports summarizing special order, research } \\
\text { and development, analytical development, } \\
\text { production support (recovery development). }\end{array}$ & $\begin{array}{l}1986 . \\
\text { June } 13 .\end{array}$ \\
\hline P201 & $\begin{array}{l}\text { Chemistry Research and Development } \\
\text { Annual Progress Report. October 1, } 1984 \text { to } \\
\text { September 30, 1985. RFP-3931. }\end{array}$ & $\begin{array}{l}\text { Reports summarizing special order, research } \\
\text { and development, analytical development, } \\
\text { production support (recovery development). }\end{array}$ & $\begin{array}{c}1986 . \\
\text { August } 18 .\end{array}$ \\
\hline P202 & $\begin{array}{l}\text { Chemistry R\&D Monthly Progress Report. } \\
\text { R\&D 86-012. }\end{array}$ & $\begin{array}{l}\text { Reports summarizing special order, research } \\
\text { and development, analytical development, } \\
\text { production support (recovery development). }\end{array}$ & $\begin{array}{l}1986 . \\
\text { January. }\end{array}$ \\
\hline P203 & $\begin{array}{l}\text { Interim Guidance on Ensuring that Waste } \\
\text { Qualifies for Disposal at the Waste Isolation } \\
\text { Pilot Plant. }\end{array}$ & $\begin{array}{l}\text { Guidance to assist the transuranic waste sites } \\
\text { in establishing and demonstrating that only } \\
\text { TRU waste generated by atomic energy } \\
\text { defense activities is certified for disposal at } \\
\text { WIPP. }\end{array}$ & $\begin{array}{l}1997 . \\
\text { February } 13 .\end{array}$ \\
\hline P204 & $\begin{array}{l}\text { Linking Legacies. } \\
\text { Connecting the Cold War Nuclear Weapons } \\
\text { Production Processes To Their } \\
\text { Environmental Consequences. DOE/EM- } \\
0319 .\end{array}$ & $\begin{array}{l}\text { Historical report connecting the missions and } \\
\text { functions of the nuclear weapons facility with } \\
\text { the inventory of waste and materials remaining } \\
\text { at the site. }\end{array}$ & $\begin{array}{l}1997 . \\
\text { January. }\end{array}$ \\
\hline U001 & $\begin{array}{l}\text { The Rocky Flats Historical Public Exposures } \\
\text { Studies Phase II: Toxicity Assessment and } \\
\text { Risk Characterization (Draft). } \\
\text { Technical Memorandum. Task 2. An Analysis } \\
\text { of Historical Source Term Estimates for } \\
\text { Carbon Tetrachloride at the Rocky Flats } \\
\text { Plant. }\end{array}$ & $\begin{array}{l}\text { Information on use and release of carbon } \\
\text { tetrachloride at RFP. }\end{array}$ & 1996. \\
\hline U002 & $\begin{array}{l}\text { Rocky Flats Dose Reconstruction Project } \\
\text { Phase II Toxicity Assessment and Risk } \\
\text { Characterization (Draft). Task 2: The Rocky } \\
\text { Flats Plant } 903 \text { Area Plutonium Source Term } \\
\text { Development. }\end{array}$ & $\begin{array}{l}\text { Description of storage of wastes at the } 903 \\
\text { Area. Leakage of Pu contaminated oil/solvent } \\
\text { is estimated in this document. }\end{array}$ & 1996. \\
\hline U003 & $\begin{array}{l}\text { (Draft) Rocky Flats Plant TRU Mixed Waste } \\
\text { Plan. }\end{array}$ & $\begin{array}{l}\text { Process information, inventory, and RCRA } \\
\text { characterization for RFP transuranic wastes in } \\
1989 .\end{array}$ & 1990. \\
\hline U004 & $\begin{array}{l}\text { Evaluation of Residue Drum Storage Safety } \\
\text { Risks. RO 93-002. }\end{array}$ & $\begin{array}{l}\text { Evaluation of safety concerns with residues } \\
\text { stored at RFP. Some of the residue IDCs are } \\
\text { also generated as transuranic waste. }\end{array}$ & 1993. \\
\hline
\end{tabular}




\begin{tabular}{|l|l|l|l|l|}
\hline REF \# & TITLE & SUMMARY & DATE \\
\hline
\end{tabular}

\begin{tabular}{|c|c|c|c|}
\hline U005 & $\begin{array}{l}\text { Results of the SWEPP Certified Waste } \\
\text { Sampling Program for FY-1991. } \\
\text { Engineering Design File. RWMC-563. }\end{array}$ & $\begin{array}{l}\text { Results from a comparison of nondestructive } \\
\text { and visual examination of drums at INEL. }\end{array}$ & 1992. \\
\hline U006 & $\begin{array}{l}\text { Memorandum from F. G. Trevino to W. D. } \\
\text { Reinhart. "Waste Shipment Summary for } \\
\text { April Cost Month } 1987 . "\end{array}$ & Waste shipment records for April 1987. & $\begin{array}{l}1987 . \\
\text { April } 27 .\end{array}$ \\
\hline$\cup 007$ & $\begin{array}{l}\text { VOC Gas Chromatography/Mass } \\
\text { Spectrometry Results. WIPP Experimental } \\
\text { Waste Characterization Program data } \\
\text { printout. }\end{array}$ & $\begin{array}{l}\text { Volatile organic headspace gas data from } \\
\text { wastes stored at RFP. }\end{array}$ & $\begin{array}{c}1994 . \\
\text { Query date } \\
\text { June 3, } 1994 \text {. }\end{array}$ \\
\hline บ008 & $\begin{array}{l}\text { Improvements to a 55-Gallon DOT } 17 \mathrm{C} \\
\text { Shipping Container for Alpha-Emitting } \\
\text { Transuranium Waste. CRDL-950703-001. }\end{array}$ & $\begin{array}{l}\text { Information on development of rigid liners for } \\
55 \text {-gallon drums. }\end{array}$ & 1972. \\
\hline U009 & $\begin{array}{l}\text { Characterization of Spent HEPA Filters from } \\
\text { Rocky Flats Plant. PSD } 86-056 \text {. }\end{array}$ & $\begin{array}{l}\text { Information on certification of HEPA filters. } \\
\text { The emphasis of the document is on particulate } \\
\text { size analysis. }\end{array}$ & 1986. \\
\hline U010 & $\begin{array}{l}\text { OASIS Solidification and Off Gas Analysis. } \\
\text { PSD 88-038. }\end{array}$ & $\begin{array}{l}\text { Study of volatile solvent off gas from OASIS } \\
\text { drums. }\end{array}$ & 1988. \\
\hline U011 & $\begin{array}{l}\text { Results of the SWEPP Certified Waste } \\
\text { Sampling Program for FY-94 (Draft). } \\
\text { Engineering Design File. RWMC-844. }\end{array}$ & $\begin{array}{l}\text { Comparison of nondestructive examination at } \\
\text { SWEPP to visual examination of waste at ANL- } \\
\text { W. }\end{array}$ & 1996. \\
\hline$\cup 012$ & Waste Processing Requests. & $\begin{array}{l}\text { Form from waste generators requesting } \\
\text { treatment of liquid waste. Treatment } \\
\text { information is included in most cases. }\end{array}$ & $1983-1984$. \\
\hline U013 & $\begin{array}{l}\text { (Draft) Rocky Flats Plant Computer } \\
\text { Simulation. User Requirements for Aqueous } \\
\text { Recovery Operations Building } 771 \text {. UNC-AL- } \\
\text { TR-24-01. }\end{array}$ & $\begin{array}{l}\text { In-depth descriptions of the Building } 771 \\
\text { recovery processes. }\end{array}$ & 1989. \\
\hline U014 & $\begin{array}{l}\text { Information and Brief History of Waste } \\
\text { Content Codes Associated with the Rocky } \\
\text { Flats Plant. }\end{array}$ & $\begin{array}{l}\text { Description of revisions, deletions, and } \\
\text { additions to RFP IDCs in the } 1980 \mathrm{~s} \text {. }\end{array}$ & 1995. \\
\hline U015 & $\begin{array}{l}\text { Results of the SWEPP Certified Waste } \\
\text { Sampling Program for FY } 1992 \text { and FY } 1993 . \\
\text { RWMC-675. }\end{array}$ & $\begin{array}{l}\text { Comparison of nondestructive examination to } \\
\text { visual examination of RFP waste drums at } \\
\text { INEL. }\end{array}$ & 1993. \\
\hline บ016 & $\begin{array}{l}\text { Quantification of Radionuclides. } \\
\text { WIPP-0217-RTS-0192. }\end{array}$ & $\begin{array}{l}\text { Information on assay of special nuclear } \\
\text { material at RFP including gamma and neutron } \\
\text { methods. }\end{array}$ & 1988. \\
\hline U017 & J. K. Paynter personal log book excerpt. & $\begin{array}{l}\text { Note regarding drum of tritium waste without an } \\
\text { IDC record in SWIMS on the log book. }\end{array}$ & $\begin{array}{l}1987 . \\
\text { July } 7\end{array}$ \\
\hline U018 & J. K. Paynter personal log book excerpt. & $\begin{array}{l}\text { Note }(2 / 8 / 89) \text { for solvent substitution: } \\
\text { trichloroethane - trichloroethylene; } \\
\text { perchloroethylene - carbon tetrachloride. }\end{array}$ & $\begin{array}{l}1989 . \\
\text { February } 8 .\end{array}$ \\
\hline U019 & J. K. Paynter personal log book excerpt. & $\begin{array}{l}\text { Note regarding five drums of IDC } 480 \text { tritium- } \\
\text { contaminated waste. }\end{array}$ & $\begin{array}{c}1987 \\
\text { August } 28 .\end{array}$ \\
\hline U020 & $\begin{array}{l}\text { Analytical Report for Filter Plenum Samples. } \\
\text { Lab Report No. AL586.0679. }\end{array}$ & $\begin{array}{l}\text { Samples taken and analyzed to support that the } \\
\text { HEPA filters from the Building } 771 \text { plenum were } \\
\text { not ignitable, corrosive, or reactive. }\end{array}$ & $\begin{array}{c}1986 . \\
\text { September } 9 \text {. }\end{array}$ \\
\hline บ021 & History of RFP IDC Certification. & $\begin{array}{l}\text { Chronology of transuranic waste certification } \\
\text { activities at RFP. }\end{array}$ & Undated. \\
\hline
\end{tabular}




\begin{tabular}{|c|c|c|c|}
\hline REF \# & TITLE & SUMMARY & DATE \\
\hline$\cup 022$ & $\begin{array}{l}\text { Analytical reports, documentation, and } \\
\text { external letter from J. K. Paynter to Dale } \\
\text { Wells, EG\&G Idaho, Inc. "Additions to Rocky } \\
\text { Flats Transuranic Waste Profiles." 89-RF- } \\
\text { 0713. }\end{array}$ & $\begin{array}{l}\text { Waste profiles for IDC } 342 \text { and IDC } 338 \text { from } \\
\text { RFP to INEL RWMC. }\end{array}$ & $\begin{array}{l}1989 . \\
\text { February } 27 .\end{array}$ \\
\hline U023 & $\begin{array}{l}\text { Waste profile statement sheets and external } \\
\text { letter from J. K. Paynter to Dale Wells, } \\
\text { EG\&G Idaho, Inc. "Additions to Rocky Flats } \\
\text { Transuranic Waste Profiles." 89-RF-1245. }\end{array}$ & $\begin{array}{l}\text { Waste profiles for IDCs } 809,854,855 \text {, and } \\
856, \text { from RFP to INEL. }\end{array}$ & $\begin{array}{r}1989 . \\
\text { April } 6\end{array}$ \\
\hline U024 & $\begin{array}{l}\text { RTR Weight Estimations data and internal } \\
\text { correspondence from K. S. Kosco to Jerry } \\
\text { O'Leary. "Waste Calculations for Bin-Scale } \\
\text { Test." }\end{array}$ & $\begin{array}{l}\text { Estimates of drum contents based on RTR } \\
\text { examination. }\end{array}$ & $\begin{array}{c}1991 . \\
\text { May } 10 .\end{array}$ \\
\hline U025 & $\begin{array}{l}\text { Rocky Flats Environmental Technology Site } \\
\text { Miscellaneous Aqueous Waste Handling and } \\
\text { Solidification (Draft). } \\
\text { 4-A73-POPM-774-WO-2005. }\end{array}$ & Draft operating procedure for IDC 802 waste. & 1996. \\
\hline U026 & $\begin{array}{l}\text { "Rocky Flats Plant TRU Waste Thermal } \\
\text { Power Characterization Incremented in } 0.05 \\
\text { Watt Segments from } 0.05 \text { Watts through }> \\
\text { 0.60 Watts." Data table produced from } \\
\text { SWIMS Database. }\end{array}$ & $\begin{array}{l}\text { Distribution of thermal wattage in transuranic } \\
\text { waste. This data table was produced to assess } \\
\text { the impacts of wattage limits within the } \\
\text { TRUPACT II shipping container. }\end{array}$ & Undated. \\
\hline U027 & $\begin{array}{l}\text { "Rocky Flats Plant TRU Certified Containers." } \\
\text { Data table from the SWIMS Database. }\end{array}$ & $\begin{array}{l}\text { Tabulation of Transuranic waste containers } \\
\text { shipped }(9 / 85-8 / 89) \text { and on hand }(8 / 89) \text {. }\end{array}$ & Undated. \\
\hline U028 & $\begin{array}{l}\text { "X-Ray Radiography Station Data" and } \\
\text { "WIPP Container Certification Document." } \\
\text { Raw data. EG\&G Idaho, Inc. } \\
\end{array}$ & $\begin{array}{l}\text { Example RTR data for waste examined at } \\
\text { SWEPP. }\end{array}$ & $\begin{array}{l}1993 . \\
\text { April } 13 \text { and April } \\
14 \text {, respectively. }\end{array}$ \\
\hline U029 & Volatiles Report 374 and 774 sludge. & $\begin{array}{l}\text { Volatile organic results for Building } 374 / 774 \\
\text { sludges. Possible mis-identification of samples } \\
\text { based on } 13 \% \text { carbon tetrachloride in aqueous } \\
\text { waste. }\end{array}$ & $\begin{array}{c}1988 \\
\text { October } 23 .\end{array}$ \\
\hline U030 & $\begin{array}{l}\text { VOC Gas Chromatography/Mass } \\
\text { Spectrometry Results. WIPP Experimental } \\
\text { Waste Characterization Program data } \\
\text { printout. }\end{array}$ & $\begin{array}{l}\text { Volatile organic drum headspace data from } \\
\text { RFP transuranic waste. }\end{array}$ & $\begin{array}{l}1996 . \\
\text { Query date } \\
\text { March } 27 .\end{array}$ \\
\hline U031 & $\begin{array}{l}\text { Rocky Flats Radioactive Waste Flow } \\
\text { diagram. }\end{array}$ & $\begin{array}{l}\text { Flow chart (10/85) of RFP radioactive waste } \\
\text { flow. }\end{array}$ & $\begin{array}{c}1985 . \\
\text { October. }\end{array}$ \\
\hline U032 & $\begin{array}{l}\text { WSRIC Waste Streams sorted by IDC. } \\
\text { WSRIC Database program. Report RWS09. }\end{array}$ & $\begin{array}{l}\text { September } 1992 \text { sort of the WSRIC Database } \\
\text { by IDC. Also, the line-/nonline-generation field } \\
\text { is included. }\end{array}$ & $\begin{array}{c}1992 . \\
\text { Query date } \\
\text { September } 29 .\end{array}$ \\
\hline U033 & $\begin{array}{l}\text { Building } 774 \text { First Stage Treatment Log } \\
\text { Book. }\end{array}$ & $\begin{array}{l}\text { Records of liquid transferred via pipeline from } \\
\text { Building } 771 \text { to Building } 774 \text { in } 1969 .\end{array}$ & 1969 \\
\hline U034 & $\begin{array}{l}\text { Building } 774 \text { First Stage Treatment Log } \\
\text { Book. }\end{array}$ & $\begin{array}{l}\text { Records of liquid transferred from Building } 771 \\
\text { to Building } 774 \text { in } 1989 .\end{array}$ & 1989. \\
\hline บ035 & $\begin{array}{l}\text { Building } 774 \text { First Stage Treatment Log } \\
\text { Book. }\end{array}$ & $\begin{array}{l}\text { Records of liquid transferred from Building } 771 \\
\text { to Building } 774 \text { in } 1982 \text {. }\end{array}$ & 1982. \\
\hline U036 & Building 774 Water Results Log Book. & $\begin{array}{l}\text { Information on incoming pipeline waste (other } \\
\text { than first stage receiving) and outgoing } \\
\text { transfers to the ponds and Building } 374 \text {. }\end{array}$ & $1980-1983$. \\
\hline บ037 & $\begin{array}{l}\text { Building } 774 \text { Second Stage Treatment Log } \\
\text { Book. }\end{array}$ & Waste treatment information. & 1981. \\
\hline บ038 & $\begin{array}{l}\text { Building } 774 \text { First Stage Treatment Log } \\
\text { Book. }\end{array}$ & $\begin{array}{l}\text { Records of liquid transferred via pipeline from } \\
\text { Building } 771 \text { to Building } 774 \text { in } 1984 \text { and } 1985 .\end{array}$ & 1984. \\
\hline
\end{tabular}




\begin{tabular}{|l|l|l|l|}
\hline REF \# & TITLE & SUMMARY & DATE \\
\hline
\end{tabular}

\begin{tabular}{|c|c|c|c|}
\hline v039 & $\begin{array}{l}\text { Building } 774 \text { First Stage Flocculator Samples } \\
\text { Log Book. }\end{array}$ & $\begin{array}{l}\text { First stage liquid samples and } 2 \text { nd stage sludge } \\
\text { samples. }\end{array}$ & $1968-1970$. \\
\hline U040 & $\begin{array}{l}\text { Building } 774 \text { Low Level Organic and TRU- } \\
\text { Waste Organic Waste Log Book. }\end{array}$ & $\begin{array}{l}\text { Records for pipeline- and container-received } \\
\text { organic waste in Building } 774 \text { from various } \\
\text { buildings. }\end{array}$ & $1976-1990$. \\
\hline บ041 & Building 774 Car Log Book. & $\begin{array}{l}\text { Record of liquid waste transfers from various } \\
\text { buildings to the } 207 \text { Ponds, Building } 374 \text {, and } \\
\text { Building } 774 \text { (during 1982). }\end{array}$ & 1982. \\
\hline U042 & Building 774 Record Book. & $\begin{array}{l}\text { Log Book to trace estimated fissile contents } \\
\text { within treatment tanks. }\end{array}$ & 1985. \\
\hline U043 & Building 774 Set Up Log Book. & $\begin{array}{l}\text { List of containerized waste treated in Building } \\
774 \text { from } 1973 \text { to } 1990 \text {. }\end{array}$ & $1973-1990$. \\
\hline U044 & Building 774 Water Results Log Book. & & $1984-1995$. \\
\hline U045 & Monthly Report - Liquid Waste Operations. & $\begin{array}{l}\text { Liquid waste processing records from CY } 1988 \text {, } \\
1989,1990 \text {, and } 1991 \text {. }\end{array}$ & $1981-1991$. \\
\hline$\cup 046$ & $\begin{array}{l}\text { Evaluation of the EPA Code D001, } \\
\text { Ignitability; D002, Corrosivity; and D003, } \\
\text { Reactivity; Designations for RFP IDCs that } \\
\text { are Stored at the INEL. }\end{array}$ & $\begin{array}{l}\text { Technical analysis of wastes assigned EPA } \\
\text { Codes D001-D003 that are stored at INEL. }\end{array}$ & $\begin{array}{l}1996 . \\
\text { February } 29 .\end{array}$ \\
\hline U047 & $\begin{array}{l}\text { A History of the Rocky Flats } \\
\text { Plutonium/Actinide Recovery Plant } 1952 \text { to } \\
1991 \text { (Draft 10/30/91). }\end{array}$ & $\begin{array}{l}\text { Detailed description of the actinide recovery } \\
\text { and waste treatment processes at RFP. }\end{array}$ & 1991. \\
\hline U048 & $\begin{array}{l}\text { Building } 374 \text { Log Book for Time Period } \\
12 / 24 / 86 \text { to } 12 / 29 / 88 \text {. }\end{array}$ & $\begin{array}{l}\text { Log of waste volume, building of generation, } \\
\text { radioactive contamination level (total alpha or } \\
\text { Pu gram/liter), } \mathrm{pH} \text { and beryllium results for } \\
\text { incoming liquid waste. }\end{array}$ & 1988. \\
\hline บ049 & $\begin{array}{l}\text { Building } 374 \text { Log Book for Time Period } \\
12 / 26 / 82 \text { to } 12 / 24 / 85 \text {. }\end{array}$ & $\begin{array}{l}\text { Log of waste volume, building of generation, } \\
\text { radioactive contamination level (total alpha or } \\
\text { Pu gram/liter), pH, and beryllium results for } \\
\text { incoming liquid waste }\end{array}$ & 1985. \\
\hline บ050 & $\begin{array}{l}\text { Building } 374 \text { Log Book for Time Period } \\
\text { 04/12/91 to 09/27/93. }\end{array}$ & $\begin{array}{l}\mathrm{pH} \text { and total alpha contamination results for } \\
\text { decontaminated liquid leaving Tanks D826A } \\
\text { and B (clarifier). }\end{array}$ & 1993. \\
\hline บ051 & $\begin{array}{l}\text { Building } 371 \text { Log Book for Time Period } \\
04 / 07 / 82 \text { to } 12 / 29 / 85 \text {. }\end{array}$ & $\begin{array}{l}\text { Log of waste volume, Pu content, and Am } \\
\text { content for liquid waste from Building } 371 \\
\text { shipped to Building } 374 \text {. }\end{array}$ & 1985. \\
\hline U052 & $\begin{array}{l}\text { "Graphite Waste - Rock Flats Environmental } \\
\text { Technology Site." }\end{array}$ & $\begin{array}{l}\text { Process summary of graphite waste from } \\
\text { Rocky Flats. }\end{array}$ & Date Unknown. \\
\hline U053 & $\begin{array}{l}\text { "Building } 374 \text { Solidified Sludge, Rocky Flats } \\
\text { Environmental Technology Site." }\end{array}$ & $\begin{array}{l}\text { Process summary of Building } 374 \text { aqueous } \\
\text { sludge. }\end{array}$ & Unknown \\
\hline U054 & $\begin{array}{l}\text { Toxicity Characteristic Leaching Procedure } \\
\text { Test Results of Cemented Surrogate } \\
\text { Analytical Laboratory Solution Waste - Part } 2 .\end{array}$ & $\begin{array}{l}\text { Results of TCLP testing of solidified laboratory } \\
\text { waste prepared with RCRA metal spiked, } \\
\text { surrogate liquid waste. }\end{array}$ & 1994. \\
\hline U055 & Sorting of Radioactive waste at Rocky Flats & Segregating and Sorting of radioactive residues & $\begin{array}{l}1970 . \\
\text { February } 11 \\
\end{array}$ \\
\hline บ056 & $\begin{array}{l}\text { Rocky Flats History of Fitter Changes and } \\
\text { Plenum Modifications }\end{array}$ & $\begin{array}{l}\text { Summary of filter changes and plenum } \\
\text { modifications (1953-1975) }\end{array}$ & $\begin{array}{c}1975 . \\
\text { September }\end{array}$ \\
\hline บ057 & Building 881 . Presentation by Ernie English. & $\begin{array}{l}\text { Handout from a presentation by Ernie English } \\
\text { of } M . H \text {. Chew } \& \text { Assoc. describing historical } \\
\text { processing operations in Building } 881\end{array}$ & $\begin{array}{l}1996 . \\
\text { July } 3\end{array}$ \\
\hline U058 & $\begin{array}{l}\text { (This reference has been combined with } \\
\text { P033). }\end{array}$ & & \\
\hline
\end{tabular}




\begin{tabular}{|l|l|l|l|l|}
\hline REF \# & TITLE & SUMMARY & DATE \\
\hline
\end{tabular}

\begin{tabular}{|c|c|c|c|}
\hline U059 & $\begin{array}{l}\text { Drum Prefix Numbers and Corresponding } \\
\text { Material Balance Areas. }\end{array}$ & $\begin{array}{l}\text { Drum prefix numbers with corresponding } \\
\text { material balance areas (MBA) and MBA title. } \\
\text { Provides the building and area from which } \\
\text { wastes were generated. }\end{array}$ & $1994,1991$. \\
\hline U060 & $\begin{array}{l}\text { Chemical Constituents in Transuranic Storage } \\
\text { Area (TSA) Waste. } \\
\text { Engineering Design File. RWMC-803. }\end{array}$ & $\begin{array}{l}\text { Provides chemical constituents that are } \\
\text { contained in or are suspected to be contained } \\
\text { in various wastes stored at the TSA of the } \\
\text { RWMC. }\end{array}$ & 1996. \\
\hline U061 & $\begin{array}{l}\text { Sampling and Analysis Plan for } \\
\text { Pyrochemical Salts. 1-100000-EQA. }\end{array}$ & $\begin{array}{l}\text { Sampling and analysis plan (draft) for } \\
\text { pyrochemical salts; including inventory } \\
\text { description and packaging. }\end{array}$ & $\begin{array}{c}1992 . \\
\text { September } 31 .\end{array}$ \\
\hline U062 & $\begin{array}{l}\text { Presence of Chromium Pyrochemical Salt. } \\
\text { Residues at Rocky Flats Plant. }\end{array}$ & $\begin{array}{l}\text { KMI Services report concluding that chromium } \\
\text { will not be present at regulatory levels. }\end{array}$ & 1993. \\
\hline บ063 & $\begin{array}{l}\text { Laboratory Analysis Results for } \\
\text { Electrorefining Salt. }\end{array}$ & $\begin{array}{l}\text { Visual inspection and emission spectra results } \\
\text { metals in ER salt samples. }\end{array}$ & $\begin{array}{l}1987 . \\
\text { December. }\end{array}$ \\
\hline U064 & $\begin{array}{l}\text { Radioactive Materials Associated with Rocky } \\
\text { Flats. }\end{array}$ & Table of radioactive materials. & $\begin{array}{c}1977 . \\
\text { April } 14 .\end{array}$ \\
\hline บ065 & $\begin{array}{l}\text { Radioactive Materials Associated with Rocky } \\
\text { Flats. Presentation Slides. }\end{array}$ & Presentation slides for radioactive materials. & $\begin{array}{r}1983 . \\
\text { March. }\end{array}$ \\
\hline U066 & $\begin{array}{l}\text { Radionuclides Quantities Received and } \\
\text { Dispatched from RFP from } 1951 \text { to Present. } \\
\text { J003499. }\end{array}$ & Table of radionuclides. & Unknown. \\
\hline U067 & $\begin{array}{l}\text { 881-CSL Physical Inventory of } \\
\text { Radionuclides. }\end{array}$ & Table of radionuclide materials. & $\begin{array}{l}1990 . \\
\text { August } 14 .\end{array}$ \\
\hline U068 & $\begin{array}{l}\text { Analytical Data from Liquid Stabilization } \\
\text { Database at Rocky Flats. }\end{array}$ & $\begin{array}{l}G / L, C l \text {, isotopic, and metals data for IDCs } 070 \text {, } \\
400,401,500,503,508,527,533, \text { and } 541 \\
\text { (also on disk in Excel spreadsheet). }\end{array}$ & $\begin{array}{c}1997 . \\
\text { March } 3\end{array}$ \\
\hline U069 & Drum Prefix Issue Dates Log Book. & $\begin{array}{l}\text { Shows drum prefix corresponding MBA, and } \\
\text { dates that a group of extended drum numbers } \\
\text { were issued. }\end{array}$ & $1987-1997$ \\
\hline U070 & $\begin{array}{l}\text { Handbook of the Rocky Flats Plant } \\
\text { Production Non-Destructive Assay Systems. }\end{array}$ & Radioassay systems used at Rocky Flats. & $\begin{array}{l}1984 . \\
\text { June. }\end{array}$ \\
\hline U071 & Material Balance for Size Reduction Vault. & $\begin{array}{l}\text { Drums of Rocky Flats waste stored at INEL } \\
\text { shipped back to Rocky Flats for visual } \\
\text { examination. This material balance log shows } \\
\text { the original drum number and new drum } \\
\text { number after repackaging in size reduction } \\
\text { vault. Repackaged drums were shipped back } \\
\text { to INEL. }\end{array}$ & $1984-85$ \\
\hline U072 & $\begin{array}{l}\text { Waste Stream and Residue Identification and } \\
\text { Characterization Building } 371 . \\
\text { September } 1990 \text {. }\end{array}$ & $\begin{array}{l}\text { Uncontrolled electronic copy of Version } 2.0 \\
\text { WSRIC Program, Building Book } 371 .\end{array}$ & $\begin{array}{l}1990 . \\
\text { September. }\end{array}$ \\
\hline บ073 & $\begin{array}{l}\text { Waste Stream and Residue Identification and } \\
\text { Characterization Building } 559 \text {. Volume I. } \\
\text { September } 1990 \text {. }\end{array}$ & $\begin{array}{l}\text { Uncontrolled electronic copy of Version } 2.0 \\
\text { WSRIC Program, Building Book } 559 .\end{array}$ & $\begin{array}{l}1990 . \\
\text { September. }\end{array}$ \\
\hline U074 & $\begin{array}{l}\text { Waste Stream and Residue Identification and } \\
\text { Characterization Building } 707 \text {. Volume I. } \\
\text { September } 1990 .\end{array}$ & $\begin{array}{l}\text { Uncontrolled electronic copy of Version } 2.0 \\
\text { WSRIC Program, Building Book } 707 \text {. }\end{array}$ & $\begin{array}{l}1990 . \\
\text { September. }\end{array}$ \\
\hline U075 & $\begin{array}{l}\text { Waste Stream and Residue Identification and } \\
\text { Characterization Building } 771 \text {. Volume I. } \\
\text { August } 1990 .\end{array}$ & $\begin{array}{l}\text { Uncontrolled electronic copy of Version } 1.0 \\
\text { WSRIC Program, Building Book } 771 .\end{array}$ & $\begin{array}{l}1990 . \\
\text { August. }\end{array}$ \\
\hline U076 & $\begin{array}{l}\text { Waste Stream and Residue Identification and } \\
\text { Characterization Building 774. August } 1990 \text {. }\end{array}$ & $\begin{array}{l}\text { Uncontrolled electronic copy of Version } 1.0 \\
\text { WSRIC Program, Building Book } 774 \text {. }\end{array}$ & $\begin{array}{l}1990 . \\
\text { August. }\end{array}$ \\
\hline
\end{tabular}




\begin{tabular}{|l|l|l|l|l|}
\hline REF \# & TITLE & SUMMARY & DATE \\
\hline
\end{tabular}

\begin{tabular}{|c|c|c|c|}
\hline U077 & $\begin{array}{l}\text { Waste Stream and Residue Identification and } \\
\text { Characterization Building } 776 \text {. August } 1990 \text {. }\end{array}$ & $\begin{array}{l}\text { Uncontrolled electronic copy of Version } 1.0 \\
\text { WSRIC Program, Building Book } 776 \text {. }\end{array}$ & $\begin{array}{l}1990 . \\
\text { August. }\end{array}$ \\
\hline U078 & $\begin{array}{l}\text { Waste Stream and Residue Identification and } \\
\text { Characterization Building } 777 \text {. Volume I. } \\
\text { August } 1990 .\end{array}$ & $\begin{array}{l}\text { Uncontrolled electronic copy of Version } 1.0 \\
\text { WSRIC Program, Building Book } 777 \text {. }\end{array}$ & $\begin{array}{l}1990 . \\
\text { August. }\end{array}$ \\
\hline U079 & $\begin{array}{l}\text { Waste Stream and Residue Identification and } \\
\text { Characterization Building } 779 \text {. Volume I. } \\
\text { August } 1990 .\end{array}$ & $\begin{array}{l}\text { Uncontrolled electronic copy of Version } 1.0 \\
\text { WSRIC Program, Building Book } 779 .\end{array}$ & $\begin{array}{l}1990 . \\
\text { August. }\end{array}$ \\
\hline U080 & $\begin{array}{l}\text { Waste Stream and Residue Identification and } \\
\text { Characterization Building } 886 \text {. August } 1990 \text {. }\end{array}$ & $\begin{array}{l}\text { Uncontrolled electronic copy of Version } 2.0 \\
\text { WSRIC Program, Building Book } 886 \text {. }\end{array}$ & $\begin{array}{l}1990 . \\
\text { August. }\end{array}$ \\
\hline U081 & $\begin{array}{l}\text { Nuclear Material Transaction Report. } \\
\text { Transfer Series: ARF - VAB -000197. }\end{array}$ & $\begin{array}{l}\text { Form } 741 \text { shipping records showing IDCs and } \\
\text { drum numbers shipped to the Nevada Test Site } \\
\text { between } 9 / 18 / 85 \text { and } 2 / 7 / 88 \text {. }\end{array}$ & $1985-1988$ \\
\hline U082 & $\begin{array}{l}\text { EG\&G Rocky Flats Plant Radionuclide and } \\
\text { Hazardous Constituent Reportable Quantity } \\
\text { Determination Guide. 1-10000-RQ. }\end{array}$ & $\begin{array}{l}\text { Reportable quantities of hazardous constituents } \\
\text { and radionuclides per } 49 \text { CFR, Part } 172.101 \text { for } \\
\text { radioactive wastes at Rocky Flats. Information } \\
\text { is summarized by IDC. }\end{array}$ & $\begin{array}{c}1992 . \\
\text { December } 15 .\end{array}$ \\
\hline U083 & $\begin{array}{l}\text { Internal Memorandum from J. T. Gilmartin to } \\
\text { J. K. Wrapp, Kaiser-Hill, "Redesignation of } \\
\text { Item Description Code (IDC) 393." } \\
\text { With unpublished document, "Analysis of IDC } \\
393 \text { for the RCRA Designation D007 Based } \\
\text { on Process and Storage Conditions } \\
\text { Necessary for Formation and Continued } \\
\text { Existence of Hexavalent Chromium }\left(\mathrm{CR}^{+6}\right) \text {. }\end{array}$ & $\begin{array}{l}\text { Justification for removing Do07 from SS\&C } \\
\text { Heel (IDC 393). }\end{array}$ & $\begin{array}{c}1997 . \\
\text { August } 6 .\end{array}$ \\
\hline U084 & $\begin{array}{l}\text { Waste Stream and Residue Identification and } \\
\text { Characterization Building } 778 \text {. January } 1991 .\end{array}$ & $\begin{array}{l}\text { Uncontrolled copy of archived Version } 3.0 \\
\text { WSRIC Building Book } 778 \text {. }\end{array}$ & $\begin{array}{l}1991 . \\
\text { January. }\end{array}$ \\
\hline U085 & $\begin{array}{l}\text { Analytical Data and Summary of Samples } \\
\text { from IDC } 310 \text { and } 312 \text {. }\end{array}$ & $\begin{array}{l}\text { Analysis of analytical data (IDCs } 310 \text { and } 312 \text { ) } \\
\text { demonstrating that graphite does not exceed } \\
\text { TCLP limits. }\end{array}$ & $\begin{array}{c}1998 . \\
\text { January } 22 .\end{array}$ \\
\hline U086 & $\begin{array}{l}\text { Analytical Data for IDC } 411 \text {. Includes } \\
\text { external correspondence, "Assessment of } \\
\text { RCRA Metal Contaminating Plutonium," from } \\
\text { Kevin Peters (KJP/108/0198) to Pam Edrich, } \\
\text { RMRS Waste Systems. }\end{array}$ & $\begin{array}{l}\text { Data packages and letter supporting that } \\
\text { plutonium will not cause TRU and low-level } \\
\text { wastes to be RCRA regulated for metals. }\end{array}$ & $\begin{array}{c}1998 . \\
\text { January } 29 .\end{array}$ \\
\hline UD87 & $\begin{array}{l}\text { Discrepancy Report from Kevin J. Peters to } \\
\text { Sheila Hailey, LMITCO. "Graphite Waste." } \\
\text { KJP/003/0298. }\end{array}$ & $\begin{array}{l}\text { Determination that graphite wastes were not } \\
\text { mixed with spent solvents and therefore do not } \\
\text { meet the definition of an F-listed hazardous } \\
\text { waste. Includes excerpts from various source } \\
\text { documents. }\end{array}$ & $\begin{array}{c}1998 . \\
\text { February } 3 .\end{array}$ \\
\hline บ088 & $\begin{array}{l}\text { Discrepancy Report from Kevin J. Peters to } \\
\text { Sheila Hailey, LMITCO. "Evaluation of } \\
\text { Potential Sources of RCRA Compounds } \\
\text { Found in Graphite Waste Headspace." } \\
\text { KJP/114/0298. }\end{array}$ & $\begin{array}{l}\text { Assessment of historical use of solvents in the } \\
\text { foundry and other potential sources, and RCRA } \\
\text { assessment of solvents and metals. } \\
\text { References excerpts from various source } \\
\text { documents, and includes an interview about } \\
\text { 1,4-dioxane, a } 1970 \text { report about organics in } \\
\text { glovebox atmosphere, and analytical data } \\
\text { paints and thinners. }\end{array}$ & $\begin{array}{c}1998 . \\
\text { February } 25 .\end{array}$ \\
\hline U089 & $\begin{array}{l}\text { Discrepancy Report from Kevin J. Peters to } \\
\text { Sheila Hailey, LMITCO. "Assessment of } \\
\text { Graphite Waste Matrix and Solvent Usage." } \\
\text { KJP/004/0398. }\end{array}$ & $\begin{array}{l}\text { Interviews conducted to determine if other } \\
\text { materials were mixed with graphite waste and } \\
\text { how solvents were used in casting operations. }\end{array}$ & $\begin{array}{c}1998 . \\
\text { March } 3 .\end{array}$ \\
\hline
\end{tabular}


APPENDIX B

INEEL Accessible Storage TRU Waste Inventory-Rocky Flats Waste

\begin{tabular}{|c|c|c|c|c|c|c|c|}
\hline (1) & 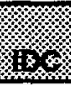 & 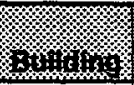 & 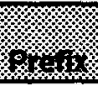 & (6) & Yim & (1) & (6) \\
\hline 5 & 375 & 559 & 0029 & Analytical Laboratory & 3 & $8 / 10 / 84$ & WG PU, EU, Am-241, DU \\
\hline 5 & 375 & 771 & 0001 & Aqueous Recovery & 1 & $2 / 28 / 83$ & WG Pu, EU, Am-241 \\
\hline 6 & 241 & 771 & 0001 & Aqueous Recovery & 1 & $12 / 5 / 72$ & Am-241, WG Pu \\
\hline 7 & 302 & 771 & 0002 & Aqueous Recovery & 4 & $1 / 21 / 73-8 / 27 / 85$ & WG PU \\
\hline 7 & 302 & 776 & 0019 & Size Reduction & 3 & $4 / 19 / 85$ & WG Pu, EU, Am-241, DU, U-233 \\
\hline 7 & 302 & 776 & 0025 & Drum Repack & 5 & $3 / 14 / 85-4 / 17 / 85$ & WG Pu, EU, Am-241, DU, U-233 \\
\hline 7 & 302 & 779 & 0052 & Pyrochemistry Process Development & 1 & $2 / 12 / 86$ & WG Pu, Am-241 \\
\hline 7 & 464 & 771 & 0001 & Aqueous Recovery & 2 & $11 / 19 / 72-12 / 29 / 72$ & WG PU \\
\hline 8 & 374 & $?$ & 0089 & Note 12 & 43 & $12 / 5 / 72-5 / 16 / 73$ & Unknown \\
\hline 8 & 374 & $?$ & 0389 & Note 1 & 2 & $3 / 28 / 73-3 / 29 / 74$ & Not assessed \\
\hline 8 & 374 & 371 & 0030 & Note 4 & 1 & $2 / 19 / 82$ & WG Pu, EU, Am-241, DU \\
\hline 8 & 374 & 371 & 0032 & Note 3 & 1 & $2 / 2 / 73$ & Unknown \\
\hline 8 & 374 & 371 & 0032 & Aqueous Recovery & 13 & $1 / 6 / 84-9 / 30 / 87$ & WG Pu, Am-241 \\
\hline 8 & 374 & 371 & 0048 & Note 4 & 2 & $4 / 3 / 84-12 / 9 / 86$ & WG Pu, EU, Am-241, DU \\
\hline 8 & 374 & 371 & 0071 & Analytical/Standards Laboratory & 1 & $2 / 17 / 85$ & WG Pu, EU, Am-241, DU \\
\hline 8 & 374 & 371 & 0092 & Aqueous Recovery & 5 & $2 / 6 / 85-9 / 11 / 87$ & WG Pu, Am-241 \\
\hline 8 & 374 & 374 & 0747 & Liquid Waste Treatment & 1 & $1 / 24 / 85$ & WG Pu, EU, Am-241, DU \\
\hline 8 & 374 & 374 & 0749 & Liquid Waste Treatment & 2 & $10 / 21 / 84$ & WG Pu, EU, Am-241, DU \\
\hline 8 & 374 & 559 & 0029 & Analytical Laboratory & 14 & $6 / 22 / 83-6 / 22 / 88$ & WG Pu, EU, Am-241, DU \\
\hline 8 & 374 & 707 & 0012 & Foundry and Casting Opertations & 10 & $10 / 23 / 81-7 / 14 / 86$ & WG Pu \\
\hline 8 & 374 & 707 & 0022 & Metal Fabrication-Machining & 17 & $4 / 28 / 83-9 / 28 / 87$ & WG Pu \\
\hline 8 & 374 & 771 & 0002 & Aqueous Recovery & 114 & $2 / 6 / 73-2 / 5 / 88$ & WG Pu \\
\hline 8 & 374 & 771 & 0042 & Chemical Technology & 8 & $2 / 27 / 81-3 / 26 / 81$ & WG Pu, EU, Am-241, DU, U-233 \\
\hline 8 & 374 & 771 & 0078 & Plutonium Metallurgy Development & 6 & $2 / 18 / 82-4 / 14 / 83$ & WG Pu, EU, Am-241, DU, U-233 \\
\hline 8 & 374 & 774 & 0746 & Liquid Waste Treatment & 22 & $9 / 23 / 86-3 / 6 / 87$ & WG Pu, EU, Am-241, DU \\
\hline 8 & 374 & 776 & 0003 & Pyrochemical Operations & 1 & $10 / 9 / 87$ & WG Pu, Am-241 \\
\hline 8 & 374 & 776 & 0019 & Size Reduction & 21 & $6 / 22 / 83-4 / 23 / 87$ & WG Pu, EU, Am-241, DU, U-233 \\
\hline 8 & 374 & 776 & 0041 & Waste Processing/Final Packaging & 2 & $4 / 23 / 82$ & WG Pu, EU, Am-241, DU, U-233 \\
\hline 8 & 374 & 776 & 0075 & Waste Processing Development & 6 & $7 / 21 / 81-7 / 24 / 81$ & WG Pu \\
\hline 8 & 374 & 777 & 0004 & Radiography & 1 & $4 / 23 / 82$ & WG Pu, EU \\
\hline 8 & 374 & 777 & 0023 & Metal Fabrication-Machining & 136 & $6 / 9 / 81-5 / 18 / 88$ & WG PU, EU \\
\hline 8 & 374 & 777 & 0024 & Metal Fabrication-Disassembly & 6 & $1 / 13 / 86-3 / 18 / 86$ & WG Pu, EU \\
\hline 8 & 374 & 779 & 0054 & Research and Development & 11 & $1 / 18 / 83-11 / 6 / 85$ & WG Pu, EU, Am-241, DU, U-233 \\
\hline 8 & 374 & 779 & 0055 & Hydride Operations & 10 & $8 / 6 / 81-8 / 18 / 81$ & WG Pu \\
\hline 8 & 374 & 991 & 0013 & Storage \& Off-Site Ship. \& Rec. & 1 & $6 / 23 / 86$ & Unknown \\
\hline 9 & 330 & $?$ & 0000 & Prefix Not Assigned & 2 & $12 / 05 / 72-12 / 29 / 72$ & Unknown \\
\hline 9 & 330 & $?$ & 0089 & Note 12 & 37 & $1 / 5 / 73-5 / 4 / 73$ & Unknown \\
\hline 9 & 330 & $?$ & 0090 & Note 13 & 25 & $4 / 26 / 72-5 / 29 / 73$ & Unknown \\
\hline 9 & 330 & $?$ & 0389 & Note 1 & 75 & $7 / 27 / 79-1 / 25 / 86$ & Not assessed \\
\hline 9 & 330 & $?$ & 0065 & Note 10 & 8 & $12 / 28 / 72-5 / 5 / 73$ & Unknown \\
\hline 9 & 330 & 371 & 0017 & Note 3 & 33 & $12 / 18 / 72-5 / 11 / 73$ & Unknown \\
\hline 9 & 330 & 371 & 0032 & Note 3 & 39 & $2 / 7 / 73-5 / 17 \pi 3$ & Unknown \\
\hline 9 & 330 & 371 & 0036 & Note 3 & 22 & $12 / 20 / 72-5 / 17 / 73$ & Unknown \\
\hline 9 & 330 & 371 & 0043 & Stacker/Retriever & 1 & $1 / 16 / 85$ & WG PU, EU, Am-241, DU \\
\hline 9 & 330 & 371 & 0048 & Note 4 & 1 & $5 / 18 / 83$ & WG Pu, EU, Am-241, DU \\
\hline 9 & 330 & 371 & 0073 & Note 3 & 2 & $2 / 12 / 73$ & Unknown \\
\hline 9 & 330 & 371 & 0076 & Note 3 & 3. & $12 / 18 / 72-6 / 5 / 80$ & Unknown \\
\hline 9 & 330 & 371 & 0076 & Repackaging Residues & 4 & $2 / 19 / 82$ & WG Pu, EU, Am-241, DU \\
\hline 9 & 330 & 707 & 0012 & Foundry and Casting Opertations & 1 & $12 / 15 / 84$ & WG Pu \\
\hline 9 & 330 & 707 & 0018 & Note 5 & 2 & $1 / 9 / 73-1 / 12 / 73$ & WG Pu \\
\hline 9 & 330 & 707 & 0022 & Metal Fabrication-Machining & 2 & $12 / 10 / 81$ & WG Pu \\
\hline 9 & 330 & 707 & 0028 & Note 5 & 3 & $8 / 17 / 82-8 / 26 / 82$ & WG Pu \\
\hline 9 & 330 & 707 & 0031 & Metal Fabrication-Assembly & 4 & $11 / 11 / 80-10 / 23 / 81$ & WG Pu \\
\hline 9 & 330 & 771 & 0001 & Aqueous Recovery & 50 & $12 / 6 / 72-1 / 16 / 73$ & WG Pu \\
\hline 9 & 330 & 771 & 0002 & Aqueous Recovery & 106 & $1 / 17 / 73-3 / 26 / 82$ & WG Pu \\
\hline
\end{tabular}




\begin{tabular}{|c|c|c|c|c|c|c|c|}
\hline$\%$ & stos & 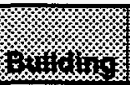 & 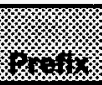 & 1.\%. & Whong & (1) & 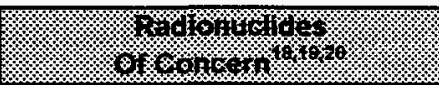 \\
\hline 9 & 330 & 771 & 0038 & Chemical Standards Laboratory & 7 & $1 / 17 / 73-4 / 20 / 83$ & WG Pu, EU, Am-241, DU, U-233 \\
\hline 9 & 330 & 771 & 0042 & Chemical Technology & 2 & $1 / 16 / 85-9 / 11 / 85$ & WG Pu, EU, Am-241, DU \\
\hline 9 & 330 & 771 & 0047 & Note 22 & 1 & $3 / 18 / 83$ & WG Pu, EU, Am-241, DU \\
\hline 9 & 330 & 771 & 0078 & Plutonium Metallurgy Development & 1 & $6 / 28 / 82$ & WG Pu, EU, Am-241, DU, U-233 \\
\hline 9 & 330 & 774 & 0746 & Liquid Waste Treatment & 9 & $2 / 2 / 73-5 / 17 / 73$ & WG Pu, EU, Am-241, DU, U-233 \\
\hline 9 & 330 & 776 & 0003 & Pyrochemical Operations & 3 & $12 / 29 / 84-11 / 19-86$ & WG Pu, Am-241 \\
\hline 9 & 330 & 776 & 0019 & Size Reduction & 3 & $10 / 18 / 83-12 / 5 / 83$ & WG Pu, EU, Am-241, DU, U-233 \\
\hline 9 & 330 & 776 & 0041 & Waste Processing/Final Packaging & 1 & $6 / 8 / 82$ & WG Pu, EU, Am-241, DU, U-233 \\
\hline 9 & 330 & 776 & 0075 & Waste Processing Development & 14 & $12 / 26 / 72-7 / 24 / 81$ & WG Pu \\
\hline 9 & 330 & 777 & 0024 & Metal Fabrication-Disassembly & 2 & $4 / 24 / 81$ & WG Pu, EU \\
\hline 9 & 330 & 777 & 0080 & Note 1 & 326 & $9 / 9 / 85-4 / 13 / 88$ & Not Assessed \\
\hline 9 & 330 & 779 & 0027 & Note 6 & 1 & $5 / 12 / 81$ & WG Pu, EU, Am-241, DU, U-233 \\
\hline 9 & 330 & 779 & 0054 & Research and Development & 4 & $2 / 19 / 82-3 / 11 / 85$ & WG Pu, EU, Am-241, DU, U-233 \\
\hline 9 & 330 & 779 & 0055 & Hydride Operations & 21 & $7 / 16 / 80-6 / 15 / 82$ & WG Pu \\
\hline 9 & 330 & 779 & 0072 & Joining Tech-Joining D-38 & 1 & $6 / 11 / 82$ & WG Pu, DU \\
\hline 9 & 330 & $?$ & 0046 & Note 9 & 1 & $12 / 8 / 81$ & Unknown \\
\hline 9 & 330 & Note 11 & 0067 & $?$ & 1 & $2 / 14 / 73$ & Unknown \\
\hline 9 & 336 & $?$ & 0089 & Note 12 & 196 & $11 / 21 / 72-5 / 9 / 73$ & Unknown \\
\hline 9 & 336 & $?$ & 0090 & Note 13 & 24 & $4 1 0 \longdiv { 7 3 - 6 / 2 3 / 8 2 }$ & Unknown \\
\hline 9 & 336 & $?$ & 0389 & Note 1 & 19 & $9 / 27 / 85-1 / 22 / 86$ & Not assessed \\
\hline 9 & 336 & $?$ & 0065 & Note 10 & 15 & $12 / 22 / 72-5 / 0 / 73$ & Unknown \\
\hline 9 & 336 & 371 & 0011 & Note 3 & 1 & $5 / 1 / 73$ & Unknown \\
\hline 9 & 336 & 371 & 0017 & Note 3 & 3 & $2 / 8 / 73-11 / 13 / 80$ & Unknown \\
\hline 9 & 336 & 371 & 0017 & Aqueous Recovery & 1 & $2 / 15 / 83$ & WG Pu, Am-241 \\
\hline 9 & 336 & 371 & 0036 & Note 3 & 2 & $4 / 19 / 73-5 / 15 / 73$ & Unknown \\
\hline 9 & 336 & 371 & 0039 & Note 4 & 2 & $4 / 28 / 83-6 / 23 / 83$ & WG Pu, EU, Am-241, DU \\
\hline 9 & 336 & 371 & 0048 & Note 4 & 1 & $8 / 27 / 82$ & WG Pu, EU, Am-241, DU \\
\hline 9 & 336 & 371 & 0073 & Note 3 & 1 & $2 / 12 / 73$ & Unknown \\
\hline 9 & 336 & 371 & 0076 & Repackaging Residues & 1 & $4 / 28 / 83$ & WG Pu, EU, Am-241, DU \\
\hline 9 & 336 & 371 & 0092 & Note 3 & 2 & $5 / 25 / 73-5 / 29 / 73$ & Unknown \\
\hline 9 & 336 & 707 & 0012 & Foundry and Casting Opertations & 2 & $1 / 15 / 73-4 / 10 / 73$ & WG Pu \\
\hline 9 & 336 & 707 & 0031 & Metal Fabrication-Assembly & 1 & $2 / 7 / 73$ & WG Pu \\
\hline 9 & 336 & 771 & 0001 & Aqueous Recovery & 97 & $11 / 20 / 72-1 / 17 / 73$ & WG Pu \\
\hline 9 & 336 & 771 & 0002 & Aqueous Recovery & 243 & $1 / 13 / 72-9 / 11 / 85$ & WG Pu \\
\hline 9 & 336 & 771 & 0005 & Aqueous Recovery & 6 & $5 / 15 / 73-4 / 23 / 82$ & WG Pu \\
\hline 9 & 336 & 771 & 0006 & Aqueous Recovery (Americium) & 24 & $12 / 19 / 84-2 / 21 / 85$ & Am-241, WG Pu \\
\hline 9 & 336 & 771 & 0009 & Aqueous Recovery-Filter Plenums & 2 & $2 / 15 / 82$ & WG Pu, EU, Am-241, DU, U-233 \\
\hline 9 & 336 & 771 & 0037 & Analytical Laboratory & 20 & $12 / 12 / 72-7 / 27 / 82$ & WG Pu, EU, Am-241, DU, U-233 \\
\hline 9 & 336 & 771 & 0038 & Chemical Standards Laboratory & 1 & $7 / 22 / 82$ & WG Pu, EU, Am-241, DU, U-233 \\
\hline 9 & 336 & 771 & 0042 & Chemical Technology & 14 & $8 / 3 / 81-8 / 6 / 82$ & WG Pu, EU, Am-241, DU, U-233 \\
\hline 9 & 336 & 771 & 0074 & Oralloy Leach & 1 & $7 / 27 / 82$ & EU, WG Pu \\
\hline 9 & 336 & 771 & 0078 & Plutonium Metallurgy Development & 1 & $1 / 20 / 81$ & WG Pu, EU, Am-241, DU, U-233 \\
\hline 9 & 336 & $771 / 881$ & 0045 & Note 8 & 1 & $3 / 26 / 82$ & WG Pu, EU, Am-241, DU, U-233 \\
\hline 9 & 336 & 774 & 0746 & Liquid Waste Treatment & 2 & $4 / 28 / 83-8 / 22 / 83$ & WG Pu, EU, Am-241, DU \\
\hline 9 & 336 & 776 & 0003 & Pyrochemical Operations & 1 & $7 / 29 / 80$ & WG Pu, Am-241 \\
\hline 9 & 336 & 776 & 0025 & Drum Repack & 6 & $4 / 25 / 73-11 / 21 / 80$ & WG Pu, EU, Am-241, DU, U-233 \\
\hline 9 & 336 & 777 & 0023 & Metal Fabrication-Machining & 11 & $12 / 21 / 72-5 / 18 / 83$ & WG Pu, EU \\
\hline 9 & 336 & 777 & 0080 & Note 1 & 314 & $9 / 29 / 85-4 / 13 / 88$ & Not Assessed \\
\hline 9 & 336 & 779 & 0072 & Joining Tech-Joining D-38 & 1 & $3 / 26 / 82$ & WG Pu, DU \\
\hline 9 & 337 & $?$ & 0089 & Note 12 & 4 & $1 / 16 / 73$ & Unknown \\
\hline 9 & 337 & $?$ & 0090 & Note 13 & 1. & $5 / 25 / 73$ & Unknown \\
\hline 9 & 337 & $?$ & 0091 & Note 14 & 1. & $4 / 13 / 73$ & Unknown \\
\hline 9 & 337 & $?$ & 0065 & Note 10 & 1 & $4 / 2 / 73$ & Unknown \\
\hline 9 & 337 & 371 & 0017 & Note 3 & 38 & $11 / 20 / 72-5 / 4 / 73$ & Unknown \\
\hline 9 & 337 & 371 & 0032 & Note 3 & 2 & $1 / 11 / 73$ & Unknown \\
\hline 9 & 337 & 371 & 0036 & Note 3 & 1 & $12 / 15 / 72$ & Unknown \\
\hline 9 & 337 & 371 & 0043 & Stacker/Retriever & 3 & 1/16/85-1/17/85 & WG Pu, EU, Am-241, DU \\
\hline 9 & 337 & 559 & 0029 & Analytical Laboratory & 1. & $4 / 20 / 83$ & WG Pu, EU, Am-241, DU \\
\hline
\end{tabular}




\begin{tabular}{|c|c|c|c|c|c|c|c|}
\hline \% & S: & (60) & 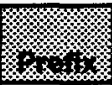 & 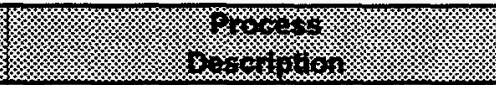 & IIIn: & 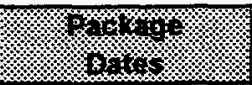 & (1) \\
\hline 9 & 337 & 707 & 0012 & Foundry and Casting Opertations & 1 & $1 / 10 / 73$ & WG Pu \\
\hline 9 & 337 & 707 & 0018 & Note 5 & 2 & $1 / 9 / 73-1 / 26 / 73$ & WG Pu \\
\hline 8 & 337 & 707 & 0022 & Metal Fabrication-Machining & 4 & $1 / 12 / 73-4 / 25 / 73$ & WG Pu \\
\hline 9 & 337 & 707 & 0031 & Metal Fabrication-Assembly & 10 & $1 / 2 / 73-4 / 23 / 73$ & WG Pu \\
\hline 9 & 337 & 771 & 0001 & Aqueous Recovery & 17 & $12 / 14 \sqrt[72]{ }-1 / 17 \pi 73$ & WG Pu \\
\hline 9 & 337 & 771 & 0002 & Aqueous Recovery & 109 & $1 / 17 / 73-5 / 18 / 73$ & WG Pu \\
\hline 9 & 337 & 771 & 0006 & Aqueous Recovery (Americium) & 21 & $2 / 12 / 80-2 / 21 / 85$ & Am-241, WG Pu \\
\hline 9 & 337 & 771 & 0037 & Analytical Laboratory & 7 & $12 / 18 / 72-5 / 6 / 73$ & WG Pu, EU, Am-241, DU, U-233 \\
\hline 9 & 337 & 771 & 0042 & Chemical Technology & 9 & $7 / 29 / 80-1 / 17 / 85$ & WG Pu, EU, Am-241, DU, U-233 \\
\hline 9 & 337 & 774 & 0744 & Liquid Waste Treatment & 51 & $2 \pi / 83-7 / 25 / 83$ & WG Pu, EU, Am-241, DU \\
\hline 9 & 337 & 774 & 0744 & Liquid Waste Treatment & 194 & $12 / 26 / 72-12 / 17 / 82$ & WG Pu, EU, Am-241, DU, U-233 \\
\hline 9 & 337 & 774 & 0746 & Liquid Waste Treatment & 6 & $1 / 26 / 73-4 / 25 / 73$ & WG Pu, EU, Am-241, DU, U-233 \\
\hline 9 & 337 & 777 & 0004 & Radiography & 2 & $1 / 2 / 73-2 / 6-73$ & WG PU, EU \\
\hline$\overline{9}$ & 337 & 777 & 0023 & Metal Fabrication-Machining & 2 & $1 / 8 / 73$ & WG Pu, EU \\
\hline 9 & 337 & 777 & 0080 & Note 1 & 4 & $8 / 5 / 86-4 / 13 / 87$ & Not Assessed \\
\hline 9 & 337 & 779 & 0052 & Pyrochemistry Process Development & 1 & $3 / 26 / 81$ & WG Pu, Am-241 \\
\hline 9 & 337 & 779 & 0055 & Hydride Operations & 14 & 10/8/81-6/3/83 & WG Pu \\
\hline 9 & 337 & 881 & 0033 & Note 7 & 1. & $6 / 25 / 82$ & Unknown \\
\hline 10 & 328 & 771 & 0002 & Aqueous Recovery & 6 & $12 / 8 / 82-2 / 1 / 83$ & WG Pu \\
\hline 10 & 328 & 776 & 0041 & Waste Processing/Final Packaging & 3 & $4 / 23 / 82$ & WG Pu, EU, Am-241, DU, U-233 \\
\hline 10 & 335 & 371 & 0011 & Note 3 & 1. & $4 / 1 7 \longdiv { 7 3 }$ & Unknown \\
\hline 10 & 335 & 371 & 0036 & Note 3 & 2 & $1 / 8 / 73$ & Unknown \\
\hline 10 & 335 & 371 & 0073 & Note 3 & 2 & $2 / 12 / 73-2 / 13-73$ & Unknown \\
\hline 10 & 335 & 371 & 0092 & Aqueous Recovery & 1 & $4 / 28 / 83$ & WG Pu, Am-241 \\
\hline 10 & 335 & 771 & 0002 & Aqueous Recovery & 3 & $4 / 26 / 73-9 / 8 / 82$ & WG Pu \\
\hline 10 & 335 & 771 & 0037 & Analytical Laboratory & 3 & $1 / 23 / 73-5 / 25 / 73$ & WG Pu, EU, Am-241, DU, U-233 \\
\hline 10 & 335 & 776 & 0003 & Pyrochemical Operations & 7 & $3 / 23 / 83-9 / 11 / 85$ & WG Pu, EU, Am-241 \\
\hline 10 & 335 & 776 & 0019 & Size Reduction & 9 & $8 / 26 / 85$ & WG Pu, EU, Am-241, DU, U-233 \\
\hline 10 & 335 & 777 & 0004 & Radiography & 1 & $5 / 1 / 73$ & WG Pu, EU \\
\hline 10 & 338 & $?$ & 0089 & Note 12 & 7. & $1 / 2 / 73-3 / 22 / 73$ & Unknown \\
\hline 10 & 338 & $?$ & 0090 & Note 13 & 1 & $4 / 17 / 73$ & Unknown \\
\hline 10 & 338 & 707 & 0012 & Foundry and Casting Opertations & 1 & $4 / 25 / 73$ & WG Pu \\
\hline 10 & 338 & 771 & 0001 & Aqueous Recovery & 1 & $1 / 12 / 73$ & WG Pu \\
\hline 10 & 338 & 771 & 0002 & Aqueous Recovery & 20 & $1 / 17 / 73-5 / 28 / 73$ & WG Pu \\
\hline 10 & 360 & $?$ & 0089 & Note 12 & 1 & $1 / 26 / 73$ & Unknown \\
\hline 10 & 376 & $?$ & 0389 & Note 1 & 2 & $7 / 22 / 80$ & Not assessed \\
\hline 10 & 376 & 371 & 0092 & Aqueous Recovery & 1 & $7 / 18 / 84$ & WG Pu, Am-241 \\
\hline 10 & 376 & 707 & 0012 & Foundry and Casting Opertations & 1 & $12 / 19 / 81$ & WG Pu \\
\hline 10 & 376 & 771 & 0002 & Aqueous Recovery & 4 & $11 / 5 / 83-10 / 22 / 85$ & WG Pu \\
\hline 10 & 376 & 776 & 0019 & Size Reduction & 37 & $12 / 8 / 81-1 / 9 / 86$ & WG Pu, EU, Am-241, DU, U-233 \\
\hline 10 & 376 & 776 & 0040 & Waste Processing/Final Packaging & 847 & $4 / 9 / 84-7 / 16 / 87$ & WG Pu, EU, Am-241, DU, U-233 \\
\hline 10 & 376 & 776 & 0041 & Waste Processing/Final Packaging & 1013 & $4 / 23 / 80-9 / 15 / 88$ & WG Pu, EU, Am-241, DU, U-233 \\
\hline 10 & 376 & 779 & 0010 & Pyrochemical Technology & 1 & $6 / 4 / 84$ & WG Pu, Am-241 \\
\hline 10 & 490 & $?$ & 0389 & Note 1 & 38 & $12 / 21 / 72-1 / 8 / 86$ & Not assessed \\
\hline 10 & 490 & 771 & 0001 & Aqueous Recovery & 1 & $1 / 12 \sqrt{73}$ & WG PU \\
\hline 10 & 490 & 771 & 0002 & Aqueous Recovery & 1 & $5 / 14 / 73$ & WG Pu \\
\hline 10 & 490 & 771 & 0037 & Analytical Laboratory & 1 & $2 / 14 / 73$ & WG PU, EU, Am-241, DU, U-233 \\
\hline 10 & 490 & 776 & 0019 & Size Reduction & 47 & $8 / 26 / 85-3 / 22 / 88$ & WG PU, EU, Am-241, DU, U-233 \\
\hline 10 & 490 & 777 & 0080 & Note 1 & 110 & $2 / 6 / 86-7 / 11 / 89$ & Not Assessed \\
\hline 11 & 440 & $?$ & 0089 & Note 12 & 1 & $1 1 / 1 7 \longdiv { 7 2 }$ & Unknown \\
\hline 11 & 440 & $?$ & 0389 & Note 1 & 2 & $12 / 6 / 85-12 / 17 / 85$ & Not assessed \\
\hline 11 & 440 & $?$ & 0065 & Note 10 & 1 & $4 / 25 / 73$ & Unknown \\
\hline 11 & 440 & 371 & 0017 & Aqueous Recovery & 2 & $9 / 24 / 82-7 / 18 / 84$ & WG Pu, Am-241 \\
\hline 11 & 440 & 371 & 0036 & Note 3 & 2 & $2 / 9 / 73-4 / 10 / 73$ & Unknown \\
\hline 11 & 440 & 371 & 0039 & Note 4 & 2 & $7 / 18 / 84-11 / 9 / 84$ & WG Pu, EU, Am-241, DU \\
\hline 11 & 440 & 371 & 0071 & Analytical/Standards Laboratory & 15 & $1 / 18 / 83-2 / 6 / 85$ & WG Pu, EU, Am-241, DU \\
\hline 11 & 440 & 371 & 0073 & Aqueous Recovery & 2 & $9 / 14 / 82-4 / 3 / 84$ & WG PU, Am-241 \\
\hline 11 & 440 & 371 & 0076 & Note 3 & 1 & $3 / 26 / 81$ & Unknown \\
\hline
\end{tabular}




\begin{tabular}{|c|c|c|c|c|c|c|c|}
\hline rorro & 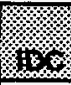 & 6 & 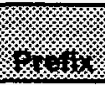 & (3), & 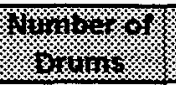 & 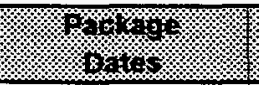 & 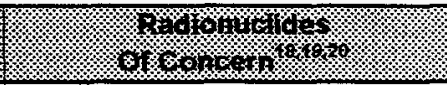 \\
\hline 11 & 440 & 371 & 0076 & Repackaging Residues & 5 & $1 / 22 / 82-6 / 3 / 83$ & WG Pu, EU, Am-241, DU \\
\hline 11 & 440 & 371 & 0092 & Aqueous Recovery & 6 & $9 / 14 / 82-11 / 14 / 84$ & WG Pu, Am-241 \\
\hline 11 & 440 & 559 & 0029 & Analytical Laboratory & 93 & $12 / 12 / 80-2 / 6 / 85$ & WG Pu, EU, Am-241, DU \\
\hline 11 & 440 & 707 & 0012 & Foundry and Casting Opertations & 9 & $9 / 17 / 82-11 / 14 / 84$ & WG Pu \\
\hline 11 & 440 & 707 & 0018 & Note 5 & 2 & $2 / 5 / 73-2 / 8 / 73$ & WG Pu \\
\hline 11 & 440 & 707 & 0028 & Note 5 & 48 & $6 / 10 / 80-12 / 22 / 82$ & WG Pu \\
\hline 11 & 440 & 771 & 0001 & Aqueous Recovery & 3 & $12 / 22 / 72-12 / 28 / 72$ & WG Pu \\
\hline 11 & 440 & 771 & 0002 & Aqueous Recovery & 33 & $1 / 21 / 73-11 / 3-84$ & WG Pu \\
\hline 11 & 440 & 771 & 0006 & Aqueous Recovery (Americium) & 2 & $9 / 15 / 80-9 / 8 / 82$ & Am-241, WG Pu \\
\hline 11 & 440 & 771 & 0037 & Analytical Laboratory & 69 & $1 / 10 / 83-5 / 8 / 84$ & WG Pu, EU, Am-241, DU \\
\hline 11 & 440 & 771 & 0037 & Analytical Laboratory & 116 & $12 / 16 / 72-12 / 21 / 82$ & WG Pu, EU, Am-241, DU, U-233 \\
\hline 11 & 440 & 771 & 0042 & Chemical Technology & 5 & $3 / 16 / 81-6 / 7 / 84$ & WG Pu, EU, Am-241, DU, U-233 \\
\hline 11 & 440 & 771 & 0074 & Oralloy Leach & 1 & $8 / 22 / 83$ & EU, WG PU \\
\hline 11 & 440 & $771 / 881$ & 0045 & Note 8 & 5 & 9/8/82-9/8/83 & WG Pu, EU, Am-241, DU, U-233 \\
\hline 11 & 440 & 776 & 0003 & Pyrochemical Operations & 21 & $8 / 19 / 85-12 / 15 / 86$ & WG Pu, Am-241 \\
\hline 11 & 440 & 776 & 0019 & Size Reduction & 25 & $7 / 24 / 81-12 / 1 / 84$ & WG Pu, EU, Am-241, DU, U-233 \\
\hline 11 & 440 & 776 & 0025 & Drum Repack & 1 & $3 / 14 / 85$ & WG Pu, EU, Am-241, DU, U-233 \\
\hline 11 & 440 & 776 & 0041 & Waste Processing/Final Packaging & 1 & $1 / 10 / 83$ & WG PU, EU, Am-241, DU, U-233 \\
\hline 11 & 440 & 776 & 0075 & Waste Processing Development & 1 & $6 / 23 / 81$ & WG PU \\
\hline 11 & 440 & 777 & 0016 & Coating Laboratory & 2 & $4 / 23 / 82$ & WG Pu, EU \\
\hline 11 & 440 & 777 & 0023 & Metal Fabrication-Machining & 7 & $1 / 12 / 81-11 / 5 / 83$ & WG Pu, EU \\
\hline 11 & 440 & 777 & 0080 & Note 1 & 23 & $1 / 16 / 86-2 / 19 / 88$ & Not Assessed \\
\hline 11 & 440 & 779 & 0054 & Research and Development & 9 & $10 / 22 / 80-11 / 3 / 84$ & WG Pu, EU, Am-241, DU, U-233 \\
\hline 11 & 440 & $?$ & 0056 & Note 9 & 1 & $4 / 3 / 84$ & Unknown \\
\hline 12 & 300 & 371 & 0011 & Note 3 & 1 & $1 / 9 / 73$ & Unknown \\
\hline 12 & 300 & 371 & 0011 & Note 4 & 4 & $4 / 28 / 83-5 / 23 / 83$ & WG Pu, EU, Am-241, DU \\
\hline 12 & 300 & 371 & 0032 & Aqueous Recovery & 81 & $1 / 17 / 83-4 / 111 / 84$ & WG PU \\
\hline 12 & 300 & 371 & 0039 & Note 4 & 1 & $2 / 1 / 83$ & WG Pu, EU, Am-241, DU \\
\hline 12 & 300 & 371 & 0073 & Aqueous Recovery & 2 & $9 / 7 / 82$ & WG Pu \\
\hline 12 & 300 & 559 & 0029 & Analytical Laboratory & 6 & $6 / 12 / 81-7 / 17 / 87$ & WG Pu, EU \\
\hline 12 & 300 & 707 & 0012 & Foundry and Casting Opertations & 1125 & $12 / 11 / 72-6 / 8 / 88$ & WG Pu \\
\hline 12 & 300 & 707 & 0028 & Note 5 & 3 & $3 / 26 / 82-6 / 25 / 82$ & WG Pu \\
\hline 12 & 300 & 707 & 0031 & Metal Fabrication-Assembly & 1 & $3 / 18 / 82$ & WG Pu \\
\hline 12 & 300 & 771 & 0001 & Aqueous Recovery & 18 & $11 / 16 / 72-1 / 11 / 73$ & WG Pu \\
\hline 12 & 300 & 771 & 0002 & Aqueous Recovery & 1 & $9 / 7 / 82$ & WG PU \\
\hline 12 & 300 & 771 & 0042 & Chemical Technology & 1 & $8 / 14 / 85$ & WG PU, EU, Am-241, DU \\
\hline 12 & 300 & 771 & 0078 & Plutonium Metallurgy Development & 6 & $5 / 22 / 81-6 / 24 / 86$ & WG Pu, EU, Am-241, DU, U-233 \\
\hline 12 & 300 & 771 & 0743 & Graphite Scarfing $^{15}$ & 10 & $8 / 27 / 85$ & WG PU \\
\hline 12 & 300 & 776 & 0019 & Size Reduction & 7 & $8 / 29 / 83-10 / 18 / 83$ & WG Pu, EU, Am-241, DU, U-233 \\
\hline 12 & 300 & 776 & 0025 & Drum Repack & 16 & $9 / 13 / 82-8 / 7 / 86$ & WG Pu, EU, Am-241, DU, U-233 \\
\hline 12 & 300 & 776 & 0026 & Size Reduction & 8 & $8 / 26 / 80-9 / 13 / 82$ & WG Pu, EU, Am-241, DU, U-233 \\
\hline 12 & 300 & 776 & 0040 & Waste Processing/Final Packaging & 2 & $12 / 1 / 84-1 / 11 / 85$ & WG Pu, EU, Am-241, DU, U-233 \\
\hline 12 & 300 & 776 & 0041 & Waste Processing/Final Packaging & 7 & $9 / 20 / 82-1 / 10 / 83$ & WG Pu, EU, Am-241, DU, U-233 \\
\hline 12 & 301 & 371 & 0011 & Note 3 & 2 & $4 / 4 / 73-4 / 18 / 73$ & Unknown \\
\hline 12 & 301 & 371 & 0073 & Aqueous Recovery & 1 & $9 / 10 / 82$ & WG Pu \\
\hline 12 & 301 & 559 & 0029 & Analytical Laboratory & 1 & $6 / 23 / 83$ & WG Pu, EU \\
\hline 12 & 301 & 707 & 0012 & Foundry and Casting Opertations & 1 & $2 / 13 / 85$ & WG Pu \\
\hline 12 & 303 & 371 & 0032 & Aqueous Recovery & 86 & $3 / 26 / 85-4 / 11 / 88$ & WG Pu \\
\hline 12 & 303 & 776 & 0025 & Drum Repack & 3 & $8 / 6 / 86-8 / 7 / 86$ & WG Pu, EU, Am-241, DU, U-233 \\
\hline 12 & 310 & 371 & 0032 & Aqueous Recovery & 1 & $12 / 14 / 83$ & WG Pu \\
\hline 12 & 312 & 371 & 0032 & Aqueous Recovery & 7 & $11 / 8 / 83$ & WG PU \\
\hline 12 & 312 & 776 & 0025 & Drum Repack & 2 & $6 / 7 / 84$ & WG Pu, EU, Am-241, DU, U-233 \\
\hline 13 & 372 & 707 & 0012 & Foundry and Casting Opertations & 1 & $1 / 24 / 84$ & WG Pu \\
\hline 13 & 372 & 771 & 0001 & Aqueous Recovery & 12 & $11 / 15 / 82-2 / 15 / 83$ & WG Pu \\
\hline 14 & 292 & 371 & 0011 & Note 4 & 154 & $10 / 23 / 85-5 / 1 / 86$ & WG Pu, EU, Am-241 \\
\hline 14 & 292 & 371 & 0032 & Aqueous Recovery & 9 & $11 / 5 / 83-9 / 24 / 85$ & WG Pu, EU, Am-241 \\
\hline 14 & 292 & 371 & 0048 & Note 4 & 1 & $7 / 27 / 82$ & WG Pu, EU, Am-241 \\
\hline 14 & 292 & 371 & 0076 & Note 3 & 3 & $3 / 18 / 81$ & Unknown \\
\hline
\end{tabular}




\begin{tabular}{|c|c|c|c|c|c|c|c|}
\hline 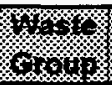 & 6 & 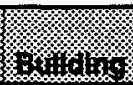 & 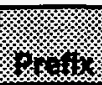 & \% & 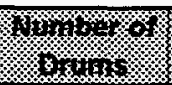 & 3.1. & 1) \\
\hline 14 & 292 & 771 & 0001 & Aqueous Recovery & 3 & $5 / 28 / 80-5 / 21 / 82$ & WG Pu, EU, Am-241 \\
\hline 14 & 292 & 771 & 0002 & Aqueous Recovery & 138 & $9 / 25 / 81-8 / 14 / 85$ & WG Pu, EU, Am-241 \\
\hline 14 & 292 & 776 & 0003 & Pyrochemical Operations & 1 & $6 / 16 / 83$ & WG Pu, EU, Am-241 \\
\hline 14 & 292 & 776 & 0019 & Size Reduction & 11 & $8 / 29 / 83-9 / 12 / 85$ & WG Pu, EU, Am-241 \\
\hline 14 & 292 & 776 & 0025 & Drum Repack & 2 & $7 / 13 / 84-3 / 29 / 85$ & WG Pu, EU, Am-241 \\
\hline 14 & 292 & 776 & 0040 & Waste Processing/Final Packaging & 45 & $6 / 16 / 80-9 / 14 / 82$ & WG Pu, EU, Am-241 \\
\hline 14 & 292 & 776 & 0041 & Waste Processing/Final Packaging & 3 & $4 / 23 / 82-4 / 3 / 84$ & WG Pu, EU, Am-241 \\
\hline 14 & 292 & 776 & 0075 & Waste Processing Development & 5 & $4 / 17 / 85$ & WG PU \\
\hline 14 & 371 & $?$ & 0089 & Note 12 & 8 & $12 / 26 / 72-4 / 23 / 73$ & Unknown \\
\hline 14 & 371 & 371 & 0036 & Note 3 & 1 & $1 / 25 / 73$ & Unknown \\
\hline 14 & 371 & 371 & 0076 & Note 3 & 3 & $12 / 18 / 72-1 / 16 / 73$ & Unknown \\
\hline 14 & 371 & 374 & 0747 & Liquid Waste Treatment & 1 & $1 / 24 / 85$ & prefixide conflict \\
\hline 14 & 371 & 707 & 0018 & Note 5 & 1 & $12 / 13 / 72$ & prefixfide conflict \\
\hline 14 & 371 & 771 & 0001 & Aqueous Recovery & 16 & $12 / 2 / 72-1 / 11 / 73$ & WG Pu, EU, Am-241 \\
\hline 14 & 371 & 771 & 0002 & Aqueous Recovery & 90 & $1 / 22 / 73-5 / 18 / 87$ & WG Pu, EU, Am-241 \\
\hline 14 & 371 & 776 & 0019 & Size Reduction & 8 & $6 / 4 / 84-2 / 18 / 86$ & WG Pu, EU, Am-241 \\
\hline 14 & 371 & 776 & 0025 & Drum Repack & 8 & $4 / 30 / 84-4 / 23 / 85$ & WG Pu, EU, Am-241 \\
\hline 14 & 377 & 771 & 0002 & Aqueous Recovery & 29 & $5 / 19 / 87-5 / 20 / 87$ & WG Pu, EU, Am-241 \\
\hline 14 & 377 & 776 & 0025 & Drum Repack & 1 & $3 / 29 / 85$ & WG Pu, EU, Am-241 \\
\hline 14 & 420 & 771 & 0001 & Aqueous Recovery & 2 & $12 / 16 / 83-4 / 11 / 84$ & WG Pu, EU, Am-241 \\
\hline 14 & 422 & 371 & 0011 & Note 4 & 4 & $1 / 29 / 86-2 / 6 / 86$ & WG Pu, EU, Am-241 \\
\hline 14 & 422 & 771 & 0001 & Aqueous Recovery & 5 & $3 / 18 / 82-6 / 3 / 83$ & WG Pu, EU, Am-241 \\
\hline 14 & 422 & 779 & 0010 & Pyrochemical Technology & 1 & $3 \pi / 85$ & prefix/idc conflict \\
\hline 14 & 425 & 776 & 0075 & Waste Processing Development & 9 & $7 / 21 / 81-7 / 24 / 81$ & WG Pu \\
\hline 14 & 807 & 371 & 0011 & Note 4 & 202 & $11 / 15 / 85-3 / 20 / 87$ & WG Pu, EU, Am-241 \\
\hline 14 & 807 & 371 & 0032 & Aqueous Recovery & 1 & $4 / 21 / 86$ & WG Pu, EU, Am-241 \\
\hline 14 & 807 & 776 & 0019 & Size Reduction & 2 & $8 / 12 / 86-11 / 17 / 86$ & WG Pu, EU, Am-241 \\
\hline 14 & 818 & 371 & 0011 & Note 4 & 8 & $10 / 13 / 86-10 / 24 / 86$ & WG Pu, EU, Am-241 \\
\hline 14 & 820 & 371 & 0011 & Note 4 & 28 & $1 / 1 / 86-10 / 22 / 86$ & WG Pu, EU, Am-241 \\
\hline 15 & 320 & $\pi 77$ & 0016 & Coating Laboratory & 3 & $8 / 11 / 82-7 / 14 / 86$ & WG PU, EU \\
\hline 15 & 320 & 371 & 0017 & Aqueous Recovery & 1 & $10 / 8 / 85$ & WG Pu, Am-241 \\
\hline 15 & 320 & 371 & 0032 & Aqueous Recovery & 1 & $12 / 4 / 86$ & WG Pu, Am-241 \\
\hline 15 & 320 & 371 & 0039 & Note 4 & 1 & $11 / 6 / 85$ & WG Pu, EU, Am-241, DU \\
\hline 15 & 320 & 371 & 0073 & Note 3 & 1 & $7 / 23 / 79$ & Unknown \\
\hline 15 & 320 & 559 & 0029 & Analytical Laboratory & 7 & $3 / 24 / 83-5 / 7 / 85$ & WG Pu, EU, Am-241, DU \\
\hline 15 & 320 & 707 & 0012 & Foundry and Casting Opertations & 54 & $3 / 23 / 81-6 / 24 / 88$ & WG PU \\
\hline 15 & 320 & 707 & 0015 & Metal Fabrication-Part V & 1 & $6 / 13 / 80$ & WG Pu \\
\hline 15 & 320 & 707 & 0022 & Metal Fabrication-Machining & 8 & $7 / 13 / 84-12 / 18 / 87$ & WG Pu \\
\hline 15 & 320 & 707 & 0031 & Metal Fabrication-Assembly & 12 & $8 / 8 / 85-2 / 23 / 87$ & WG Pu \\
\hline 15 & 320 & 771 & 0002 & Aqueous Recovery & 27 & $4 / 11 / 73-10 / 22 / 85$ & WG Pu \\
\hline 15 & 320 & 771 & 0005 & Aqueous Recovery & 1 & $11 / 6 / 85$ & WG Pu \\
\hline 15 & 320 & 771 & 0037 & Analytical Laboratory & 1 & $3 / 18 / 82$ & WG Pu, EU, Am-241, DU, U-233 \\
\hline 15 & 320 & 771 & 0078 & Plutonium Metallurgy Development & 2 & $8 / 18 / 80-5 / 2 / 85$ & WG Pu, EU, Am-241, DU, U-233 \\
\hline 15 & 320 & $771 / 881$ & 0045 & Note 8 & 1 & $7 / 21 / 81$ & WG Pu, EU, Am-241, DU, U-233 \\
\hline 15 & 320 & 776 & 0003 & Pyrochemical Operations & 5 & $4 / 17 / 85-10 / 24 / 86$ & WG Pu, Am-241 \\
\hline 15 & 320 & 776 & 0019 & Size Reduction & 37 & $3 / 7 / 85-11 / 11 / 86$ & WG Pu, EU, Am-241, DU, U-233 \\
\hline 15 & 320 & 776 & 0025 & Drum Repack & 2 & $3 / 29 / 85-8 / 7 / 86$ & WG Pu, EU, Am-241, DU, U-233 \\
\hline 15 & 320 & 776 & 0050 & Fluid-Bed Incinerator & 1 & Date Missing & WG Pu \\
\hline 15 & 320 & 776 & 0057 & Advanced Size Reduction & 1 & $10 / 24 / 86$ & WG Pu, EU, Am-241, DU, U-233 \\
\hline 15 & 320 & 776 & 0075 & Waste Processing Development & 5 & $2 / 20 / 73-8 / 8 / 85$ & WG Pu \\
\hline 15 & 320 & 777 & 0004 & Radiography & 1 & $12 / 17 / 85$ & WG Pu, EU \\
\hline 15 & 320 & 777 & 0024 & Metal Fabrication-Disassembly & 1 & $7 / 14 / 86$ & WG Pu, EU \\
\hline 15 & 320 & 777 & 0066 & Special Assembly & 1 & $1 / 29 / 73$ & WG Pu, EU, Am-241, DU, U-233 \\
\hline 15 & 320 & 779 & 0010 & Pyrochemical Technology & 1 & $9 / 26 / 85$ & WG Pu, Am-241 \\
\hline 15 & 320 & 779 & 0055 & Hydride Operations & 110 & $2 / 5 / 80-4 / 24 / 86$ & WG Pu \\
\hline 15 & 321 & 707 & 0022 & Metal Fabrication-Machining & 1 & $10 / 9 / 87$ & WG Pu \\
\hline 15 & 321 & 776 & 0003 & Pyrochemical Operations & 1 & $11 / 6 / 87$ & WG Pu, Am-241 \\
\hline 15 & 321 & 776 & 0057 & Advanced Size Reduction & 2 & $10 / 9 / 87$ & WG Pu, EU, Am-241, DU, U-233 \\
\hline
\end{tabular}




\begin{tabular}{|c|c|c|c|c|c|c|c|}
\hline 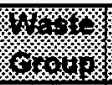 & 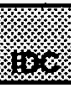 & 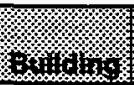 & 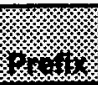 & 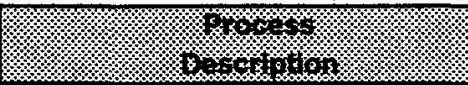 & 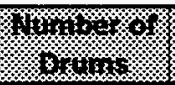 & 10. & oforom \\
\hline 15 & 339 & 371 & 0011 & Note 4 & 2 & $4 / 21 / 87$ & WG Pu, EU, Am-241, DU \\
\hline 15 & 339 & 371 & 0032 & Aqueous Recovery & 7 & $12 / 17 / 86-5 / 12 / 87$ & WG Pu, Am-241 \\
\hline 15 & 339 & 371 & 0039 & Note 4 & 4 & $11 / 84-11 / 85^{2}$ & WG Pu, EU, Am-241, DU \\
\hline 15 & 339 & 371 & 0092 & Aqueous Recovery & 5 & $11 / 5 / 87-7 / 8 / 88$ & WG Pu, Am-241 \\
\hline 15 & 339 & 707 & 0012 & Foundry and Casting Opertations & 29 & $4 / 8 / 85-4 / 29-88$ & WG Pu \\
\hline 15 & 339 & 707 & 0015 & Metal Fabrication-Part V & 3 & $12 / 17 / 85-11 / 24 / 87$ & WG Pu \\
\hline 15 & 339 & 707 & 0022 & Metal Fabrication-Machining & 40 & $4 / 8 / 85-6 / 23 / 88$ & WG Pu \\
\hline 15 & 339 & 707 & 0031 & Metal Fabrication-Assembly & 4 & $2 / 3 / 86-1987$ & WG Pu \\
\hline 15 & 339 & 771 & 0002 & Aqueous Recovery & 1. & $7 / 22 / 85$ & WG Pu \\
\hline 15 & 339 & 776 & 0003 & Pyrochemical Operations & 4 & $1 / 23 / 86-7 / 11 / 88$ & WG Pu, Am-241 \\
\hline 15 & 339 & 776 & 0019 & Size Reduction & 296 & $1 / 23 / 75-5 / 23 / 88$ & WG Pu, EU, Am-241, DU, U-233 \\
\hline 15 & 339 & 776 & 0025 & Drum Repack & 6 & $4 / 30 / 84-8 / 12 / 86$ & WG Pu, EU, Am-241, DU, U-233 \\
\hline 15 & 339 & 776 & 0041 & Waste Processing/Final Packaging & 1 & $10 / 23 / 81$ & WG Pu, EU, Am-241, DU, U-233 \\
\hline 15 & 339 & 776 & 0057 & Advanced Size Reduction & 1 & $12 / 17 / 87$ & WG Pu, EU, Am-241, DU, U-233 \\
\hline 15 & 339 & 777 & 0016 & Coating Laboratory & 1 & $7 / 14 / 86$ & WG Pu, EU \\
\hline 15 & 339 & 777 & 0021 & Metallography Laboratory & 1 & $2 \pi 773$ & WG Pu, EU, Am-241, DU, U-233 \\
\hline 15 & 339 & 777 & 0023 & Metal Fabrication-Machining & 23 & $4 / 8 / 85-6 / 23 / 88$ & WG Pu, EU \\
\hline 15 & 339 & 777 & 0024 & Metal Fabrication-Disassembly & 5 & $11 / 27 / 85-5 / 29 / 86$ & WG Pu, EU \\
\hline 15 & 339 & 777 & 0066 & Special Assembly & 2 & $5 / 11 / 87-?$ & WG Pu, EU, Am-241, DU \\
\hline 15 & 339 & 779 & 0054 & Research and Development & 2 & $3 / 7 / 86-3 / 21 / 86$ & WG Pu, EU, Am-241, DU \\
\hline 16 & 480 & $?$ & 0089 & Note 12 & 4 & $12 / 18 / 72-2 / 7 / 73$ & Unknown \\
\hline 16 & 480 & $?$ & 0389 & Note 1 & 82 & $3 / 2272-1 / 27 / 86$ & Not assessed \\
\hline 16 & 480 & $?$ & 1677 & Note 16 & 1 & $11 / 17 / 72$ & Unknown \\
\hline 16 & 480 & 371 & 0017 & Note 3 & 11 & $12 / 12 / 72-5 / 10 / 73$ & Unknown \\
\hline 16 & 480 & 371 & 0017 & Aqueous Recovery & 2 & $8 / 6 / 82-1 / 24 / 84$ & WG Pu, Am-241 \\
\hline 16 & 480 & 371 & 0030 & Note 4 & 6 & $3 / 18 / 82-2 / 16 / 83$ & WG Pu, EU, Am-241, DU \\
\hline 16 & 480 & 371 & 0034 & Aqueous Recovery & 2 & $1 / 17 / 83$ & WG Pu, Am-241 \\
\hline 16 & 480 & 371 & 0036 & Note 3 & 5 & $1 / 5 / 73-6 / 19 / 80$ & Unknown \\
\hline 16 & 480 & 371 & 0039 & Note 4 & 2 & $1 / 10 / 83-5 / 28 / 83$ & WG Pu, EU, Am-241, DU \\
\hline 16 & 480 & 371 & 0048 & Note 4 & 7 & $5 / 21 / 82-1 / 17 / 83$ & WG Pu, EU, Am-241, DU \\
\hline 16 & 480 & 371 & 0073 & Aqueous Recovery & 8 & $7 / 27 / 82-12 / 21 / 82$ & WG Pu, Am-241 \\
\hline 16 & 480 & 371 & 0076 & Note 3 & 7 & $7 / 25 / 80-10 / 13 / 81$ & Unknown \\
\hline 16 & 480 & 371 & 0092 & Aqueous Recovery & 9 & $5 / 21 / 82-9 / 23 / 83$ & WG Pu, Am-241 \\
\hline 16 & 480 & 374 & 0749 & Liquid Waste Treatment & 1 & $11 / 11 / 82$ & WG Pu, EU, Am-241, DU, U-233 \\
\hline 16 & 480 & 559 & 0029 & Analytical Laboratory & 14 & $11 / 12 / 81-2 / 3 / 84$ & WG Pu, EU, Am-241, DU, U-233 \\
\hline 16 & 480 & 707 & 0012 & Foundry and Casting Opertations & 5 & $2 / 2 / 73-2 / 22 / 84$ & WG Pu \\
\hline 16 & 480 & 707 & 0015 & Metal Fabrication-Part V & 5 & $12 / 10 / 81-12 / 14 / 82$ & WG Pu \\
\hline 16 & 480 & 707 & 0018 & Note 5 & 2 & $12 / 19 / 72$ & WG Pu \\
\hline 16 & 480 & 707 & 0022 & Metal Fabrication-Machining & 13 & $4 / 22 / 82-3 / 14 / 84$ & WG Pu \\
\hline 16 & 480 & 707 & 0028 & Note 5 & 13 & $10 / 15 / 80-11 / 2 / 82$ & WG Pu \\
\hline 16 & 480 & 707 & 0031 & Metal Fabrication-Assembly & 172 & $1 / 18 / 73-2 / 26 / 84$ & WG Pu \\
\hline 16 & 480 & 771 & 0001 & Aqueous Recovery & 26 & $11 / 25 / 72-1 / 17 / 73$ & WG Pu \\
\hline 16 & 480 & 771 & 0002 & Aqueous Recovery & 386 & $1 / 20 / 73-6 / 15 / 84$ & WG Pu \\
\hline 16 & 480 & 771 & 0005 & Aqueous Recovery & 3 & $2 / 2 / 81-10 / 23 / 81$ & WG Pu \\
\hline 16 & 480 & 771 & 0006 & Aqueous Recovery (Americium) & 1 & $6 / 19 / 80$ & Am-241, WG Pu \\
\hline 16 & 480 & 771 & 0009 & Aqueous Recovery-Filter Plenums & 4 & $10 / 22 / 80-5 / 7 / 82$ & WG Pu, EU, Am-241, DU, U-233 \\
\hline 16 & 480 & 771 & 0037 & Analytical Laboratory & 8 & 4/30/73-2/15/83 & WG Pu, EU, Am-241, DU, U-233 \\
\hline 16 & 480 & 771 & 0038 & Chemical Standards Laboratory & 2 & $6 / 19 / 80-11 / 20 / 81$ & WG Pu, EU, Am-241, DU, U-233 \\
\hline 16 & 480 & 771 & 0042 & Chemical Technology & 6 & $11 / 11 / 80-2 / 19 / 82$ & WG Pu, EU, Am-241, DU, U-233 \\
\hline 16 & 480 & 771 & 0074 & Oralloy Leach & 2 & $8 / 8 / 80-2 / 19 / 82$ & EU, WG Pu \\
\hline 16 & 480 & 771 & 0078 & Plutonium Metallurgy Development & 3 & $3 / 24 / 83-6 / 7 / 84$ & WG Pu, EU, Am-241, DU \\
\hline 16 & 480 & $771 / 881$ & 0045 & Note 8 & 15 & $1 / 31 / 73-3 / 18 / 83$ & WG Pu, EU, Am-241, DU, U-233 \\
\hline 16 & 480 & 774 & 0746 & Liquid Waste Treatment & 1 & $2 / 15 / 73$ & WG Pu, EU, Am-241, DU, U-233 \\
\hline 16 & 480 & 776 & 0003 & Pyrochemical Operations & 7 & $2 / 20 / 81-11 / 10 / 86$ & WG Pu, Am-241 \\
\hline 16 & 480 & 776 & 0019 & Size Reduction & 11 & $7 / 10 / 81-3 / 20 / 86$ & WG Pu, EU, Am-241, DU, U-233 \\
\hline 16 & 480 & 776 & 0025 & Drum Repack & 6 & $1 / 22 / 73-5 / 16 / 84$ & WG Pu, EU, Am-241, DU, U-233 \\
\hline 16 & 480 & 776 & 0026 & Size Reduction & 1 & Date Missing & WG Pu, EU, Am-241, DU, U-233 \\
\hline 16 & 480 & 776 & 0075 & Waste Processing Development & 2 & $1 / 8 / 73-7 / 21 / 81$ & WG Pu \\
\hline
\end{tabular}




\begin{tabular}{|c|c|c|c|c|c|c|c|}
\hline Wrave & $x$ & (6) & 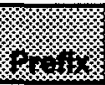 & (6. & 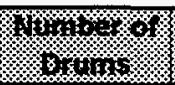 & \% & (6) \\
\hline 16 & 480 & 777 & 0004 & Radiography & 1 & $4 / 23 / 82$ & WG Pu, EU \\
\hline 16 & 480 & 777 & 0016 & Coating Laboratory & 7 & $6 / 19 / 80-3 / 24 / 83$ & WG Pu, EU \\
\hline 16 & 480 & 777 & 0021 & Metallography Laboratory & 2 & $1 / 19 / 82-2 / 15 / 82$ & WG Pu, EU, Am-241, DU, U-233 \\
\hline 16 & 480 & 777 & 0023 & Metal Fabrication-Machining & 60 & $1 / 18 / 73-11 / 14 / 84$ & WG Pu, EU \\
\hline 16 & 480 & 777 & 0024 & Metal Fabrication-Disassembly & 21 & $10 / 8 / 81-5 / 13 / 88$ & WG Pu, EU \\
\hline 16 & 480 & 777 & 0066 & Special Assembly & 6 & $10 / 6 / 81-6 / 7 / 84$ & WG Pu, EU, Am-241, DU, U-233 \\
\hline 16 & 480 & 777 & 0080 & Note 1 & 440 & $11 / 11 / 85-7 / 11 / 89$ & Not Assessed \\
\hline 16 & 480 & 779 & 0052 & Pyrochemistry Process Development & 1 & $9 / 10 / 81$ & WG Pu, Am-241 \\
\hline 16 & 480 & 779 & 0054 & Research and Development & 18 & $6 / 19 / 80-4 / 14 / 83$ & WG Pu, EU, Am-241, DU, U-233 \\
\hline 16 & 480 & 779 & 0055 & Hydride Operations & 7 & $10 / 23 / 81-2 / 21 / 83$ & WG Pu \\
\hline 16 & 480 & $?$ & 0056 & Note 9 & 2 & $1 / 9 / 81-4 / 28 / 83$ & Unknown \\
\hline 16 & 480 & Note 11 & 0067 & $?$ & 1 & $7 / 16 / 80$ & Unknown \\
\hline 16 & 481 & $?$ & 0089 & Note 12 & 1 & $12 / 21 / 72$ & Unknown \\
\hline 16 & 481 & 371 & 0076 & Note 3 & 3 & $12 / 18 \pi / 2-4 / 11 / 73$ & Unknown \\
\hline 16 & 481 & 371 & 0076 & Repackaging Residues & 1 & $4 / 28 / 83$ & WG Pu, EU, Am-241, DU \\
\hline 16 & 481 & 371 & 0092 & Aqueous Recovery & 2 & $6 / 21 / 82-4 / 28 / 83$ & WG Pu, Am-241 \\
\hline 16 & 481 & 707 & 0022 & Metal Fabrication-Machining & 1 & $5 / 12 / 83$ & WG Pu \\
\hline 16 & 481 & 707 & 0031 & Metal Fabrication-Assembly & 2 & $12 / 21 / 82-10 / 12 / 84$ & WG Pu \\
\hline 16 & 481 & 771 & 0002 & Aqueous Recovery & 2 & $5 / 21 / 82$ & WG Pu \\
\hline 16 & 481 & 776 & 0019 & Size Reduction & 107 & $5 / 28 / 80-8 / 15 / 84$ & WG Pu, EU, Am-241, DU, U-233 \\
\hline 16 & 481 & 776 & 0025 & Drum Repack & 1 & $11 / 11 / 80$ & WG Pu, EU, Am-241, DU, U-233 \\
\hline 16 & 481 & 776 & 0026 & Size Reduction & 1 & $9 / 5 / 80$ & WG Pu, EU, Am-241, DU, U-233 \\
\hline 16 & 481 & 777 & 0023 & Metal Fabrication-Machining & 1 & $9 / 16 / 81$ & WG Pu, EU \\
\hline 17 & 806 & 371 & 0011 & Note 4 & 38 & $4 / 3 / 87-10 / 14 / 87$ & WG Pu, EU, Am-241 \\
\hline 17 & 806 & 371 & 0032 & Aqueous Recovery & 1 & $3 / 22 / 88$ & WG Pu, EU, Am-241 \\
\hline 17 & 806 & 776 & 0025 & Drum Repack & 1 & $9 / 2 / 87$ & WG Pu, EU, Am-241 \\
\hline 17 & 806 & 779 & 0055 & Hydride Operations & 1 & $8 / 21 / 87$ & WG Pu \\
\hline 17 & 823 & 371 & 0011 & Note 4 & 18 & $1 / 23 / 87-3 / 6 / 87$ & WG Pu, EU, Am-241 \\
\hline 18 & 409 & 771 & 0001 & Aqueous Recovery & 2 & $9 / 10 / 82-11 / 3 / 82$ & WG Pu, Am-241, EU \\
\hline 18 & 409 & 776 & 0003 & Pyrochemical Operations & 25 & $12 / 6 / 84-1 / 23 / 86$ & WG Pu, Am-241, EU \\
\hline 18 & 409 & 776 & 0025 & Drum Repack & 3 & $4 / 30 / 84-3 / 21 / 85$ & WG Pu, Am-241, EU \\
\hline 18 & 411 & 371 & 0076 & Repackaging Residues & 14 & $1 / 15 / 86-3 / 5 / 86$ & WG Pu, Am-241, EU \\
\hline 18 & 411 & 771 & 0001 & Aqueous Recovery & 4 & $4 / 12 / 82$ & WG Pu, Am-241, EU \\
\hline 18 & 411 & 776 & 0025 & Drum Repack & 1 & $8 / 8 / 86$ & WG Pu, Am-241, EU \\
\hline 18 & 412 & 779 & 0052 & Pyrochemistry Process Development & 1 & $8 / 29 / 80$ & WG Pu, Am-241, EU \\
\hline 18 & 414 & 771 & 0001 & Aqueous Recovery & 4 & $5 / 7 / 82-10 / 15 / 82$ & WG Pu \\
\hline 18 & 414 & 776 & 0003 & Pyrochemical Operations & 1 & $8 / 27 / 85$ & WG Pu \\
\hline 18 & 416 & 779 & 0054 & Research and Development & 1 & $10 / 22 / 80-11 / 3 / 84$ & WG Pu, Am-241, EU \\
\hline 19 & 441 & $?$ & 0089 & Note 12 & 2 & $4 / 25 / 73-5 / 23 / 73$ & Unknown \\
\hline 19 & 441 & 707 & 0012 & Foundry and Casting Opertations & 2 & $4 / 9 / 73-4 / 17 \pi 73$ & WG Pu \\
\hline 19 & 441 & 771 & 0002 & Aqueous Recovery & 1 & $4 / 11 / 73$ & WG Pu \\
\hline 19 & 441 & $771 / 881$ & 0045 & Note 8 & 1 & $12 / 15 / 81$ & WG Pu, EU, Am-241, DU, U-233 \\
\hline 19 & 441 & 776 & 0019 & Size Reduction & 1 & $9 / 13 / 83$ & WG Pu, EU, Am-241, DU, U-233 \\
\hline 19 & 441 & 777 & 0080 & Note 1 & 1 & $7 / 7 / 86$ & Not Assessed \\
\hline 19 & 442 & 371 & 0017 & Note 3 & 31 & $11 / 7 / 80-11 / 21 / 80$ & Unknown \\
\hline 19 & 442 & 371 & 0032 & Aqueous Recovery & 1 & $1 / 87-9 / 87^{2}$ & WG Pu \\
\hline 19 & 442 & 707 & 0022 & Metal Fabrication-Machining & 74 & $1 / 15 / 81-4 / 9 / 84$ & WG Pu \\
\hline 19 & 442 & 707 & 0028 & Note 5 & 1 & $4 / 23 / 82$ & WG Pu \\
\hline 19 & 442 & 771 & 0002 & Aqueous Recovery & 193 & $2 / 27 / 81-7 / 13 / 84$ & WG Pu \\
\hline 19 & 442 & 771 & 0005 & Aqueous Recovery & 361 & $4 / 30 / 79-4 / 23 / 82$ & WG Pu \\
\hline 19 & 442 & 771 & 0042 & Chemical Technology & 14 & $3 / 13 / 81-4 / 11 / 84$ & WG Pu, EU, Am-241, DU, U-233 \\
\hline 19 & 442 & $771 / 881$ & 0045 & Note 8 & 9 & $5 / 9 / 88-5 / 16 / 88$ & WG Pu, EU, Am-241, DU, U-233 \\
\hline 19 & 442 & 776 & 0003 & Pyrochemical Operations & 4 & $8 / 22 / 83$ & prefix/idc conflict \\
\hline 19 & $\mathbf{4 4 2}$ & 776 & 0019 & Size Reduction & 13 & $6 / 22 / 83-8 / 20 / 84$ & WG Pu, EU, Am-241, DU, U-233 \\
\hline 19 & 442 & 776 & 0025 & Drum Repack & 4 & $3 / 14 / 85-3 / 29 / 85$ & WG Pu, EU, Am-241, DU, U-233 \\
\hline 19 & 442 & 776 & 0041 & Waste Processing/Final Packaging & 21 & $7 / 8 / 82-8 / 3 / 82$ & WG Pu, EU, Am-241, DU, U-233 \\
\hline 19 & 442 & 776 & 0057 & Advanced Size Reduction & 18 & $5 / 23 / 88-6 / 6 / 88$ & WG Pu, EU, Am-241, DU, U-233 \\
\hline 19 & 442 & 777 & 0023 & Metal Fabrication-Machining & 16 & $3 / 13 / 81-8 / 22 / 83$ & WG PU, EU \\
\hline
\end{tabular}




\begin{tabular}{|c|c|c|c|c|c|c|c|}
\hline Sor.w. & $\log$ & 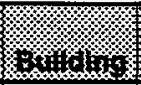 & $6 x$ & 4. & Hing & 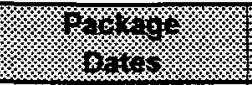 & 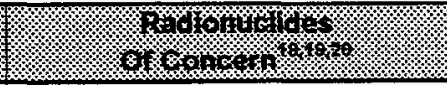 \\
\hline 19 & 442 & 777 & 0080 & Note 1 & 22 & $2 / 19 / 86-3 / 18 / 88$ & Not Assessed \\
\hline 20 & 432 & 371 & 0011 & Note 4 & 3 & $1 / 17 / 86$ & WG Pu, EU, Am-241 \\
\hline 20 & 432 & 371 & 0032 & Aqueous Recovery & 31 & $11 / 5 / 83-3 / 31 / 86$ & WG Pu, EU, Am-241 \\
\hline 20 & 432 & 771 & 0001 & Aqueous Recovery & 16 & $12 / 1 / 72-1 / 16 / 73$ & WG Pu, EU, Am-241 \\
\hline 20 & 432 & 771 & 0002 & Aqueous Recovery & 34 & $1 / 19 / 72-4 / 19 / 85$ & WG Pu, EU, Am-241 \\
\hline 20 & 432 & 776 & 0019 & Size Reduction & 4 & 9/8/83-10/10/83 & WG Pu, EU, Am-241 \\
\hline 20 & 432 & 776 & 0025 & Drum Repack & 8 & $3 / 14 / 85-8 / 12 / 86$ & WG Pu, EU, Am-241 \\
\hline 20 & 432 & $?$ & 0056 & Note 9 & 2 & $12 / 9 / 83-12 / 8 / 84$ & Unknown \\
\hline 20 & 822 & 371 & 0011 & Note 4 & 17 & $1 / 17 / 86-2 / 19 / 87$ & WG Pu, EU, Am-241 \\
\hline 20 & 822 & 371 & 0032 & Aqueous Recovery & 13 & $2 / 20 / 86-3 / 31 / 86$ & WG Pu, EU, Am-241 \\
\hline 21 & 370 & 559 & 0029 & Analytical Laboratory & 1 & $1 / 12 / 81$ & WG Pu \\
\hline 21 & 370 & 707 & 0028 & Note 5 & 2 & $10 / 22 / 80-6 / 21 / 82$ & prefix/idc conflict \\
\hline 21 & 391 & 771 & 0001 & Aqueous Recovery & 2 & $12 / 8 / / 82-8 / 30 / 83$ & WG Pu \\
\hline 21 & 391 & 779 & 0052 & Pyrochemistry Process Development & 1 & $2 / 3 / 84$ & WG Pu \\
\hline 21 & 391 & 779 & 0054 & Research and Development & 1 & $6 / 10 / 80$ & WG Pu \\
\hline 21 & 392 & 776 & 0040 & Waste Processing/Final Packaging & 1 & $7 / 10 / 81$ & WG Pu \\
\hline 21 & 393 & 771 & 0001 & Aqueous Recovery & 13 & $8 / 26 / 80-10 / 2 / 85$ & WG PU \\
\hline 21 & 393 & 779 & $0010^{21}$ & Pyrochemical Technology & 16 & $5 / 1 / 84-7 / 22 / 85$ & WG PU \\
\hline 21 & 817 & 371 & 0011 & Note 4 & 27 & $10 / 22 / 86-1 / 7 / 87$ & WG Pu \\
\hline 22 & 007 & 374 & 0747 & Liquid Waste Treatment & 5080 & $1 / 3 / 83-3 / 18 / 87$ & WG Pu, EU, Am-241, DU \\
\hline 22 & 007 & 374 & 0747 & Liquid Waste Treatment & 171 & $12 / 1 / 82-12 / 15 / 82$ & WG Pu, EU, Am-241, DU, U-233 \\
\hline 22 & 007 & 774 & 7412 & Liquid Waste Treatment & 1 & $4 / 2 / 84$ & prefixfidc conflict \\
\hline 22 & 007 & 776 & 0019 & Size Reduction & 49 & $3 / 11 / 85-2 / 21 / 86$ & WG Pu, EU, Am-241, DU, U-233 \\
\hline 22 & 007 & 776 & 0025 & Drum Repack & 22 & $5 / 16 / 84-8 / 5 / 86$ & WG Pu, EU, Am-241, DU, U-233 \\
\hline 22 & 007 & 776 & 0040 & Waste Processing/Final Packaging & 8 & $6 / 13 / 86$ & WG Pu, EU, Am-241, DU, U-233 \\
\hline 22 & 803 & 374 & 0747 & Liquid Waste Treatment & 156 & $4 / 10 / 86-5 / 8 / 87$ & WG Pu, EU, Am-241, DU \\
\hline 22 & 803 & 776 & 0040 & Waste Processing/Final Packaging & 8 & $6 / 13 / 86$ & WG PU, EU, Am-241, DU \\
\hline 22 & 807 & 374 & 0747 & Liquid Waste Treatment & 1041 & $3 / 18 / 87-7 / 1 / 88$ & WG Pu, EU, Am-241, DU \\
\hline 23 & 001 & 774 & 0741 & Liquid Waste Treatment & 426 & $1 / 3 / 72-6 / 2879$ & WG Pu, EU, Am-241, DU, U-233 \\
\hline 23 & 001 & 774 & 0742 & Liquid Waste Treatment & 1 & $5 / 4 / 73$ & WG Pu, EU, Am-241, DU, U-233 \\
\hline 23 & 001 & 774 & 0743 & Liquid Waste Treatment & 13 & $1 / 27 / 84-4 / 30 / 86$ & WG Pu, EU, Am-241, DU \\
\hline 23 & 001 & 774 & 0743 & Liquid Waste Treatment & 8 & $5 / 19 / 82$ & WG Pu, EU, Am-241, DU, U-233 \\
\hline 23 & 001 & 774 & 0744 & Liquid Waste Treatment & 3 & $6 / 10 / 80-12 / 9 / 82$ & WG Pu, EU, Am-241, DU, U-233 \\
\hline 23 & 001 & 774 & 7412 & Liquid Waste Treatment & 3457 & $1 / 3 / 83-8 / 26 / 86$ & WG Pu, EU, Am-241, DU \\
\hline 23 & 001 & 774 & 7412 & Liquid Waste Treatment & 1942 & $10 / 15 / 79-12 / 22 / 82$ & WG Pu, EU, Am-241, DU, U-233 \\
\hline 23 & 001 & 776 & 0019 & Size Reduction & 35 & 1/8/85-7/17/85 & WG Pu, EU, Am-241, DU, U-233 \\
\hline 23 & 001 & 776 & 0025 & Drum Repack & 18 & $11 / 11 / 80-7 / 30 / 85$ & WG Pu, EU, Am-241, DU, U-233 \\
\hline 23 & 002 & 774 & 0742 & Liquid Waste Treatment & 256 & $8 / 29 / 72-12 / 7 / 83$ & WG Pu, EU, Am-241, DU, U-233 \\
\hline 23 & 002 & 776 & 0019 & Size Reduction & 2 & $1 / 8 / 85-7 / 30 / 85$ & WG Pu, EU, Am-241, DU, U-233 \\
\hline 23 & 002 & 776 & 0025 & Drum Repack & 5 & $6 / 5 / 84-2 / 4 / 85$ & WG Pu, EU, Am-241, DU, U-233 \\
\hline 23 & 800 & 774 & 0744 & Liquid Waste Treatment & 2 & $11 / 19 / 86-3 / 22 / 88$ & WG Pu, EU, Am-241, DU \\
\hline 23 & 800 & 774 & 7412 & Liquid Waste Treatment & 1562 & $12 / 17 / 85-9 / 19 / 88$ & WG Pu, EU, Am-241, DU \\
\hline 23 & 800 & 776 & 0025 & Drum Repack & 20 & $8 / 31 / 87-10 / 12 / 87$ & WG Pu, EU, Am-241, DU \\
\hline 24 & 004 & 774 & 0743 & Liquid Waste Treatment & 2 & $4 / 23 / 85$ & WG Pu, EU, Am-241, DU \\
\hline 24 & 004 & 774 & 0744 & Liquid Waste Treatment & 224 & $2 / 7 / 83-6 / 3 / 86$ & WG Pu, EU, Am-241, DU \\
\hline 24 & 004 & 774 & 0744 & Liquid Waste Treatment & 188 & $12 / 14 / 72-12 / 17 / 82$ & WG Pu, EU, Am-241, DU, U-233 \\
\hline 24 & 004 & 776 & 0019 & Size Reduction & 12 & $9 / 19 / 83-11 / 17 / 86$ & WG Pu, EU, Am-241, DU, U-233 \\
\hline 24 & 004 & 776 & 0025 & Drum Repack & 11 & $2 / 4 / 85-8 / 11 / 86$ & WG Pu, EU, Am-241, DU, U-233 \\
\hline 24 & 802 & 774 & 0744 & Liquid Waste Treatment & 75 & $6 / 19 / 86-4 / 16 / 88$ & WG Pu, EU, Am-241, DU \\
\hline 24 & 802 & 776 & 0019 & Size Reduction & 1 & $9 / 3 / 87$ & WG Pu, EU, Am-241, DU \\
\hline 24 & 802 & 776 & 0025 & Drum Repack & 2 & $9 / 3 / 87$ & WG Pu, EU, Am-241, DU \\
\hline 25 & 003 & 774 & 0743 & Liquid Waste Treatment & 1110 & 1/6/83-3/12/86 & WG Pu, EU, Am-241, DU \\
\hline 25 & 003 & 774 & 0743 & Liquid Waste Treatment & 1518 & $8 / 24 \Pi 72-11 / 10 / 82$ & WG Pu, EU, Am-241, DU, U-233 \\
\hline 25 & 003 & 774 & 0744 & Liquid Waste Treatment & 6 & $12 / 18 / 84$ & WG Pu, EU, Am-241, DU \\
\hline 25 & $\infty 03$ & 774 & 7412 & Liquid Waste Treatment & 1 & $10 / 10 / 80$ & WG Pu, EU, Am-241, DU, U-233 \\
\hline 25 & 003 & 776 & 0019 & Size Reduction & 4 & $1 / 8 / 85-5 / 31 / 85$ & WG Pu, EU, Am-241, DU, U-233 \\
\hline 25 & 003 & 776 & 0025 & Drum Repack & 14 & $5 / 16 / 84-8 / 26 / 85$ & 5 WG Pu, EU, Am-241, DU, U-233 \\
\hline 25 & 700 & 774 & 0743 & Liquid Waste Treatment & 60 & $3 / 12 / 86-5 / 13 / 86$ & WG PU, EU, Am-241, DU \\
\hline
\end{tabular}




\begin{tabular}{|c|c|c|c|c|c|c|c|}
\hline \% & 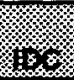 & 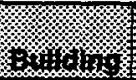 & 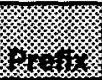 & א.\% & W.1.1. & 16\% & 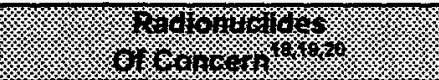 \\
\hline 25 & 801 & 371 & 0011 & Note 4 & 1 & $5 / 1 / 86$ & WG Pu, EU, Am-241, DU \\
\hline 25 & 801 & 774 & 0743 & Liquid Waste Treatment & 765 & $1 / 7 / 86-9 / 19 / 88$ & WG PU, EU, Am-241, DU \\
\hline 25 & 801 & 774 & RFPR & Note 17 & 1 & Date Missing & WG Pu, EU, Am-241, DU \\
\hline 25 & 801 & 776 & 0019 & Size Reduction & 16 & $8 / 24 / 87-9 / 8 / 87$ & WG Pu, EU, Am-241, DU \\
\hline 25 & 801 & 776 & 0025 & Drum Repack & 12 & $9 / 1 / 87-9 / 15 / 88$ & WG Pu, EU, Am-241, DU \\
\hline 26 & 900 & 774 & 0746 & Liquid Waste Treatment & 27 & $12 / 14 / 72-5 / 18 / 73$ & WG Pu, EU, Am-241, DU, U-233 \\
\hline 26 & 950 & $?$ & 0389 & Note 1 & 1 & $12 / 28 / 72$ & Not assessed \\
\hline 26 & 950 & $?$ & 1371 & Note 1 & 2 & $3 / 8 / 73-3 / 9 / 73$ & Not assessed \\
\hline 26 & 950 & 774 & $\overline{0746}$ & Liquid Waste Treatment & 4 & $12 / 30 / 72$ & WG Pu, EU, Am-241, DU, U-233 \\
\hline 26 & 960 & $?$ & 0089 & Note 12 & 24 & $1 / 13 / 72-1 / 23 / 73$ & Unknown \\
\hline 26 & 960 & 771 & 0001 & Aqueous Recovery & 26 & $11 / 30 / 72-1 / 15 / 73$ & WG PU \\
\hline 26 & 960 & 774 & 0746 & Liquid Waste Treatment & 3 & $5 / 3 / 73$ & WG Pu, EU, Am-241, DU, U-233 \\
\hline 26 & 970 & $?$ & 0089 & Note 12 & 1 & $1 / 4 / 73$ & Unknown \\
\hline 26 & 970 & $?$ & 0389 & Note 1 & 7 & $7 / 11 / 72-4 / 18 / 73$ & Not assessed \\
\hline 26 & 970 & 771 & 0001 & Aqueous Recovery & 4 & $1 / 5 / 73-1 / 7 / 73$ & WG Pu \\
\hline$?$ & 000 & 774 & 7412 & Liquid Waste Treatment & 1 & $10 / 4 / 82$ & Unknown \\
\hline$?$ & 111 & 374 & 0747 & Liquid Waste Treatment & 12 & $10 / 22 / 85$ & Not assessed \\
\hline $14 / 22$ & 807 & 776 & 0025 & Drum Repack & 8 & $9 / 1 / 87-10 / 12 / 87$ & WG Pu, EU, Am-241, DU, U-233 \\
\hline N/A & 368 & 776 & 0003 & Pyrochemical Operations & 1 & $8 / 83-11 / 86^{2}$ & Not Assessed \\
\hline NIA & 421 & 771 & 0001 & Aqueous Recovery & 1 & $12 / 8 / 77$ & Not Assessed \\
\hline N/A & 488 & 777 & 0080 & Note 1 & 3 & $7 / 9 / 88-7 / 14 / 88$ & Not Assessed \\
\hline N/A & 491 & 777 & 0080 & Note 1 & 3 & $10 / 2 / 87-12 / 15 / 87$ & Not Assessed \\
\hline N/A & 831 & 777 & 0080 & Note 1 & 71 & $4 / 6 / 88-7 / 12 / 89$ & Not Assessed \\
\hline N/A & 832 & 777 & 0080 & Note 1 & 96 & $12 / 12 / 87-3 / 23 / 89$ & Not Assessed \\
\hline N/A & 833 & 777 & 0080 & Note 1 & 9 & $7 / 7 / 88-12 / 1 / 88$ & Not Assessed \\
\hline & & & & Total number of containers $=$ & 29707 & & \\
\hline
\end{tabular}

Key: WG PU weapons-grade plutonium

EU enriched uranium

DU depleted uranium

Notes: 1. All wastes generated in prefixes 0080,0389 , and 1371 are packaged in boxes which were not assessed.

2. The date range is estimated based on the sequence the container was filled.

3. Building 371 was not in operation when this waste was generated.

4. This prefix was assigned to an MBA in Building 371 that is not defined or was redefined after this waste was generated. It is assumed that this waste could contain any of the radionuclides handled in Building 371 unless the IDC further defines what radionuclides are in the waste.

5. This prefix was assigned to an MBA in Building 707 that is not defined or was redefined after this waste was generated. It is assumed that this waste could contain any of the radionuclides handled in Building 707 unless the IDC further defines what radionuclides are in the waste.

6. This prefix was assigned to an MBA in Building 779 that is not defined or was redefined after this waste was generated. It is assumed that this waste could contain any of the radionuclides handled in Building 779 unless the IDC further defines what radionuclides are in the waste.

7. This prefix was assigned to an MBA in Building 881 that is not defined or was redefined after this waste was generated. It is assumed that this waste could contain any of the radionuclides handled in Building 881 unless the IDC further defines what radionuclides are in the waste.

8. Prefix 45 appears to have been assigned to MBAs in both Buildings 771 and 881 at different times. Prefix 45 was used for Special Recovery Anion Exchange in Building 771 and Construction Management in Building 881.

9. Building 865 did not process transuranic radionuclides; this waste most likely contains depleted uranium and beryllium, or was not generated in this area.

10. Prefix 65 was assigned to MBA 0376-23 in Building 123, Health Physics Lab., beginning in 1990. Prior to this date, it is assumed that prefix 65 was assigned to a different MBA in Building 123. However, it is unlikely that Building 123 generated transuranic waste due to the small quantities of plutonium used in the Health Physics Lab. 
11. Prefix 67 was not identified in any of the documentation and, therefore, the generation building is unknown.

12. Prefix 89 was assigned to MBA $0389-87$ on the 904 Pad beginning in 1990 . Prior to this date, it is not known what prefix 89 was assigned to because the 904 Pad was constructed in the late 1980 s. It is possible that the waste with prefix 89 was generated from cleanup of the 903 Pad.

13. Prefix 90 was assigned to the Valve Vaults (liquid waste transfer system); however, the Valve Vault system did not exist at the time most of this waste was generated. Additionally, it is unlikely the Valve Vaults generated transuranic waste.

14. Prefix 91 was assigned to MBA 0389-91 beginning in 1992. Prior to this date, it is not known what prefix 89 was assigned to because MBA 0389-91 was a general prefix used for waste generated outside the Protected Area (non-plutonium buildings).

15. Prefix 743 was assigned to MBA 0389-74, Liquid Waste Treatment; however, graphite was not generated by these operations. It is assumed that this waste was generated from graphite scarfing operations in prefix 07, line 43 (See C173 and C177).

16. Prefix 1677 was not identified in any of the documentation and, therefore, the generation building is unknown.

17. Prefix RFPR is not defined; however, it is assumed that this waste was generated in Building 774 based on the IDC.

18. Radionuclides of concern are only those radioisotopes that will be monitored by WIPP or are concerns for transporation; Am-241, Pu-238, Pu-239, Pu-240, Pu-242, U-233, U-234, U-235, U-238. Radioisotopes such as Cm-244, Np-237, and not be reported in this table; however, the presence of these isotopes will be reported within each waste group chapter, as applicable.

19. Am-241 is indicated for wastes generated from americium operations (i.e., recovery from site-returns, waste treatment, analytical testing, and R\&D). Am-241 is not indicated if it is expected to be present only due to plutonium-241 decay.

20. Pu-238, Pu-239, Pu-240, Pu-241, and Pu-242 from R\&D and special order work are not specified as radionuclides of concern because they will be negligible compared to the contribution of these isotopes from WG PU.

21. This prefix should be 01 . IDC 393 was generated from recovery operations in Building 771 . The package dates and the last five digits of these container numbers are in the proper sequence if the prefix is changed to 01 .

22. This prefix was assigned to an MBA in Building 771 that is not defined or was redefined after this waste was generated. It is assumed that this waste could contain any of the radionuclides handled in Building 771 unless the IDC further defines what radionuclides are in the waste.

References: C184, C197, P052, U059, U069 